\author{
MATHEUS DAVID INOCENTE DOMINGOS
}

\title{
Caracterização do comportamento fluência- recuperação de ligantes asfálticos modificados virgens e envelhecidos
}

\begin{abstract}
Dissertação apresentada ao Departamento de Engenharia de Transportes da Escola de Engenharia de São Carlos, da Universidade de São Paulo, como parte dos requisitos para obtenção do título de Mestre em Engenharia Civil.
\end{abstract}

Área de Concentração: Infraestrutura de Transportes

Orientador: Prof. Dr. Adalberto Leandro Faxina

São Carlos

Dezembro 
AUTORIZO A REPRODUÇÃO E DIVULGAÇÃO TOTAL OU PARCIAL DESTE TRABALHO, POR QUALQUER MEIO CONVENCIONAL OU ELETRÔNICO, PARA FINS DE ESTUDO E PESQUISA, DESDE QUE CITADA A FONTE.

Ficha catalográfica preparada pela Seção de Tratamento da Informação do Serviço de Biblioteca - EESC-USP

\begin{tabular}{|c|c|}
\hline \multirow[t]{3}{*}{ D671C } & $\begin{array}{l}\text { Domingos, Matheus David Inocente. } \\
\quad \text { Caracterização do comportamento fluência-recuperação } \\
\text { de ligantes asfálticos modificados virgens e } \\
\text { envelhecidos. / Matheus David Inocente Domingos ; } \\
\text { orientador Adalberto Leandro Faxina. São Carlos, } 2011 .\end{array}$ \\
\hline & $\begin{array}{l}\text { Dissertação - Mestrado (Programa de Pós-Graduação em } \\
\text { Engenharia de Transportes e Área de Concentração em } \\
\text { Infraestrutura de Transportes)-- Escola de Engenharia de } \\
\text { São Carlos da Universidade de São Paulo, } 2011 \text {. }\end{array}$ \\
\hline & $\begin{array}{l}\text { 1. Asfalto. 2. MSCR. 3. Ligantes asfálticos } \\
\text { modificados. 4. Envelhecimento a curto prazo. 5. Ácido } \\
\text { polisfosfórico. 6. Polímeros. 7. Borracha moída. I. } \\
\text { Título. }\end{array}$ \\
\hline
\end{tabular}


FOLHA DE JULGAMENTO

Candidato: Engenheiro MATHEUS DAVID INOCENTE DOMINGOS

Título da dissertação: "Caracterização do comportamento fluência-recuperação de ligantes asfálticos modificados virgens e envelhecidos."

Data da defesa: $13 / 12 / 2011$ :

Comissão Julgadora:

Prof. Dr. Adalberto Leandro Faxina (Orientador)

(Escola de Engenharia de São Carlos/EESC)

Prof. Dr. Glauco Túlio Pessa Fabbri

(Escola de Engenharia de São Carlos/EESC)

$\mathrm{Dr}^{\mathrm{a}}$. Leni Figueiredo Mathias Leite

(Centro de Pesquisas da Petrobrás/CENPES-Rio de Janeiro)
Resultado:

APROVADO

ARRovato

APROVADO

Coordenador do Programa de Pós-Graduação em Engenharia de Transportes e Presidente da Comissão de Pós-Graduação:

Prof. Associado Paulo Cesar Lima Segantine 



\section{DEDICATÓRIA}

Ao meu avô Batista Inocente, in memoriam. 



\section{AGRADECIMENTOS}

A Deus, pela misericórdia, a força espiritual, o conhecimento e a motivação que me tem proporcionado durante todos estes anos.

Ao Prof. Dr. Adalberto Leandro Faxina, pela orientação, incentivo, amizade e, sobretudo, pela confiança em mim depositada ao longo do desenvolvimento da dissertação, sem os quais certamente este trabalho não teria sido concretizado.

Aos meus pais Josué David Domingos e Suzana Inocente Domingos e ao meu irmão Murilo José Inocente Domingos, pelo apoio constante e incentivo.

À Coordenação de Aperfeiçoamento de Pessoal de Nível Superior (CAPES), pela concessão da bolsa de estudos.

À minha namorada e futura esposa Letícia Eliza Vieira e a toda sua família, pelo apoio e incentivo constantes durante a elaboração desta dissertação.

A todos os professores do Departamento de Engenharia de Transportes da EESC-USP, pelas oportunidades, amizades e apoio constantes.

Aos funcionários do Departamento de Engenharia de Transportes da EESC-USP: Heloísa Morgado Belo, Elizabeth Ortega, Sueli L. Chinaglia, Antonia Magaly M. César, Alexandre R. de Oliveira, Paulo e Lílian Rossi, ao técnico em informática Antonio Carlos Mariano, aos técnicos de laboratório Antonio Carlos Gigante, Paulo Toyama e João Pereira Filho e a todos os demais funcionários do Departamento.

Aos colegas de pós-graduação André Anitelli, Andressa Ka Yan Ng, Marcela Navarro Pianucci, Gustavo Henrique Santana Dantas, Diego de Oliveira Martins, David Alex Arancibia Suárez, Marília Gabriela Alencar de Morais, Amanda Oliveira Justino Eler, Antonio Nilson Zamunér Filho, Fernando Hideki Hirose, Karla Cristina Rodrigues Silva, Jemysson Jean de Oliveira, Jorge Tiago Bastos, Cassiano Augusto Isler, Gustavo Riente de Andrade, Joicy Poloni Silva, Rafael Cavalcanti Bizerra, Talita Caetano de Morais, Raul Honorato de Amorim Neto, Lígia Gesteira Coelho e Leandro Nunes Azevedo, pelas coisas boas que compartilharam comigo nestes últimos anos. 



\section{RESUMO}

DOMINGOS, M. D. I. Caracterização do comportamento fluência-recuperação de ligantes asfálticos modificados virgens e envelhecidos. 2011. 300 p. Dissertação (Mestrado) Escola de Engenharia de São Carlos, Universidade de São Paulo, São Carlos, 2011.

O ensaio de fluência e recuperação sob tensão múltipla (MSCR) é resultado do aperfeiçoamento do ensaio de fluência repetida e recuperação (RCRT) pela Administração Rodoviária Federal dos Estados Unidos (FHWA) e tem por objetivo avaliar o percentual de recuperação, a compliância não-recuperável e a dependência dos ligantes asfálticos, especialmente os modificados, quanto ao nível de tensão. O MSCR foi utilizado neste estudo para caracterizar o comportamento fluência-recuperação de diversos ligantes asfálticos modificados virgens e envelhecidos a curto prazo. Foi empregado o procedimento da norma ASTM D7405, que prescreve os tempos de fluência e recuperação de 1 e $9 \mathrm{~s}$, e avaliada a influência do aumento dos tempos de fluência e recuperação de 1 e $9 \mathrm{~s}$ para 2 e $18 \mathrm{~s}$ nas propriedades dos ligantes asfálticos envelhecidos a curto prazo. Além dos resultados destes ensaios, foram utilizados os valores de penetração, ponto de amolecimento, viscosidade rotacional, penetração retida, incremento do ponto de amolecimento, incremento de viscosidade e perda de massa para verificar quais ligantes asfálticos apresentam melhor comportamento à luz das propriedades e parâmetros considerados. Foram preparados doze materiais modificados e de classificação PG 76-XX tendo como base um CAP 50/70 de classificação PG 64-XX: $\mathrm{CAP}+\mathrm{PPA}, \quad \mathrm{CAP}+\mathrm{Elvaloy}+\mathrm{PPA}, \mathrm{CAP}+$ borracha, $\mathrm{CAP}+$ borracha+PPA, $\mathrm{CAP}+\mathrm{SBS}$, $\mathrm{CAP}+\mathrm{SBS}+\mathrm{PPA}, \quad \mathrm{CAP}+\mathrm{EVA}, \mathrm{CAP}+\mathrm{EVA}+\mathrm{PPA}, \mathrm{CAP}+\mathrm{PE}, \mathrm{CAP}+\mathrm{PE}+\mathrm{PPA}, \mathrm{CAP}+\mathrm{SBR}$ e $\mathrm{CAP}+\mathrm{SBR}+\mathrm{PPA}$. O CAP+Elvaloy+PPA apresenta, em um contexto geral, o melhor desempenho nas propriedades e parâmetros analisados em virtude dos bons resultados do percentual de recuperação e da compliância não-recuperável e das menores sensibilidades à tensão. $O$ $\mathrm{CAP}+\mathrm{PE}$ apresenta o pior desempenho geral dentre os materiais estudados, na medida em que os resultados do percentual de recuperação e da compliância não-recuperável deste ligante asfáltico são ruins e as sensibilidades ao aumento nos tempos de fluência e recuperação de 1 e $9 \mathrm{~s}$ para 2 e $18 \mathrm{~s}$ são elevadas. Ao ordenar os ligantes asfálticos do melhor para o pior à luz das propriedades e parâmetros considerados, o resultado é: CAP+Elvaloy+PPA, CAP+EVA, $\mathrm{CAP}+\mathrm{EVA}+\mathrm{PPA}, \quad \mathrm{CAP}+\mathrm{PPA}, \mathrm{CAP}+$ borracha+PPA$, \mathrm{CAP}+\mathrm{SBR}+\mathrm{PPA}, \mathrm{CAP}+\mathrm{SBS}+\mathrm{PPA}$, $\mathrm{CAP}+\mathrm{SBS}, \mathrm{CAP}+\mathrm{PE}+\mathrm{PPA}, \mathrm{CAP}+$ borracha, $\mathrm{CAP}+\mathrm{SBR}, \mathrm{CAP}$ 50/70 e CAP+PE.

Palavras-chave: MSCR, ligantes asfálticos modificados, envelhecimento a curto prazo, ácido polisfosfórico, polímeros, borracha moída. 

DOMINGOS, M. D. I. Characterization of the creep-recovery behavior of unaged and short-term aged modified asphalt binders. Dissertation (Masters) - Escola de Engenharia de São Carlos, Universidade de São Paulo, São Carlos, 2011.

The multiple stress creep and recovery (MSCR) test is the result of a refinement of the repeated creep and recovery test (RCRT). This refinement was performed by the United States Federal Highway Administration (FHWA) with the aim of evaluating the percent recovery, the non-recoverable compliance and the stress dependency of asphalt binders, especially the modified ones. The MSCR test was applied in this study in order to characterize the creep-recovery behavior of unaged and short-term aged modified asphalt binders. The test procedure prescribed in ASTM D7405 specification was adopted and, to evaluate the influence of a greater creep-recovery time in the behavior of asphalt binders, the creep and recovery times of 2 and $18 \mathrm{~s}$ were also adopted in additional tests. The results of these tests, as well as the penetration, softening point, rotational viscosity, retained penetration, softening point increase, viscosity increase and mass loss data and mixing and compaction temperatures, were used with the objectives of ranking the asphalt binders and checking the ones with the best results in the parameters and properties considered. By using a PG $64-X X$ base asphalt-binder of $50 / 70$ penetration grade, the following PG $76-X X$ modified asphalt binders were prepared: $A C+P P A, A C+E l v a l o y+P P A, A C+c r u m b$ rubber, $A C+$ crumb rubber+PPA, AC+SBS, AC+SBS+PPA, AC+EVA, AC+EVA+PPA, AC+PE, $A C+P E+P P A, A C+S B R$ and $A C+S B R+P P A$. In general, $A C+E l v a l o y+P P A$ has the best results in the parameters and properties considered in this study, especially due to the good results in the percent recovery and non-recoverable compliance and the lower stress sensitivity. In general, AC+PE has the worst results among the asphalt binders considered in this work, due to the facts that the percent recovery and non-recoverable compliance results are not good and the sensitivities to the creep-recovery times are high. By taking the results of this study and ranking the asphalt binders from the best to the worst, the following sequence is obtained: $A C+E l v a l o y+P P A, A C+E V A, A C+E V A+P P A, A C+P P A, A C+c r u m b$

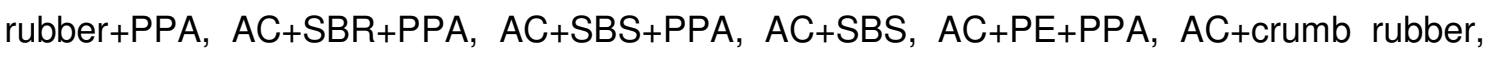
$A C+S B R$, neat $A C$ and $A C+P E$.

Keywords: MSCR, modified asphalt binders, short-term aging, polyphosphoric acid, polymers, crumb rubber. 



\section{LISTA DE TABELAS}

Tabela 1 - Classificação dos ligantes asfálticos quanto ao valor de $\mathrm{J}_{\mathrm{nr}}$ de acordo com o critério proposto pelo FHWA [Tabela 3 da norma AASHTO M320]

Tabela 2 - Valores recomendados para o percentual de recuperação de acordo com o critério proposto pelo FHWA [D’Angelo (2010a)]

Tabela 3 - Pontos de amolecimento dos ligantes asfálticos modificados com Elvaloy antes e após períodos de cura de 24 e 48 h [Adaptado de Polacco et al. (2004)]

Tabela 4 - Formulações dos ligantes asfálticos, classificações PG e perdas de massa

Tabela 5 - Variáveis de processamento dos ligantes asfálticos

Tabela 6 - Dados do ensaio de viscosidade rotacional

Tabela 7 - Variabilidades máximas permitidas para a compliância não-recuperável em ensaios realizados pelo mesmo operador [ASTM D7405]

Tabela 8 - Valores de penetração (PEN) e graus de modificação dos ligantes asfálticos virgens e envelhecidos a curto prazo

Tabela 9 - Pontos de amolecimento (PA) e graus de modificação dos ligantes asfálticos virgens e envelhecidos a curto prazo

Tabela 10 - Temperaturas de usinagem e de compactação dos ligantes asfálticos de acordo com o critério tradicional

Tabela 11 - Estruturação dos grupos de ligantes asfálticos

Tabela 12 - Percentuais de recuperação (R) do CAP 50/70, do CAP+PPA e do CAP+Elvaloy+PPA nos tempos de 1 e $9 \mathrm{~s}$ e na condição virgem

Tabela 13 - Compliâncias não-recuperáveis $\left(\mathrm{J}_{n r}\right)$ do CAP 50/70, do CAP+PPA e do $\mathrm{CAP}+$ Elvaloy+PPA nos tempos de 1 e $9 \mathrm{~s}$ e na condição virgem

Tabela 14 - Percentuais de recuperação (R) do CAP 50/70, do CAP+PPA e do CAP+Elvaloy+PPA nos tempos de 1 e 9 s e na condição envelhecida

Tabela 15 - Compliâncias não-recuperáveis $\left(\mathrm{J}_{\text {nr }}\right)$ do CAP 50/70, do CAP+PPA e do $\mathrm{CAP}+$ Elvaloy+PPA nos tempos de 1 e 9 s e na condição envelhecida

Tabela 16 - Relações entre as compliâncias não-recuperáveis $\left(R_{J}\right)$ do CAP 50/70, do $\mathrm{CAP}+\mathrm{PPA}$ e do CAP+Elvaloy+PPA nos tempos de 1 e $9 \mathrm{~s}$ 
Tabela 17 - Relações entre os percentuais de recuperação $\left(R_{R}\right)$ do CAP 50/70, do $\mathrm{CAP}+\mathrm{PPA}$ e do CAP+Elvaloy+PPA nos tempos de 1 e $9 \mathrm{~s}$

Tabela 18 - Diferenças percentuais entre as compliâncias não-recuperáveis $\left(J_{\text {nr,diff }}\right)$ do CAP 50/70, do CAP+PPA e do CAP+Elvaloy+PPA nos tempos de 1 e $9 \mathrm{~s}$

Tabela 19 - Percentuais de recuperação (R) do CAP 50/70, do CAP+PPA, do CAP+borracha e do CAP+borracha+PPA nos tempos de 1 e $9 \mathrm{~s}$ e na condição virgem

Tabela 20 - Compliâncias não-recuperáveis $\left(\mathrm{J}_{\mathrm{nr}}\right)$ do CAP 50/70, do CAP+PPA, do CAP+borracha e do CAP+borracha+PPA nos tempos de 1 e $9 \mathrm{~s}$ e na condição virgem

Tabela 21 - Percentuais de recuperação $(R)$ do CAP 50/70, do CAP+PPA, do CAP+borracha e do CAP+borracha+PPA nos tempos de 1 e $9 \mathrm{~s}$ e na condição envelhecida

Tabela 22 - Compliâncias não-recuperáveis $\left(\mathrm{J}_{\mathrm{nr}}\right)$ do CAP 50/70, do CAP+PPA, do CAP+borracha e do CAP+borracha+PPA nos tempos de 1 e 9 s e na condição envelhecida

Tabela 23 - Relações entre as compliâncias não-recuperáveis $\left(R_{J}\right)$ do CAP 50/70, do $\mathrm{CAP}+\mathrm{PPA}$, do CAP+borracha e do CAP+borracha+PPA nos tempos de 1 e $9 \mathrm{~s}$

Tabela 24 - Relações entre os percentuais de recuperação $\left(R_{R}\right)$ do CAP 50/70, do CAP+PPA, do CAP+borracha e do CAP+borracha+PPA nos tempos de 1 e $9 \mathrm{~s}$

Tabela 25- Diferenças percentuais entre as compliâncias não-recuperáveis $\left(\mathrm{J}_{\text {nr,diff }}\right)$ do CAP 50/70, do CAP+PPA, do CAP+borracha e do CAP+borracha+PPA nos tempos de 1 e $9 \mathrm{~s}$

Tabela 26 - Percentuais de recuperação (R) do CAP 50/70, do CAP+PPA, do $\mathrm{CAP}+\mathrm{SBS}$ e do CAP+SBS+PPA nos tempos de 1 e $9 \mathrm{~s}$ e na condição virgem

Tabela 27 - Compliâncias não-recuperáveis $\left(\mathrm{J}_{n r}\right)$ do CAP 50/70, do CAP+PPA, do $\mathrm{CAP}+\mathrm{SBS}$ e do $\mathrm{CAP}+\mathrm{SBS}+\mathrm{PPA}$ nos tempos de 1 e $9 \mathrm{~s}$ e na condição virgem

Tabela 28 - Percentuais de recuperação $(R)$ do CAP 50/70, do CAP+PPA, do $\mathrm{CAP}+\mathrm{SBS}$ e do $\mathrm{CAP}+\mathrm{SBS}+\mathrm{PPA}$ nos tempos de 1 e $9 \mathrm{~s}$ e na condição envelhecida

Tabela 29 - Compliâncias não-recuperáveis $\left(\mathrm{J}_{\text {nr }}\right)$ do CAP 50/70, do CAP+PPA, do $\mathrm{CAP}+\mathrm{SBS}$ e do CAP+SBS+PPA nos tempos de 1 e $9 \mathrm{~s}$ e na condição envelhecida 
Tabela 30 - Relações entre as compliâncias não-recuperáveis $\left(R_{J}\right)$ do CAP 50/70, do $\mathrm{CAP}+\mathrm{PPA}$, do $\mathrm{CAP}+\mathrm{SBS}$ e do CAP+SBS+PPA nos tempos de 1 e $9 \mathrm{~s}$

Tabela 31 - Relações entre os percentuais de recuperação $\left(R_{R}\right)$ do CAP 50/70, do $\mathrm{CAP}+\mathrm{PPA}$, do CAP+SBS e do CAP+SBS+PPA nos tempos de 1 e $9 \mathrm{~s}$

Tabela 32 - Diferenças percentuais entre as compliâncias não-recuperáveis $\left(J_{n r, \text { diff }}\right)$ do CAP 50/70, do CAP+PPA, do CAP+SBS e do CAP+SBS+PPA nos tempos de 1 e $9 \mathrm{~s}$

Tabela 33 - Percentuais de recuperação $(R)$ do CAP 50/70, do CAP+PPA, do CAP+EVA e do CAP+EVA+PPA nos tempos de 1 e $9 \mathrm{~s}$ e na condição virgem

Tabela 34 - Compliâncias não-recuperáveis $\left(\mathrm{J}_{\text {nr }}\right)$ do CAP 50/70, do CAP+PPA, do CAP+EVA e do CAP+EVA+PPA nos tempos de 1 e $9 \mathrm{~s}$ e na condição virgem

Tabela 35 - Percentuais de recuperação (R) do CAP 50/70, do CAP+PPA, do $\mathrm{CAP}+\mathrm{EVA}$ e do CAP+EVA+PPA nos tempos de 1 e $9 \mathrm{~s}$ e na condição envelhecida

Tabela 36 - Compliâncias não-recuperáveis $\left(\mathrm{J}_{\mathrm{nr}}\right)$ do CAP 50/70, do CAP+PPA, do CAP+EVA e do CAP+EVA+PPA nos tempos de 1 e $9 \mathrm{~s}$ e na condição envelhecida

Tabela 37 - Relações entre as compliâncias não-recuperáveis $\left(R_{J}\right)$ do CAP 50/70, do $\mathrm{CAP}+\mathrm{PPA}$, do CAP+EVA e do CAP+EVA+PPA nos tempos de 1 e $9 \mathrm{~s}$

Tabela 38 - Relações entre os percentuais de recuperação $\left(R_{R}\right)$ do CAP 50/70, do $\mathrm{CAP}+\mathrm{PPA}$, do CAP+EVA e do CAP+EVA+PPA nos tempos de 1 e $9 \mathrm{~s}$

Tabela 39- Diferenças percentuais entre as compliâncias não-recuperáveis $\left(J_{\text {nr, diff }}\right)$ do CAP 50/70, do CAP+PPA, do CAP+EVA e do CAP+EVA+PPA nos tempos de 1 e $9 \mathrm{~s}$

Tabela 40 - Percentuais de recuperação $(R)$ do CAP 50/70, do CAP+PPA, do CAP+PE e do $\mathrm{CAP}+\mathrm{PE}+\mathrm{PPA}$ nos tempos de 1 e 9 s e na condição virgem

Tabela 41 - Compliâncias não-recuperáveis $\left(\mathrm{J}_{\text {nr }}\right)$ do CAP 50/70, do CAP+PPA, do $\mathrm{CAP}+\mathrm{PE}$ e do CAP+PE+PPA nos tempos de 1 e $9 \mathrm{~s}$ e na condição virgem

Tabela 42 - Percentuais de recuperação $(R)$ do CAP 50/70, do CAP+PPA, do CAP+PE e do $C A P+P E+P P A$ nos tempos de 1 e 9 s e na condição envelhecida

Tabela 43 - Compliâncias não-recuperáveis $\left(J_{\text {nr }}\right)$ do CAP 50/70, do CAP+PPA, do $\mathrm{CAP}+\mathrm{PE}$ e do CAP+PE+PPA nos tempos de 1 e $9 \mathrm{~s}$ e na condição envelhecida 
Tabela 44 - Relações entre as compliâncias não-recuperáveis $\left(R_{J}\right)$ do CAP 50/70, do $\mathrm{CAP}+\mathrm{PPA}$, do $\mathrm{CAP}+\mathrm{PE}$ e do $\mathrm{CAP}+\mathrm{PE}+\mathrm{PPA}$ nos tempos de 1 e $9 \mathrm{~s}$

Tabela 45 - Relações entre os percentuais de recuperação $\left(R_{R}\right)$ do CAP 50/70, do CAP+PPA, do CAP+PE e do CAP+PE+PPA nos tempos de 1 e $9 \mathrm{~s}$

Tabela 46- Diferenças percentuais entre as compliâncias não-recuperáveis $\left(\mathrm{J}_{\text {nr,diff }}\right)$ do CAP 50/70, do CAP+PPA, do CAP+PE e do CAP+PE+PPA nos tempos de 1 e $9 \mathrm{~s}$

Tabela 47- Percentuais de recuperação (R) do CAP 50/70, do CAP+PPA, do $\mathrm{CAP}+\mathrm{SBR}$ e do CAP+SBR+PPA nos tempos de 1 e $9 \mathrm{~s}$ e na condição virgem

Tabela 48 - Compliâncias não-recuperáveis $\left(\mathrm{J}_{\text {nr }}\right)$ do CAP 50/70, do CAP+PPA, do $\mathrm{CAP}+\mathrm{SBR}$ e do $\mathrm{CAP}+\mathrm{SBR}+\mathrm{PPA}$ nos tempos de 1 e $9 \mathrm{~s}$ e na condição virgem

Tabela 49 - Percentuais de recuperação (R) do CAP 50/70, do CAP+PPA, do $\mathrm{CAP}+\mathrm{SBR}$ e do $\mathrm{CAP}+\mathrm{SBR}+\mathrm{PPA}$ nos tempos de 1 e $9 \mathrm{~s}$ e na condição envelhecida

Tabela 50 - Compliâncias não-recuperáveis $\left(\mathrm{J}_{\mathrm{nr}}\right)$ do CAP 50/70, do CAP+PPA, do $\mathrm{CAP}+\mathrm{SBR}$ e do $\mathrm{CAP}+\mathrm{SBR}+\mathrm{PPA}$ nos tempos de 1 e $9 \mathrm{~s}$ e na condição envelhecida

Tabela 51 - Relações entre as compliâncias não-recuperáveis $\left(R_{J}\right)$ do CAP 50/70, do $\mathrm{CAP}+\mathrm{PPA}$, do $\mathrm{CAP}+\mathrm{SBR}$ e do $\mathrm{CAP}+\mathrm{SBR}+\mathrm{PPA}$ nos tempos de 1 e $9 \mathrm{~s}$

Tabela 52 - Relações entre os percentuais de recuperação $\left(R_{R}\right)$ do CAP 50/70, do $\mathrm{CAP}+\mathrm{PPA}$, do $\mathrm{CAP}+\mathrm{SBR}$ e do $\mathrm{CAP}+\mathrm{SBR}+\mathrm{PPA}$ nos tempos de 1 e $9 \mathrm{~s}$

Tabela 53- Diferenças percentuais entre as compliâncias não-recuperáveis $\left(\mathrm{J}_{\mathrm{nr}, \text { diff }}\right)$ do CAP 50/70, do CAP+PPA, do CAP+SBR e do $\mathrm{CAP}+\mathrm{SBR}+\mathrm{PPA}$ nos tempos de 1 e $9 \mathrm{~s}$

Tabela 54 - Percentuais de recuperação (R) do CAP 50/70, do CAP+PPA e do CAP+Elvaloy+PPA nos tempos de 2 e $18 \mathrm{~s}$ e na condição envelhecida

Tabela 55 - Compliâncias não-recuperáveis $\left(\mathrm{J}_{\mathrm{nr}}\right)$ do CAP 50/70, do CAP+PPA e do CAP+Elvaloy+PPA nos tempos de 2 e 18 s e na condição envelhecida

Tabela 56- Diferenças percentuais entre as compliâncias não-recuperáveis $\left(\mathrm{J}_{\text {nr, diff }}\right)$ do CAP 50/70, do CAP+PPA e do CAP+Elvaloy+PPA nos tempos de 2 e $18 \mathrm{~s}$

Tabela 57 - Percentuais de recuperação (R) do CAP 50/70, do CAP+PPA, do CAP+borracha e do CAP+borracha+PPA nos tempos de 2 e $18 \mathrm{~s}$ e na condição envelhecida 
Tabela 58 - Compliâncias não-recuperáveis $\left(J_{n r}\right)$ do CAP 50/70, do CAP+PPA, do CAP+borracha e do CAP+borracha+PPA nos tempos de 2 e $18 \mathrm{~s}$ e na condição envelhecida

Tabela 59 - Diferenças percentuais entre as compliâncias não-recuperáveis $\left(\mathrm{J}_{\text {nr,diff }}\right)$ do CAP 50/70, do CAP+PPA, do CAP+borracha e do CAP+borracha+PPA nos tempos de 2 e $18 \mathrm{~s}$

Tabela 60 - Percentuais de recuperação $(R)$ do CAP 50/70, do CAP+PPA, do $\mathrm{CAP}+\mathrm{SBS}$ e do CAP+SBS+PPA nos tempos de 2 e $18 \mathrm{~s}$ e na condição envelhecida

Tabela 61 - Compliâncias não-recuperáveis $\left(\mathrm{J}_{\mathrm{nr}}\right)$ do CAP 50/70, do CAP+PPA, do $\mathrm{CAP}+\mathrm{SBS}$ e do $\mathrm{CAP}+\mathrm{SBS}+\mathrm{PPA}$ nos tempos de 2 e $18 \mathrm{~s}$ e na condição envelhecida

Tabela 62- Diferenças percentuais entre as compliâncias não-recuperáveis $\left(J_{\text {nr,diff }}\right)$ do CAP 50/70, do CAP+PPA, do CAP+SBS e do CAP+SBS+PPA nos tempos de 2 e $18 \mathrm{~s}$

Tabela 63 - Percentuais de recuperação (R) do CAP 50/70, do CAP+PPA, do $\mathrm{CAP}+\mathrm{EVA}$ e do CAP+EVA+PPA nos tempos de 2 e $18 \mathrm{~s}$ e na condição envelhecida

Tabela 64 - Compliâncias não-recuperáveis $\left(\mathrm{J}_{\text {nr }}\right)$ do CAP 50/70, do CAP+PPA, do CAP+EVA e do CAP+EVA+PPA nos tempos de 2 e $18 \mathrm{~s}$ e na condição envelhecida

Tabela 65- Diferenças percentuais entre as compliâncias não-recuperáveis $\left(J_{\text {nr, diff }}\right)$ do CAP 50/70, do CAP+PPA, do CAP+EVA e do CAP+EVA+PPA nos tempos de 2 e $18 \mathrm{~s}$

Tabela 66 - Percentuais de recuperação $(R)$ do CAP 50/70, do CAP+PPA, do CAP+PE e do CAP+PE+PPA nos tempos de 2 e $18 \mathrm{~s}$ e na condição envelhecida

Tabela 67 - Compliâncias não-recuperáveis $\left(\mathrm{J}_{\text {nr }}\right)$ do CAP 50/70, do CAP+PPA, do $\mathrm{CAP}+\mathrm{PE}$ e do $\mathrm{CAP}+\mathrm{PE}+\mathrm{PPA}$ nos tempos de 2 e $18 \mathrm{~s}$ e na condição envelhecida

Tabela 68- Diferenças percentuais entre as compliâncias não-recuperáveis $\left(J_{n r, \text { diff }}\right)$ do CAP 50/70, do CAP+PPA, do CAP+PE e do CAP+PE+PPA nos tempos de 2 e $18 \mathrm{~s}$

Tabela 69 - Percentuais de recuperação (R) do CAP 50/70, do CAP+PPA, do $\mathrm{CAP}+\mathrm{SBR}$ e do CAP+SBR+PPA nos tempos de 2 e $18 \mathrm{~s}$ e na condição envelhecida

Tabela 70 - Compliâncias não-recuperáveis $\left(\mathrm{J}_{\text {nr }}\right)$ do CAP 50/70, do CAP+PPA, do $\mathrm{CAP}+\mathrm{SBR}$ e do CAP+SBR+PPA nos tempos de 2 e $18 \mathrm{~s}$ e na condição envelhecida 
Tabela 71 - Diferenças percentuais entre as compliâncias não-recuperáveis $\left(J_{\text {nr,diff }}\right)$ do CAP 50/70, do CAP+PPA, do CAP+SBR e do CAP+SBR+PPA nos tempos de 2 e $18 \mathrm{~s}$

Tabela 72 - Relações entre os percentuais de recuperação $\left(R_{P}\right)$ nos tempos de 1 e 9 $\mathrm{s}$ e nos tempos de 2 e $18 \mathrm{~s}$ para os ligantes asfálticos na condição envelhecida

Tabela 73 - Relações entre as compliâncias não-recuperáveis $\left(R_{C}\right)$ nos tempos de 2 e $18 \mathrm{~s}$ e nos tempos de 1 e $9 \mathrm{~s}$ para os ligantes asfálticos na condição envelhecida

Tabela 74 - Percentuais de recuperação normalizados $\left(N_{R}\right)$ dos ligantes asfálticos virgens em relação ao CAP 50/70 e nos tempos de 1 e $9 \mathrm{~s}$

Tabela 75 - Compliâncias não-recuperáveis normalizadas $\left(\mathrm{N}_{\mathrm{C}}\right)$ dos ligantes asfálticos virgens em relação ao CAP 50/70 e nos tempos de 1 e 9 s

Tabela 76 - Percentuais de recuperação normalizados $\left(N_{R}\right)$ dos ligantes asfálticos virgens em relação ao CAP+PPA e nos tempos de 1 e $9 \mathrm{~s}$

Tabela 77 - Compliâncias não-recuperáveis normalizadas $\left(\mathrm{N}_{\mathrm{C}}\right)$ dos ligantes asfálticos virgens em relação ao CAP+PPA e nos tempos de 1 e $9 \mathrm{~s}$

Tabela 78 - Percentuais de recuperação normalizados $\left(N_{R}\right)$ dos ligantes asfálticos envelhecidos em relação ao CAP 50/70 e nos tempos de 1 e $9 \mathrm{~s}$

Tabela 79 - Compliâncias não-recuperáveis normalizadas $\left(\mathrm{N}_{\mathrm{C}}\right)$ dos ligantes asfálticos envelhecidos em relação ao CAP 50/70 e nos tempos de 1 e $9 \mathrm{~s}$

Tabela 80 - Percentuais de recuperação normalizados $\left(N_{R}\right)$ dos ligantes asfálticos envelhecidos em relação ao CAP+PPA e nos tempos de 1 e $9 \mathrm{~s}$

Tabela 81 - Compliâncias não-recuperáveis normalizadas $\left(\mathrm{N}_{\mathrm{C}}\right)$ dos ligantes asfálticos envelhecidos em relação ao CAP+PPA e nos tempos de 1 e $9 \mathrm{~s}$

Tabela 82 - Percentuais de recuperação normalizados $\left(N_{R}\right)$ dos ligantes asfálticos envelhecidos em relação ao CAP 50/70 e nos tempos de 2 e $18 \mathrm{~s}$

Tabela 83 - Compliâncias não-recuperáveis normalizadas $\left(\mathrm{N}_{\mathrm{C}}\right)$ dos ligantes asfálticos envelhecidos em relação ao CAP 50/70 e nos tempos de 2 e $18 \mathrm{~s}$

Tabela 84 - Percentuais de recuperação normalizados $\left(N_{R}\right)$ dos ligantes asfálticos envelhecidos em relação ao CAP+PPA e nos tempos de 2 e $18 \mathrm{~s}$

Tabela 85 - Compliâncias não-recuperáveis normalizadas $\left(\mathrm{N}_{\mathrm{C}}\right)$ dos ligantes asfálticos envelhecidos em relação ao CAP+PPA e nos tempos de 2 e $18 \mathrm{~s}$ 
Tabela 86 - Propriedades dos ligantes asfálticos envelhecidos a curto prazo na temperatura do PG, no nível de tensão de 3.200 Pa e nos tempos de 1 e $9 \mathrm{~s}$

Tabela 87 - Propriedades dos ligantes asfálticos envelhecidos a curto prazo na temperatura do PG, no nível de tensão de 3.200 Pa e nos tempos de 2 e $18 \mathrm{~s}$

Tabela 88 - Classificação dos ligantes asfálticos segundo o critério de tráfego do FHWA nos tempos de 1 e $9 \mathrm{~s}$

Tabela 89 - Ordenações dos ligantes asfálticos em todas as propriedades e parâmetros 248

Tabela 90 - Posições médias dos ligantes asfálticos por requisitos de interesse 



\section{LISTA DE FIGURAS}

Figura 1 - Deformações acumuladas a $6.400 \mathrm{~Pa}$ e $46^{\circ} \mathrm{C}$ para um ligante asfáltico modificado com SBS e PG 70-28 [Adaptado de Delgadillo et al. (2006)] _

Figura 2 - Representação das tensões e deformações durante a realização do ensaio MSCR [Adaptado de D’Angelo e Dongré (2009)]

Figura 3- Localização das deformações $\varepsilon_{0}$, $\varepsilon_{c}$ e $\varepsilon_{r}$ em um ciclo de fluência e recuperação do ensaio MSCR

Figura 4- Relação entre as compliâncias não-recuperáveis e os percentuais de recuperação a 3.200 Pa [Adaptado de Anderson (2010)]

Figura 5 - Representação esquemática de moléculas de SBS envolvidas por um ligante asfáltico de base [Adaptado de Shell (2003) apud Bernucci et al. (2006)]

Figura 6 - Estrutura química básica do copolímero SBR [Adaptado de Rajpal (2005)]

Figura 7 - Esquema de produção do asfalto-borracha, via processo úmido, pelo método de mistura estocável ou "terminal-blending" [Bernucci et al. (2006)]

Figura 8- Representação da estrutura química básica do copolímero EVA [Adaptado de Bernucci et al. (2006)] 70

Figura 9 - Mecanismo proposto de reação química entre um polímero etileno-glicidilacrilato e uma molécula de asfalteno [Adaptado de DuPont Website (2008b)]

Figura 10 - Penetrações retidas dos ligantes asfálticos 93

Figura 11 - Incrementos nos pontos de amolecimento (PA) dos ligantes asfálticos _ 97

Figura 12 - Viscosidades rotacionais a $135^{\circ} \mathrm{C}$ para os ligantes asfálticos virgens 98

Figura 13 - Viscosidades rotacionais a $143^{\circ} \mathrm{C}$ para os ligantes asfálticos virgens 99

Figura $14-$ Viscosidades rotacionais a $150^{\circ} \mathrm{C}$ para os ligantes asfálticos virgens 100

Figura 15 - Viscosidades rotacionais a $163^{\circ} \mathrm{C}$ para os ligantes asfálticos virgens 101

Figura 16 - Viscosidades rotacionais a $177^{\circ} \mathrm{C}$ para os ligantes asfálticos virgens 102

Figura 17 - Viscosidades rotacionais a $135^{\circ} \mathrm{C}$ para os ligantes asfálticos envelhecidos a curto prazo 
Figura 18 - Viscosidades rotacionais a $143^{\circ} \mathrm{C}$ para os ligantes asfálticos envelhecidos a curto prazo

Figura 19 - Viscosidades rotacionais a $150^{\circ} \mathrm{C}$ para os ligantes asfálticos envelhecidos a curto prazo

Figura 20 - Viscosidades rotacionais a $163^{\circ} \mathrm{C}$ para os ligantes asfálticos envelhecidos a curto prazo

Figura 21 - Viscosidades rotacionais a $177^{\circ} \mathrm{C}$ para os ligantes asfálticos envelhecidos a curto prazo

Figura 22 - Relações entre as viscosidades rotacionais virgens e envelhecidas dos ligantes asfálticos $\left(R_{V}\right)$ na temperatura de $135^{\circ} \mathrm{C}$

Figura 23 - Relações entre as viscosidades rotacionais virgens e envelhecidas dos ligantes asfálticos $\left(R_{V}\right)$ na temperatura de $143^{\circ} \mathrm{C}$

Figura 24 - Relações entre as viscosidades rotacionais virgens e envelhecidas dos ligantes asfálticos $\left(R_{\mathrm{V}}\right)$ na temperatura de $150^{\circ} \mathrm{C}$

Figura 25 - Relações entre as viscosidades rotacionais virgens e envelhecidas dos ligantes asfálticos $\left(R_{v}\right)$ na temperatura de $163^{\circ} \mathrm{C}$

Figura 26 - Relações entre as viscosidades rotacionais virgens e envelhecidas dos ligantes asfálticos $\left(R_{\mathrm{V}}\right)$ na temperatura de $177^{\circ} \mathrm{C}$

Figura 27 - Percentuais de recuperação (R) do CAP 50/70, do CAP+PPA e do CAP+Elvaloy+PPA na condição virgem e nos tempos de 1 e $9 \mathrm{~s}$

Figura 28 - Compliâncias não-recuperáveis $\left(\mathrm{J}_{\mathrm{nr}}\right)$ do CAP 50/70, do CAP+PPA e do CAP+Elvaloy+PPA na condição virgem e nos tempos de 1 e $9 \mathrm{~s}$

Figura 29 - Compliâncias não-recuperáveis $\left(\mathrm{J}_{\mathrm{nr}}\right)$ do CAP+PPA e do $\mathrm{CAP}+$ Elvaloy+PPA na condição virgem e nos tempos de 1 e $9 \mathrm{~s}$

Figura 30 - Percentuais de recuperação (R) do CAP 50/70, do CAP+PPA e do CAP+Elvaloy+PPA na condição envelhecida e nos tempos de 1 e $9 \mathrm{~s}$

Figura 31 - Compliâncias não-recuperáveis $\left(J_{n r}\right)$ do CAP+PPA e do CAP+Elvaloy+PPA na condição envelhecida e nos tempos de 1 e $9 \mathrm{~s}$

Figura 32 - Relações entre as compliâncias não-recuperáveis $\left(R_{J}\right)$ do CAP 50/70, do $\mathrm{CAP}+\mathrm{PPA}$ e do CAP+Elvaloy+PPA nos tempos de 1 e $9 \mathrm{~s}$

Figura 33 - Relações entre os percentuais de recuperação $\left(R_{R}\right)$ do CAP 50/70, do $\mathrm{CAP}+\mathrm{PPA}$ e do CAP+Elvaloy+PPA nos tempos de 1 e $9 \mathrm{~s}$ 
Figura 34 - Diferenças percentuais entre as compliâncias não-recuperáveis $\left(\mathrm{J}_{\text {nr,diff }}\right)$ do CAP 50/70, do CAP+PPA e do CAP+Elvaloy+PPA nos tempos de 1 e $9 \mathrm{~s}$

Figura 35 - Percentuais de recuperação (R) do CAP 50/70, do CAP+PPA, do CAP+borracha e do CAP+borracha+PPA na condição virgem e nos tempos de 1 e $9 \mathrm{~s}$

Figura 36 - Compliâncias não-recuperáveis $\left(\mathrm{J}_{\text {nr }}\right)$ do CAP 50/70, do CAP+PPA, do CAP+borracha e do CAP+borracha+PPA na condição virgem e nos tempos de 1 e $9 \mathrm{~s}$

Figura 37 - Percentuais de recuperação (R) do CAP 50/70, do CAP+PPA, do CAP+borracha e do CAP+borracha+PPA na condição envelhecida e nos tempos de 1 e $9 \mathrm{~s}$

Figura 38 - Compliâncias não-recuperáveis $\left(\mathrm{J}_{n r}\right)$ do CAP+PPA, do CAP+borracha e do CAP+borracha+PPA na condição envelhecida e nos tempos de 1 e $9 \mathrm{~s}$

Figura 39 - Relações entre as compliâncias não-recuperáveis $\left(R_{J}\right)$ do CAP 50/70, do CAP+PPA, do CAP+borracha e do CAP+borracha+PPA nos tempos de 1 e $9 \mathrm{~s}$

Figura 40 - Relações entre os percentuais de recuperação $\left(R_{R}\right)$ CAP 50/70, do CAP+PPA, do CAP+borracha e do CAP+borracha+PPA nos tempos de 1 e $9 \mathrm{~s}$

Figura 41 - Diferenças percentuais entre as compliâncias não-recuperáveis $\left(J_{n r, d i f f}\right)$ do CAP 50/70, do CAP+PPA, do CAP+borracha e do CAP+borracha+PPA nos tempos de 1 e $9 \mathrm{~s}$

Figura 42 - Percentuais de recuperação $(R)$ do CAP 50/70, do CAP+PPA, do CAP+SBS e do $C A P+S B S+P P A$ na condição virgem e nos tempos de 1 e $9 \mathrm{~s}$

Figura 43 - Compliâncias não-recuperáveis $\left(J_{\text {nr }}\right)$ do CAP+PPA, do CAP+SBS e do $\mathrm{CAP}+\mathrm{SBS}+\mathrm{PPA}$ na condição virgem e nos tempos de 1 e $9 \mathrm{~s}$

Figura 44- Percentuais de recuperação (R) do CAP 50/70, do CAP+PPA, do $\mathrm{CAP}+\mathrm{SBS}$ e do $\mathrm{CAP}+\mathrm{SBS}+\mathrm{PPA}$ na condição envelhecida e nos tempos de 1 e $9 \mathrm{~s}$

Figura 45 - Compliâncias não-recuperáveis $\left(J_{n r}\right)$ do CAP+PPA, do CAP+SBS e do $\mathrm{CAP}+\mathrm{SBS}+\mathrm{PPA}$ na condição envelhecida e nos tempos de 1 e $9 \mathrm{~s}$

Figura 46 - Relações entre as compliâncias não-recuperáveis $\left(R_{J}\right)$ do CAP 50/70, do $\mathrm{CAP}+\mathrm{PPA}$, do $\mathrm{CAP}+\mathrm{SBS}$ e do $\mathrm{CAP}+\mathrm{SBS}+\mathrm{PPA}$ nos tempos de 1 e $9 \mathrm{~s}$

Figura 47 - Relações entre os percentuais de recuperação $\left(R_{R}\right)$ do CAP 50/70, do $\mathrm{CAP}+\mathrm{PPA}$, do $\mathrm{CAP}+\mathrm{SBS}$ e do $\mathrm{CAP}+\mathrm{SBS}+\mathrm{PPA}$ nos tempos de 1 e $9 \mathrm{~s}$ 
Figura 48 - Diferenças percentuais entre as compliâncias não-recuperáveis $\left(J_{n r, d i f f}\right)$ do CAP 50/70, do CAP+PPA, do CAP+SBS e do CAP+SBS+PPA nos tempos de 1 e $9 \mathrm{~s}$

Figura 49 - Percentuais de recuperação $(R)$ do CAP 50/70, do CAP+PPA, do CAP+EVA e do CAP+EVA+PPA na condição virgem e nos tempos de 1 e $9 \mathrm{~s}$

Figura 50 - Compliâncias não-recuperáveis $\left(J_{n r}\right)$ do CAP+PPA, do CAP+EVA e do CAP+EVA+PPA na condição virgem e nos tempos de 1 e $9 \mathrm{~s}$

Figura 51 - Percentuais de recuperação (R) do CAP 50/70, do CAP+PPA, do CAP+EVA e do CAP+EVA+PPA na condição envelhecida e nos tempos de 1 e $9 \mathrm{~s}$

Figura 52 - Compliâncias não-recuperáveis $\left(\mathrm{J}_{\mathrm{nr}}\right)$ do CAP+PPA, do CAP+EVA e do CAP+EVA+PPA na condição envelhecida e nos tempos de 1 e $9 \mathrm{~s}$

Figura 53 - Relações entre as compliâncias não-recuperáveis $\left(R_{J}\right)$ do CAP 50/70, do $\mathrm{CAP}+\mathrm{PPA}$, do CAP+EVA e do CAP+EVA+PPA nos tempos de 1 e $9 \mathrm{~s}$

Figura 54 - Relações entre os percentuais de recuperação $\left(R_{R}\right)$ do CAP 50/70, do CAP+PPA, do CAP+EVA e do CAP+EVA+PPA nos tempos de 1 e $9 \mathrm{~s}$

Figura 55 - Diferenças percentuais entre as compliâncias não-recuperáveis $\left(J_{n r}\right.$,diff $)$ do CAP 50/70, do CAP+PPA, do CAP+EVA e do CAP+EVA+PPA nos tempos de 1 e $9 \mathrm{~s}$

Figura 56 - Percentuais de recuperação $(R)$ do CAP 50/70, do CAP+PPA, do CAP+PE e do $\mathrm{CAP}+\mathrm{PE}+\mathrm{PPA}$ na condição virgem e nos tempos de 1 e $9 \mathrm{~s}$

Figura 57 - Compliâncias não-recuperáveis $\left(\mathrm{J}_{n r}\right)$ do CAP+PPA, do CAP+PE e do $\mathrm{CAP}+\mathrm{PE}+\mathrm{PPA}$ na condição virgem e nos tempos de 1 e $9 \mathrm{~s}$

Figura 58 - Percentuais de recuperação $(R)$ do CAP 50/70, do CAP+PPA, do $\mathrm{CAP}+\mathrm{PE}$ e do CAP+PE+PPA na condição envelhecida e nos tempos de 1 e $9 \mathrm{~s}$

Figura 59 - Compliâncias não-recuperáveis $\left(\mathrm{J}_{n r}\right)$ do CAP+PPA, do CAP+PE e do $\mathrm{CAP}+\mathrm{PE}+\mathrm{PPA}$ na condição envelhecida e nos tempos de 1 e $9 \mathrm{~s}$

Figura 60 - Relações entre as compliâncias não-recuperáveis $\left(R_{J}\right)$ do CAP 50/70, do $\mathrm{CAP}+\mathrm{PPA}$, do $\mathrm{CAP}+\mathrm{PE}$ e do $\mathrm{CAP}+\mathrm{PE}+\mathrm{PPA}$ nos tempos de 1 e $9 \mathrm{~s}$

Figura 61 - Relações entre os percentuais de recuperação $\left(R_{R}\right)$ do CAP $50 / 70$, do $\mathrm{CAP}+\mathrm{PPA}$, do CAP+PE e do CAP+PE+PPA nos tempos de 1 e $9 \mathrm{~s}$

Figura 62 - Diferenças percentuais entre as compliâncias não-recuperáveis $\left(\mathrm{J}_{\text {nr, diff }}\right)$ do CAP 50/70, do CAP+PPA, do CAP+PE e do CAP+PE+PPA nos tempos de 1 e $9 \mathrm{~s}$ 
Figura 63 - Percentuais de recuperação $(R)$ do CAP 50/70, do CAP+PPA, do CAP+SBR e do $C A P+S B R+P P A$ na condição virgem e nos tempos de 1 e $9 \mathrm{~s}$

Figura 64 - Compliâncias não-recuperáveis $\left(\mathrm{J}_{n r}\right)$ do CAP+PPA, do CAP+SBR e do $\mathrm{CAP}+\mathrm{SBR}+\mathrm{PPA}$ na condição virgem e nos tempos de 1 e $9 \mathrm{~s}$

Figura 65 - Percentuais de recuperação (R) do CAP 50/70, do CAP+PPA, do $\mathrm{CAP}+\mathrm{SBR}$ e do $\mathrm{CAP}+\mathrm{SBR}+\mathrm{PPA}$ na condição envelhecida e nos tempos de 1 e $9 \mathrm{~s}$

Figura 66 - Compliâncias não-recuperáveis $\left(\mathrm{J}_{\mathrm{nr}}\right)$ do CAP+PPA, do CAP+SBR e do CAP+SBR+PPA na condição envelhecida e nos tempos de 1 e $9 \mathrm{~s}$

Figura 67 - Relações entre as compliâncias não-recuperáveis $\left(R_{J}\right)$ do CAP 50/70, do $\mathrm{CAP}+\mathrm{PPA}$, do $\mathrm{CAP}+\mathrm{SBR}$ e do $\mathrm{CAP}+\mathrm{SBR}+\mathrm{PPA}$ nos tempos de 1 e $9 \mathrm{~s}$

Figura 68 - Relações entre os percentuais de recuperação $\left(R_{R}\right)$ do CAP 50/70, do CAP+PPA, do CAP+SBR e do CAP+SBR+PPA nos tempos de 1 e $9 \mathrm{~s}$

Figura 69 - Diferenças percentuais entre as compliâncias não-recuperáveis $\left(\mathrm{J}_{\text {nr,diff }}\right)$ do CAP 50/70, do CAP+PPA, do CAP+SBR e do CAP+SBR+PPA nos tempos de 1 e $9 \mathrm{~s}$

Figura 70 - Percentuais de recuperação $(R)$ do CAP 50/70, do CAP+PPA e do CAP+Elvaloy+PPA na condição envelhecida e nos tempos de 2 e $18 \mathrm{~s}$

Figura 71 - Compliâncias não-recuperáveis $\left(\mathrm{J}_{\mathrm{nr}}\right)$ do CAP+PPA e do CAP+Elvaloy+PPA na condição envelhecida e nos tempos de 2 e $18 \mathrm{~s}$

Figura 72 - Diferenças percentuais entre as compliâncias não-recuperáveis $\left(J_{\text {rr,diff }}\right)$ do CAP 50/70, do CAP+PPA e do CAP+Elvaloy+PPA nos tempos de 2 e $18 \mathrm{~s}$

Figura 73 - Percentuais de recuperação (R) do CAP 50/70, do CAP+PPA, do CAP+borracha e do CAP+borracha+PPA na condição envelhecida e nos tempos de 2 e $18 \mathrm{~s}$

Figura 74 - Compliâncias não-recuperáveis $\left(\mathrm{J}_{\text {nr }}\right)$ do CAP+PPA, do CAP+borracha e do CAP+borracha+PPA na condição envelhecida e nos tempos de 2 e $18 \mathrm{~s}$

Figura 75 - Diferenças percentuais entre as compliâncias não-recuperáveis $\left(\mathrm{J}_{\text {nr,diff }}\right)$ do CAP 50/70, do CAP+PPA, do CAP+borracha e do CAP+borracha+PPA nos tempos de 2 e $18 \mathrm{~s}$

Figura 76 - Percentuais de recuperação (R) do CAP 50/70, do CAP+PPA, do $\mathrm{CAP}+\mathrm{SBS}$ e do $\mathrm{CAP}+\mathrm{SBS}+\mathrm{PPA}$ na condição envelhecida e nos tempos de 2 e $18 \mathrm{~s}$

Figura 77 - Compliâncias não-recuperáveis $\left(J_{n r}\right)$ do CAP+PPA, do CAP+SBS e do $\mathrm{CAP}+\mathrm{SBS}+\mathrm{PPA}$ na condição envelhecida e nos tempos de 2 e $18 \mathrm{~s}$ 
Figura 78 - Diferenças percentuais entre as compliâncias não-recuperáveis $\left(J_{n r, d i f f}\right)$ do CAP 50/70, do CAP+PPA, do CAP+SBS e do CAP+SBS+PPA nos tempos de 2 e $18 \mathrm{~s}$

Figura 79 - Percentuais de recuperação (R) do CAP 50/70, do CAP+PPA, do $\mathrm{CAP}+\mathrm{EVA}$ e do CAP+EVA+PPA na condição envelhecida e nos tempos de 2 e $18 \mathrm{~s}$

Figura 80 - Compliâncias não-recuperáveis $\left(\mathrm{J}_{\mathrm{nr}}\right)$ do $\mathrm{CAP}+\mathrm{PPA}$, do $\mathrm{CAP}+\mathrm{EVA}$ e do $\mathrm{CAP}+\mathrm{EVA}+\mathrm{PPA}$ na condição envelhecida e nos tempos de 2 e $18 \mathrm{~s}$

Figura 81 - Diferenças percentuais entre as compliâncias não-recuperáveis $\left(J_{n r, d i f f}\right)$ do CAP 50/70, do CAP+PPA, do CAP+EVA e do CAP+EVA+PPA nos tempos de 2 e $18 \mathrm{~s}$

Figura 82 - Percentuais de recuperação $(R)$ do CAP 50/70, do CAP+PPA, do $\mathrm{CAP}+\mathrm{PE}$ e do $\mathrm{CAP}+\mathrm{PE}+\mathrm{PPA}$ na condição envelhecida e nos tempos de 2 e $18 \mathrm{~s}$

Figura 83 - Compliâncias não-recuperáveis $\left(\mathrm{J}_{\mathrm{nr}}\right)$ do $\mathrm{CAP}+\mathrm{PPA}$, do $C A P+P E$ e do $\mathrm{CAP}+\mathrm{PE}+\mathrm{PPA}$ na condição envelhecida e nos tempos de 2 e $18 \mathrm{~s}$

Figura 84 - Diferenças percentuais entre as compliâncias não-recuperáveis $\left(\mathrm{J}_{\text {nr,diff }}\right)$ do CAP 50/70, do CAP+PPA, do CAP+PE e do CAP+PE+PPA nos tempos de 2 e $18 \mathrm{~s}$

Figura 85 - Percentuais de recuperação $(R)$ do CAP 50/70, do CAP+PPA, do CAP+SBR e do $\mathrm{CAP}+\mathrm{SBR}+\mathrm{PPA}$ na condição envelhecida e nos tempos de 2 e $18 \mathrm{~s}$

Figura 86 - Compliâncias não-recuperáveis $\left(\mathrm{J}_{\text {nr }}\right)$ do CAP 50/70, do CAP+PPA, do $\mathrm{CAP}+\mathrm{SBR}$ e do $\mathrm{CAP}+\mathrm{SBR}+\mathrm{PPA}$ na condição envelhecida e nos tempos de 2 e $18 \mathrm{~s}$

Figura 87 - Diferenças percentuais entre as compliâncias não-recuperáveis $\left(J_{\text {nr,diff }}\right)$ do CAP 50/70, do CAP+PPA, do CAP+SBR e do CAP+SBR+PPA nos tempos de 2 e $18 \mathrm{~s}$

Figura 88- Verificação do nível de elasticidade do CAP+Elvaloy+PPA e do $\mathrm{CAP}+\mathrm{SBR}+\mathrm{PPA}$ na temperatura de $76^{\circ} \mathrm{C}$ e nos tempos de 1 e $9 \mathrm{~s}$

Figura 89- Verificação do nível de elasticidade do CAP+Elvaloy+PPA na temperatura de $76^{\circ} \mathrm{C}$ e nos tempos de 2 e $18 \mathrm{~s}$

Figura 90 - Posição dos ligantes asfálticos segundo os critérios contemplados neste estudo

Figura 91 - Posições médias dos ligantes asfálticos virgens e envelhecidos a curto prazo com base nos resultados do percentual de recuperação $(R)$ a 100 e a $3.200 \mathrm{~Pa}$ 
Figura 92 - Posições médias dos ligantes asfálticos virgens e envelhecidos a curto prazo com base nos resultados da compliância não-recuperável $\left(J_{n r}\right)$ a 100 e a $3.200 \mathrm{~Pa}$

Figura 93 - Posições médias dos ligantes asfálticos virgens e envelhecidos a curto prazo com base nos resultados da diferença percentual entre compliâncias $\left(J_{n r, \text { diff }}\right)$

Figura 94 - Percentuais de recuperação $(R)$ dos ligantes asfálticos a $100 \mathrm{~Pa}$ na condição virgem e nos tempos de 1 e $9 \mathrm{~s}$

Figura 95 - Percentuais de recuperação $(R)$ dos ligantes asfálticos a $3.200 \mathrm{~Pa}$ na condição virgem e nos tempos de 1 e $9 \mathrm{~s}$

Figura 96 - Compliâncias não-recuperáveis $\left(\mathrm{J}_{\mathrm{nr}}\right)$ dos ligantes asfálticos modificados na condição virgem, na tensão de $100 \mathrm{~Pa}$ e nos tempos de 1 e $9 \mathrm{~s}$

Figura 97 - Compliâncias não-recuperáveis $\left(\mathrm{J}_{n r}\right)$ dos ligantes asfálticos modificados na condição virgem, na tensão de $3.200 \mathrm{~Pa}$ e nos tempos de 1 e $9 \mathrm{~s}$

Figura 98 - Percentuais de recuperação $(R)$ dos ligantes asfálticos na condição envelhecida, na tensão de $100 \mathrm{~Pa}$ e nos tempos de 1 e $9 \mathrm{~s}$

Figura 99 - Percentuais de recuperação $(R)$ dos ligantes asfálticos na condição envelhecida, na tensão de $3.200 \mathrm{~Pa}$ e nos tempos de 1 e $9 \mathrm{~s}$

Figura 100 - Compliâncias não-recuperáveis $\left(\mathrm{J}_{\text {nr }}\right)$ dos ligantes asfálticos modificados na condição envelhecida, na tensão de $100 \mathrm{~Pa}$ e nos tempos de 1 e $9 \mathrm{~s}$

Figura 101 - Compliâncias não-recuperáveis $\left(\mathrm{J}_{\mathrm{nr}}\right)$ dos ligantes asfálticos modificados na condição envelhecida, na tensão de $3.200 \mathrm{~Pa}$ e nos tempos de 1 e $9 \mathrm{~s}$

Figura 102 - Percentuais de recuperação $(R)$ dos ligantes asfálticos na condição envelhecida, na tensão de $100 \mathrm{~Pa}$ e nos tempos de 2 e $18 \mathrm{~s}$

Figura 103 - Percentuais de recuperação $(R)$ dos ligantes asfálticos na condição envelhecida, na tensão de $3.200 \mathrm{~Pa}$ e nos tempos de 2 e $18 \mathrm{~s}$

Figura 104 - Compliâncias não-recuperáveis $\left(J_{\mathrm{nr}}\right)$ dos ligantes asfálticos na condição envelhecida, na tensão de $100 \mathrm{~Pa}$ e nos tempos de 2 e $18 \mathrm{~s}$

Figura 105 - Compliâncias não-recuperáveis $\left(\mathrm{J}_{\mathrm{nr}}\right)$ dos ligantes asfálticos na condição envelhecida, na tensão de $3.200 \mathrm{~Pa}$ e nos tempos de 2 e $18 \mathrm{~s}$

Figura 106 - Diferenças percentuais entre as compliâncias não-recuperáveis $\left(\mathrm{J}_{\text {nr,diff }}\right)$ dos ligantes asfálticos na condição virgem e nos tempos de 1 e $9 \mathrm{~s}$ 
Figura 107 - Diferenças percentuais entre as compliâncias não-recuperáveis $\left(J_{n r, d i f f}\right)$ dos ligantes asfálticos na condição envelhecida e nos tempos de 1 e $9 \mathrm{~s}$

Figura 108 - Diferenças percentuais entre as compliâncias não-recuperáveis $\left(J_{\text {nr,diff }}\right)$ dos ligantes asfálticos na condição envelhecida e nos tempos de 2 e $18 \mathrm{~s}$

Figura 109 - Relações entre os percentuais de recuperação $\left(R_{R}\right)$ dos ligantes asfálticos na tensão de $100 \mathrm{~Pa}$ e nos tempos de 1 e $9 \mathrm{~s}$

Figura 110 - Relações entre os percentuais de recuperação $\left(R_{R}\right)$ dos ligantes asfálticos na tensão de 3.200 Pa e nos tempos de 1 e $9 \mathrm{~s}$

Figura 111- Relações entre as compliâncias não-recuperáveis $\left(R_{J}\right)$ dos ligantes asfálticos na tensão de $100 \mathrm{~Pa}$ e nos tempos de 1 e $9 \mathrm{~s}$

Figura 112 - Relações entre as compliâncias não-recuperáveis $\left(R_{J}\right)$ dos ligantes asfálticos na tensão de $3.200 \mathrm{~Pa}$ e nos tempos de 1 e $9 \mathrm{~s}$

Figura 113 - Relações entre os percentuais de recuperação a 1 e 9 s e 2 e 18 s ( $\left(R_{P}\right)$ no nível de tensão de $100 \mathrm{~Pa}$

Figura 114 - Relações entre os percentuais de recuperação a 1 e 9 s e 2 e 18 s ( $\left(R_{P}\right)$ no nível de tensão de $3.200 \mathrm{~Pa}$

Figura 115 - Relações entre as compliâncias não-recuperáveis a 2 e 18 s e 1 e 9 s ( $\left(R_{C}\right)$ no nível de tensão de $100 \mathrm{~Pa}$

Figura 116 - Relações entre as compliâncias não-recuperáveis a 2 e 18 s e 1 e 9 s ( $\left.R_{C}\right)$ no nível de tensão de $3.200 \mathrm{~Pa}$ 


\section{LISTA DE SÍMBOLOS}

\begin{tabular}{|c|c|}
\hline$\% \gamma_{\text {per }}$ & Porcentagem de deformação permanente \\
\hline Yper & Deformação permanente do ligante asfáltico \\
\hline$\delta$ & Ângulo de fase \\
\hline$\varepsilon_{0}$ & Deformação medida no início de um ciclo de fluência e recuperação \\
\hline$\varepsilon_{\mathrm{c}}$ & Deformação medida no final do ciclo de fluência e início do ciclo de recuperação \\
\hline$\varepsilon_{\mathrm{r}}$ & Deformação medida no final de um ciclo de fluência e recuperação \\
\hline n' & Viscosidade de armazenamento do ligante asfáltico \\
\hline$\sigma$ & Tensão aplicada em um ciclo de fluência e recuperação \\
\hline$\sigma_{0}$ & Tensão aplicada no ligante asfáltico em um tempo de 't' segundos \\
\hline$\omega$ & Frequência de carregamento do ensaio em regime oscilatório \\
\hline$a, b, c$ & Parâmetros de regressão \\
\hline $\mathrm{E}$ & Tráfego extremamente pesado \\
\hline $\mathrm{G}^{*}$ & Módulo complexo de cisalhamento em regime oscilatório \\
\hline $\mathrm{G}^{*} / \operatorname{sen} \delta$ & Parâmetro de deformação permanente \\
\hline G' & Módulo de armazenamento em regime oscilatório (componente em fase) \\
\hline G” & Módulo de dissipação em regime oscilatório (componente defasado) \\
\hline $\mathrm{G}_{\mathrm{M}}$ & Grau de modificação \\
\hline $\mathrm{H}$ & Tráfego pesado \\
\hline $\mathrm{I}_{\mathrm{PA}}$ & Incremento do ponto de amolecimento \\
\hline $\mathrm{J}_{\mathrm{nr}}$ & Compliância não-recuperável do ligante asfáltico \\
\hline $\mathrm{Jnr}_{1-9}$ & Compliância não-recuperável do ligante asfáltico nos tempos de 1 e $9 \mathrm{~s}$ \\
\hline $\mathrm{Jnr}_{2-18}$ & Compliância não-recuperável do ligante asfáltico nos tempos de 2 e $18 \mathrm{~s}$ \\
\hline Jnr100 & Compliância não-recuperável na tensão de $100 \mathrm{~Pa}$ \\
\hline Jnr3200 & Compliância não-recuperável na tensão de 3.200 Pa \\
\hline$J_{n r, \text { diff }}$ & $\begin{array}{l}\text { Diferença percentual entre as compliâncias não-recuperáveis nas tensões de } 100 \\
\text { e } 3.200 \mathrm{~Pa}\end{array}$ \\
\hline $\mathrm{Jnr}_{\mathrm{MAT}}$ & Compliância não-recuperável do ligante asfáltico em questão \\
\hline $\mathrm{Jnr}_{\mathrm{REF}}$ & Compliância não-recuperável do ligante asfáltico de referência \\
\hline $\mathrm{J}_{\mathrm{nr}} \mathrm{RT}$ & Compliância não-recuperável do ligante asfáltico envelhecido a curto prazo \\
\hline $\mathrm{J}_{\mathrm{nr}} \mathrm{V}$ & Compliância não-recuperável do ligante asfáltico virgem \\
\hline k & Constante empírica \\
\hline N & Número do ciclo de fluência e recuperação \\
\hline $\mathrm{N}_{\mathrm{C}}$ & Valor normalizado da compliância não-recuperável \\
\hline $\mathrm{N}_{\mathrm{R}}$ & Valor normalizado do percentual de recuperação \\
\hline
\end{tabular}




\begin{tabular}{|c|c|}
\hline$P_{\text {CAP }}$ & Valor da propriedade no ligante asfáltico puro \\
\hline $\mathrm{P}_{\mathrm{MOD}}$ & Valor da propriedade no ligante asfáltico modificado \\
\hline $\mathrm{R}$ & Percentual de recuperação do ligante asfáltico \\
\hline$R_{1-9}$ & Percentual de recuperação do ligante asfáltico nos tempos de 1 e $9 \mathrm{~s}$ \\
\hline $\mathrm{R}_{2-18}$ & Percentual de recuperação do ligante asfáltico nos tempos de 2 e $18 \mathrm{~s}$ \\
\hline R100 & Percentual de recuperação na tensão de $100 \mathrm{~Pa}$ \\
\hline R3200 & Percentual de recuperação na tensão de $3.200 \mathrm{~Pa}$ \\
\hline $\mathrm{R}_{\mathrm{C}}$ & $\begin{array}{l}\text { Relação entre as compliâncias não-recuperáveis nos tempos de } 2 \text { e } 18 \mathrm{~s} \text { e nos } \\
\text { tempos de } 1 \text { e } 9 \mathrm{~s}\end{array}$ \\
\hline $\mathrm{R}_{\mathrm{J}}$ & $\begin{array}{l}\text { Relação entre as compliâncias não-recuperáveis nas condições virgem e } \\
\text { envelhecida a curto prazo }\end{array}$ \\
\hline $\mathrm{R}_{\text {MAT }}$ & Percentual de recuperação do ligante asfáltico em questão \\
\hline $\mathrm{R}_{\mathrm{P}}$ & $\begin{array}{l}\text { Relação entre os percentuais de recuperação nos tempos de } 1 \text { e } 9 \mathrm{~s} \text { e nos tempos } \\
\text { de } 2 \text { e } 18 \mathrm{~s}\end{array}$ \\
\hline $\mathrm{R}_{\mathrm{R}}$ & $\begin{array}{l}\text { Relação entre os percentuais de recuperação nas condições envelhecida a curto } \\
\text { prazo e virgem }\end{array}$ \\
\hline $\mathrm{R}_{\mathrm{REF}}$ & Percentual de recuperação do ligante asfáltico de referência \\
\hline $\mathrm{R}_{\mathrm{RTFOT}}$ & Percentual de recuperação do ligante asfáltico envelhecido a curto prazo \\
\hline $\mathrm{R}_{\mathrm{V}}$ & $\begin{array}{l}\text { Relação entre as viscosidades rotacionais nas condições envelhecida a curto } \\
\text { prazo e virgem }\end{array}$ \\
\hline $\mathrm{R}_{\mathrm{VIRGEM}}$ & Percentual de recuperação do ligante asfáltico virgem \\
\hline S & Tráfego padrão \\
\hline $\mathrm{T}$ & Temperatura superior da especificação dos ligantes asfálticos \\
\hline $\mathrm{T}_{\mathrm{e}}$ & Temperatura de rigidez equivalente \\
\hline V & Tráfego muito pesado \\
\hline $\mathrm{V}_{1}$ & Valor numérico obtido na amostra original \\
\hline $\mathrm{V}_{2}$ & Valor numérico obtido na réplica \\
\hline $\mathrm{V}_{\mathrm{ENV}}$ & Viscosidade rotacional do ligante asfáltico na condição envelhecida a curto prazo \\
\hline $\mathrm{V}_{\mathrm{VIR}}$ & Viscosidade rotacional do ligante asfáltico na condição virgem \\
\hline $\mathrm{X}_{0}, \mathrm{Y}_{0}$ & Parâmetros de regressão \\
\hline
\end{tabular}




\section{LISTA DE SIGLAS E ABREVIAÇÕES}

AASHTO "American Association of State Highway and Transportation Officials"

AC Cimento asfáltico (“asphalt cement”)

ANP Agência Nacional do Petróleo, Gás Natural e Biocombustíveis

AR Resíduo do ligante asfáltico após o envelhecimento a curto prazo ("aged residue")

ASTM "American Society for Testing and Materials"

CAP Cimento Asfáltico de Petróleo

DNIT Departamento Nacional de Infraestrutura de Transportes

DSR Reômetro de cisalhamento dinâmico

ESAL Número equivalente de passadas de um eixo-padrão simples

EVA Copolímero de etileno acetato de vinila

FHWA Administração Rodoviária Federal dos Estados Unidos

GMA Glicidilmetacrilato

I-80 Interstate 80 (rodovia norte-americana)

IS Série informativa

ISL "Instrumentation Scientifique de Laboratoire"

LAS Varredura com amplitude linear

MSCR Fluência e recuperação sob tensão múltipla

NB Asfalto natural

NCHRP "National Cooperative Highway Research Program"

PA Ponto de amolecimento

$\mathrm{PA}_{\mathrm{RTFO}}$ Ponto de amolecimento do ligante asfáltico envelhecido a curto prazo

PA $A_{\text {VIRGEM }}$ Ponto de amolecimento do ligante asfáltico virgem

PE Polietileno

PEN Penetração

PEN RET $_{\text {Penetração retida }}$

PEN $N_{\text {RTFOT }}$ Penetração obtida no ligante asfáltico envelhecido a curto prazo

PEN VIRGEM Penetração obtida no ligante asfáltico virgem

PET Politereftalato de etileno

PG Grau de desempenho

PPA Ácido polisfosfórico

RCRT Ensaio de fluência repetida e recuperação

REPLAN Refinaria de Paulínia (SP)

RSST-CH Ensaio de cisalhamento repetido simplificado com altura constante

RTFOT Ensaio da estufa de filme fino rotativo, material envelhecido a curto prazo 
SBR Borracha de estireno-butadieno

SBS Copolímero de estireno-butadieno-estireno

SHRP "Strategic Highway Research Program"

TUCs Temperaturas de usinagem e de compactação

VAR Variabilidade 
SUMÁRIO

1. INTRODUÇÃO _ 35

2. REVISÃO BIBLIOGRÁFICA _ 39

2.1. Parâmetro de deformação permanente da especificação Superpave G*/senర: problemas e algumas soluções propostas 39

2.2. O ensaio de fluência e recuperação sob tensão múltipla (MSCR) _ 46

2.2.1. Desenvolvimento, características e propriedades obtidas ___ 46

2.2.2. Vantagens do ensaio MSCR em relação ao ensaio de regime oscilatório em temperaturas altas

2.2.3. Novo critério para caracterização da resistência dos ligantes asfálticos à deformação permanente _ 50

2.2.4. Comentários adicionais sobre o ensaio MSCR __ 53

2.3. Temperaturas de usinagem e de compactação dos ligantes asfálticos _ 54

2.4. Exemplos de modificadores do ligante asfáltico _ 56

2.4.1. Copolímero de estireno-butadieno-estireno (SBS) __ 58

2.4.2. Borracha de estireno-butadieno (SBR) _ 60

2.4.3. Borracha moída de pneus __ 62

2.4.4. Polietileno (PE) __ 65

2.4.5. Copolímero de etileno acetato de vinila (EVA)__ 69

2.4.6. Elvaloy _ 71

2.4.7. Ácido polisfosfórico (PPA) __ 75

3. MATERIAIS E MÉTODOS

3.1. Formulações dos ligantes asfálticos e ensaios de caracterização __ 79

3.2. Análises de sensibilidade e outras considerações ___ 85

4. RESULTADOS E DISCUSSÃo __ 91

4.1. Resultados dos ensaios de penetração e de ponto de amolecimento e discussão _ 91

4.2. Resultados dos ensaios de viscosidade rotacional e discussão ___

4.2.1. Ligantes asfálticos virgens ___ 98

4.2.2. Ligantes asfálticos envelhecidos a curto prazo ___ 102

4.2.3. Incrementos de viscosidade rotacional após o envelhecimento a curto prazo 107

4.2.4. Temperaturas de usinagem e de compactação dos ligantes asfálticos ___ 112

4.3. Resultados do ensaio MSCR para os tempos de 1 e 9 s e discussão _ 113

4.3.1. CAP 50/70, CAP+PPA e CAP+Elvaloy+PPA 114

4.3.2. CAP 50/70, CAP+PPA, CAP+borracha e CAP+borracha+PPA 126 
4.3.3. CAP 50/70, CAP+PPA, CAP+SBS e CAP+SBS+PPA 139

4.3.4. CAP 50/70, CAP+PPA, CAP+EVA e CAP+EVA+PPA 152

4.3.5. CAP 50/70, CAP+PPA, CAP+PE e CAP+PE+PPA 165

4.3.6. CAP 50/70, CAP+PPA, CAP+SBR e CAP+SBR+PPA 176

4.4. Resultados do ensaio MSCR para os tempos de 2 e 18 s e discussão 188

4.4.1. CAP 50/70, CAP+PPA e CAP+Elvaloy+PPA 188

4.4.2. CAP 50/70, CAP+PPA, CAP+borracha e CAP+borracha+PPA 193

4.4.3. CAP 50/70, CAP+PPA, CAP+SBS e CAP+SBS+PPA 198

4.4.4. CAP 50/70, CAP+PPA, CAP+EVA e CAP+EVA+PPA 203

4.4.5. CAP 50/70, CAP+PPA, CAP+PE e CAP+PE+PPA 208

4.4.6. CAP 50/70, CAP+PPA, CAP+SBR e CAP+SBR+PPA 213

4.5. Efeitos do aumento dos tempos de fluência e recuperação nas propriedades dos ligantes asfálticos envelhecidos a curto prazo

4.6. Tabelas normalizadas dos ligantes asfálticos e discussão 223

4.6.1. Tempos de 1 e $9 \mathrm{~s}$ e condição virgem 224

4.6.2. Tempos de 1 e $9 \mathrm{~s}$ e condição envelhecida a curto prazo 230

4.6.3. Tempos de 2 e $18 \mathrm{~s}$ e condição envelhecida a curto prazo 236

4.7. Elasticidade dos ligantes asfálticos envelhecidos a curto prazo e na temperatura do PG

4.8. Classificação dos ligantes asfálticos no critério de tráfego do FHWA _ 245

4.9. Análises simultâneas dos resultados dos ligantes asfálticos 246

5. CONCLUSÕES E SUGESTÕES DE PESQUISAS 283

5.1. Conclusões principais 283

5.2. Considerações finais 292

5.3. Sugestões para pesquisas futuras 293 REFERÊNCIAS BIBLIOGRÁFICAS 295 


\section{INTRODUÇÃO}

A modificação dos ligantes asfálticos é adotada como uma maneira de melhorar o desempenho destes materiais em campo, uma vez que o número de veículos nas rodovias, as cargas por eixo dos veículos comerciais e as pressões dos pneus vêm aumentando nos últimos anos (AIREY, 2002). Uma revisão bibliográfica realizada por Bahia et al. (2001) mostra que os modificadores do ligante asfáltico podem ser classificados com base em diversos critérios, tais como o tipo de mecanismo por meio do qual eles alteram as propriedades do ligante asfáltico, a composição química e a natureza física do modificador ou a propriedade-alvo do ligante asfáltico que necessita de melhorias. Dentre os modificadores existentes, Bahia et al. (2001) citam o copolímero de estireno-butadieno-estireno, o copolímero de etileno acetato de vinila, o polietileno e a borracha de estireno-butadieno, além de outros como a borracha moída de pneus, as fibras e os hidrocarbonetos.

Como uma alternativa à modificação dos ligantes asfálticos, algumas melhorias nas propriedades destes materiais são alcançadas através da seleção de um petróleo adequado de origem ou do ajuste do processo de refinamento utilizado para produzi-los. Entretanto, estas opções são limitadas pelos poucos tipos de petróleo capazes de produzir bons ligantes asfálticos e pelo baixo número de ações que podem ser tomadas para controlar os processos de refinamento do petróleo bruto (BECKER et al., 2001). Em outras palavras, esta alternativa não se configurou como a melhor solução para a obtenção de melhores propriedades dos ligantes asfálticos, devido às suas limitações técnicas e de disponibilidade de petróleo bruto para a produção dos ligantes asfálticos desejados. Desta maneira, os processos de modificação vêm se consolidando como a solução mais adequada para atender às necessidades constantes de aumento de desempenho dos ligantes asfálticos.

Com o propósito de caracterizar a resistência dos ligantes asfálticos à deformação permanente, a especificação Superpave adotou um parâmetro que combina o módulo complexo de cisalhamento $\left(G^{*}\right)$, representativo da resistência total do ligante asfáltico à deformação sob o carregamento do tráfego, e o ângulo de fase (ס), representativo da distribuição relativa da resposta total do ligante asfáltico entre um componente em fase e outro defasado, de acordo com a equação $G^{*} /$ senঠ (BAHIA e ANDERSON, 1995). Este parâmetro, entretanto, vem recebendo diversas críticas por parte dos pesquisadores, os quais relatam sua incapacidade em caracterizar a resistência dos ligantes asfálticos modificados à deformação permanente de maneira adequada. Dentre as deficiências 
relatadas na literatura, podem-se citar a determinação do valor de $G^{*} / \operatorname{sen} \delta$ na faixa de viscoelasticidade linear dos ligantes asfálticos (DELGADILLO et al., 2006) e a não consideração de toda a contribuição elástica oriunda da adição de modificadores ao ligante asfáltico (ANDERSON et al., 2010).

Tendo conhecimento das deficiências do parâmetro $G^{*} / \operatorname{sen} \delta$, muitas alternativas foram propostas pelos pesquisadores a fim de obter uma melhor caracterização da resistência dos ligantes asfálticos modificados à deformação permanente. Estas alternativas contemplam especificações suplementares e ensaios adicionais à especificação Superpave (D'ANGELO et al., 2007), refinamentos do parâmetro G*/senঠ (BOULDIN et al., 2001; SHENOY, 2001; SHENOY, 2004) e o desenvolvimento de novos ensaios em substituição ao ensaio de regime oscilatório em temperaturas altas (BAHIA et al., 2001; D'ANGELO et al., 2007). Neste aspecto, o ensaio de fluência e recuperação sob tensão múltipla (MSCR) tem mostrado bons resultados quanto à distinção entre as propriedades dos vários tipos de ligantes asfálticos modificados, sendo capaz de distinguir os benefícios proporcionados pela adição de cada tipo de modificador. As vantagens deste ensaio em relação ao ensaio de regime oscilatório da especificação Superpave em temperaturas altas - e, por consequência, ao parâmetro $G^{*} /$ senঠ - são mencionadas em diversos estudos (D'ANGELO et al., 2007; ANDERSON et al., 2010; ASPHALT INSTITUTE, 2010a) e, dentre estas vantagens, podem ser destacadas as seguintes:

a) Os resultados do MSCR podem ser utilizados tanto para os ligantes asfálticos puros quanto para os modificados, o que elimina a necessidade de realização de ensaios adicionais para a caracterização adequada do desempenho de ligantes asfálticos modificados em temperaturas altas;

b) O ensaio MSCR possibilita a avaliação da dependência dos ligantes asfálticos modificados com polímeros quanto à tensão, o que não é possível de ser feito em outros ensaios porque estes são executados na faixa de comportamento viscoelástico linear dos ligantes asfálticos;

c) O aumento do grau de desempenho (PG) para os ligantes asfálticos submetidos a volumes elevados de tráfego e carregamentos de baixa velocidade, procedimento conhecido na especificação Superpave como "grade-bumping", não é necessária no MSCR porque as temperaturas deste ensaio levam em consideração os valores reais de temperaturas altas do pavimento;

d) O valor da compliância não-recuperável do ligante asfáltico possibilita a verificação do tipo de tráfego adequado ao material, sendo eles o padrão $(\mathrm{S})$, o pesado $(\mathrm{H})$, o muito pesado $(\mathrm{V})$ e o extremamente pesado (E). 
Admitindo tal panorama, o objetivo principal desta pesquisa é avaliar o efeito do tipo de modificador no comportamento fluência-recuperação de ligantes asfálticos modificados em temperaturas altas, considerando os procedimentos de ensaio prescritos na norma ASTM D7405 (1 s de carregamento e $9 \mathrm{~s}$ de recuperação) e utilizando materiais em suas condições virgem e envelhecida a curto prazo na estufa de filme fino rotativo. Além do MSCR, a caracterização dos ligantes asfálticos também contempla os resultados de penetração, ponto de amolecimento e viscosidade rotacional ou Brookfield, considerando materiais nas duas condições de envelhecimento. A fim de proporcionar análises mais detalhadas dos comportamentos dos ligantes asfálticos, foram delineados os seguintes objetivos secundários:

a) Verificar a sensibilidade dos ligantes asfálticos ao envelhecimento a curto prazo e ao nível de tensão, considerando os tempos de carregamento e de repouso de 1 e $9 \mathrm{~s}$ prescritos na norma ASTM D7405;

b) Caracterizar o comportamento fluência-recuperação dos ligantes asfálticos envelhecidos a curto prazo para os tempos de $2 \mathrm{~s}$ de carregamento e $18 \mathrm{~s}$ de recuperação, tomando como base as sugestões de Dongré (comunicação pessoal) ${ }^{1}$ para tempos maiores de fluência e recuperação;

c) Comparar os resultados obtidos no MSCR para os tempos de carregamento e de repouso de 1 e $9 \mathrm{~s}$, prescritos na norma ASTM D7405, e os de 2 e $18 \mathrm{~s}$.

Estrutura do texto da dissertação. O Capítulo 1 mostra uma introdução sobre os ligantes asfálticos modificados, as deficiências do parâmetro $G^{*} /$ senঠ na caracterização da resistência dos ligantes asfálticos modificados à deformação permanente e as vantagens do MSCR sobre o ensaio da especificação Superpave em regime oscilatório, bem como os objetivos da pesquisa. O capítulo termina com a descrição e a organização de cada um dos seis capítulos deste estudo.

O Capítulo 2 apresenta uma revisão bibliográfica sobre a caracterização da resistência dos ligantes asfálticos à deformação permanente, abrangendo tópicos como as críticas dos pesquisadores ao parâmetro $\mathrm{G}^{*} / \mathrm{sen} \delta$ e algumas soluções apresentadas em estudos, uma descrição sobre o MSCR e as principais vantagens em relação ao ensaio da especificação Superpave em regime oscilatório. Esta revisão aborda, na sequência, alguns métodos e especificações para cálculo das temperaturas de usinagem e de compactação dos ligantes asfálticos, dentre os quais estão os métodos tradicional e

\footnotetext{
${ }^{1}$ Informação fornecida por Raj Dongré a Adalberto Leandro Faxina em 2010 e recebida no dia 24 de janeiro de 2011 por matinocente10@hotmail.com.
} 
Casola e as Especificações de Serviço 112/2009 e 385/1999 do Departamento Nacional de Infraestrutura de Transportes (DNIT). O capítulo termina com as descrições de alguns tipos de modificadores do ligante asfáltico - copolímero de estireno-butadieno-estireno, borracha de estireno-butadieno, borracha moída de pneus, polietileno, copolímero de etileno acetato de vinila, Elvaloy e ácido polisfosfórico - e dos efeitos destes materiais em propriedades específicas dos CAPs, tendo como base os resultados e as análises de estudos laboratoriais.

O Capítulo 3 destaca os materiais e métodos utilizados na pesquisa, apresentando as formulações e variáveis de processamento dos ligantes asfálticos modificados e os ensaios, critérios e parâmetros para avaliação da sensibilidade destes materiais ao envelhecimento a curto prazo, ao aumento do nível de tensão de 100 para 3.200 Pa e ao aumento dos tempos de fluência e recuperação de 1 e $9 \mathrm{~s}$ para 2 e $18 \mathrm{~s}$. O capítulo apresenta também os resultados de perda de massa dos ligantes asfálticos, destacando os materiais com maiores e menores valores e algumas considerações sobre os fenômenos de oxidação e de evaporação nos resultados deste parâmetro.

O Capítulo 4 apresenta os resultados e as respectivas discussões dos ensaios de caracterização dos ligantes asfálticos (penetração, ponto de amolecimento, viscosidade rotacional ou Brookfield e MSCR), bem como as análises de sensibilidade destes materiais ao envelhecimento a curto prazo, ao aumento do nível de tensão de 100 para 3.200 Pa e ao aumento dos tempos de fluência e recuperação de 1 e $9 \mathrm{~s}$ para 2 e 18 s. O capítulo apresenta, na sequência, as tabelas normalizadas do percentual de recuperação e da compliância não-recuperável dos ligantes asfálticos em relação aos resultados do CAP 50/70 e do CAP+PPA, seguido pela verificação do nível de elasticidade e depois pela classificação dos materiais no critério de tráfego proposto pelo FHWA. O capítulo termina com uma análise simultânea dos resultados dos ligantes asfálticos em todas as propriedades e parâmetros analisados, tendo como base a ordenação destes materiais em uma escala numérica de 1 (melhor resultado) a 13 (pior resultado) e algumas considerações a respeito dos pesos de cada propriedade e parâmetro no valor da média global.

O Capítulo 5 apresenta as conclusões principais do estudo em termos de propriedades e parâmetros de interesse, as considerações finais e algumas sugestões de futuras pesquisas. Ao final, são apresentadas as referências bibliográficas utilizadas nesta dissertação. 


\section{REVISÃO BIBLIOGRÁFICA}

Este capítulo apresenta o parâmetro $\mathrm{G}^{*} / \operatorname{sen} \delta$ e as principais falhas encontradas pelos pesquisadores, bem como algumas soluções propostas em estudos. Na sequência, apresentam-se detalhamentos sobre o MSCR e as principais vantagens deste ensaio em relação ao ensaio da especificação Superpave em temperaturas altas, seguidos por comentários adicionais e pela descrição do novo critério de resistência dos ligantes asfálticos à deformação permanente. O capítulo termina com uma revisão da literatura sobre alguns procedimentos para cálculo das temperaturas de usinagem e de compactação dos ligantes asfálticos, seguida por descrições de alguns tipos de modificadores e dos efeitos de cada um deles em propriedades específicas do ligante asfáltico.

\subsection{Parâmetro de deformação permanente da especificação Superpave G*/senס: problemas e algumas soluções propostas}

O parâmetro $G^{*} /$ senס foi adotado pela especificação Superpave para expressar a resistência dos ligantes asfálticos à deformação permanente. Este parâmetro combina o módulo complexo de cisalhamento $\left(\mathrm{G}^{*}\right)$, representativo da resistência total do ligante asfáltico à deformação sob o carregamento do tráfego, e o ângulo de fase (ס), representativo da distribuição relativa da resposta total do ligante asfáltico entre um componente em fase e outro defasado. O componente em fase (G') é o componente elástico e pode ser diretamente relacionado à energia armazenada na amostra a cada ciclo de carregamento, ao passo que o componente defasado (G") representa o componente viscoso e pode ser diretamente relacionado à quantidade de energia dissipada a cada ciclo de carregamento. $A$ lógica associada ao parâmetro $\mathrm{G}^{*} / \operatorname{sen} \delta$ é a de que a contribuição do ligante asfáltico na resistência da mistura asfáltica à deformação permanente pode ser aumentada de duas maneiras: (1) uma resistência total maior, o que implica um valor maior de $G^{*}$; ou (2) uma elasticidade maior, o que implica um valor menor de $\delta$ (BAHIA e ANDERSON, 1995).

Posteriormente à implantação da especificação Superpave, constatou-se que o parâmetro $\mathrm{G}^{*} / \mathrm{sen} \delta$ seria inadequado para avaliar ligantes asfálticos modificados quanto à resistência à deformação permanente e, assim, tornou-se motivo de preocupação para muitos pesquisadores (STUART e MOGAWER, 1997; BAHIA et al., 2001; BOULDIN et al., 2001; SHENOY, 2001; SHENOY, 2004; DONGRÉ et al., 2004; D’ANGELO et al., 2007). Sua falha 
foi constatada em ensaios de laboratório realizados durante o desenvolvimento do "National Cooperative Highway Research Program" (NCHRP) 9-10 (BAHIA et al., 2001) e também por meio de dados de campo obtidos durante os ensaios no Centro de Pesquisas Rodoviárias de Turner-Fairbank, no estado norte-americano da Virginia (STUART e MOGAWER, 1997).

O parâmetro $\mathrm{G}^{*} /$ senঠ se tem mostrado inadequado por conta da sua incapacidade na detecção de toda a contribuição elástica proporcionada pela adição de polímeros aos ligantes asfálticos. As especificações por viscosidade (especificações AC e AR) e a utilização deste parâmetro como critério de deformação permanente funcionam bem para ligantes asfálticos puros, pois estes materiais praticamente não apresentam deformação recuperável e, desta maneira, a deformação acumulada é igual à deformação total. No desenvolvimento da especificação Superpave, este fato foi reconhecido e ponderado pelo ajuste de $\mathrm{G}^{*}$ com o termo 1/senঠ, resultando na expressão $G^{*} / \operatorname{sen} \delta$ (BOULDIN et al., 2001). Este ajuste, no entanto, não consegue considerar todas as contribuições da elasticidade proporcionada pela adição de modificadores ao ligante asfáltico, uma vez que o impacto do valor de $\delta$ no valor global do parâmetro $G^{*} /$ senঠ é relativamente pequeno (ANDERSON et al., 2010). Assim, previsões de desempenho obtidas por este parâmetro não se correlacionam com as evidências empíricas de pistas experimentais para alguns ligantes asfálticos modificados, como citado nos estudos de Bouldin et al. (2001).

Outro problema associado ao parâmetro $\mathrm{G}^{*} / \operatorname{sen} \delta$ está na sua determinação na faixa de viscoelasticidade linear dos ligantes asfálticos. Em geral, os ensaios de deformação permanente destes materiais são realizados em níveis baixos de tensão, devido principalmente à simplicidade. Uma vez que as tensões elevadas são evitadas, o ligante asfáltico comporta-se como um material viscoelástico linear e, desta maneira, a deformação é proporcional à tensão. No entanto, as tensões e deformações no ligante asfáltico podem ser muito maiores do que o limite de comportamento linear, fazendo com que a faixa de comportamento não-linear do material seja alcançada. Trabalhos já publicados mostram que, dependendo da estrutura do pneu do veículo, as tensões na superfície do pavimento podem atingir níveis de até $10^{6} \mathrm{~Pa}$ ou $1.000 \mathrm{kPa}$ (DELGADILLO et al., 2006).

Tendo conhecimento dos problemas referentes ao parâmetro $\mathrm{G}^{\star} / \mathrm{sen} \delta$, algumas agências rodoviárias dos Estados Unidos passaram a adotar especificações suplementares, chamadas de ensaios Superpave "PG+" ou "SHRP+", como uma maneira de garantir que os ligantes asfálticos adquiridos seriam realmente modificados (D'ANGELO et al., 2007). Dentre as medidas tomadas, algumas destas agências adicionaram ensaios de natureza empírica como a recuperação elástica e a tenacidade; outras, por sua vez, adotaram 
exigências especiais para o ângulo de fase (DELGADILLO et al., 2006). Outro motivo associado à utilização destas especificações é o de que, antes da incorporação dos ensaios "PG+" ou "SHRP+", as empresas de ligantes asfálticos vendiam materiais de mesmo PG (como um exemplo, CAP+SBS e CAP+gilsonita de classificação PG 76-XX) com custos equivalentes e propriedades elásticas diferentes de um material para outro, de modo que os ensaios adicionais possibilitavam a distinção entre os ligantes asfálticos de mesmo PG (e mesmo custo) em termos das suas propriedades elásticas. Segundo D’Angelo et al. (2007), o problema oriundo da adoção destes tipos de ensaios é que eles não estão relacionados ao desempenho do ligante asfáltico em muitos dos casos, pois apenas indicam a presença ou ausência de modificadores no material. Assim, esta solução não se mostrou a melhor opção para substituir ou refinar o parâmetro $\mathrm{G}^{*} / \operatorname{sen} \delta$, o que levou os pesquisadores a continuar as buscas por outras alternativas.

Dentre estas alternativas, Shenoy (2001) sugere um refinamento do parâmetro $\mathrm{G}^{*} /$ senঠ por meio de derivação teórica baseada em conceitos fundamentais. A expressão obtida por este pesquisador para o cálculo da porcentagem de deformação permanente é a mostrada na Equação 1:

$$
\% \gamma_{p e r}=\frac{100 \cdot \sigma_{0}}{G^{*}} \cdot\left(1-\frac{1}{\tan \delta \cdot \operatorname{sen} \delta}\right)
$$

onde $\% Y_{\text {per }}$ é a porcentagem de deformação permanente e $\sigma_{0}$ é a tensão aplicada no material por um período de tempo de 't' segundos. Uma vez que $G^{*}$ e $\delta$ são funções da frequência e da temperatura, os efeitos da temperatura do pavimento e da velocidade do tráfego são considerados nesta equação. Para que a deformação permanente seja minimizada, o seguinte termo deve ser maximizado:

$$
\frac{G^{*}}{\left(1-\frac{1}{\tan \delta \cdot \operatorname{sen} \delta}\right)}
$$

Shenoy (2001) propôs este novo parâmetro (Equação 2) como um substituto do parâmetro $G^{*} / \operatorname{sen} \delta$. A temperatura alta da especificação Superpave pode ser determinada como aquela em que o termo dado pela Equação 2 resulta no valor de 1,0 kPa para um ligante asfáltico puro e 2,2 kPa para um material envelhecido na estufa de filme fino rotativo. Estes valores foram mantidos para que a nova equação pudesse prever as temperaturas para os ligantes asfálticos convencionais, de acordo com os parâmetros da especificação Superpave. 
Posteriormente, Shenoy (2004) propôs uma reformulação do seu critério de especificação porque ele verificou que, da maneira como estava estabelecido, o desempenho dos ligantes asfálticos em campo não era adequadamente caracterizado. Assim, sua primeira sugestão para o cálculo da temperatura superior de especificação dos ligantes asfálticos $(T)$, nomeada como Critério 1, consiste em determinar o valor de $\mathrm{T}$ no qual o parâmetro expresso pela Equação 2 é igual a 50 Pa para uma frequência angular de ensaio ( $\omega$ ) igual a 0,25 rad/s. Uma segunda sugestão (Critério 2) consiste em calcular o valor de $\mathrm{T}$ através de uma nova equação, uma vez que, segundo o autor, houve um caso ímpar de um ligante asfáltico do Projeto Nevada I-80 cujo desempenho não fora corretamente previsto pelo Critério 1. Esta nova equação está expressa na Equação 3:

$$
T=\frac{T_{e}}{\left(1-\frac{1}{\tan \delta \cdot \operatorname{sen} \delta}\right)}
$$

em que $T_{e}$ é a chamada temperatura de rigidez equivalente, sendo determinada como a temperatura na qual $\mathrm{G}^{*}=50 \mathrm{~Pa}$ para $\omega=0,25 \mathrm{rad} / \mathrm{s}$, e $\delta$ é o valor do ângulo de fase na temperatura $T_{e}$. No estudo conduzido por Shenoy (2004), o Critério 2 forneceu uma boa correlação entre as temperaturas de especificação de dois ligantes asfálticos utilizados no Projeto Nevada I-80 (um modificado e outro não modificado) e o desempenho real destes materiais em campo, entretanto o autor reconhece que são necessários dados adicionais de campo para verificar se este critério fornece previsões reais de desempenho para outros ligantes asfálticos em pistas experimentais.

Em outro estudo, Bahia et al. (2001) propuseram duas hipóteses principais para selecionar um procedimento de ensaio que pudesse ser um indicador mais efetivo da contribuição do ligante asfáltico na deformação permanente da mistura asfáltica. A primeira delas diz que a deformação do ligante asfáltico é significativamente maior do que a utilizada no ensaio da especificação Superpave em regime oscilatório, o que levou os autores à realização de ensaios de varreduras de deformação, de tensão, de tempo sob tensão constante e de tempo sob deformação constante para verificação da hipótese. A segunda diz que a utilização de carregamento cíclico com uma completa reversão na tensão ou na deformação não é o método mais adequado para determinar a contribuição do ligante na resistência da mistura asfáltica à deformação permanente, uma vez que esta deformação é causada, na mistura, por um carregamento cíclico de natureza irreversível. A verificação da primeira hipótese levou os autores à conclusão de que os ensaios de regime oscilatório não proporcionam uma boa indicação da resistência à deformação permanente, ao passo que a segunda hipótese conduziu ao desenvolvimento de um ensaio de fluência repetida e 
recuperação (RCRT - "repeated creep and recovery test") para verificar o comportamento dos ligantes asfálticos à deformação permanente. O protocolo recomendado para o RCRT consiste na aplicação de uma tensão de cisalhamento entre 30 e 300 Pa por 100 ciclos, em que cada ciclo é constituído de um tempo de carregamento de $1 \mathrm{~s}$ (tempo de fluência) e um tempo de repouso de $9 \mathrm{~s}$ (tempo de recuperação).

Neste mesmo estudo, Bahia et al. (2001) observaram que o RCRT soluciona dois problemas fundamentais vinculados ao parâmetro $\mathrm{G}^{*}$ /senঠ, sendo eles: (1) o parâmetro é derivado de respostas viscoelásticas lineares medidas após poucos ciclos de carregamento, o que não permite a avaliação do comportamento dos ligantes asfálticos aos danos sofridos durante o ensaio; e (2) ele é derivado de carregamentos cíclicos reversíveis, os quais não indicam adequadamente o acúmulo de deformação permanente do ligante asfáltico durante um carregamento de fluência repetida e não possibilitam uma medição direta deste tipo de deformação. Segundo Anderson et al. (2010) e Asphalt Institute (2010a), o RCRT foi baseado em um ensaio de caracterização do desempenho de misturas asfálticas à deformação permanente, designado como ensaio de cisalhamento repetido simplificado com altura constante ("repeated simple shear test at constant height" - RSST-CH) e no qual a amostra é submetida a ciclos repetidos de $0,1 \mathrm{~s}$ de carregamento e $0,6 \mathrm{~s}$ de repouso. Um exemplo de gráfico do RCRT é apresentado na Figura 1.

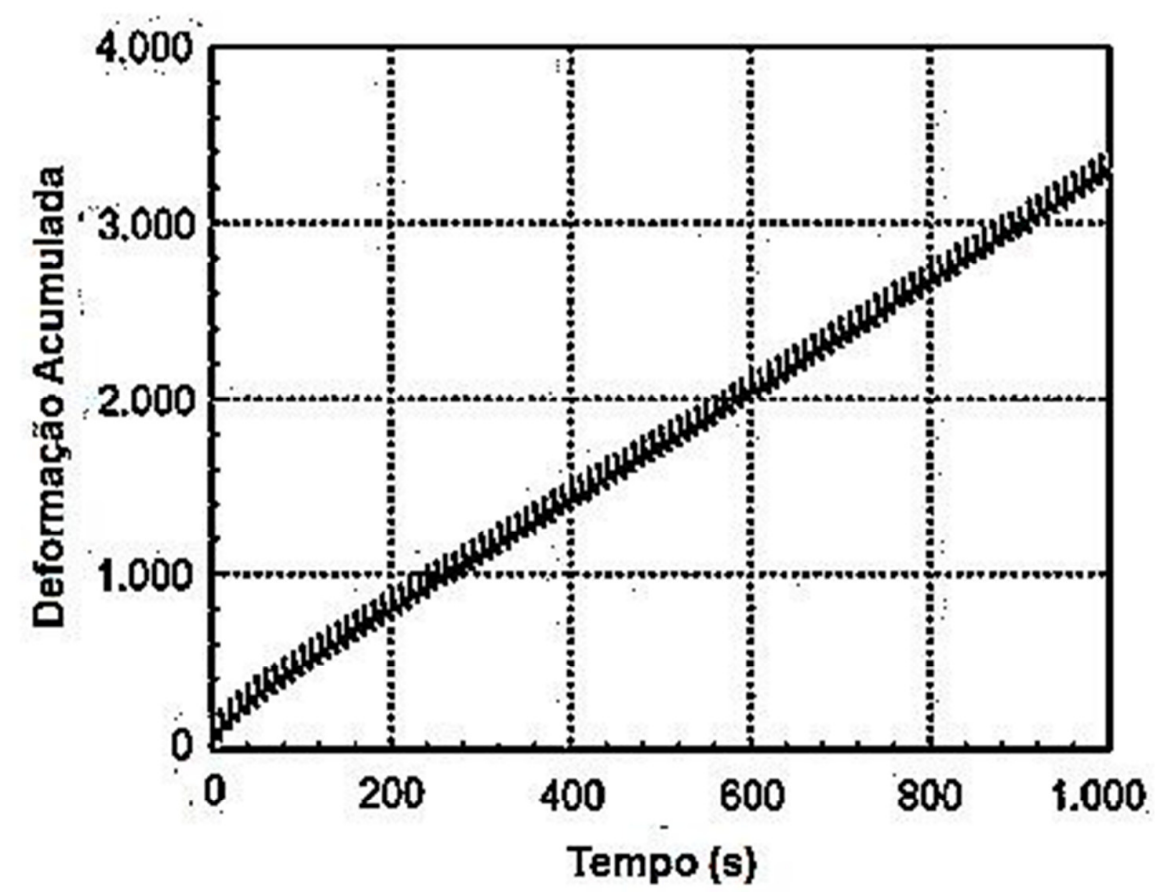

Figura 1- Deformações acumuladas a $6.400 \mathrm{~Pa}$ e $46^{\circ} \mathrm{C}$ para um ligante asfáltico modificado com SBS e PG 70-28 [Adaptado de Delgadillo et al. (2006)] 
Estudos envolvendo o RCRT e a deformação permanente de misturas asfálticas foram realizados por Delgadillo et al. (2006) dentre outros pesquisadores, os quais observaram que, considerando as limitações dos resultados, a deformação acumulada medida no RCRT fornece uma boa indicação da deformação permanente da mistura asfáltica após um número determinado de ciclos. Bahia et al. (2001) obtiveram conclusões similares em uma avaliação geral dos resultados de laboratório, mas destacam que as correlações são diferentes de acordo com o tipo de agregado utilizado na mistura asfáltica, uma vez que os agregados possuem influência significativa no comportamento das misturas asfálticas à deformação permanente. Assim, as correlações obtidas são boas para alguns tipos de agregados e ruins para outros, como observado nos estudos destes autores.

Outra solução é a apresentada por Bouldin et al. (2001), os quais utilizaram o RCRT em estudos anteriores para coletar dados de resistência de ligantes asfálticos à deformação permanente e, com base nestes resultados, elaboraram um modelo do tipo semi-empírico para refinar o parâmetro $\mathrm{G}^{\star} / \mathrm{sen} \delta$. Esta foi a abordagem considerada porque, segundo os autores, seria uma forma mais apropriada de considerar a influência do ângulo de fase na deformação acumulada do ligante asfáltico. O modelo é baseado nos pressupostos de que, sob valores apropriados de temperatura e de taxa de cisalhamento, a taxa de deformação acumulada depende da rigidez do ligante asfáltico e da contribuição visco elástica $f(\delta)$ e que as duas contribuições são independentes entre si. O melhor ajuste dos dados foi obtido por meio da função hiperbólica expressa na Equação 4:

$$
\left(\gamma_{p e r}\right)^{-1}=k \cdot G^{*} \cdot\left\{Y_{0}+a \cdot\left[1-\frac{1}{\left[\frac{\left|\left(\delta-X_{0}+b \cdot \ln (2)^{\frac{1}{c}}\right)\right|}{b}\right]}\right]\right\}
$$

onde $Y_{\text {per }}$ é a deformação permanente, $k$ é uma constante e $Y_{0}, X_{0}, a$, b e c são parâmetros empíricos de regressão. Os autores argumentam que a Equação 4 pondera melhor o efeito do ângulo de fase sobre a deformação permanente do ligante asfáltico que o parâmetro $\mathrm{G}^{*} / \mathrm{sen}$, uma vez que este último utiliza apenas o termo (1/senঠ) como a função de ponderação do ângulo de fase. Entretanto, esta solução não se mostrou ideal para substituir o parâmetro G*/senঠ porque, segundo Shenoy (2001), seus parâmetros empíricos provavelmente serão diferentes se mais dados forem analisados ou se dados experimentais de réplicas forem utilizados no lugar daqueles das amostras originais, o que limita a utilidade da equação. 
Outra solução é a apresentada por Dongré et al. (2004), os quais desenvolveram um estudo para avaliar a possibilidade de adoção da viscosidade de armazenamento do ligante asfáltico ( $\eta$ '), calculada pela razão entre o valor de G" e a frequência angular $\omega$, como o parâmetro de especificação dos ligantes asfálticos em temperaturas altas. Esta avaliação consistia em determinar se os valores de n' à frequência angular de 0,01 rad/s apresentavam uma boa correlação com os desempenhos, quanto à deformação permanente, de misturas asfálticas ensaiadas em laboratório. Ao final do estudo, os autores concluíram que a correlação entre as deformações acumuladas de algumas misturas asfálticas ensaiadas e os valores de n' era razoável e, portanto, o valor de n' poderia substituir o parâmetro G*/senঠ com certa razoabilidade. Neste novo critério, a temperatura máxima de especificação dos ligantes asfálticos foi estipulada pelos autores como aquela na qual n' $=220$ Pa.s, obtido pela divisão do valor-limite para os ligantes asfálticos envelhecidos a curto prazo (2.200 Pa) pela frequência angular utilizada no ensaio da especificação Superpave (10 rad/s).

Esta solução, entretanto, foi criticada por Aroon Shenoy (da discussão em DONGRÉ et al. 2004), o qual questionou os conceitos utilizados por Dongré et al. (2004) para sugerir a utilização de n' como critério de especificação de temperaturas altas do Superpave. Segundo este pesquisador, a principal diferença entre os ligantes asfálticos modificados com polímeros e os puros está principalmente na elasticidade reforçada dos materiais modificados e, por consequência, um futuro substituto do parâmetro $G^{*} /$ senঠ deve justamente realçar estes efeitos da elasticidade proporcionada pela adição de polímeros e não, como é o caso de n', diminuí-los. Além disso, são também questionadas as taxas de cisalhamento e as frequências utilizadas por Dongré et al. (2004), que seriam extremamente baixas se comparadas aos valores reais de campo e, portanto, incompatíveis com a realidade.

Em resposta às críticas de Aroon Shenoy, Dongré et al. (2004) argumentaram que a viscosidade de armazenamento do ligante asfáltico foi escolhida porque, em teoria, poderia facilmente identificar a presença e o impacto da adição de polímeros nas propriedades reológicas dos ligantes asfálticos, além da facilidade em determiná-la com o emprego dos métodos e "softwares" existentes atualmente. Segundo os autores, poucos dados estavam disponíveis quando da conclusão do programa SHRP em verificar a habilidade do parâmetro G*/senర̄ na previsão do desempenho de ligantes asfálticos modificados com polímeros ou de outros ligantes asfálticos com ângulo de fase inferior a $80^{\circ}$. Ainda segundo Dongré et al. (2004), não se deve apenas enfatizar valores baixos de ângulo de fase para os ligantes asfálticos quando se está desenvolvendo uma nova especificação, pois esta atitude pode acarretar uma especificação que superestima o desempenho dos ligantes asfálticos e, desta maneira, produzir materiais extremamente elásticos e pouco resistentes. 


\subsection{O ensaio de fluência e recuperação sob tensão múltipla (MSCR)}

\subsubsection{Desenvolvimento, características e propriedades obtidas}

O ensaio MSCR foi desenvolvido pela Administração Rodoviária Federal dos Estados Unidos por meio de um aperfeiçoamento do RCRT, sendo uma alternativa ao ensaio do Superpave em regime oscilatório para a caracterização da resistência dos ligantes asfálticos à deformação permanente. No MSCR, utiliza-se o reômetro de cisalhamento dinâmico (DSR) para aplicar uma carga constante de $1 \mathrm{~s}$ em uma amostra de ligante asfáltico, removendo-a em seguida e permitindo que o material repouse por um período de tempo de $9 \mathrm{~s}$. Este ciclo é repetido por 10 vezes em 11 níveis diferentes de tensão, sem intervalos de tempo entre um nível e outro. Os níveis variam de 25 a $25.600 \mathrm{~Pa}$ e foram implantados pelo FHWA com os objetivos de verificar a dependência dos ligantes asfálticos à tensão e reduzir o número necessário de amostras (D’ANGELO et al., 2007). Na norma ASTM D7405, o número de níveis foi reduzido para apenas dois valores (100 e $3.200 \mathrm{~Pa}$ ) como exemplificado na Figura 2, sendo que os tempos de carregamento e de repouso e o número de ciclos em cada nível de tensão foram mantidos.

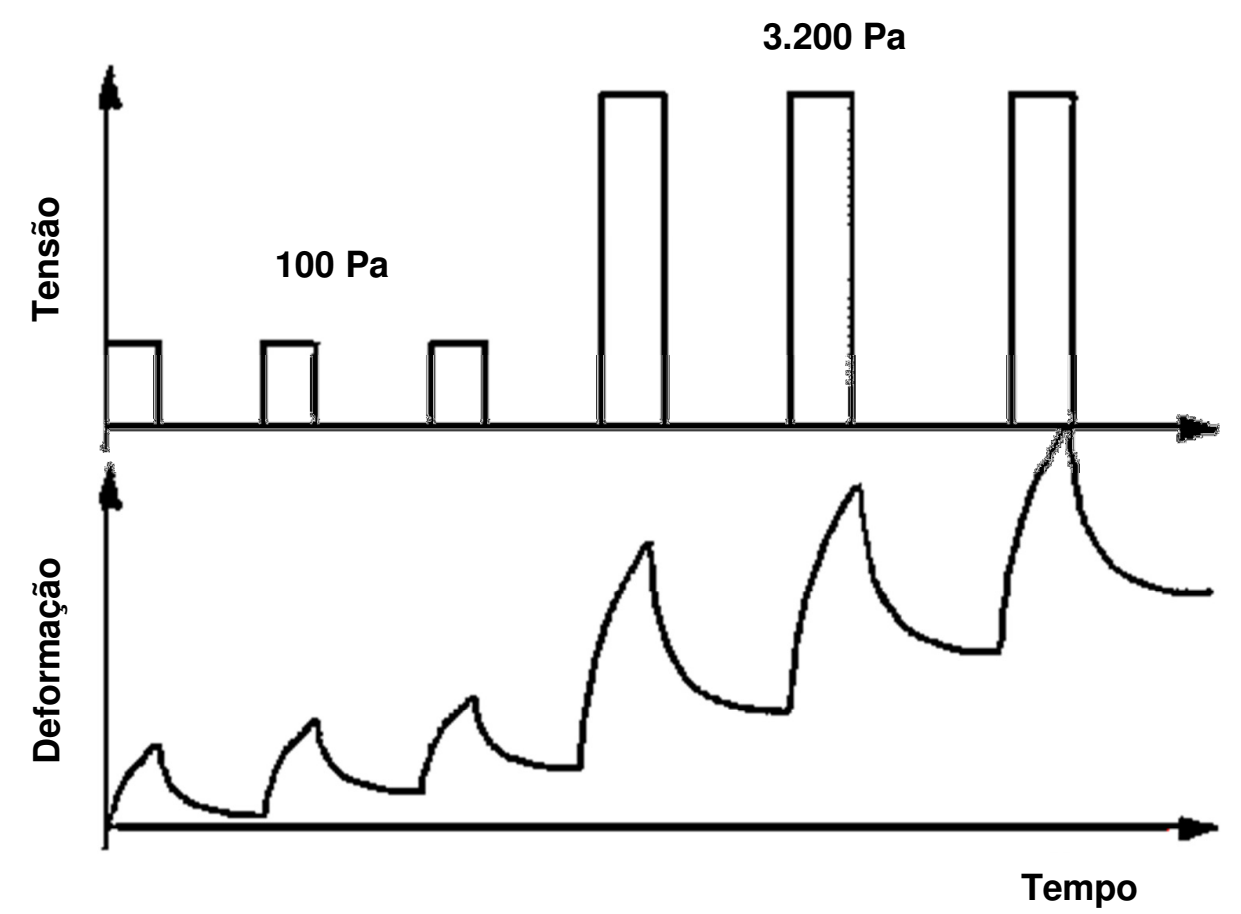

Figura 2 - Representação das tensões e deformações durante a realização do ensaio MSCR [Adaptado de D'Angelo e Dongré (2009)] 
Duas propriedades são obtidas no MSCR: o percentual de recuperação $(R)$ e a compliância não-recuperável $\left(\mathrm{J}_{\mathrm{nr}}\right)$. Ambas são determinadas por meio de três leituras de deformação na amostra de ligante asfáltico em cada um dos 10 ciclos de fluência e recuperação, sendo elas: (1) uma no início do ciclo de fluência $\left(\varepsilon_{0}\right)$, medida no tempo de $0 \mathrm{~s}$; (2) outra no final do ciclo de fluência $\left(\varepsilon_{c}\right)$, medida no tempo de $1 \mathrm{~s}$; e (3) outra no final do ciclo de recuperação $\left(\varepsilon_{\mathrm{r}}\right)$, medida no tempo de $10 \mathrm{~s}$. A Figura 3 ilustra a localização destas deformações em um ciclo de fluência e recuperação.

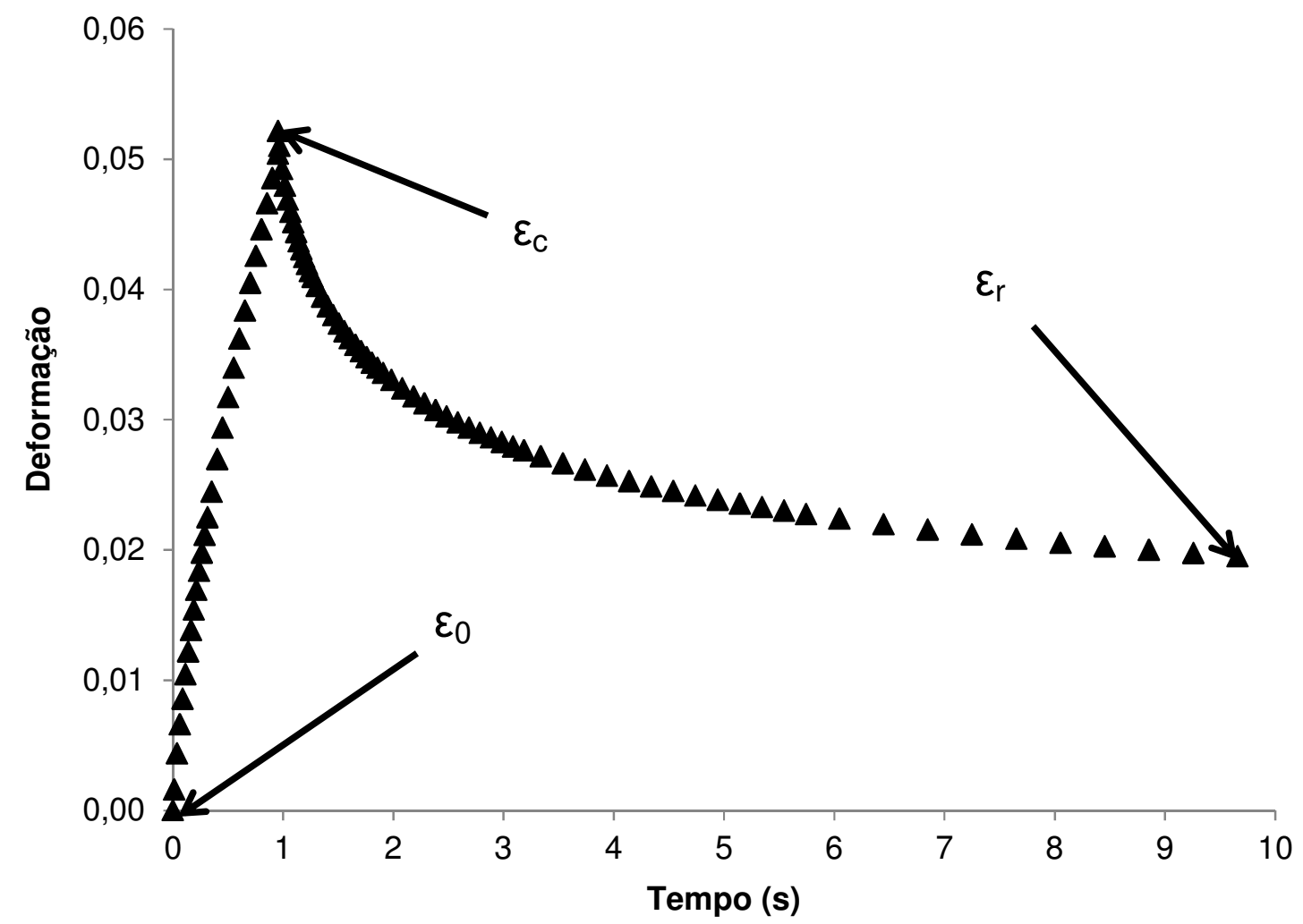

Figura 3 - Localização das deformações $\varepsilon_{0}$, $\varepsilon_{c}$ e $\varepsilon_{r}$ em um ciclo de fluência e recuperação do ensaio MSCR

Os cálculos do percentual de recuperação e da compliância não-recuperável são realizados por meio de equações prescritas na norma ASTM D7405. No caso do percentual de recuperação, este cálculo é efetuado por meio da Equação 5:

$$
R(\sigma, N)=\frac{\left[\left(\varepsilon_{c}-\varepsilon_{0}\right)-\left(\varepsilon_{r}-\varepsilon_{0}\right)\right] \cdot 100}{\varepsilon_{c}-\varepsilon_{0}}
$$

onde $R(\sigma, N)$ é o percentual de recuperação na tensão $\sigma$ (para $\sigma=100 \mathrm{~Pa}$ ou $3.200 \mathrm{~Pa}$ ) para o ciclo de fluência e recuperação número $\mathrm{N}$ (onde $1 \leq \mathrm{N} \leq 10$ ). No caso da compliância não-recuperável, este cálculo é efetuado por meio da Equação 6: 


$$
J_{n r}(\sigma, N)=\frac{\varepsilon_{r}-\varepsilon_{0}}{\sigma}
$$

onde $J_{n r}(\sigma, N)$ é a compliância não-recuperável na tensão de $\sigma \mathrm{Pa}$ e no ciclo de fluência e recuperação número $\mathrm{N}$, para $\sigma$ e $\mathrm{N}$ apresentando os mesmos valores mencionados anteriormente ( $\sigma=100$ ou $3.200 \mathrm{~Pa}$ e $1 \leq \mathrm{N} \leq 10$ ). De posse de todos os valores individuais de $R(\sigma, N)$ e $J_{n r}(\sigma, N)$ nos 10 ciclos de fluência e recuperação, seus resultados médios são calculados por meio da média aritmética simples dos valores obtidos nestes 10 ciclos (ANDERSON et al., 2010), em cada uma das temperaturas de realização do ensaio MSCR.

Com a determinação de todos os valores individuais e médios dos percentuais de recuperação e das compliâncias não-recuperáveis do ligante asfáltico em estudo, o comportamento fluência-recuperação do material pode ser determinado e avaliado. A avaliação deste tipo de comportamento permite, como observado por Bahia et al. (2001) em seus estudos com o RCRT, uma diferenciação mais adequada dos comportamentos dos ligantes asfálticos modificados por meio dos valores de deformação acumulada com o tempo. Para ligantes asfálticos modificados com polímeros e submetidos a níveis elevados de tensão e de deformação, visualiza-se que estes modificadores apresentam um comportamento do tipo não-linear, o que pode ser explicado pela formação de regiões vítreas e cristalinas em seu interior e pelo emaranhamento de suas cadeias internas (D'ANGELO et al., 2007). Como consequência destes fenômenos, alterações na morfologia e nas propriedades físicas dos polímeros são verificadas.

Em uma modelagem matemática, a resposta de fluência e recuperação de materiais viscoelásticos é tipicamente feita por meio do modelo de Burgers, o qual combina, em série, um modelo de Kelvin-Voigt e um modelo de Maxwell (D’ANGELO et al., 2007). A vantagem da utilização desse modelo é a de que a resposta do material pode ser dividida em suas partes variadas para se estimar a componente viscosa, à qual se atribui a causa da deformação permanente, e o acúmulo desta deformação nas misturas empregadas em pavimentação (BAHIA et al., 2001). Nas modelagens realizadas por D’Angelo et al. (2007), observou-se que os ligantes asfálticos modificados com polímeros apresentam alterações nos parâmetros do modelo de Burgers com o aumento da tensão, o que indica um comportamento não-linear destes materiais. Neste mesmo estudo, D’Angelo et al. (2007) também observaram que os ligantes asfálticos puros possuem comportamento próximo ao Newtoniano, uma vez que os parâmetros de modelagem variaram pouco com o incremento do nível de tensão. 
2.2.2. Vantagens do ensaio MSCR em relação ao ensaio de regime oscilatório em temperaturas altas

O ensaio MSCR possui vantagens em comparação ao parâmetro $G^{*} / \operatorname{sen} \delta$, ao ensaio da especificação Superpave em regime oscilatório e às outras sugestões propostas pelos pesquisadores. Uma delas está na possibilidade de avaliação da dependência dos ligantes asfálticos modificados com polímeros quanto à tensão, o que não é possível de ser feito em outros ensaios porque estes são executados na faixa de comportamento viscoelástico linear dos ligantes asfálticos. O conhecimento desta dependência é extremamente importante para a caracterização adequada dos ligantes asfálticos, especialmente daqueles modificados com polímeros, uma vez que estes modificadores apresentam uma resposta mais complexa às tensões e deformações elevadas (D'ANGELO et al., 2007).

Outra vantagem reside no valor de $\mathrm{J}_{\mathrm{nr}}$, o qual tem proporcionado correlações melhores com as deformações permanentes de pistas experimentais de campo ou de laboratório em relação ao parâmetro $\mathrm{G}^{*} / \operatorname{sen} \delta$, como mostrado em estudos de muitos pesquisadores (D'ANGELO et al., 2007; D'ANGELO, 2008; DREESSEN et al., 2009; D’ANGELO, 2010a). Estes resultados ocorreram porque o parâmetro atual de deformação permanente $\mathrm{G}^{*}$ /senס não representa, de maneira adequada, a habilidade de alguns ligantes asfálticos modificados com polímeros em resistir à deformação permanente. Esta deficiência é atribuída, dentre outros fatores, aos níveis baixos de tensão e de deformação aplicados durante o ensaio de regime oscilatório, fazendo com que a rede polimérica presente no ligante asfáltico nunca seja realmente ativada. Em virtude das condições do ensaio de regime oscilatório, o polímero é visualizado apenas como um fíler que enrijece o ligante asfáltico (ANDERSON et al., 2010; D’ANGELO, 2010a).

Uma terceira vantagem do MSCR está na não necessidade de elevação de temperatura para o caso de ligantes asfálticos utilizados em carregamentos de baixa velocidade e altos volumes de tráfego. Esta elevação, chamada de "grade-bumping" e descrita como um método artificial de se ajustar às situações extremas de tráfego, consiste na escolha de ligantes asfálticos com grau de desempenho maior do que o prescrito pelas temperaturas reais, mesmo que a temperatura do pavimento nunca atinja o valor máximo da classificação escolhida. No caso do MSCR, a temperatura de ensaio não depende das condições de carregamento e de volume de tráfego porque ela é selecionada com base nos valores reais de temperaturas altas do pavimento (ANDERSON et al., 2010). Como uma alternativa ao "grade-bumping", D’Angelo et al. (2007) sugerem a utilização de um 
nível de tensão maior para a classificação do ligante asfáltico submetido a estas condições extremas, o que seria uma condição mais próxima da que realmente ocorre nos pavimentos em serviço.

Além destas vantagens, os resultados obtidos no MSCR podem ser utilizados tanto para os ligantes asfálticos puros quanto os modificados, o que elimina a necessidade de ensaios adicionais para a caracterização adequada do desempenho de ligantes asfálticos modificados em temperaturas altas. A recuperação do material medida no MSCR também é mais fácil e rápida de ser obtida do que em ensaios como a recuperação elástica, além de fornecer uma melhor caracterização dos ligantes asfálticos modificados com polímeros. Em complemento, a aplicação do MSCR traz consigo um critério que permite a eliminação de ligantes asfálticos muito sensíveis à tensão, os quais podem ser suscetíveis à deformação permanente mesmo que tenham passado nos critérios da classificação PG (ANDERSON et al., 2010; ASPHALT INSTITUTE, 2010a).

\subsubsection{Novo critério para caracterização da resistência dos ligantes asfálticos à deformação permanente}

Em decorrência dos estudos envolvendo o MSCR, uma nova classificação dos ligantes asfálticos foi desenvolvida. Nela, os ligantes asfálticos são classificados em quatro níveis diferentes de acordo com o valor de $\mathrm{J}_{\mathrm{nr}}$, considerando materiais em sua condição envelhecida a curto prazo (RTFOT). Cada nível representa um tipo de carregamento do tráfego (volume e/ou velocidade) adequado ao material e as designações são feitas pelas letras S (padrão), H (pesado), V (muito pesado) e $E$ (extremamente pesado), conforme Tabela 1. Como um exemplo, um ligante asfáltico envelhecido a curto prazo e de classificação PG 64-22 poderia ser classificado como PG 64S-22, PG 64H-22, PG 64V-22 ou mesmo PG 64E-22, dependendo do seu valor de $J_{n r}$ a 3.200 Pa na temperatura de $64^{\circ} \mathrm{C}$. Para situações de tráfego mais pesado como carregamentos de velocidade baixa ou volumes de tráfego elevados, a consideração é feita por meio da redução do valor máximo de $J_{n r}$ do ligante asfáltico, resultando em um material mais rígido e, por consequência, menos suscetível à deformação permanente.

Embora a compliância não-recuperável seja a propriedade representativa da suscetibilidade do ligante asfáltico à deformação permanente, valores mínimos do percentual de recuperação são recomendados para os ligantes asfálticos de acordo com o valor desta 
compliância (Tabela 2). Os materiais que apresentam $\mathrm{J}_{\mathrm{nr}}>2,0 \mathrm{kPa}^{-1}$ não são considerados nestas recomendações, ou seja, não há um valor mínimo de $\mathrm{R}$ recomendado para tais ligantes asfálticos. De acordo com Anderson et al. (2010) e com Asphalt Institute (2010a), o percentual de recuperação fornece uma indicação da resposta elástica retardada do ligante asfáltico, de modo que valores elevados para esta propriedade sinalizam uma componente elástica significativa no material na temperatura de realização do ensaio MSCR.

Tabela 1 - Classificação dos ligantes asfálticos quanto ao valor de $\mathrm{J}_{\mathrm{nr}}$ de acordo com o

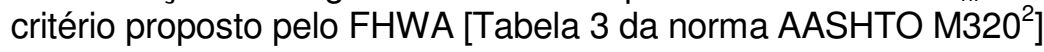

\begin{tabular}{cccc}
\hline Propriedade & $\begin{array}{c}\text { Valor máximo } \\
\left(\text { em } \mathrm{kPa}^{-1}\right)\end{array}$ & Tipo de tráfego & $\begin{array}{c}\text { Número de passadas } \\
\text { de um eixo padrão } \\
\text { simples (ESAL) }\end{array}$ \\
\hline & 4,0 & Padrão $(\mathrm{S})$ & $<10$ milhões \\
$\mathrm{J}_{\mathrm{nr}}$ a 3.200 Pa e & 2,0 & Pesado $(\mathrm{H})$ & $>10$ milhões \\
na temperatura & 1,0 & Muito Pesado $(\mathrm{V})$ & $>30$ milhões \\
máxima do PG & 0,5 & Extremamente Pesado $(\mathrm{E})$ & $>100$ milhões \\
\hline
\end{tabular}

Tabela 2 - Valores recomendados para o percentual de recuperação de acordo com o critério proposto pelo FHWA [D’Angelo (2010a)]

\begin{tabular}{cc}
\hline $\begin{array}{c}\text { Compliância não-recuperável a } \\
\text { 3.200 Pa (em kPa-1) }\end{array}$ & $\begin{array}{c}\text { Percentual de recuperação } \\
\text { mínimo (em \%) }\end{array}$ \\
\hline 1,01 a 2,00 & 30 \\
0,51 a 1,00 & 35 \\
0,251 a 0,50 & 45 \\
0,125 a 0,25 & 50 \\
\hline
\end{tabular}

Além do formato tabular, os valores mínimos do percentual de recuperação também podem ser apresentados na forma gráfica, como mostrado na Figura 4. Os ligantes asfálticos com pares ordenados $\left(J_{n r}, R\right)$ acima da curva são considerados de alta elasticidade, ao passo que aqueles com pares ordenados $\left(\mathrm{J}_{\mathrm{nr}}, \mathrm{R}\right)$ abaixo da curva são considerados de baixa elasticidade. Em uma comparação com os resultados da Tabela 2, a zona de alta elasticidade seria aquela na qual o valor de $\mathrm{R}$ é superior ao mínimo recomendado para um determinado valor de $J_{n r}$ e, da mesma maneira, a zona de baixa elasticidade é aquela na qual o valor de $R$ é inferior ao mínimo recomendado para um determinado valor de $J_{n r}$. A interrupção da curva em $J_{\mathrm{nr}}=2,0 \mathrm{kPa}^{-1}$ significa que não há qualquer recomendação de percentual mínimo de recuperação para os ligantes asfálticos com valores de $J_{n r}$ superiores a 2,0 $\mathrm{kPa}^{-1}$.

\footnotetext{
${ }^{2}$ AMERICAN ASSOCIATION OF STATE HIGHWAY AND TRANSPORTATION OFFICALS. AASHTO M320: Standard Specification for Performance-Graded Asphalt Binder. Washington, D.C.
} 


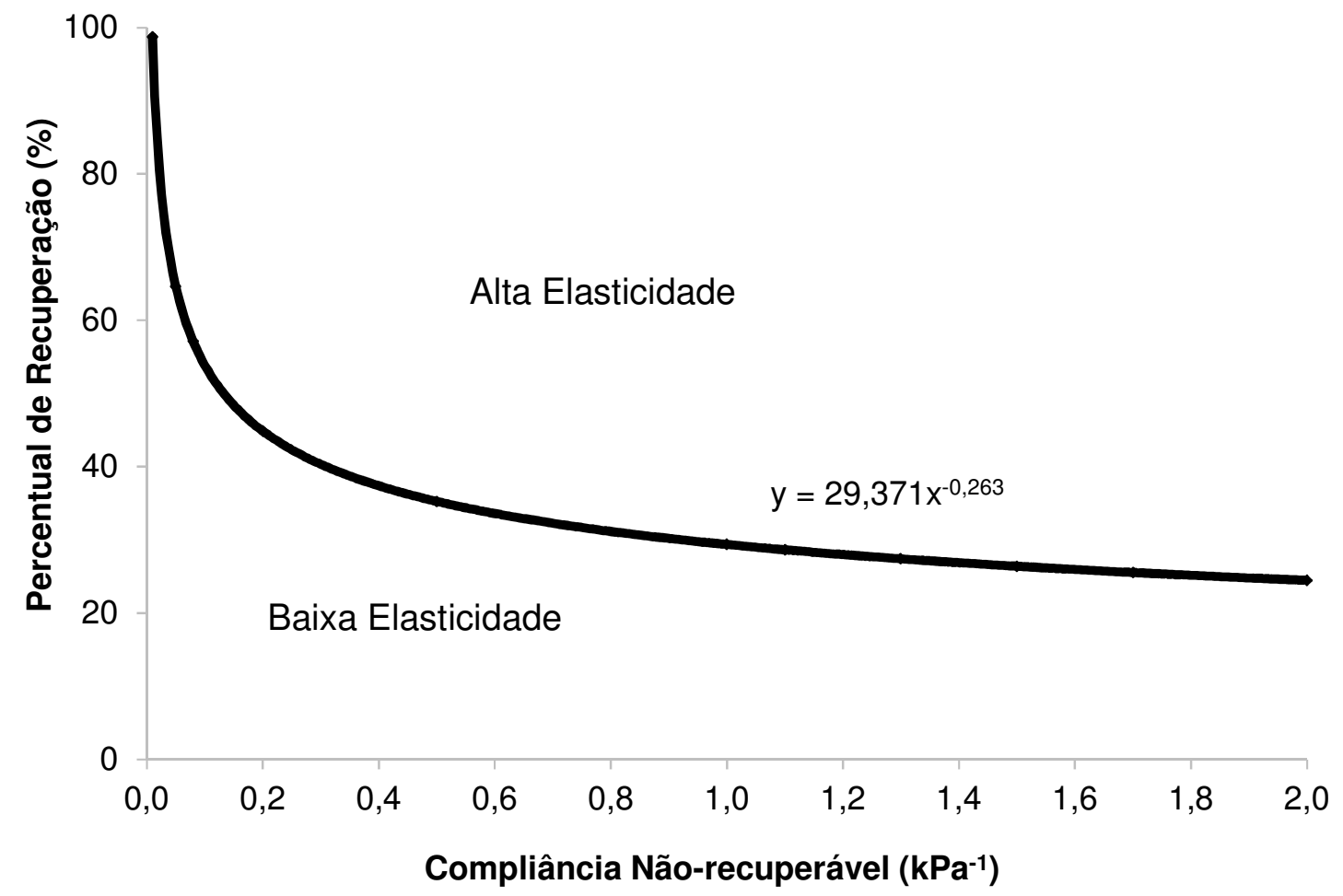

Figura 4- Relação entre as compliâncias não-recuperáveis e os percentuais de recuperação a 3.200 Pa [Adaptado de Anderson (2010)]

Apesar de o novo critério de resistência dos ligantes asfálticos à deformação permanente levar em consideração a compliância não-recuperável a $3.200 \mathrm{~Pa}$, o valor desta mesma propriedade a $100 \mathrm{~Pa}$ também é importante. A fim de assegurar que o material não seja demasiadamente sensível a mudanças no nível de tensão, a relação entre as compliâncias não-recuperáveis a 100 Pa (Jnr100) e a 3.200 Pa (Jnr3200),

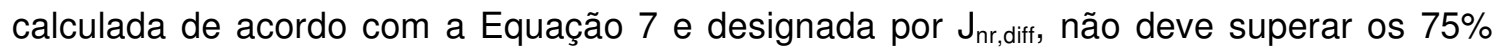
(ANDERSON et al., 2010; ASPHALT INSTITUTE, 2010a, 2010b). De acordo com Asphalt Institute (2010a), estas mudanças contemplam os carregamentos elevados não previstos e a ocorrência de temperaturas maiores que as esperadas para o pavimento.

$$
J_{n r, \text { diff }}=\left(\frac{J n r 3200-J n r 100}{J n r 100}\right) \cdot 100
$$

Como observado acima, o novo critério de resistência dos ligantes asfálticos à deformação permanente apresenta vantagens em relação ao critério original da especificação Superpave. Uma delas está na não elevação da temperatura do PG do ligante asfáltico, de modo que o material não tem sua temperatura máxima alterada por conta dos fatores de tráfego. Outra vantagem, relacionada à primeira, está na consideração dos 
carregamentos de tráfego mais pesados, a qual é feita de uma maneira mais próxima daquela que realmente ocorre nos pavimentos e não por meio de ajustes simplificados para a obtenção de ligantes asfálticos mais rígidos. De acordo com D’Angelo (2010b), a deformação permanente é um fenômeno não-linear de tensões e deformações elevadas e, assim, a consideração de temperaturas muito superiores à prevista acarreta resultados incompatíveis com o desempenho do ligante asfáltico em campo.

\subsubsection{Comentários adicionais sobre o ensaio MSCR}

Uma vez que as condições de realização do MSCR são diferentes das observadas em outros ensaios, correlações boas entre os resultados não devem ser esperadas pelos pesquisadores. Como um exemplo, Dreessen et al. (2009) avaliaram as correlações entre a compliância não-recuperável a $25.600 \mathrm{~Pa}$ e $60^{\circ} \mathrm{C}$ e duas propriedades tradicionais dos ligantes asfálticos, sendo elas a penetração (PEN) e o ponto de amolecimento (PA). Os autores observaram que não há qualquer correlação entre as propriedades e que ligantes asfálticos com o mesmo valor de PEN ou de PA podem apresentar valores de $J_{n r}$ diferentes entre si, o que mostra a capacidade da compliância não-recuperável em realizar esta distinção. A mesma observação é feita por D’Angelo et al. (2007), os quais atribuem esta capacidade à normalização da resposta de deformação dos ligantes asfálticos pela tensão aplicada.

Em relação aos tempos de fluência e recuperação, a norma ASTM D7405 contempla os valores de $1 \mathrm{~s}$ para o carregamento e $9 \mathrm{~s}$ para a recuperação do ligante asfáltico. Entretanto, outros tempos também devem ser levados em consideração nas pesquisas, pois enquanto alguns tipos de polímeros continuam a sofrer recuperação após $9 \mathrm{~s}$, outros podem ter sua recuperação finalizada antes deste período e, assim, as avaliações dos resultados dos estudos poderão ser diferentes se tempos diferentes são levados em consideração (Y. Richard Kim, da discussão em D'ANGELO et al., 2007). Em resposta ao comentário feito por Y. Richard Kim, John D'Angelo (da discussão em D'ANGELO et al., 2007) afirma que a escolha do tempo de $9 \mathrm{~s}$ para a recuperação no MSCR foi tomada com o intuito de evitar um ensaio excessivamente longo, embora se saiba que a obtenção de uma recuperação completa do ligante asfáltico em $9 \mathrm{~s}$ não é possível. Ainda de acordo com este pesquisador, os critérios do MSCR são razoavelmente bons quando se busca apenas uma classificação mais adequada dos ligantes asfálticos quanto à propensão à deformação permanente. 
Embora os benefícios do MSCR já tenham sido observados em diversos estudos, pesquisas adicionais sobre este ensaio ainda precisam ser realizadas com 0 objetivo de sanar eventuais dúvidas dos pesquisadores. Um exemplo de estudo em andamento é a pesquisa de Abadie e Kabir (em fase de elaboração) ${ }^{3}$, os quais desejam avaliar a viabilidade da incorporação do MSCR na especificação de ligantes asfálticos do Departamento de Transportes e Desenvolvimento do estado da Louisiana (EUA) e, em complemento, a existência ou não de correlações entre os resultados deste ensaio e os de outros ensaios.

\subsection{Temperaturas de usinagem e de compactação dos ligantes asfálticos}

A viscosidade rotacional dos ligantes asfálticos, além de ser utilizada como propriedade de controle na formulação destes materiais, também é empregada na estimativa das temperaturas de usinagem e de compactação da massa asfáltica. Tal estimativa é feita com base em intervalos equidistantes de temperatura, com o propósito de normalizar o efeito da rigidez do ligante asfáltico nas propriedades volumétricas da mistura asfáltica. Em geral, estas temperaturas são indicadas em faixas de 5 a $7^{\circ} \mathrm{C}$ e os procedimentos de usinagem e de compactação são realizados em temperaturas próximas ao valor médio destas faixas (ASPHALT INSTITUTE ONLINE, 2003). De acordo com o manual de projeto de misturas asfálticas do Superpave, a temperatura apropriada de usinagem é aquela na qual o ligante asfáltico apresenta uma viscosidade Brookfield de 0,17 $\pm 0,02$ Pa.s, enquanto que a temperatura de compactação é aquela em que o ligante asfáltico apresenta uma viscosidade Brookfield de 0,28 \pm 0,03 Pa.s. Estes valores são tradicionalmente aplicados a ligantes asfálticos não-modificados e têm sido utilizados também na determinação das temperaturas de usinagem e de compactação dos materiais modificados.

Além destes limites tradicionais, outras relações também são utilizadas para se estimar as temperaturas de usinagem e de compactação de ligantes asfálticos modificados. No caso do ligante asfalto-borracha moída, por exemplo, a Especificação de Serviço 112/2009 do DNIT menciona que a temperatura de aquecimento deve estar entre $170^{\circ} \mathrm{C}$ e $180^{\circ} \mathrm{C}$ e que a temperatura mínima recomendável para a compactação é de

\footnotetext{
${ }^{3}$ ABADIE, C.; KABIR, S. Validity of Multiple Stress Creep Recovery Test for DOTD Asphalt Binder Specification. A ser editado por Transportation Research Board, 2012.
} 
$145^{\circ} \mathrm{C}$. No caso dos materiais modificados com polímeros, por exemplo, a Especificação de Serviço 385/1999 do DNIT menciona que a temperatura conveniente para aquecimento do material é de $150^{\circ} \mathrm{C}$ acrescida de $3^{\circ} \mathrm{C}$ para cada $1 \%$ de estireno-butadieno-estireno (SBS) até um limite máximo de $180^{\circ} \mathrm{C}$, com a temperatura recomendável para a compactação sendo de $140^{\circ} \mathrm{C}$ acrescida de $3^{\circ} \mathrm{C}$ para cada $1 \%$ de SBS.

A determinação das temperaturas de usinagem e de compactação dos ligantes asfálticos também pode ser realizada por meio do DSR. Neste método, conhecido como método Casola, é realizada uma varredura de frequência de 0,001 a $100 \mathrm{rad} / \mathrm{s}$ em uma faixa de temperaturas que varia de acordo com o PG do ligante asfáltico, de modo a obter o ângulo de fase de $86^{\circ}$. O cálculo destas temperaturas (West et al., 2010) é feito de acordo com as Equações 8 e 9, em que TC é a temperatura de compactação (em $\left.{ }^{\circ} \mathrm{F}\right)$, TU é a temperatura de usinagem (em ${ }^{\circ} \mathrm{F}$ ) e $\omega$ é a frequência, em $\mathrm{rad} / \mathrm{s}$, correspondente ao ângulo de fase de $86^{\circ}$.

$$
\begin{gathered}
T C=300 .(\omega)^{-0,012} \\
T U=325 .(\omega)^{-0,0135}
\end{gathered}
$$

Embora o método tradicional forneça temperaturas razoáveis de usinagem e de compactação para os ligantes asfálticos não-modificados, para os quais foi desenvolvido, o mesmo pode não ocorrer com os ligantes asfálticos modificados. Para estes materiais, os cálculos das temperaturas em que as viscosidades são iguais a 0,17 $\pm 0,02$ Pa.s para usinagem e 0,28 \pm 0,03 Pa.s para compactação podem fornecer valores muito elevados, nos quais o ligante asfáltico não pode ser aquecido por conta de riscos à segurança dos operadores e problemas ambientais (YILDIRIM et al., 2000). Isto ocorre porque, diferentemente dos materiais puros, a viscosidade dos ligantes asfálticos modificados depende não apenas da temperatura, mas também da taxa de cisalhamento. Desta maneira, é necessária a compreensão do comportamento pseudoplástico dos ligantes asfálticos modificados no estudo da influência do comportamento reológico destes materiais sobre as temperaturas de usinagem e de compactação (KHATRI et al., 2001).

Estudos como os de Yildirim et al. (2000) levaram em consideração o efeito da pseudoplasticidade dos ligantes asfálticos modificados sobre as temperaturas de usinagem e de compactação de misturas asfálticas e observou-se que, ao considerar a taxa de cisalhamento sofrida pelo material durante o processo de compactação, as 
temperaturas de processamento podem ser reduzidas de 10 a $40^{\circ} \mathrm{C}$. Em outro estudo, Yildirim et al. (2006) compararam as faixas de temperaturas de usinagem e de compactação obtidas pelo método tradicional e as calculadas para uma taxa de cisalhamento maior $\left(500 \mathrm{~s}^{-1}\right)$ e para uma faixa diferente de viscosidades $(0,275 \pm 0,03$ Pa.s para a usinagem e 0,550 \pm 0,06 Pa.s para a compactação) e concluíram que, em relação aos valores obtidos pelo método tradicional, as temperaturas de processamento diminuíram de 13 a $52^{\circ} \mathrm{C}$ para os ligantes asfálticos considerados. A adoção de viscosidades mais elevadas para a usinagem e a compactação de muitos ligantes asfálticos modificados é compartilhada por Asphalt Institute Online (2003), o qual atribui esta possibilidade às características peculiares dos materiais modificados.

Em um estudo envolvendo o volume de vazios de misturas asfálticas preparadas no compactador giratório Superpave e a viscosidade de ligantes asfálticos convencionais e modificados, Khatri et al. (2001) observaram que as misturas compostas com ligantes asfálticos modificados possuíam volumes de vazios maiores do que as compostas com ligantes asfálticos convencionais. Estes autores correlacionaram o volume de vazios das misturas asfálticas e as viscosidades medidas a diversas taxas de cisalhamento e, a partir dos resultados, concluíram que a variabilidade do volume de vazios é mais bem explicada pela viscosidade medida a taxas de cisalhamento baixas. Segundo os autores, a viscosidade a taxas baixas pode combinar os efeitos da taxa de cisalhamento e da viscosidade sobre a compactação em apenas um indicador e, com seu uso, é possível tornar a determinação das temperaturas de processamento das misturas asfálticas independente do tipo de ligante asfáltico. Para casos em que a determinação das viscosidades dos ligantes asfálticos em taxas de cisalhamento baixas não é possível, o estudo sugere a utilização das faixas de viscosidade de 1,4 \pm 0,1 Pa.s para a compactação e de 0,75 \pm 0,1 Pa.s para a usinagem, ambas medidas com o "spindle" 27 e a 20 rpm, como uma simplificação promissora e uma boa aproximação.

\subsection{Exemplos de modificadores do ligante asfáltico}

Dentre os modificadores do ligante asfáltico, podem ser mencionados os polímeros dos mais diversos tipos e categorias. A utilização destes materiais na modificação de ligantes asfálticos vem consolidando-se como a melhor maneira para obter pavimentos de alto desempenho. A utilização de ligantes asfálticos modificados com polímeros em pavimentos faz com que estas estruturas possuam maiores resistências à deformação 
permanente e às trincas de origem térmica, bem como menores danos por fadiga e menores suscetibilidades ao descolamento do ligante asfáltico e à temperatura (YILDIRIM, 2007). Além destes benefícios, os ligantes asfálticos modificados com polímeros também permitem a utilização de técnicas de pavimentação antes consideradas inviáveis, tais como os microrrevestimentos e os tratamentos superficiais com emulsões asfálticas em rodovias com volumes elevados de tráfego (BECKER et al., 2001).

Estudos como os de King et al. (1999), Becker et al. (2001) e Yildirim (2007) apresentam descrições sobre alguns tipos de polímeros utilizados na modificação dos ligantes asfálticos. Dentre os polímeros abordados, dois deles são os mais utilizados nos processos de modificação: o copolímero de estireno-butadieno-estireno (SBS) e a borracha moída de pneus (BECKER et al., 2001). Outros, tais como o copolímero de etileno acetato de vinila (EVA), o polietileno (PE) e o Elvaloy, foram objeto de estudo de pesquisadores como Airey (2002), Polacco et al. (2004, 2005) e Kalantar et al. (2010), os quais avaliaram os efeitos da incorporação destes modificadores em propriedades tradicionais e reológicas do ligante asfáltico. Dentre os estudos realizados no Brasil e que envolvem um ou mais tipos de ligantes asfálticos modificados, podem-se mencionar os trabalhos de Leite (1999), Oda (2000), Bringel et al. (2005), Tomé et al. (2005) e Faxina (2006).

Em complemento aos polímeros, o ácido polisfosfórico (PPA) também pode ser utilizado na modificação dos ligantes asfálticos. Uma revisão bibliográfica realizada por Kodrat et al. (2007) aponta que o PPA pode ser empregado de três maneiras diferentes nestes processos de modificação: (1) como um catalisador na modificação dos ligantes asfálticos por sopragem ${ }^{4}$, permitindo a elevação do ponto de amolecimento sem reduzir excessivamente a penetração; (2) como um aditivo puro e sem a modificação do ligante asfáltico por sopragem, acarretando a elevação do grau de desempenho deste material; e (3) como um acelerador da reação química entre um terpolímero reativo ${ }^{5}$ e o ligante asfáltico, acarretando também a redução do teor de polímero. Quando utilizado em combinação com um polímero, Buncher (2005) menciona que o PPA fornece flexibilidade na obtenção das especificações de ensaio exigidas e, ao mesmo tempo, limita o incremento da viscosidade do ligante asfáltico na temperatura de $135^{\circ} \mathrm{C}$.

\footnotetext{
${ }^{4}$ Sopragem: Processo de modificação no qual o ligante asfáltico é submetido a um aquecimento e mistura na presença de um gás como o ar, o oxigênio ou o oxigênio e um gás inerte, podendo ou não haver um catalisador (GOODRICH, 1982).

5 Terpolímero reativo: Polímero formado por três monômeros diferentes e que, por conta da sua distribuição química, pode reagir com os asfaltenos do ligante asfáltico para formar um composto inseparável (BRINGEL et al., 2005).
} 
Os subitens 2.4.1 a 2.4.7 apresentam descrições de alguns tipos de modificadores e os efeitos de cada um deles em determinadas propriedades do ligante asfáltico, tendo como base os resultados de estudos laboratoriais. Em alguns casos, outros aspectos importantes dos ligantes asfálticos modificados também foram levados em consideração, caso da estabilidade à estocagem em temperaturas altas.

\subsubsection{Copolímero de estireno-butadieno-estireno (SBS)}

O SBS é descrito como um copolímero ${ }^{6}$ em bloco, cuja composição química é formada por um bloco de poliestireno quimicamente combinado com um bloco de polibutadieno e com outro de poliestireno (KING et al., 1999), como ilustrado na Figura 5. Quando em concentrações ideais no ligante asfáltico, geralmente de 5 a $7 \%$ em peso, há a formação de uma rede polimérica contínua em todo o ligante asfáltico modificado, alterando significativamente as propriedades do material. Uma vez que as massas moleculares das cadeias poliméricas são iguais ou maiores que as dos asfaltenos, ocorre uma competição entre ambos pelo poder solvente da fase maltênica do ligante asfáltico e, caso a quantidade de maltenos seja insuficiente, existe a possibilidade de uma separação de fases. Esta separação é um indicador da incompatibilidade entre o ligante asfáltico de base e o polímero, a qual pode ser melhorada pela adição de óleos aromáticos. Entretanto, uma quantidade excessiva destes óleos acarretará uma dissolução dos blocos de poliestireno e, em consequência, a perda dos benefícios da adição do SBS ao ligante asfáltico (AIREY, 2003).

Em decorrência da possibilidade de variações em itens como as massas moleculares e os comprimentos das cadeias dos blocos de estireno e de butadieno, existe uma variedade de copolímeros SBS utilizados na modificação de ligantes asfálticos. Estas variações influenciam na compatibilidade e nas propriedades físicas limites do ligante asfáltico modificado e, por consequência, no seu desempenho em campo (KING et al., 1999). A despeito das vantagens da incorporação do SBS ao ligante asfáltico, alguns autores alegam que o seu uso apresenta não apenas limitações econômicas, mas também técnicas. Algumas desvantagens relacionadas ao emprego

\footnotetext{
${ }^{6}$ Copolímero: Polímero formado por dois ou mais tipos diferentes de monômeros. Nos copolímeros aleatórios, os monômeros estão distribuídos aleatoriamente na cadeia polimérica. Nos copolímeros em bloco, um polímero constituído por um determinado tipo de monômero está unido quimicamente a um bloco de outro tipo de monômero (KING et al., 1999).
} 
deste copolímero incluem seu alto custo e sua baixa resistência ao calor e à oxidação em comparação aos poliolefinos (BECKER et al., 2001).

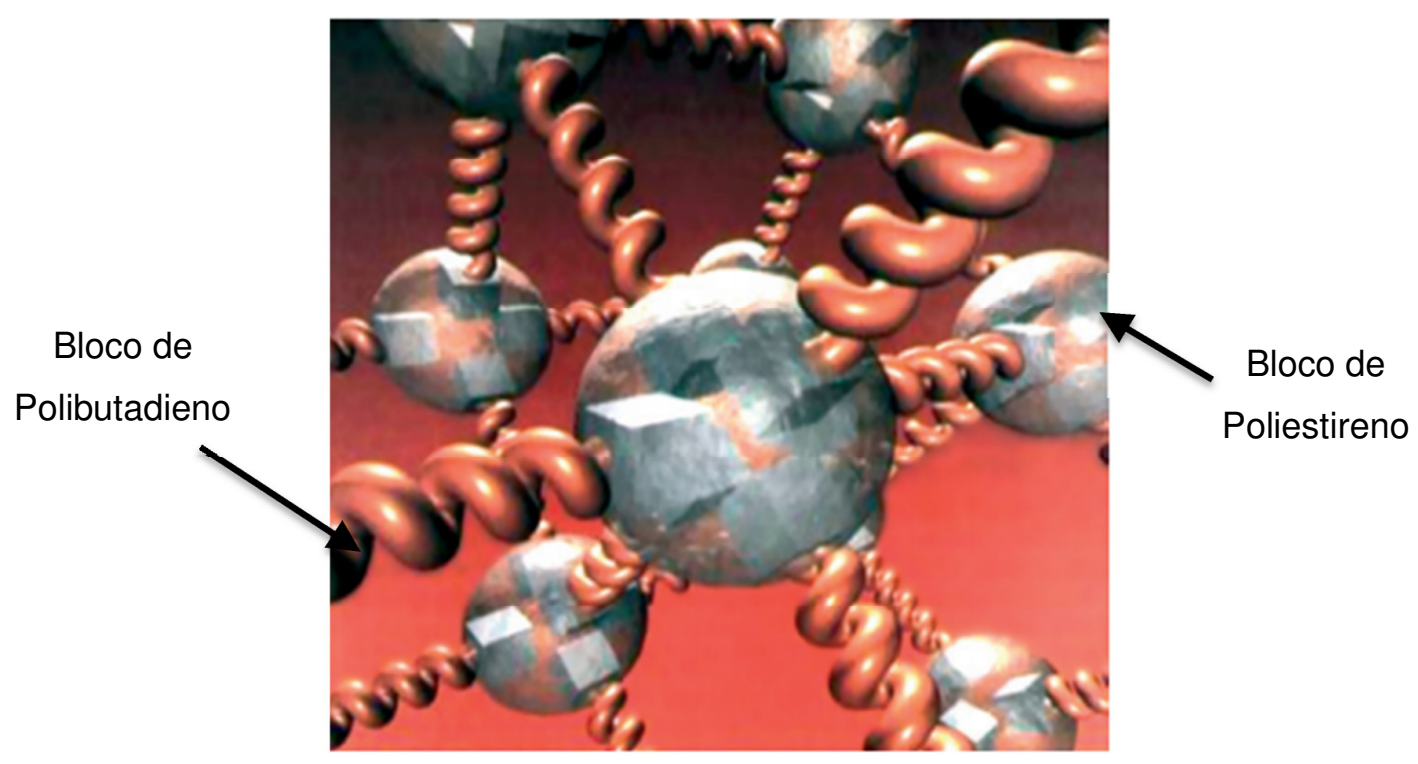

Figura 5 - Representação esquemática de moléculas de SBS envolvidas por um ligante asfáltico de base [Adaptado de Shell (2003) ${ }^{7}$ apud Bernucci et al. (2006)]

Em termos de propriedades tradicionais, estudos como os de Airey (2003) e de Silva et al. (2004) mostraram que os ligantes asfálticos modificados com SBS possuem maiores pontos de amolecimento, menores valores de penetração e maiores viscosidades rotacionais em comparação ao ligante asfáltico de base. Segundo Airey (2003), estas alterações fornecem uma indicação clara do enrijecimento do ligante asfáltico por conta da adição do SBS, embora não seja possível a detecção de diferenças reológicas significativas entre grupos diferentes de ligantes asfálticos modificados ou entre os ligantes asfálticos puros e os modificados, como observado nos estudos deste pesquisador.

Com relação às propriedades reológicas, Airey (2003) e Silva et al. (2004) dentre outros apontaram um aumento do módulo complexo de cisalhamento do material após a incorporação do SBS ao CAP, ao mesmo tempo em que houve uma redução do ângulo de fase. A extensão destas modificações, entretanto, mostrou-se dependente de fatores como o ligante asfáltico de base e a compatibilidade do sistema CAP+polímero, como observado nos dois grupos de ligantes asfálticos avaliados por Airey (2003). Como característica interessante das curvas mestras de $\delta$, ambos os estudos destacaram a presença de regiões planas (ou platôs) em faixas específicas de temperatura ou frequência, regiões estas que sinalizam a existência de

\footnotetext{
${ }^{7}$ SHELL. (2003). The Shell Bitumen Handbook. 5. ed. Cambridge.
} 
redes poliméricas no ligante asfáltico modificado. De acordo com Silva et al. (2004), a presença destes platôs indica uma contribuição mais efetiva do modificador na resposta mecânica do ligante asfáltico e, por consequência, uma melhor interação entre ambos os materiais. No caso dos ligantes asfálticos modificados com SBS, Airey (2003) menciona que as redes poliméricas são formadas pelo entrelaçamento físico dos blocos de poliestireno.

A estabilidade de ligantes asfálticos modificados com SBS quanto à estocagem foi avaliada em estudos como os de Silva et al. (2004), os quais compararam os resultados deste ensaio com as fotomicrografias dos ligantes asfálticos e com os formatos das curvas mestras de $\delta$ para cada material. $O$ procedimento de ensaio seguido pelos autores consiste em submeter um tubo de ensaio, preenchido com ligante asfáltico, a uma temperatura de $160^{\circ} \mathrm{C}$ por 4 dias, seguido de determinação dos pontos de amolecimento de amostras do topo e do fundo deste tubo e posterior verificação da diferença entre os valores (diferenças inferiores a $4^{\circ} \mathrm{C}$ correspondem a materiais estáveis à estocagem). A avaliação destes autores foi a de que existe uma concordância entre os resultados, uma vez que os ligantes asfálticos com os maiores platôs e as maiores estabilidades à estocagem possuíram também uma dispersão relativamente homogênea do modificador no ligante asfáltico de base.

\subsubsection{Borracha de estireno-butadieno (SBR)}

A borracha de estireno-butadieno (SBR) é descrita como um copolímero aleatório, sendo composta pelos mesmos monômeros constituintes do SBS. Apesar desta igualdade, suas propriedades físicas não são iguais às do SBS por conta da distribuição aleatória dos monômeros na cadeia polimérica (KING et al., 1999). Suas partículas são extremamente pequenas e uniformes quando estão em emulsão e, ao entrarem em contato com o ligante asfáltico durante o processo de mistura, dispersam-se rapidamente e de maneira uniforme por todo o material, formando uma reforçada estrutura em rede. Esta modificação altera várias características do ligante asfáltico e, por consequência, contribui para aumentar a durabilidade e o desempenho do material modificado em comparação ao material puro (BATES e WORCH, 1987). A Figura 6 ilustra a estrutura química básica do copolímero SBR.

Com relação a benefícios, a incorporação do SBR acarreta um aumento na ductilidade do ligante asfáltico a baixas temperaturas, proporciona melhorias nas propriedades de adesão e de coesão do material e ocasiona uma redução na sua taxa de 
oxidação. Por conta destes benefícios, o pavimento passa a ser mais resistente às trincas de origem térmica, à abrasão superficial e ao desgaste, ao mesmo tempo em que se verifica uma diminuição dos efeitos do envelhecimento. Em geral, um teor de 3 a $5 \%$ de SBR em peso é suficiente para melhorar as propriedades físicas do ligante asfáltico, sendo que o custo adicional desta modificação é de aproximadamente $20 \%$ para as misturas asfálticas a quente (BATES e WORCH, 1987).

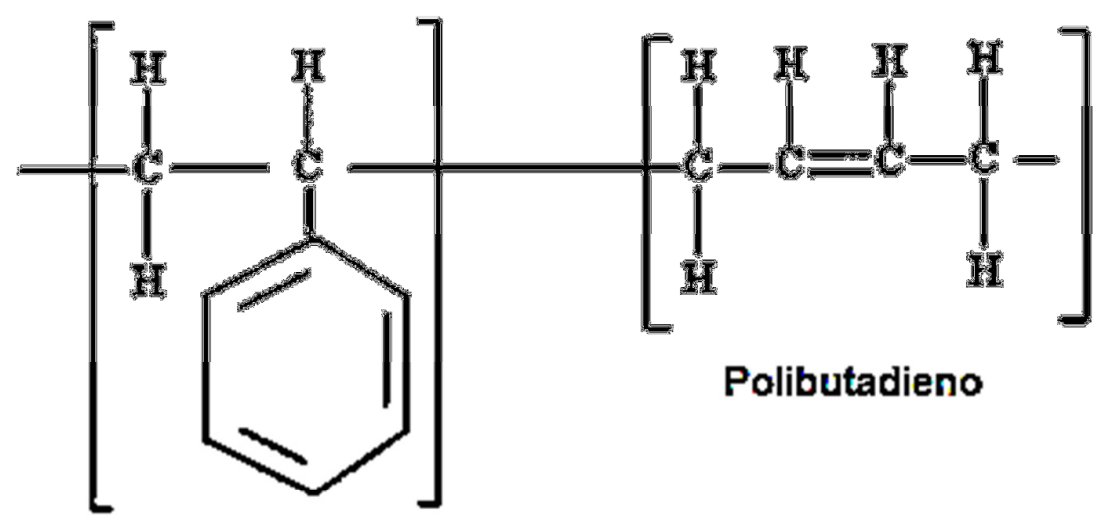

\section{Poliestireno}

Figura 6 - Estrutura química básica do copolímero SBR [Adaptado de Rajpal (2005)]

Estudos como os de Zhang et al. (2009) mostraram que a incorporação do SBR acarreta um aumento no ponto de amolecimento e uma redução na penetração do ligante asfáltico a $25^{\circ} \mathrm{C}$, bem como um incremento significativo na ductilidade do material a $5^{\circ} \mathrm{C}$. Estes autores também avaliaram o efeito da adição de asfalto natural ("natural bitumen" - NB) nas propriedades tradicionais do ligante asfáltico modificado com SBR, levando-se em consideração os teores de 1 a 3\% em peso de NB e material proveniente da Fábrica de Minerais da Província de Xinjiang (China). Para teores de 2 e $3 \%$ de SBR em peso, os autores observaram que a incorporação do NB proporcionou um incremento no ponto de amolecimento até o teor de $2 \%$, não acarretando, porém, alterações relevantes na ductilidade do material a $5^{\circ} \mathrm{C}$. Os resultados do ensaio de estabilidade à estocagem, por sua vez, apontaram reduções nas diferenças entre os pontos de amolecimento das amostras do topo e do fundo do tubo de ensaio após a adição do NB, aumentando, assim, a estabilidade do ligante asfáltico. O estudo concluiu que o SBR possui um efeito significativo nas propriedades do ligante asfáltico em baixas temperaturas (ductilidade) e na resistência ao envelhecimento, ao passo que o NB proporciona uma maior estabilidade do material à estocagem em altas temperaturas.

Com relação à viscosidade rotacional e tendo como referência a limitação imposta pela especificação Superpave (máximo de 3,0 Pa.s a $135^{\circ} \mathrm{C}$ ), o estudo realizado 


\section{2}

por Zhang et al. (2009) mostrou que as viscosidades dos ligantes asfálticos modificados com SBR e com NB são mais elevadas que as do material puro e, ao mesmo tempo, não ultrapassam o valor máximo permitido pela especificação na temperatura de $135^{\circ} \mathrm{C}$. Neste estudo, o aumento da viscosidade rotacional não se mostrou grande o suficiente a ponto de prejudicar atividades como o bombeamento do material modificado. Em termos de diferenças entre os resultados, estas se mostraram mais significativas nas temperaturas inferiores a $160^{\circ} \mathrm{C}$.

Além das alterações nas propriedades tradicionais, o estudo conduzido por Zhang et al. (2009) também apontou um aumento do parâmetro G*/senঠ após a incorporação de SBR e de NB ao ligante asfáltico e, por consequência, do grau de desempenho do material. Dentre as amostras avaliadas, a maior temperatura do $P G\left(82^{\circ} \mathrm{C}\right)$ foi obtida para o ligante asfáltico modificado com 3\% de SBR e 3\% de NB, ambos em peso. Assim, tem-se a indicação de que maiores teores de modificadores correspondem a um maior grau de desempenho do ligante asfáltico em altas temperaturas.

\subsubsection{Borracha moída de pneus}

A utilização da borracha moída de pneus como modificador dos ligantes asfálticos consiste em uma forma de minimizar impactos ambientais e, ao mesmo tempo, melhorar a qualidade dos pavimentos rodoviários e reduzir os custos deste processo de modificação (NAVARRO et al., 2002). As características deste tipo de ligante asfáltico modificado dependem do tipo e do tamanho das partículas de borracha, da composição química do ligante asfáltico de base, do tempo da reação de incorporação e da temperatura utilizada no processo de modificação. Eventuais mudanças na formulação do material modificado, tais como tipos diferentes de ligante asfáltico ou de borracha moída de pneus, devem ser verificados quanto à compatibilidade entre seus componentes, especialmente quando a utilização de um agente compatibilizante se faz necessária (KING et al., 1999).

Além das vantagens ambientais e do menor custo do processo de modificação, a incorporação da borracha moída ao ligante asfáltico proporciona outros benefícios como uma maior resistência às trincas por fadiga e uma redução das trincas por reflexão. Entretanto, são necessárias temperaturas elevadas e longos tempos de mistura para que o modificador seja disperso adequadamente no ligante asfáltico. Caso a borracha moída não tenha passado por uma desvulcanização parcial antes da sua mistura com o ligante 
asfáltico, o produto final será uma mistura heterogênea na qual o modificador atuará principalmente como um fíler flexível (BECKER et al., 2001).

A incorporação deste tipo de modificador no ligante asfáltico é geralmente feita através de dois processos: úmido e seco. No processo úmido (Figura 7), a borracha reciclada é misturada com o ligante asfáltico antes de se adicionar o agregado. Por conta desta mistura, ocorre uma reação entre os componentes e a alteração de suas propriedades originais: quando a borracha é misturada ao ligante asfáltico quente, suas partículas aumentam de 3 a 5 vezes o valor do tamanho original e amolecem devido à absorção dos componentes aromáticos do ligante asfáltico. O resultado deste processo é um ligante asfáltico com menor suscetibilidade à temperatura, maior elasticidade e maior viscosidade em altas temperaturas (KING et al., 1999).

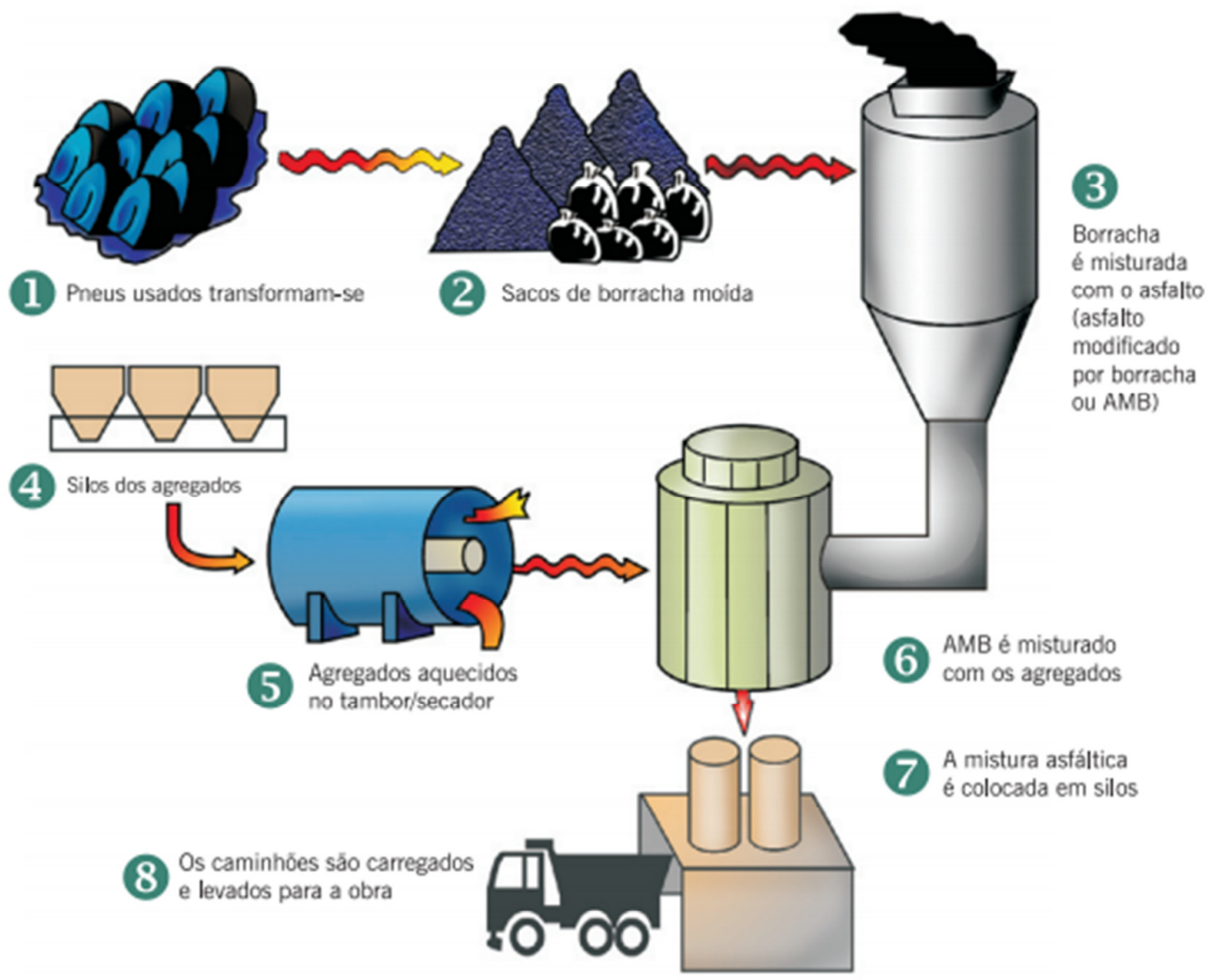

Figura 7 - Esquema de produção do asfalto-borracha, via processo úmido, pelo método de mistura estocável ou "terminal-blending" [Bernucci et al. (2006)]

No caso do processo seco, a borracha moída é adicionada como parte da fração de agregados na mistura asfáltica a quente. Em comparação ao processo úmido, a reação do modificador com o ligante asfáltico é menos completa porque o tempo de contato entre 
ambos os materiais é menor e a temperatura de contato é mais baixa. Por conta destas características, acredita-se que a reação entre o modificador e o ligante asfáltico ocorra apenas na superfície da maioria das partículas de borracha, acarretando uma mistura asfáltica com um componente elástico nos agregados. Devido à natureza elástica da mistura, a compactação do material exige mudanças em relação aos métodos empregados para misturas convencionais, a fim de garantir a massa específica adequada e minimizar o desgaste do pavimento final (KING et al., 1999).

Uma revisão bibliográfica realizada por Billiter et al. (1996) aponta que, embora a adição de borracha moída de pneus proporcione benefícios ao ligante asfáltico, a viscosidade rotacional do material modificado aumenta significativamente nas temperaturas de 149 a $193^{\circ} \mathrm{C}$, o que pode ocasionar problemas durante a compactação em campo. Os problemas estariam atrelados à existência de partículas não dissolvidas de borracha e, assim, a eliminação destas partículas produziria um ligante asfáltico modificado com uma viscosidade de compactação menos prejudicial (mais baixa). Este cenário foi tomado como referência para o estudo de Billiter et al. (1996), os quais avaliaram a influência do tempo de mistura, da temperatura de mistura e dos tipos e intensidades da energia mecânica na preparação dos asfaltos-borracha. A conclusão obtida pelos autores foi a de que, para que as partículas de borracha possam ser adequadamente desvulcanizadas e despolimerizadas e o ligante asfáltico resultante seja homogêneo e realmente elástico, é necessário observar três condições importantes: (1) a utilização de uma taxa elevada de cisalhamento, (2) uma alta temperatura de mistura e (3) um tempo adequado para a duração da mistura. Segundo os autores, a observância destas condições fará com que não haja a presença de partículas não dissolvidas de borracha dentro do ligante asfáltico e, consequentemente, o processo de compactação da mistura asfáltica será facilitado.

Estudos como os de Khedaywi et al. (1993) foram realizados com o intuito de avaliar os efeitos da adição de borracha moída de pneus nas propriedades tradicionais do ligante asfáltico. Neste estudo, os autores empregaram um ligante asfáltico de classificação por penetração 80/100 e três granulometrias diferentes de borracha moída (peneiras \#16-20, \#20-50 e \#50-200), para as quais foram estabelecidos teores diferentes de modificador (0, 5, 1015 e, em alguns casos, $20 \%$ em peso). As amostras ensaiadas pelos autores mostraram decréscimos na penetração e no ponto de fulgor com o aumento do teor de borracha, sendo que as modificadas com as maiores partículas (peneiras \#16-20) possuíram os menores resultados para ambas as propriedades. Os pontos de amolecimento aumentaram com o incremento do teor de borracha, ao passo que os valores de ductilidade sofreram reduções até o teor de $5 \%$ e aumentos para teores acima de $5 \%$. 
Em outro estudo, Mohamed et al. (2008) avaliaram os efeitos da adição de borracha moída com antioxidantes nas propriedades reológicas do ligante asfáltico. Neste estudo, foram verificadas as alterações no módulo complexo e no ângulo de fase de um ligante asfáltico de classificação por penetração 80/100 após a incorporação do modificador em teores de $1 \%$ e $5 \%$ em peso, considerando materiais não envelhecidos e envelhecidos em uma estufa a $60^{\circ} \mathrm{C}$ por 3 e 9 dias. Os aumentos de $\mathrm{G}^{*}$ se mostraram mais intensos nas temperaturas de 30 a $40^{\circ} \mathrm{C}$ para os materiais não envelhecidos, sendo maiores para os ligantes asfálticos com maiores teores de borracha. As reduções de $\delta$ se mostraram mais elevadas nas temperaturas de 10 a $40^{\circ} \mathrm{C}$ para estes mesmos materiais e, nas temperaturas iguais ou superiores a $40^{\circ} \mathrm{C}$, tanto os ligantes asfálticos puros quanto os modificados tenderam ao comportamento puramente viscoso $\left(\delta=90^{\circ}\right)$. Os ligantes asfálticos apresentaram maiores valores de $\mathrm{G}^{\star}$ e menores valores de $\delta$ após o envelhecimento, sendo que as alterações de $\mathrm{G}^{*}$ se mostraram pequenas na temperatura de $10^{\circ} \mathrm{C}$.

Em outra pesquisa, Kim et al. (2010) conduziram análises reológicas em ligantes asfálticos modificados com teores de 10, 15 e 20\% de borracha moída em peso por peso de ligante asfáltico, tendo como base um material puro de classificação PG 64-22. Estas análises incluíram (1) ensaios de fluência repetida e recuperação a $10 \mathrm{~Pa}$ para os tempos de $1 \mathrm{~s}$ de carregamento e $9 \mathrm{~s}$ de recuperação e um total de 52 ciclos; (2) ensaios de fluência e recuperação nas tensões de 3, 10 e $50 \mathrm{~Pa}$; (3) ensaios de regime oscilatório em temperaturas de 25 a $80^{\circ} \mathrm{C}$ para uma frequência de $1,59 \mathrm{~Hz}$; e (4) alterações na viscosidade a $60^{\circ} \mathrm{C}$ com a taxa de cisalhamento para os materiais modificados e não modificados. Nesta pesquisa, a adição de borracha moída ao ligante asfáltico aumentou significativamente a viscosidade e alterou as características de fluxo do material (de Newtoniano para pseudoplástico), especialmente no teor de $20 \%$. Em complemento, os materiais modificados apresentaram menores valores de deformação permanente nos ensaios de fluência e recuperação e menores potenciais à deformação permanente no RCRT, com os melhores resultados pertencendo aos ligantes asfálticos com maiores teores de borracha. No caso dos ensaios oscilatórios, foi verificado que a adição de borracha moída aumentou os valores de $G^{*}$ nas temperaturas mais altas e reduziu os valores de $\delta$ nas mais baixas.

\subsubsection{Polietileno (PE)}

$O$ polietileno (PE) consiste em um material semicristalino com excelente resistência química e boa resistência ao desgaste, além de apresentar uma ampla gama 
de propriedades. Este material possui também resistência elevada a solventes orgânicos, com baixas taxas de absorção de umidade. A estrutura química de suas moléculas é extremamente simples, caracterizando-se por uma longa cadeia de átomos de carbono a cada um dos quais dois átomos de hidrogênio estão ligados quimicamente (AWWAD e SHBEEB, 2007). Sua utilização pode ser feita em uma variedade de aplicações industriais, tais como revestimentos de tubos e mangueiras, embalagens para defensivos agrícolas, revestimentos de fios e cabos e fabricação de mancais e tubos (COUTINHO et al., 2003). O emprego do PE na modificação de ligantes asfálticos também vem sendo estudado pelos pesquisadores, incluindo materiais em sua forma reciclada, como o fizeram Yousefi et al. (2000) e Kalantar et al. (2010) dentre outros.

Assim como o polipropileno, o polietileno caracteriza-se como um plastômero ${ }^{8}$ e, por conta desta característica, pode aumentar a rigidez dos materiais e reduzir significativamente as deformações oriundas da passagem das cargas do tráfego (POLACCO et al., 2005). Esta redução das deformações do revestimento é compartilhada por Bates e Worch (1990), segundo os quais a incorporação do PE também melhora a adesão do ligante asfáltico com o agregado. Outras vantagens deste modificador, de acordo com uma revisão bibliográfica realizada por Becker et al. (2001), estão no baixo custo e nas resistências ao envelhecimento e às altas temperaturas.

Apesar dos benefícios, o polietileno é um material extremamente imiscível com o ligante asfáltico e, desta maneira, seu uso é geralmente restrito a aplicações industriais de vários tipos (POLACCO et al., 2006). Por conta da baixa miscibilidade, os ligantes asfálticos modificados com polietileno apresentam uma tendência de separação entre as fases ricas em modificador e em ligante asfáltico, a qual realmente ocorre quando o material modificado é armazenado em tanques a temperaturas elevadas e sem um constante agitamento. Esta ausência de agitação faz com que a fase rica em polietileno migre para a superfície do ligante asfáltico modificado, enquanto que a parte rica em ligante asfáltico fica segregada no fundo do tanque. O resultado deste processo é um material extremamente heterogêneo e impróprio para uso em pavimentação, o qual pode causar problemas se utilizado por conta da elevada viscosidade da parte com alto teor de polímero (POLACCO et al, 2005). A fim de evitar esta segregação ou estratificação de fases, o CAP modificado com PE deve ser armazenado em tanques equipados com agitadores mecânicos (BATES e WORCH, 1990).

\footnotetext{
${ }^{8}$ Plastômero: Este tipo de polímero é caracterizado pela formação de uma rede tridimensional rígida, o que ocasiona um enrijecimento no ligante asfáltico e, por consequência, uma resistência inicial maior para suportar carregamentos mais elevados. Esta maior resistência, entretanto, pode fazer com que o material sofra trincas em situações de alta deformação (KING et al., 1999).
} 
Para a produção do ligante asfáltico modificado com PE, geralmente são utilizados teores entre 4 e $6 \%$ de polietileno, principalmente o chamado polietileno de baixa densidade ${ }^{9}$. A baixa miscibilidade deste modificador no ligante asfáltico faz com que a utilização de altas taxas de cisalhamento no processo de modificação seja necessária. A mistura deste material modificado com os agregados é feita com o emprego de equipamentos convencionais, com a temperatura de mistura sendo levemente superior à utilizada para os ligantes asfálticos puros e variando entre 149 e $166^{\circ} \mathrm{C}$ (BATES e WORCH, 1990).

A fim de avaliar as alterações nas propriedades tradicionais e na viscosidade rotacional do ligante asfáltico após a modificação com polietileno, Kalantar et al. (2010) utilizaram politereftalato de etileno $(\mathrm{PET})^{10}$ reciclado em teores de 2 a $10 \%$ em peso em um CAP 80/100. Os resultados obtidos pelos autores mostram que a incorporação do modificador reduz a penetração, aumenta o ponto de amolecimento e aumenta a viscosidade rotacional do ligante asfáltico, sendo que estes efeitos são tanto maiores quando maior é o teor de PET. Os aumentos percentuais de viscosidade rotacional a $135^{\circ} \mathrm{C}$ variaram entre 0 e $100 \%$ para os ligantes asfálticos estudados pelos autores, sendo que o maior aumento foi observado no material com $10 \%$ de PET.

Estudos como os de Pérez-Lepe et al. (2006) foram realizados com o intuito de avaliar a estabilidade de ligantes asfálticos modificados com PE quanto à estocagem, assim como as alterações nas propriedades reológicas destes materiais após a estocagem. Os autores utilizaram um polietileno de alta densidade na modificação de um CAP 60/70, em teores que variaram de 1 a $5 \%$ de polímero. Nas avaliações reológicas (G', tanঠ e fluxo viscoso), os materiais submetidos à estocagem por $24 \mathrm{~h}$ a $180^{\circ} \mathrm{C}$ apresentaram comportamentos muito próximos para qualquer teor de polímero, o que, segundo os autores, evidencia o alto grau de separação do modificador da matriz betuminosa do CAP. Em seguida, os autores submeteram amostras de ligante asfáltico modificado com $5 \%$ de PE a um aquecimento a $100^{\circ} \mathrm{C}$ e outras a $150^{\circ} \mathrm{C}$, ambas por períodos variados de tempo, com o intuito de compreender o processo de separação da fase polimérica durante o aquecimento do CAP em temperaturas altas. Os resultados obtidos pelos autores não apontaram alterações significativas na morfologia dos

\footnotetext{
${ }^{9}$ Polietileno de baixa densidade: Polímero parcialmente cristalino e com temperatura de fusão entre 110 e $115^{\circ} \mathrm{C}$. Possui alta resistência ao impacto, alta flexibilidade e notáveis propriedades elétricas, além de ser altamente resistente à água e a algumas soluções aquosas. Dentre outras aplicações, é utilizado em filmes para embalagens industriais e agrícolas e em embalagens para produtos farmacêuticos (COUTINHO et al., 2003).

${ }_{10}$ Politereftalato de etileno (PET): Polímero termoplástico da família do poliéster. Possui grande resistência à abrasão, baixa absorção de água e, na temperatura ambiente, é resistente à ação de substâncias como álcool, óleos, gorduras e sais, dentre outras propriedades. Sua temperatura de trabalho está entre -40 e $100^{\circ} \mathrm{C}$ e, quando no estado amorfo, é um material transparente. É empregado, por exemplo, em fibras sintéticas e na produção de recipientes para bebidas e comidas (PLASTICS FEDERATION OF SOUTH AFRICA, 2011).
} 
materiais estocados a $100^{\circ} \mathrm{C}$ (abaixo do ponto de fusão do PE no CAP modificado $\left(\approx 123^{\circ} \mathrm{C}\right)$ ) mesmo após um período de tempo de $12 \mathrm{~h}$, o contrário ocorrendo com os materiais estocados a $150^{\circ} \mathrm{C}$ (alterações significativas na morfologia após períodos curtos de tempo).

Em outro estudo, Polacco et al. (2005) empregaram vários tipos de polietileno na modificação de um CAP 70/100, considerando um teor de $6 \%$ em peso para todos os ligantes asfálticos modificados. O ensaio de estabilidade à estocagem consistia em submeter um tubo de ensaio preenchido com ligante asfáltico a uma temperatura de $180^{\circ} \mathrm{C}$ por aproximadamente $72 \mathrm{~h}$, seguido de verificação das diferenças entre os pontos de amolecimento de amostras do topo e do fundo deste tubo. As análises morfológicas foram realizadas nos ligantes asfálticos modificados após o processo de mistura e, em alguns casos, também após períodos pré-determinados de cura a uma temperatura de $180^{\circ} \mathrm{C}$. Nenhum dos materiais considerados neste estudo apresentou uma estabilidade adequada à estocagem, mesmo aqueles cujos modificadores possuíam grupos funcionais ${ }^{11}$ na composição química. $\mathrm{Na}$ avaliação dos autores, a presença dos grupos funcionais permitiu uma maior miscibilidade entre o modificador e o ligante asfáltico, porém esta melhoria não se mostrou suficiente para obter uma mistura homogênea e estável.

No campo das propriedades reológicas, Kalantar et al. (2010) dentre outros observaram que o módulo complexo de cisalhamento aumenta com a adição do polietileno ao ligante asfáltico de base, ao passo que o ângulo de fase diminui com esta adição. Neste estudo, observou-se que o valor de $\mathrm{G}^{*}$ é tanto maior quanto maior o teor de PET no ligante asfáltico, ao passo que o valor de $\delta$ é tanto menor quanto maior o teor de modificador. Para ambas as propriedades, as diferenças mais significativas entre os valores foram observadas nas temperaturas mais baixas.

Em outro estudo, Yeh et al. (2010) avaliaram as alterações no parâmetro G*/senঠ após as modificações de um ligante asfáltico de base com teores de 3 e $5 \%$ em peso, levando em consideração vários tipos de polietileno. Em uma varredura de temperaturas à frequência de $1,6 \mathrm{~Hz}$, observou-se que os ligantes asfálticos modificados possuíam valores mais elevados de $\mathrm{G}^{*} / \mathrm{sen} \delta$ e, dentre estes materiais, apenas o modificado com polietileno de alta densidade ${ }^{12}$

\footnotetext{
${ }^{11}$ Grupo funcional: Um grupo funcional é um átomo, ou um grupo de átomos, que possui propriedades químicas similares em qualquer composto que se fizer presente. Este grupo define as propriedades físicas e químicas características de famílias de grupos orgânicos (IUPAC, 2006).

12 Polietileno de alta densidade: Este material possui baixa permeabilidade à água e a gases inorgânicos e, em comparação ao polietileno de baixa densidade, apresenta menor permeabilidade a gases como o oxigênio e o nitrogênio. É utilizado, por exemplo, na fabricação de embalagens para detergentes e para defensivos agrícolas (COUTINHO et al., 2003).
} 
atendeu ao critério da especificação Superpave na temperatura de $76^{\circ} \mathrm{C}\left(\mathrm{G}^{*} / \mathrm{sen} \delta>1,0 \mathrm{kPa}\right)$. Em outro ensaio deste estudo, os ligantes asfálticos modificados com 3\% de PE em peso foram submetidos a varreduras de frequência nas temperaturas de 30 e de $60^{\circ} \mathrm{C}$ e se observou que, dentre os variados tipos de modificadores, os maiores valores de $\mathrm{G}^{*} / \mathrm{sen} \delta$ eram encontrados nos materiais modificados com polietileno de baixa densidade. Assim, é possível observar que a adição de PE aumenta os valores do parâmetro $\mathrm{G}^{*} /$ senঠ em magnitudes que variam de acordo com o tipo e o teor de modificador.

\subsubsection{Copolímero de etileno acetato de vinila (EVA)}

O copolímero de etileno acetato de vinila (EVA) é formado pela inserção de moléculas de vinil-acetato em uma cadeia de polietileno, acarretando, dentre outros fatores, uma redução do potencial de cristalização do material (VLACHOVICOVA et al., 2005). Esta redução é decorrente da presença de um grupo funcional éster na estrutura do EVA, o que, em conjunto com outros fatores, aumenta a compatibilidade do modificador com o ligante asfáltico. Em geral, os EVAs utilizados na modificação de ligantes asfálticos possuem teores de vinil-acetato entre 18 e $28 \%$ em peso (POLACCO et al., 2006). Maiores teores de acetato ocasionam um aumento no caráter amorfo do EVA, de modo que as propriedades do material se aproximam às de um elastômero; por outro lado, menores teores de acetato acarretam uma maior cristalinidade e, portanto, um maior comportamento plastomérico (BERNUCCl et al., 2006). A Figura 8 da página seguinte apresenta uma ilustração do EVA, com destaques para a molécula de vinil-acetato e para o grupo funcional éster.

De acordo com uma revisão bibliográfica realizada por Becker et al. (2001), a utilização do EVA na modificação de ligantes asfálticos possui uma série de vantagens tais como a produção de CAPs modificados termicamente estáveis nas temperaturas convencionais de mistura e manuseio e um baixo custo se comparado aos copolímeros em bloco. Bringel et al. (2005) destacam estas mesmas vantagens (estabilidade térmica e custo razoável) e apontam que a utilização do EVA também proporciona resistência à flexão. Uma grande motivação para o estudo da incorporação deste copolímero ao ligante asfáltico vem, segundo Bringel et al. (2005), da possibilidade de utilização de resíduos de EVA gerados pela indústria calçadista, o que traria benefícios à empresa por conta da destinação dos resíduos para a reciclagem. Como um exemplo de trabalho científico envolvendo a adição de EVA reciclado ao ligante asfáltico, pode-se mencionar o estudo de García-Morales et al. (2004). 


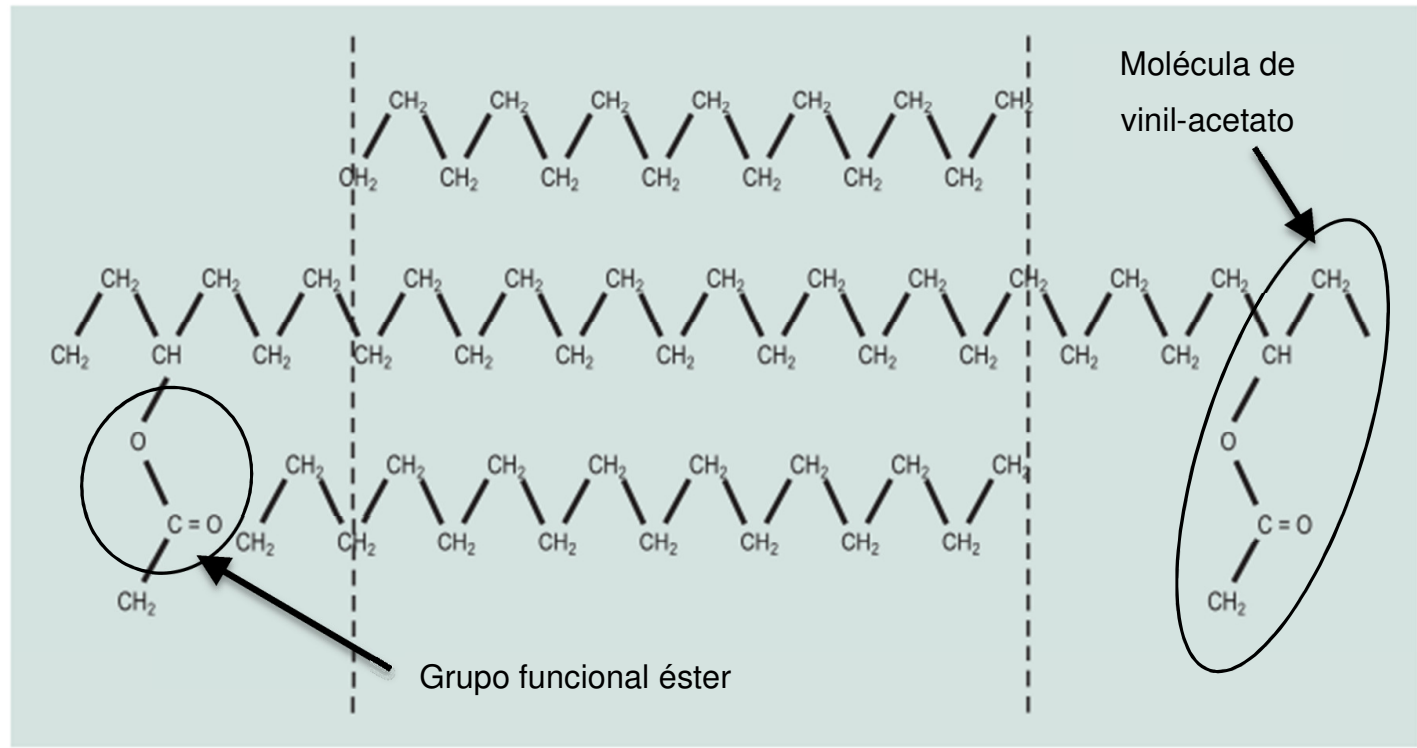

Figura 8 - Representação da estrutura química básica do copolímero EVA [Adaptado de Bernucci et al. (2006)]

As propriedades tradicionais e de viscosidade rotacional de ligantes asfálticos modificados com EVA foram avaliadas em estudos como o de Airey (2002), o qual utilizou três tipos diferentes de ligantes asfálticos de base e teores de EVA iguais a 3, 5 e 7\% em peso para cada ligante asfáltico. Os resultados apontaram reduções na penetração e aumentos nos pontos de amolecimento dos ligantes asfálticos modificados em relação aos correspondentes puros, bem como aumentos consistentes na viscosidade rotacional após o processo de modificação. As alterações nestas propriedades mostram, segundo o autor, os efeitos enrijecedores da adição do EVA ao ligante asfáltico. Os resultados também apontaram que os incrementos de viscosidade são relativamente similares entre diferentes grupos de ligantes asfálticos de base, o que segundo o autor, estaria mais relacionado a uma modificação do tipo preenchimento do que do tipo polimérica. De acordo com Airey (2002), este fenômeno ocorre porque o copolímero EVA possui um ponto de fusão entre 65 e $80^{\circ} \mathrm{C}$, estando, portanto, no estado líquido para temperaturas de $100^{\circ} \mathrm{C}$ e superiores.

No campo das propriedades reológicas, Airey (2002) e Bringel et al. (2005) dentre outros pesquisadores avaliaram as alterações no módulo complexo de cisalhamento e no ângulo de fase do ligante asfáltico após a adição do copolímero EVA. Os resultados destes estudos mostraram que a incorporação do EVA aumenta a rigidez (maior $\mathrm{G}^{\star}$ ) e o comportamento elástico (menor $\delta$ ) do ligante asfáltico, sendo que, no caso do estudo de Airey (2002), a natureza da modificação se mostrou dependente da compatibilidade entre o ligante asfáltico de base e o copolímero e do grau de modificação. Em virtude destas diferenças, o pesquisador destaca que alguns ligantes asfálticos modificados apresentam 
graus de modificação maiores que outros, tais como regiões de platôs e presença de "ondas" nas curvas de $G^{*}$ e $\delta$. Ainda sobre os resultados de Airey (2002), os graus de modificação foram maiores nas temperaturas elevadas e frequências baixas, nas quais, segundo Goodrich (1990), a viscosidade do CAP é baixa o suficiente para permitir que a rede polimérica domine as propriedades mecânicas do material modificado.

\subsubsection{Elvaloy}

O Elvaloy consiste em um terpolímero reativo composto pelos monômeros etileno, normal-butacrilato e glicidilmetacrilato (GMA). Acredita-se que seja a porção de GMA da molécula deste terpolímero a responsável pela reação observada quando da sua adição e mistura com o ligante asfáltico quente. Em virtude desta reação química, é produzido um sistema interligado asfalto-polímero (Figura 9) com propriedades de desempenho superiores às do ligante asfáltico puro (BECKER et al., 2001; DUPONT WEBSITE, 2008a). É adicionado e misturado ao ligante asfáltico em forma de pastilhas sólidas, as quais sofrem fusão quando em temperaturas altas e reagem com o ligante asfáltico, produzindo, assim, um material modificado homogêneo e estável (DUPONT WEBSITE, 2008c). Um cuidado especial deve ser tomado com relação à quantidade quando o Elvaloy ou outros polímeros reativos são utilizados na modificação de ligantes asfálticos, pois quantidades excessivas destes modificadores acarretam a produção de um asfalto-gel de natureza insolúvel e com ponto de fusão elevado (POLACCO et al., 2004). Assim, polímeros desta natureza são adicionados aos ligantes asfálticos em teores baixos, os quais geralmente se situam na faixa de $1,5 \%$ a $2,5 \%$ em peso (POLACCO et al., 2004, 2006).

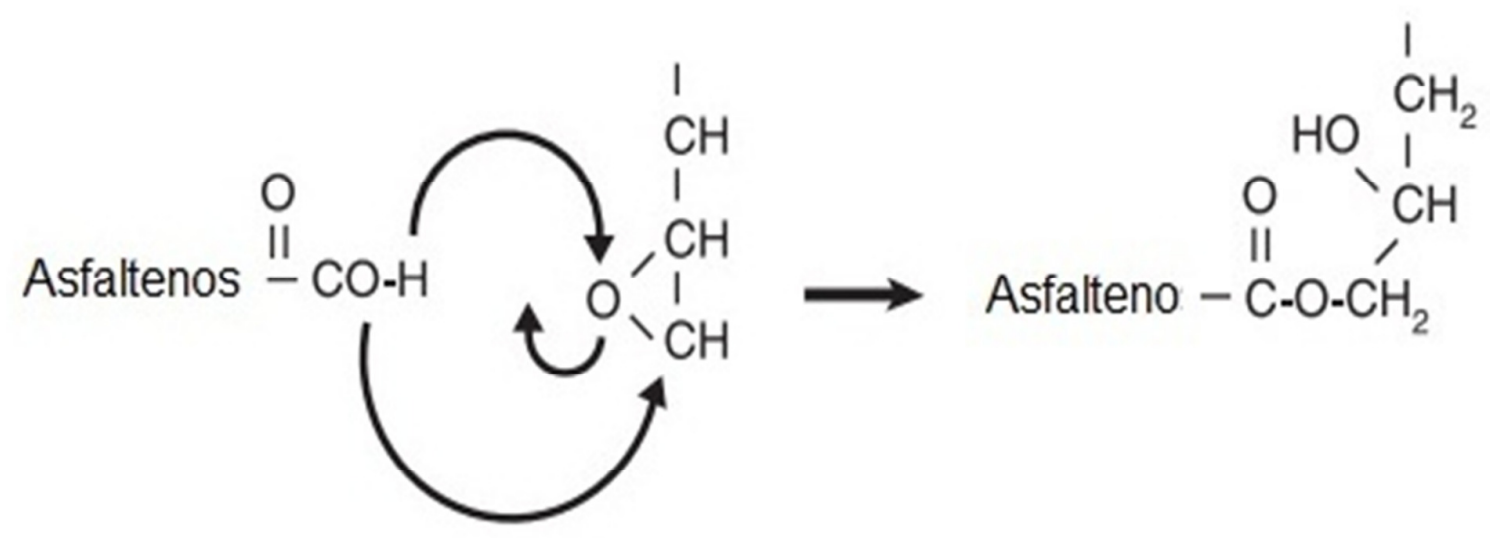

Figura 9 - Mecanismo proposto de reação química entre um polímero etileno-glicidil-acrilato e uma molécula de asfalteno [Adaptado de DuPont Website (2008b)] 
Ao contrário dos ligantes asfálticos modificados com polímeros não reativos, cuja composição química apresenta uma natureza multifásica que pode evoluir para uma separação macroscópica de fases durante a estocagem, os modificados com Elvaloy ou outros polímeros reativos geralmente apresentam uma dissolução homogênea da fase polimérica na fase asfáltica. Isto se deve a fatores como, por exemplo, a baixa quantidade de polímero adicionada ao ligante asfáltico e a formação de uma ligação química entre o polímero e o CAP, ligação esta que ajuda a impedir a separação de fases durante a estocagem. Em complemento, o período de estocagem coincide com o tempo durante o qual se supõe que os grupos funcionais do polímero e do ligante asfáltico reajam entre si. Desta maneira, o único problema significativo relacionado à estocagem deste tipo de ligante asfáltico modificado seria a formação de um asfalto-gel, que ocorre nos casos onde a quantidade de polímero não foi corretamente escolhida (POLACCO et al., 2004).

Embora o risco da separação de fases neste tipo de ligante asfáltico modificado seja reduzido por conta da reação química entre os grupos funcionais dos polímeros reativos e as moléculas do ligante asfáltico, o tempo desta reação deve ser mantido abaixo de um determinado limite, no qual a viscosidade do ligante asfáltico modificado diverge para um valor infinito. Se tal situação ocorrer, a utilização do material modificado será impossível de ser feita, pois até mesmo a sua retirada do tanque de armazenamento não será possível devido à elevada viscosidade. Desta maneira, a reação química ocasionada pela utilização dos polímeros reativos pode solucionar o problema da compatibilidade entre o ligante asfáltico de base e o modificador, mas, ao mesmo tempo, constitui-se um limite para as máximas melhorias nas propriedades do ligante asfáltico modificado (POLACCO et al., 2004).

A fim de avaliar a capacidade do ligante asfáltico modificado com Elvaloy em resistir à separação de fases durante a estocagem sob altas temperaturas, foram realizados estudos como o publicado em DuPont Website (2008a), o qual considerou amostras de um CAP modificado com $2 \%$ de Elvaloy e de outro com $5 \%$ de SBS. As análises de estabilidade à estocagem foram realizadas com base nas diferenças entre os pontos de amolecimento de porções retiradas do topo e do fundo de amostras destes ligantes asfálticos, ambos condicionados por 5 dias a uma temperatura de $139^{\circ} \mathrm{C}$ para simular as condições de estocagem. Os resultados mostraram que, enquanto as diferenças entre os pontos de amolecimento das amostras do ligante asfáltico modificado com SBS foram relativamente elevadas, as do modificado com Elvaloy tiveram valores menores. Como conclusão deste estudo, o ligante asfáltico modificado com Elvaloy apresentou uma maior estabilidade à estocagem em altas temperaturas do que o material modificado com SBS. 
Estudos envolvendo a incorporação de Elvaloy ao ligante asfáltico foram realizados por pesquisadores como Polacco et al. (2004), os quais avaliaram os efeitos da adição deste terpolímero em dois tipos diferentes de ligantes asfálticos de base, para teores de 1,0 a 2,5\% em peso e para tempos diferentes de cura a $180^{\circ} \mathrm{C}(0,24$ e $48 \mathrm{~h})$. Neste estudo, os materiais modificados e não submetidos ao processo de cura mostraram incrementos nulos ou pequenos para o ponto de amolecimento, sendo que os maiores aumentos foram observados nos ligantes asfálticos com teores mais elevados de modificador (Tabela 3). Segundo os autores, estes incrementos baixos mostram que o tempo de mistura do Elvaloy com o CAP (15 min) não foi o suficiente para permitir uma reação química significativa entre os dois materiais. Para o caso dos ligantes asfálticos submetidos ao processo de cura por 24 ou 48 h, observou-se que alguns materiais sofreram gelatinização em condições específicas de teor de modificador e de tempo de cura, sendo que um dos ligantes asfálticos apresentou maior tendência de gelatinização do que o outro após a incorporação do Elvaloy (Tabela 3). Estes resultados permitem dizer que o processo de gelatinização é dependente de fatores como o tipo de ligante asfáltico de base, o tempo de cura e o teor de glicidil presente no Elvaloy.

Tabela 3 - Pontos de amolecimento dos ligantes asfálticos modificados com Elvaloy antes e após períodos de cura de 24 e 48 h [Adaptado de Polacco et al. (2004)]

\begin{tabular}{|c|c|c|c|}
\hline \multirow{2}{*}{ Ligante asfáltico } & \multicolumn{3}{|c|}{ Pontos de amolecimento $\left({ }^{\circ} \mathrm{C}\right)$} \\
\hline & Sem tempo de cura & Após cura de $24 \mathrm{~h}$ & Após cura de $48 \mathrm{~h}$ \\
\hline CAP tipo $A^{1}$ & 46 & - & - \\
\hline $\mathrm{A}+1,5 \%$ Elvaloy $\mathrm{AM}^{3}$ & 46 & 51 & 53,5 \\
\hline$A+2,0 \%$ Elvaloy $A M$ & 48 & 52 & 55 \\
\hline $\mathrm{A}+2,5 \%$ Elvaloy $\mathrm{AM}$ & 52 & 56 & 59 \\
\hline$A+1,5 \%$ Elvaloy $E P^{4}$ & 47 & 51 & 53,6 \\
\hline $\mathrm{A}+2,0 \%$ Elvaloy EP & 49 & 67,5 & Gel \\
\hline $\mathrm{A}+2,5 \%$ Elvaloy EP & 51 & Gel & Gel \\
\hline CAP tipo $B^{2}$ & 47 & - & - \\
\hline $\mathrm{B}+1,5 \%$ Elvaloy AM & 47 & 51 & 54 \\
\hline $\mathrm{B}+1,75 \%$ Elvaloy $\mathrm{AM}$ & 50 & 53 & 59 \\
\hline $\mathrm{B}+2,0 \%$ Elvaloy AM & 52 & 54 & Gel \\
\hline $\mathrm{B}+2,5 \%$ Elvaloy $\mathrm{AM}$ & 53 & Gel & Gel \\
\hline $\mathrm{B}+1,0 \%$ Elvaloy EP & 49 & 52 & 55 \\
\hline $\mathrm{B}+1,5 \%$ Elvaloy EP & 50 & 55 & Gel \\
\hline B + 1,75\% Elvaloy EP & 52 & Gel & Gel \\
\hline
\end{tabular}


Uma observação importante deve ser feita a respeito dos tempos de cura após a incorporação do Elvaloy ao ligante asfáltico. Tempos elevados de cura, tais como os valores de 24 e 48 h adotados no estudo de Polacco et al. (2004), são levados em consideração quando o modificador é adicionado sem a presença do ácido polisfosfórico, uma vez que este ácido funciona como um catalisador da reação química entre um terpolímero reativo e o ligante asfáltico de base e pode também reduzir a quantidade de polímero na formulação (VAN DER WERFF e NGUYEN, 1996; KODRAT et al., 2007). No caso deste estudo, o tempo de preparo de um ligante asfáltico modificado com Elvaloy+PPA foi de apenas $2 \mathrm{~h}$ (Capítulo 3, Tabela 5), significativamente menor do que os tempos de cura de 24 e $48 \mathrm{~h}$ empregados no estudo de Polacco et al. (2004).

Em outro estudo, Tomé et al. (2005) avaliaram as alterações na viscosidade rotacional de um CAP 50/60 após a adição do terpolímero Elvaloy e de 0,22\% de ácido polisfosfórico em peso de CAP, dentre outros itens. O ligante asfáltico puro apresentou comportamento Newtoniano em todas as temperaturas estudadas pelos autores $(135,150 \mathrm{e}$ $175^{\circ} \mathrm{C}$ ), o mesmo não ocorrendo com o material modificado. Em termos numéricos, as viscosidades rotacionais do CAP modificado se mostraram mais elevadas que as do CAP puro, o que acarreta maiores temperaturas de usinagem e de compactação para o ligante asfáltico modificado. Estes incrementos também foram observados no estudo de Polacco et al. (2004), os quais destacam, além da modificação em si, a influência do tempo de cura no valor da viscosidade e no comportamento do ligante asfáltico modificado.

No campo das propriedades reológicas de ligantes asfálticos modificados com Elvaloy, Polacco et al. (2004) avaliaram as alterações nos valores de G' e G” para um ligante asfáltico modificado com $1,75 \%$ de Elvaloy em peso, considerando dois tempos de cura do material $\left(0\right.$ e $48 \mathrm{~h}$ ). Tendo como referência uma temperatura de $0^{\circ} \mathrm{C}$, os autores não observaram distinções significativas entre os comportamentos dos dois materiais na região de frequências elevadas, o contrário ocorrendo nas frequências baixas. Nas frequências baixas, observaram-se inclinações relativamente semelhantes nas curvas de G' e G" para o ligante asfáltico submetido a uma cura de 48 h, o mesmo não ocorrendo para o ligante asfáltico não submetido ao processo de cura. Segundo os autores, estas diferenças estariam atreladas à redução da dependência de (tanర) do valor da frequência ou, em outras palavras, à convergência do valor de (tanঠ) para um valor único e independente da frequência de carregamento, o que poderia ser interpretado como um estado de pré-gelatinização do material. Este mesmo fenômeno foi visualizado em uma avaliação das resultados de (tanঠ) com o tempo de cura para cinco níveis de frequência de carregamento $(1,0 ; 2,5 ; 5,0 ; 7,5$ e $10 \mathrm{~Hz})$, na qual os autores observaram uma 
convergência dos valores de (tanঠ) para um valor comum (e independente da frequência) à medida que o tempo de cura aumentava.

\subsection{7. Ácido Polifosfórico (PPA)}

Uma revisão bibliográfica realizada por Masson (2008) aponta que o ácido polisfosfórico é um oligômero do ácido fosfórico, sendo que a produção de PPA com alto grau de pureza pode ser realizada tanto pela desidratação do ácido fosfórico quanto pelo aquecimento de pentóxido de fósforo disperso em ácido fosfórico. Segundo Buncher (2005), a mistura do PPA com um CAP puro ou modificado com polímeros não acarreta qualquer tipo de problema de estocagem do ligante asfáltico, como separação de fases ou corrosão. Os benefícios visualizados pela adição do PPA não são os mesmos para todos os ligantes asfálticos, uma vez que, como a maioria dos modificadores, a interação do PPA com o CAP é dependente da composição química do material de base.

A primeira patente descrevendo a modificação de ligantes asfálticos com PPA foi publicada em 1973. Desde o início dos anos 90, o PPA também vem sendo utilizado em combinação com vários tipos de polímeros, com o intuito de melhorar a qualidade dos ligantes asfálticos empregados em pavimentação. Entretanto, as preocupações de alguns órgãos consumidores no que diz respeito à qualidade do desempenho deste tipo de CAP modificado resultaram em inúmeros estudos por parte dos pesquisadores. A publicação IS- $220^{13}$ resume nove artigos que foram publicados desde 2001 na área de modificação dos ligantes asfálticos com PPA, além de resumos de apresentações feitas em eventos (BUNCHER, 2005).

O mecanismo de interação entre o PPA e o ligante asfáltico ainda não é conhecido pelos pesquisadores (BAUMGARDNER et al., 2005; MASSON, 2008; FEE et al., 2010), de modo que várias teorias a respeito deste mecanismo foram propostas pela comunidade científica. De acordo com uma revisão bibliográfica realizada por Fee et al. (2010), uma destas teorias sugere que o PPA reage com vários grupos funcionais do ligante asfáltico, rompendo os aglomerados de asfaltenos e permitindo que as unidades individuais destas moléculas formem uma maior dispersão na fase rica em maltenos. Uma vez dispersas, as unidades de asfaltenos possuem maior capacidade de formar longas redes dentro do ligante asfáltico e, com isso, alteram as características físicas e reológicas do material.

\footnotetext{
${ }^{13}$ ASPHALT INSTITUTE. (2005). IS-220: Polyphosphoric Acid Modification of Asphalt. ISBN 9781934154472.
} 
Vários pesquisadores realizaram estudos com o objetivo de esclarecer melhor este mecanismo de interação. Um dos estudos é o realizado por Baumgardner et al. (2005), os quais analisaram dois tipos diferentes de ligantes asfálticos em suas condições modificadas com PPA e não-modificadas, sendo um de classificação PG 64-22 e outro de classificação PG 67-22. O primeiro foi modificado com $1,2 \%$ de PPA em peso e o segundo foi modificado com $0,62 \%$ de PPA em peso, de modo que, após a modificação, ambos os ligantes asfálticos atingiram a classificação PG 70-22. Neste estudo, os autores concluíram que o efeito enrijecedor do PPA é dependente da composição química do ligante asfáltico, pois este ácido afetou a fase dispersa em um ligante asfáltico e a matriz em outro. Diversos mecanismos foram propostos para explicar o enrijecimento dos ligantes asfálticos devido à adição de PPA, porém a determinação de qual mecanismo (ou quais mecanismos) prevalece sobre os demais dependerá, segundo estes autores, de análises físico-químicas detalhadas.

Um dos polímeros com os quais o PPA pode ser utilizado é o SBS. Neste tipo de modificação, os teores típicos de SBS variam entre 2,5 e 5,0\% em peso e os de PPA, entre $0,2 \%$ e $1,0 \%$ em peso. Os níveis apropriados de ambos dependerão do tipo de CAP e das exigências da especificação a ser atendida. Em usinas de ligante asfáltico, as temperaturas de estocagem deste tipo de material modificado geralmente estão situadas entre $155^{\circ} \mathrm{C}$ e $177^{\circ} \mathrm{C}$ no caso de utilização imediata e, para os casos de estocagem por mais de duas semanas (longo prazo), o procedimento usual é suspender o aquecimento do ligante asfáltico e depois reaquecê-lo vagarosamente até uma temperatura máxima de $177^{\circ} \mathrm{C}$ (ICL PERFORMANCE PRODUCTS LP, 2008).

Estudos como o de Cao et al. (2011) foram realizados com o intuito de investigar, dentre outros aspectos, as alterações nas propriedades tradicionais e de viscosidade rotacional de ligantes asfálticos modificados somente com PPA. Estes pesquisadores selecionaram um CAP 60/80 e prepararam misturas CAP+PPA em quatro teores diferentes do modificador por peso de CAP, sendo eles 0,6\%, 1,0\%, 1,5\% e 2,0\%. Os resultados deste estudo mostraram que a incorporação do PPA acarreta aumento no ponto de amolecimento, redução na penetração e aumento na viscosidade rotacional do ligante asfáltico, sendo que estes efeitos foram maiores para os teores mais elevados de modificador. No campo da viscosidade, os resultados obtidos por Cao et al. (2011) na temperatura de $135^{\circ} \mathrm{C}$ não superaram o limite estabelecido pela especificação Superpave (3,0 Pa.s), uma vez que a viscosidade máxima foi de 1,15 Pa.s para o CAP modificado com 2,0\% de PPA. Neste aspecto, a conclusão dos autores foi a de que a adição de PPA aumenta a viscosidade rotacional do ligante asfáltico, mantendo, porém, uma trabalhabilidade adequada para o material. 
Com relação ao desempenho em temperaturas altas e baixas para os ligantes asfálticos modificados com PPA, Buncher (2005) menciona que este ácido pode aumentar o PG do ligante asfáltico em temperaturas altas e, em alguns casos, pode também aumentar o $P G$ em temperaturas baixas. Estas características foram visualizadas em estudos como o de Kodrat et al. (2007), os quais não observaram alterações significativas na temperatura mínima da classificação PG dos ligantes asfálticos após a adição do PPA e, ao mesmo tempo, incrementos significativos na temperatura máxima da classificação PG dos ligantes asfálticos após a adição do PPA. Em outro estudo, Cao et al. (2011) observaram incrementos pequenos da rigidez do ligante asfáltico em temperaturas baixas $(\mathrm{S}(\mathrm{t}))$ após a adição de PPA, incrementos estes que, após uma análise estatística, não foram considerados significativos pelos pesquisadores. Com relação à taxa de relaxação $(m(t))$ dos ligantes asfálticos em temperaturas baixas, Buncher (2005) menciona que a incorporação do PPA não acarreta oxidação do ligante asfáltico e, assim, as questões associadas à fragilidade excessiva do CAP+PPA em tais temperaturas são evitadas.

Em outro estudo, Fee et al. (2010) avaliaram as alterações no percentual de recuperação e na compliância não-recuperável de ligantes asfálticos modificados com PPA em comparação ao material puro e a materiais modificados com SBS e Elvaloy. Os resultados obtidos pelos autores mostraram reduções na compliância não-recuperável e incrementos pequenos do percentual de recuperação após a incorporação do PPA ao ligante asfáltico, sendo que os materiais modificados com SBS e Elvaloy apresentaram percentuais de recuperação superiores a $30 \%$ e os materiais puros apresentaram valores muito pequenos para esta propriedade. Como destacado por estes autores, o percentual de recuperação obtido no MSCR permitiu uma identificação clara da presença dos polímeros SBS e Elvaloy nos ligantes asfálticos modificados, diferenciando-os dos materiais puros e dos modificados somente com PPA. 


\section{MATERIAIS E MÉTODOS}

Os materiais e métodos utilizados no desenvolvimento do estudo são descritos neste capítulo, bem como os ensaios e as propriedades envolvidas. São destacados os parâmetros para análise de sensibilidade dos ligantes asfálticos a fatores como o envelhecimento a curto prazo, mudanças no nível de tensão e alterações nos tempos de fluência e recuperação, à luz dos resultados de viscosidade rotacional, percentual de recuperação e compliância não-recuperável. São destacados também os resultados de perda de massa e os parâmetros de avaliação da penetração e do ponto de amolecimento dos ligantes asfálticos antes e após o RTFOT, estes nomeados respectivamente como penetração retida $\left(P E N_{R E T}\right)$ e incremento do ponto de amolecimento $\left(I_{P A}\right)$. As análises de perdas de massa levam em consideração aspectos como similaridade de valores, maiores e menores resultados dentre todos os ligantes asfálticos em estudo e comparações entre os resultados dos ligantes asfálticos modificados e o do material de base.

\subsection{Formulações dos ligantes asfálticos e ensaios de caracterização}

Foram preparados doze ligantes asfálticos modificados tendo um CAP 50/70 fornecido pela REPLAN-Petrobras e de classificação PG 64-XX como material de base. As formulações foram escolhidas com 0 propósito de se obterem ligantes asfálticos modificados de classificação PG 76-XX, correspondente a dois graus acima do PG do CAP. Estas classificações foram obtidas com base no critério original da especificação Superpave, segundo o qual a temperatura máxima do PG é aquela em que o parâmetro G*/senঠ apresenta os valores mínimos de 1,0 e 2,2 kPa para o material virgem e o envelhecido a curto prazo, respectivamente. No novo critério da especificação Superpave, a temperatura máxima do $P G$ é aquela em que o parâmetro $\mathrm{G}^{*} /$ senঠ apresenta o valor mínimo de 1,0 kPa para o material virgem, não sendo estabelecido, portanto, qualquer limitação de $\mathrm{G}^{*} /$ senঠ para o material envelhecido a curto prazo. A Tabela 4 apresenta as formulações de cada ligante asfáltico, juntamente com suas classificações PG no critério original do Superpave e as respectivas perdas de massa. Os modificadores utilizados nestes preparos foram os seguintes:

a) A borracha moída de pneu, fornecida pela empresa Ecija Comércio Exportação e Importação de Produtos Ltda, resultante do processo de trituração de bandas de rodagem de pneus de veículos de passeio e com partículas passantes na peneira $n^{\circ} 30$; 
b) O PPA de designação comercial Innovalt E-200, fornecido pela Innophos Inc. dos Estados Unidos;

c) O SBS tipo TR-1101, adquirido da Kraton e fornecido pela Betunel, dotado das seguintes características técnicas: teor de poliestireno de $31 \%$, densidade igual a 0,94 , resistência à tração de $33 \mathrm{MPa}$ e alongamento na ruptura igual a $880 \%$;

d) O SBR tipo Solprene 1205, adquirido da Dynasol e fornecido pela Betunel, dotado das seguintes características técnicas: teor de estireno de $25 \%, 0,1 \%$ de insolúveis e densidade igual a 0,93;

e) O EVA tipo HM 728, adquirido da Politeno e fornecido pelo CENPES-Petrobras, dotado das seguintes características técnicas: teor de acetato de vinila igual a $28 \%$, ponto de fusão de $77^{\circ} \mathrm{C}$ e temperatura de amolecimento Vicat igual a $49^{\circ} \mathrm{C}$;

f) O PE tipo UB160-C de baixa densidade, produzido pela Unipar; e

g) O terpolímero Elvaloy tipo 4170, fornecido pela empresa Dupont e com as seguintes características técnicas: massa específica igual a $0,94 \mathrm{~g} / \mathrm{cm}^{3}$, ponto de fusão de $72{ }^{\circ} \mathrm{C}$ e temperatura máxima de processamento igual a $310^{\circ} \mathrm{C}$.

Tabela 4 - Formulações dos ligantes asfálticos, classificações PG e perdas de massa

\begin{tabular}{cccccc}
\hline \multirow{2}{*}{$\begin{array}{c}\text { Ligante } \\
\text { asfáltico }\end{array}$} & $\begin{array}{c}\text { Classificação PG no } \\
\text { critério original }^{\mathrm{A}}\end{array}$ & \multicolumn{2}{c}{ Formulações (\% em massa) } & Perda de \\
\cline { 3 - 5 } 50/70 & $64-\mathrm{XX}$ & 100,0 & - & - & $-0,1094$ \\
PPA & $76-X X$ & 98,8 & - & 1,2 & $-0,2263$ \\
Elvaloy+PPA & $76-X X$ & 98,4 & 1,3 & 0,3 & $-0,0421$ \\
Borracha & $76-X X$ & 86,0 & 14,0 & - & $-0,2402$ \\
Borracha+PPA & $76-X X$ & 88,5 & 11,0 & 0,5 & $-0,2987$ \\
SBS & $76-X X$ & 95,5 & 4,5 & - & $-0,1166$ \\
SBS+PPA & $76-X X$ & 96,5 & 3,0 & 0,5 & $-0,2035$ \\
EVA & $76-X X$ & 92,0 & 8,0 & - & $-0,2044$ \\
EVA+PPA & $76-X X$ & 96,6 & 3,0 & 0,4 & $-0,0600$ \\
PE & $76-X X$ & 94,0 & 6,0 & - & $-0,0980$ \\
PE+PPA & $76-X X$ & 96,5 & 3,0 & 0,5 & $-0,2025$ \\
SBR & $76-X X$ & 94,5 & 5,5 & - & $-0,0815$ \\
SBR+PPA & $76-X X$ & 96,0 & 3,5 & 0,5 & $-0,2499$ \\
\hline
\end{tabular}

A Critério Original: Segundo este critério, a temperatura máxima do PG é aquela em que o parâmetro $\mathrm{G}^{*} / \mathrm{sen}$ apresenta os valores mínimos de 1,0 e 2,2 kPa para o material virgem e o envelhecido a curto prazo, respectivamente.

Em relação aos misturadores, foram utilizados um de baixo cisalhamento e outro de alto cisalhamento no preparo dos ligantes asfálticos modificados. O misturador de baixo 
cisalhamento é o da marca Fisatom, modelo 722D, e o de alto cisalhamento é o da marca Silverson, modelo L4R. As variáveis de processamento dos CAPs modificados são apresentadas na Tabela 5.

Tabela 5 - Variáveis de processamento dos ligantes asfálticos

\begin{tabular}{ccccc}
\hline \multirow{2}{*}{ Ligante asfáltico } & \multicolumn{4}{c}{ Variáveis de processamento } \\
\cline { 2 - 5 } & Cisalhamento & $\begin{array}{c}\text { Rotação } \\
(\text { rpm })\end{array}$ & $\begin{array}{c}\text { Temperatura } \\
\left(\mathrm{em}^{\circ} \mathrm{C}\right)\end{array}$ & Tempo (min) \\
\hline $50 / 70$ & - & - & - & - \\
PPA & baixo & 300 & 130 & 30 \\
Elvaloy+PPA & baixo & 300 & 190 & 120, PPA aos 60 \\
Borracha & alto & 4.000 & 190 & 90 \\
Borracha+PPA & alto & 4.000 & 190 & 120, PPA aos 90 \\
SBS & alto & 4.000 & 180 & 120 \\
SBS+PPA & alto & 4.000 & 180 & 120, PPA aos 60 \\
EVA & baixo & 300 & 180 & 120 \\
EVA+PPA & baixo & 300 & 180 & 120, PPA aos 90 \\
PE & baixo & 440 & 150 & 120 \\
PE+PPA & baixo & 400 & 150 & 120, PPA aos 60 \\
SBR & baixo & 400 & 180 & 120 \\
SBR+PPA & baixo & 300 & 180 & 120, PPA aos 90 \\
\hline
\end{tabular}

Os resultados de perda de massa (Tabela 4) mostram que o CAP puro, o CAP+SBS e o CAP+PE apresentam valores comparáveis (em torno de 0,10\%). Um destaque especial pode ser dado ao CAP+Elvaloy+PPA, ao CAP+EVA+PPA e ao $\mathrm{CAP}+\mathrm{SBR}$, os quais apresentam perdas de massa entre 0,04 e 0,09\% e, portanto, inferiores à do CAP puro. Boa parte das formulações apresenta perdas de massa superiores à do CAP puro (entre 0,20 e 0,30\%), sendo elas o CAP+PPA, o CAP+borracha, - CAP+borracha+PPA, o CAP+SBS+PPA, O CAP+EVA, O CAP+PE+PPA e 0 CAP+SBR+PPA. O CAP+borracha+PPA possui a maior perda de massa $(0,30 \%)$ e o CAP+Elvaloy+PPA, a menor (0,04\%). Três formulações apresentam perdas de massa idênticas (0,20\%): CAP+SBS+PPA, CAP+EVA e CAP+PE+PPA. Na extensão em que é válida a aplicação do limite de perda de massa de 0,50\% especificado pelo Regulamento Técnico 03/2005 ${ }^{14}$ da Agência Nacional do Petróleo, Gás Natural e Biocombustíveis (ANP) a CAPs modificados, todos os materiais modificados seriam adequados do ponto de vista

14 AGÊNCIA NACIONAL DO PETRÓLEO, GÁS NATURAL E BIOCOMBUSTíVEIS. (2005). Regulamento Técnico 03/2005: Cimento Asfáltico de Petróleo. Brasília, DF. 
de perda de massa. É importante observar que a perda de massa é constituída de um balanço entre os fenômenos de oxidação e evaporação e que, no caso de valores negativos, o fenômeno de evaporação foi mais intenso do que o de oxidação. No caso do CAP+Elvaloy+PPA, a menor perda de massa obtida para este material pode ser devido à maior oxidação do que a evaporação em comparação aos demais CAPs modificados.

Para a caracterização dos ligantes asfálticos modificados e do CAP 50/70, ambos nas condições virgem e envelhecida a curto prazo, foram selecionados os seguintes ensaios e normas da ASTM: penetração (ASTM D5), ponto de amolecimento (ASTM D36), viscosidade rotacional (ASTM D4402) e MSCR (ASTM D7405). O envelhecimento dos materiais modificados e do CAP foi realizado no ensaio da estufa de filme fino rotativo (RTFOT), de acordo com os procedimentos da norma ASTM D2872. Os cálculos das temperaturas de usinagem e de compactação (TUCs) dos ligantes asfálticos virgens foram realizados com base nos limites tradicionais de viscosidade rotacional, sendo eles: 0,17 \pm 0,02 Pa.s para a usinagem e 0,28 \pm 0,03 Pa.s para a compactação.

O ensaio de penetração consiste na determinação da profundidade, em décimos de milímetro ( $\mathrm{dmm}$ ), que uma agulha de massa padronizada (100 g) penetra em uma amostra de ligante asfáltico durante um período de tempo de $5 \mathrm{~s}$, à temperatura de $25^{\circ} \mathrm{C}$. São realizadas ao menos três medidas individuais de penetração em cada ensaio, sendo que a média dos valores é calculada e aceita como o resultado final caso a diferença entre eles não ultrapasse um limite especificado em norma. Para a realização do ensaio, foi utilizado um penetrômetro universal fornecido pela Solotest. Os resultados dos ligantes asfálticos virgens e envelhecidos a curto prazo (em $\mathrm{dmm}$ ) foram calculados com base nas médias de quatro medições individuais realizadas em cada material.

O ensaio de ponto de amolecimento, também conhecido como "ensaio anel e bola", consiste na obtenção da temperatura em que uma amostra de ligante asfáltico, condicionada em um anel metálico padronizado, toca a placa do fundo do conjunto padrão de ensaio devido ao peso de uma esfera metálica colocada sobre o material. $\mathrm{O}$ banho é aquecido a uma taxa constante de $5^{\circ} \mathrm{C} / \mathrm{min}$ e duas amostras do mesmo material são consideradas no ensaio. Se a diferença entre as temperaturas das duas amostras exceder o valor de $1^{\circ} \mathrm{C}$ (ASTM D36), o procedimento deve ser repetido. Neste ensaio, foi utilizado um equipamento automático modelo RB 36-5G fornecido pela "Instrumentation Scientifique de Laboratoire" (ISL) da França e, para o cálculo do ponto de amolecimento $\left(\mathrm{em}^{\circ} \mathrm{C}\right)$ de cada tipo de ligante asfáltico, foram realizados dois ensaios, totalizando quatro réplicas. 
O ensaio de viscosidade rotacional é caracterizado pelo cálculo da viscosidade de um ligante asfáltico tendo, como referência, o torque necessário para imprimir uma velocidade constante a uma haste ("spindle") imersa na amostra do material. Os resultados são geralmente expressos em centipoise $(\mathrm{cP})$, onde $1 \mathrm{cP}=0,001 \mathrm{~Pa}$.s. $\mathrm{O}$ equipamento utilizado foi um viscosímetro Brookfield modelo DVII+Pro acoplado a um controlador de temperatura Thermosel, considerando o "spindle" $\mathrm{n}^{\circ} .21$ nas medições. Foram ensaiadas réplicas das amostras a fim de controlar a variabilidade dos resultados dentro dos limites estipulados pela ASTM D4402, sendo que as viscosidades finais de cada ensaio foram obtidas pela média aritmética dos 10 valores fornecidos pelo equipamento, em cada temperatura. As viscosidades finais dos CAPs foram calculadas pela média dos valores obtidos na amostra original e na réplica em cada temperatura e a unidade de medida escolhida foi Pascal-segundo (Pa.s). As temperaturas e as velocidades de rotação, bem como as respectivas taxas de cisalhamento, estão indicadas na Tabela 6. A escolha destas velocidades foi feita com o objetivo de se realizarem medições dentro dos limites de porcentagem de torque de 10 a 98\% estipulados pela ASTM D4402, sem a necessidade da troca do "spindle".

Tabela 6 - Dados do ensaio de viscosidade rotacional

\begin{tabular}{ccc}
\hline Temperatura $\left({ }^{\circ} \mathrm{C}\right)$ & Velocidade $(\mathrm{rpm})$ & Taxa de cisalhamento $\left(\mathrm{s}^{-1}\right)$ \\
\hline 135 & 10 & 9 \\
143 & 15 & 14 \\
150 & 20 & 19 \\
163 & 30 & 28 \\
177 & 50 & 47 \\
\hline
\end{tabular}

Ainda sobre a viscosidade rotacional, a norma ASTM D4402 estabelece uma variabilidade máxima de $3,50 \%$ entre os resultados de dois ensaios distintos com um mesmo tipo de ligante asfáltico. Este limite foi atendido em praticamente todas as temperaturas e nas duas condições (virgem e RTFOT) no caso do CAP 50/70, do CAP+PPA, do CAP+PE e do $\mathrm{CAP}+\mathrm{SBR}$, para os quais foram verificadas as variabilidades máximas de 3,51\%, 3,26\%, 3,55\% e 2,33\%, respectivamente. No caso dos demais ligantes asfálticos, a variabilidade de $3,50 \%$ não foi atendida em pelo menos uma temperatura e em uma condição do material (limite máximo de duas temperaturas não atendidas por condição do ligante asfáltico), embora vários ensaios tenham sido realizados com o intuito de adequar os valores ao limite de norma. Neste estudo, as variabilidades finais estão entre 0,73 e 8,73\% para o CAP+Elvaloy+PPA, entre 0,36 e 8,34\% para o CAP+borracha, entre 0,97 e 6,35\% para o CAP+borracha+PPA, entre 0,23 e 5,32\% para o CAP+SBS, entre 0,54 e 7,00\% para o CAP+SBS+PPA, entre 0,16 e 7,20\% para o CAP+EVA, entre 0,37 e 4,08\% para o CAP+EVA+PPA, entre 0,24 e 3,93\% para o CAP+PE+PPA e entre 
0,28 e 4,36\% para o CAP+SBR+PPA. Em síntese, o processo de controle das variabilidades dos resultados é composto pelas seguintes etapas:

a) Realização dos ensaios com a amostra original e a réplica e verificação das variabilidades entre os resultados das duas amostras: se os limites de norma forem atendidos, estes resultados serão considerados no cálculo dos valores finais e o processo é dado como encerrado;

b) Caso as variabilidades obtidas no item (a) superem significativamente os limites especificados em norma, realizar um ensaio adicional e verificar as variabilidades entre os resultados das amostras, duas a duas;

c) Caso as variabilidades obtidas no item (b) ainda superem significativamente os limites de norma, realizar quantos ensaios adicionais forem necessários até que se obtenha um par de amostras cujas variabilidades estejam dentro dos limites de norma.

Para a realização dos ensaios MSCR, empregou-se um reômetro TA Instruments modelo AR-2000ex. A fim de controlar a variabilidade dos resultados dentro dos limites da ASTM D7405, foram ensaiadas réplicas das amostras. Os níveis de tensão, o número de ciclos por nível e os tempos de fluência e de recuperação, considerando os valores prescritos na ASTM D7405, foram adotados nos ensaios com as amostras virgens e as envelhecidas a curto prazo. Foram considerados também os tempos de $2 \mathrm{~s}$ para o carregamento e de $18 \mathrm{~s}$ para 0 repouso em ensaios adicionais com as amostras envelhecidas a curto prazo, a fim de verificar os impactos destas alterações nas propriedades dos ligantes asfálticos. Estes valores foram tomados com base nas sugestões do pesquisador Raj Dongré para tempos maiores de fluência e recuperação (nota de rodapé 1 , página 35 ). Os valores de $R$ e de $J_{n r}$ foram determinados para todos os ciclos e, ao final de cada conjunto de 10 ciclos, obtiveram-se os respectivos valores médios para cada uma das cinco temperaturas $\left(52,58,64,70\right.$ e $\left.76{ }^{\circ} \mathrm{C}\right)$. As amostras utilizadas possuíam diâmetro de $25 \mathrm{~mm}$ e distância entre placas ("gap”) igual a 1,0 mm. De maneira resumida, a realização do ensaio MSCR contempla as seguintes etapas:

a) Estabilização da temperatura da amostra de ligante asfáltico por um período de tempo de 10 minutos;

b) Aplicação de 10 ciclos sucessivos de carregamento e de repouso na amostra de ligante asfáltico, considerando o nível de tensão de $100 \mathrm{~Pa}$;

c) Aplicação de 10 ciclos sucessivos de carregamento e de repouso na amostra de ligante asfáltico, considerando o nível de tensão de 3.200 Pa;

d) Aquecimento do ligante asfáltico até a temperatura subsequente de ensaio, seguido de estabilização desta temperatura por um período de 10 minutos;

e) Repetição dos itens (b), (c) e (d), nesta ordem, para todas as temperaturas adotadas no ensaio. 
Ainda sobre o MSCR, a norma ASTM D7405 estabelece as variabilidades máximas de $6,7 \%$ e $8,5 \%$ para os valores de $\mathrm{R}$ nas tensões de 100 e $3.200 \mathrm{~Pa}$, respectivamente, e ensaios realizados pelo mesmo operador. No caso de $J_{n r}$, a variabilidade máxima permitida depende do valor desta propriedade e do nível de tensão, segundo os limites da Tabela 7 para ensaios com o mesmo operador. O processo de controle das variabilidades dos resultados do MSCR foi o mesmo adotado no ensaio de viscosidade rotacional. As variabilidades dos ligantes asfálticos ensaiados nas condições da ASTM D7405 foram todas respeitadas com relação à compliância não-recuperável, embora o mesmo não tenha ocorrido com o percentual de recuperação para todos os materiais. No caso desta última propriedade, os limites de 6,7\% e $8,5 \%$ foram respeitados em todas as temperaturas e níveis de tensão apenas pelo CAP+Elvaloy+PPA, pelo $\mathrm{CAP}+$ borracha+PPA, pelo $\mathrm{CAP}+\mathrm{EVA}+\mathrm{PPA}$, pelo $\mathrm{CAP}+\mathrm{PE}+\mathrm{PPA}$ e pelo $\mathrm{CAP}+\mathrm{SBR}$, os quais apresentaram variabilidades máximas de $2,73 \%, 3,71 \%, 4,91 \%, 1,20 \%$ e $6,45 \%$, respectivamente. Para os demais ligantes asfálticos ensaiados nas condições da ASTM D7405, as variabilidades de 6,7 e 8,5\% não foram atendidas em, no máximo, três temperaturas por ligante asfáltico. Neste estudo, as variabilidades finais estão entre 0,2 e 50,5\% para o CAP puro, entre 0,4 e $31,2 \%$ para o CAP+PPA, entre 0,3 e 23,0\% para o CAP+borracha, entre 1,4 e 12,5\% para o $C A P+S B S$, entre 0,4 e $11,4 \%$ para o $C A P+E V A$, entre 0,1 e $8,1 \%$ para o CAP+PE e entre 2,1 e $13,0 \%$ para o CAP+SBR+PPA, sendo de até 7,0\% para o CAP+SBS+PPA.

Tabela 7 - Variabilidades máximas permitidas para a compliância não-recuperável em ensaios realizados pelo mesmo operador [ASTM D7405]

\begin{tabular}{ccc}
\hline Tensão $(\mathrm{Pa})$ & Intervalo de valores de $\mathrm{J}_{\mathrm{nr}}\left(\mathrm{kPa}^{-1}\right)$ & Variabilidade máxima (\%) \\
\hline 100 & Acima de 1,00 & 12,8 \\
100 & Entre 0,26 e 1,00 & 15,2 \\
100 & Entre 0,10 e 0,25 & 38,3 \\
100 & Abaixo de 0,10 & - \\
3.200 & Acima de 1,00 & 16,0 \\
3.200 & Entre 0,26 e 1,00 & 15,3 \\
3.200 & Entre 0,10 e 0,25 & 26,6 \\
3.200 & Abaixo de 0,10 & - \\
\hline
\end{tabular}

\subsection{Análises de sensibilidade e outras considerações}

As variabilidades dos resultados dos ensaios MSCR e de viscosidade rotacional foram calculadas de acordo com a Equação 10, na qual VAR é a variabilidade, $V_{1}$ é o valor 
86

obtido na amostra original e $V_{2}$ é o valor obtido na réplica. Esta equação leva em conta a diferença entre os valores $V_{1}$ e $V_{2}$ pela média aritmética simples de ambos.

$$
\operatorname{VAR}(\%)=\frac{\left(V_{1}-V_{2}\right)}{0,50 \cdot\left(V_{1}+V_{2}\right)} \cdot 100
$$

As análises dos resultados de penetração levaram em conta o valor da penetração retida dos ligantes asfálticos, a qual é calculada pela razão entre a penetração do ligante

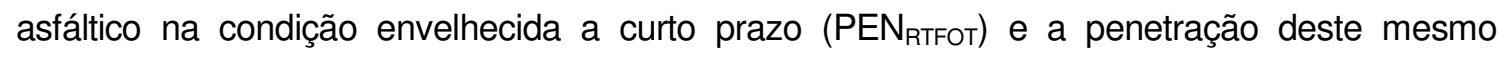

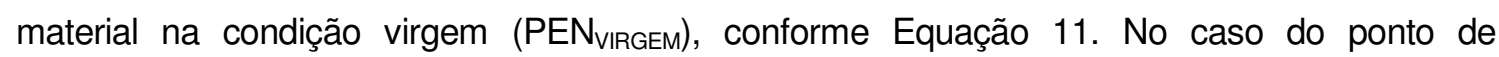
amolecimento, as análises dos resultados levaram em conta o incremento do ponto de amolecimento dos ligantes asfálticos $\left(\mathrm{I}_{\mathrm{PA}}\right)$, o qual é calculado pela diferença entre o ponto de amolecimento do material na condição envelhecida a curto prazo (PA $\mathrm{RTFOT}_{\text {) }}$ e o ponto de

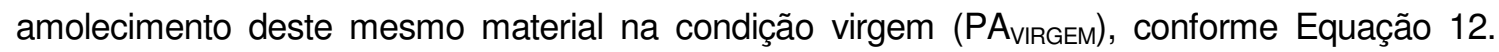
Valores altos para PEN $\mathrm{NET}_{\mathrm{P}}$ e $\mathrm{I}_{\mathrm{PA}}$ indicam uma sensibilidade elevada do ligante asfáltico ao envelhecimento a curto prazo, à luz dos resultados destas propriedades.

$$
\begin{gathered}
P E N_{R E T}(\%)=\frac{P E N_{R T F O T}}{P E N_{V I R G E M}} \cdot 100 \\
I_{P A}=P A_{R T F O T}-P A_{V I R G E M}
\end{gathered}
$$

As alterações nas propriedades de penetração e de ponto de amolecimento após a modificação do CAP 50/70 foram analisadas em termos do grau de modificação do material, designado por $G_{M}$ e calculado pela razão entre o valor da propriedade para o material modificado $\left(\mathrm{P}_{\mathrm{MOD}}\right)$ e o valor desta mesma propriedade para o material puro ( $\left.\mathrm{P}_{\mathrm{CAP}}\right)$, conforme Equação 13. Valores superiores à unidade $\left(G_{M}>1\right)$ correspondem a um incremento da propriedade para o ligante asfáltico modificado em relação ao CAP 50/70, ao passo que valores inferiores à unidade $\left(G_{M}<1\right)$ correspondem a uma redução da propriedade para o material modificado em relação ao material puro.

$$
G_{M}=\frac{P_{M O D}}{P_{C A P}}
$$

Os incrementos de viscosidade dos ligantes asfálticos após o envelhecimento a curto prazo foram avaliados pela relação entre as viscosidades rotacionais, designada como $R_{V}$ e calculada pela razão entre as viscosidades na condição envelhecida $\left(\mathrm{V}_{\mathrm{ENV}}\right)$ e na condição virgem $\left(\mathrm{V}_{\mathrm{VIR}}\right)$, conforme Equação 14. Este parâmetro expressa quantas vezes a viscosidade na 
condição envelhecida é maior do que na condição virgem, ou ainda, quantas vezes a viscosidade rotacional aumentou por conta do envelhecimento a curto prazo. Assim, valores mais elevados de $R_{V}$ estão associados a uma sensibilidade maior do ligante asfáltico ao envelhecimento a curto prazo, à luz dos resultados de viscosidade rotacional.

$$
R_{V}=\frac{V_{E N V}}{V_{V I R}}
$$

A fim de avaliar os efeitos do envelhecimento no percentual de recuperação e na compliância não-recuperável dos ligantes asfálticos, foi realizada uma análise das variações de $R$ e de $J_{n r}$ antes e após o envelhecimento a curto prazo. No caso de $J_{n r}$, utilizou-se a Equação 15 para determinar a relação entre as compliâncias não-recuperáveis $\left(R_{\jmath}\right)$, sendo $\mathrm{J}_{\mathrm{nr}} \mathrm{V}$ a compliância obtida para o material virgem e $\mathrm{J}_{\mathrm{nr}} \mathrm{RT}$ a compliância obtida para o material envelhecido a curto prazo. Os valores indicam quantas vezes a compliância não-recuperável do material virgem é maior que a do material envelhecido a curto prazo ou, em outras palavras, quantas vezes o valor de $J_{n r}$ diminuiu por causa do envelhecimento. Desta maneira, valores mais elevados de $R_{J}$ correspondem a uma sensibilidade maior do ligante asfáltico ao envelhecimento, à luz dos valores de compliância não-recuperável. Os resultados deste parâmetro permitirão observar como a temperatura e o nível de tensão afetam a compliância não-recuperável após o envelhecimento a curto prazo.

$$
R_{J}=\frac{J_{n r} V}{J_{n r} R T}
$$

De maneira similar à análise da compliância não-recuperável, utilizou-se a Equação 16 para calcular a relação entre os percentuais de recuperação $\left(R_{R}\right)$, sendo $R_{\text {VIRGEM }} 0$ percentual de recuperação obtido no ligante asfáltico virgem e $R_{R T F O T}$, o percentual de recuperação obtido no ligante asfáltico envelhecido a curto prazo. Os valores indicam quantas vezes a recuperação do material envelhecido a curto prazo é maior que a do material virgem ou, em outras palavras, quantas vezes o valor de $\mathrm{R}$ aumentou por causa do envelhecimento. Desta maneira, valores mais elevados de $R_{R}$ correspondem a uma sensibilidade maior do ligante asfáltico ao envelhecimento, à luz do percentual de recuperação. Os resultados deste parâmetro permitirão observar como a temperatura e o nível de tensão afetam o percentual de recuperação após o envelhecimento a curto prazo.

$$
R_{R}=\frac{R_{R T F O T}}{R_{V I R G E M}}
$$


Com o intuito de avaliar a sensibilidade dos ligantes asfálticos à tensão, foi calculada a diferença percentual entre as compliâncias não-recuperáveis para estes materiais nas condições virgem e envelhecida a curto prazo (Equação 7, página 52), seguindo as recomendações prescritas por Anderson et al. (2010) e por Asphalt Institute (2010a, 2010b). Foi dado um destaque aos ligantes asfálticos que ultrapassaram o valor de $75 \%$ estabelecido pela norma AASHTO MP19 ${ }^{15}$ na temperatura máxima do PG e na condição envelhecida a curto prazo para os tempos de fluência e recuperação de 1 e $9 \mathrm{~s}$, o que indica uma sensibilidade excessiva à tensão. É importante observar que tanto a norma AASHTO MP19 quanto o limite de $75 \%$ para o parâmetro $J_{\text {nr,diff }}$ foram submetidos a revisão, como apontado por Dongré (informação pessoal) ${ }^{16}$, de modo que alterações podem ter sido (ou poderão ser) realizadas em um ou ambos os itens. É importante observar também que este limite de $75 \%$ é especificado para ligantes asfálticos ensaiados na temperatura do PG e classificados segundo o novo critério da especificação Superpave, de modo que as avaliações realizadas neste estudo foram feitas apenas a título de comparação.

Os efeitos dos tempos de fluência e recuperação nos comportamentos dos ligantes asfálticos foram analisados em termos do percentual de recuperação e da compliância nãorecuperável. Neste aspecto, dois parâmetros foram levados em consideração: (1) a relação entre os percentuais de recuperação dos ligantes asfálticos nos tempos de 1 e $9 \mathrm{~s}\left(\mathrm{R}_{1-9}\right)$ e nos tempos de 2 e 18 s $\left(R_{2-18}\right)$, designada como $R_{P}$ e calculada pela Equação 17; e (2) a relação entre as compliâncias não-recuperáveis nos tempos de 2 e $18 \mathrm{~s}\left(\mathrm{Jnr}_{2-18}\right)$ e nos tempos de 1 e $9 \mathrm{~s}$ (Jnr $\left.{ }_{1-9}\right)$, designada como $R_{C}$ e calculada pela Equação 18. Para valores superiores à unidade, o parâmetro $R_{P}$ especifica quantas vezes o percentual de recuperação diminuiu por conta das alterações nos tempos de fluência e recuperação, ao passo que o parâmetro $R_{C}$ especifica quantas vezes a compliância não-recuperável aumentou por conta destas alterações. Valores inferiores à unidade para ambos os parâmetros mostram efeitos contrários nas propriedades dos ligantes asfálticos, ou seja, aumentos nos percentuais de recuperação $\left(R_{P}<1\right)$ e reduções nas compliâncias não-recuperáveis $\left(R_{C}<1\right)$. Valores mais elevados ou mais baixos para estes parâmetros estão associados a uma sensibilidade maior do ligante asfáltico ao aumento dos tempos de fluência e recuperação de 1 e $9 \mathrm{~s}$ para 2 e $18 \mathrm{~s}$, ao passo que valores muito próximos à unidade para um ou ambos $\left(\mathrm{R}_{\mathrm{P}} \approx 1\right.$ e/ou $\left.\mathrm{R}_{\mathrm{C}} \approx 1\right)$ indicam uma sensibilidade baixa dos ligantes asfálticos ao aumento dos tempos de fluência e recuperação.

\footnotetext{
${ }^{15}$ AMERICAN ASSOCIATION OF STATE HIGHWAY AND TRANSPORTATION OFFICIALS. AASHTO MP19: Standard Specification for Performance-Graded Asphalt Binder Using Multiple Stress Creep Recovery (MSCR) Test. Washington, D.C.

16 Dongré, R. Questions about the MSCR Test and specification. Mensagem recebida por matinocente10@hotmail.com em 13 jan. 2012.
} 


$$
\begin{gathered}
R_{P}=\frac{R_{1-9}}{R_{2-18}} \\
R_{C}=\frac{J n r_{2-18}}{J n r_{1-9}}
\end{gathered}
$$

A construção das tabelas normalizadas foi realizada com base nos resultados do CAP 50/70 e do CAP+PPA. A escolha do CAP 50/70 foi motivada pela avaliação do efeito de um grau de desempenho maior do ligante asfáltico por conta da adição de modificadores; por sua vez, a escolha do CAP+PPA foi motivada pela comparação entre os efeitos da adição de polímeros e borracha moída ao ligante asfáltico (com ou sem PPA) e os da adição isolada de PPA ao material, embora a classificação PG seja a mesma para todos os CAPs modificados segundo o critério original da especificação Superpave. Nos cálculos do percentual de recuperação, os valores normalizados desta propriedade $\left(N_{R}\right)$ foram obtidos pela razão entre o valor do ligante asfáltico em questão $\left(R_{M A T}\right)$ e o do ligante asfáltico de referência $\left(R_{R E F}\right)$, conforme Equação 19. Valores de $N_{R}>1$ correspondem a maiores percentuais de recuperação do material em questão em relação ao material de referência, ao passo que valores de $N_{R}<1$ correspondem a menores percentuais de recuperação do material em questão em relação ao material de referência. No caso do CAP puro, os resultados de $N_{R}$ permitem observar quantas vezes o percentual de recuperação aumentou por conta das modificações. No caso do CAP+PPA, os resultados de $N_{R}$ permitem observar quais materiais possuem percentuais de recuperação maiores $\left(N_{R}>1\right)$ e menores $\left(N_{R}<1\right)$ em relação a este CAP de referência.

$$
N_{R}=\frac{R_{M A T}}{R_{R E F}}
$$

Nos cálculos de $J_{n r}$, os valores normalizados desta propriedade $\left(N_{C}\right)$ foram obtidos pela razão entre a compliância não-recuperável do CAP de referência ( $\mathrm{Jnr}_{\mathrm{REF}}$ ) e a do CAP em questão ( Jnr $_{\text {MAT }}$ ), conforme Equação 20. Valores de $\mathrm{N}_{\mathrm{C}}>1$ correspondem a menores compliâncias não-recuperáveis do material em questão em relação ao material de referência, ao passo que valores de $\mathrm{N}_{\mathrm{C}}<1$ correspondem a maiores compliâncias não-recuperáveis do material em questão em relação ao material de referência. No caso do CAP 50/70, os resultados de $\mathrm{N}_{\mathrm{C}}$ permitem observar quantas vezes o valor de $\mathrm{J}_{\mathrm{nr}}$ diminuiu por conta das modificações. No caso do CAP+PPA, os resultados de $\mathrm{N}_{C}$ permitem observar quais ligantes asfálticos possuem compliâncias menores $\left(N_{C}>1\right)$ e maiores $\left(N_{C}<1\right)$ em relação a este material de referência.

$$
N_{C}=\frac{J n r_{R E F}}{J n r_{M A T}}
$$




\section{RESULTADOS E DISCUSSÃO}

Este capítulo apresenta os resultados dos ensaios de caracterização reológica dos ligantes asfálticos modificados e do CAP 50/70, nas condições virgem e envelhecida a curto prazo na estufa de filme fino rotativo e considerando os ensaios de penetração, ponto de amolecimento, viscosidade rotacional e MSCR. Também são apresentadas as análises destes resultados e as comparações entre os ligantes asfálticos, destacando itens como similaridades de valores e materiais que apresentam os maiores e menores resultados em cada propriedade e parâmetro. Destaques especiais são dados aos ligantes asfálticos que apresentam comportamentos peculiares, ou seja, muito diferentes do observado na maioria dos ligantes asfálticos ou com resultados próximos aos de outro material.

\subsection{Resultados dos ensaios de penetração e de ponto de amolecimento e discussão}

Os valores médios de penetração para os ligantes asfálticos virgens e envelhecidos a curto prazo, bem como seus respectivos graus de modificação, são apresentados na Tabela 8. A adição dos modificadores provoca, em linhas gerais, redução na penetração do ligante asfáltico virgem, o que indica uma maior rigidez do material modificado em relação ao CAP 50/70 na temperatura de $25^{\circ} \mathrm{C}$. Embora todos os ligantes asfálticos modificados apresentem o mesmo PG, o efeito das modificações é sentido de maneira expressiva a $25^{\circ} \mathrm{C}$. A adição de polietileno provocou, na condição virgem, a maior redução na penetração do CAP 50/70 (menor valor de $\mathrm{G}_{\mathrm{M}}$ ), ao passo que a menor variação de penetração é obtida para o CAP+Elvaloy+PPA ( $G_{M}$ mais próximo de 1). Em uma ordenação dos demais ligantes asfálticos virgens em relação ao CAP 50/70, observa-se que o CAP+PE+PPA é o segundo mais rígido $\left(G_{M}=0,55\right)$, seguido do $C A P+E V A+P P A$, do $C A P+S B S+P P A$ e do CAP+PPA, os três com graus de modificação aproximadamente igual a 0,6. Em seguida vem o $\operatorname{CAP}+\operatorname{SBR}\left(\mathrm{G}_{M}=0,67\right)$, seguido pelo $C A P+$ borracha+PPA $\left(\mathrm{G}_{M}=0,73\right)$, depois pelo $C A P+S B S\left(G_{M}=0,77\right)$, depois pelo $C A P+E V A$, então pelo $C A P+S B R+P P A$ e finalmente o CAP+borracha, estes três últimos com graus de modificação ao redor de 0,8.

Com o envelhecimento a curto prazo na estufa de filme fino rotativo, o quadro das penetrações dos ligantes asfálticos é alterado. Da mesma maneira que para os materiais virgens, os resultados da Tabela 8 mostram que o CAP+PE e o CAP+PE+PPA possuem as 
menores penetrações dentre os ligantes asfálticos envelhecidos a curto prazo (menores valores de $\left.G_{M}\right)$, seguidos pelos materiais modificados com PPA $\left(G_{M}=0,77\right)$, EVA+PPA $\left(G_{M}=0,79\right)$, EVA $\left(G_{M}=0,83\right)$, SBS+PPA, SBS e borracha+PPA, estes três últimos com grau de modificação igual a 0,85. Interessante observar que, na condição envelhecida a curto prazo, o $\mathrm{CAP}+$ Elvaloy+PPA, o $\mathrm{CAP}+\mathrm{SBR}$ e o $\mathrm{CAP}+\mathrm{SBR}+\mathrm{PPA}$ apresentam penetrações superiores às do CAP 50/70 ( $\left.G_{M}>1\right)$, o mesmo não sendo visualizado em qualquer material modificado e na condição virgem. Do ponto de vista de formulação e tomando por base as amostras envelhecidas, o CAP 50/70 e os CAPs modificados com Elvaloy+PPA e SBR+PPA são comparáveis em termos de penetração $\left(G_{M} \approx 1\right)$, o mesmo ocorrendo com 0 CAP+borracha+PPA, o CAP+SBS, o CAP+SBS+PPA e o CAP+EVA $\left(G_{M} \approx 0,85\right)$. No caso dos ligantes asfálticos virgens, esta comparação pode ser observada em dois grupos: um formado pelo $C A P+E V A+P P A$, pelo $C A P+S B S+P P A$ e pelo $C A P+P P A\left(G_{M} \approx 0,6\right)$ e outro formado pelo $\mathrm{CAP}+\mathrm{EVA}$, pelo $\mathrm{CAP}+\mathrm{SBR}+\mathrm{PPA}$ e pelo $\mathrm{CAP}+$ borracha $\left(\mathrm{G}_{\mathrm{M}} \approx 0,8\right)$.

Tabela 8 - Valores de penetração (PEN) e graus de modificação dos ligantes asfálticos virgens e envelhecidos a curto prazo

\begin{tabular}{ccccc}
\hline \multirow{2}{*}{ Ligante asfáltico } & \multicolumn{2}{c}{ Material virgem } & \multicolumn{2}{c}{ Material envelhecido a curto prazo } \\
\cline { 2 - 5 } & PEN $_{\text {VIRGEM }}(\mathrm{dmm})$ & $\mathrm{G}_{\mathrm{M}}$ & PEN $_{\text {RTFOT }}(\mathrm{dmm})$ & $\mathrm{G}_{\mathrm{M}}$ \\
\hline $50 / 70$ & 58,0 & 1,00 & 30,8 & 1,00 \\
PPA & 36,5 & 0,63 & 23,8 & 0,77 \\
Elvaloy+PPA & 52,0 & 0,90 & 31,8 & 1,03 \\
Borracha & 48,0 & 0,83 & 29,0 & 0,94 \\
Borracha+PPA & 42,3 & 0,73 & 26,0 & 0,85 \\
SBS & 44,5 & 0,77 & 26,0 & 0,85 \\
SBS+PPA & 36,3 & 0,63 & 26,0 & 0,85 \\
EVA & 46,3 & 0,80 & 25,5 & 0,83 \\
EVA+PPA & 35,8 & 0,62 & 24,3 & 0,79 \\
PE & 25,0 & 0,43 & 20,3 & 0,66 \\
PE+PPA & 31,8 & 0,55 & 23,0 & 0,75 \\
SBR & 39,0 & 0,67 & 37,0 & 1,20 \\
SBR+PPA & 47,0 & 0,81 & 31,3 & 1,02 \\
\hline
\end{tabular}

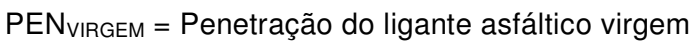

PEN $N_{\text {RTFOT }}=$ Penetração do ligante asfáltico envelhecido a curto prazo $\mathrm{G}_{\mathrm{M}}=$ Grau de modificação do ligante asfáltico

Ainda sobre os resultados da Tabela 8, pode-se dizer que o envelhecimento a curto prazo destaca o efeito dos modificadores em amenizar o efeito do envelhecimento. Exceções a esta constatação são apenas os CAPs modificados com SBS e com EVA, para os quais o grau 
de modificação variou pouco após o RTFOT. Como observado na Equação 13 (página 86), o valor de $G_{M}$ é obtido pela razão entre a penetração do ligante asfáltico modificado e a do material puro. Se o CAP sofrer uma redução maior da penetração do que os ligantes asfálticos modificados, maiores graus de modificação serão obtidos para os materiais envelhecidos, destacando o papel dos modificadores em amenizar o efeito do envelhecimento a curto prazo. Em linhas gerais, o envelhecimento a curto prazo provoca um aumento de 0,1 a 0,2 nos valores de $\mathrm{G}_{M}$ dos materiais, chegando a um máximo de 0,5 para o $C A P+S B R$.

A Figura 10 apresenta as penetrações retidas dos ligantes asfálticos, cujos valores são calculados pela razão entre a penetração após o RTFOT e a penetração virgem, conforme Equação 11 (página 86). Os ligantes asfálticos modificados apresentam penetrações retidas maiores que o CAP 50/70, sendo que os cinco valores mais elevados são encontrados no $\mathrm{CAP}+\mathrm{SBR}$ (95\%), no CAP+PE (81\%), no CAP+PE+PPA (73\%), no $\mathrm{CAP}+\mathrm{SBS}+\mathrm{PPA}(72 \%)$ e no CAP+EVA+PPA (68\%). Ainda sobre os ligantes asfálticos modificados, as cinco menores penetrações retidas são encontradas no CAP+EVA (55\%), no CAP+SBS (58\%), no CAP+borracha (60\%), no CAP+Elvaloy+PPA (61\%) e no CAP+borracha+PPA (62\%). O CAP+PPA e o CAP+SBR+PPA apresentam penetrações retidas entre 65 e $67 \%$, com o maior valor pertencendo ao CAP+SBR+PPA.

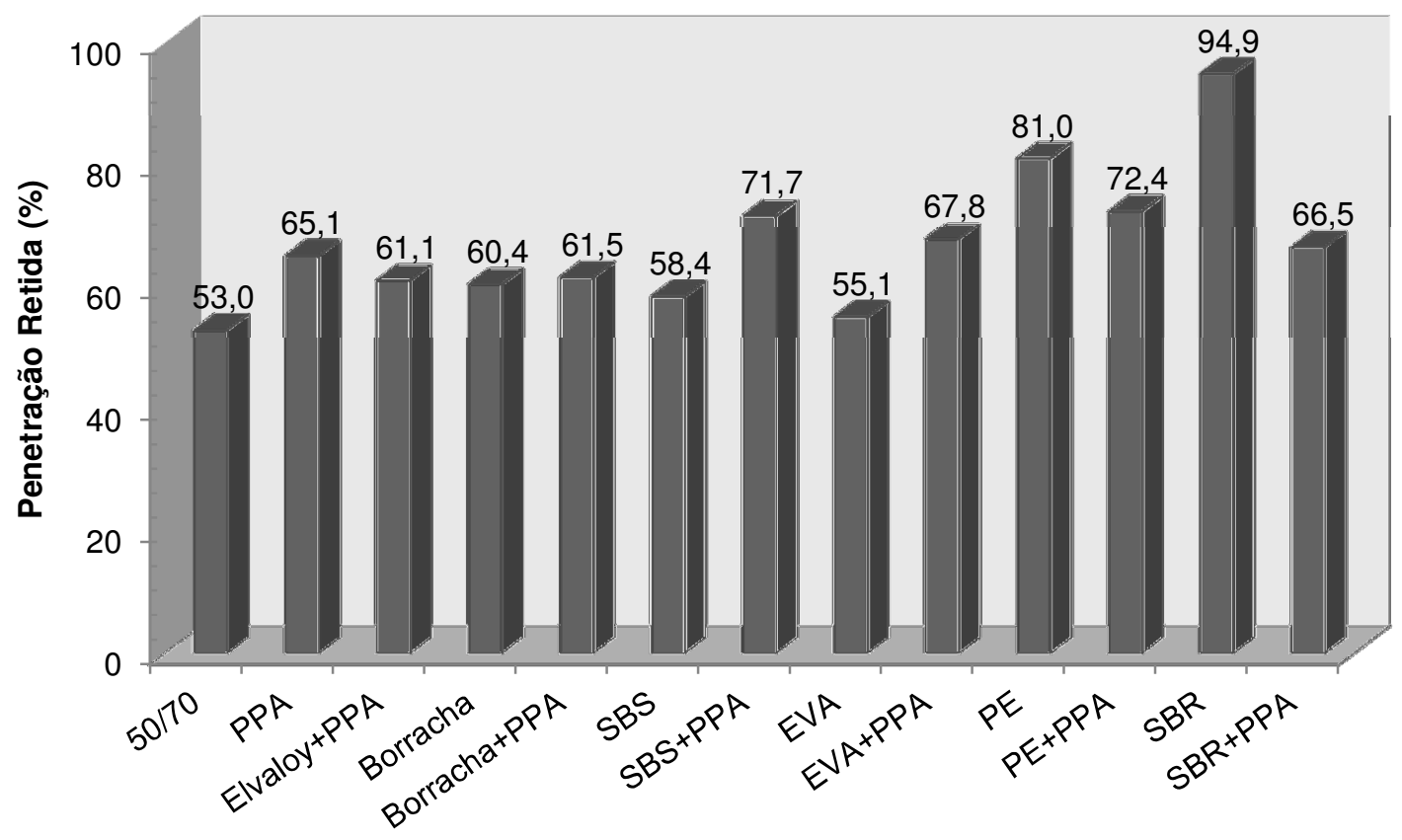

Figura 10 - Penetrações retidas dos ligantes asfálticos

Admitindo a penetração retida como um indicador da sensibilidade dos ligantes asfálticos ao envelhecimento a curto prazo, pode-se dizer que o $C A P+S B R$, o $C A P+P E$ e o 
$\mathrm{CAP}+\mathrm{PE}+\mathrm{PPA}$ são os materiais menos sensíveis ao envelhecimento (maiores penetrações retidas) e que o CAP 50/70, o CAP+EVA e o CAP+SBS são os mais sensíveis (menores penetrações retidas). O CAP+borracha+PPA apresenta uma penetração retida próxima à do CAP+borracha, com valores em torno de $61 \%$ para ambos os materiais. O CAP+SBS e o $C A P+E V A$ apresentam penetrações retidas inferiores às do $C A P+S B S+P P A$ e do $C A P+E V A+P P A$, respectivamente. O CAP+PE e o CAP+SBR apresentam valores de penetração retida superiores aos do $C A P+P E+P P A$ e do $C A P+S B R+P P A$, respectivamente.

Na medida em que é válida a aplicação dos limites mínimos de penetração retida especificados pelo Regulamento Técnico 03/2005 da ANP a ligantes asfálticos modificados, dois valores devem ser considerados nesta análise: (1) a penetração retida mínima de 55\% para os ligantes asfálticos com penetração entre 50 e 70 dmm, faixa na qual se enquadram o CAP 50/70 e o CAP+Elvaloy+PPA; e (2) a penetração retida mínima de $60 \%$ para os ligantes asfálticos com penetração entre 30 e $45 \mathrm{dmm}$, faixa na qual se enquadram todos os demais ligantes asfálticos modificados à exceção do CAP+PE. O CAP 50/70 não se enquadra no limite de 55\%, uma vez que sua penetração retida (53\%) é inferior a este valor. No caso do limite de $60 \%$, não se enquadram os ligantes asfálticos modificados com SBS e com EVA, cujas penetrações retidas são iguais a 58 e $55 \%$, respectivamente.

Em uma avaliação sintetizada dos resultados de penetração, é possível observar que os dois ligantes asfálticos modificados com polietileno (CAP+PE e CAP+PE+PPA) apresentam os valores mais baixos de penetração, tanto na condição virgem quanto na envelhecida a curto prazo, o que indica uma maior rigidez destes materiais em relação aos demais ligantes asfálticos. Os valores mais elevados de penetração são encontrados no CAP 50/70 e no CAP+Elvaloy+PPA na condição virgem, sendo que o CAP+Elvaloy+PPA e o $\mathrm{CAP}+\mathrm{SBR}$ possuem estes maiores valores na condição envelhecida a curto prazo. Embora apresente a maior penetração na condição envelhecida (superando inclusive a penetração do CAP 50/70), o CAP+SBR possui a maior penetração retida dentre os ligantes asfálticos estudados, seguido pelo $\mathrm{CAP}+\mathrm{PE}$ e pelo $\mathrm{CAP}+\mathrm{PE}+\mathrm{PPA}$. Os valores mais baixos para este parâmetro são encontrados no CAP 50/70 e no CAP+EVA, com o CAP+Elvaloy+PPA apresentando uma penetração retida de aproximadamente $61 \%$.

A Tabela 9 mostra os valores médios de PA dos ligantes asfálticos virgens e envelhecidos a curto prazo, juntamente com seus respectivos graus de modificação. Em linhas gerais, as modificações aumentam o ponto de amolecimento tanto dos materiais virgens quanto dos envelhecidos a curto prazo, o que indica uma maior rigidez dos ligantes asfálticos modificados em relação ao CAP 50/70. Embora todos os materiais modificados apresentem o 
mesmo PG, o efeito das modificações é sentido de maneira expressiva sobre o ponto de amolecimento. Os valores para os ligantes asfálticos modificados variam entre 56 e $67^{\circ} \mathrm{C}$ na condição virgem e entre 64 e $71^{\circ} \mathrm{C}$ na condição envelhecida a curto prazo, o que mostra o efeito do envelhecimento na minimização das diferenças entre os pontos de amolecimento das formulações. Dentre os materiais virgens, os seis maiores valores de PA são encontrados no $\mathrm{CAP}+\mathrm{PE}\left(67^{\circ} \mathrm{C}\right)$, no $\mathrm{CAP}+\mathrm{EVA}\left(65^{\circ} \mathrm{C}\right)$, no $\mathrm{CAP}+\mathrm{Elvaloy}+\mathrm{PPA}\left(64^{\circ} \mathrm{C}\right)$, no $\mathrm{CAP}+\mathrm{SBR}\left(63^{\circ} \mathrm{C}\right)$, no $\mathrm{CAP}+\mathrm{EVA}+\mathrm{PPA}$ e no $\mathrm{CAP}+\mathrm{SBS}$, estes dois últimos com pontos de amolecimento de $61^{\circ} \mathrm{C}$. Em seguida vem o CAP+PE+PPA $\left(60^{\circ} \mathrm{C}\right), \quad 0 \mathrm{CAP}+\mathrm{SBS}+\mathrm{PPA}\left(59^{\circ} \mathrm{C}\right)$, O CAP+borracha e 0 $\mathrm{CAP}+\mathrm{SBR}+\mathrm{PPA}$, estes dois últimos com pontos de amolecimento entre 57 e $58^{\circ} \mathrm{C}$. À exceção do CAP 50/70 (PA $=49^{\circ} \mathrm{C}$ ) os dois menores valores de PA são encontrados no CAP+PPA $\left(57^{\circ} \mathrm{C}\right)$ e no $\mathrm{CAP}+$ borracha+PPA $\left(56^{\circ} \mathrm{C}\right)$, este último com menor ponto de amolecimento entre os ligantes asfálticos modificados virgens.

Tabela 9 - Pontos de amolecimento (PA) e graus de modificação dos ligantes asfálticos virgens e envelhecidos a curto prazo

\begin{tabular}{ccccc}
\hline \multirow{2}{*}{ Ligante asfáltico } & \multicolumn{2}{c}{ Material virgem } & \multicolumn{2}{c}{ Material envelhecido a curto prazo } \\
\cline { 2 - 5 } & $\mathrm{PA}_{\text {VIRGEM }}\left({ }^{\circ} \mathrm{C}\right)$ & $\mathrm{G}_{\mathrm{M}}$ & $\mathrm{PA}_{\mathrm{RTFOT}}\left({ }^{\circ} \mathrm{C}\right)$ & $\mathrm{G}_{\mathrm{M}}$ \\
\hline $50 / 70$ & 49,4 & 1,00 & 56,1 & 1,00 \\
PPA & 56,8 & 1,15 & 67,2 & 1,20 \\
Elvaloy+PPA & 63,6 & 1,29 & 70,9 & 1,26 \\
Borracha & 57,9 & 1,17 & 65,2 & 1,16 \\
Borracha+PPA & 56,0 & 1,14 & 65,3 & 1,16 \\
SBS & 60,8 & 1,23 & 64,8 & 1,15 \\
SBS+PPA & 58,9 & 1,19 & 65,7 & 1,17 \\
EVA & 64,8 & 1,31 & 69,3 & 1,23 \\
EVA+PPA & 60,9 & 1,23 & 70,3 & 1,25 \\
PE & 66,7 & 1,35 & 68,8 & 1,23 \\
PE+PPA & 60,4 & 1,22 & 67,2 & 1,20 \\
SBR & 63,3 & 1,28 & 65,7 & 1,17 \\
SBR+PPA & 57,3 & 1,16 & 66,0 & 1,18 \\
\hline
\end{tabular}

PAVIRGEM = Ponto de amolecimento do ligante asfáltico na condição virgem

$\mathrm{PA}_{\mathrm{RTFOT}}=$ Ponto de amolecimento do ligante asfáltico na condição envelhecida a curto prazo $\mathrm{G}_{\mathrm{M}}=$ Grau de modificação do ligante asfáltico

No caso dos ligantes asfálticos envelhecidos a curto prazo, os resultados da Tabela 9 mostram que os cinco maiores valores de PA pertencem ao CAP+Elvaloy+PPA $\left(71^{\circ} \mathrm{C}\right)$, ao $\mathrm{CAP}+\mathrm{EVA}+\mathrm{PPA}\left(70^{\circ} \mathrm{C}\right)$, ao $\mathrm{CAP}+\mathrm{EVA}$, ao $\mathrm{CAP}+\mathrm{PE}\left(\right.$ ambos com $\left.69^{\circ} \mathrm{C}\right)$ e ao $\mathrm{CAP}+\mathrm{PE}+\mathrm{PPA}\left(67^{\circ} \mathrm{C}\right)$. À exceção do CAP $50 / 70\left(\mathrm{PA}=56^{\circ} \mathrm{C}\right)$, os cinco menores valores de 
$\mathrm{PA}$ pertencem ao $\mathrm{CAP}+\mathrm{SBS}$, ao $\mathrm{CAP}+$ borracha, ao $\mathrm{CAP}+$ borracha+PPA, ao CAP+SBS+PPA e ao $\mathrm{CAP}+\mathrm{SBR}$, todos com pontos de amolecimento entre 64 e $66^{\circ} \mathrm{C}$. O CAP+PPA apresenta um ponto de amolecimento de $67^{\circ} \mathrm{C}$, com o do CAP+SBR+PPA sendo aproximadamente $1^{\circ} \mathrm{C}$ inferior a este valor.

Em uma análise dos valores de PA para os ligantes asfálticos virgens, os dados da Tabela 9 mostram que as formulações CAP+modificador (CAP+borracha, CAP+SBS, $\mathrm{CAP}+\mathrm{EVA}, \mathrm{CAP}+\mathrm{PE}$ e $\mathrm{CAP}+\mathrm{SBR}$ ) apresentam maiores pontos de amolecimento do que as formulações correspondentes CAP+modificador+PPA (CAP+borracha+PPA, CAP+SBS+PPA, $\mathrm{CAP}+\mathrm{EVA}+\mathrm{PPA}, \mathrm{CAP}+\mathrm{PE}+\mathrm{PPA}$ e $\mathrm{CAP}+\mathrm{SBR}+\mathrm{PPA}$, respectivamente), sendo que as maiores diferenças numéricas entre os valores são encontradas no CAP+PE e no CAP+SBR e as menores, no CAP+borracha e no CAP+SBS. No caso dos ligantes asfálticos envelhecidos a curto prazo, visualiza-se que o $C A P+S B S+P P A$ e o $C A P+E V A+P P A$ apresentam pontos de amolecimento ligeiramente maiores $\left(\approx 1^{\circ} \mathrm{C}\right)$ que os do CAP+SBS e do CAP+EVA, respectivamente. Não são observadas diferenças significativas entre os pontos de amolecimento do CAP+borracha e do CAP+borracha+PPA, bem como entre o CAP+SBR e o $\mathrm{CAP}+\mathrm{SBR}+\mathrm{PPA}$. O ponto de amolecimento do CAP+PE é ligeiramente maior que o do $\mathrm{CAP}+\mathrm{PE}+\mathrm{PPA}$, com uma diferença numérica de $1,6^{\circ} \mathrm{C}$ entre os dois valores.

No que se refere aos graus de modificação à luz dos ensaios de ponto de amolecimento (Tabela 9), visualiza-se que os valores de $G_{M}$ se mantiveram praticamente inalterados para a maioria das formulações após o envelhecimento a curto prazo. Estas formulações incluem o CAP+PPA, o CAP+Elvaloy+PPA, o CAP+borracha, 0 $\mathrm{CAP}+$ borracha+PPA, O CAP+SBS+PPA, O CAP+EVA+PPA, $0 \quad \mathrm{CAP}+\mathrm{PE}+\mathrm{PPA}$ e 0 CAP+SBR+PPA. São exceções o CAP+SBS, o CAP+EVA, o CAP+PE e o CAP+SBR, para os quais os graus de modificação sofreram redução com o envelhecimento a curto prazo. $O$ primeiro grupo corresponde às formulações pouco sensíveis ao envelhecimento no que se refere ao enrijecimento provocado pelas modificações e, à exceção do CAP+borracha, todas elas apresentam o PPA nas suas composições. O segundo grupo compreende as formulações para as quais o efeito das modificações é minimizado pelo envelhecimento a curto prazo, sendo composto por formulações sem PPA.

A Figura 11 mostra os incrementos nos pontos de amolecimento dos ligantes asfálticos, cujos valores são obtidos pela diferença entre os pontos de amolecimento do material envelhecido a curto prazo e deste mesmo material na condição virgem (Equação 12, página 86). Os cinco maiores valores de $I_{P A}$ são encontrados no $C A P+P P A\left(10^{\circ} \mathrm{C}\right)$, no $C A P+E V A+P P A$, no $\mathrm{CAP}+$ borracha+PPA e no $\mathrm{CAP}+\mathrm{SBR}+\mathrm{PPA}$, estes três últimos com incrementos ao redor de 
$9^{\circ} \mathrm{C}$. Em seguida vem o CAP+Elvaloy+PPA, O CAP+borracha, o CAP+SBS+PPA, 0 $\mathrm{CAP}+\mathrm{PE}+\mathrm{PPA}$ e o CAP 50/70, com resultados de aproximadamente $7^{\circ} \mathrm{C}$ para todos eles. Os menores incrementos do PA são encontrados no CAP+EVA, no CAP+SBS, no CAP+SBR e no $\mathrm{CAP}+\mathrm{PE}$, com valores de aproximadamente $4^{\circ} \mathrm{C}$ para os dois primeiros e de aproximadamente $2^{\circ} \mathrm{C}$ para os dois últimos. Na extensão em que é válida a aplicação do valor máximo de $8^{\circ} \mathrm{C}$ para o parâmetro I IA a CAPs, especificado pelo Regulamento Técnico 03/2005 da ANP, quatro dos treze ligantes asfálticos não seriam considerados adequados: o CAP+PPA, 0 CAP+borracha+PPA, o CAP+EVA+PPA e o CAP+SBR+PPA.

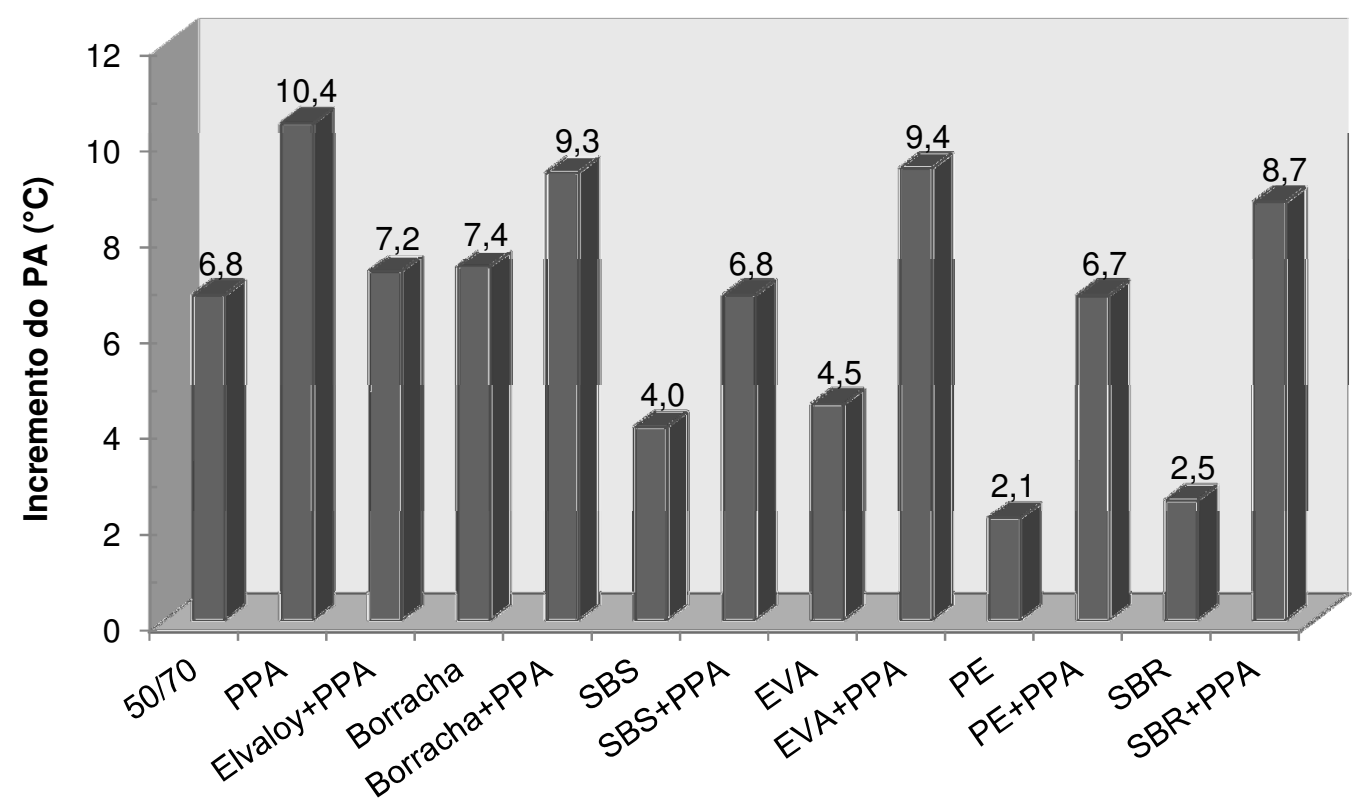

Figura 11 - Incrementos nos pontos de amolecimento (PA) dos ligantes asfálticos

Em uma avaliação sintetizada dos resultados de PA, visualiza-se que os maiores pontos de amolecimento são encontrados no CAP+PE e no CAP+EVA na condição virgem e que os menores são encontrados no CAP 50/70 e no CAP+PPA nesta mesma condição. Com o envelhecimento dos ligantes asfálticos na estufa de filme fino rotativo, os maiores valores de PA são observados no CAP+Elvaloy+PPA e no CAP+EVA+PPA e os menores são observados no CAP 50/70 e no CAP+SBS. Interessante observar que o ligante asfáltico modificado apenas com PPA apresenta o maior valor de $I_{P A}$ dentre os materiais estudados, sendo que o ponto de amolecimento deste material é um dos mais baixos na condição virgem e apresenta um valor intermediário na condição envelhecida a curto prazo. No caso do CAP+EVA+PPA, este material apresenta um valor intermediário de PA na condição virgem e um dos valores mais elevados na condição envelhecida a curto prazo, bem como um incremento significativo de PA após o RTFOT. Os valores mais baixos de PA $_{\mathrm{PA}}$ sa observados no $\mathrm{CAP}+\mathrm{PE}$ e no $\mathrm{CAP}+\mathrm{SBR}$, com resultados inferiores a $3^{\circ} \mathrm{C}$ para ambos os materiais. 


\subsection{Resultados dos ensaios de viscosidade rotacional e discussão}

\subsubsection{Ligantes asfálticos virgens}

A Figura 12 mostra as viscosidades rotacionais dos ligantes asfálticos na temperatura de $135^{\circ} \mathrm{C}$. O CAP+EVA apresenta a maior viscosidade (2,94 Pa.s), seguido pelo CAP+borracha (2,30 Pa.s), depois pelo CAP+borracha+PPA (1,82 Pa.s) e em seguida pelo CAP+Elvaloy+PPA (1,71 Pa.s). A menor viscosidade rotacional é encontrada no ligante asfáltico puro (0,36 Pa.s), seguido pelo CAP+PPA (0,72 Pa.s), depois pelo CAP+SBR+PPA (1,11 Pa.s) e em seguida pelo CAP+SBR (1,13 Pa.s). Viscosidades praticamente semelhantes são encontradas entre os CAPs modificados com SBS, PE e PE+PPA (1,3 Pa.s), o mesmo sendo observado para o CAP+SBR e o CAP+SBR+PPA (1,1 Pa.s). As formulações $\mathrm{CAP}+$ modificador+PPA apresentam viscosidades rotacionais menores em comparação às formulações correspondentes CAP+modificador. Estas diferenças são mais elevadas no caso dos CAPs modificados com borracha moída de pneus (2,30 e 1,82 Pa.s) e com EVA (2,94 e 1,41 Pa.s), sendo pequenas no caso dos CAPs modificados com SBS (1,34 e 1,20 Pa.s), com PE (1,34 e 1,27 Pa.s) e com SBR (1,13 e 1,11 Pa.s).

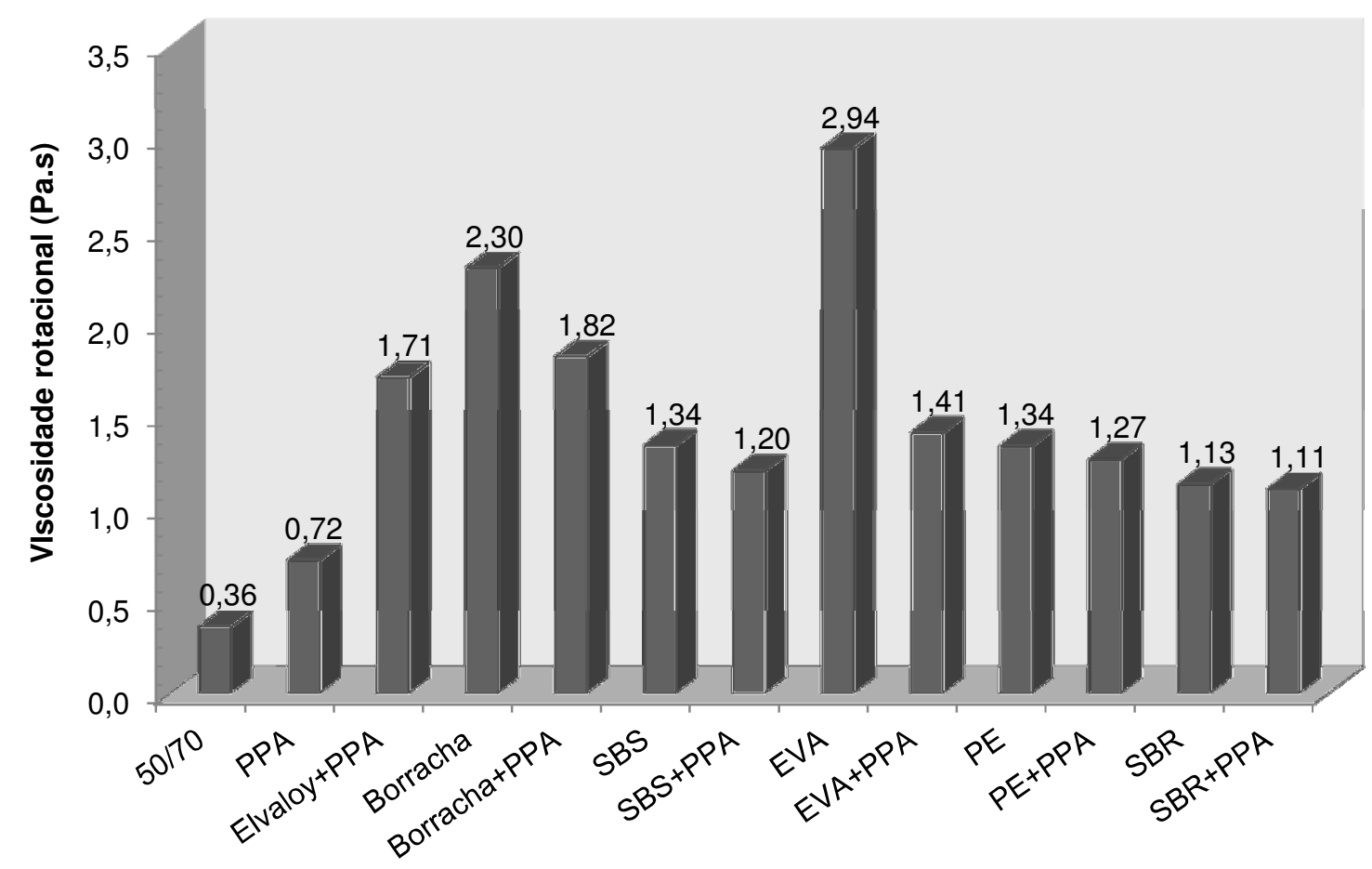

Figura 12 - Viscosidades rotacionais a $135^{\circ} \mathrm{C}$ para os ligantes asfálticos virgens 
A Figura 13 apresenta as viscosidades rotacionais dos ligantes asfálticos na temperatura de $143^{\circ} \mathrm{C}$. Assim como na temperatura de $135^{\circ} \mathrm{C}$, o CAP+EVA possui a maior viscosidade (1,67 Pa.s), seguido pelo CAP+borracha (1,34 Pa.s), depois pelo CAP+borracha+PPA (1,10 Pa.s) e em seguida pelo CAP+Elvaloy+PPA (0,92 Pa.s). O ligante asfáltico puro apresenta a menor viscosidade (0,24 Pa.s), seguido pelo CAP+PPA (0,46 Pa.s) e pelo $C A P+S B R+P P A(0,72$ Pa.s). Viscosidades praticamente iguais são observadas para os CAPs modificados com SBS, SBS+PPA, PE+PPA e SBR (0,8 Pa.s), bem como entre os materiais modificados com EVA+PPA e com PE (0,9 Pa.s). As diferenças entre as viscosidades das formulações CAP+modificador+PPA e das formulações correspondentes CAP+modificador dependem do tipo de modificador, sendo mais elevadas no caso dos materiais modificados com EVA (1,67 e 0,90 Pa.s) e com borracha moída de pneus (1,34 e 1,10 Pa.s) e mais baixas no caso dos materiais modificados com SBS (0,76 e 0,78 Pa.s), com $\operatorname{SBR}(0,76$ e 0,72 Pa.s) e com PE (0,88 e 0,79 Pa.s).

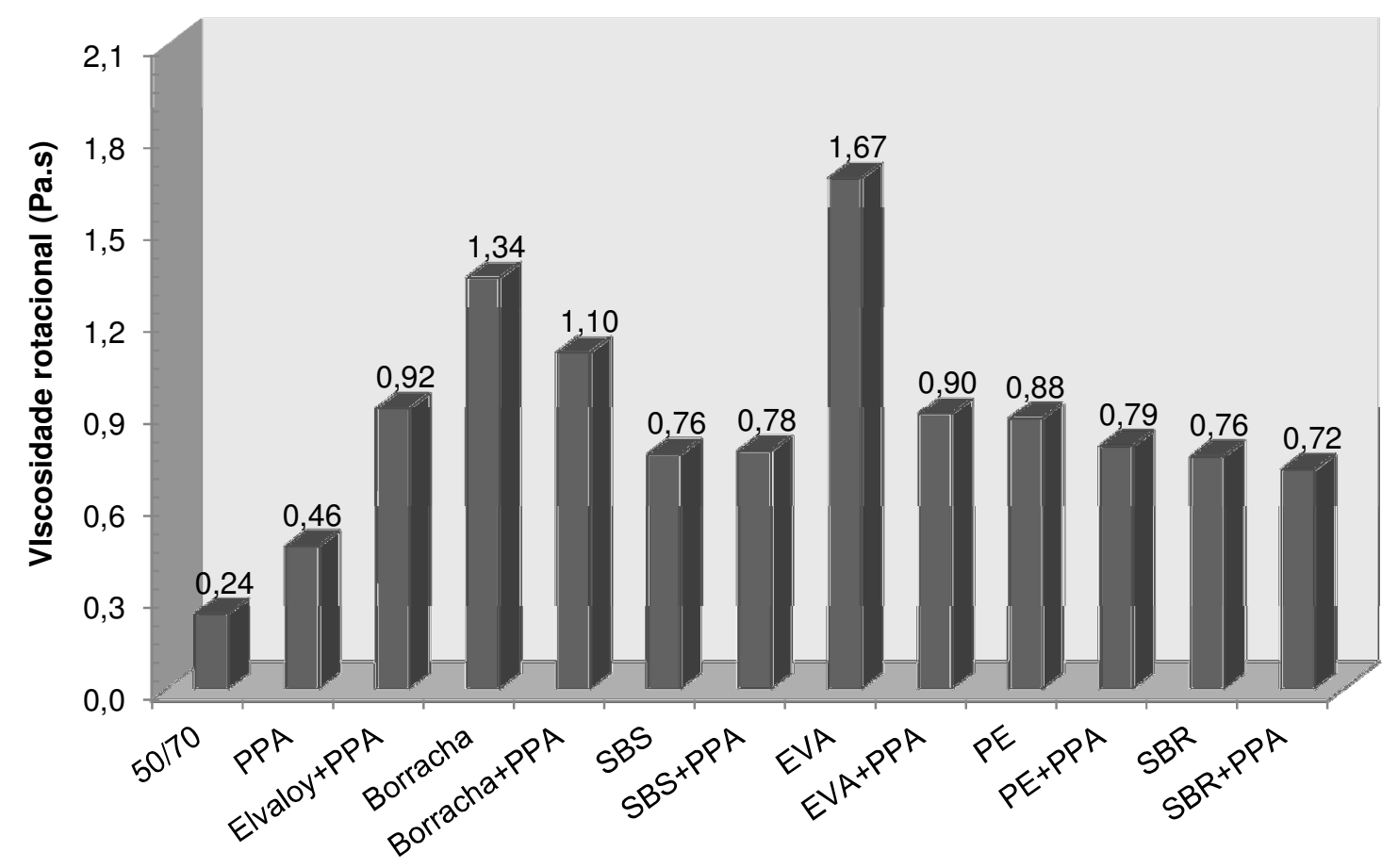

Figura 13 - Viscosidades rotacionais a $143^{\circ} \mathrm{C}$ para os ligantes asfálticos virgens

A Figura 14 apresenta as viscosidades rotacionais dos ligantes asfálticos na temperatura de $150^{\circ} \mathrm{C}$. O CAP+EVA mantém a maior viscosidade (1,19 Pa.s), seguido pelo CAP+borracha (1,00 Pa.s), depois pelo CAP+borracha+PPA (0,77 Pa.s) e depois pelo CAP+Elvaloy+PPA (0,60 Pa.s). O CAP 50/70 mantém a menor viscosidade (0,18 Pa.s), seguido pelo CAP+PPA (0,33 Pa.s) e depois pelo CAP+SBR+PPA (0,51 Pa.s). Viscosidades 
praticamente iguais são encontradas nos CAPs modificados com SBS, SBS+PPA, EVA+PPA, PE, PE+PPA e SBR, com valores de aproximadamente 0,6 Pa.s para todos eles. A diferença entre as viscosidades das formulações CAP+modificador+PPA e das formulações correspondentes CAP+modificador é elevada no caso do EVA (1,19 e 0,63 Pa.s) e da borracha moída (1,00 e 0,77 Pa.s), sendo pequena no caso do $\operatorname{SBR}(0,56$ e 0,51 Pa.s) e do PE (0,65 e 0,56 Pa.s) e praticamente nula para o SBS (0,57 e 0,58 Pa.s).

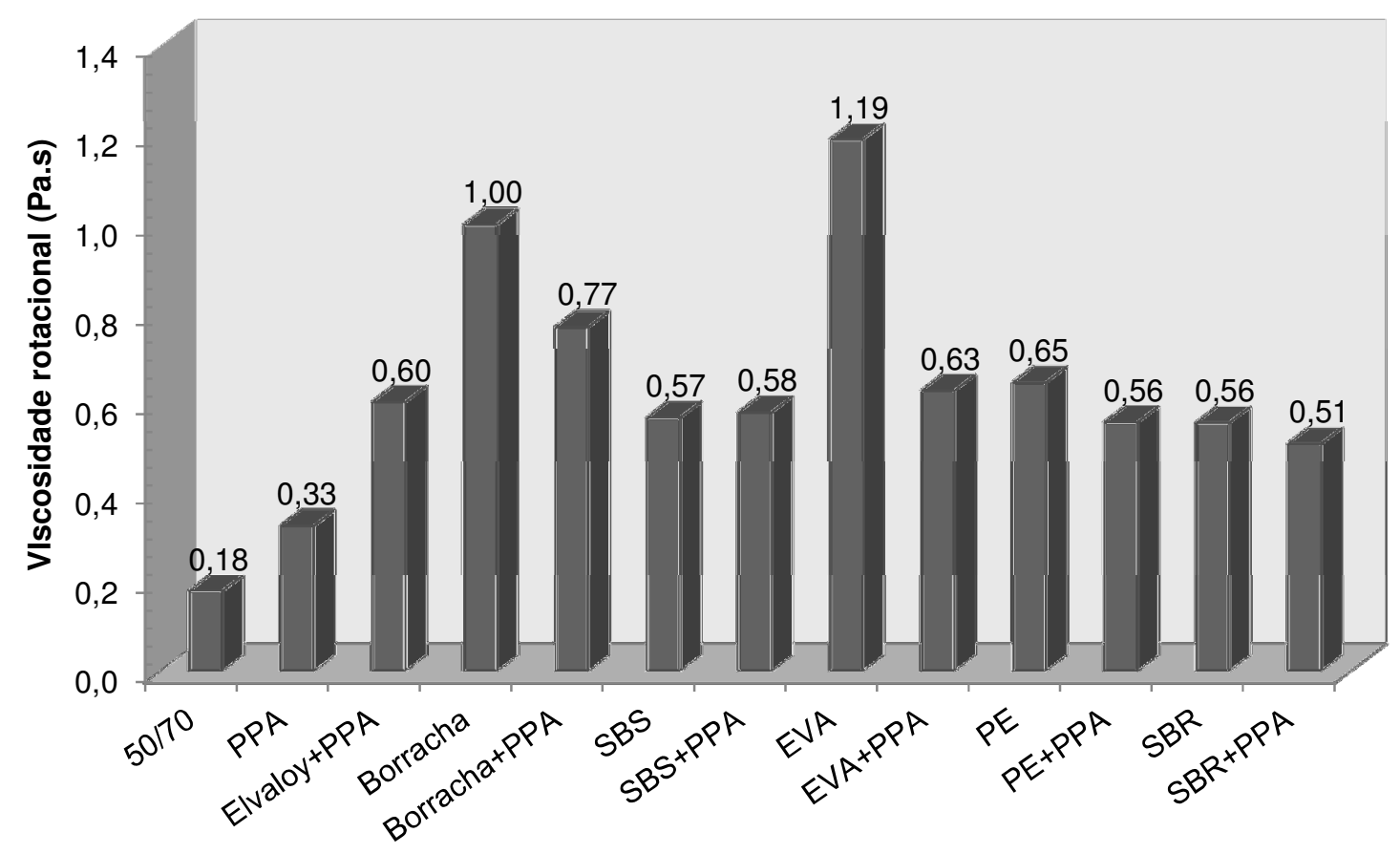

Figura 14 - Viscosidades rotacionais a $150^{\circ} \mathrm{C}$ para os ligantes asfálticos virgens

A Figura 15 apresenta as viscosidades rotacionais dos ligantes asfálticos na temperatura de $163^{\circ} \mathrm{C}$. O CAP+EVA mantém a maior viscosidade $(0,69 \mathrm{~Pa} . \mathrm{s})$, porém com uma diferença inferior a 0,1 Pa.s para o CAP+borracha (0,60 Pa.s) e inferior a 0,3 Pa.s para o CAP+borracha+PPA (0,47 Pa.s). O ligante asfáltico puro mantém a menor viscosidade (0,11 Pa.s), seguido pelo CAP+PPA (0,18 Pa.s) e depois pelo CAP+SBR+PPA (0,29 Pa.s). Viscosidades em torno de 0,4 Pa.s são encontradas nos CAPs modificados com SBS, SBS+PPA, EVA+PPA e PE e, da mesma maneira, os CAPs modificados com Elvaloy+PPA, $\mathrm{PE}+\mathrm{PPA}, \mathrm{SBR}$ e SBR+PPA apresentam viscosidades em torno de 0,3 Pa.s. As diferenças entre as viscosidades das formulações CAP+modificador+PPA e das correspondentes CAP+modificador são mais elevadas no caso dos ligantes asfálticos modificados com EVA (0,69 e 0,36 Pa.s) e com borracha moída de pneus (0,60 e 0,47 Pa.s), sendo mais baixas no caso dos materiais modificados com SBS (0,36 e 0,35 Pa.s), com PE (0,38 e 0,32 Pa.s) e com SBR (0,33 e 0,29 Pa.s). 


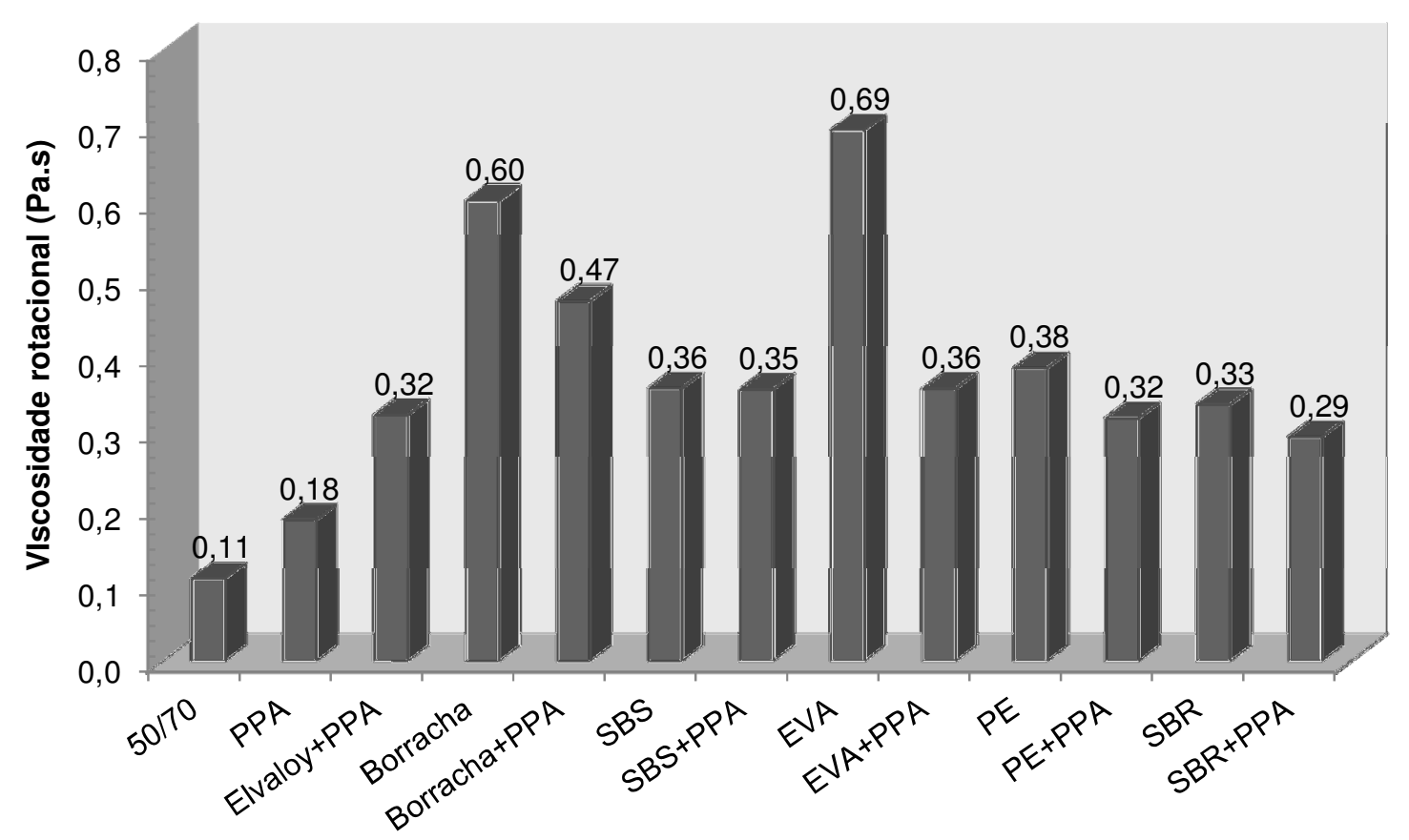

Figura 15 - Viscosidades rotacionais a $163^{\circ} \mathrm{C}$ para os ligantes asfálticos virgens

A Figura 16 apresenta as viscosidades rotacionais dos ligantes asfálticos na temperatura de $177^{\circ} \mathrm{C}$. As variações destas viscosidades são pequenas entre os materiais, sendo todas inferiores a 0,4 Pa.s. Os ligantes asfálticos modificados com EVA, com borracha moída e com borracha moída e PPA apresentam as maiores viscosidades (valores em torno de 0,4 Pa.s), com as menores pertencendo ao ligante asfáltico puro e ao CAP+PPA (valores em torno de 0,1 Pa.s). Viscosidades de aproximadamente 0,2 Pa.s são encontradas nos CAPs modificados com Elvaloy+PPA, SBS, SBS+PPA, EVA+PPA, PE, $\mathrm{PE}+\mathrm{PPA}, \mathrm{SBR}$ e SBR+PPA. A diferença entre as viscosidades rotacionais do CAP+EVA e do CAP+EVA+PPA é elevada, sendo de aproximadamente 0,2 Pa.s. O mesmo, entretanto, não ocorre entre as demais formulações CAP+modificador+PPA e suas correspondentes $\mathrm{CAP}+$ modificador, para as quais as diferenças são de no máximo 0,05 Pa.s.

Em uma avaliação global dos resultados apresentados nas Figuras 12 a 16, referentes aos ligantes asfálticos virgens, é possível observar que (1) as viscosidades dos materiais modificados são distintas entre si embora a classificação PG de todos eles seja a mesma segundo o critério original da especificação Superpave (PG 76-XX); e (2) o CAP 50/70 possui viscosidade inferior à de qualquer CAP modificado. O CAP+EVA, o CAP+borracha e o CAP+borracha+PPA apresentam as maiores viscosidades em todo o espectro de temperaturas, com as menores pertencendo ao CAP 50/70 e ao CAP+PPA. As diferenças entre as viscosidades do CAP+EVA e do CAP+EVA+PPA são elevadas em todas as 
temperaturas, o mesmo ocorrendo com as viscosidades do CAP+borracha e do CAP+borracha+PPA nas temperaturas de 135, 143, 150 e $163^{\circ} \mathrm{C}$. Estas diferenças são pequenas para os ligantes asfálticos modificados com SBS e com SBR em todo o espectro de temperaturas, com valores de até 0,2 Pa.s para ambos os materiais.

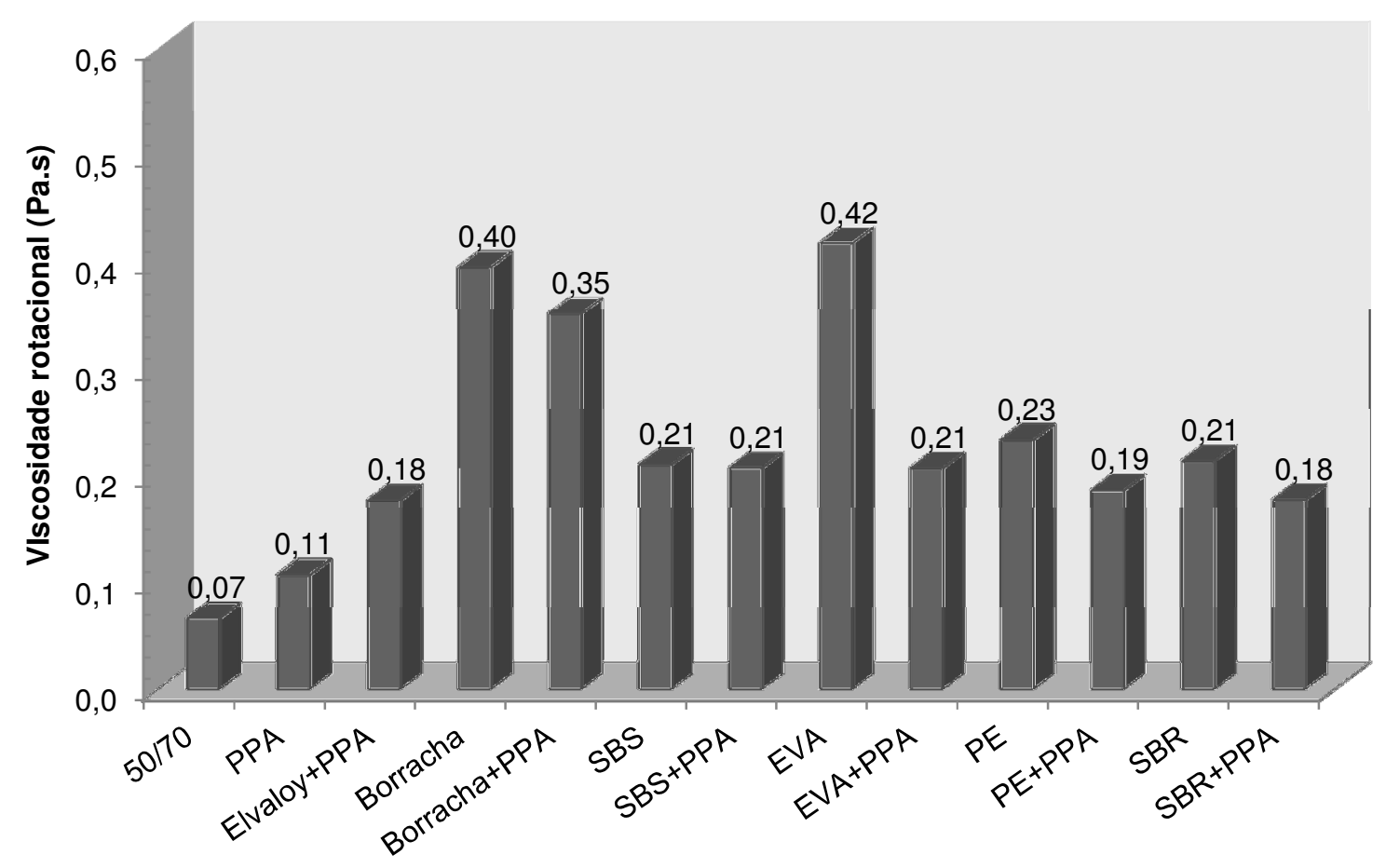

Figura 16 - Viscosidades rotacionais a $177^{\circ} \mathrm{C}$ para os ligantes asfálticos virgens

\subsubsection{Ligantes asfálticos envelhecidos a curto prazo}

A Figura 17 apresenta as viscosidades dos ligantes asfálticos envelhecidos a curto prazo, considerando a temperatura de $135^{\circ} \mathrm{C}$. O CAP+borracha+PPA possui a maior viscosidade (4,96 Pa.s), seguido pelo CAP+borracha (4,56 Pa.s), depois pelo CAP+EVA (4,49 Pa.s), em seguida pelo CAP+Elvaloy+PPA (3,67 Pa.s) e então pelo $\mathrm{CAP}+\mathrm{SBR}+\mathrm{PPA}(3,16$ Pa.s). O ligante asfáltico puro possui a menor viscosidade rotacional (0,59 Pa.s), seguido pelo $C A P+S B R$, depois pelo CAP+SBS (ambos com viscosidade de 1,83 Pa.s), em seguida pelo CAP+PPA (1,94 Pa.s) e então pelo CAP+PE (2,09 Pa.s). Os ligantes asfálticos modificados com EVA+PPA, PE+PPA e SBS+PPA apresentam viscosidades rotacionais próximas entre si, com valores entre 2,1 e 2,4 Pa.s para todos eles. A diferença entre as viscosidades do CAP+EVA e do CAP+EVA+PPA é 
elevada (superior a 2,0 Pa.s), o mesmo ocorrendo com o CAP+SBR e o CAP+SBR+PPA (superior a 1,0 Pa.s). Estas diferenças são pequenas para os demais ligantes asfálticos modificados, sendo de 0,4 Pa.s para os modificados com borracha moída de pneus (CAP+borracha e CAP+borracha+PPA) e de no máximo 0,3 Pa.s para os modificados com SBS (CAP+SBS e CAP+SBS+PPA) e com PE (CAP+PE e CAP+PE+PPA).

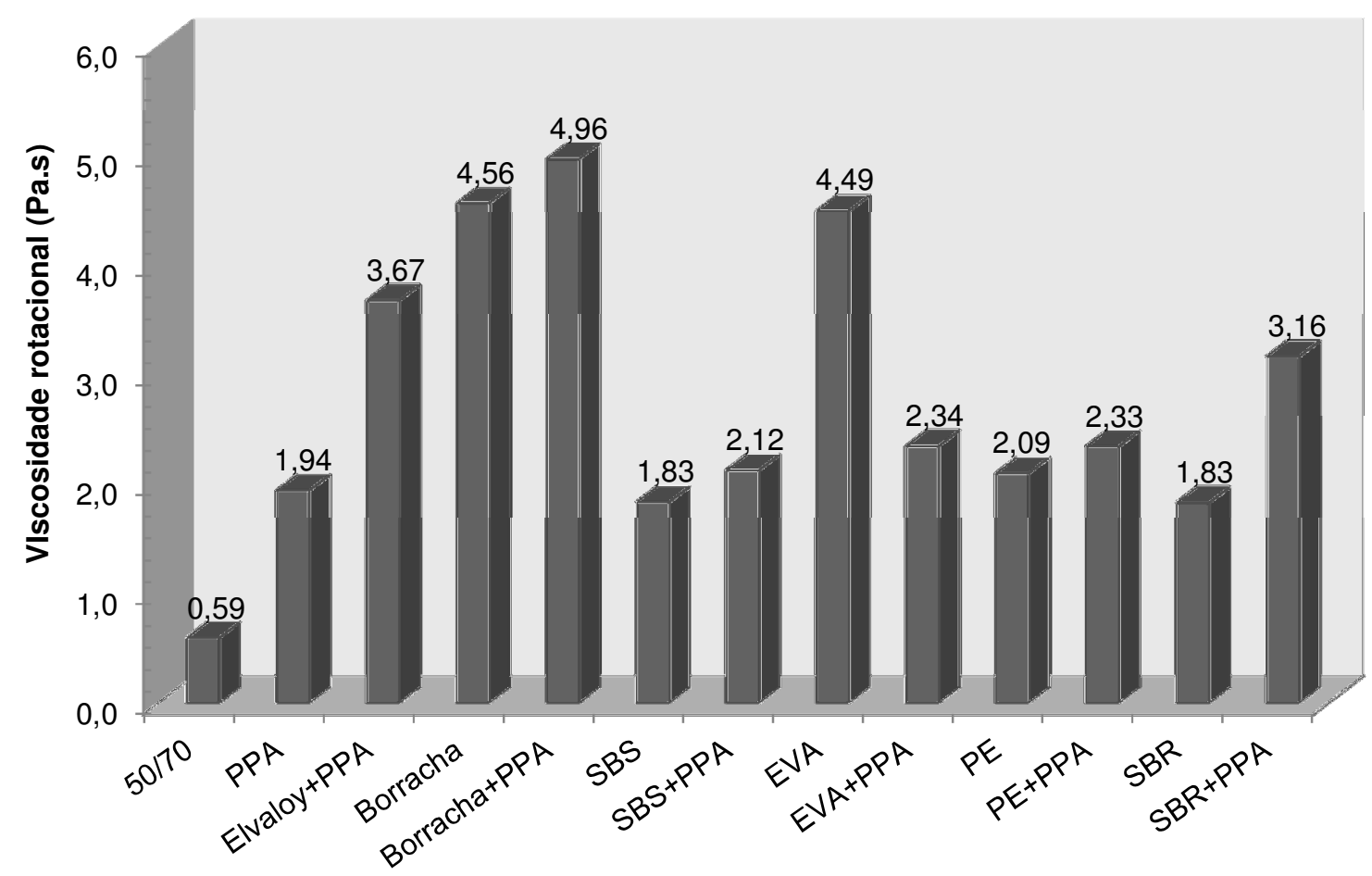

Figura 17 - Viscosidades rotacionais a $135^{\circ} \mathrm{C}$ para os ligantes asfálticos envelhecidos a curto prazo

A Figura 18 apresenta as viscosidades rotacionais dos ligantes asfálticos envelhecidos a curto prazo, considerando a temperatura de $143^{\circ} \mathrm{C}$. O CAP+borracha+PPA mantém a maior viscosidade (2,97 Pa.s), seguido pelo CAP+borracha (2,87 Pa.s), depois pelo CAP+EVA (2,74 Pa.s), em seguida pelo CAP+Elvaloy+PPA (1,97 Pa.s) e então pelo CAP+EVA+PPA (1,47 Pa.s). O CAP 50/70 mantém a menor viscosidade (0,38 Pa.s), seguido pelo CAP+PPA (1,02 Pa.s), depois pelo CAP+SBR (1,08 Pa.s), em seguida pelo CAP+SBS (1,20 Pa.s) e então pelo CAP+PE (1,34 Pa.s). Os ligantes asfálticos modificados com $\mathrm{PE}+\mathrm{PPA}, \mathrm{SBS}+\mathrm{PPA}$ e SBR+PPA apresentam viscosidades rotacionais semelhantes, com valores de aproximadamente 1,4 Pa.s para todos eles. A diferença entre as viscosidades rotacionais do CAP+EVA e do CAP+EVA+PPA é elevada (1,27 Pa.s), o mesmo sendo observado nos ligantes asfálticos modificados com borracha moída de pneus ( 0,1 Pa.s), SBS (0,19 Pa.s), PE (0,08 Pa.s) e SBR (0,29 Pa.s). 


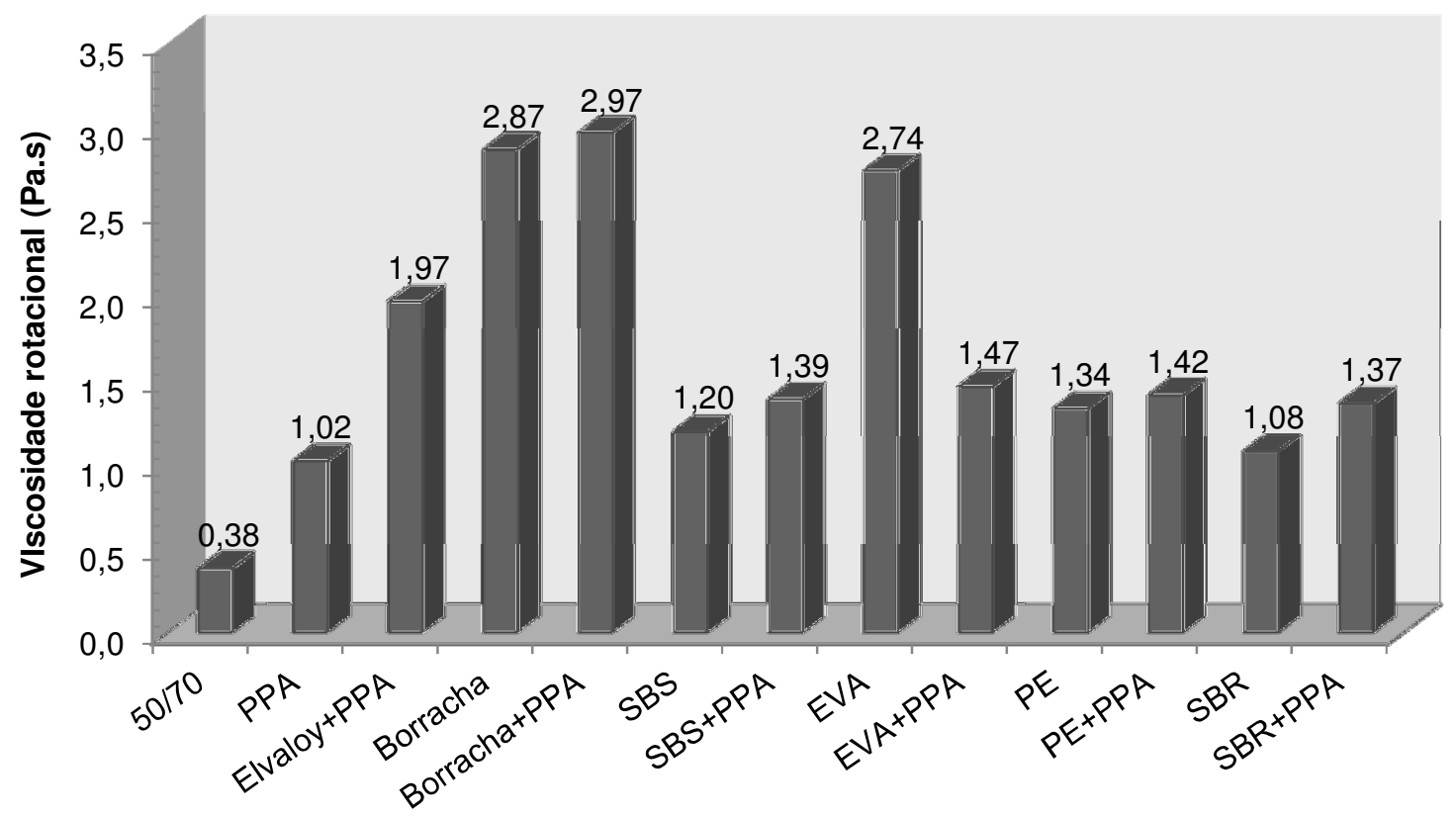

Figura 18 - Viscosidades rotacionais a $143^{\circ} \mathrm{C}$ para os ligantes asfálticos envelhecidos a curto prazo

A Figura 19 mostra as viscosidades rotacionais dos ligantes asfálticos envelhecidos a curto prazo, considerando a temperatura de $150^{\circ} \mathrm{C}$. Assim como observado nas temperaturas de 135 e $143^{\circ} \mathrm{C}$, o CAP+borracha+PPA apresenta a maior viscosidade rotacional dentre os materiais estudados (2,05 Pa.s), seguido pelo CAP+borracha (1,93 Pa.s), depois pelo CAP+EVA (1,92 Pa.s), em seguida pelo CAP+Elvaloy+PPA (1,23 Pa.s) e então pelo CAP+EVA+PPA (1,01 Pa.s). O CAP 50/70 apresenta a menor viscosidade rotacional (0,27 Pa.s), seguido pelo CAP+PPA (0,68 Pa.s), depois pelo CAP+SBR (0,77 Pa.s), em seguida pelo CAP+SBS (0,86 Pa.s) e então pelo CAP+SBR+PPA (0,93 Pa.s). Os ligantes asfálticos modificados com SBS+PPA, PE+PPA, SBR+PPA e PE apresentam viscosidades próximas entre si, com valores entre 0,9 e 1,0 Pa.s para todos estes materiais. A viscosidade do CAP+EVA apresenta uma diferença elevada para a viscosidade do CAP+EVA+PPA (aproximadamente 0,9 Pa.s), o mesmo não sendo verificado entre as viscosidades dos ligantes asfálticos modificados com borracha moída, SBS, SBR e PE.

A Figura 20 mostra as viscosidades rotacionais dos ligantes asfálticos envelhecidos a curto prazo, considerando a temperatura de $163^{\circ} \mathrm{C}$. O CAP+borracha, o CAP+borracha+PPA e o CAP+EVA apresentam viscosidades próximas entre si, com valores de aproximadamente 1,1 Pa.s para os três materiais. O CAP 50/70 possui a menor viscosidade rotacional (0,16 Pa.s), seguido pelo CAP+PPA (0,35 Pa.s) e depois pelo CAP+SBR (0,45 Pa.s). Viscosidades de aproximadamente 0,5 Pa.s são encontradas nos ligantes asfálticos modificados com PE, SBS, PE+PPA e SBR+PPA e, da mesma maneira, viscosidades em torno de 0,55 Pa.s são 
encontradas nos materiais modificados com Elvaloy+PPA, SBS+PPA e EVA+PPA. A diferença entre as viscosidades rotacionais do CAP+EVA e do CAP+EVA+PPA é elevada (0,51 Pa.s), sendo que, no caso dos materiais modificados com borracha moída, SBS, PE e SBR, estas diferenças são de no máximo 0,05 Pa.s.

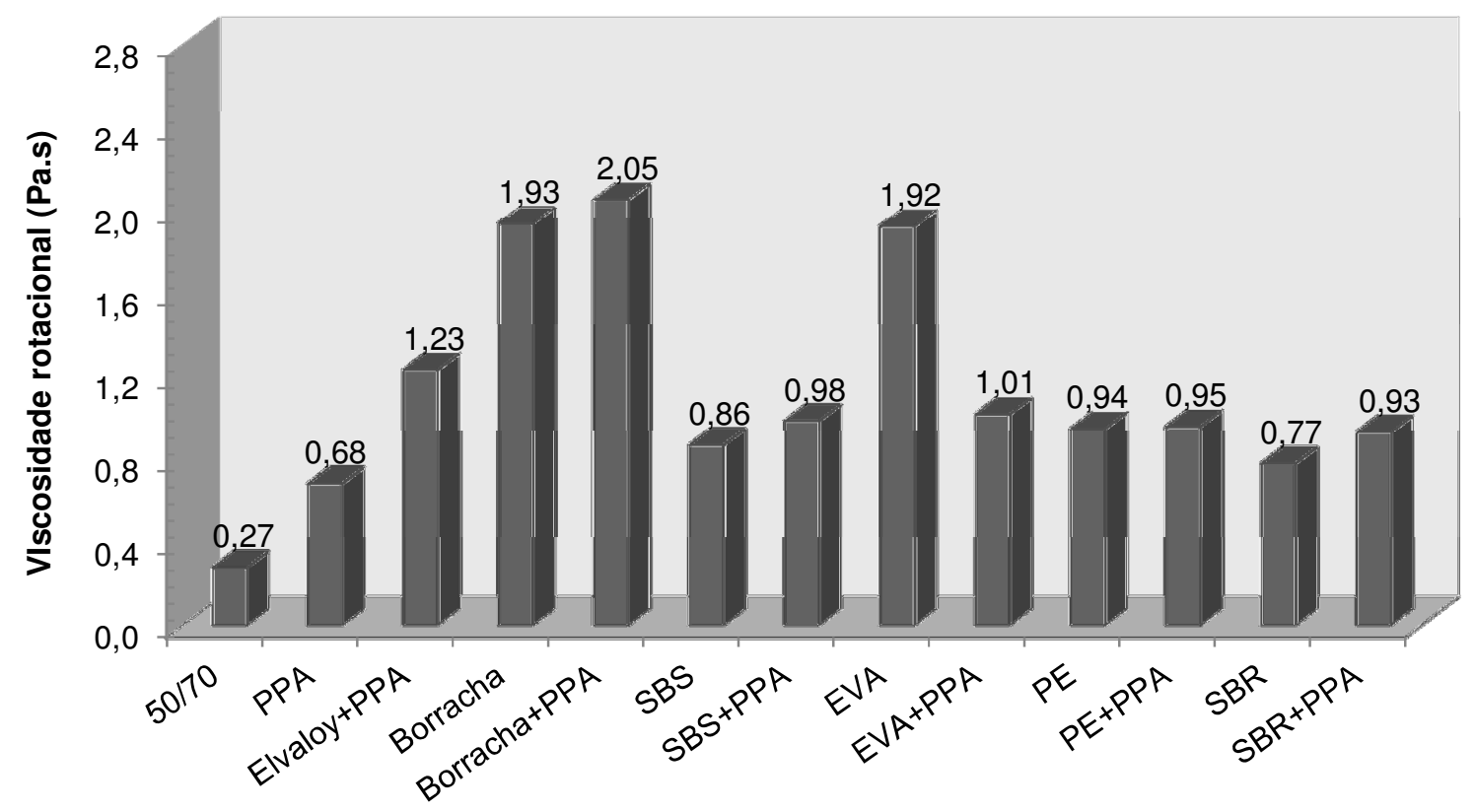

Figura 19 - Viscosidades rotacionais a $150^{\circ} \mathrm{C}$ para os ligantes asfálticos envelhecidos a curto prazo

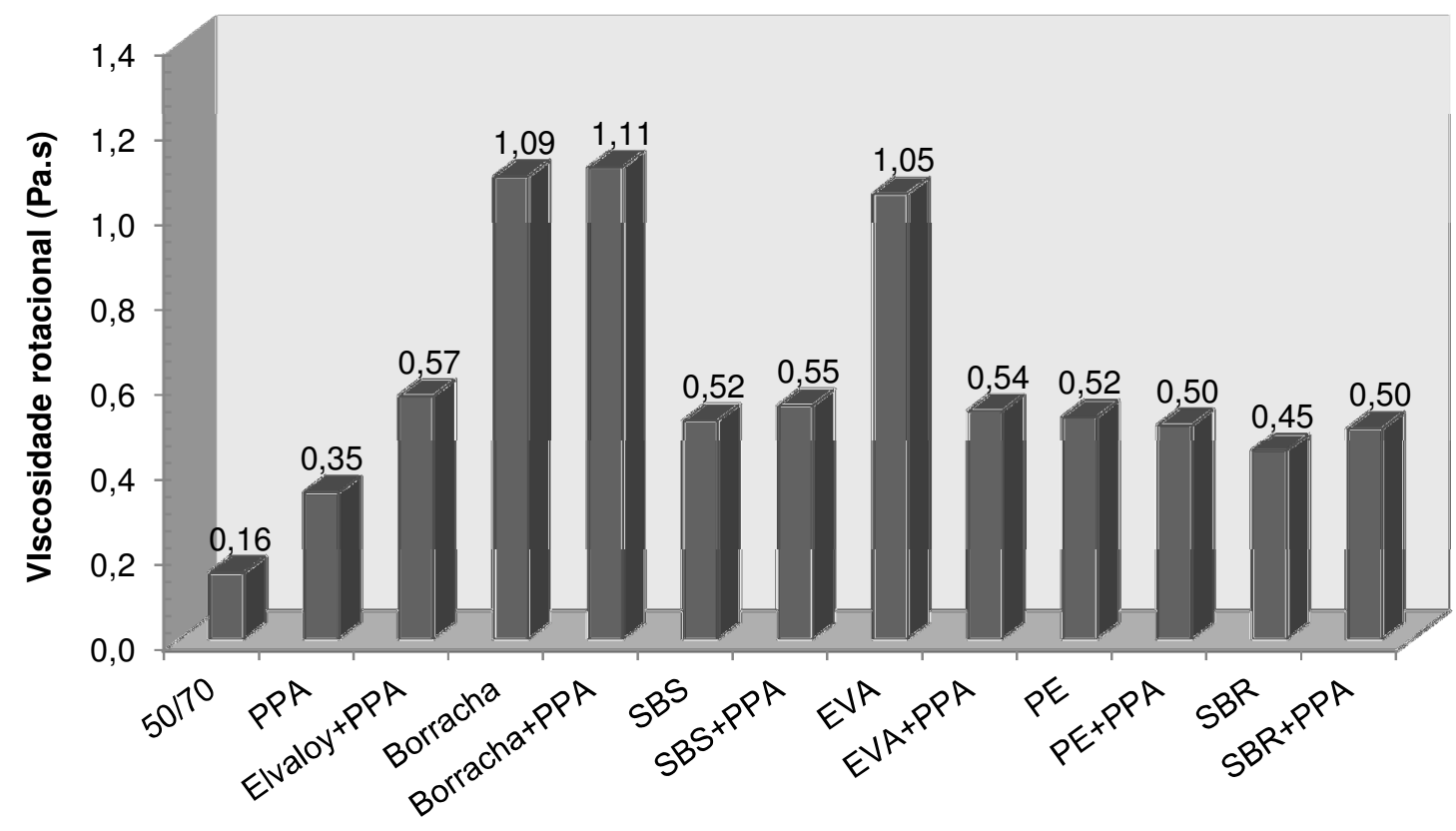

Figura 20 - Viscosidades rotacionais a $163^{\circ} \mathrm{C}$ para os ligantes asfálticos envelhecidos a curto prazo 
A Figura 21 apresenta as viscosidades rotacionais dos ligantes asfálticos envelhecidos a curto prazo, considerando a temperatura de $177^{\circ} \mathrm{C}$. O CAP+borracha+PPA mantém a maior viscosidade rotacional (0,66 Pa.s), seguido pelo CAP+borracha (0,64 Pa.s) e depois pelo CAP+EVA (0,59 Pa.s). O ligante asfáltico puro mantém a menor viscosidade (0,09 Pa.s), seguido pelo CAP+PPA (0,19 Pa.s) e depois pelo CAP+SBR (0,26 Pa.s). Viscosidades rotacionais de aproximadamente 0,3 Pa.s são encontradas nos ligantes asfálticos modificados com Elvaloy+PPA, SBS, SBS+PPA, EVA+PPA, PE, PE+PPA, SBR e SBR+PPA. A diferença entre as viscosidades do CAP+EVA e do CAP+EVA+PPA é elevada (0,3 Pa.s), sendo extremamente baixa no caso dos materiais modificados com borracha moída de pneus, SBS, PE e SBR (valores inferiores a 0,03 Pa.s).

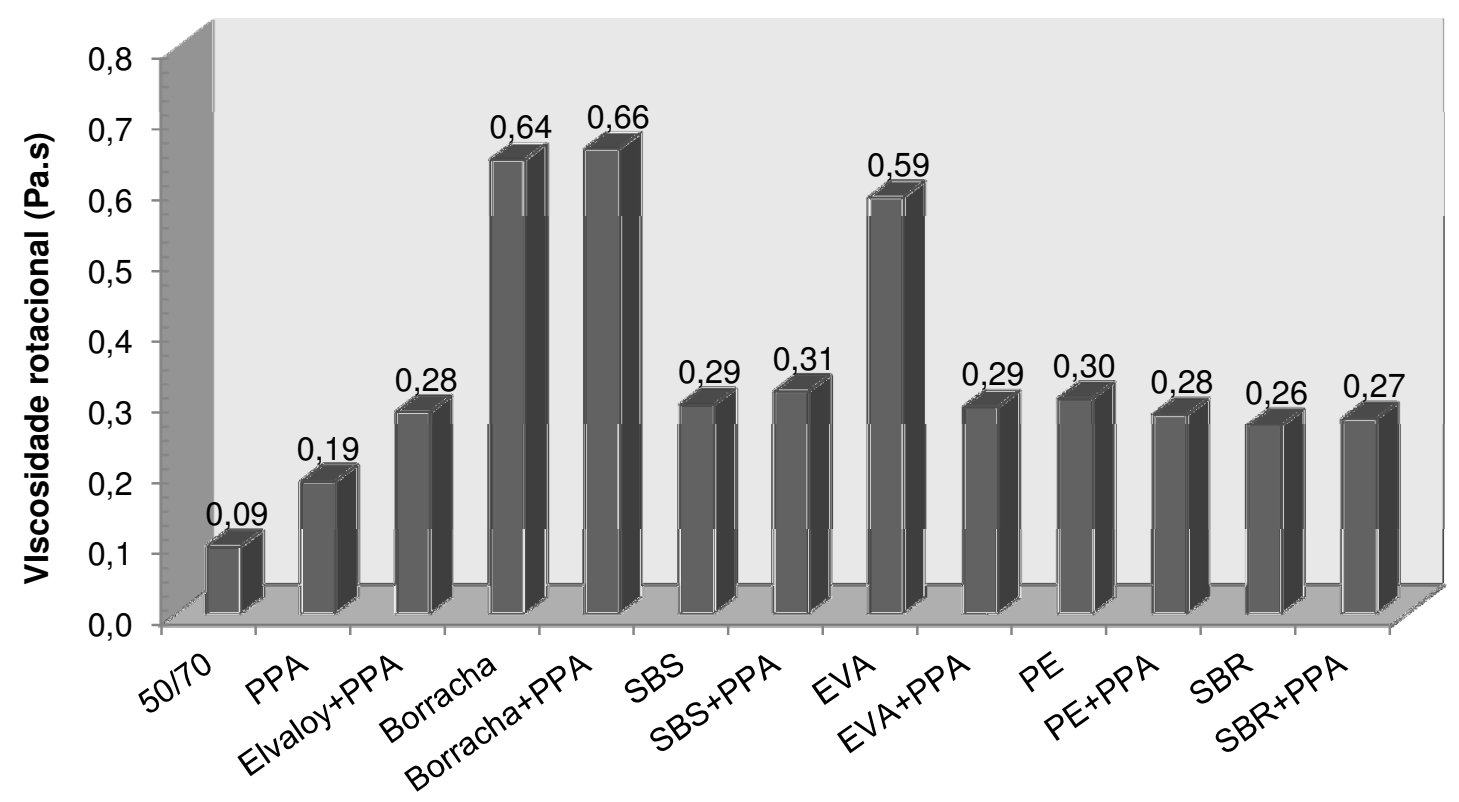

Figura 21 - Viscosidades rotacionais a $177^{\circ} \mathrm{C}$ para os ligantes asfálticos envelhecidos a curto prazo

Em uma avaliação dos resultados apresentados nas Figuras 17 a 21, referentes aos ligantes asfálticos envelhecidos a curto prazo, observa-se que as viscosidades dos materiais modificados são distintas entre si embora a classificação PG seja a mesma para todos eles segundo o critério original especificação Superpave (PG 76-XX). O CAP+borracha+PPA, o CAP+borracha e o CAP+EVA apresentam as maiores viscosidades em todo o espectro de temperaturas, com as menores pertencendo ao CAP 50/70 neste mesmo espectro. Os ligantes asfálticos modificados com PPA e SBR apresentam, à exceção do material puro, as menores viscosidades nas temperaturas de $143,150,163$ e $177^{\circ} \mathrm{C}$. O CAP+Elvaloy+PPA possui valores elevados de viscosidade nas temperaturas de 135, 143, 150 e $163^{\circ} \mathrm{C}$, apresentando um valor intermediário na temperatura mais elevada $\left(177^{\circ} \mathrm{C}\right)$. O CAP+SBS possui, em comparação aos 
demais ligantes asfálticos modificados, uma viscosidade baixa nas temperaturas de até $150^{\circ} \mathrm{C}$, apresentando valores intermediários nas temperaturas de 163 e $177^{\circ} \mathrm{C}$. As diferenças entre as viscosidades do CAP+EVA e do CAP+EVA+PPA são elevadas em todo o espectro de temperaturas, o mesmo não sendo visualizado na maioria destas temperaturas para as demais formulações CAP+modificador+PPA e suas correspondentes CAP+modificador.

\subsubsection{Incrementos de viscosidade rotacional após o envelhecimento a curto prazo}

A Figura 22 apresenta as relações entre as viscosidades rotacionais dos ligantes asfálticos (parâmetro $R_{V}$ ) na temperatura de $135^{\circ} \mathrm{C}$. O maior incremento de viscosidade rotacional após o envelhecimento a curto prazo é encontrado no CAP+SBR+PPA (2,85 vezes), seguido pelo CAP+borracha+PPA (2,73 vezes), depois pelo CAP+PPA (2,68 vezes), em seguida pelo CAP+Elvaloy+PPA (2,15 vezes) e então pelo CAP+borracha (1,98 vezes). O menor incremento de viscosidade rotacional é observado no CAP+SBS (1,37 vezes), seguido pelo CAP+EVA (1,53 vezes), depois pelo CAP+PE (1,57 vezes), em seguida pelo CAP+SBR (1,61 vezes) e então pelo CAP 50/70 (1,63 vezes). O CAP 50/70 e os ligantes asfálticos modificados com PE+PPA, SBS+PPA, EVA+PPA e SBR apresentam incrementos parecidos de viscosidade rotacional após o RTFOT, com valores de $R_{V}$ entre 1,6 e 1,9 para todos eles. Interessante observar que as formulações CAP+modificador+PPA possuem valores mais elevados de $R_{V}$ em comparação às suas correspondentes CAP+modificador, indicando que as formulações com PPA são mais sensíveis ao envelhecimento a curto prazo do que aquelas sem PPA, à luz dos resultados de viscosidade. As diferenças entre os valores de $R_{V}$ são mais elevadas no caso das formulações com SBR e com borracha moída, sendo mais baixas para as formulações com SBS, EVA e PE.

A Figura 23 apresenta as relações entre as viscosidades rotacionais dos ligantes asfálticos na temperatura de $143^{\circ} \mathrm{C}$. O maior incremento de viscosidade após o RTFOT é observado no CAP+borracha+PPA (2,70 vezes), seguido pelo CAP+PPA (2,21 vezes), depois pelo $\mathrm{CAP}+$ Elvaloy+PPA (2,15 vezes), em seguida pelo CAP+borracha (2,14 vezes) e então pelo $\mathrm{CAP}+\mathrm{SBR}+\mathrm{PPA}$ (1,91 vezes). O menor incremento de viscosidade rotacional é encontrado no $\mathrm{CAP}+\mathrm{SBR}$ (1,43 vezes), seguido pelo CAP+PE (1,51 vezes), depois pelo CAP+SBS (1,57 vezes), em seguida pelo CAP 50/70 (1,58 vezes) e então pelo CAP+EVA+PPA (1,63 vezes). Os ligantes asfálticos modificados com SBS+PPA e PE+PPA possuem incrementos semelhantes de viscosidade rotacional (1,79 vezes), com o CAP+EVA possuindo um valor ligeiramente menor (1,65 vezes). À exceção do CAP+EVA e do 
$\mathrm{CAP}+\mathrm{EVA}+\mathrm{PPA}$, as formulações $\mathrm{CAP}+$ modificador+PPA apresentam valores de $\mathrm{R}_{\mathrm{V}}$ maiores do que as formulações correspondentes CAP+modificador, o que indica, em linhas gerais, uma maior sensibilidade das formulações com PPA ao envelhecimento a curto prazo em relação às formulações sem PPA, à luz dos resultados de viscosidade rotacional. Estas diferenças são mais elevadas no caso dos ligantes asfálticos modificados com borracha moída e com SBR, sendo menores para os materiais modificados com SBS e com PE.

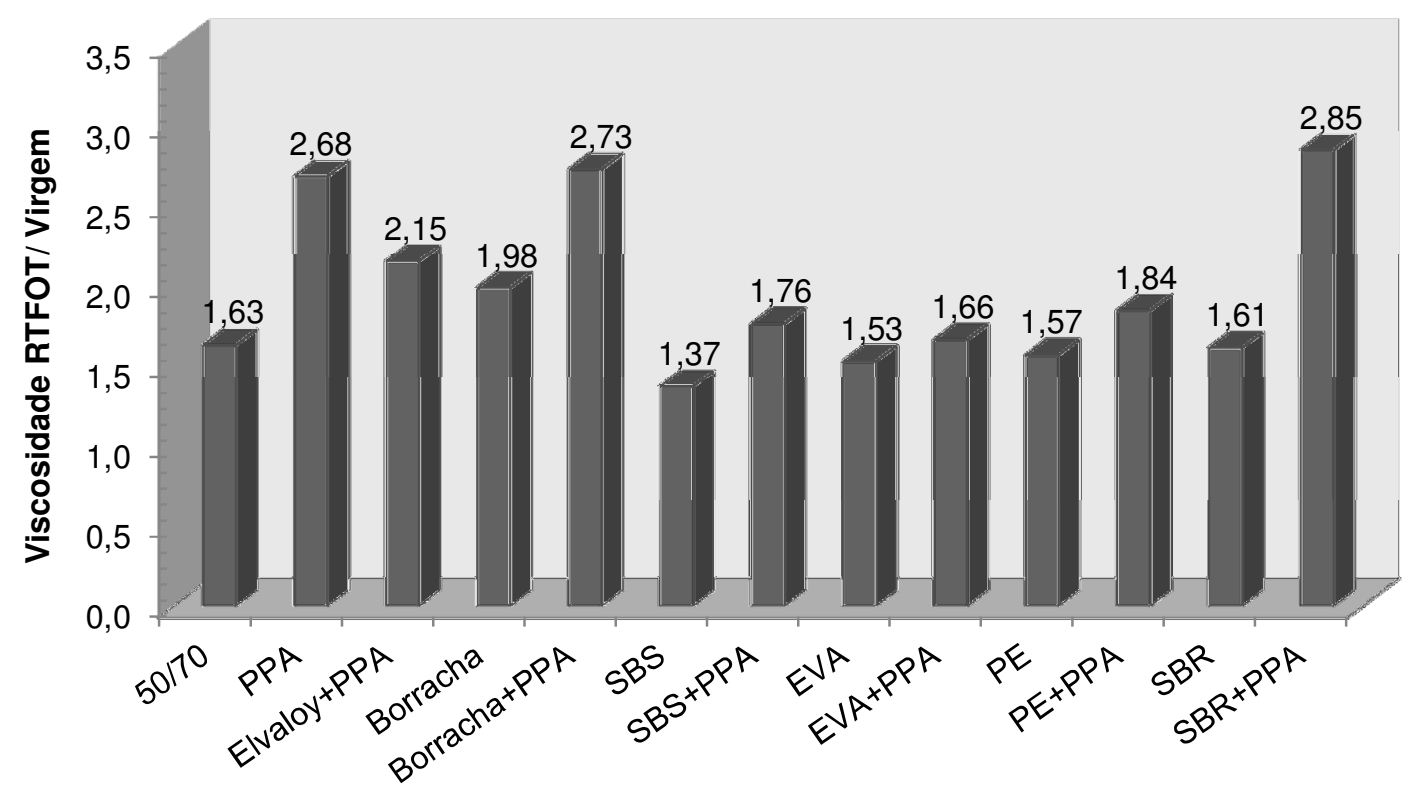

Figura 22 - Relações entre as viscosidades rotacionais virgens e envelhecidas dos ligantes asfálticos $\left(R_{v}\right)$ na temperatura de $135^{\circ} \mathrm{C}$

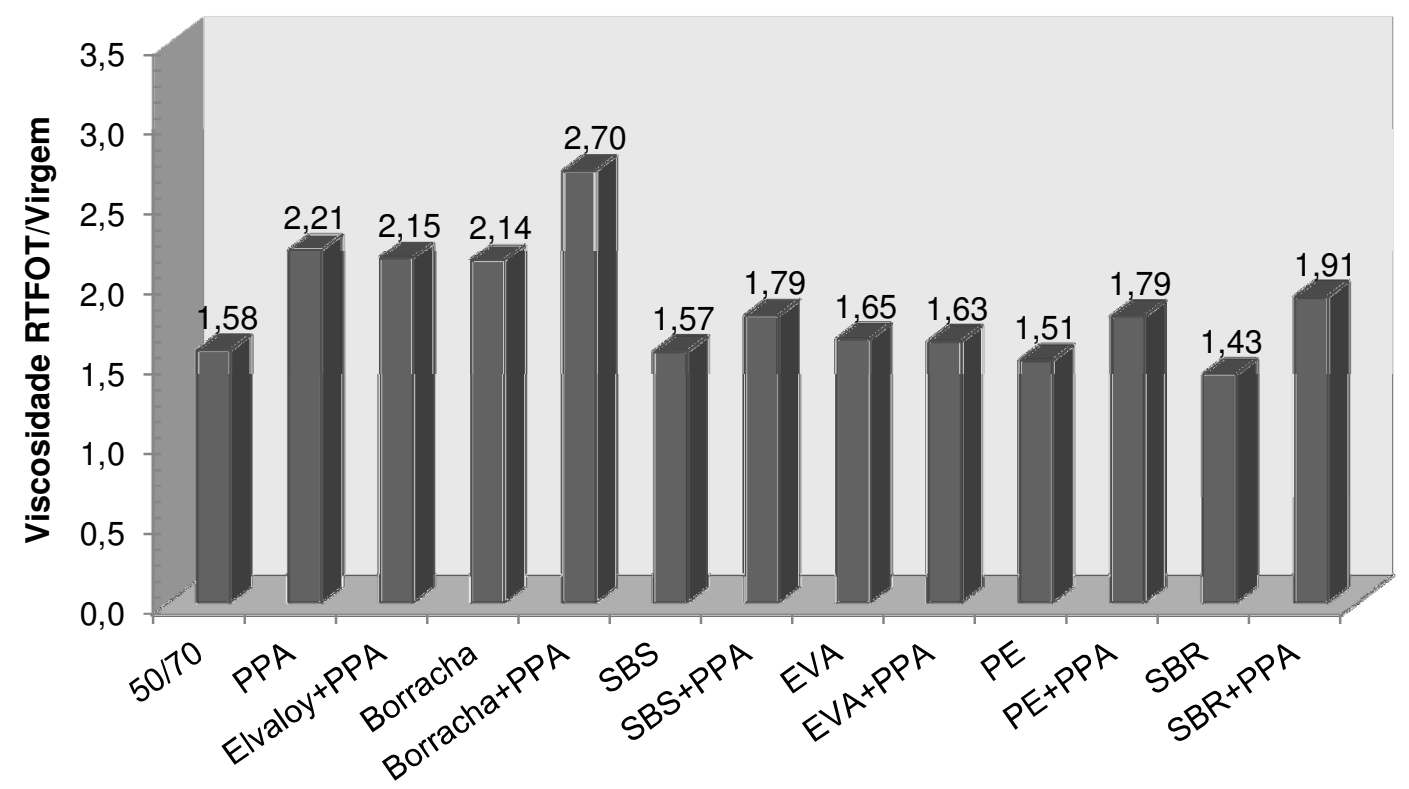

Figura 23 - Relações entre as viscosidades rotacionais virgens e envelhecidas dos ligantes asfálticos $\left(R_{V}\right)$ na temperatura de $143^{\circ} \mathrm{C}$ 
A Figura 24 mostra as relações entre as viscosidades dos ligantes asfálticos na temperatura de $150^{\circ} \mathrm{C}$. O maior incremento de viscosidade rotacional após o envelhecimento a curto prazo é encontrado no CAP+borracha+PPA (2,65 vezes), seguido pelo CAP+PPA (2,08 vezes), depois pelo CAP+Elvaloy+PPA (2,03 vezes), em seguida pelo CAP+borracha (1,93 vezes) e então pelo CAP+SBR+PPA (1,82 vezes). O menor incremento de viscosidade rotacional após o RTFOT é encontrado no CAP+SBR (1,39 vezes), seguido pelo CAP+PE (1,46 vezes), depois pelo CAP+SBS e pelo CAP 50/70 (ambos com 1,52 vezes) e então pelo CAP+EVA e pelo CAP+EVA+PPA (ambos com 1,61 vezes). O CAP+PE+PPA e o $\mathrm{CAP}+\mathrm{SBS}+\mathrm{PPA}$ apresentam incrementos parecidos de viscosidade rotacional, sendo de aproximadamente 1,7 vezes para ambos os ligantes asfálticos. À exceção do CAP+EVA e do $C A P+E V A+P P A$, as formulações $C A P+$ modificador+PPA apresentam maiores valores de $R_{V}$ (maior sensibilidade ao envelhecimento a curto prazo) em comparação às formulações correspondentes CAP+modificador, sendo que as maiores diferenças entre os valores são visualizadas nas formulações com borracha moída e com SBR e as menores são visualizadas nas formulações com SBS e com PE.

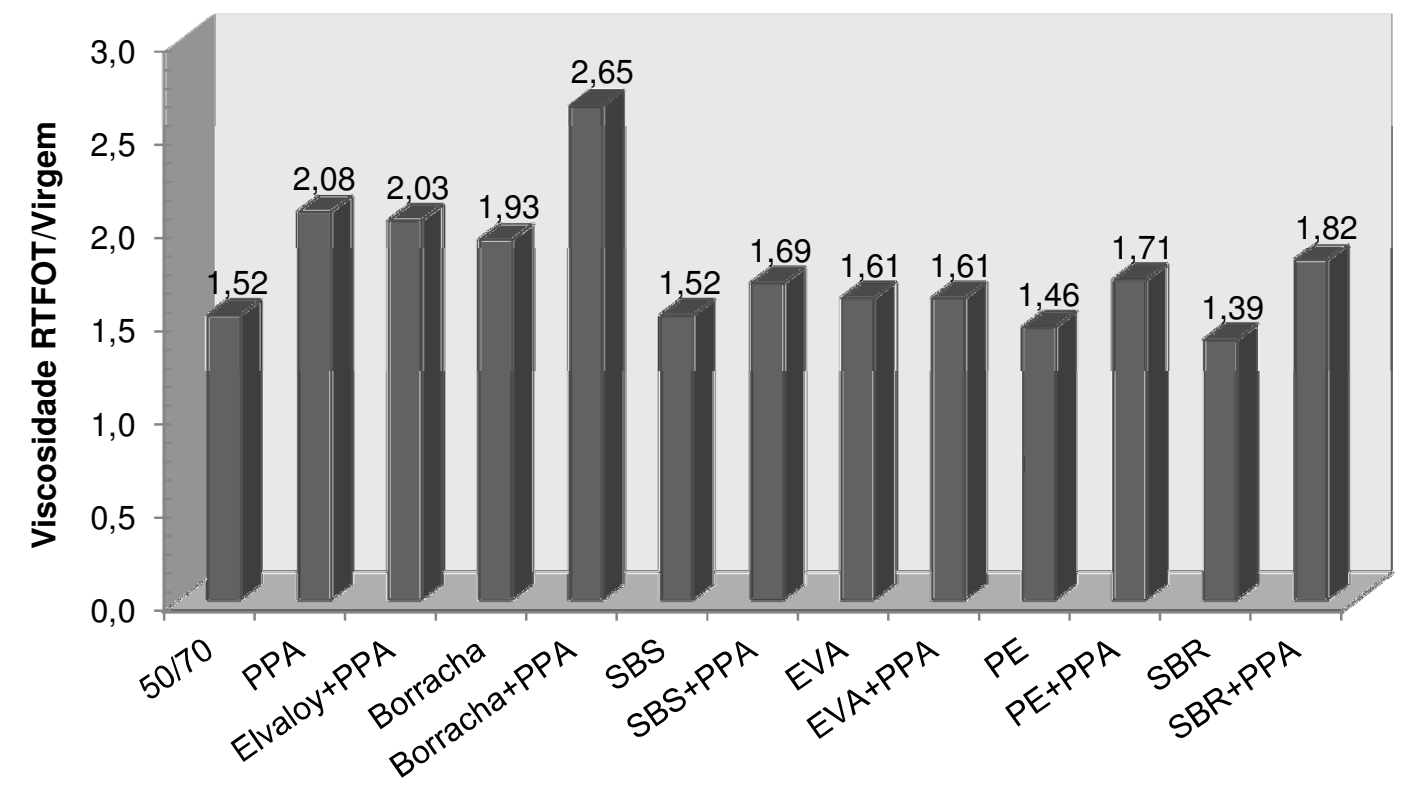

Figura 24 - Relações entre as viscosidades rotacionais virgens e envelhecidas dos ligantes asfálticos $\left(R_{V}\right)$ na temperatura de $150^{\circ} \mathrm{C}$

A Figura 25 apresenta as relações entre as viscosidades rotacionais dos ligantes asfálticos na temperatura de $163^{\circ} \mathrm{C}$. O CAP+borracha+PPA possui o maior incremento de viscosidade rotacional após o envelhecimento a curto prazo (2,36 vezes), seguido pelo CAP+PPA (1,88 vezes), depois pelo CAP+borracha (1,81 vezes) e então pelo CAP+Elvaloy+PPA (1,78 vezes). O menor incremento de viscosidade é observado no 
CAP+SBR (1,33 vezes), seguido pelo CAP+PE (1,37 vezes), depois pelo CAP+SBS (1,45 vezes) e então pelo CAP 50/70 (1,46 vezes). Os ligantes asfálticos modificados com EVA, EVA+PPA, SBS+PPA e PE+PPA possuem valores de $R_{V}$ próximos entre si, com resultados entre 1,5 e 1,6 para todos estes materiais. O CAP+SBR+PPA apresenta um incremento de viscosidade de 1,7 vezes após o envelhecimento a curto prazo, superando, assim, o valor obtido para o CAP+SBR $(1,33)$ em 0,37 vezes. Estes maiores valores de $R_{V}$ para as formulações com PPA são visualizados nos materiais com borracha moída, SBS, PE e SBR, o que indica, em linhas gerais, uma maior sensibilidade das formulações CAP+modificador+PPA ao envelhecimento a curto prazo em relação às formulações correspondentes CAP+modificador. As diferenças entre os incrementos de viscosidade são mais elevadas nas formulações com borracha moída e SBR, sendo pequenas ou nulas para as formulações com SBS, EVA e PE.

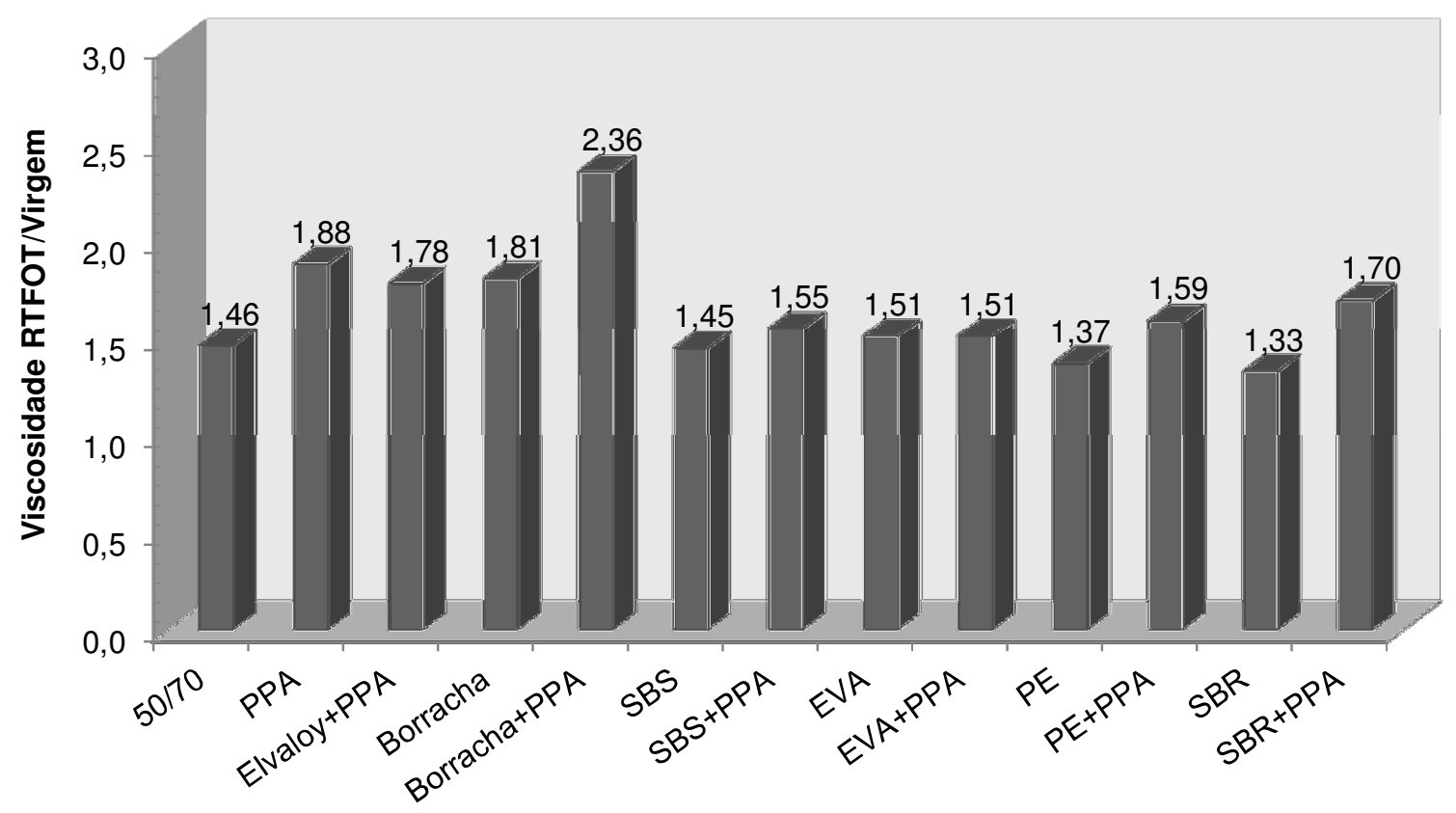

Figura 25 - Relações entre as viscosidades rotacionais virgens e envelhecidas dos ligantes asfálticos $\left(R_{\mathrm{V}}\right)$ na temperatura de $163^{\circ} \mathrm{C}$

A Figura 26 mostra as relações entre as viscosidades rotacionais dos ligantes asfálticos na temperatura de $177^{\circ} \mathrm{C}$. As diferenças entre os valores de $R_{V}$ são pequenas entre os materiais, sendo de no máximo 0,7 vezes. O CAP+borracha+PPA mantém o maior incremento de viscosidade dentre os ligantes asfálticos estudados (1,86 vezes), seguido pelo CAP+PPA (1,73 vezes), depois pelo CAP+borracha (1,62 vezes), em seguida pelo CAP+Elvaloy+PPA (1,60 vezes) e então pelo CAP+SBR+PPA (1,55 vezes). O menor incremento de viscosidade rotacional é encontrado no CAP+SBR (1,24 vezes), seguido pelo 
$\mathrm{CAP}+\mathrm{PE}$ (1,30 vezes), depois pelo CAP+SBS, pelo CAP+EVA+PPA (ambos com 1,40 vezes), em seguida pelo CAP+EVA (1,41 vezes) e então pelo CAP 50/70 (1,42 vezes). O $\mathrm{CAP}+\mathrm{SBS}+\mathrm{PPA}$ e o $\mathrm{CAP}+\mathrm{PPE}+\mathrm{PPA}$ apresentam incrementos praticamente semelhantes de viscosidade rotacional, sendo de aproximadamente 1,50 vezes para ambos os materiais. As formulações CAP+modificador+PPA apresentam, em linhas gerais, incrementos de viscosidade maiores do que as formulações correspondentes CAP+modificador, o que indica uma sensibilidade maior das primeiras ao envelhecimento a curto prazo. São exceções a este grupo as duas formulações com EVA (CAP+EVA e CAP+EVA+PPA), para as quais a diferença entre os incrementos de viscosidade é praticamente nula.

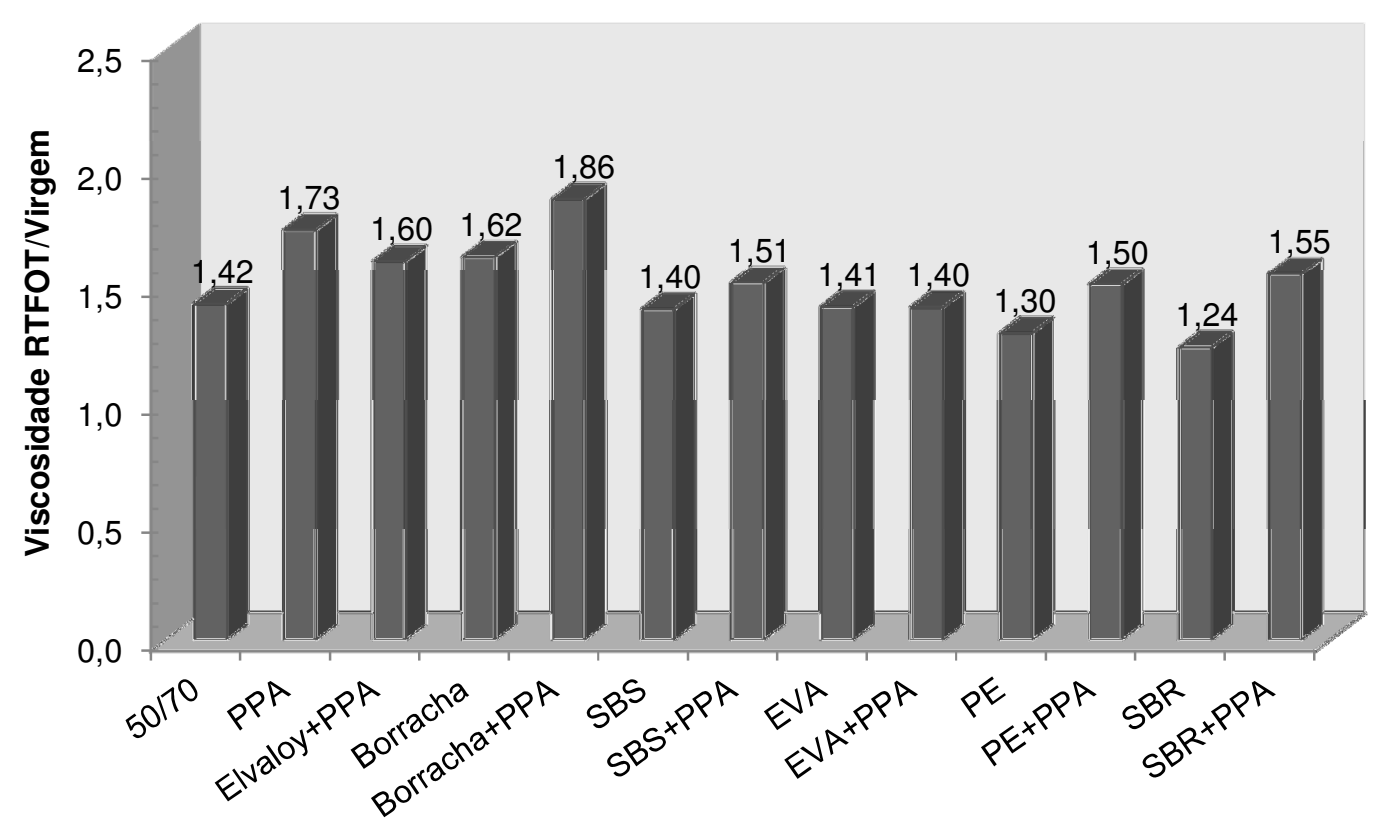

Figura 26 - Relações entre as viscosidades rotacionais virgens e envelhecidas dos ligantes asfálticos $\left(R_{V}\right)$ na temperatura de $177^{\circ} \mathrm{C}$

Em uma avaliação dos resultados apresentados nas Figuras 22 a 26, referentes aos incrementos de viscosidade rotacional após o RTFOT, observa-se que os ligantes asfálticos modificados com borracha+PPA, PPA, borracha, Elvaloy+PPA e SBR+PPA possuem os maiores valores de $R_{V}$ em todo o espectro de temperaturas, o que indica a elevada sensibilidade destes materiais ao envelhecimento a curto prazo. O CAP puro e os materiais modificados com SBS, PE e SBR possuem os menores valores de $R_{V}$ em quase todas as temperaturas, indicando a baixa sensibilidade destes materiais ao envelhecimento a curto prazo. Interessante observar que, dentre as cinco formulações com maiores incrementos de viscosidade, quatro delas (borracha+PPA, Elvaloy+PPA, PPA e SBR+PPA) apresentam PPA em sua composição, sendo que o CAP+borracha+PPA apresenta os maiores resultados em 4 das 5 temperaturas consideradas. Observa-se também que todas as formulações 
(incluindo o CAP 50/70) com baixos incrementos de viscosidade não possuem PPA em sua composição e, destas, os menores resultados pertencem ao CAP+SBR na maioria das temperaturas. Estes resultados permitem dizer que, de uma maneira geral, a presença do PPA nas formulações acarreta uma maior sensibilidade dos ligantes asfálticos ao envelhecimento a curto prazo.

\subsubsection{Temperaturas de usinagem e de compactação dos ligantes asfálticos}

As temperaturas de usinagem e de compactação dos ligantes asfálticos, ambas calculadas segundo o critério tradicional, são apresentadas na Tabela 10. Para o CAP 50/70, estas temperaturas estão entre 149 e $155^{\circ} \mathrm{C}$ (média de $152^{\circ} \mathrm{C}$ ) para a usinagem e entre $138 \mathrm{e}$ $142^{\circ} \mathrm{C}$ (média de $140^{\circ} \mathrm{C}$ ) para a compactação. As temperaturas obtidas para os ligantes asfálticos modificados são maiores que as do material puro, chegando a resultados superiores a $200^{\circ} \mathrm{C}$ para a usinagem e superiores a $185^{\circ} \mathrm{C}$ para a compactação no caso do CAP+borracha, do CAP+borracha+PPA e do CAP+EVA. Temperaturas desta ordem são impraticáveis e revelam a inadequação deste critério para a estimativa das temperaturas de usinagem e compactação para formulações desta natureza. O CAP+PPA apresenta temperaturas próximas às do CAP 50/70, com valores entre 162 e $168^{\circ} \mathrm{C}$ (média de $165^{\circ} \mathrm{C}$ ) para a usinagem e entre 151 e $156^{\circ} \mathrm{C}$ (média de $154^{\circ} \mathrm{C}$ ) para a compactação. As formulações CAP+modificador+PPA apresentam, na maioria dos casos, TUCs inferiores às das formulações correspondentes $\mathrm{CAP}+$ modificador, com as diferenças mais elevadas sendo observadas entre o CAP+EVA e o $\mathrm{CAP}+\mathrm{EVA}+\mathrm{PPA}\left(19^{\circ} \mathrm{C}\right.$ na compactação e $20^{\circ} \mathrm{C}$ na usinagem) e as mais baixas sendo observadas entre o $\mathrm{CAP}+\mathrm{SBS}$ e $\circ \mathrm{CAP}+\mathrm{SBS}+\mathrm{PPA}\left(1^{\circ} \mathrm{C}\right.$ na compactação e $1^{\circ} \mathrm{C}$ na usinagem). À exceção do CAP 50/70 e dos CAPs modificados com PPA, borracha, borracha+PPA e EVA, as temperaturas dos demais ligantes asfálticos estão entre 160 e $175^{\circ} \mathrm{C}$ (média de $168^{\circ} \mathrm{C}$ ) para a compactação e entre 175 e $190^{\circ} \mathrm{C}$ (média de $183^{\circ} \mathrm{C}$ ) para a usinagem.

Uma comparação dos resultados da Tabela 10 e das Figuras 12 a 16 (viscosidades dos ligantes asfálticos virgens) mostra que o CAP+borracha, o CAP+borracha+PPA e 0 CAP+EVA possuem as maiores viscosidades e, por consequência, as maiores TUCs. Para o CAP+borracha e o CAP+borracha+PPA, os resultados não satisfazem ao critério da Especificação de Serviço 112/2009 do DNIT, pois, embora as temperaturas de compactação sejam superiores ao mínimo de $145^{\circ} \mathrm{C}$, as temperaturas de usinagem superam o valor máximo permitido de $180^{\circ} \mathrm{C}$. Para o CAP+SBS, a temperatura de usinagem calculada de acordo com a Especificação de Serviço 385/1999 do DNIT é de aproximadamente $164^{\circ} \mathrm{C}$ e a de compactação 
é de aproximadamente $154^{\circ} \mathrm{C}$, ambas inferiores às temperaturas de usinagem e de compactação obtidas para este material e apresentadas na Tabela 10. No caso do $\mathrm{CAP}+\mathrm{SBS}+\mathrm{PPA}$, para o qual o critério do DNIT sugere as temperaturas de $159^{\circ} \mathrm{C}$ para a usinagem e de $149^{\circ} \mathrm{C}$ para a compactação, as temperaturas obtidas são superiores às recomendadas pelo critério tradicional.

Tabela 10 - Temperaturas de usinagem e de compactação dos ligantes asfálticos de acordo com o critério tradicional

\begin{tabular}{ccccc}
\hline \multirow{2}{*}{ Ligante asfáltico } & \multicolumn{2}{c}{ Compactação $\left(\mathrm{em}^{\circ} \mathrm{C}\right)$} & \multicolumn{2}{c}{ Usinagem $\left(\mathrm{em}{ }^{\circ} \mathrm{C}\right)$} \\
\cline { 2 - 5 } & Intervalo & Valor médio & Intervalo & Valor médio \\
\hline $50 / 70$ & $138-142$ & 140 & $149-155$ & 152 \\
PPA & $151-156$ & 154 & $162-168$ & 165 \\
Elvaloy+PPA & $164-169$ & 167 & $175-181$ & 178 \\
Borracha & $185-192$ & 189 & $201-210$ & 206 \\
Borracha+PPA & $181-192$ & 187 & $204-214$ & 209 \\
SBS & $167-173$ & 170 & $180-186$ & 183 \\
SBS+PPA & $166-172$ & 169 & $179-185$ & 182 \\
EVA & $185-191$ & 188 & $199-205$ & 202 \\
EVA+PPA & $166-172$ & 169 & $179-185$ & 182 \\
PE & $169-175$ & 172 & $183-189$ & 186 \\
PE+PPA & $164-169$ & 167 & $183-189$ & 186 \\
SBR & $165-171$ & 168 & $180-187$ & 184 \\
SBR+PPA & $161-167$ & 164 & $175-181$ & 178 \\
\hline
\end{tabular}

\subsection{Resultados do ensaio MSCR para os tempos de 1 e $9 \mathrm{~s}$ e discussão}

As análises dos resultados do ensaio MSCR foram realizadas por grupos de ligantes asfálticos. O CAP 50/70 e o CAP+PPA foram adotados como ligantes asfálticos de referência e a composição destes grupos está apresentada na Tabela 11. Ao escolher o CAP 50/70 como referência, é possível verificar as alterações nas propriedades ( $R$ e $\left.J_{n r}\right)$ e parâmetros de análise $\left(R_{J}, R_{R}\right.$ e $\left.J_{n r \text {,diff }}\right)$ após a incorporação dos modificadores. No caso do CAP+PPA, a escolha foi motivada pela comparação entre os resultados de formulações $\mathrm{CAP}+$ modificador e $\mathrm{CAP}+$ modificador+PPA e os resultados do ligante asfáltico modificado somente com PPA, sendo que a classificação PG destes materiais modificados é a mesma segundo o critério original da especificação Superpave (PG 76-XX). 
Tabela 11 - Estruturação dos grupos de ligantes asfálticos

\begin{tabular}{cc}
\hline Nomenclatura & Ligantes asfálticos analisados \\
\hline Grupo 1 & 50/70, PPA e Elvaloy+PPA \\
Grupo 2 & 50/70, PPA, Borracha e Borracha+PPA \\
Grupo 3 & $50 / 70$, PPA, SBS e SBS+PPA \\
Grupo 4 & 50/70, PPA, EVA e EVA+PPA \\
Grupo 5 & $50 / 70$, PPA, PE e PE+PPA \\
Grupo 6 & 50/70, PPA, SBR e SBR+PPA \\
\hline
\end{tabular}

Com o intuito de uniformizar as análises, os textos dos grupos de ligantes asfálticos foram divididos em 11 etapas: (1) percentuais de recuperação dos materiais virgens; (2) compliâncias não-recuperáveis dos materiais virgens; (3) resumo das análises dos materiais virgens; (4) percentuais de recuperação dos materiais envelhecidos a curto prazo; (5) compliâncias não-recuperáveis dos materiais envelhecidos a curto prazo; (6) resumo das análises dos materiais envelhecidos a curto prazo; (7) relação entre as compliâncias não-recuperáveis $R_{J}$; (8) relação entre os percentuais de recuperação $R_{R}$; (9) resumo das análises dos parâmetros $R_{J}$ e $R_{R}$; (10) diferença percentual entre as compliâncias não-recuperáveis $\mathrm{J}_{\mathrm{nr} \text {,diff }}$ e (11) resumos globais.

\subsubsection{CAP 50/70, CAP+PPA e CAP+Elvaloy+PPA}

A Tabela 12 mostra os percentuais de recuperação do CAP 50/70 e dos ligantes asfálticos modificados com PPA e Elvaloy+PPA, para materiais na condição virgem. O CAP+Elvaloy+PPA possui os percentuais mais elevados ao longo de todo 0 espectro de temperaturas a 100 e a $3.200 \mathrm{~Pa}$, sendo o que recupera mais em todas as temperaturas. Em termos numéricos, os percentuais do CAP+Elvaloy+PPA variam entre 45 e $73 \%$ a $100 \mathrm{~Pa}$ e entre 23 e 73\% a $3.200 \mathrm{~Pa}$. O CAP+PPA apresenta percentuais de recuperação entre 2 e $35 \%$ a $100 \mathrm{~Pa}$, sendo de no máximo $28 \%$ a $3.200 \mathrm{~Pa}$. O ligante asfáltico puro possui os menores percentuais em qualquer temperatura e nível de tensão, sendo o que recupera menos em todas as temperaturas. As recuperações do CAP 50/70 são de no máximo 4\% a $100 \mathrm{~Pa}$ e, a $3.200 \mathrm{~Pa}$, este material não apresenta recuperação em qualquer temperatura, mesmo nas mais baixas. Uma vez que o percentual de recuperação identifica a resposta elástica do ligante asfáltico, um valor nulo para esta propriedade indica que a deformação acumulada no material não sofre qualquer recuperação. 
Tabela 12 - Percentuais de recuperação (R) do CAP 50/70, do CAP+PPA e do CAP+Elvaloy+PPA nos tempos de 1 e 9 s e na condição virgem

\begin{tabular}{ccccccccccc}
\hline \multirow{2}{*}{$\begin{array}{c}\text { Ligante } \\
\text { asfáltico }\end{array}$} & \multicolumn{4}{c}{$100 \mathrm{~Pa}(\mathrm{R} 100)$, em \% } & \multicolumn{5}{c}{$3.200 \mathrm{~Pa}(\mathrm{R} 3200), \mathrm{em} \%$} \\
\cline { 2 - 10 } & $52^{\circ} \mathrm{C}$ & $58^{\circ} \mathrm{C}$ & $64^{\circ} \mathrm{C}$ & $70^{\circ} \mathrm{C}$ & $76^{\circ} \mathrm{C}$ & $52^{\circ} \mathrm{C}$ & $58^{\circ} \mathrm{C}$ & $64^{\circ} \mathrm{C}$ & $70^{\circ} \mathrm{C}$ & $76^{\circ} \mathrm{C}$ \\
\hline $50 / 70$ & 4,1 & 0,8 & 0,0 & 0,0 & 0,0 & 0,0 & 0,0 & 0,0 & 0,0 & 0,0 \\
PPA & 34,4 & 23,9 & 14,9 & 7,5 & 2,6 & 27,7 & 11,8 & 0,7 & 0,0 & 0,0 \\
Elvaloy+PPA & 72,4 & 69,4 & 63,6 & 55,5 & 45,5 & 72,9 & 68,1 & 58,2 & 42,9 & 23,3 \\
\hline
\end{tabular}

A Figura 27 ilustra as variações do percentual de recuperação com a temperatura para o CAP 50/70 e os materiais modificados com PPA e Elvaloy+PPA, todos na condição virgem. Os decréscimos nos percentuais do CAP+PPA e do CAP+Elvaloy+PPA seguem tendências aproximadamente lineares na tensão de $100 \mathrm{~Pa}$, o mesmo não sendo observado na tensão de $3.200 \mathrm{~Pa}$. No caso do CAP+PPA, a presença do modificador não é sentida nas temperaturas mais altas a $3.200 \mathrm{~Pa}$ porque os percentuais de recuperação são nulos nestas condições. As diferenças entre os percentuais a 100 e a 3.200 Pa são pequenas para o $\mathrm{CAP}+$ Elvaloy+PPA nas temperaturas de até $64^{\circ} \mathrm{C}$, o contrário ocorrendo nas temperaturas superiores a $64^{\circ} \mathrm{C}$. Situação diferente ocorre com o CAP+PPA, para o qual as diferenças entre os percentuais de recuperação são significativas a 58 e a $64^{\circ} \mathrm{C}$ e pequenas nas demais temperaturas.

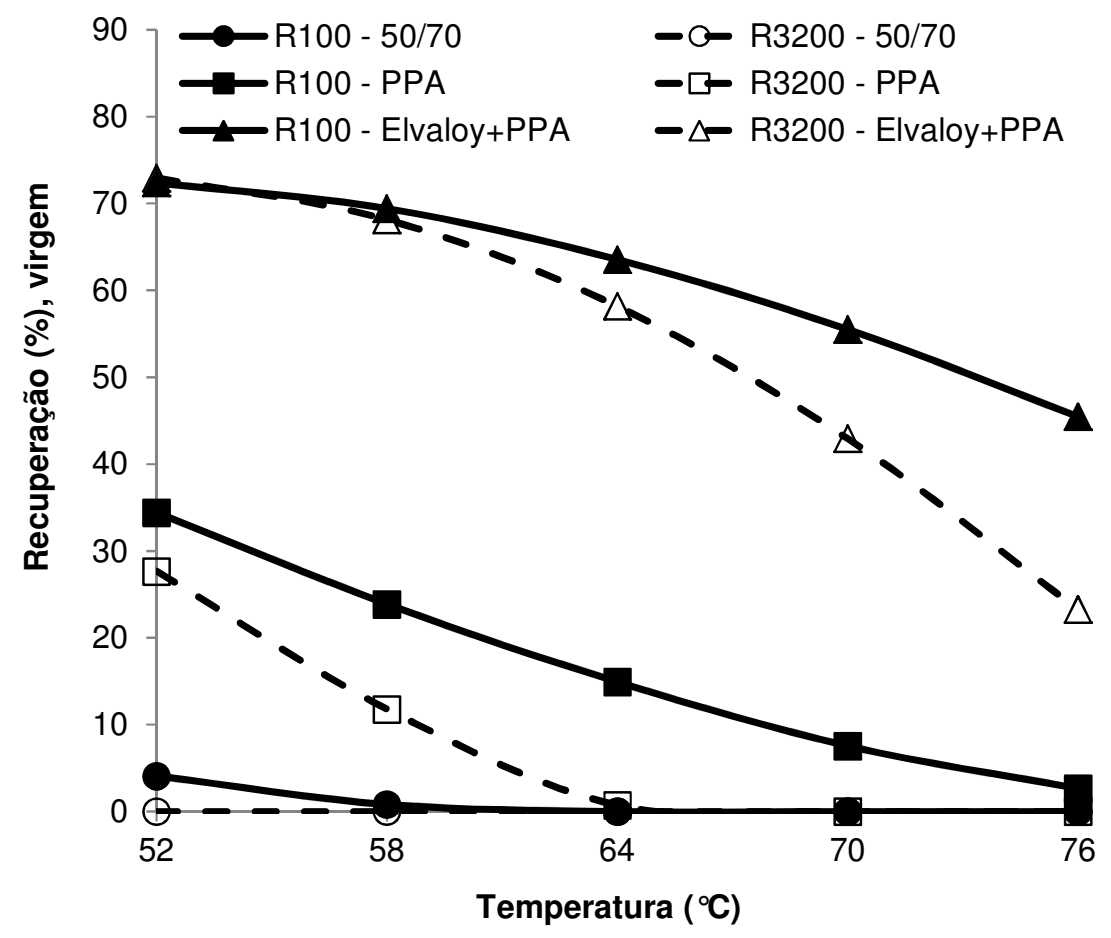

Figura 27- Percentuais de recuperação (R) do CAP 50/70, do CAP+PPA e do CAP+Elvaloy+PPA na condição virgem e nos tempos de 1 e $9 \mathrm{~s}$ 
A Tabela 13 mostra as compliâncias não-recuperáveis do CAP 50/70 e dos ligantes asfálticos modificados com PPA e Elvaloy+PPA, para materiais na condição virgem. $O$ CAP 50/70 possui os valores mais elevados de compliância não-recuperável em todas as temperaturas a 100 e a $3.200 \mathrm{~Pa}$, com resultados numéricos entre 1 e $34 \mathrm{kPa}^{-1}$ a $100 \mathrm{~Pa}$ e entre 1 e $37 \mathrm{kPa}^{-1}$ a $3.200 \mathrm{~Pa}$. O CAP+Elvaloy+PPA possui os valores mais baixos para esta propriedade em qualquer temperatura e tensão, com valores de até $3,2 \mathrm{kPa}^{-1}$ a $100 \mathrm{~Pa}$ e de até $4,2 \mathrm{kPa}^{-1}$ a $3.200 \mathrm{~Pa}$. O CAP+PPA apresenta resultados mais próximos aos do $\mathrm{CAP}+$ Elvaloy+PPA, especialmente nas temperaturas de até $64^{\circ} \mathrm{C}$ a 100 e a $3.200 \mathrm{~Pa}$. Em termos numéricos, as compliâncias não-recuperáveis do CAP+PPA estão entre 0,1 e 7,7 kPa-1 a $100 \mathrm{~Pa}$ e entre 0,2 e 10,8 $\mathrm{kPa}^{-1}$ a $3.200 \mathrm{~Pa}$. Uma vez que o valor de $\mathrm{J}_{\mathrm{nr}}$ está relacionado à suscetibilidade do ligante asfáltico à deformação permanente, pode-se dizer que o CAP 50/70 apresenta a maior suscetibilidade e que o CAP+Elvaloy+PPA possui a menor, ambos em qualquer situação de temperatura e de nível de tensão.

Tabela 13 - Compliâncias não-recuperáveis $\left(\mathrm{J}_{\mathrm{nr}}\right)$ do CAP 50/70, do CAP+PPA e do CAP+Elvaloy+PPA nos tempos de 1 e 9 s e na condição virgem

\begin{tabular}{ccccccccccc}
\hline \multirow{2}{*}{$\begin{array}{c}\text { Ligante } \\
\text { asfáltico }\end{array}$} & \multicolumn{4}{c}{$100 \mathrm{~Pa}\left(\mathrm{~J}_{\mathrm{nr}} 100\right), \mathrm{em} \mathrm{kPa}^{-1}$} & \multicolumn{4}{c}{$3.200 \mathrm{~Pa}\left(\mathrm{~J}_{\mathrm{nr}} 3200\right), \mathrm{em} \mathrm{kPa}^{-1}$} \\
\cline { 2 - 11 } & $52^{\circ} \mathrm{C}$ & $58^{\circ} \mathrm{C}$ & $64^{\circ} \mathrm{C}$ & $70^{\circ} \mathrm{C}$ & $76^{\circ} \mathrm{C}$ & $52^{\circ} \mathrm{C}$ & $58^{\circ} \mathrm{C}$ & $64^{\circ} \mathrm{C}$ & $70^{\circ} \mathrm{C}$ & $76^{\circ} \mathrm{C}$ \\
\hline $50 / 70$ & 1,05 & 2,73 & 6,88 & 15,77 & 33,36 & 1,16 & 3,17 & 7,88 & 17,74 & 36,80 \\
PPA & 0,18 & 0,50 & 1,34 & 3,31 & 7,65 & 0,20 & 0,61 & 1,76 & 4,56 & 10,76 \\
Elvaloy+PPA & 0,14 & 0,30 & 0,65 & 1,44 & 3,16 & 0,13 & 0,29 & 0,68 & 1,64 & 4,11 \\
\hline
\end{tabular}

A Figura 28 ilustra os gráficos da compliância não-recuperável para o CAP 50/70, o CAP+PPA e o CAP+Elvaloy+PPA, todos na condição virgem. As diferenças entre as compliâncias não-recuperáveis do CAP 50/70 e dos materiais modificados são significativas em qualquer temperatura e nível de tensão, o que, até certo ponto, dificulta a análise dos comportamentos dos ligantes asfálticos modificados. Assim, optou-se pela elaboração de um novo gráfico de $\mathrm{J}_{\mathrm{nr}}$ contendo apenas os resultados do CAP+PPA e do CAP+Elvaloy+PPA (Figura 29), sendo que esta estratégia foi mantida para todos os demais grupos de ligantes asfálticos. Não são observadas distinções significativas entre os modificadores nas temperaturas de 52 e $58^{\circ} \mathrm{C}$ porque as diferenças entre as compliâncias não-recuperáveis são pequenas e, desta maneira, os valores podem ser considerados equivalentes. As diferenças entre as compliâncias a 100 e a $3.200 \mathrm{~Pa}$ são maiores para o CAP+PPA do que para o $\mathrm{CAP}+$ Elvaloy+PPA nas temperaturas de 64,70 e $76^{\circ} \mathrm{C}$, o que indica, à luz dos resultados de $\mathrm{J}_{\mathrm{nr}}$, uma maior sensibilidade do CAP+PPA ao incremento do nível de tensão. No caso do $\mathrm{CAP}+$ Elvaloy+PPA, observa-se que estas diferenças são pequenas (inferiores a $1,0 \mathrm{kPa}^{-1}$ conforme Tabela 13) em qualquer temperatura, mesmo nas mais elevadas. 


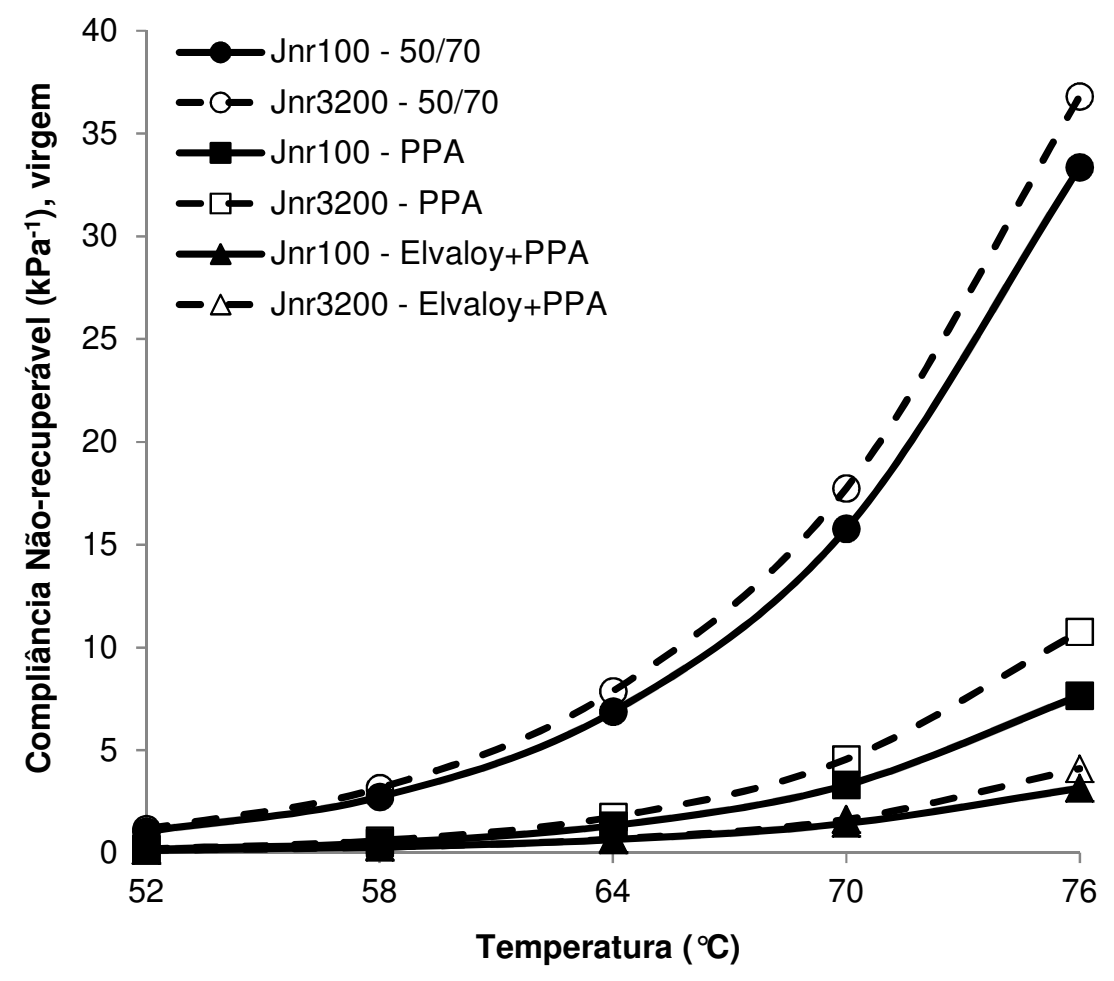

Figura 28 - Compliâncias não-recuperáveis $\left(\mathrm{J}_{n r}\right)$ do CAP 50/70, do CAP+PPA e do $\mathrm{CAP}+$ Elvaloy+PPA na condição virgem e nos tempos de 1 e $9 \mathrm{~s}$

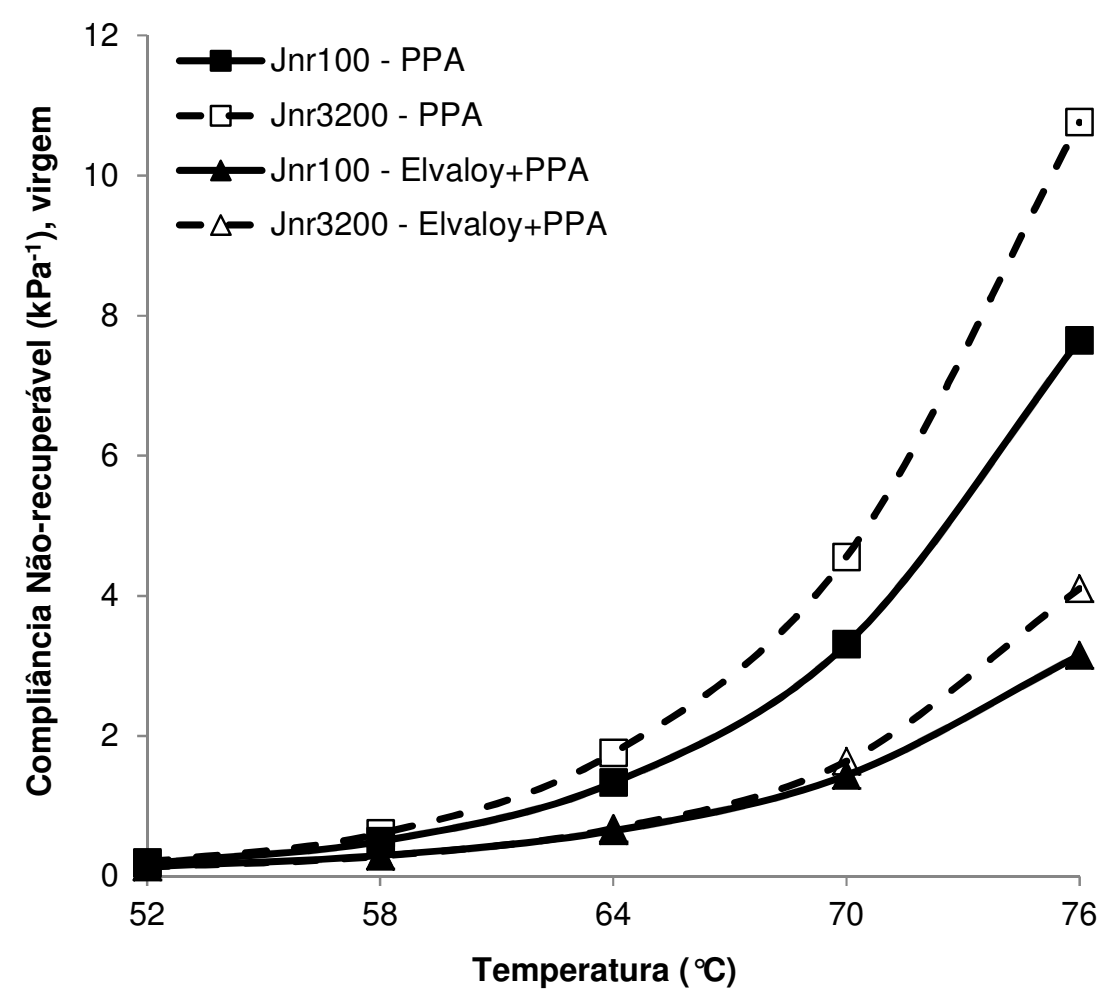

Figura 29 - Compliâncias não-recuperáveis $\left(J_{n r}\right)$ do CAP+PPA e do CAP+Elvaloy+PPA na condição virgem e nos tempos de 1 e $9 \mathrm{~s}$ 
Em uma avaliação dos resultados das Tabelas 12 e 13 e das Figuras 27 a 29, referentes aos ligantes asfálticos virgens, observa-se que o CAP+Elvaloy+PPA apresenta os maiores percentuais de recuperação e as menores compliâncias não-recuperáveis em todas as temperaturas e níveis de tensão da condição virgem, o que pode ser interpretado como uma menor suscetibilidade deste material à deformação permanente e uma maior recuperação elástica da sua deformação total. Uma vez que o percentual de recuperação tem apresentado correlações com a quantidade de polímero e com a extensão da rede polimérica no ligante asfáltico (D'ANGELO, 2010b), os valores elevados de R para o CAP+Elvaloy+PPA indicam a presença de uma rede polimérica bem estabelecida no material, a qual the confere respostas elásticas significativas aos carregamentos aplicados. Desta maneira, visualiza-se que a adição de Elvaloy e PPA ao ligante asfáltico não apenas proporcionou um enrijecimento do material de base (redução de $\mathrm{J}_{\mathrm{nr}}$ ), mas também uma elasticidade elevada (aumento de R) em uma faixa ampla de temperaturas.

A Tabela 14 apresenta os percentuais de recuperação do CAP 50/70 e dos CAPs modificados com PPA e com Elvaloy+PPA, para materiais na condição envelhecida a curto prazo. O envelhecimento na estufa de filme fino rotativo proporciona, em linhas gerais, um aumento nos valores de $R$, sobretudo dos ligantes asfálticos modificados. $O$ CAP+Elvaloy+PPA mantém os percentuais de recuperação mais elevados ao longo de todo o espectro de temperaturas a 100 e a $3.200 \mathrm{~Pa}$, com valores superiores a 60\% (picos de $80 \%$ ) em qualquer condição de temperatura e de tensão. O CAP 50/70 mantém os valores mais baixos para esta propriedade em todas as temperaturas e níveis de tensão, com resultados de até $13 \%$ a $100 \mathrm{~Pa}$ e de até 9\% a $3.200 \mathrm{~Pa}$. O CAP+PPA apresenta recuperações mais próximas às do $C A P+E l v a l o y+P P A$, especialmente nas temperaturas de 52 e $58^{\circ} \mathrm{C}$ a $100 \mathrm{~Pa}$. Os valores de $\mathrm{R}$ se situam entre 24 e 64\% a $100 \mathrm{~Pa}$ para o CAP+PPA, sendo de até $63 \%$ a $3.200 \mathrm{~Pa}$.

Tabela 14 - Percentuais de recuperação (R) do CAP 50/70, do CAP+PPA e do $\mathrm{CAP}+$ Elvaloy+PPA nos tempos de 1 e $9 \mathrm{~s}$ e na condição envelhecida

\begin{tabular}{ccccccccccc}
\hline \multirow{2}{*}{$\begin{array}{c}\text { Ligante } \\
\text { asfáltico }\end{array}$} & \multicolumn{4}{c}{$100 \mathrm{~Pa}(\mathrm{R} 100), \mathrm{em} \%$} & \multicolumn{5}{c}{$3.200 \mathrm{~Pa}(\mathrm{R} 3200), \mathrm{em} \%$} \\
\cline { 2 - 11 } & $52^{\circ} \mathrm{C}$ & $58^{\circ} \mathrm{C}$ & $64^{\circ} \mathrm{C}$ & $70^{\circ} \mathrm{C}$ & $76^{\circ} \mathrm{C}$ & $52^{\circ} \mathrm{C}$ & $58^{\circ} \mathrm{C}$ & $64^{\circ} \mathrm{C}$ & $70^{\circ} \mathrm{C}$ & $76{ }^{\circ} \mathrm{C}$ \\
\hline $50 / 70$ & 12,4 & 5,8 & 1,0 & 0,0 & 0,0 & 8,9 & 0,5 & 0,0 & 0,0 & 0,0 \\
PPA & 63,7 & 55,2 & 44,6 & 34,1 & 24,0 & 62,4 & 49,8 & 31,3 & 12,1 & 0,8 \\
Elvaloy+PPA & 80,3 & 79,8 & 77,1 & 72,5 & 66,0 & 80,7 & 79,8 & 77,2 & 71,4 & 60,5 \\
\hline
\end{tabular}

A Figura 30 ilustra os gráficos de variação do percentual de recuperação com a temperatura para o CAP 50/70 e os CAPs modificados com PPA e Elvaloy+PPA, 
considerando a condição envelhecida destes materiais. No caso do CAP+PPA, observa-se que o decréscimo dos valores de $\mathrm{R}$ segue uma tendência aproximadamente linear, tanto a 100 quanto a 3.200 Pa. Para o CAP+Elvaloy+PPA, os valores de R a 100 e a $3.200 \mathrm{~Pa}$ são praticamente iguais nas temperaturas de $52,58,64$ e $70^{\circ} \mathrm{C}$, com a distinção entre as duas curvas sendo mais visível a $76^{\circ} \mathrm{C}$. O CAP 50/70 não apresenta qualquer recuperação nas temperaturas acima de $64^{\circ} \mathrm{C}$, mesmo para o nível de tensão de $100 \mathrm{~Pa}$. As distâncias entre as curvas de $\mathrm{R}$ a 100 e a $3.200 \mathrm{~Pa}$ aumentam com o aumento da temperatura especialmente no caso do CAP+PPA, de modo que que o percentual de recuperação deste material é praticamente nulo na temperatura do $P G\left(76^{\circ} \mathrm{C}\right)$ e a $3.200 \mathrm{~Pa}$. Este fenômeno, entretanto, não é verificado no CAP+Elvaloy+PPA, para o qual as variações de $R$ a 100 e a 3.200 Pa são pequenas mesmo nas temperaturas de 70 e $76^{\circ} \mathrm{C}$.

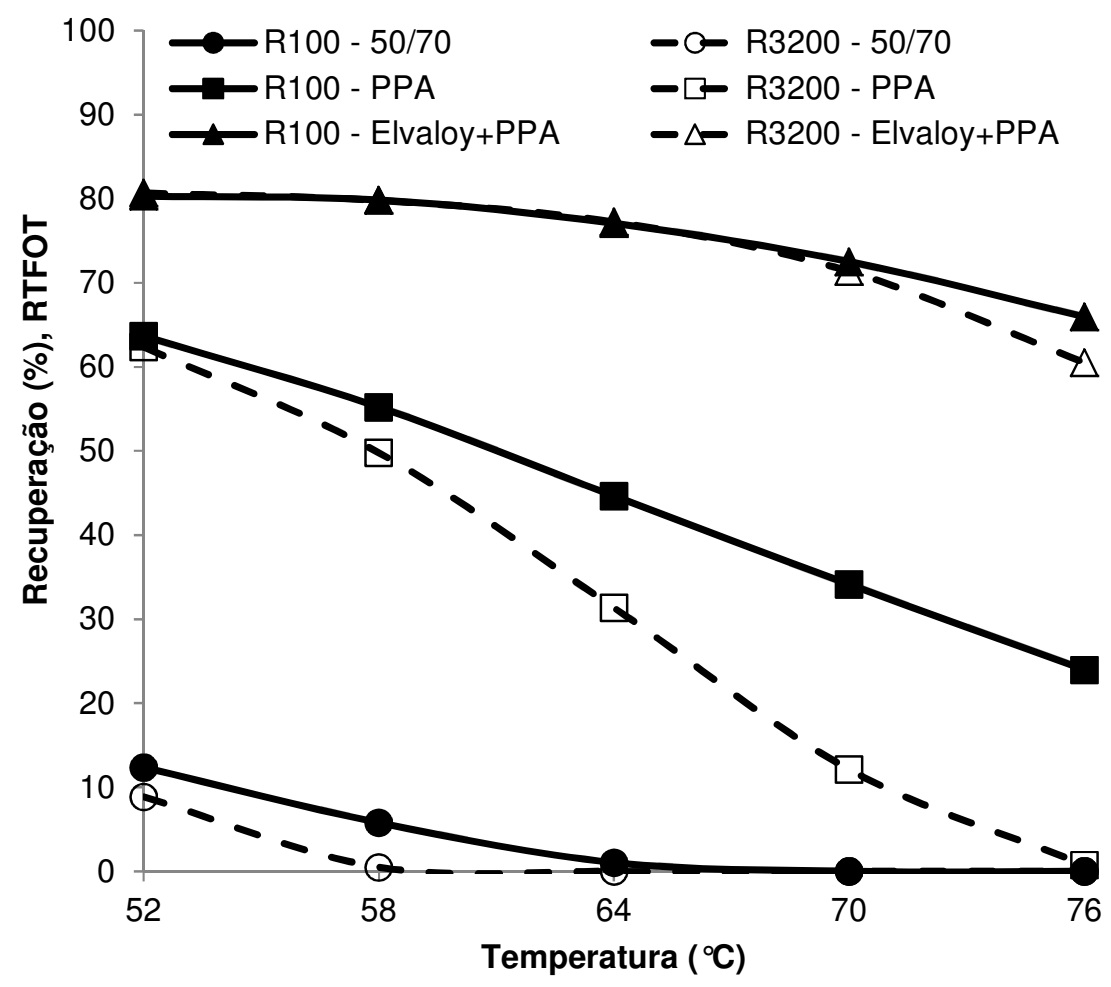

Figura 30 - Percentuais de recuperação $(R)$ do CAP 50/70, do CAP+PPA e do CAP+Elvaloy+PPA na condição envelhecida e nos tempos de 1 e $9 \mathrm{~s}$

A Tabela 15 mostra as compliâncias não-recuperáveis do CAP 50/70 e dos ligantes asfálticos modificados com PPA e Elvaloy+PPA, considerando materiais envelhecidos a curto prazo. O envelhecimento a curto prazo proporciona uma redução nos valores de $J_{n r}$ dos ligantes asfálticos, sendo que o CAP+Elvaloy+PPA apresenta os menores resultados em ambos os níveis de tensão. Assim como observado na condição virgem, o CAP 50/70 apresenta os maiores valores de $\mathrm{J}_{\mathrm{nr}}$ em todas as temperaturas a 100 
e a $3.200 \mathrm{~Pa}$, com resultados de até $14 \mathrm{kPa}^{-1}$ a $100 \mathrm{~Pa}$ e de até $16 \mathrm{kPa}^{-1}$ a $3.200 \mathrm{~Pa}$. O CAP+PPA possui compliâncias não-recuperáveis próximas às do CAP+Elvaloy+PPA em ambos os níveis de tensão, especialmente nas temperaturas de até $64^{\circ} \mathrm{C}$. Em termos numéricos, o CAP+PPA possui compliâncias não-recuperáveis de até $1,5 \mathrm{kPa}^{-1}$ a $100 \mathrm{~Pa} \mathrm{e}$ de até $2,4 \mathrm{kPa}^{-1}$ a $3.200 \mathrm{~Pa}$, sendo que estes valores não ultrapassam $1,0 \mathrm{kPa}^{-1}$ para o CAP+Elvaloy+PPA em qualquer condição de temperatura e tensão.

Tabela 15 - Compliâncias não-recuperáveis $\left(\mathrm{J}_{\mathrm{nr}}\right)$ do CAP 50/70, do CAP+PPA e do CAP+Elvaloy+PPA nos tempos de 1 e 9 s e na condição envelhecida

\begin{tabular}{ccccccccccc}
\hline \multirow{2}{*}{$\begin{array}{c}\text { Ligante } \\
\text { asfáltico }\end{array}$} & \multicolumn{4}{c}{$100 \mathrm{~Pa}\left(\mathrm{~J}_{\mathrm{nr}} 100\right), \mathrm{em} \mathrm{kPa}^{-1}$} & \multicolumn{5}{c}{$3.200 \mathrm{~Pa}\left(\mathrm{~J}_{\mathrm{nr}} 3200\right), \mathrm{em} \mathrm{kPa}^{-1}$} \\
\cline { 2 - 11 } & $52^{\circ} \mathrm{C}$ & $58^{\circ} \mathrm{C}$ & $64^{\circ} \mathrm{C}$ & $70^{\circ} \mathrm{C}$ & $76^{\circ} \mathrm{C}$ & $52^{\circ} \mathrm{C}$ & $58^{\circ} \mathrm{C}$ & $64^{\circ} \mathrm{C}$ & $70^{\circ} \mathrm{C}$ & $76^{\circ} \mathrm{C}$ \\
\hline $50 / 70$ & 0,33 & 0,92 & 2,44 & 5,96 & 13,53 & 0,35 & 1,02 & 2,78 & 6,79 & 15,23 \\
PPA & 0,03 & 0,08 & 0,23 & 0,59 & 1,48 & 0,03 & 0,09 & 0,29 & 0,86 & 2,38 \\
Elvaloy+PPA & 0,03 & 0,07 & 0,15 & 0,31 & 0,68 & 0,03 & 0,07 & 0,14 & 0,29 & 0,66 \\
\hline
\end{tabular}

A Figura 31 apresenta os gráficos de variação de $J_{n r}$ para os ligantes asfálticos modificados com PPA e com Elvaloy+PPA, considerando materiais envelhecidos a curto prazo. As compliâncias não-recuperáveis do CAP+PPA e do CAP+Elvaloy+PPA são praticamente iguais nas temperaturas de 52 e $58^{\circ} \mathrm{C}$, sendo que esta distinção é mais visível a 64,70 e $76^{\circ} \mathrm{C}$. No caso do CAP+Elvaloy+PPA, os valores de $J_{n r}$ a 100 e a $3.200 \mathrm{~Pa}$ são muito próximos entre si em todas as temperaturas, com diferenças numéricas inferiores a $0,03 \mathrm{kPa}^{-1}$ entre os resultados (Tabela 15). O mesmo, entretanto, não ocorre com o CAP+PPA, cujas curvas de $J_{n r}$ a 100 e a 3.200 Pa estão mais distantes entre si sobretudo nas temperaturas de 70 e $76^{\circ} \mathrm{C}$. À luz destes resultados de compliância não-recuperável, pode-se dizer que a sensibilidade do CAP+PPA ao incremento do nível de tensão é maior que a do CAP+Elvaloy+PPA.

Em uma avaliação dos resultados das Tabelas 14 e 15 e das Figuras 30 e 31, referentes aos materiais envelhecidos a curto prazo, é possível observar que o CAP+Elvaloy+PPA apresenta os maiores percentuais de recuperação e as menores compliâncias não-recuperáveis em comparação ao CAP 50/70 e ao CAP+PPA, além das menores variações entre os valores de ambas as propriedades a 100 e a $3.200 \mathrm{~Pa}$. Assim como na condição virgem, os baixos resultados para a compliância não-recuperável indicam que o CAP+Elvaloy+PPA possui a menor suscetibilidade à deformação permanente dentre os materiais analisados. Em outro extremo, o CAP 50/70 possui os maiores valores de $\mathrm{J}_{\mathrm{nr}}$ e os menores percentuais de recuperação nas condições de realização do ensaio MSCR, o que mostra a incapacidade deste material em atender, por si só, às condições mais severas de 
carregamento do tráfego. No caso do CAP+PPA, este material apresenta resultados intermediários entre o ligante asfáltico puro e o CAP+Elvaloy+PPA, tanto no percentual de recuperação quanto na compliância não-recuperável.

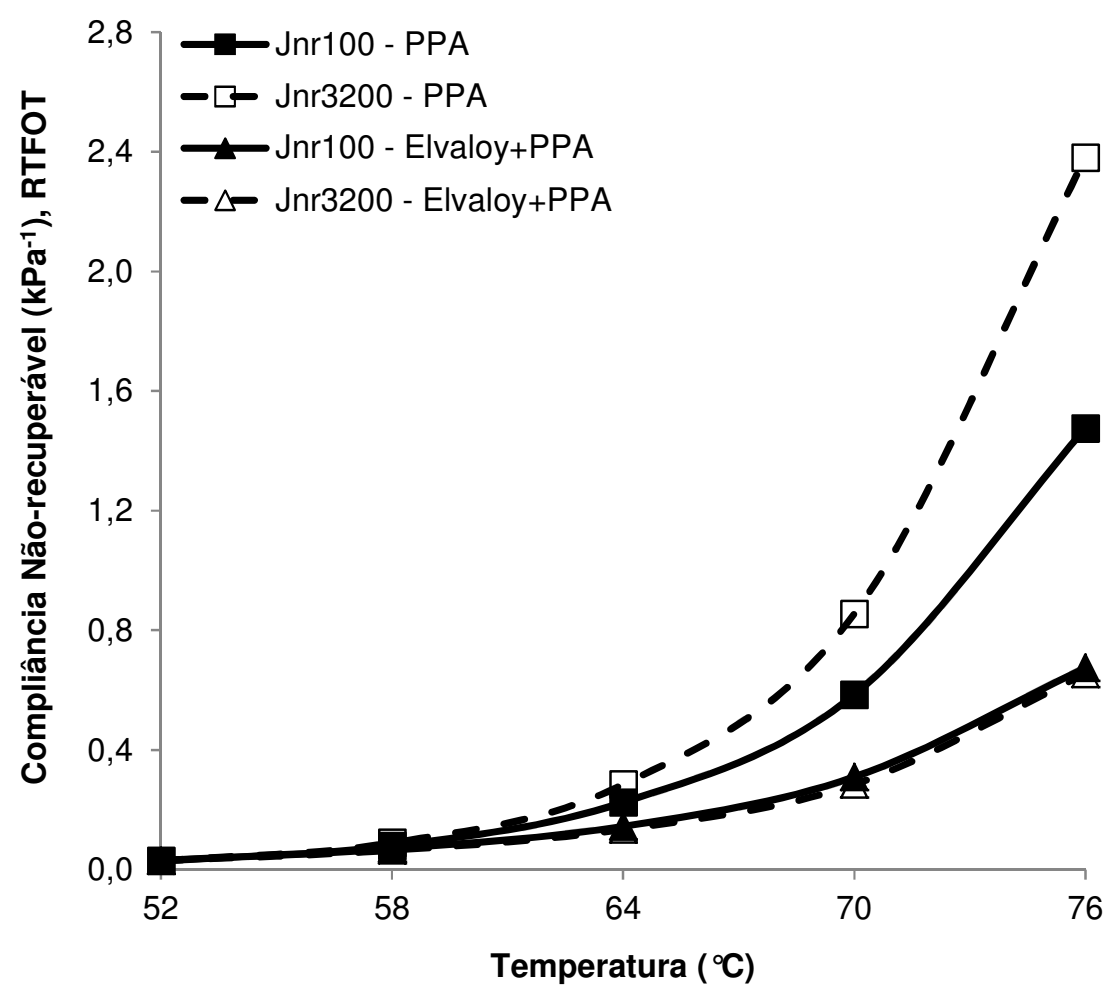

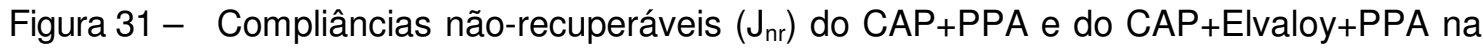
condição envelhecida e nos tempos de 1 e $9 \mathrm{~s}$

A Tabela 16 apresenta as relações entre as compliâncias não-recuperáveis $\left(R_{J}\right)$ para o CAP 50/70 e os materiais modificados com PPA e Elvaloy+PPA. O envelhecimento a curto prazo proporciona uma redução entre 2 e 7 vezes na compliância não-recuperável dos ligantes asfálticos. O CAP+PPA possui os maiores valores de $\mathrm{R}_{\mathrm{J}}$ em todas as temperaturas a $100 \mathrm{~Pa}$ e nas temperaturas de até $64^{\circ} \mathrm{C}$ a $3.200 \mathrm{~Pa}$, sendo, portanto, o material que mais enrijece após o RTFOT nestas condições. O CAP 50/70 possui os menores valores de $\mathrm{R}_{\mathrm{J}}$ em todas as temperaturas a 100 e a $3.200 \mathrm{~Pa}$, sendo o material que menos enrijece após o envelhecimento a curto prazo. Em termos numéricos, os valores de $R_{J}$ estão entre 2 e 4 para o CAP 50/70 e entre 4 e 7 para o CAP+PPA e o CAP+Elvaloy+PPA em qualquer condição de temperatura e de tensão.

A Figura 32 ilustra os gráficos de $\mathrm{R}_{\mathrm{J}}$ com a temperatura para o CAP 50/70, o $\mathrm{CAP}+\mathrm{PPA}$ e o CAP+Elvaloy+PPA. As diferenças entre os valores de $\mathrm{R}_{\mathrm{J}}$ a 100 e a $3.200 \mathrm{~Pa}$ se mostram pequenas para a maioria dos ligantes asfálticos, o que indica que, em linhas 
gerais, o efeito do nível de tensão não é muito significativo na alteração da sensibilidade dos ligantes asfálticos ao envelhecimento a curto prazo, à luz dos resultados de compliância não-recuperável. No caso do CAP 50/70 e do CAP+PPA, o incremento do nível de tensão de 100 para 3.200 Pa acarreta um aumento dos valores de $R_{\jmath}$ nas temperaturas de até $64^{\circ} \mathrm{C}$ e uma redução deste parâmetro nas temperaturas de 70 e $76^{\circ} \mathrm{C}$. No caso do $\mathrm{CAP}+$ Elvaloy+PPA, este incremento da tensão ocasiona um aumento do parâmetro $R_{J}$ nas temperaturas de $58,64,70$ e $76^{\circ} \mathrm{C}$, de maneira mais significativa nas duas últimas. Estas análises permitem dizer que o nível de tensão atua de maneira diferente na sensibilidade dos ligantes asfálticos ao envelhecimento a curto prazo, sendo uma função de fatores como o tipo de modificador e a temperatura.

Tabela 16 - Relações entre as compliâncias não-recuperáveis $\left(R_{J}\right)$ do CAP 50/70, do CAP+PPA e do CAP+Elvaloy+PPA nos tempos de 1 e $9 \mathrm{~s}$

\begin{tabular}{ccccccccccc}
\hline Ligante & \multicolumn{4}{c}{$100 \mathrm{~Pa}$} & \multicolumn{5}{c}{$3.200 \mathrm{~Pa}$} \\
\cline { 2 - 12 } asfáltico & $52^{\circ} \mathrm{C}$ & $58^{\circ} \mathrm{C}$ & $64^{\circ} \mathrm{C}$ & $70^{\circ} \mathrm{C}$ & $76^{\circ} \mathrm{C}$ & $52^{\circ} \mathrm{C}$ & $58^{\circ} \mathrm{C}$ & $64{ }^{\circ} \mathrm{C}$ & $70^{\circ} \mathrm{C}$ & $76{ }^{\circ} \mathrm{C}$ \\
\hline $50 / 70$ & 3,2 & 3,0 & 2,8 & 2,6 & 2,5 & 3,3 & 3,1 & 2,8 & 2,6 & 2,4 \\
PPA & 6,0 & 6,3 & 5,9 & 5,7 & 5,2 & 6,7 & 6,8 & 6,2 & 5,3 & 4,5 \\
Elvaloy+PPA & 4,5 & 4,2 & 4,5 & 4,6 & 4,7 & 4,3 & 4,4 & 5,0 & 5,8 & 6,3 \\
\hline
\end{tabular}

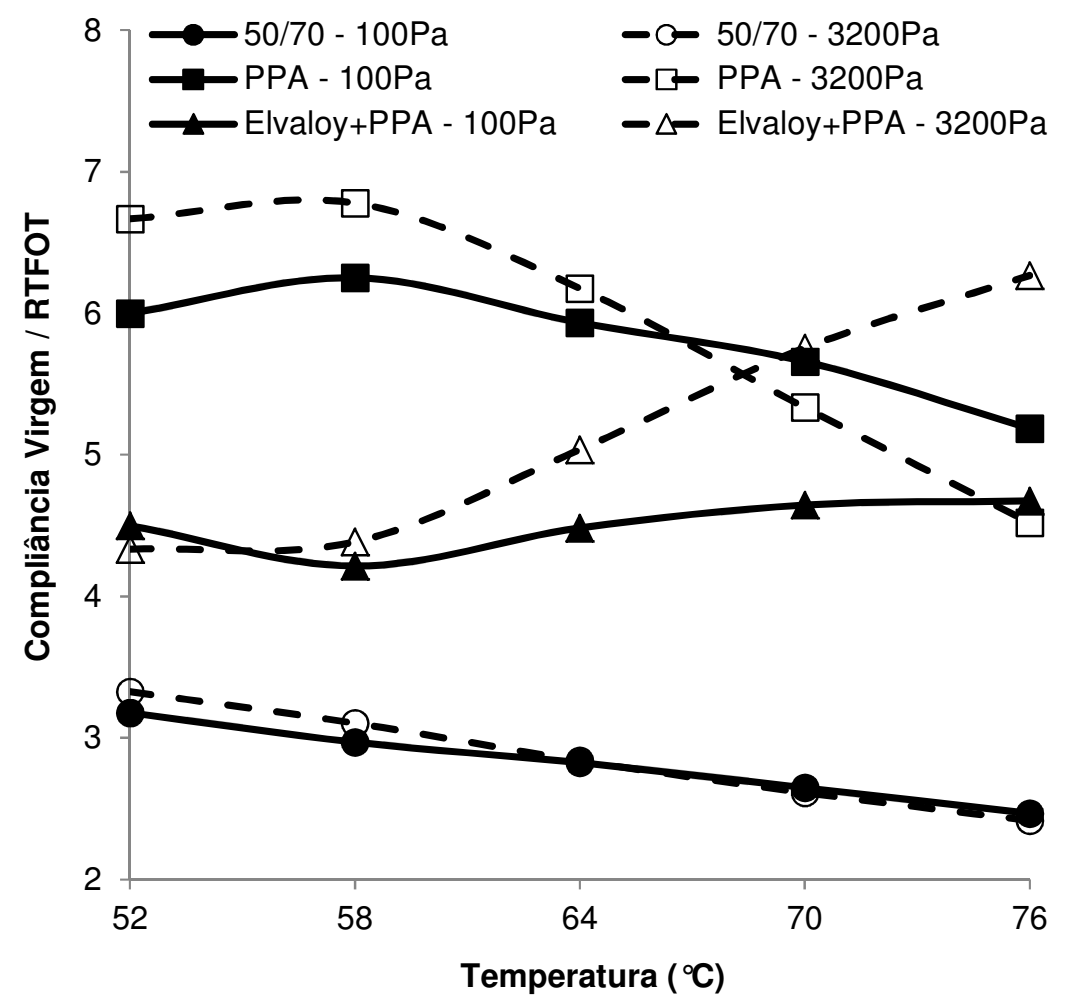

Figura 32 - Relações entre as compliâncias não-recuperáveis $\left(R_{J}\right)$ do CAP 50/70, do CAP+PPA e do CAP+Elvaloy+PPA nos tempos de 1 e $9 \mathrm{~s}$ 
A Tabela 17 mostra as relações entre os percentuais de recuperação $\left(R_{R}\right)$ para 0 CAP 50/70 e os materiais modificados com PPA e com Elvaloy+PPA, com a representação gráfica sendo mostrada na Figura 33 (página seguinte). Alguns valores não puderam ser calculados porque o percentual de recuperação do material é nulo na condição virgem e em certas condições de temperatura e de tensão. Em linhas gerais, os valores de $R_{R}$ variam com maior intensidade de um nível de tensão para outro em uma mesma temperatura e para um mesmo tipo de ligante asfáltico, indicando que o efeito do nível de tensão é significativo na alteração da sensibilidade do material ao envelhecimento a curto prazo, à luz dos resultados do percentual de recuperação. Dentre os materiais analisados, o CAP+Elvaloy+PPA apresenta os menores valores de $R_{R}$ (resultados entre 1 e 3) e, ao mesmo tempo, variações pequenas deste parâmetro com a temperatura em um mesmo nível de tensão. Chama a atenção a elevação significativa de $R_{R}$ para o CAP+PPA a $3.200 \mathrm{~Pa}$, em que os valores aumentaram de 2,3 para 42,9 com o incremento de 52 para $64^{\circ} \mathrm{C}$ na temperatura. Poucos resultados puderam ser calculados para o CAP 50/70, sendo apenas dois $(3,0$ e 7,2) na tensão de $100 \mathrm{~Pa}$ e nenhum na tensão de $3.200 \mathrm{~Pa}$.

Tabela 17 - Relações entre os percentuais de recuperação $\left(R_{R}\right)$ do CAP 50/70, do CAP+PPA e do CAP+Elvaloy+PPA nos tempos de 1 e $9 \mathrm{~s}$

\begin{tabular}{ccccccccccc}
\hline \multirow{2}{*}{$\begin{array}{c}\text { Ligante } \\
\text { asfáltico }\end{array}$} & \multicolumn{1}{c}{$100 \mathrm{~Pa}$} \\
\cline { 2 - 10 } & $52^{\circ} \mathrm{C}$ & $58^{\circ} \mathrm{C}$ & $64^{\circ} \mathrm{C}$ & $70^{\circ} \mathrm{C}$ & $76^{\circ} \mathrm{C}$ & $52^{\circ} \mathrm{C}$ & $58^{\circ} \mathrm{C}$ & $64^{\circ} \mathrm{C}$ & $70^{\circ} \mathrm{C}$ & $76^{\circ} \mathrm{C}$ \\
\hline $50 / 70$ & 3,0 & 7,2 & - & - & - & - & - & - & - & - \\
PPA & 1,8 & 2,3 & 3,0 & 4,5 & 9,1 & 2,3 & 4,2 & 42,9 & - & - \\
Elvaloy+PPA & 1,1 & 1,1 & 1,2 & 1,3 & 1,5 & 1,1 & 1,2 & 1,3 & 1,7 & 2,6 \\
\hline
\end{tabular}

Uma comparação dos resultados das Tabelas 16 e 17 e das Figuras 32 e 33 permite observar que, no nível de tensão de $100 \mathrm{~Pa}$, o CAP 50/70 possui os menores valores de $R_{J}$ e os maiores valores de $R_{R}$ em todas as temperaturas analisadas, indicando uma elevada sensibilidade do percentual de recuperação e uma baixa sensibilidade da compliância não-recuperável ao envelhecimento a curto prazo. Esta baixa sensibilidade de $\mathrm{J}_{\mathrm{nr}}$ é mantida a 3.200 Pa, indicando que o aumento do nível de tensão não alterou significativamente a sensibilidade do material puro ao envelhecimento a curto prazo. O CAP+Elvaloy+PPA apresenta os valores mais baixos de $R_{J}$ e de $R_{R}$ ao longo de todo o espectro de temperaturas dentre os ligantes asfálticos modificados, o que mostra que o incremento do percentual de recuperação e a redução na compliância não-recuperável após o RTFOT são menores neste material em comparação ao CAP+PPA. Com o aumento da tensão de 100 para $3.200 \mathrm{~Pa}$, o CAP+Elvaloy+PPA passa a apresentar os menores valores de $R_{J}$ apenas nas temperaturas de 52, 58 e $64^{\circ} \mathrm{C}$, mantendo, porém, os menores valores de $R_{R}$. Em linhas gerais, 0 
CAP+Elvaloy+PPA apresenta uma menor sensibilidade ao envelhecimento a curto prazo do que o CAP+PPA por conta das menores variações de suas propriedades na maioria das condições de temperatura e de tensão. Por outro lado, valores elevados de $R_{J}$ e de $R_{R}$ mostram que o envelhecimento a curto prazo reduziu a compliância não-recuperável e aumentou o percentual de recuperação de maneira significativa, o que é bom para a resistência à deformação permanente. Sob esta ótica, o CAP+PPA apresenta melhores resultados por conta do maior ganho de $\mathrm{R}$ e da maior redução de $\mathrm{J}_{\mathrm{nr}}$ após o envelhecimento a curto prazo em comparação ao CAP+Elvaloy+PPA.

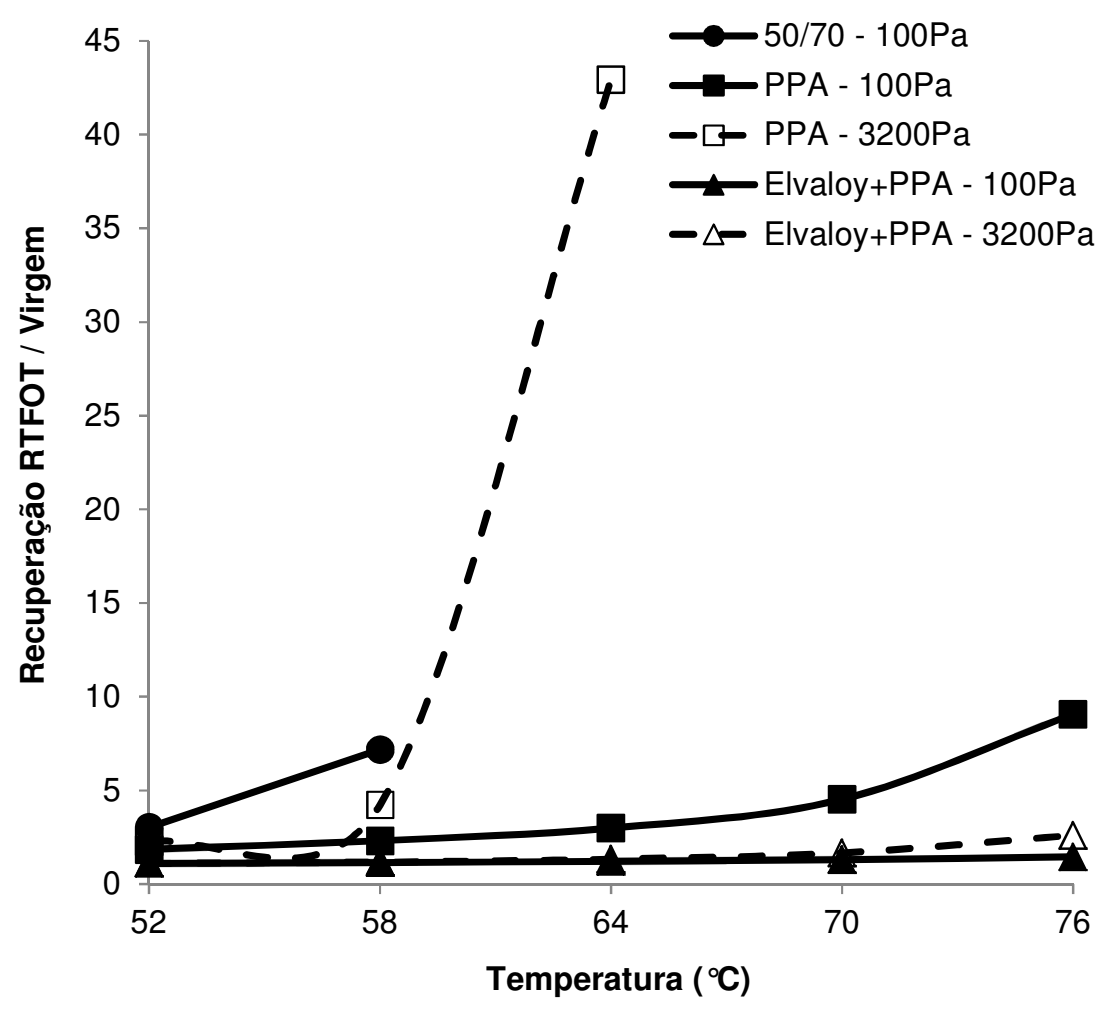

Figura 33 - Relações entre os percentuais de recuperação $\left(R_{R}\right)$ do CAP 50/70, do CAP+PPA e do CAP+Elvaloy+PPA nos tempos de 1 e $9 \mathrm{~s}$

A Tabela 18 apresenta as diferenças percentuais entre as compliâncias $\left(\mathrm{J}_{\mathrm{nr}, \mathrm{diff}}\right)$ do CAP 50/70 e dos materiais modificados com PPA e com Elvaloy+PPA, tanto na condição virgem quanto na envelhecida a curto prazo. Os ligantes asfálticos envelhecidos a curto prazo e ensaiados na temperatura do PG não apresentam resultados de $J_{n r, d i f f}$ superiores ao valor de 75\% estipulado pela norma AASHTO MP19, sendo que o CAP+PPA é o ligante asfáltico com valor de $J_{\text {nr,diff }}$ mais próximo deste percentual $(61,4 \%)$. A incorporação do PPA ao material puro acarreta um aumento do parâmetro $J_{n r, \text { dift }}$ na maioria das condições de envelhecimento e de temperatura, o que, em linhas gerais, indica uma maior sensibilidade ao incremento do nível de tensão de 100 para 3.200 Pa. Este cenário, entretanto, não é observado na maioria das 
temperaturas quando o ligante asfáltico puro recebe a adição de Elvaloy+PPA, uma vez que o CAP+Elvaloy+PPA apresenta os valores mais baixos de $J_{n r, d i f f}$ em quase todas as condições e, por consequência, uma sensibilidade menor ao aumento do nível de tensão. Os valores de $\mathrm{J}_{\text {nr,diff }}$ estão situados entre 6 e 16\% para o CAP 50/70 e entre 0 e 62\% para o CAP+PPA, sendo todos inferiores a $31 \%$ (em módulo) para o CAP+Elvaloy+PPA.

Tabela 18 - Diferenças percentuais entre as compliâncias não-recuperáveis $\left(\mathrm{J}_{\mathrm{nr}, \mathrm{diff}}\right)$ do CAP 50/70, do CAP+PPA e do CAP+Elvaloy+PPA nos tempos de 1 e $9 \mathrm{~s}$

\begin{tabular}{ccccccccccc}
\hline Ligante & \multicolumn{4}{c}{ Materiais virgens } & \multicolumn{4}{c}{ Materiais envelhecidos (RTFOT) } \\
\cline { 2 - 11 } asfáltico & $52^{\circ} \mathrm{C}$ & $58^{\circ} \mathrm{C}$ & $64^{\circ} \mathrm{C}$ & $70^{\circ} \mathrm{C}$ & $766^{\circ} \mathrm{C}$ & $52^{\circ} \mathrm{C}$ & $58^{\circ} \mathrm{C}$ & $64^{\circ} \mathrm{C}$ & $70^{\circ} \mathrm{C}$ & $76^{\circ} \mathrm{C}$ \\
\hline $50 / 70$ & 11,0 & 15,9 & 14,5 & 12,5 & 10,3 & 6,1 & 10,9 & 14,0 & 14,0 & 12,6 \\
PPA & 11,1 & 22,0 & 31,8 & 37,8 & 40,7 & 0,0 & 12,5 & 26,7 & 46,2 & 61,4 \\
Elvaloy+PPA & $-3,7$ & $-3,4$ & 4,6 & 13,9 & 30,1 & 0,0 & $-7,1$ & $-6,9$ & $-8,1$ & 3,0 \\
\hline
\end{tabular}

A Figura 34 ilustra os gráficos de $\mathrm{J}_{\mathrm{nr} \text {,diff }}$ com a temperatura para o CAP puro e os materiais modificados com PPA e com Elvaloy+PPA. O CAP+Elvaloy+PPA apresenta os valores mais baixos de $\mathrm{J}_{\mathrm{nr} \text {, diff }}$ nas temperaturas de até $64^{\circ} \mathrm{C}$ na condição virgem, bem como na maioria das temperaturas da condição envelhecida a curto prazo. O CAP+PPA possui os valores mais elevados de $J_{n r \text {,diff }}$ em todas as temperaturas da condição virgem e nas temperaturas de $58,64,70$ e $76^{\circ} \mathrm{C}$ da condição envelhecida. No caso do CAP+Elvaloy+PPA, observa-se que o envelhecimento a curto prazo proporciona uma redução do parâmetro $\mathrm{J}_{\mathrm{nr} \text {,diff }}$ nas temperaturas de $58,64,70$ e $76^{\circ} \mathrm{C}$, com maior intensidade nas duas últimas. Este envelhecimento, entretanto, atua de maneira diferente no CAP 50/70 e no CAP+PPA, para os quais há uma redução de $\mathrm{J}_{\text {nr,diff }}$ nas temperaturas de 52,58 e $64^{\circ} \mathrm{C}$ e um aumento de $J_{\text {nr,diff }}$ nas temperaturas de 70 e $76^{\circ} \mathrm{C}$ após o RTFOT. De uma maneira geral, pode-se dizer que o envelhecimento reduz a sensibilidade dos ligantes asfálticos ao aumento do nível de tensão de 100 para 3.200 Pa, com maior intensidade no caso do CAP+Elvaloy+PPA (redução de $\mathrm{J}_{\mathrm{nr} \text {, diff }}$ em quase todas as temperaturas) e com menor intensidade no caso do CAP 50/70 (variações pequenas de $\mathrm{J}_{\mathrm{nr} \text {,diff }}$ com o envelhecimento).

Em uma análise sintetizada dos resultados das Tabelas 12 a 18 e dos gráficos das Figuras 27 a 34, é possível observar que o CAP+Elvaloy+PPA apresenta os maiores percentuais de recuperação e as menores compliâncias não-recuperáveis em todas as temperaturas e níveis de tensão da condição virgem, o mesmo ocorrendo na condição envelhecida a curto prazo. Em outro extremo, o CAP 50/70 apresenta valores pequenos do percentual de recuperação e elevados de compliância não-recuperável para ambas as condições, o que indica a incapacidade deste material em atender, por si só, a condições 
severas de carregamento do tráfego. As análises dos resultados de $R_{J}$ e de $R_{R}$ mostram que, em linhas gerais, o CAP+Elvaloy+PPA possui uma sensibilidade menor ao envelhecimento a curto prazo do que o CAP+PPA devido às variações menores de suas propriedades na maioria das condições de temperatura e de tensão. Estas análises também mostram que a compliância não-recuperável do CAP 50/70 possui uma baixa sensibilidade ao envelhecimento a curto prazo, o mesmo não ocorrendo com o percentual de recuperação. Os resultados do parâmetro $J_{n r, d i f f}$ apontam que, de uma maneira geral, o CAP+Elvaloy+PPA possui a menor sensibilidade à tensão e que o CAP+PPA possui a maior, tanto na condição virgem quanto na envelhecida a curto prazo. O CAP+Elvaloy+PPA apresenta, em comparação ao CAP+PPA e ao CAP 50/70, uma maior redução da sensibilidade ao nível de tensão após o envelhecimento a curto prazo, com maior intensidade nas temperaturas de 70 e $76^{\circ} \mathrm{C}$.

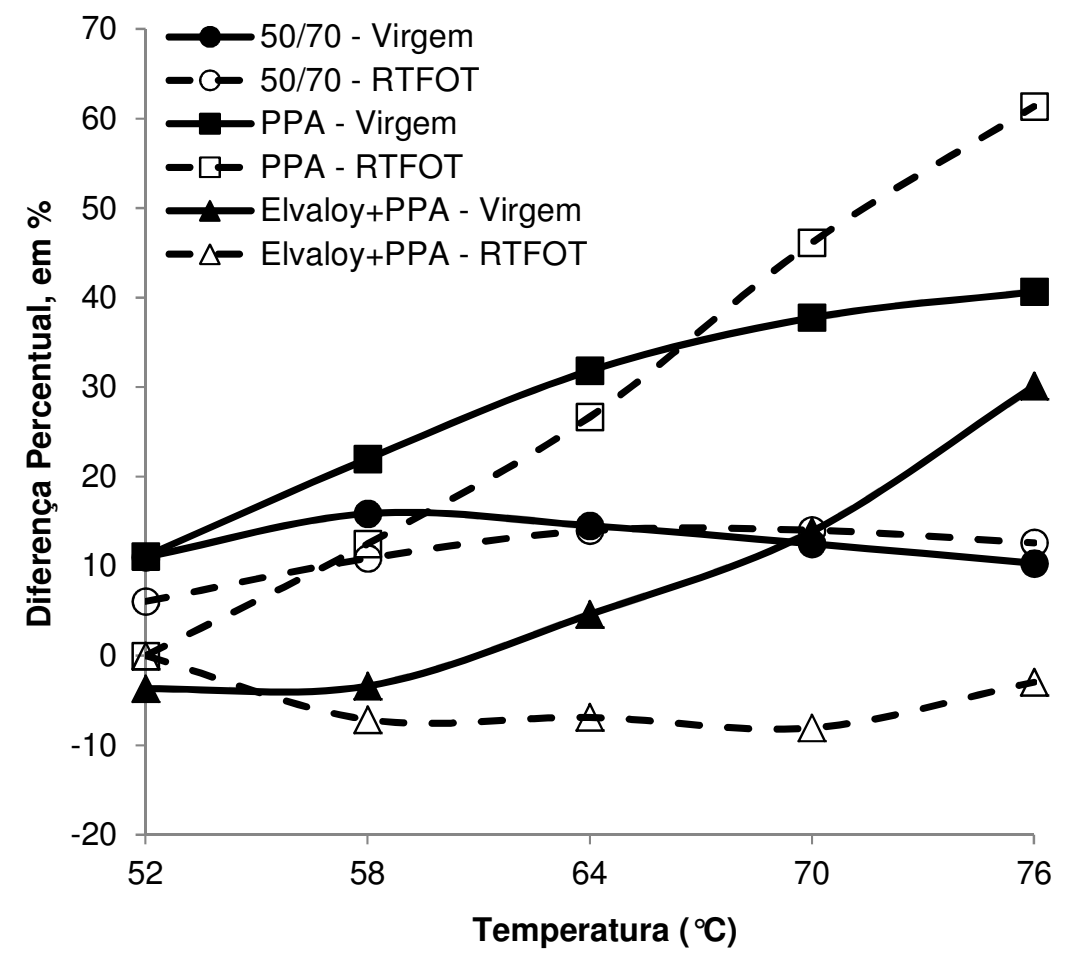

Figura 34 - Diferenças percentuais entre as compliâncias não-recuperáveis $\left(J_{\text {nr,diff }}\right)$ do CAP 50/70, do CAP+PPA e do CAP+Elvaloy+PPA nos tempos de 1 e $9 \mathrm{~s}$

\subsection{2. $C A P 50 / 70, C A P+P P A, C A P+$ borracha e $C A P+$ borracha+PPA}

A Tabela 19 apresenta os percentuais de recuperação do CAP 50/70 e dos ligantes asfálticos modificados com PPA, borracha e borracha+PPA, todos na condição virgem. A incorporação dos modificadores acarreta, em linhas gerais, um aumento do percentual de 
recuperação dos ligantes asfálticos, o que indica uma maior componente elástica da deformação total sofrida por estes materiais. O CAP+borracha+PPA possui os valores mais elevados de $\mathrm{R}$ ao longo de todo o espectro de temperaturas a $100 \mathrm{~Pa}$, o mesmo não sendo observado a 3.200 $\mathrm{Pa}$. Os valores de $\mathrm{R}$ para o CAP+borracha são ligeiramente menores que os encontrados no CAP+borracha+PPA e as diferenças entre os valores são menores a 100 do que a 3.200 Pa. O CAP+PPA possui, dentre os ligantes asfálticos modificados, os menores percentuais a $100 \mathrm{~Pa}$ e os maiores nas temperaturas de 52 e $58^{\circ} \mathrm{C}$ a $3.200 \mathrm{~Pa}$. Nenhum dos ligantes asfálticos deste grupo apresenta qualquer recuperação nas condições mais críticas de ensaio: temperaturas elevadas $\left(70\right.$ e $\left.76^{\circ} \mathrm{C}\right)$ e nível de tensão de $3.200 \mathrm{~Pa}$. Em termos do percentual de recuperação, pode-se dizer que o CAP+borracha+PPA possui os maiores resultados a $100 \mathrm{~Pa}$, sendo o que recupera mais neste nível de tensão. Da mesma maneira, o $\mathrm{CAP}+\mathrm{PPA}$ apresenta os maiores resultados nas temperaturas de 52 e $58^{\circ} \mathrm{C}$ a $3.200 \mathrm{~Pa}$, sendo o que recupera mais nestas condições.

Tabela 19 - Percentuais de recuperação $(\mathrm{R})$ do CAP 50/70, do CAP+PPA, do CAP+borracha e do CAP+borracha+PPA nos tempos de 1 e 9 s e na condição virgem

\begin{tabular}{ccccccccccc}
\hline \multirow{2}{*}{$\begin{array}{c}\text { Ligante } \\
\text { asfáltico }\end{array}$} & \multicolumn{4}{c}{$100 \mathrm{~Pa}(\mathrm{R} 100)$, em \% } & \multicolumn{3}{c}{$3.200 \mathrm{~Pa}(\mathrm{R} 3200)$, em \% } \\
\cline { 2 - 11 } & $52^{\circ} \mathrm{C}$ & $58^{\circ} \mathrm{C}$ & $64^{\circ} \mathrm{C}$ & $70^{\circ} \mathrm{C}$ & $76^{\circ} \mathrm{C}$ & $52^{\circ} \mathrm{C}$ & $58^{\circ} \mathrm{C}$ & $64^{\circ} \mathrm{C}$ & $70^{\circ} \mathrm{C}$ & $76^{\circ} \mathrm{C}$ \\
\hline $50 / 70$ & 4,1 & 0,8 & 0,0 & 0,0 & 0,0 & 0,0 & 0,0 & 0,0 & 0,0 & 0,0 \\
PPA & 34,4 & 23,9 & 14,9 & 7,5 & 2,6 & 27,7 & 11,8 & 0,7 & 0,0 & 0,0 \\
Borracha & 39,0 & 32,6 & 25,4 & 19,3 & 13,5 & 19,9 & 6,9 & 0,0 & 0,0 & 0,0 \\
Borracha+PPA & 43,9 & 35,6 & 27,1 & 20,0 & 14,8 & 24,7 & 10,0 & 1,4 & 0,0 & 0,0 \\
\hline
\end{tabular}

A Figura 35 mostra os gráficos do percentual de recuperação com a temperatura para o CAP 50/70, o CAP+PPA, o CAP+borracha e o CAP+borracha+PPA, todos na condição virgem. Os decréscimos nos valores de $R$ dos ligantes asfálticos modificados seguem uma tendência aproximadamente linear no nível de tensão de $100 \mathrm{~Pa}$, o mesmo não ocorrendo na tensão de $3.200 \mathrm{~Pa}$. Os percentuais de recuperação do CAP+borracha e do CAP+borracha+PPA são comparáveis na tensão de $100 \mathrm{~Pa}$ e nas temperaturas de 64, 70 e $76^{\circ} \mathrm{C}$, uma vez que as diferenças entre os resultados destes materiais são inferiores a $2 \%$ conforme Tabela 19. Um destaque especial pode ser dado à redução do percentual de recuperação a 3.200 Pa para os ligantes asfálticos modificados, a qual ocorre em um intervalo menor de temperaturas do que a verificada a $100 \mathrm{~Pa}$ : entre 52 e $64^{\circ} \mathrm{C}$ a $3.200 \mathrm{~Pa}$ e entre 52 e $76^{\circ} \mathrm{C}$ a $100 \mathrm{~Pa}$. Ou seja, o aumento da tensão ativa o comportamento viscoso a temperaturas mais baixas e, uma vez que o CAP 50/70 apresenta recuperação não-nula apenas nas temperaturas de 52 e $58^{\circ} \mathrm{C}$ a $100 \mathrm{~Pa}$, é necessária a adição de modificadores para se obterem percentuais de recuperação maiores. 


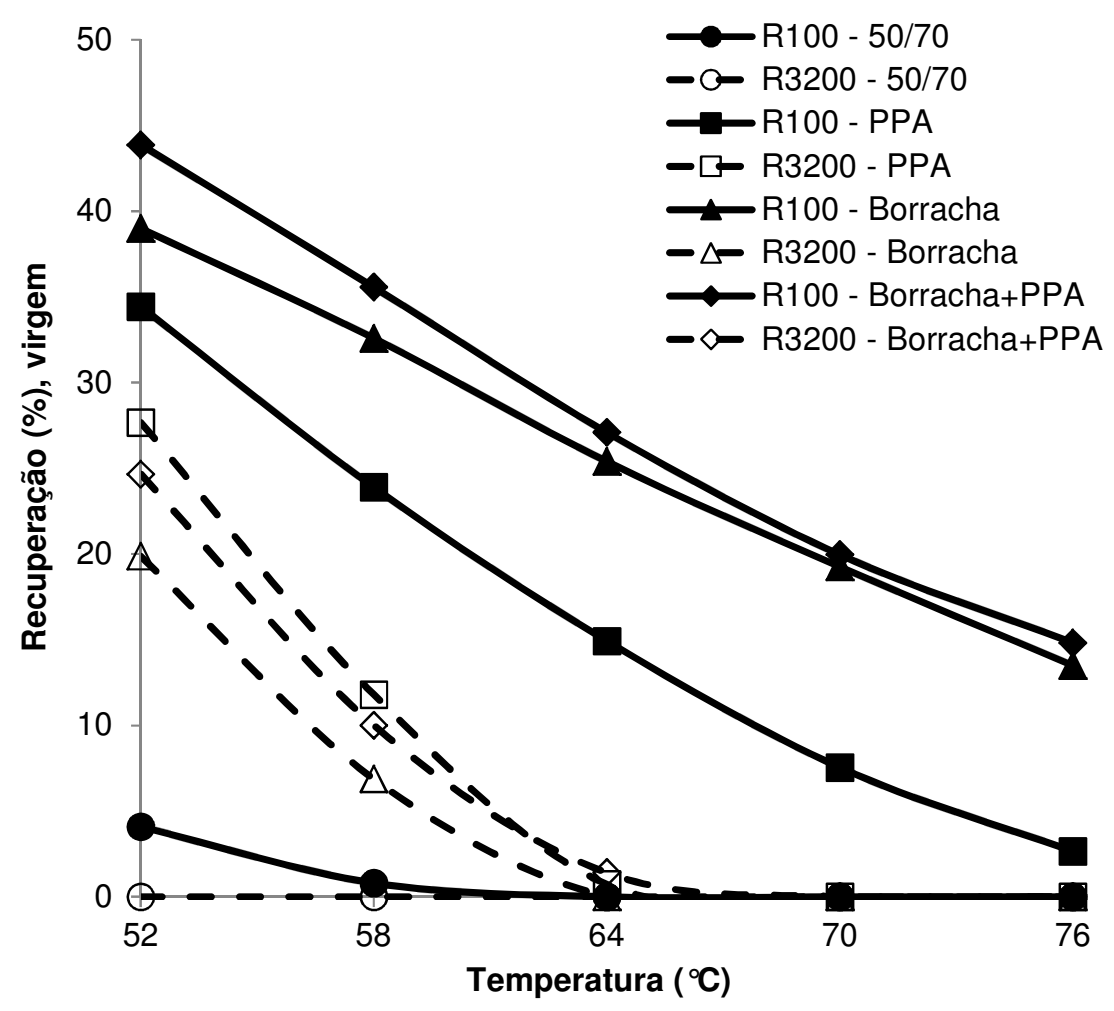

Figura 35 - Percentuais de recuperação $(R)$ do CAP 50/70, do CAP+PPA, do CAP+borracha e do CAP+borracha+PPA na condição virgem e nos tempos de 1 e $9 \mathrm{~s}$

A Tabela 20 apresenta as compliâncias não-recuperáveis do CAP 50/70 e dos ligantes asfálticos modificados com PPA, borracha e borracha+PPA, considerando apenas a condição virgem destes materiais. A incorporação dos modificadores ocasiona uma redução na compliância não-recuperável dos ligantes asfálticos. O CAP+PPA possui os valores mais baixos de $\mathrm{J}_{\mathrm{nr}}$ nas temperaturas de 52 e $58^{\circ} \mathrm{C}$ a $100 \mathrm{~Pa}$, bem como nas temperaturas de até $70^{\circ} \mathrm{C}$ a $3.200 \mathrm{~Pa}$. O CAP+borracha possui compliâncias não-recuperáveis maiores que as do CAP+borracha+PPA em todas as temperaturas e níveis de tensão, o que indica uma suscetibilidade maior da formulação sem PPA em deformar plasticamente. $O$ CAP+borracha+PPA apresenta os menores valores de $\mathrm{J}_{\text {nr }}$ nas temperaturas de 64,70 e $76^{\circ} \mathrm{C}$ a $100 \mathrm{~Pa}$, o mesmo ocorrendo na temperatura de $76^{\circ} \mathrm{C}$ a $3.200 \mathrm{~Pa}$. Em termos numéricos, as compliâncias não-recuperáveis dos ligantes asfálticos modificados estão situadas entre 0,1 e $11,4 \mathrm{kPa}^{-1}$ para qualquer condição de temperatura e nível de tensão, sendo que o CAP+borracha possui os resultados mais elevados a 100 e a $3.200 \mathrm{~Pa}$.

A Figura 36 ilustra os gráficos de $\mathrm{J}_{\mathrm{nr}}$ com a temperatura para o CAP+PPA, o $\mathrm{CAP}+$ borracha e o $\mathrm{CAP}+$ borracha+PPA, todos na condição virgem. Não são visualizadas distinções entre os modificadores nas temperaturas de 52 e $58^{\circ} \mathrm{C}$ a 100 e a 3.200 Pa porque as diferenças entre as compliâncias não-recuperáveis são pequenas, podendo ser 
consideradas equivalentes. Esta equivalência também é observada na temperatura de $64^{\circ} \mathrm{C}$ e a $100 \mathrm{~Pa}$, porém, com o aumento da tensão de 100 para 3.200 Pa, as distinções entre os valores de $\mathrm{J}_{\mathrm{nr}}$ são mais visíveis. O CAP+PPA e o CAP+borracha possuem compliâncias não-recuperáveis muito próximas entre si na temperatura de $70^{\circ} \mathrm{C}$ e a $100 \mathrm{~Pa}$ (valores de aproximadamente $3,3 \mathrm{kPa}^{-1}$ para ambos os materiais), porém superiores ao valor obtido para o CAP+borracha+PPA $\left(2,77 \mathrm{kPa}^{-1}\right)$. Um destaque especial pode ser dado ao CAP+PPA, o qual apresenta incrementos de $J_{n r}$ superiores aos do CAP+borracha+PPA nas temperaturas acima de $64^{\circ} \mathrm{C}$ tanto a 100 quanto a $3.200 \mathrm{~Pa}$.

Tabela 20 - Compliâncias não-recuperáveis $\left(\mathrm{J}_{\text {nr }}\right)$ do CAP 50/70, do CAP+PPA, do CAP+borracha e do CAP+borracha+PPA nos tempos de 1 e $9 \mathrm{~s}$ e na condição virgem

\begin{tabular}{ccccccccccc}
\hline \multirow{2}{*}{$\begin{array}{c}\text { Ligante } \\
\text { asfáltico }\end{array}$} & \multicolumn{3}{c}{$100 \mathrm{~Pa}\left(\mathrm{~J}_{\mathrm{nr}} 100\right), \mathrm{em} \mathrm{kPa}^{-1}$} & \multicolumn{5}{c}{$3.200 \mathrm{~Pa}\left(\mathrm{~J}_{\mathrm{nr}} 3200\right), \mathrm{em} \mathrm{kPa}^{-1}$} \\
\cline { 2 - 11 } & $52^{\circ} \mathrm{C}$ & $58^{\circ} \mathrm{C}$ & $64^{\circ} \mathrm{C}$ & $70^{\circ} \mathrm{C}$ & $76^{\circ} \mathrm{C}$ & $52^{\circ} \mathrm{C}$ & $58^{\circ} \mathrm{C}$ & $64^{\circ} \mathrm{C}$ & $70^{\circ} \mathrm{C}$ & $76{ }^{\circ} \mathrm{C}$ \\
\hline $50 / 70$ & 1,05 & 2,73 & 6,88 & 15,77 & 33,36 & 1,16 & 3,17 & 7,88 & 17,74 & 36,80 \\
PPA & 0,18 & 0,50 & 1,34 & 3,31 & 7,65 & 0,20 & 0,61 & 1,76 & 4,56 & 10,76 \\
Borracha & 0,25 & 0,64 & 1,52 & 3,33 & 6,77 & 0,35 & 0,99 & 2,45 & 5,49 & 11,38 \\
Borracha+PPA & 0,20 & 0,51 & 1,24 & 2,77 & 5,68 & 0,28 & 0,81 & 2,05 & 4,67 & 9,82 \\
\hline
\end{tabular}

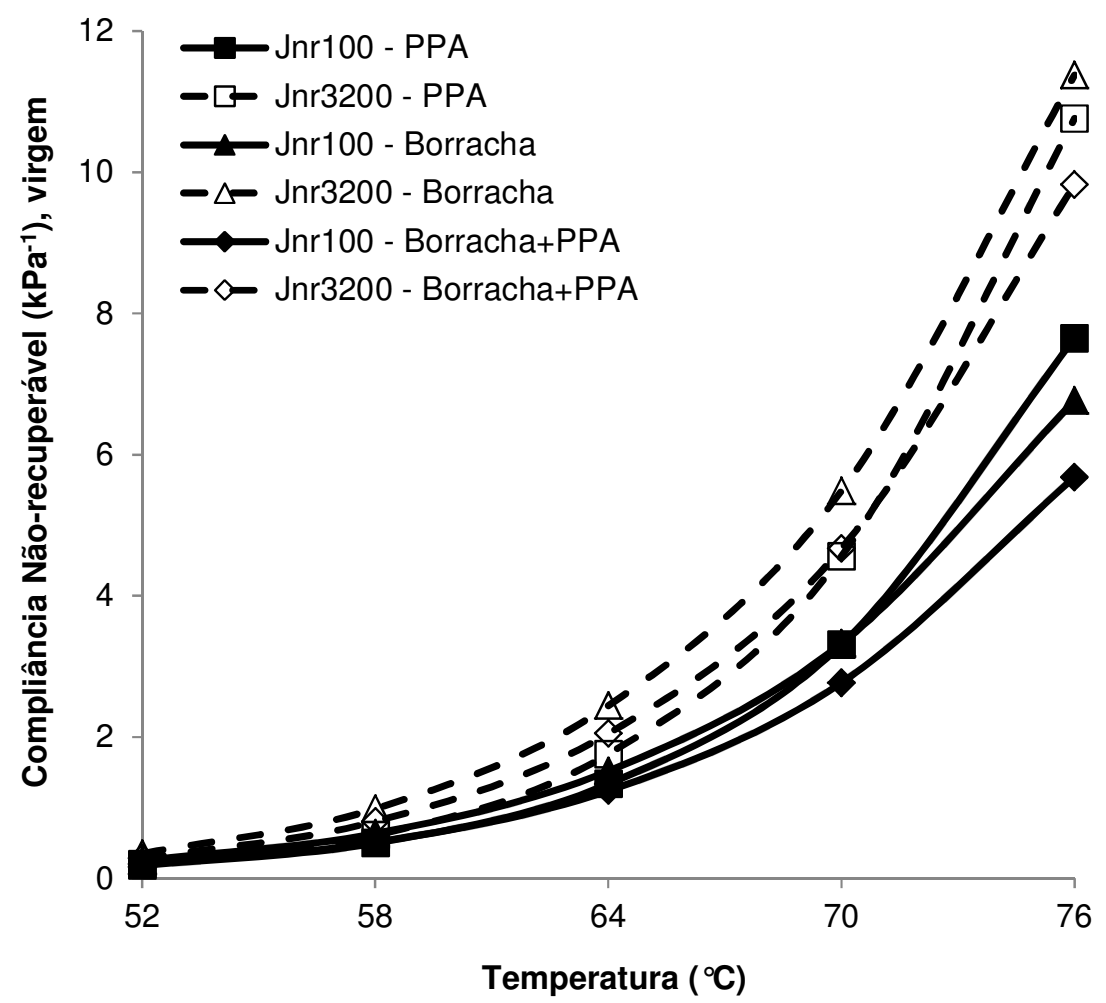

Figura 36 - Compliâncias não-recuperáveis $\left(\mathrm{J}_{n r}\right)$ do CAP 50/70, do CAP+PPA, do CAP+borracha e do CAP+borracha+PPA na condição virgem e nos tempos de 1 e $9 \mathrm{~s}$ 
Em uma análise dos resultados apresentados nas Tabelas 19 e 20 e nos gráficos das Figuras 35 e 36, referentes aos ligantes asfálticos virgens, visualiza-se que o CAP+borracha+PPA possui os maiores percentuais de recuperação em todo o espectro de temperaturas a $100 \mathrm{~Pa}$, bem como as menores compliâncias não-recuperáveis nas temperaturas de 64,70 e $76^{\circ} \mathrm{C}$ a $100 \mathrm{~Pa}$. O CAP+PPA possui os menores percentuais de recuperação em todo o espectro de temperaturas a 100 Pa e a maior compliância nãorecuperável na temperatura de $76^{\circ} \mathrm{C}$ a $100 \mathrm{~Pa}$. O CAP+borracha possui, dentre os materiais modificados, os menores valores de $R$ nas temperaturas de 52 e $58^{\circ} \mathrm{C}$ a $3.200 \mathrm{~Pa}$ e os maiores valores de $J_{n r}$ em todas as temperaturas a $3.200 \mathrm{~Pa}$, sendo que o CAP+PPA apresenta os maiores valores de $\mathrm{R}$ a 52 e $58^{\circ} \mathrm{C}$ a $3.200 \mathrm{~Pa}$ e o CAP+borracha+PPA possui o menor valor de $\mathrm{J}_{\mathrm{nr}}$ a $76^{\circ} \mathrm{C}$ e $3.200 \mathrm{~Pa}$.

A Tabela 21 mostra os percentuais de recuperação do CAP 50/70 e dos ligantes asfálticos modificados com PPA, borracha e borracha+PPA, todos na condição envelhecida a curto prazo. Em linhas gerais, o envelhecimento proporciona um aumento dos percentuais de recuperação dos ligantes asfálticos, sobretudo dos materiais modificados. O CAP+PPA apresenta os valores mais elevados de $\mathrm{R}$ (resultados de até $63 \%$ ) em todo o espectro de temperaturas a 3.200 Pa e o CAP+borracha, os mais elevados (resultados entre 34 e $64 \%$ ) em todas as temperaturas a $100 \mathrm{~Pa}$. À exceção do CAP 50/70, o qual apresenta percentuais de recuperação nulos ou baixos em qualquer condição de temperatura e nível de tensão, o CAP+borracha+PPA possui os valores mais baixos de $R$ (resultados entre 25 e 61\%) nas temperaturas de até $70^{\circ} \mathrm{C}$ a $100 \mathrm{~Pa}$ e o CAP+borracha possui estes valores mais baixos (resultados de até $54 \%$ ) nas temperaturas de até $64^{\circ} \mathrm{C}$ a $3.200 \mathrm{~Pa}$.

Tabela 21 - Percentuais de recuperação $(R)$ do CAP 50/70, do CAP+PPA, do CAP+borracha e do CAP+borracha+PPA nos tempos de 1 e 9 s e na condição envelhecida

\begin{tabular}{ccccccccccc}
\hline \multirow{2}{*}{$\begin{array}{c}\text { Ligante } \\
\text { asfáltico }\end{array}$} & \multicolumn{4}{c}{$100 \mathrm{~Pa}(\mathrm{R} 100), \mathrm{em} \%$} & \multicolumn{4}{c}{$3.200 \mathrm{~Pa}(\mathrm{R} 3200), \mathrm{em} \%$} \\
\cline { 2 - 11 } & $52^{\circ} \mathrm{C}$ & $58^{\circ} \mathrm{C}$ & $64^{\circ} \mathrm{C}$ & $70^{\circ} \mathrm{C}$ & $76^{\circ} \mathrm{C}$ & $52^{\circ} \mathrm{C}$ & $58^{\circ} \mathrm{C}$ & $64^{\circ} \mathrm{C}$ & $70^{\circ} \mathrm{C}$ & $76^{\circ} \mathrm{C}$ \\
\hline $50 / 70$ & 12,4 & 5,8 & 1,0 & 0,0 & 0,0 & 8,9 & 0,5 & 0,0 & 0,0 & 0,0 \\
PPA & 63,7 & 55,2 & 44,6 & 34,1 & 24,0 & 62,4 & 49,8 & 31,3 & 12,1 & 0,8 \\
Borracha & 64,0 & 57,9 & 50,1 & 41,1 & 34,7 & 53,2 & 37,4 & 19,8 & 7,5 & 0,8 \\
Borracha+PPA & 61,0 & 53,0 & 44,5 & 34,0 & 25,5 & 54,0 & 38,1 & 20,0 & 6,6 & 0,0 \\
\hline
\end{tabular}

A Figura 37 ilustra os gráficos do percentual de recuperação com a temperatura para o CAP 50/70, o CAP+PPA, o CAP+borracha e o CAP+borracha+PPA, todos na condição envelhecida a curto prazo. O ligante asfáltico puro possui recuperações muito inferiores às observadas nos materiais modificados, tanto a 100 quanto a 3.200 Pa. No nível de tensão de 
$100 \mathrm{~Pa}$, observa-se que o envelhecimento destaca a curva do CAP+borracha e faz com que os percentuais de recuperação do CAP+PPA e do CAP+borracha+PPA sejam muito próximos entre si, com diferenças pequenas entre os resultados dos dois materiais. No nível de tensão de 3.200 Pa, entretanto, o envelhecimento destaca a curva do CAP+PPA e faz com que as recuperações do CAP+borracha e do CAP+borracha+PPA sejam quase que coincidentes, com diferenças muito pequenas (inferiores a 3\% conforme Tabela 21 ) entre os resultados dos dois materiais. Do ponto de vista do percentual de recuperação, pode-se dizer que as formulações do CAP+PPA e do CAP+borracha+PPA são equivalentes no nível de tensão de $100 \mathrm{~Pa}$, o mesmo ocorrendo com as formulações do CAP+borracha e do CAP+borracha+PPA no nível de tensão de 3.200 Pa.

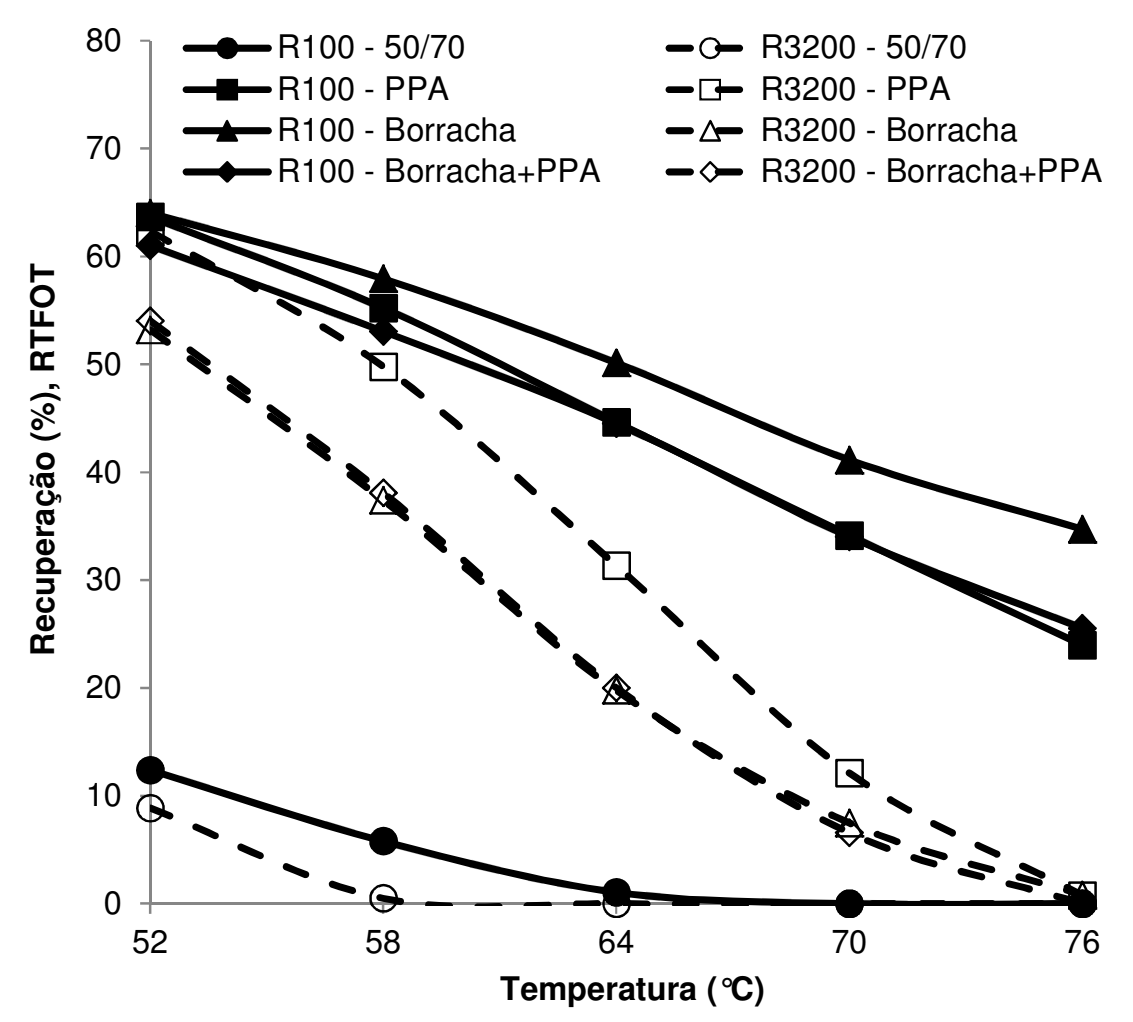

Figura 37 - Percentuais de recuperação (R) do CAP 50/70, do CAP+PPA, do CAP+borracha e do CAP+borracha+PPA na condição envelhecida e nos tempos de 1 e $9 \mathrm{~s}$

A Tabela 22 apresenta as compliâncias não-recuperáveis do CAP 50/70 e dos ligantes asfálticos modificados com PPA, borracha e borracha+PPA, todos na condição envelhecida a curto prazo. O envelhecimento proporciona uma diminuição da compliância não-recuperável dos ligantes asfálticos, o que indica menores suscetibilidades destes materiais à deformação permanente. À exceção do CAP 50/70, cujos valores de $\mathrm{J}_{\mathrm{nr}}$ superam os $6,0 \mathrm{kPa}^{-1}$ em determinadas condições de temperatura e tensão, o CAP+borracha+PPA possui os maiores valores desta propriedade (resultados entre 0,05 e 1,85 $\mathrm{kPa}^{-1}$ ) nas 
132

temperaturas de 64,70 e $76^{\circ} \mathrm{C}$ a $100 \mathrm{~Pa}$ e o CAP+borracha possui os maiores em todas as temperaturas a $3.200 \mathrm{~Pa}$ (resultados entre 0,07 e 3,40 $\mathrm{kPa}^{-1}$ ). O CAP+PPA apresenta as compliâncias mais baixas a 100 e a $3.200 \mathrm{~Pa}$, com valores de até $1,5 \mathrm{kPa}^{-1}$ a $100 \mathrm{~Pa}$ e de até 2,40 $\mathrm{kPa}^{-1}$ a $3.200 \mathrm{~Pa}$. Estes resultados permitem dizer que, em linhas gerais, $\mathrm{o}$ CAP+borracha+PPA possui a maior suscetibilidade à deformação permanente a $100 \mathrm{~Pa}$ e o CAP+borracha possui a maior suscetibilidade a $3.200 \mathrm{~Pa}$, sendo que o CAP+PPA possui a menor suscetibilidade em ambos os níveis de tensão.

Tabela 22 - Compliâncias não-recuperáveis $\left(\mathrm{J}_{n r}\right)$ do CAP 50/70, do CAP+PPA, do CAP+borracha e do CAP+borracha+PPA nos tempos de 1 e 9 s e na condição envelhecida

\begin{tabular}{ccccccccccc}
\hline \multirow{2}{*}{$\begin{array}{c}\text { Ligante } \\
\text { asfáltico }\end{array}$} & \multicolumn{4}{c}{$100 \mathrm{~Pa}\left(\mathrm{~J}_{\mathrm{nr}} 100\right), \mathrm{em} \mathrm{kPa}^{-1}$} & \multicolumn{4}{c}{$3.200 \mathrm{~Pa}\left(\mathrm{~J}_{\mathrm{nr}} 3200\right), \mathrm{em} \mathrm{kPa}^{-1}$} \\
\cline { 2 - 11 } & $52^{\circ} \mathrm{C}$ & $58^{\circ} \mathrm{C}$ & $64^{\circ} \mathrm{C}$ & $70^{\circ} \mathrm{C}$ & $76^{\circ} \mathrm{C}$ & $52^{\circ} \mathrm{C}$ & $58^{\circ} \mathrm{C}$ & $64^{\circ} \mathrm{C}$ & $70^{\circ} \mathrm{C}$ & $76^{\circ} \mathrm{C}$ \\
\hline $50 / 70$ & 0,33 & 0,92 & 2,44 & 5,96 & 13,53 & 0,35 & 1,02 & 2,78 & 6,79 & 15,23 \\
PPA & 0,03 & 0,08 & 0,23 & 0,59 & 1,48 & 0,03 & 0,09 & 0,29 & 0,86 & 2,38 \\
Borracha & 0,05 & 0,13 & 0,32 & 0,78 & 1,65 & 0,07 & 0,20 & 0,59 & 1,48 & 3,38 \\
Borracha+PPA & 0,05 & 0,13 & 0,33 & 0,81 & 1,83 & 0,06 & 0,18 & 0,53 & 1,39 & 3,30 \\
\hline
\end{tabular}

A Figura 38 ilustra os gráficos de $\mathrm{J}_{\mathrm{nr}}$ com a temperatura para o CAP+PPA, 0 CAP+borracha e o CAP+borracha+PPA, todos na condição envelhecida a curto prazo. Não são observadas distinções entre os modificadores nas temperaturas de 52 e $58^{\circ} \mathrm{C}$, tanto a 100 quanto a 3.200 Pa, uma vez que a faixa de variação das compliâncias não-recuperáveis é pequena $\left(0,03\right.$ a $0,20 \mathrm{kPa}^{-1}$ conforme Tabela 22) nestas condições de ensaio. As compliâncias não-recuperáveis do CAP+borracha e do CAP+borracha+PPA são próximas entre si ao longo de todo o espectro de temperaturas a 3.200 Pa, o mesmo ocorrendo nas temperaturas de até $70^{\circ} \mathrm{C}$ a $100 \mathrm{~Pa}$. O CAP+PPA apresenta, na tensão de $3.200 \mathrm{~Pa}$, valores de $\mathrm{J}_{\mathrm{nr}}$ comparáveis aos de todos os ligantes asfálticos modificados e submetidos à tensão de $100 \mathrm{~Pa}$, exceção feita à temperatura de $76^{\circ} \mathrm{C}$.

Em uma avaliação dos resultados apresentados nas Tabelas 21 e 22 e dos gráficos das Figuras 37 e 38, referentes aos ligantes asfálticos envelhecidos a curto prazo, visualiza-se que o CAP+borracha possui os maiores percentuais de recuperação e compliâncias não-recuperáveis próximas às do CAP+PPA e do CAP+borracha+PPA, considerando o nível de tensão de $100 \mathrm{~Pa}$. Para o nível de tensão de $3.200 \mathrm{~Pa}$, observa-se que o CAP+PPA possui os maiores percentuais de recuperação e as menores compliâncias não-recuperáveis em todo o espectro de temperaturas, sendo que o CAP+borracha e o CAP+borracha+PPA apresentam comportamentos muito parecidos em ambas as 
propriedades. De uma maneira geral, pode-se dizer que o CAP+borracha apresenta os melhores resultados a $100 \mathrm{~Pa}$ (maiores valores de $\mathrm{R}$ e valores de $\mathrm{J}_{\mathrm{nr}}$ comparáveis aos dos demais ligantes asfálticos modificados) e o CAP+PPA, os melhores resultados a $3.200 \mathrm{~Pa}$ (maiores valores de $\mathrm{R}$ e menores de $\mathrm{J}_{\mathrm{nr}}$ ).

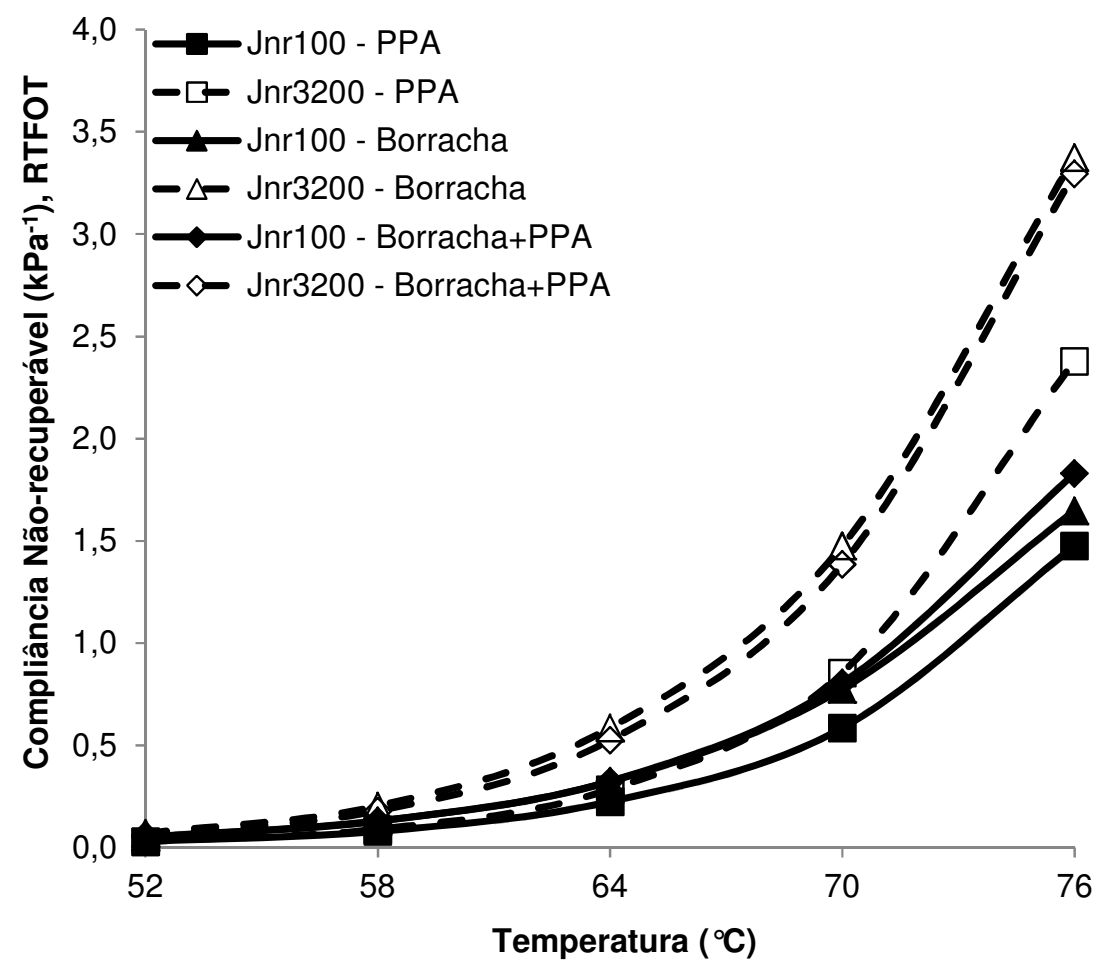

Figura 38 - Compliâncias não-recuperáveis $\left(\mathrm{J}_{n r}\right)$ do CAP+PPA, do CAP+borracha e do CAP+borracha+PPA na condição envelhecida e nos tempos de 1 e $9 \mathrm{~s}$

A Tabela 23 mostra as relações entre as compliâncias não-recuperáveis $\left(R_{J}\right)$ do CAP 50/70 e dos ligantes asfálticos modificados com PPA, borracha e borracha+PPA. Os valores de $R_{J}$ estão situados entre 2 e 7 para todos os ligantes asfálticos, o que indica que o envelhecimento a curto prazo proporciona uma redução entre 2 e 7 vezes nas compliâncias não-recuperáveis destes materiais. As diferenças entre os valores de $R_{J}$ a 100 e a $3.200 \mathrm{~Pa}$ se mostram pequenas para um mesmo tipo de ligante asfáltico e uma mesma temperatura, o que indica que o efeito do nível de tensão não é muito significativo na alteração da sensibilidade dos materiais ao RTFOT, à luz dos resultados de $\mathrm{J}_{n r}$. Como um exemplo, o valor de $\mathrm{R}_{\mathrm{J}}$ para o CAP+borracha é igual a 4,3 na temperatura de $70^{\circ} \mathrm{C}$ e a $100 \mathrm{~Pa}$, sendo igual a 3,7 para este mesmo tipo de ligante asfáltico e esta mesma temperatura a 3.200 Pa, uma diferença de 0,6. Exemplos similares podem ser observados para os outros ligantes asfálticos.

A Figura 39 mostra os gráficos de $R_{J}$ com a temperatura para o CAP 50/70, o $\mathrm{CAP}+\mathrm{PPA}$, o CAP+borracha e o CAP+borracha+PPA. O CAP+PPA apresenta os valores mais 
elevados de $R_{J}$ em todo o espectro de temperaturas a 100 e a $3.200 \mathrm{~Pa}$, sendo, portanto, o material que mais enrijece após o envelhecimento a curto prazo. $O$ material puro possui os valores mais baixos de $R_{J}$, sendo, portanto, o material que menos enrijece após o RTFOT. $O$ CAP+borracha é o segundo que mais enrijece, seguido pelo CAP+borracha+PPA. O incremento do nível de tensão de 100 para 3.200 Pa acarreta um aumento dos valores de $R_{J}$ nas temperaturas de até $64^{\circ} \mathrm{C}$ e um aumento nas temperaturas acima de $64^{\circ} \mathrm{C}$ no caso do CAP puro, do CAP+PPA e do CAP+borracha+PPA. Para o CAP+borracha, este incremento da tensão resulta em um aumento de $R_{J}$ na temperatura de $52^{\circ} \mathrm{C}$ e reduções nas demais temperaturas, com maior intensidade a 70 e a $76^{\circ} \mathrm{C}$.

Tabela 23 - Relações entre as compliâncias não-recuperáveis $\left(R_{J}\right)$ do CAP 50/70, do CAP+PPA, do CAP+borracha e do CAP+borracha+PPA nos tempos de 1 e $9 \mathrm{~s}$

\begin{tabular}{ccccccccccc}
\hline Ligante & \multicolumn{4}{c}{$100 \mathrm{~Pa}$} \\
\cline { 2 - 11 } asfáltico & $52^{\circ} \mathrm{C}$ & $58^{\circ} \mathrm{C}$ & $64^{\circ} \mathrm{C}$ & $70^{\circ} \mathrm{C}$ & $76{ }^{\circ} \mathrm{C}$ & $52^{\circ} \mathrm{C}$ & $58^{\circ} \mathrm{C}$ & $64^{\circ} \mathrm{C}$ & $70^{\circ} \mathrm{C}$ & $76^{\circ} \mathrm{C}$ \\
\hline $50 / 70$ & 3,2 & 3,0 & 2,8 & 2,6 & 2,5 & 3,3 & 3,1 & 2,8 & 2,6 & 2,4 \\
PPA & 6,0 & 6,3 & 5,9 & 5,7 & 5,2 & 6,7 & 6,8 & 6,2 & 5,3 & 4,5 \\
Borracha & 4,8 & 4,9 & 4,7 & 4,3 & 4,1 & 5,0 & 4,8 & 4,2 & 3,7 & 3,4 \\
Borracha+PPA & 4,0 & 3,9 & 3,8 & 3,4 & 3,1 & 4,7 & 4,5 & 3,9 & 3,4 & 3,0 \\
\hline
\end{tabular}

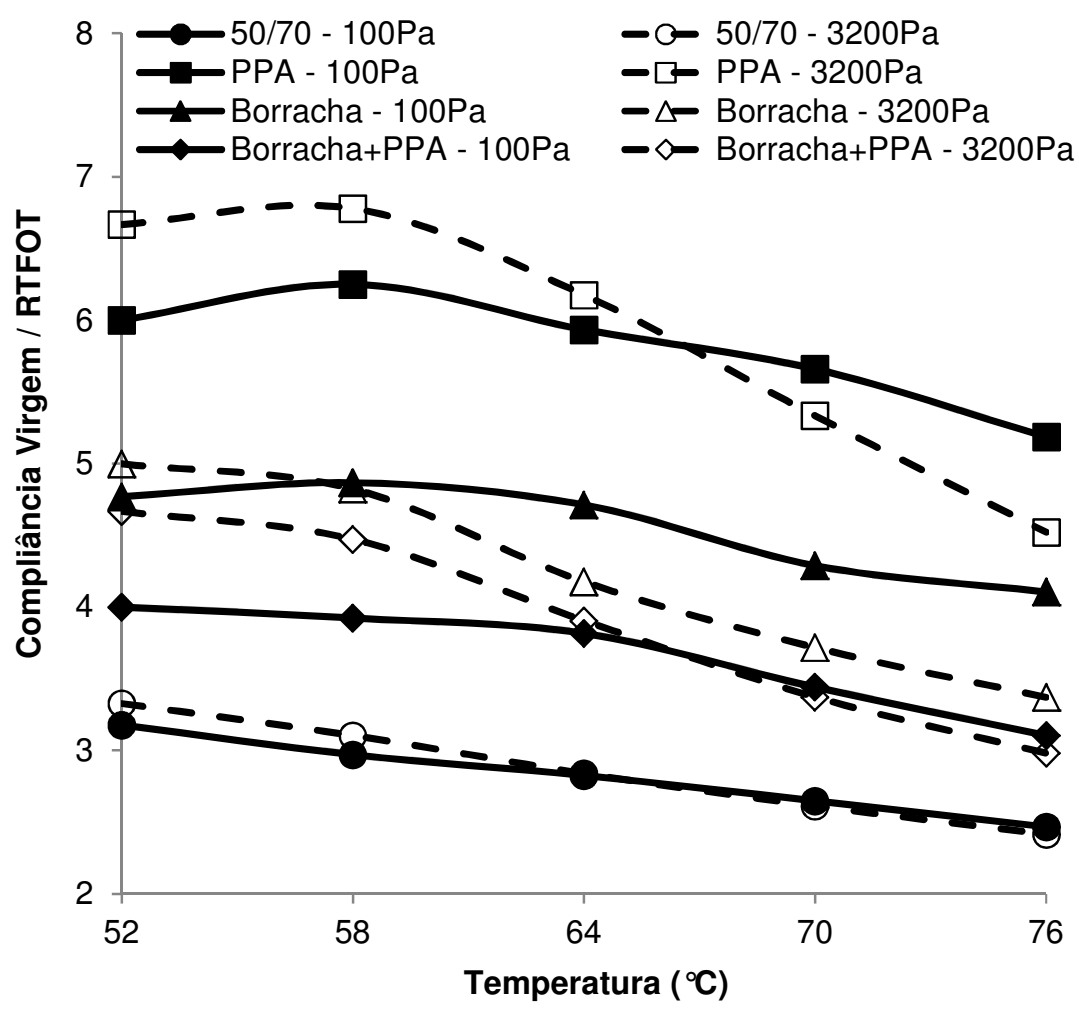

Figura 39 - Relações entre as compliâncias não-recuperáveis $\left(R_{J}\right)$ do CAP 50/70, do CAP+PPA, do CAP+borracha e do CAP+borracha+PPA nos tempos de 1 e $9 \mathrm{~s}$ 
A Tabela 24 apresenta as relações entre os percentuais de recuperação $\left(R_{R}\right)$ do CAP 50/70, do CAP+PPA, do CAP+borracha e do CAP+borracha+PPA, com a representação gráfica sendo mostrada na Figura 40 (página seguinte). Alguns valores de $R_{R}$ não puderam ser calculados porque o percentual de recuperação dos materiais virgens é nulo nestas condições de temperatura e de tensão. Em comparação aos resultados de $R_{J}$, as diferenças entre os valores de $R_{R}$ a 100 e a 3.200 Pa são mais significativas para um mesmo tipo de ligante asfáltico e uma mesma temperatura, indicando que o efeito do nível de tensão possui um impacto maior na alteração da sensibilidade dos materiais ao envelhecimento a curto prazo, à luz dos percentuais de recuperação. À exceção do CAP puro, o CAP+PPA apresenta os maiores ganhos de recuperação (maiores valores de $R_{R}$ ) em todo o espectro de temperaturas a $100 \mathrm{~Pa}$, seguido pelo CAP+borracha e depois pelo CAP+borracha+PPA. Chamam a atenção os incrementos elevados de R para o CAP+PPA e o CAP+borracha+PPA na temperatura de $64^{\circ} \mathrm{C}$ e a $3.200 \mathrm{~Pa}$, chegando a 43 vezes para o CAP+PPA e a 14 vezes para o CAP+borracha+PPA.

Tabela 24 - Relações entre os percentuais de recuperação $\left(R_{R}\right)$ do CAP 50/70, do $\mathrm{CAP}+\mathrm{PPA}$, do CAP+borracha e do CAP+borracha+PPA nos tempos de 1 e $9 \mathrm{~s}$

\begin{tabular}{ccccccccccc}
\hline Ligante & \multicolumn{9}{c}{$100 \mathrm{~Pa}$} \\
\cline { 2 - 11 } asfáltico & $52^{\circ} \mathrm{C}$ & $58^{\circ} \mathrm{C}$ & $64^{\circ} \mathrm{C}$ & $70^{\circ} \mathrm{C}$ & $76^{\circ} \mathrm{C}$ & $52^{\circ} \mathrm{C}$ & $58^{\circ} \mathrm{C}$ & $64^{\circ} \mathrm{C}$ & $70^{\circ} \mathrm{C}$ & $76^{\circ} \mathrm{C}$ \\
\hline $50 / 70$ & 3,0 & 7,2 & - & - & - & - & - & - & - & - \\
PPA & 1,8 & 2,3 & 3,0 & 4,5 & 9,1 & 2,3 & 4,2 & 42,9 & - & - \\
Borracha & 1,6 & 1,8 & 2,0 & 2,1 & 2,6 & 2,7 & 5,4 & - & - & - \\
Borracha+PPA & 1,4 & 1,5 & 1,6 & 1,7 & 1,7 & 2,2 & 3,8 & 14,2 & - & - \\
\hline
\end{tabular}

Em uma análise dos resultados das Tabelas 24 e 25 e dos gráficos das Figuras 39 e 40 para os ligantes asfálticos modificados, observa-se que o CAP+PPA possui os valores mais elevados de $R_{J}$ e de $R_{R}$ ao longo de todo o espectro de temperaturas a $100 \mathrm{~Pa}$, sendo que o CAP+borracha+PPA possui os valores mais baixos para ambos os parâmetros em todas as temperaturas a $100 \mathrm{~Pa}$. O aumento da tensão de 100 para $3.200 \mathrm{~Pa}$ não acarreta alterações no quadro das reduções de $J_{n r}$ após o envelhecimento a curto prazo, ou seja, o CAP+PPA mantém os maiores valores de $R_{\jmath}$ em todas as temperaturas a $3.200 \mathrm{~Pa}$ e o CAP+borracha+PPA mantém os menores valores. Com relação ao percentual de recuperação, o CAP+PPA apresenta um incremento significativo de $\mathrm{R}$ na temperatura de $64^{\circ} \mathrm{C}$ e a $3.200 \mathrm{~Pa}$ (42,9 vezes), o mesmo ocorrendo com o CAP+borracha+PPA (14,2 vezes). Em linhas gerais, pode-se dizer que o CAP+PPA possui a maior sensibilidade ao envelhecimento a curto prazo e que o CAP+borracha+PPA possui a menor sensibilidade, levando-se em consideração as maiores ou menores variações de $R$ e de $J_{n r}$ após o RTFOT. Por outro lado, 
valores elevados de $R_{J}$ e de $R_{R}$ indicam que o envelhecimento a curto prazo aumentou o percentual de recuperação e reduziu a compliância não-recuperável de maneira acentuada, o que é bom para a resistência à deformação permanente. Deste ponto de vista, o CAP+PPA apresenta melhores resultados do que o CAP+borracha e o CAP+borracha+PPA por conta do maior ganho de $\mathrm{R}$ e da maior redução de $\mathrm{J}_{\mathrm{nr}}$ após o envelhecimento a curto prazo.

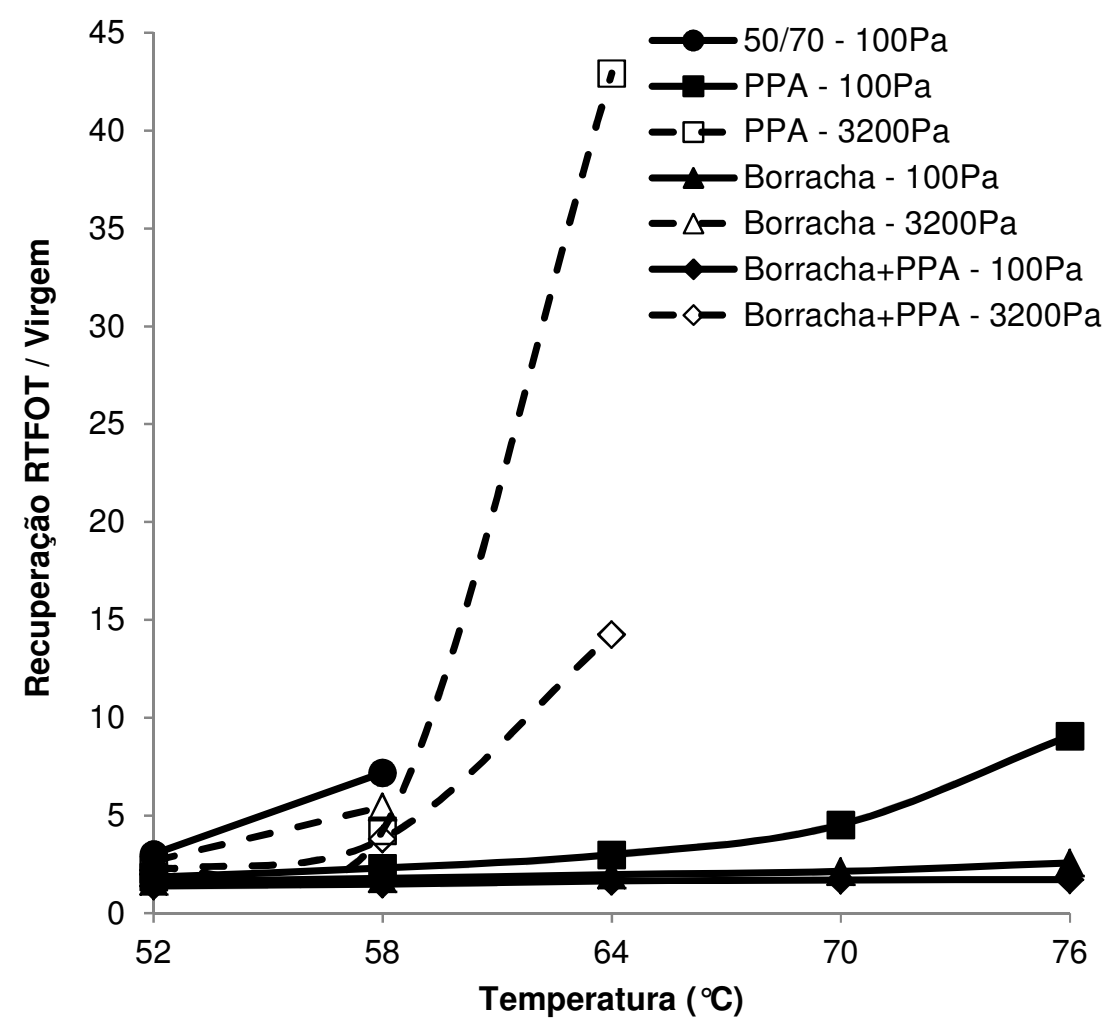

Figura 40 - Relações entre os percentuais de recuperação $\left(R_{R}\right)$ CAP 50/70, do CAP+PPA, do CAP+borracha e do CAP+borracha+PPA nos tempos de 1 e $9 \mathrm{~s}$

A Tabela 25 mostra as diferenças percentuais entre as compliâncias $\left(J_{n r, d i f f}\right)$ do CAP puro e dos ligantes asfálticos modificados com PPA, borracha e borracha+PPA, tanto na condição virgem quanto na envelhecida a curto prazo. De uma maneira geral, a incorporação dos modificadores ao CAP 50/70 resulta em um aumento de $J_{\text {nr,diff, }}$ o que indica um aumento da sensibilidade dos ligantes asfálticos à tensão. O CAP puro apresenta uma baixa sensibilidade à tensão para ambas as condições, com valores de $J_{n r \text {,diff }}$ inferiores a $15 \%$ na condição virgem e de no máximo $14 \%$ na envelhecida a curto prazo. As duas formulações com borracha moída possuem, na temperatura de $76{ }^{\circ} \mathrm{C}$ a $3.200 \mathrm{~Pa}$ e na condição envelhecida a curto prazo, resultados de $J_{n r \text {,diff }}$ superiores ao valor de $75 \%$ estipulado pela AASHTO MP19, o que pode ser interpretado como uma sensibilidade excessiva destes materiais ao aumento do nível de tensão de 100 para 3.200 Pa. Dentre os ligantes asfálticos modificados, o CAP+PPA apresenta as menores diferenças percentuais 
em todo o espectro de temperaturas e em ambas as condições, com resultados numéricos de até $62 \%$. As maiores diferenças percentuais são encontradas no CAP+borracha+PPA em quase todas as temperaturas da condição virgem (resultados entre 40 e 73\%), sendo que o CAP+borracha apresenta estes maiores valores ao longo de todo o espectro de temperaturas da condição envelhecida (resultados entre 33 e 105\%). De uma maneira geral, pode-se dizer que o CAP+PPA possui a menor sensibilidade à tensão dentre os materiais modificados e que as maiores sensibilidades são encontradas no CAP+borracha na condição envelhecida e no CAP+borracha+PPA na condição virgem.

Tabela 25 - Diferenças percentuais entre as compliâncias não-recuperáveis $\left(J_{n r, d i f f}\right)$ do CAP 50/70, do CAP+PPA, do CAP+borracha e do CAP+borracha+PPA nos tempos de 1 e $9 \mathrm{~s}$

\begin{tabular}{ccccccccccc}
\hline \multirow{2}{*}{$\begin{array}{c}\text { Ligante } \\
\text { asfáltico }\end{array}$} & \multicolumn{4}{c}{ Materiais virgens } & \multicolumn{4}{c}{ Materiais envelhecidos (RTFOT) } \\
\cline { 2 - 10 } & $52^{\circ} \mathrm{C}$ & $58^{\circ} \mathrm{C}$ & $64^{\circ} \mathrm{C}$ & $70^{\circ} \mathrm{C}$ & $76^{\circ} \mathrm{C}$ & $52^{\circ} \mathrm{C}$ & $58^{\circ} \mathrm{C}$ & $64^{\circ} \mathrm{C}$ & $70^{\circ} \mathrm{C}$ & $76^{\circ} \mathrm{C}$ \\
\hline $50 / 70$ & 11,0 & 15,9 & 14,5 & 12,5 & 10,3 & 6,1 & 10,9 & 14,0 & 14,0 & 12,6 \\
PPA & 11,1 & 22,0 & 31,8 & 37,8 & 40,7 & 0,0 & 12,5 & 26,7 & 46,2 & 61,4 \\
Borracha & 40,0 & 55,1 & 60,9 & 65,0 & 68,1 & 33,6 & 56,5 & 81,5 & 90,3 & 104,8 \\
Borracha+PPA & 40,0 & 57,8 & 65,3 & 68,6 & 72,9 & 20,0 & 38,5 & 61,5 & 72,0 & 80,1 \\
\hline
\end{tabular}

A Figura 41 ilustra os gráficos de $\mathrm{J}_{\mathrm{nr} \text {, diff }}$ com a temperatura para o CAP puro e os materiais modificados com PPA, borracha e borracha+PPA, tanto na condição virgem quanto na envelhecida a curto prazo. O envelhecimento na estufa de filme fino rotativo acarreta uma redução do parâmetro $J_{\text {nr,diff }}$ nas temperaturas mais baixas $\left(52,58\right.$ e $\left.64^{\circ} \mathrm{C}\right)$ e um aumento nas mais altas $\left(70\right.$ e $\left.76^{\circ} \mathrm{C}\right)$ no caso do CAP 50/70 e dos ligantes asfálticos modificados com PPA e borracha+PPA. Situação diferente ocorre com o CAP+borracha, para o qual o envelhecimento ocasiona uma redução de $J_{n r \text {,diff }}$ na temperatura de $52^{\circ} \mathrm{C}$ e um aumento nas demais temperaturas, com maior intensidade a 70 e a $76^{\circ} \mathrm{C}$. As variações entre as diferenças percentuais do material puro são pequenas em comparação aos resultados dos materiais modificados, o que permite dizer que a sensibilidade do CAP 50/70 ao nível de tensão foi pouco afetada pelo envelhecimento. O CAP+borracha e o CAP+borracha+PPA apresentam as maiores diferenças percentuais em qualquer situação, sendo que os maiores resultados pertencem ao CAP+borracha+PPA na condição virgem e ao CAP+borracha na condição envelhecida a curto prazo. É possível observar que o envelhecimento prejudica a sensibilidade do CAP+borracha à tensão na medida em que aumenta os valores de $J_{n r \text {,diff }}$ para este material modificado em quase todas as temperaturas, ao mesmo tempo em que beneficia as sensibilidades do CAP 50/70, do CAP+PPA e do CAP+borracha+PPA nas temperaturas de até $64^{\circ} \mathrm{C}$ por conta da redução de $J_{\text {nr,diff }}$ para estes materiais. 


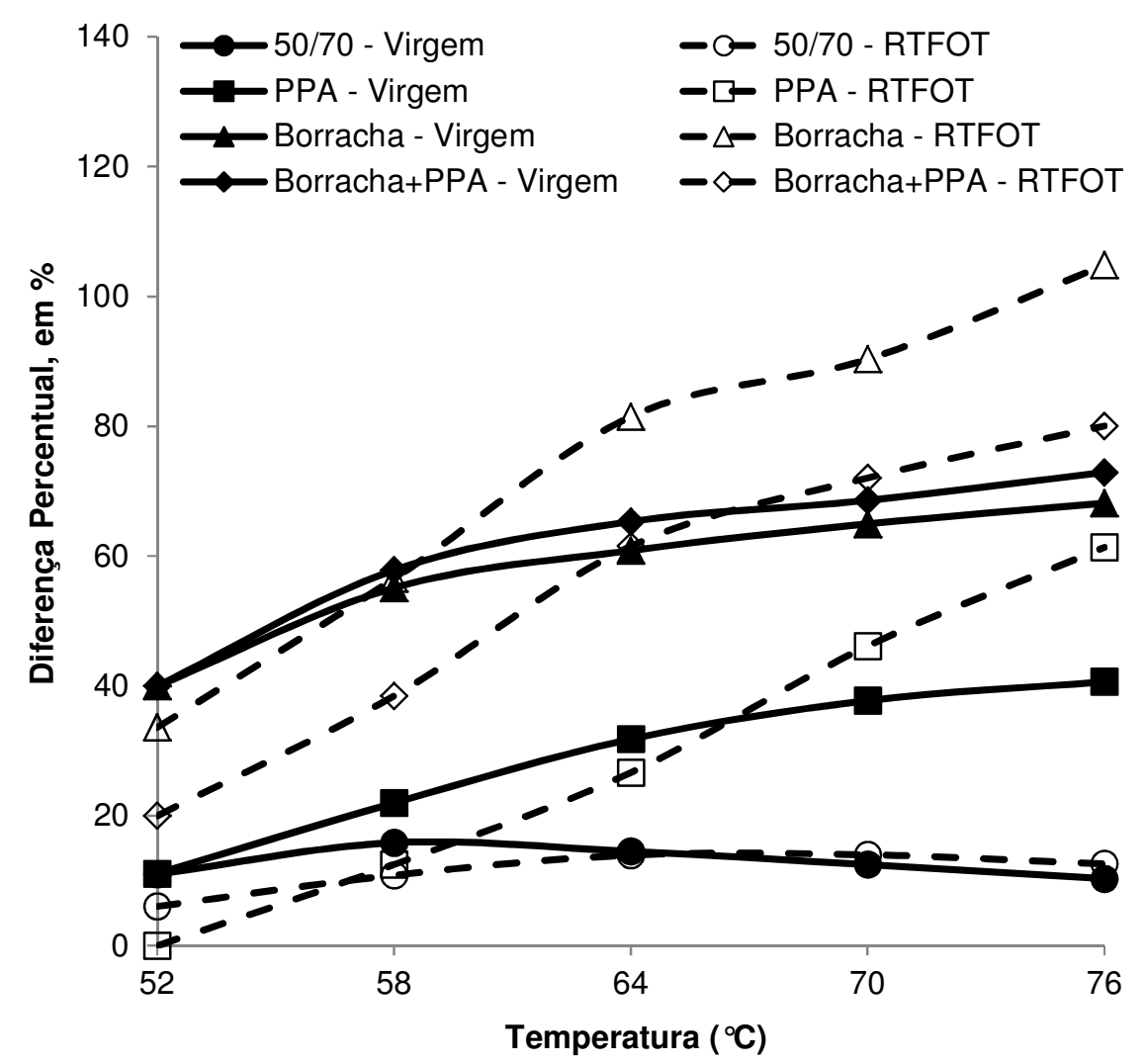

Figura 41 - Diferenças percentuais entre as compliâncias não-recuperáveis $\left(J_{n r, d i f f}\right)$ do CAP 50/70, do CAP+PPA, do CAP+borracha e do CAP+borracha+PPA nos tempos de 1 e $9 \mathrm{~s}$

Uma análise sintetizada dos resultados das Tabelas 19 a 25 e dos gráficos das Figuras 35 a 41 permite observar que o CAP+borracha+PPA possui, na condição virgem e a $100 \mathrm{~Pa}$, as maiores recuperações elásticas em todo o espectro de temperaturas e as menores compliâncias não-recuperáveis nas temperaturas de 64,70 e $76^{\circ} \mathrm{C}$. Nesta mesma condição, observa-se também que o CAP+borracha possui os menores valores de $\mathrm{R}$ nas temperaturas de 52 e $58^{\circ} \mathrm{C}$ e os maiores valores de $\mathrm{J}_{\mathrm{nr}}$ em todas as temperaturas a $3.200 \mathrm{~Pa}$, com o CAP+PPA apresentando os menores valores de $\mathrm{R}$ ao longo de todo o espectro de temperaturas a $100 \mathrm{~Pa} \mathrm{e}$ os maiores nas temperaturas de 52 e $58^{\circ} \mathrm{C}$ a $3.200 \mathrm{~Pa}$. O CAP+borracha passa a apresentar os maiores percentuais de recuperação a $100 \mathrm{~Pa}$ após o RTFOT, além de compliâncias nãorecuperáveis próximas às do $\mathrm{CAP}+\mathrm{PPA}$ e do $\mathrm{CAP}+$ borracha+PPA. O envelhecimento também faz com que o CAP+PPA apresente os maiores valores de $R$ e os menores de $J_{n r}$ a 3.200 Pa, ambos ao longo de todo o espectro de temperaturas. A avaliação da sensibilidade dos materiais modificados ao RTFOT aponta que os maiores e menores resultados de $R_{J}$ e de $R_{R}$ a $100 \mathrm{~Pa}$ são encontrados respectivamente no CAP+PPA e no CAP+borracha+PPA, com estes dois materiais possuindo também incrementos significativos de $\mathrm{R}$ a $64^{\circ} \mathrm{C}$ e a $3.200 \mathrm{~Pa}$. A avaliação da sensibilidade dos materiais modificados à tensão mostra que o CAP+PPA apresenta a menor 
sensibilidade em todas as temperaturas e nas duas condições de envelhecimento, sendo que o CAP+borracha+PPA possui a maior sensibilidade em quase todas as temperaturas da condição virgem e o CAP+borracha, a maior em todas as temperaturas da condição envelhecida.

Em uma comparação das duas formulações contendo borracha moída de pneus, observa-se que o CAP+borracha apresenta recuperações menores e compliâncias não-recuperáveis maiores quando na condição virgem, ambos ao longo de todo o espectro de temperaturas a 100 e a $3.200 \mathrm{~Pa}$. Com o envelhecimento a curto prazo, o CAP+borracha+PPA passa a apresentar os menores percentuais de recuperação e as maiores compliâncias não-recuperáveis a $100 \mathrm{~Pa}$, o contrário ocorrendo nas temperaturas de 52 e $58^{\circ} \mathrm{C}$ a $3.200 \mathrm{~Pa}$. A avaliação da sensibilidade dos dois materiais ao envelhecimento aponta que o CAP+borracha possui uma sensibilidade mais elevada do que o CAP+borracha+PPA por conta dos seus valores mais elevados de $R_{J}$ e de $R_{R}$ em todas as condições de temperatura e tensão, embora estes ganhos de $\mathrm{R}$ e estas reduções de $J_{n r}$ sejam favoráveis ao CAP+borracha no que diz respeito à resistência à deformação permanente. A avaliação da sensibilidade ao nível de tensão mostra que as duas formulações com borracha moída possuem uma sensibilidade elevada $\left(\mathrm{J}_{\mathrm{nr} \text {,diff }}>75 \%\right)$ na temperatura de $76{ }^{\circ} \mathrm{C}$ a 3.200 Pa após o envelhecimento, o que não é desejável do ponto de vista de mudanças repentinas no nível de tensão tais como carregamentos e temperaturas elevados não previstos incialmente. Em termos numéricos, o CAP+borracha+PPA possui uma maior sensibilidade à tensão do que o CAP+borracha na condição virgem, o contrário sendo observado na condição envelhecida a curto prazo.

\subsection{3. $C A P$ 50/70, $C A P+P P A, C A P+S B S$ e $C A P+S B S+P P A$}

A Tabela 26 apresenta os percentuais de recuperação do CAP 50/70 e dos ligantes asfálticos modificados com PPA, SBS e SBS+PPA, para materiais na condição virgem. A incorporação dos modificadores ao CAP 50/70 acarreta, em linhas gerais, um aumento do percentual de recuperação do material, especialmente nas temperaturas de até $64^{\circ} \mathrm{C}$. O CAP $50 / 70$ possui recuperações muito pequenas (até $4 \%$ ) em qualquer condição, mesmo nas temperaturas e níveis de tensão mais baixos. O CAP+SBS possui os maiores valores não-nulos de $R$ ao longo de todo o espectro de temperaturas a 100 e a $3.200 \mathrm{~Pa}$, sendo o que recupera mais nestas condições. O CAP+SBS+PPA possui, dentre os materiais modificados, os resultados mais baixos para esta propriedade em quase todas as condições de temperatura e tensão, sendo o que recupera menos nestas condições. Não são 
observadas recuperações nas temperaturas de 70 e $76^{\circ} \mathrm{C}$ a $3.200 \mathrm{~Pa}$, o que indica uma incapacidade dos materiais em recuperar parte da deformação total sofrida durante os ciclos de carregamento e de repouso nas situações mais críticas de ensaio. O CAP+PPA possui valores de $\mathrm{R}$ mais próximos aos do CAP+SBS, tanto a 100 quanto a $3.200 \mathrm{~Pa}$. Em termos numéricos, os percentuais de recuperação do CAP+SBS estão entre 3 e $36 \%$ a 100 Pa e atingem um máximo de $29 \%$ a $3.200 \mathrm{~Pa}$. No caso do CAP+SBS+PPA, estes valores são de no máximo 30\% a $100 \mathrm{~Pa}$ e de no máximo 25\% a $3.200 \mathrm{~Pa}$. Já para o CAP+PPA, os valores estão entre 2 e $35 \%$ a $100 \mathrm{~Pa}$ e atingem um máximo de $28 \%$ a $3.200 \mathrm{~Pa}$.

Tabela 26 - Percentuais de recuperação $(R)$ do CAP 50/70, do CAP+PPA, do CAP+SBS e do $C A P+S B S+P P A$ nos tempos de 1 e $9 \mathrm{~s}$ e na condição virgem

\begin{tabular}{ccccccccccc}
\hline Ligante & \multicolumn{4}{c}{$100 \mathrm{~Pa}(\mathrm{R} 100), \mathrm{em} \%$} & \multicolumn{5}{c}{$3.200 \mathrm{~Pa}(\mathrm{R} 3200)$, em \% } \\
\cline { 2 - 11 } asfáltico & $52^{\circ} \mathrm{C}$ & $58^{\circ} \mathrm{C}$ & $64^{\circ} \mathrm{C}$ & $70^{\circ} \mathrm{C}$ & $76^{\circ} \mathrm{C}$ & $52^{\circ} \mathrm{C}$ & $58^{\circ} \mathrm{C}$ & $64^{\circ} \mathrm{C}$ & $70^{\circ} \mathrm{C}$ & $76^{\circ} \mathrm{C}$ \\
\hline $50 / 70$ & 4,1 & 0,8 & 0,0 & 0,0 & 0,0 & 0,0 & 0,0 & 0,0 & 0,0 & 0,0 \\
PPA & 34,4 & 23,9 & 14,9 & 7,5 & 2,6 & 27,7 & 11,8 & 0,7 & 0,0 & 0,0 \\
SBS & 35,6 & 25,6 & 15,2 & 9,6 & 3,5 & 29,0 & 13,2 & 2,5 & 0,0 & 0,0 \\
SBS+PPA & 30,0 & 20,3 & 11,4 & 5,5 & 0,5 & 24,5 & 10,1 & 1,0 & 0,0 & 0,0 \\
\hline
\end{tabular}

A Figura 42 mostra os gráficos do percentual de recuperação com a temperatura para o CAP 50/70, o CAP+PPA, o CAP+SBS e o CAP+SBS+PPA, todos na condição virgem. Os percentuais de recuperação do CAP+SBS e do CAP+PPA são comparáveis ao longo de todo o espectro de temperaturas a $100 \mathrm{~Pa}$, sendo praticamente iguais a 15\% para ambos na temperatura de $64^{\circ} \mathrm{C}$. Os três ligantes asfálticos modificados apresentam tendências aproximadamente lineares para a diminuição do percentual de recuperação a $100 \mathrm{~Pa}$, o mesmo sendo observado nas temperaturas de até $64^{\circ} \mathrm{C}$ a $3.200 \mathrm{~Pa}$. A presença dos modificadores não é sentida nas temperaturas de 70 e $76^{\circ} \mathrm{C}$ a $3.200 \mathrm{~Pa}$, uma vez que os percentuais de recuperação são nulos para todos os ligantes asfálticos.

A Tabela 27 apresenta as compliâncias não-recuperáveis do CAP 50/70, do $\mathrm{CAP}+\mathrm{PPA}$, do $\mathrm{CAP}+\mathrm{SBS}$ e do $\mathrm{CAP}+\mathrm{SBS}+\mathrm{PPA}$, para materiais na condição virgem. A incorporação dos modificadores ao CAP 50/70 acarreta uma redução nos valores de $J_{n r}$, o que indica uma menor suscetibilidade dos ligantes asfálticos modificados quanto à deformação permanente. As menores compliâncias não-recuperáveis são observadas no CAP+SBS em qualquer temperatura a 100 (valores entre 0,1 e $6,1 \mathrm{kPa}^{-1}$ ) e a $3.200 \mathrm{~Pa}$ (valores entre 0,1 e $8,2 \mathrm{kPa}^{-1}$ ), sendo, portanto, o material com menor suscetibilidade à deformação permanente. Dentre os materiais modificados, o $\mathrm{CAP}+\mathrm{SBS}+\mathrm{PPA}$ possui os maiores valores de $\mathrm{J}_{\mathrm{nr}}$ nas temperaturas de 52 a $64^{\circ} \mathrm{C}$ a $100 \mathrm{~Pa}$ e de 52 e $58^{\circ} \mathrm{C}$ a $3.200 \mathrm{~Pa}$, sendo que o CAP+PPA 
possui estes maiores valores nas temperaturas de 70 e $76^{\circ} \mathrm{C}$ a $100 \mathrm{~Pa}$ e de 64 a $76{ }^{\circ} \mathrm{C}$ a 3.200 Pa. Em termos numéricos, as compliâncias não-recuperáveis do CAP+PPA estão entre 0,1 e $10,8 \mathrm{kPa}^{-1}$ e as do CAP+SBS+PPA estão entre 0,1 e 9,6 $\mathrm{kPa}^{-1}$, ambos para qualquer condição de temperatura e de nível de tensão.

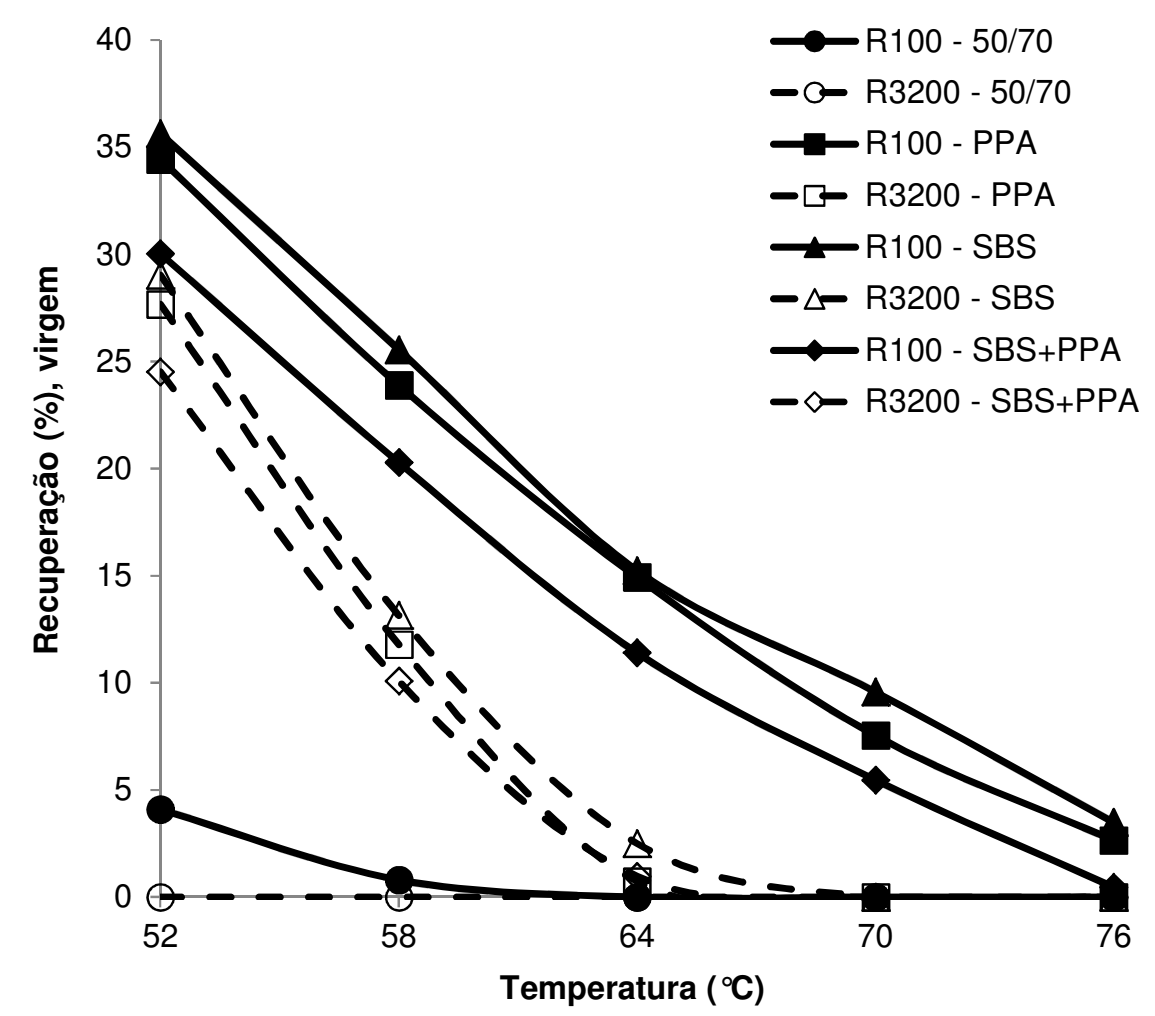

Figura 42 - Percentuais de recuperação $(R)$ do CAP 50/70, do CAP+PPA, do CAP+SBS e do $C A P+S B S+P P A$ na condição virgem e nos tempos de 1 e $9 \mathrm{~s}$

Tabela 27 - Compliâncias não-recuperáveis $\left(\mathrm{J}_{\mathrm{nr}}\right)$ do CAP 50/70, do CAP+PPA, do $\mathrm{CAP}+\mathrm{SBS}$ e do CAP+SBS+PPA nos tempos de 1 e $9 \mathrm{~s}$ e na condição virgem

\begin{tabular}{ccccccccccc}
\hline \multirow{2}{*}{$\begin{array}{c}\text { Ligante } \\
\text { asfáltico }\end{array}$} & \multicolumn{4}{c}{$100 \mathrm{~Pa}\left(\mathrm{~J}_{\mathrm{nr}} 100\right), \mathrm{em} \mathrm{kPa}^{-1}$} & \multicolumn{4}{c}{$3.200 \mathrm{~Pa}\left(\mathrm{~J}_{\mathrm{nr}} 3200\right), \mathrm{em} \mathrm{kPa}^{-1}$} \\
\cline { 2 - 11 } & $52^{\circ} \mathrm{C}$ & $58^{\circ} \mathrm{C}$ & $64^{\circ} \mathrm{C}$ & $70^{\circ} \mathrm{C}$ & $76^{\circ} \mathrm{C}$ & $52^{\circ} \mathrm{C}$ & $58^{\circ} \mathrm{C}$ & $64^{\circ} \mathrm{C}$ & $70^{\circ} \mathrm{C}$ & $76^{\circ} \mathrm{C}$ \\
\hline $50 / 70$ & 1,05 & 2,73 & 6,88 & 15,77 & 33,36 & 1,16 & 3,17 & 7,88 & 17,74 & 36,80 \\
PPA & 0,18 & 0,50 & 1,34 & 3,31 & 7,65 & 0,20 & 0,61 & 1,76 & 4,56 & 10,76 \\
SBS & 0,17 & 0,44 & 1,15 & 2,70 & 6,05 & 0,19 & 0,55 & 1,49 & 3,65 & 8,18 \\
SBS+PPA & 0,19 & 0,53 & 1,37 & 3,28 & 7,46 & 0,21 & 0,63 & 1,72 & 4,23 & 9,56 \\
\hline
\end{tabular}

A Figura 43 ilustra os gráficos de $\mathrm{J}_{\mathrm{nr}}$ com a temperatura para o CAP+PPA, o $\mathrm{CAP}+\mathrm{SBS}$ e o $\mathrm{CAP}+\mathrm{SBS}+\mathrm{PPA}$, todos na condição virgem. Os valores de $\mathrm{J}_{\mathrm{nr}}$ são muito próximos entre si para todos os materiais nas temperaturas de 52 a $64^{\circ} \mathrm{C}$ tanto a 100 quanto a 3.200 Pa, o que dificulta a distinção entre os modificadores. As compliâncias não-recuperáveis 
do $\mathrm{CAP}+\mathrm{PPA}$ e do $\mathrm{CAP}+\mathrm{SBS}+\mathrm{PPA}$ são praticamente semelhantes em todo o espectro de temperaturas a $100 \mathrm{~Pa}$ e, à luz destes resultados, as duas formulações podem ser consideradas equivalentes. Este fenômeno, entretanto, não é observado para os dois materiais nas temperaturas de 70 e $76{ }^{\circ} \mathrm{C}$ a $3.200 \mathrm{~Pa}$, nas quais as diferenças entre as compliâncias do CAP+PPA e do CAP+SBS+PPA são mais elevadas: superiores a 0,3 $\mathrm{kPa}^{-1}$ conforme resultados da Tabela 27.

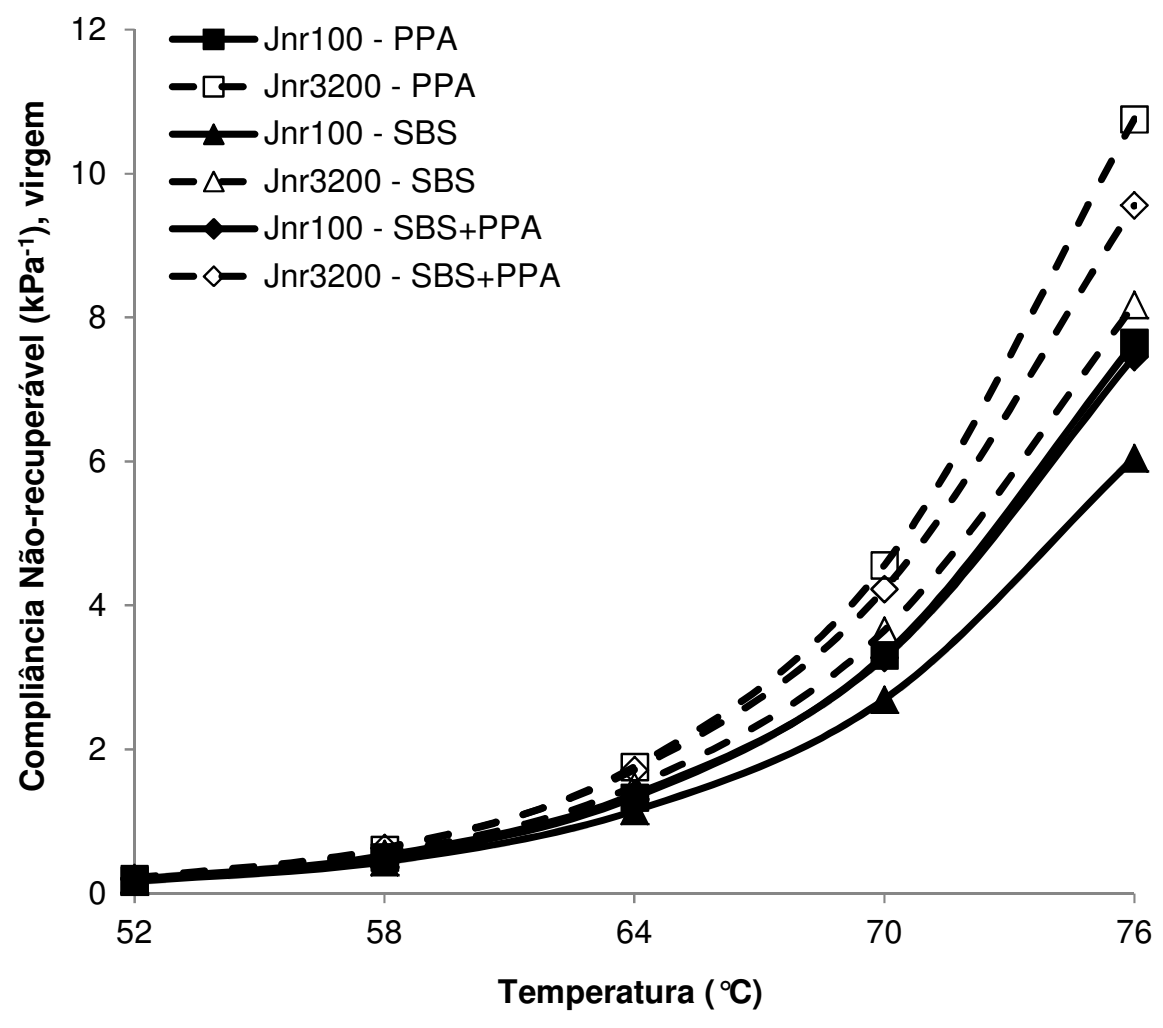

Figura 43 - Compliâncias não-recuperáveis $\left(J_{n r}\right)$ do CAP+PPA, do CAP+SBS e do $\mathrm{CAP}+\mathrm{SBS}+\mathrm{PPA}$ na condição virgem e nos tempos de 1 e $9 \mathrm{~s}$

Em uma avaliação dos resultados mostrados nas Tabelas 26 e 27 e nos gráficos das Figuras 42 e 43, referentes aos ligantes asfálticos virgens, visualiza-se que o CAP+SBS possui os maiores percentuais de recuperação e as menores compliâncias não-recuperáveis ao longo de todo o espectro de temperaturas a 100 e a $3.200 \mathrm{~Pa}$, sendo, portanto, o material com a maior componente elástica da deformação total e com a menor suscetibilidade à deformação permanente. O CAP+SBS+PPA possui os menores percentuais de recuperação em qualquer temperatura a $100 \mathrm{~Pa}$ e nas temperaturas de até $64^{\circ} \mathrm{C}$ a $3.200 \mathrm{~Pa}$ e as maiores compliâncias não-recuperáveis nas temperaturas inferiores a $64^{\circ} \mathrm{C}$ a 100 e a $3.200 \mathrm{~Pa}$, sendo, portanto, o material com a menor componente elástica da deformação total e a maior suscetibilidade à deformação permanente nas condições citadas. O CAP+PPA apresenta os maiores valores de $\mathrm{J}_{\mathrm{nr}}$ nas temperaturas acima de $64^{\circ} \mathrm{C}$ a 100 e a $3.200 \mathrm{~Pa}$ e valores de $\mathrm{R}$ 
mais próximos aos do $\mathrm{CAP}+\mathrm{SBS}+\mathrm{PPA}$ na maioria das condições de temperatura e tensão, especialmente nas temperaturas de até $64^{\circ} \mathrm{C}$ a $100 \mathrm{~Pa}$. As compliâncias não-recuperáveis do $\mathrm{CAP}+\mathrm{PPA}$ e do $\mathrm{CAP}+\mathrm{SBS}+\mathrm{PPA}$ apresentam valores muito próximos entre si em todas as temperaturas a $100 \mathrm{~Pa}$, sendo que este fenômeno também é observado para os dois ligantes asfálticos nas temperaturas de até $64^{\circ} \mathrm{C}$ a $3.200 \mathrm{~Pa}$.

A Tabela 28 mostra os percentuais de recuperação do CAP 50/70 e dos ligantes asfálticos modificados com PPA, SBS e SBS+PPA, todos na condição envelhecida a curto prazo. De uma maneira geral, o envelhecimento proporciona um aumento nos percentuais de recuperação dos ligantes asfálticos, o que indica uma maior parcela elástica da deformação total sofrida por estes materiais. O CAP+PPA possui os valores mais elevados de $\mathrm{R}$ ao longo de todo o espectro de temperaturas a 100 e a $3.200 \mathrm{~Pa}$, sendo o que recupera mais em qualquer condição de temperatura e de nível de tensão. O CAP+SBS apresenta, à exceção do material puro, os menores valores de $\mathrm{R}$ nas temperaturas de até $58^{\circ} \mathrm{C}$ a 100 e a $3.200 \mathrm{~Pa}$, sendo que o $\mathrm{CAP}+\mathrm{SBS}+\mathrm{PPA}$ apresenta estes menores valores nas temperaturas superiores a $58^{\circ} \mathrm{C}$. As diferenças entre as recuperações do CAP+PPA a 100 e a $3.200 \mathrm{~Pa}$ aumentam continuamente com o incremento da temperatura, chegando a resultados superiores a $20 \%$ nas temperaturas de 70 e $76^{\circ} \mathrm{C}$. No caso do CAP+SBS, estes aumentos são verificados nas temperaturas de até $64^{\circ} \mathrm{C}$, a partir da qual as diferenças entre os valores de $\mathrm{R}$ se estabilizam entre 11 e $12 \%$. Já para o $\mathrm{CAP}+\mathrm{SBS}+\mathrm{PPA}$, estas diferenças alcançam um valor máximo de aproximadamente $13 \%$ a $70{ }^{\circ} \mathrm{C}$, sendo de apenas $9 \%$ a $76^{\circ} \mathrm{C}$.

Tabela 28 - Percentuais de recuperação $(R)$ do CAP 50/70, do CAP+PPA, do CAP+SBS e do CAP+SBS+PPA nos tempos de 1 e $9 \mathrm{~s}$ e na condição envelhecida

\begin{tabular}{ccccccccccc}
\hline \multirow{2}{*}{$\begin{array}{c}\text { Ligante } \\
\text { asfáltico }\end{array}$} & \multicolumn{4}{c}{$100 \mathrm{~Pa}(\mathrm{R} 100), \mathrm{em} \%$} & \multicolumn{5}{c}{$3.200 \mathrm{~Pa}(\mathrm{R} 3200), \mathrm{em} \%$} \\
\cline { 2 - 11 } & $52^{\circ} \mathrm{C}$ & $58^{\circ} \mathrm{C}$ & $64^{\circ} \mathrm{C}$ & $70^{\circ} \mathrm{C}$ & $76^{\circ} \mathrm{C}$ & $52^{\circ} \mathrm{C}$ & $58^{\circ} \mathrm{C}$ & $64^{\circ} \mathrm{C}$ & $70^{\circ} \mathrm{C}$ & $76^{\circ} \mathrm{C}$ \\
\hline $50 / 70$ & 12,4 & 5,8 & 1,0 & 0,0 & 0,0 & 8,9 & 0,5 & 0,0 & 0,0 & 0,0 \\
PPA & 63,7 & 55,2 & 44,6 & 34,1 & 24,0 & 62,4 & 49,8 & 31,3 & 12,1 & 0,8 \\
SBS & 45,4 & 36,1 & 28,7 & 18,3 & 12,1 & 43,3 & 29,1 & 15,8 & 6,7 & 1,0 \\
SBS+PPA & 49,1 & 37,5 & 26,7 & 16,8 & 8,9 & 46,9 & 31,4 & 15,1 & 3,3 & 0,0 \\
\hline
\end{tabular}

A Figura 44 mostra os gráficos do percentual de recuperação com a temperatura para o CAP 50/70 e os ligantes asfálticos modificados com PPA, SBS e SBS+PPA, todos na condição envelhecida a curto prazo. Os percentuais de recuperação do $C A P+S B S$ e do $C A P+S B S+P P A$ são próximos entre si ao longo de todo o espectro de temperaturas a 100 e a $3.200 \mathrm{~Pa}$, de modo que as duas formulações podem ser consideradas equivalentes à luz destes resultados. Os decréscimos de recuperação com 
a temperatura seguem tendências aproximadamente lineares para os três ligantes asfálticos modificados, especialmente a $100 \mathrm{~Pa}$. Estes ligantes asfálticos modificados apresentam valores nulos ou muito pequenos (máximo de $1 \%$ conforme Tabela 28 ) do percentual de recuperação na situação mais crítica de ensaio: temperatura de $76^{\circ} \mathrm{C}$ e nível de tensão de $3.200 \mathrm{~Pa}$.

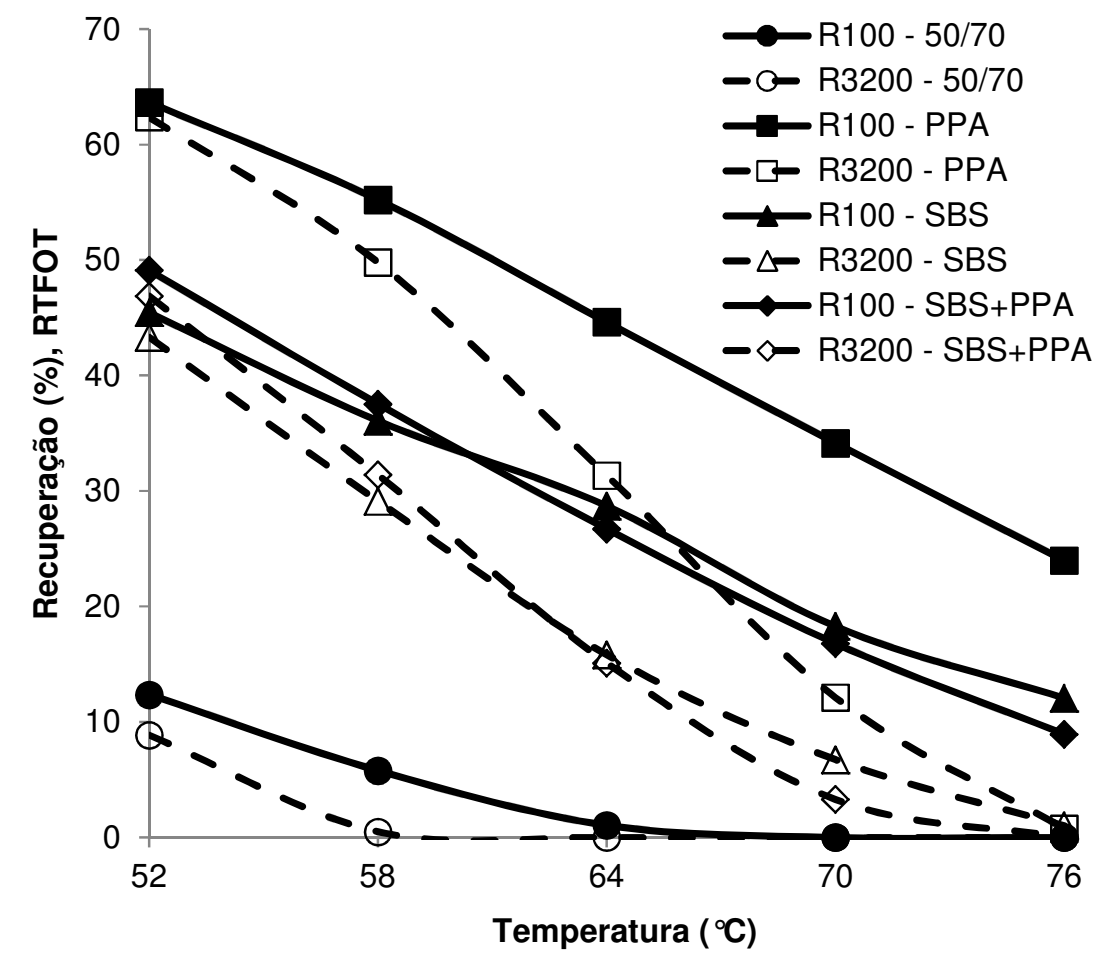

Figura 44 - Percentuais de recuperação $(R)$ do CAP 50/70, do CAP+PPA, do CAP+SBS e do CAP+SBS+PPA na condição envelhecida e nos tempos de 1 e $9 \mathrm{~s}$

A Tabela 29 apresenta as compliâncias não-recuperáveis do CAP 50/70 e dos ligantes asfálticos modificados com PPA, SBS e SBS+PPA, todos na condição envelhecida a curto prazo. O envelhecimento ocasiona uma redução nas compliâncias não-recuperáveis dos ligantes asfálticos. O CAP+PPA possui os valores mais baixos de $\mathrm{J}_{\mathrm{nr}}$ ao longo de todo o espectro de temperaturas a 100 e a $3.200 \mathrm{~Pa}$, sendo, portanto, o material com menor suscetibilidade à deformação permanente. À exceção do CAP puro, cujos valores de $\mathrm{J}_{\mathrm{nr}}$ superam os $5,0 \mathrm{kPa}^{-1}$ nas temperaturas de 70 e $76^{\circ} \mathrm{C}$ a $100 \mathrm{~Pa}$ e os $6,0 \mathrm{kPa}^{-1}$ nas mesmas temperaturas a $3.200 \mathrm{~Pa}$, O CAP+SBS possui os valores mais elevados para esta propriedade em todas as temperaturas a 100 e a $3.200 \mathrm{~Pa}$, alcançando valores de até $2,7 \mathrm{kPa}^{-1}$ a $100 \mathrm{~Pa}$ e de até $3,6 \mathrm{kPa}^{-1}$ a $3.200 \mathrm{~Pa}$. O CAP+SBS+PPA apresenta compliâncias não-recuperáveis menores que as do CAP+SBS em qualquer condição de temperatura e nível de tensão, com resultados superiores a $1,0 \mathrm{kPa}^{-1}$ nas temperaturas de 70 e $76^{\circ} \mathrm{C}$ e para ambas as tensões. 
Tabela 29 - Compliâncias não-recuperáveis $\left(J_{n r}\right)$ do CAP 50/70, do CAP+PPA, do CAP+SBS e do $\mathrm{CAP}+\mathrm{SBS}+\mathrm{PPA}$ nos tempos de 1 e $9 \mathrm{~s}$ e na condição envelhecida

\begin{tabular}{ccccccccccc}
\hline \multirow{2}{*}{$\begin{array}{c}\text { Ligante } \\
\text { asfáltico }\end{array}$} & \multicolumn{4}{c}{$100 \mathrm{~Pa}\left(\mathrm{~J}_{\mathrm{nr}} 100\right), \mathrm{em} \mathrm{kPa}^{-1}$} & \multicolumn{5}{c}{$3.200 \mathrm{~Pa}\left(\mathrm{~J}_{\mathrm{nr}} 3200\right), \mathrm{em} \mathrm{kPa}^{-1}$} \\
\cline { 2 - 11 } & $52^{\circ} \mathrm{C}$ & $58^{\circ} \mathrm{C}$ & $64^{\circ} \mathrm{C}$ & $70^{\circ} \mathrm{C}$ & $76^{\circ} \mathrm{C}$ & $52^{\circ} \mathrm{C}$ & $58^{\circ} \mathrm{C}$ & $64^{\circ} \mathrm{C}$ & $70^{\circ} \mathrm{C}$ & $76{ }^{\circ} \mathrm{C}$ \\
\hline $50 / 70$ & 0,33 & 0,92 & 2,44 & 5,96 & 13,53 & 0,35 & 1,02 & 2,78 & 6,79 & 15,23 \\
PPA & 0,03 & 0,08 & 0,23 & 0,59 & 1,48 & 0,03 & 0,09 & 0,29 & 0,86 & 2,38 \\
SBS & 0,06 & 0,17 & 0,44 & 1,12 & 2,65 & 0,07 & 0,19 & 0,55 & 1,46 & 3,58 \\
SBS+PPA & 0,05 & 0,15 & 0,41 & 1,04 & 2,49 & 0,06 & 0,17 & 0,49 & 1,34 & 3,33 \\
\hline
\end{tabular}

A Figura 45 mostra os gráficos de $\mathrm{J}_{\mathrm{nr}}$ com a temperatura para o CAP 50/70, o $\mathrm{CAP}+\mathrm{PPA}$, o CAP+SBS e o CAP+SBS+PPA, todos na condição envelhecida a curto prazo. A distinção entre os ligantes asfálticos é difícil de ser feita nas temperaturas de 52 e $58^{\circ} \mathrm{C}$ por conta dos valores parecidos de $\mathrm{J}_{\mathrm{nr}}$ dos materiais, tanto a 100 quanto a 3.200 Pa. O CAP+SBS e o CAP+SBS+PPA apresentam compliâncias não-recuperáveis próximas entre si ao longo de todo o espectro de temperaturas a 100 e a $3.200 \mathrm{~Pa}$, de modo que as duas formulações podem ser consideradas equivalentes à luz dos resultados desta propriedade. O CAP+PPA possui, para uma mesma tensão, incrementos mais baixos de compliância não-recuperável em comparação ao $\mathrm{CAP}+\mathrm{SBS}$ e ao $\mathrm{CAP}+\mathrm{SBS}+\mathrm{PPA}$ em todas as temperaturas, o que acarreta valores de 1,0 a $1,2 \mathrm{kPa}^{-1}$ menores para esta formulação na temperatura de $76^{\circ} \mathrm{C}$ conforme resultados da Tabela 29.

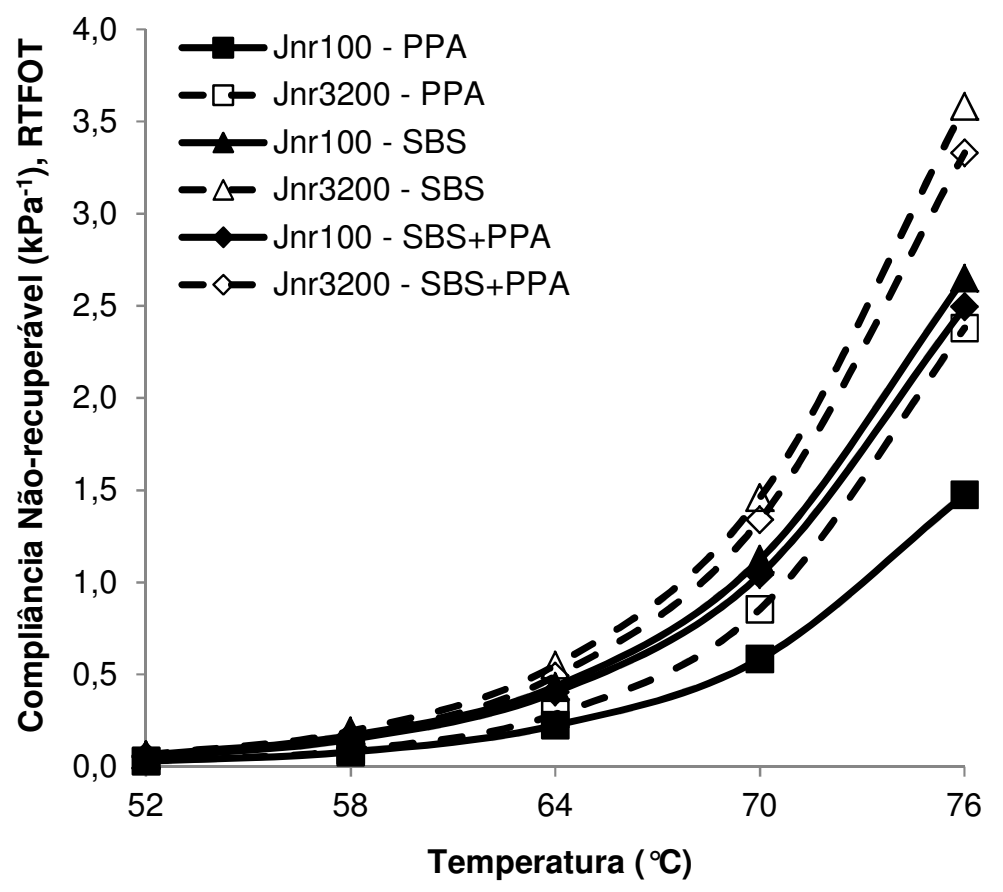

Figura 45 - Compliâncias não-recuperáveis $\left(\mathrm{J}_{\text {nr }}\right)$ do CAP+PPA, do CAP+SBS e do $\mathrm{CAP}+\mathrm{SBS}+\mathrm{PPA}$ na condição envelhecida e nos tempos de 1 e $9 \mathrm{~s}$ 
Uma análise dos resultados das Tabelas 28 e 29 e dos gráficos das Figuras 44 e 45, referentes aos ligantes asfálticos envelhecidos a curto prazo, permite observar que o CAP+PPA possui os maiores valores de $R$ e os menores de $J_{n r}$ em todo o espectro de temperaturas a 100 e a $3.200 \mathrm{~Pa}$, o que indica uma elevada componente elástica da deformação total sofrida por este material e uma baixa suscetibilidade à deformação permanente. Dentre os ligantes asfálticos modificados, o CAP+SBS apresenta os menores percentuais de recuperação nas temperaturas de 52 e $58^{\circ} \mathrm{C}$ a 100 e a $3.200 \mathrm{~Pa}$ e as maiores compliâncias não-recuperáveis em todo o espectro de temperaturas de ambos os níveis de tensão, o que indica uma maior suscetibilidade deste material à deformação permanente e uma menor parcela elástica da deformação total nas condições citadas. O CAP+SBS+PPA apresenta resultados mais próximos aos do CAP+SBS em ambas as propriedades a 100 e a 3.200 Pa, especialmente no caso da compliância não-recuperável.

A Tabela 30 apresenta as relações entre as compliâncias não-recuperáveis $\left(R_{\mathrm{J}}\right)$ para o CAP 50/70, o CAP+PPA, o CAP+SBS e o CAP+SBS+PPA. Os valores de R estão entre 2 e 7 para todos os ligantes asfálticos, o que indica uma redução entre 2 e 7 vezes no valor de $\mathrm{J}_{\mathrm{nr}}$ destes materiais após o envelhecimento a curto prazo. O CAP+SBS possui os valores mais baixos de $\mathrm{R}_{\mathrm{J}}$ ao longo de todo o espectro de temperaturas a 100 e a $3.200 \mathrm{~Pa}$, com resultados entre 2 e 3 para qualquer condição de temperatura e tensão. O CAP+PPA possui os resultados mais elevados para este parâmetro em todas as temperaturas e níveis de tensão, sendo o único material com reduções entre 4 e 7 vezes na compliância não-recuperável após 0 envelhecimento a curto prazo. O CAP+SBS+PPA e o CAP 50/70 apresentam valores maiores de $R_{J}$ em comparação ao $C A P+S B S$, porém as diferenças entre os resultados são relativamente pequenas em qualquer temperatura e nível de tensão. No caso do CAP 50/70, as reduções de compliância não-recuperável estão entre 2 e 4 vezes.

Tabela 30 - Relações entre as compliâncias não-recuperáveis $\left(R_{J}\right)$ do CAP 50/70, do $\mathrm{CAP}+\mathrm{PPA}$, do CAP+SBS e do CAP+SBS+PPA nos tempos de 1 e $9 \mathrm{~s}$

\begin{tabular}{ccccccccccc}
\hline Ligante & \multicolumn{9}{c}{$100 \mathrm{~Pa}$} \\
\cline { 2 - 11 } asfáltico & $52^{\circ} \mathrm{C}$ & $58^{\circ} \mathrm{C}$ & $64^{\circ} \mathrm{C}$ & $70^{\circ} \mathrm{C}$ & $76^{\circ} \mathrm{C}$ & $52^{\circ} \mathrm{C}$ & $58^{\circ} \mathrm{C}$ & $64^{\circ} \mathrm{C}$ & $70^{\circ} \mathrm{C}$ & $76^{\circ} \mathrm{C}$ \\
\hline $50 / 70$ & 3,2 & 3,0 & 2,8 & 2,6 & 2,5 & 3,3 & 3,1 & 2,8 & 2,6 & 2,4 \\
PPA & 6,0 & 6,3 & 5,9 & 5,7 & 5,2 & 6,7 & 6,8 & 6,2 & 5,3 & 4,5 \\
SBS & 2,7 & 2,6 & 2,6 & 2,4 & 2,3 & 2,9 & 2,8 & 2,7 & 2,5 & 2,3 \\
SBS+PPA & 3,8 & 3,5 & 3,4 & 3,1 & 3,0 & 3,8 & 3,8 & 3,5 & 3,2 & 2,9 \\
\hline
\end{tabular}

A Figura 46 ilustra as relações entre as compliâncias não-recuperáveis do CAP puro, do $C A P+P P A$, do $C A P+S B S$ e do $C A P+S B S+P P A$. As diferenças entre os valores de $R_{J} a$ 
100 e a 3.200 Pa se mostram pequenas para o CAP 50/70 e os ligantes asfálticos modificados com SBS e SBS+PPA, o que indica que o efeito do nível de tensão não é muito significativo na alteração da sensibilidade destes materiais ao envelhecimento a curto prazo, à luz dos resultados de compliância não-recuperável. Estas diferenças são menores nas temperaturas de 64, 70 e $76^{\circ} \mathrm{C}$ no caso do CAP 50/70, do CAP+SBS e do CAP+SBS+PPA, para os quais os valores de $R_{J}$ a 100 e a 3.200 Pa são praticamente semelhantes conforme Tabela 30 . O CAP+PPA é o material que mais enrijece tanto a 100 quanto a $3.200 \mathrm{~Pa}$, seguido pelo CAP+SBS+PPA, depois pelo CAP 50/70 e então pelo CAP+SBS, este último sendo o material que menos enrijece após o envelhecimento a curto prazo.

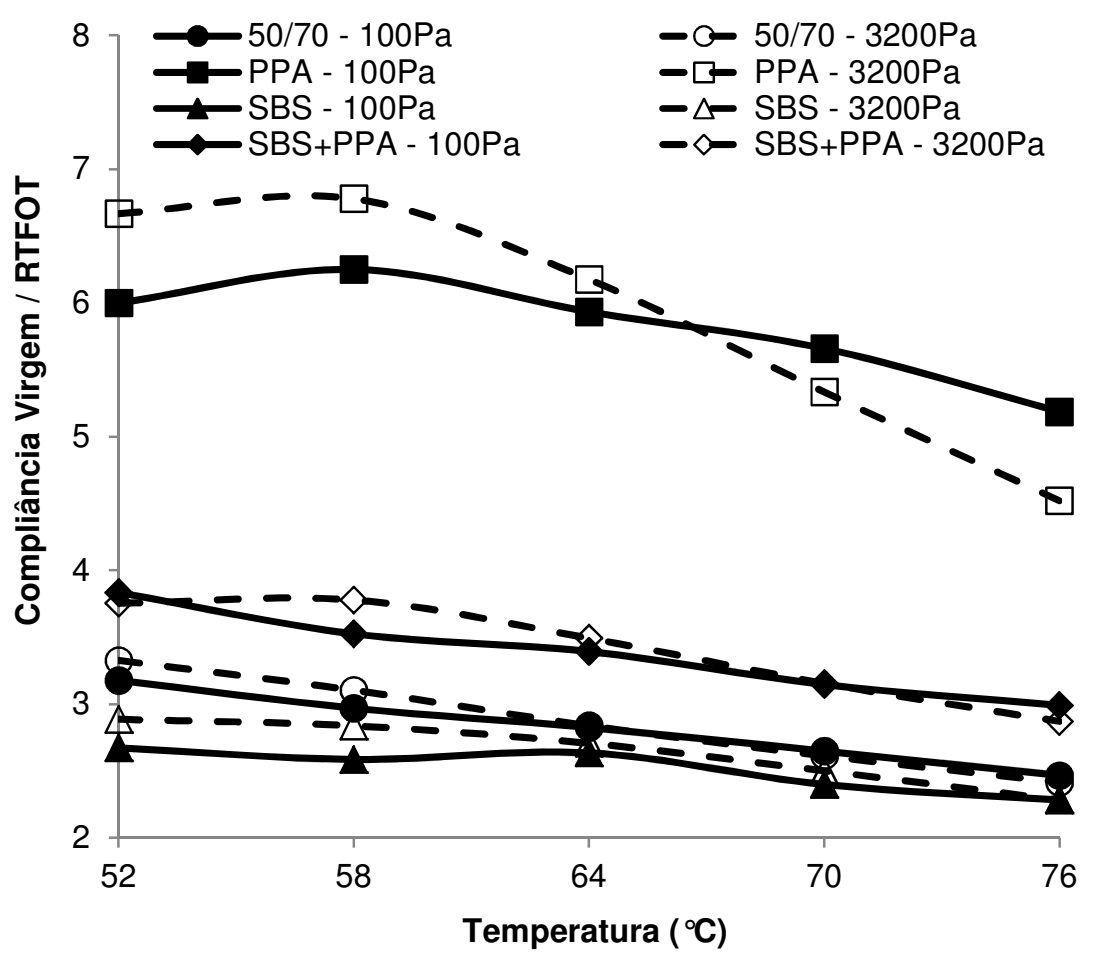

Figura 46 - Relações entre as compliâncias não-recuperáveis $\left(R_{J}\right)$ do CAP 50/70, do $\mathrm{CAP}+\mathrm{PPA}$, do $\mathrm{CAP}+\mathrm{SBS}$ e do $\mathrm{CAP}+\mathrm{SBS}+\mathrm{PPA}$ nos tempos de 1 e $9 \mathrm{~s}$

A Tabela 31 apresenta as relações entre os percentuais de recuperação $\left(R_{R}\right)$ para o CAP 50/70, o CAP+PPA, o CAP+SBS e o CAP+SBS+PPA. Em comparação aos resultados da Tabela 30, visualiza-se que as diferenças entre os resultados a 100 e a $3.200 \mathrm{~Pa}$ são mais acentuadas para o parâmetro $R_{R}$ do que o parâmetro $R_{J}$, indicando um efeito maior do nível de tensão na alteração da sensibilidade do percentual de recuperação do que na sensibilidade da compliância não-recuperável ao RTFOT. Os valores de $R_{R}$ dos ligantes asfálticos modificados não puderam ser obtidos nas temperaturas de 70 e $76^{\circ} \mathrm{C}$ a $3.200 \mathrm{~Pa}$, uma vez que os percentuais de recuperação dos materiais virgens são nulos nestas condições. No caso do CAP 50/70, os valores de $R_{R}$ somente puderam ser calculados nas temperaturas de 
52 e $58^{\circ} \mathrm{C}$ a $100 \mathrm{~Pa}$, nas quais a recuperação do material virgem não é nula. O CAP+PPA apresenta os maiores incrementos de $\mathrm{R}$ nas temperaturas de até $70^{\circ} \mathrm{C}$ a $100 \mathrm{~Pa}$ (entre 1 e 10 vezes), o mesmo ocorrendo nas temperaturas de até $64^{\circ} \mathrm{C}$ a $3.200 \mathrm{~Pa}$ (entre 2 e 43 vezes). Os menores incrementos são encontrados no CAP+SBS para todas as temperaturas e níveis de tensão, com valores entre 1 e 4 a $100 \mathrm{~Pa}$ e entre 1 e 7 a $3.200 \mathrm{~Pa}$. O CAP+SBS+PPA apresenta incrementos de recuperação maiores que os do CAP+SBS, especialmente nas temperaturas de 70 e $76{ }^{\circ} \mathrm{C}$ a $100 \mathrm{~Pa}$ e de 58 e $64^{\circ} \mathrm{C}$ a $3.200 \mathrm{~Pa}$.

Tabela 31 - Relações entre os percentuais de recuperação $\left(R_{R}\right)$ do CAP 50/70, do CAP+PPA, do CAP+SBS e do CAP+SBS+PPA nos tempos de 1 e $9 \mathrm{~s}$

\begin{tabular}{ccccccccccc}
\hline \multirow{2}{*}{$\begin{array}{c}\text { Ligante } \\
\text { asfáltico }\end{array}$} & \multicolumn{9}{c}{$100 \mathrm{~Pa}$} \\
\cline { 2 - 11 } & $52^{\circ} \mathrm{C}$ & $58^{\circ} \mathrm{C}$ & $64^{\circ} \mathrm{C}$ & $70^{\circ} \mathrm{C}$ & $76^{\circ} \mathrm{C}$ & $52^{\circ} \mathrm{C}$ & $58^{\circ} \mathrm{C}$ & $64^{\circ} \mathrm{C}$ & $70^{\circ} \mathrm{C}$ & $76^{\circ} \mathrm{C}$ \\
\hline $50 / 70$ & 3,0 & 7,2 & - & - & - & - & - & - & - & - \\
PPA & 1,8 & 2,3 & 3,0 & 4,5 & 9,1 & 2,3 & 4,2 & 42,9 & - & - \\
SBS & 1,3 & 1,4 & 1,9 & 1,9 & 3,5 & 1,5 & 2,2 & 6,3 & - & - \\
SBS+PPA & 1,6 & 1,9 & 2,3 & 3,1 & 19,3 & 1,9 & 3,1 & 15,5 & - & - \\
\hline
\end{tabular}

A Figura 47 mostra os gráficos de $R_{R}$ com a temperatura para o CAP 50/70, o CAP+PPA, o CAP+SBS e o CAP+SBS+PPA. Os aumentos do percentual de recuperação a $100 \mathrm{~Pa}$ após o envelhecimento a curto prazo são pequenos para os ligantes asfálticos modificados nas temperaturas de até $64^{\circ} \mathrm{C}$, sendo inferiores a 5 vezes para todos eles. Situação diferente ocorre nas temperaturas acima de $64^{\circ} \mathrm{C}$, nas quais os valores de $R_{R}$ aumentam consideravelmente para o $\mathrm{CAP}+\mathrm{PPA}$ e o $\mathrm{CAP}+\mathrm{SBS}+\mathrm{PPA}$ e atingem resultados superiores a 5 na temperatura do PG e a 100 Pa. O incremento do nível de tensão de 100 para 3.200 $\mathrm{Pa}$ acarreta um aumento do parâmetro $R_{R}$ para todos os ligantes asfálticos modificados e, na temperatura de $64^{\circ} \mathrm{C}$, este parâmetro alcança resultados superiores a 15 para o $\mathrm{CAP}+\mathrm{PPA}$ e o $\mathrm{CAP}+\mathrm{SBS}+\mathrm{PPA}$ e superiores a 5 para o $\mathrm{CAP}+\mathrm{SBS}$.

Em uma avaliação dos resultados apresentados nas Tabelas 30 e 31 e nas Figuras 46 e 47, visualiza-se que o CAP+PPA apresenta as maiores reduções da compliância não-recuperável em qualquer condição de temperatura e tensão, bem como os maiores incrementos do percentual de recuperação nas temperaturas de até $70^{\circ} \mathrm{C}$ a $100 \mathrm{~Pa}$ e nas temperaturas de até $64^{\circ} \mathrm{C}$ a $3.200 \mathrm{~Pa}$. Ao mesmo tempo, observa-se que o CAP+SBS apresenta as menores reduções de $\mathrm{J}_{\mathrm{nr}}$ e os menores incrementos de $\mathrm{R}$ em todas as temperaturas e níveis de tensão. Do ponto de vista de sensibilidade ao envelhecimento, pode-se dizer que o CAP+PPA possui a maior sensibilidade e que o CAP+SBS possui a menor, à luz dos incrementos do percentual de recuperação e das reduções da compliância 
não-recuperável após o RTFOT. Estes maiores valores para os parâmetros $R_{J}$ e $R_{R}$, entretanto, indicam também que o envelhecimento reduziu a compliância não-recuperável e aumentou a recuperação de maneira significativa, o que é favorável à resistência à deformação permanente. Deste ponto de vista, o CAP+PPA apresenta melhores resultados do que o CAP+SBS por conta das maiores variações de suas propriedades $\left(R\right.$ e $J_{n r}$ ) após o envelhecimento a curto prazo.

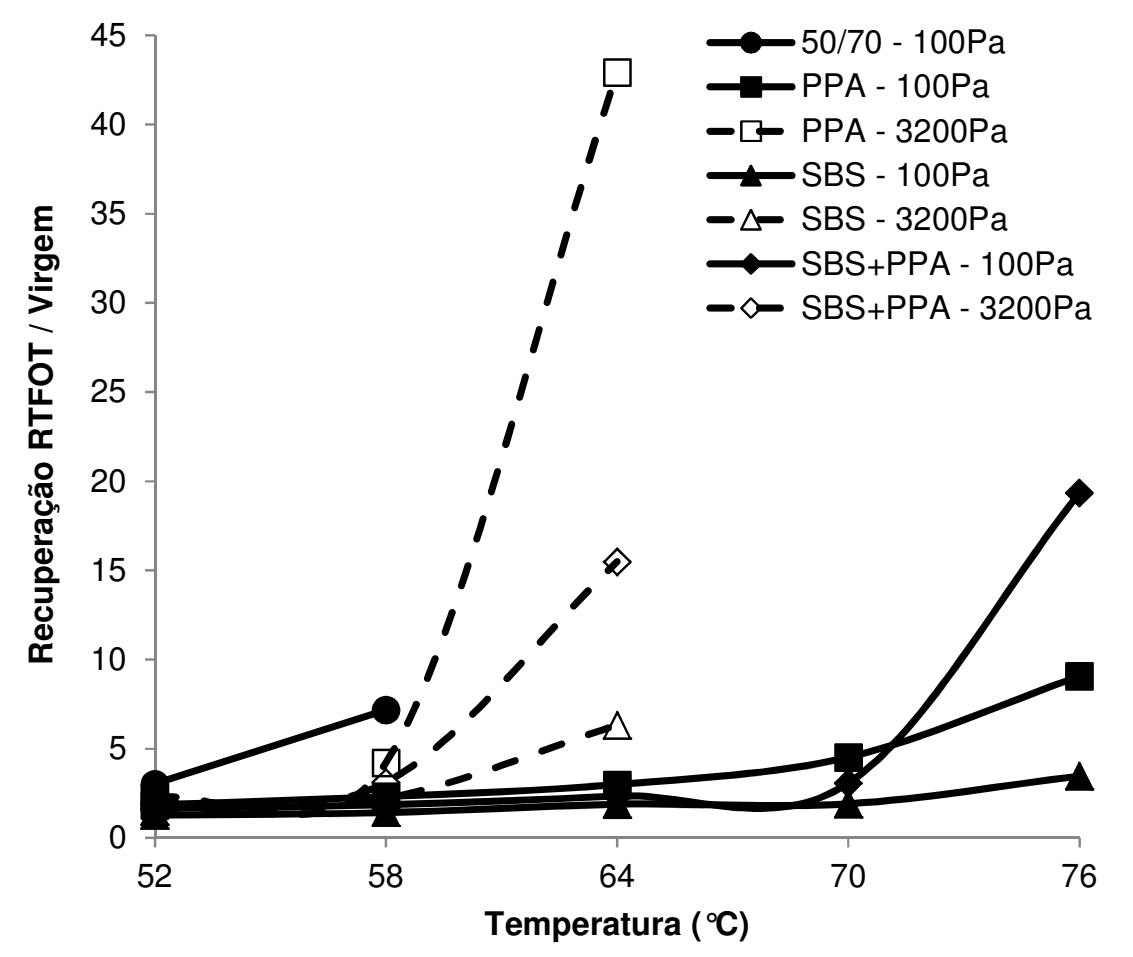

Figura 47 - Relações entre os percentuais de recuperação $\left(R_{R}\right)$ do CAP 50/70, do CAP+PPA, do CAP+SBS e do CAP+SBS+PPA nos tempos de 1 e $9 \mathrm{~s}$

A Tabela 32 apresenta as diferenças percentuais entre as compliâncias $\left(\mathrm{J}_{\mathrm{nr}, \text { diff }}\right)$ para o CAP 50/70 e os ligantes asfálticos modificados com PPA, SBS e SBS+PPA, tanto na condição virgem quanto na envelhecida a curto prazo. Os ligantes asfálticos deste grupo não apresentam, na condição envelhecida a curto prazo e na temperatura do PG, diferenças percentuais superiores ao valor de 75\% estipulado pela norma AASHTO MP19, sendo que o CAP+PPA é o ligante asfáltico com valor de $J_{n r, d i f f}$ mais próximo deste percentual $(61,4 \%)$. $O$ CAP $50 / 70$ possui as menores diferenças percentuais em todas as temperaturas das condições virgem e envelhecida a curto prazo, exceção feita à temperatura de $52^{\circ} \mathrm{C}$ para ambas as condições. O CAP+PPA possui as maiores diferenças percentuais nas temperaturas de 64,70 e $76^{\circ} \mathrm{C}$, tanto na condição virgem quanto na envelhecida a curto prazo. O CAP+SBS apresenta diferenças percentuais maiores que o CAP+SBS+PPA em todas as temperaturas da condição virgem, bem como nas temperaturas de 58, 64, 70 e 
$76{ }^{\circ} \mathrm{C}$ da condição envelhecida. Em linhas gerais, pode-se dizer que o CAP+PPA possui a maior sensibilidade à tensão e que o CAP 50/70 possui a menor sensibilidade, à luz das variações de $J_{n r}$. Em uma análise similar, observa-se que o CAP+SBS+PPA possui a menor sensibilidade à tensão dentre os materiais modificados por conta dos menores valores de $\mathrm{J}_{\text {nr,diff }}$ em quase todas as condições de temperatura e envelhecimento.

Tabela 32 - Diferenças percentuais entre as compliâncias não-recuperáveis $\left(J_{\text {rr,diff }}\right)$ do CAP 50/70, do CAP+PPA, do CAP+SBS e do CAP+SBS+PPA nos tempos de 1 e $9 \mathrm{~s}$

\begin{tabular}{ccccccccccc}
\hline \multirow{2}{*}{$\begin{array}{c}\text { Ligante } \\
\text { asfáltico }\end{array}$} & \multicolumn{4}{c}{ Materiais virgens } & \multicolumn{4}{c}{ Materiais envelhecidos (RTFOT) } \\
\cline { 2 - 11 } & $52^{\circ} \mathrm{C}$ & $58^{\circ} \mathrm{C}$ & $64^{\circ} \mathrm{C}$ & $70^{\circ} \mathrm{C}$ & $76^{\circ} \mathrm{C}$ & $52^{\circ} \mathrm{C}$ & $58^{\circ} \mathrm{C}$ & $64^{\circ} \mathrm{C}$ & $70^{\circ} \mathrm{C}$ & $76^{\circ} \mathrm{C}$ \\
\hline $50 / 70$ & 11,0 & 15,9 & 14,5 & 12,5 & 10,3 & 6,1 & 10,9 & 14,0 & 14,0 & 12,6 \\
PPA & 11,1 & 22,0 & 31,8 & 37,8 & 40,7 & 0,0 & 12,5 & 26,7 & 46,2 & 61,4 \\
SBS & 13,0 & 24,6 & 29,9 & 35,5 & 35,1 & 4,7 & 13,6 & 26,5 & 30,0 & 35,1 \\
SBS+PPA & 9,8 & 19,7 & 24,9 & 29,0 & 28,2 & 12,1 & 11,7 & 21,3 & 28,7 & 33,5 \\
\hline
\end{tabular}

A Figura 48 mostra os gráficos de $\mathrm{J}_{\mathrm{nr} \text {, diff }}$ com a temperatura para o CAP 50/70, o CAP+PPA, o CAP+SBS e o CAP+SBS+PPA, considerando as condições virgem e envelhecida a curto prazo. O envelhecimento a curto prazo atua de maneira diferente nos ligantes asfálticos, sendo uma função também da temperatura. No caso do CAP 50/70 e do CAP+PPA, o envelhecimento proporciona uma redução de $J_{n r \text {,diff }}$ nas temperaturas de 52,58 e $64^{\circ} \mathrm{C}$ e um aumento deste parâmetro nas temperaturas de 70 e $76{ }^{\circ} \mathrm{C}$, o que pode ser interpretado como uma menor sensibilidade à tensão nas temperaturas mais baixas e uma maior sensibilidade nas mais altas. Este envelhecimento ocasiona reduções de $\mathrm{J}_{\mathrm{nr} \text {,diff }}$ para o $\mathrm{CAP}+\mathrm{SBS}$ nas temperaturas de até $70^{\circ} \mathrm{C}$ e com maior intensidade nas temperaturas de $52 \mathrm{e}$ $58^{\circ} \mathrm{C}$, o que indica uma diminuição da sensibilidade do material ao incremento do nível de tensão de 100 para 3.200 Pa. Já para o CAP+SBS+PPA, observam-se reduções de $J_{\text {nr,diff }}$ nas temperaturas intermediárias $\left(58,64\right.$ e $\left.70^{\circ} \mathrm{C}\right)$ e aumentos nas temperaturas extremas (52 e $76{ }^{\circ} \mathrm{C}$ ) após o RTFOT. Em termos de benefícios com a redução de $J_{n r, d i f f}$, pode-se dizer que o CAP+SBS apresenta os melhores resultados dentre os ligantes asfálticos considerados por conta da redução da diferença percentual deste material nas temperaturas de até $70^{\circ} \mathrm{C}$ após o envelhecimento a curto prazo.

Em uma análise resumida dos valores numéricos das Tabelas 26 a 32 e dos gráficos das Figuras 42 a 48, é possível observar que o CAP+SBS apresenta os maiores percentuais de recuperação e as menores compliâncias não-recuperáveis em todas as temperaturas a 100 e a $3.200 \mathrm{~Pa}$ da condição virgem. O CAP+SBS+PPA apresenta os menores percentuais de recuperação em todas as temperaturas a $100 \mathrm{~Pa}$ e nas temperaturas 
de até $58^{\circ} \mathrm{C}$ a $3.200 \mathrm{~Pa}$, bem como as maiores compliâncias não-recuperáveis nas temperaturas de até $64^{\circ} \mathrm{C}$ a 100 e de até $58^{\circ} \mathrm{C}$ a $3.200 \mathrm{~Pa}$. Após o envelhecimento dos materiais na estufa de filme fino rotativo, o CAP+PPA passa a apresentar os maiores valores do percentual de recuperação e os menores de compliância não-recuperável em todas as temperaturas a 100 e a $3.200 \mathrm{~Pa}$, com o CAP+SBS possuindo os menores percentuais de recuperação nas temperaturas de até $64^{\circ} \mathrm{C}$ a 100 e a $3.200 \mathrm{~Pa}$ e as maiores compliâncias não-recuperáveis em todas as condições de temperatura e tensão. A avaliação da sensibilidade dos ligantes asfálticos modificados quanto ao envelhecimento a curto prazo (parâmetros $R_{J}$ e $R_{R}$ ) mostra que, em linhas gerais, o CAP+PPA possui a maior sensibilidade ao envelhecimento a curto prazo e que o $\mathrm{CAP}+\mathrm{SBS}$ possui a menor sensibilidade, à luz dos incrementos de $\mathrm{R}$ e das reduções de $\mathrm{J}_{\mathrm{nr}}$ após o RTFOT. A avaliação da sensibilidade dos ligantes asfálticos quanto ao incremento da tensão (parâmetro $J_{n r, d i f f}$ ) mostra que, de uma maneira geral, o CAP 50/70 possui a menor sensibilidade e que o CAP+PPA possui a maior sensibilidade, à luz das variações da compliância não-recuperável.

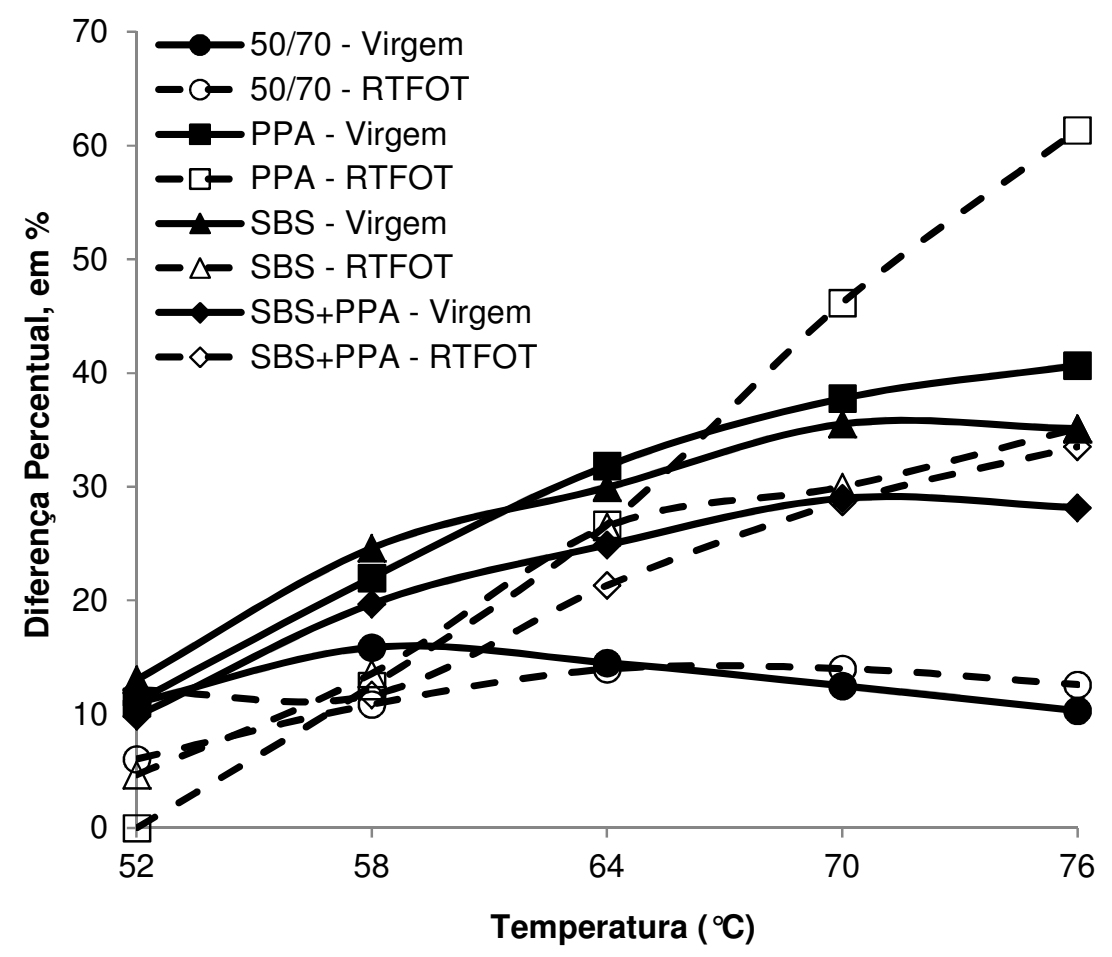

Figura 48 - Diferenças percentuais entre as compliâncias não-recuperáveis $\left(J_{n r, \text { diff }}\right)$ do CAP 50/70, do CAP+PPA, do CAP+SBS e do CAP+SBS+PPA nos tempos de 1 e $9 \mathrm{~s}$

Em uma comparação dos resultados do $C A P+S B S$ e do CAP+SBS+PPA, é possível observar que o $\mathrm{CAP}+\mathrm{SBS}$ possui maiores recuperações e menores compliâncias não-recuperáveis em todas as temperaturas a 100 e a 3.200 Pa da condição virgem, o que se traduz em uma maior componente elástica da deformação total e uma menor 
suscetibilidade deste material à deformação permanente em comparação ao CAP+SBS+PPA. Este quadro é alterado após o envelhecimento a curto prazo, pois o CAP+SBS+PPA passa a apresentar os valores mais baixos de $J_{n r}$ em qualquer condição de temperatura e tensão e os valores mais elevados de $R$ nas temperaturas de 52 e $58^{\circ} \mathrm{C}$ a 100 e a 3.200 Pa. As análises de sensibilidade ao envelhecimento a curto prazo apontam que o CAP+SBS+PPA possui os valores mais elevados de $R_{J}$ e de $R_{R}$ em todas as condições de temperatura e envelhecimento consideradas e, por consequência, uma sensibilidade maior ao RTFOT em comparação ao CAP+SBS. Embora o CAP+SBS possua uma menor sensibilidade ao envelhecimento, os resultados de $J_{\text {nr,diff }}$ indicam que este material possui uma maior sensibilidade à tensão nas temperaturas de 58, 64, 70 e $76^{\circ} \mathrm{C}$ da condição envelhecida, bem como em todas as temperaturas da condição virgem.

\subsubsection{CAP 50/70, CAP+PPA, CAP+EVA e $C A P+E V A+P P A$}

A Tabela 33 mostra os percentuais de recuperação do CAP 50/70, do $\mathrm{CAP}+\mathrm{PPA}$, do $\mathrm{CAP}+\mathrm{EVA}$ e do $\mathrm{CAP}+\mathrm{EVA}+\mathrm{PPA}$, para materiais na condição virgem. $\mathrm{A}$ incorporação dos modificadores ao CAP 50/70 ocasiona, em linhas gerais, um aumento dos percentuais de recuperação do material, sobretudo no caso do EVA e do EVA+PPA. O $\mathrm{CAP}+\mathrm{EVA}$ possui as maiores recuperações nas temperaturas de até $64^{\circ} \mathrm{C}$ a $100 \mathrm{~Pa}$, bem como nas temperaturas de até $70^{\circ} \mathrm{C}$ a $3.200 \mathrm{~Pa}$. O CAP+EVA+PPA apresenta estas recuperações mais elevadas nas temperaturas de 70 e $76^{\circ} \mathrm{C}$ a $100 \mathrm{~Pa}$, não sendo observadas distinções significativas entre os modificadores nas temperaturas de 70 e $76^{\circ} \mathrm{C}$ e no nível de tensão de $3.200 \mathrm{~Pa}$. As recuperações mais baixas são encontradas no CAP+PPA ao longo de todo o espectro de temperaturas a $100 \mathrm{~Pa}$ (valores entre 2 e $35 \%$ ) e nas temperaturas de até $64^{\circ} \mathrm{C}$ a $3.200 \mathrm{~Pa}$ (valores de até $28 \%$ ). Em termos numéricos, os percentuais de recuperação do CAP+EVA estão entre 6 e $64 \%$ a $100 \mathrm{~Pa}$, sendo de no máximo $59 \%$ a 3.200 Pa. No caso do CAP+EVA+PPA, estes percentuais variam entre $22 \mathrm{e}$ $48 \%$ a $100 \mathrm{~Pa}$ e alcançam um valor máximo de $36 \%$ a $3.200 \mathrm{~Pa}$.

A Figura 49 ilustra os gráficos do percentual de recuperação com a temperatura para o CAP 50/70, o CAP+PPA, o CAP+EVA e o CAP+EVA+PPA, considerando a condição virgem destes materiais. Os decréscimos de recuperação seguem tendências aproximadamente lineares para o $\mathrm{CAP}+\mathrm{EVA}+\mathrm{PPA}$ e o $\mathrm{CAP}+\mathrm{PPA}$ ao longo de todo o espectro de temperaturas a $100 \mathrm{~Pa}$, o mesmo sendo observado nas temperaturas de até $64^{\circ} \mathrm{C}$ a $3.200 \mathrm{~Pa}$. Situação diferente ocorre com o CAP+EVA, para o qual o aumento da temperatura acarreta reduções 
significativas de $\mathrm{R}$ tanto a 100 quanto a 3.200 Pa. Os percentuais de recuperação do CAP 50/70 são nulos ou muito pequenos em todas as condições de temperatura e tensão, sendo não-nulos apenas nas temperaturas de 52 e $58^{\circ} \mathrm{C}$ a $100 \mathrm{~Pa}$.

Tabela 33 - Percentuais de recuperação (R) do CAP 50/70, do CAP+PPA, do CAP+EVA e do $C A P+E V A+P P A$ nos tempos de 1 e 9 s e na condição virgem

\begin{tabular}{ccccccccccc}
\hline \multirow{2}{*}{$\begin{array}{c}\text { Ligante } \\
\text { asfáltico }\end{array}$} & \multicolumn{4}{c}{$100 \mathrm{~Pa}(\mathrm{R} 100)$, em \% } & \multicolumn{4}{c}{$3.200 \mathrm{~Pa}(\mathrm{R} 3200)$, em \% } \\
\cline { 2 - 11 } & $52^{\circ} \mathrm{C}$ & $58^{\circ} \mathrm{C}$ & $64^{\circ} \mathrm{C}$ & $70^{\circ} \mathrm{C}$ & $76^{\circ} \mathrm{C}$ & $52^{\circ} \mathrm{C}$ & $58^{\circ} \mathrm{C}$ & $64^{\circ} \mathrm{C}$ & $70^{\circ} \mathrm{C}$ & $76^{\circ} \mathrm{C}$ \\
\hline $50 / 70$ & 4,1 & 0,8 & 0,0 & 0,0 & 0,0 & 0,0 & 0,0 & 0,0 & 0,0 & 0,0 \\
PPA & 34,4 & 23,9 & 14,9 & 7,5 & 2,6 & 27,7 & 11,8 & 0,7 & 0,0 & 0,0 \\
EVA & 63,6 & 62,1 & 48,0 & 20,0 & 6,8 & 58,8 & 45,9 & 28,3 & 2,0 & 0,0 \\
EVA+PPA & 48,0 & 42,3 & 34,7 & 28,5 & 22,9 & 36,3 & 20,1 & 6,5 & 0,0 & 0,0 \\
\hline
\end{tabular}

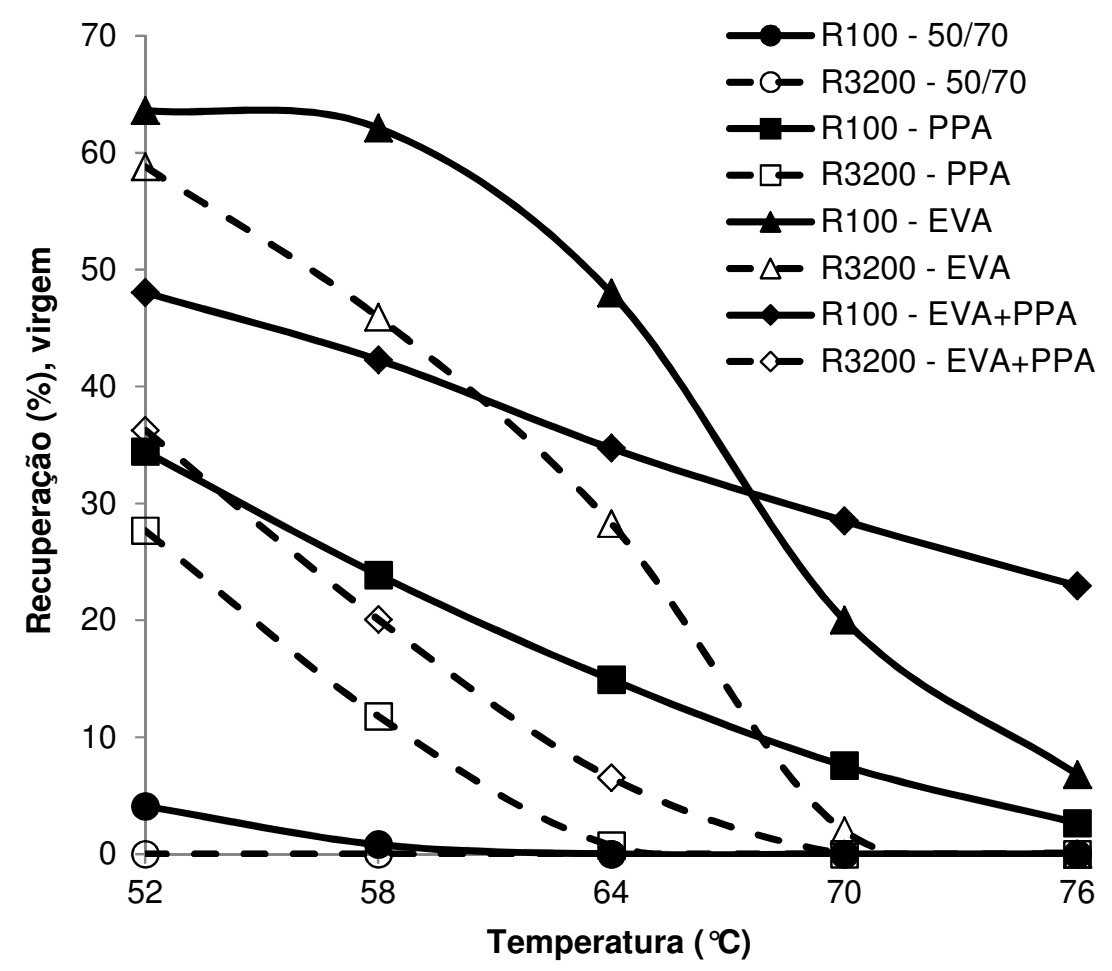

Figura 49 - Percentuais de recuperação $(\mathrm{R})$ do CAP 50/70, do CAP+PPA, do CAP+EVA e do CAP+EVA+PPA na condição virgem e nos tempos de 1 e $9 \mathrm{~s}$

A Tabela 34 apresenta as compliâncias não-recuperáveis do CAP 50/70 e dos ligantes asfálticos modificados com PPA, EVA e EVA+PPA, todos na condição virgem. A incorporação dos modificadores ocasiona uma redução na compliância não-recuperável dos ligantes asfálticos, especialmente no caso do EVA e do EVA+PPA. O CAP+EVA possui os valores mais baixos de $\mathrm{J}_{\mathrm{nr}}$ em todo o espectro de temperaturas a 3.200 $\mathrm{Pa}$, bem como nas temperaturas de até $64^{\circ} \mathrm{C}$ a $100 \mathrm{~Pa}$. O CAP+PPA possui, à exceção do ligante asfáltico puro, 
os maiores valores de $\mathrm{J}_{\mathrm{nr}}$ em todas as temperaturas a 100 e a $3.200 \mathrm{~Pa}$. O CAP+EVA e o $\mathrm{CAP}+\mathrm{EVA}+\mathrm{PPA}$ apresentam compliâncias não-recuperáveis de no máximo $3,6 \mathrm{kPa}^{-1}$ a $100 \mathrm{~Pa}$ e de no máximo $8,0 \mathrm{kPa}^{-1}$ a $3.200 \mathrm{~Pa}$, sendo que os maiores valores pertencem ao $\mathrm{CAP}+\mathrm{EVA}+\mathrm{PPA}$ nas temperaturas de até $64^{\circ} \mathrm{C}$ a $100 \mathrm{~Pa}$ e de até $70^{\circ} \mathrm{C}$ a $3.200 \mathrm{~Pa}$. O CAP puro apresenta compliâncias não-recuperáveis significativamente maiores do que 0 $\mathrm{CAP}+\mathrm{PPA}$, o CAP+EVA e o CAP+EVA+PPA, tanto a 100 quanto a $3.200 \mathrm{~Pa}$. Em linhas gerais, o CAP+EVA possui a menor suscetibilidade à deformação permanente por conta dos menores valores de $\mathrm{J}_{\mathrm{nr}}$ nas temperaturas de até $64^{\circ} \mathrm{C}$ a $100 \mathrm{~Pa}$ e em todas as temperaturas a 3.200 Pa. Da mesma maneira, o CAP+PPA possui a maior suscetibilidade à deformação permanente dentre os ligantes asfálticos modificados por conta dos maiores valores de $\mathrm{J}_{\mathrm{nr}}$ em todas as temperaturas a 100 e a $3.200 \mathrm{~Pa}$.

Tabela 34 - Compliâncias não-recuperáveis $\left(J_{n r}\right)$ do CAP 50/70, do CAP+PPA, do CAP+EVA e do CAP+EVA+PPA nos tempos de 1 e 9 s e na condição virgem

\begin{tabular}{cccccccccccc}
\hline \multirow{2}{*}{$\begin{array}{c}\text { Ligante } \\
\text { asfáltico }\end{array}$} & \multicolumn{4}{c}{$100 \mathrm{~Pa}\left(\mathrm{~J}_{\mathrm{nr}} 100\right), \mathrm{em} \mathrm{kPa}^{-1}$} & \multicolumn{5}{c}{$3.200 \mathrm{~Pa}\left(\mathrm{~J}_{\mathrm{nr}} 3200\right), \mathrm{em} \mathrm{kPa}^{-1}$} \\
\cline { 2 - 11 } & $52^{\circ} \mathrm{C}$ & $58^{\circ} \mathrm{C}$ & $64^{\circ} \mathrm{C}$ & $70^{\circ} \mathrm{C}$ & $76^{\circ} \mathrm{C}$ & $52^{\circ} \mathrm{C}$ & $58^{\circ} \mathrm{C}$ & $64^{\circ} \mathrm{C}$ & $70^{\circ} \mathrm{C}$ & $76{ }^{\circ} \mathrm{C}$ \\
\hline $50 / 70$ & 1,05 & 2,73 & 6,88 & 15,77 & 33,36 & 1,16 & 3,17 & 7,88 & 17,74 & 36,80 \\
PPA & 0,18 & 0,50 & 1,34 & 3,31 & 7,65 & 0,20 & 0,61 & 1,76 & 4,56 & 10,76 \\
EVA & 0,06 & 0,12 & 0,37 & 1,41 & 3,62 & 0,07 & 0,20 & 0,74 & 2,89 & 6,16 \\
EVA+PPA & 0,12 & 0,28 & 0,65 & 1,38 & 2,88 & 0,16 & 0,49 & 1,41 & 3,47 & 7,93 \\
\hline
\end{tabular}

A Figura 50 mostra os gráficos de $\mathrm{J}_{\mathrm{nr}}$ com a temperatura para o CAP+PPA, o CAP+EVA e o CAP+EVA+PPA, todos na condição virgem. A distinção entre os modificadores é difícil de ser realizada nas temperaturas de 52 e $58^{\circ} \mathrm{C}$ a 100 e a $3.200 \mathrm{~Pa}$, uma vez que os valores de $J_{n r}$ são parecidos (entre 0,06 e $0,61 \mathrm{kPa}^{-1}$ conforme Tabela 34) para todos os ligantes asfálticos modificados. Esta mesma situação é observada na temperatura de $70^{\circ} \mathrm{C}$ e na tensão de $100 \mathrm{~Pa}$, em que o CAP+EVA e o CAP+EVA+PPA possuem compliâncias não-recuperáveis praticamente semelhantes $\left(1,4 \mathrm{kPa}^{-1}\right)$. As compliâncias não-recuperáveis do CAP+PPA a 100 Pa e do CAP+EVA+PPA a 3.200 Pa são muito próximas entre si em todo o espectro de temperaturas, de modo que as duas formulações podem ser consideradas equivalentes, à luz destes resultados. O CAP+EVA apresenta, nas temperaturas acima de $64^{\circ} \mathrm{C}$ a $100 \mathrm{~Pa}$, incrementos maiores de $\mathrm{J}_{\mathrm{nr}}$ em comparação ao CAP+EVA+PPA, o que se reflete no cruzamento das curvas de ambos os materiais na temperatura de $70^{\circ} \mathrm{C}$.

Em uma análise dos resultados das Tabelas 33 e 34 e dos gráficos apresentados nas Figuras 49 e 50, todos referentes aos materiais virgens, visualiza-se que o CAP+EVA 
possui os maiores percentuais de recuperação nas temperaturas de até $70^{\circ} \mathrm{C}$ e as menores compliâncias não-recuperáveis em todo o espectro de temperaturas a $3.200 \mathrm{~Pa}$, bem como nas temperaturas de até $64^{\circ} \mathrm{C}$ a $100 \mathrm{~Pa}$. O CAP+PPA apresenta, à exceção do material puro, os menores percentuais de recuperação e as maiores compliâncias não-recuperáveis em todas as temperaturas a 100 e a $3.200 \mathrm{~Pa}$. O CAP+EVA+PPA possui, em comparação ao CAP+EVA, compliâncias não-recuperáveis menores e percentuais de recuperação maiores apenas nas temperaturas de 70 e $76^{\circ} \mathrm{C}$ a $100 \mathrm{~Pa}$, o contrário ocorrendo nas demais condições de temperatura e tensão.

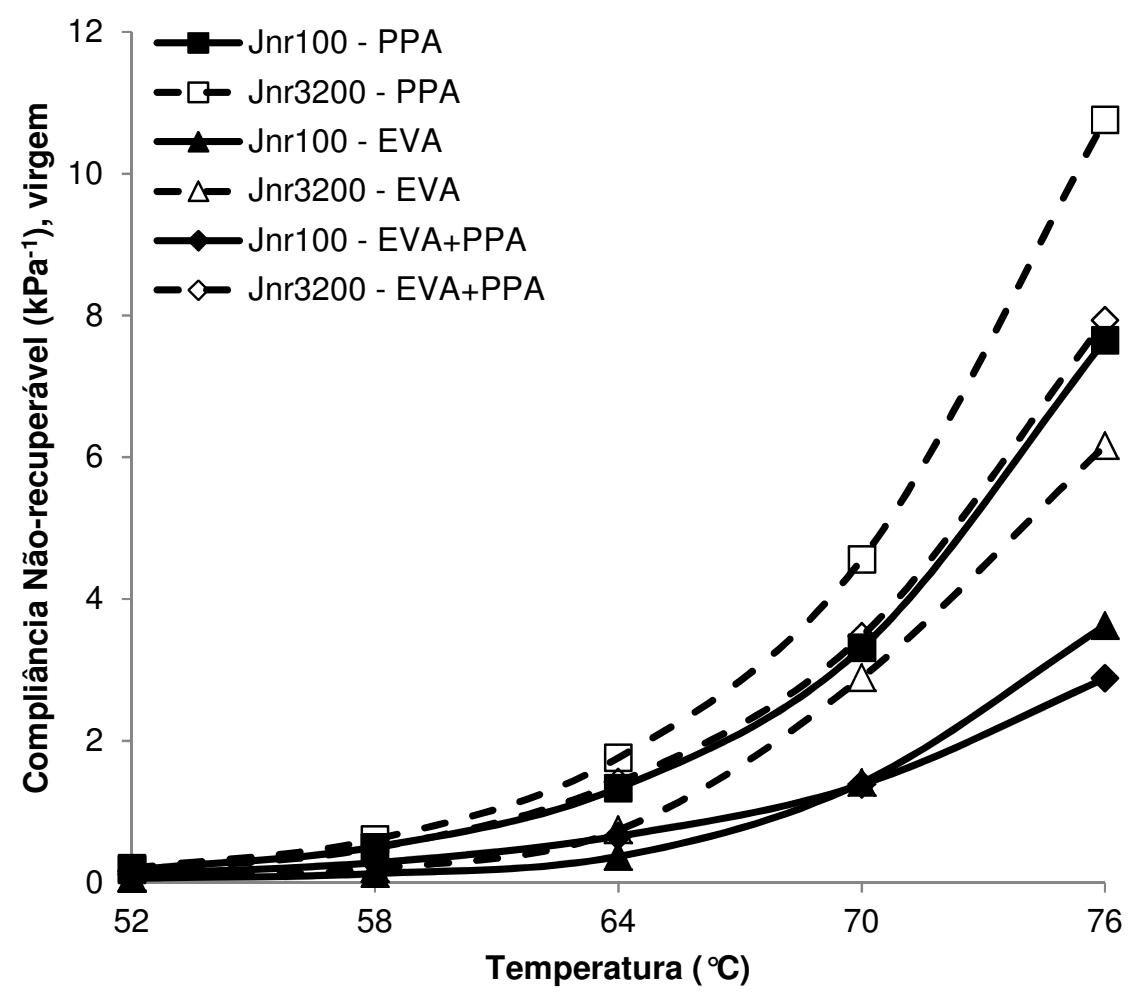

Figura 50 - Compliâncias não-recuperáveis $\left(\mathrm{J}_{\mathrm{nr}}\right)$ do CAP+PPA, do CAP+EVA e do CAP+EVA+PPA na condição virgem e nos tempos de 1 e $9 \mathrm{~s}$

A Tabela 35 apresenta os percentuais de recuperação do CAP 50/70 e dos ligantes asfálticos modificados com PPA, EVA e EVA+PPA, todos na condição envelhecida a curto prazo. De uma maneira geral, o envelhecimento proporciona um aumento nos percentuais de recuperação dos ligantes asfálticos, sobretudo dos materiais modificados. O CAP+EVA possui as maiores recuperações nas temperaturas de 52,58 e $64^{\circ} \mathrm{C}$, tanto a 100 quanto a $3.200 \mathrm{~Pa}$. À exceção do material puro, cujos percentuais de recuperação não superam os $13 \%$ a $100 \mathrm{~Pa} e$ os $9 \%$ a $3.200 \mathrm{~Pa}$, os menores valores para esta propriedade são encontrados no CAP+PPA nas temperaturas de até $70^{\circ} \mathrm{C}$ a 100 e a $3.200 \mathrm{~Pa}$. Interessante observar que o CAP+EVA apresenta, tanto a 100 quanto a $3.200 \mathrm{~Pa}$, os valores mais elevados de $\mathrm{R}$ nas temperaturas de 
até $64^{\circ} \mathrm{C}$ e os valores mais baixos para esta propriedade na temperatura de $76{ }^{\circ} \mathrm{C}$ a $100 \mathrm{~Pa} \mathrm{e}$ nas temperaturas de 70 e $76{ }^{\circ} \mathrm{C}$ a $3.200 \mathrm{~Pa}$. As recuperações do CAP+EVA estão entre 18 e $80 \%$ a $100 \mathrm{~Pa}$ e não ultrapassam os $79 \%$ a $3.200 \mathrm{~Pa}$. No caso do CAP+EVA+PPA, estas recuperações estão entre 45 e $70 \%$ a $100 \mathrm{~Pa}$ e entre 2 e $68 \%$ a $3.200 \mathrm{~Pa}$. Já para o CAP+PPA, os valores estão entre 24 e $64 \%$ a $100 \mathrm{~Pa}$ e não ultrapassam os $63 \%$ a $3.200 \mathrm{~Pa}$.

Tabela 35 - Percentuais de recuperação $(\mathrm{R})$ do CAP 50/70, do CAP+PPA, do CAP+EVA e do CAP+EVA+PPA nos tempos de 1 e 9 s e na condição envelhecida

\begin{tabular}{ccccccccccc}
\hline \multirow{2}{*}{$\begin{array}{c}\text { Ligante } \\
\text { asfáltico }\end{array}$} & \multicolumn{4}{c}{$100 \mathrm{~Pa}(\mathrm{R} 100), \mathrm{em} \%$} & \multicolumn{5}{c}{$3.200 \mathrm{~Pa}(\mathrm{R} 3200)$, em \% } \\
\cline { 2 - 11 } & $52^{\circ} \mathrm{C}$ & $58{ }^{\circ} \mathrm{C}$ & $64^{\circ} \mathrm{C}$ & $70^{\circ} \mathrm{C}$ & $76^{\circ} \mathrm{C}$ & $52^{\circ} \mathrm{C}$ & $58{ }^{\circ} \mathrm{C}$ & $64^{\circ} \mathrm{C}$ & $70^{\circ} \mathrm{C}$ & $76{ }^{\circ} \mathrm{C}$ \\
\hline $50 / 70$ & 12,4 & 5,8 & 1,0 & 0,0 & 0,0 & 8,9 & 0,5 & 0,0 & 0,0 & 0,0 \\
PPA & 63,7 & 55,2 & 44,6 & 34,1 & 24,0 & 62,4 & 49,8 & 31,3 & 12,1 & 0,8 \\
EVA & 79,8 & 78,4 & 59,5 & 34,6 & 18,1 & 78,3 & 72,5 & 48,6 & 8,4 & 0,0 \\
EVA+PPA & 69,3 & 66,7 & 56,4 & 52,8 & 45,2 & 67,9 & 60,1 & 39,6 & 16,3 & 2,6 \\
\hline
\end{tabular}

A Figura 51 mostra os gráficos do percentual de recuperação com a temperatura para o CAP 50/70, O CAP+PPA, O CAP+EVA e o CAP+EVA+PPA, todos na condição envelhecida a curto prazo. O CAP+EVA e o CAP+PPA apresentam recuperações muito próximas entre si na temperatura de $70^{\circ} \mathrm{C}$ e no nível de tensão de $100 \mathrm{~Pa}$, com valores de aproximadamente $34 \%$ para ambos os materiais conforme Tabela 35 . Os decréscimos do percentual de recuperação seguem tendências aproximadamente lineares para 0 CAP+EVA+PPA e o CAP+PPA na tensão de $100 \mathrm{~Pa}$, o mesmo não ocorrendo com o CAP+EVA. Para este ligante asfáltico, as reduções do percentual de recuperação são significativas tanto a 100 quanto a $3.200 \mathrm{~Pa}$, com maior destaque nas temperaturas de 58 , 64 e $70^{\circ} \mathrm{C}$. O CAP+EVA+PPA e o CAP+PPA também apresentam reduções significativas do percentual de recuperação a $3.200 \mathrm{~Pa}$, porém com intensidades menores do que a observada no CAP+EVA. No caso do CAP 50/70, o percentual de recuperação possui uma redução gradativa nas temperaturas de até $64^{\circ} \mathrm{C}$ a $100 \mathrm{~Pa}$ e de até $58^{\circ} \mathrm{C}$ a $3.200 \mathrm{~Pa}$, sendo nulo nas temperaturas superiores a estes valores.

A Tabela 36 apresenta as compliâncias não-recuperáveis do CAP 50/70 e dos ligantes asfálticos modificados com PPA, EVA e EVA+PPA, considerando a condição envelhecida destes materiais. $O$ envelhecimento na estufa de filme fino rotativo proporciona uma redução dos valores de $\mathrm{J}_{\mathrm{nr}}$, sobretudo dos ligantes asfálticos modificados. Assim como observado nos grupos anteriores, a distinção entre os modificadores é difícil de ser realizada nas temperaturas de 52 e $58^{\circ} \mathrm{C}$, uma vez que os valores de $J_{n r}$ são próximos entre si para todos os ligantes asfálticos. Dentre os materiais modificados, o CAP+PPA possui as maiores 
compliâncias não-recuperáveis em todas as temperaturas a 100 e a 3.200 Pa, exceções feitas à temperatura do $\mathrm{PG}$ a $100 \mathrm{~Pa}$ e às temperaturas de 70 e $76^{\circ} \mathrm{C}$ a $3.200 \mathrm{~Pa}$. O CAP+EVA apresenta as maiores compliâncias não-recuperáveis na temperatura de $76^{\circ} \mathrm{C}$, tanto a 100 $\left(1,62 \mathrm{kPa}^{-1}\right)$ quanto a $3.200 \mathrm{~Pa}\left(3,33 \mathrm{kPa}^{-1}\right)$. O CAP+EVA+PPA apresenta as menores compliâncias não-recuperáveis nas temperaturas de 64,70 e $76^{\circ} \mathrm{C}$ a 100 e a $3.200 \mathrm{~Pa}$. Em termos numéricos, os valores de $\mathrm{J}_{\mathrm{nr}}$ estão entre 0,02 e $3,33 \mathrm{kPa}^{-1}$ para o CAP+EVA e entre 0,02 e $2,58 \mathrm{kPa}^{-1}$ para o CAP+EVA+PPA.

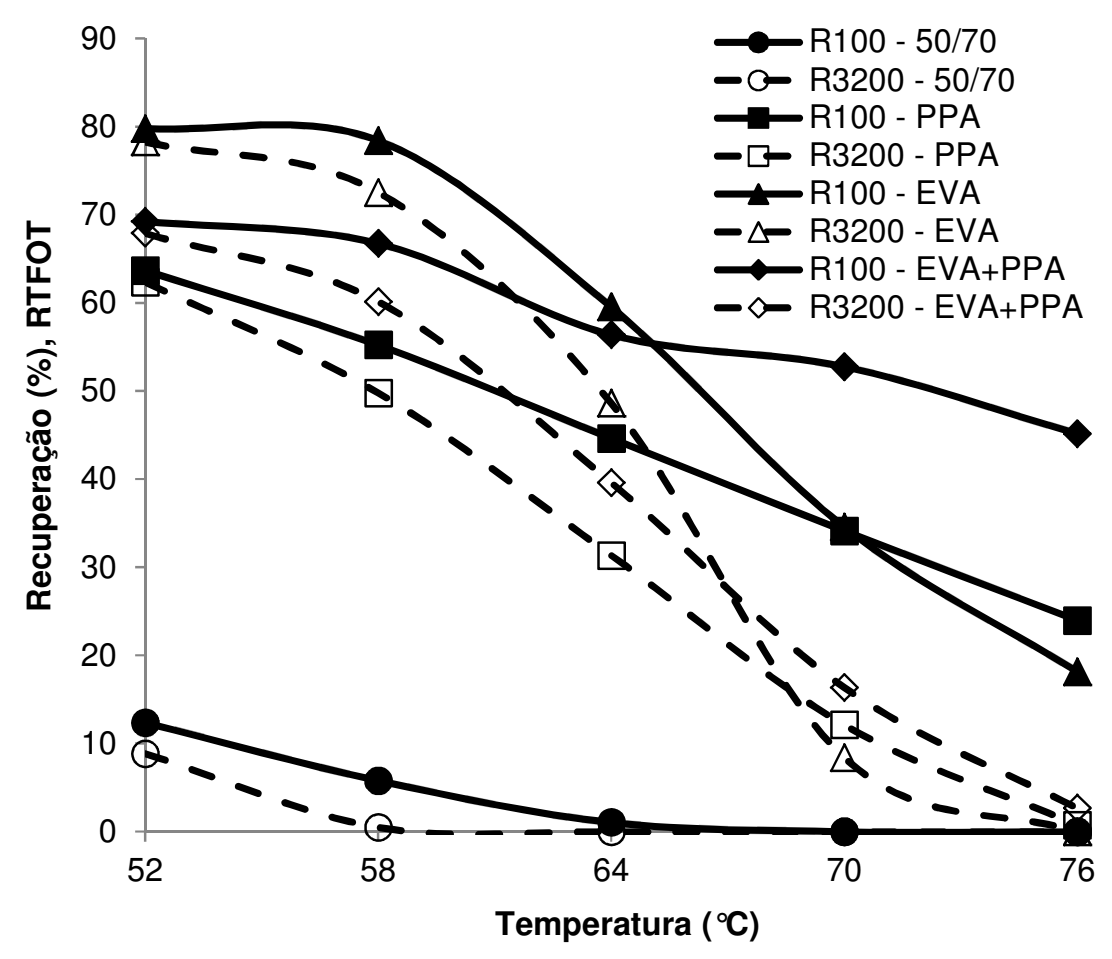

Figura 51 - Percentuais de recuperação $(R)$ do CAP 50/70, do CAP+PPA, do CAP+EVA e do CAP+EVA+PPA na condição envelhecida e nos tempos de 1 e $9 \mathrm{~s}$

Tabela 36 - Compliâncias não-recuperáveis $\left(J_{n r}\right)$ do CAP 50/70, do CAP+PPA, do CAP+EVA e do CAP+EVA+PPA nos tempos de 1 e 9 s e na condição envelhecida

\begin{tabular}{ccccccccccc}
\hline \multirow{2}{*}{$\begin{array}{c}\text { Ligante } \\
\text { asfáltico }\end{array}$} & \multicolumn{4}{c}{$100 \mathrm{~Pa}\left(\mathrm{~J}_{\mathrm{nr}} 100\right), \mathrm{em} \mathrm{kPa}^{-1}$} & \multicolumn{5}{c}{$3.200 \mathrm{~Pa}\left(\mathrm{~J}_{\mathrm{nr}} 3200\right), \mathrm{em} \mathrm{kPa}^{-1}$} \\
\cline { 2 - 11 } & $52^{\circ} \mathrm{C}$ & $58^{\circ} \mathrm{C}$ & $64^{\circ} \mathrm{C}$ & $70^{\circ} \mathrm{C}$ & $76^{\circ} \mathrm{C}$ & $52^{\circ} \mathrm{C}$ & $58^{\circ} \mathrm{C}$ & $64^{\circ} \mathrm{C}$ & $70^{\circ} \mathrm{C}$ & $76{ }^{\circ} \mathrm{C}$ \\
\hline $50 / 70$ & 0,33 & 0,92 & 2,44 & 5,96 & 13,53 & 0,35 & 1,02 & 2,78 & 6,79 & 15,23 \\
PPA & 0,03 & 0,08 & 0,23 & 0,59 & 1,48 & 0,03 & 0,09 & 0,29 & 0,86 & 2,38 \\
EVA & 0,02 & 0,04 & 0,14 & 0,54 & 1,62 & 0,02 & 0,05 & 0,24 & 1,37 & 3,33 \\
EVA+PPA & 0,02 & 0,05 & 0,12 & 0,25 & 0,56 & 0,03 & 0,07 & 0,23 & 0,88 & 2,58 \\
\hline
\end{tabular}

A Figura 52 mostra os gráficos de $\mathrm{J}_{\mathrm{nr}}$ com a temperatura para o CAP+PPA, o $\mathrm{CAP}+\mathrm{EVA}$ e o CAP+EVA+PPA, todos na condição envelhecida a curto prazo. Os valores 
de $J_{n r}$ para estes materiais são todos inferiores a $0,5 \mathrm{kPa}^{-1}$ nas temperaturas de até $64^{\circ} \mathrm{C}$ a 100 e a $3.200 \mathrm{~Pa}$, sendo que estes valores sofrem incrementos significativos nas temperaturas superiores a $64^{\circ} \mathrm{C}$ a $3.200 \mathrm{~Pa}$. O CAP+EVA e o CAP+PPA possuem compliâncias não-recuperáveis próximas entre si em todo o espectro de temperaturas a $100 \mathrm{~Pa}$, o mesmo ocorrendo com o CAP+EVA+PPA e o CAP+PPA a $3.200 \mathrm{~Pa}$. O $C A P+E V A+P P A$ apresenta incrementos de $J_{n r}$ inferiores aos observados no CAP+EVA e no CAP+PPA na tensão de $100 \mathrm{~Pa}$, de modo que as diferenças entre os valores de $\mathrm{J}_{\mathrm{nr}}$ dos materiais são significativas nas temperaturas de 70 e $76^{\circ} \mathrm{C}$. Tendo como base os resultados de compliância não-recuperável, é possível dizer que o CAP+EVA e o CAP+PPA são equivalentes em termos de formulação a $100 \mathrm{~Pa}$, o mesmo ocorrendo com o $C A P+E V A+P P A$ e o CAP+PPA a 3.200 Pa.

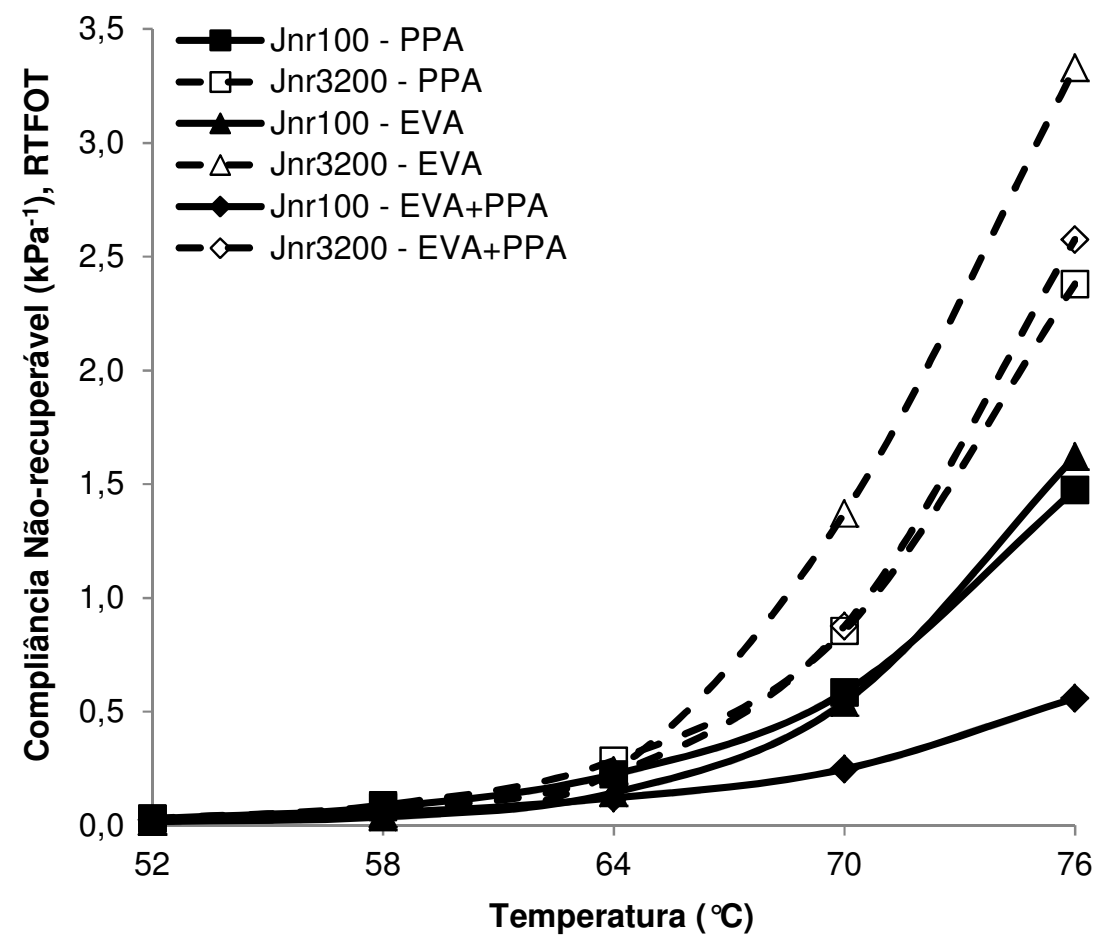

Figura 52 - Compliâncias não-recuperáveis $\left(\mathrm{J}_{\mathrm{nr}}\right)$ do CAP+PPA, do CAP+EVA e do CAP+EVA+PPA na condição envelhecida e nos tempos de 1 e $9 \mathrm{~s}$

Em uma avaliação dos resultados apresentados nas Tabelas 35 e 36 e nos gráficos das Figuras 51 e 52, referentes aos ligantes asfálticos envelhecidos a curto prazo, observa-se que o CAP+EVA possui os maiores percentuais de recuperação nas temperaturas de até $64^{\circ} \mathrm{C}$ a 100 e a $3.200 \mathrm{~Pa}$, bem como as maiores compliâncias não-recuperáveis na temperatura do $\mathrm{PG}\left(76^{\circ} \mathrm{C}\right)$. O CAP+EVA+PPA possui os maiores percentuais de recuperação nas temperaturas de 70 e $76^{\circ} \mathrm{C}$ a 100 e a $3.200 \mathrm{~Pa}$ e, ao mesmo tempo, as menores compliâncias não-recuperáveis na maioria das condições de temperatura e tensão. 0 
CAP+PPA apresenta, dentre os materiais modificados, os menores valores de $\mathrm{R}$ nas temperaturas de até $70^{\circ} \mathrm{C}$ a $100 \mathrm{~Pa}$ e de até $64^{\circ} \mathrm{C}$ a $3.200 \mathrm{~Pa}$, bem como os maiores valores de $\mathrm{J}_{\mathrm{nr}}$ nas temperaturas de 58,64 e $70^{\circ} \mathrm{C}$ a $100 \mathrm{~Pa}$ e de 58 e $64^{\circ} \mathrm{C}$ a $3.200 \mathrm{~Pa}$. Os percentuais de recuperação do CAP+EVA são superiores aos do CAP+EVA+PPA nas temperaturas de até $64^{\circ} \mathrm{C}$ a 100 e a $3.200 \mathrm{~Pa}$, o contrário ocorrendo nas temperaturas superiores a $64^{\circ} \mathrm{C}$. Em termos de compliância não-recuperável, o CAP+EVA+PPA possui valores menores para esta propriedade nas temperaturas acima de $64^{\circ} \mathrm{C}$ a $100 \mathrm{~Pa}$, sendo que o CAP+EVA possui resultados mais elevados nestas mesmas condições.

A Tabela 37 mostra as relações entre as compliâncias não-recuperáveis (parâmetro $R_{J}$ ) do CAP 50/70, do CAP+PPA, do CAP+EVA e do CAP+EVA+PPA. O envelhecimento a curto prazo proporciona uma redução entre 1,5 e 7,5 vezes no valor da compliância não-recuperável dos ligantes asfálticos. Em linhas gerais, as relações entre as compliâncias não-recuperáveis variam pouco com o incremento do nível de tensão de 100 para 3.200 Pa para um mesmo tipo de ligante asfáltico e uma mesma temperatura, o que indica que o efeito da tensão não é muito significativo na sensibilidade da maioria dos ligantes asfálticos ao envelhecimento a curto prazo. Estas variações são maiores no CAP+EVA+PPA e menores no CAP 50/70, ambos em todo o espectro de temperaturas. O CAP+PPA possui os valores mais elevados de $R_{J}$ em todas as temperaturas a $100 \mathrm{~Pa}$, bem como nas temperaturas de 52,70 e $76^{\circ} \mathrm{C}$ a $3.200 \mathrm{~Pa}$. O CAP puro apresenta os valores mais baixos de $R_{J}$ nas temperaturas de até $64^{\circ} \mathrm{C}$ a 100 e a $3.200 \mathrm{~Pa}$ e o CAP+EVA, os menores na temperatura de $76^{\circ} \mathrm{C}$ a $100 \mathrm{~Pa}$ e nas temperaturas de 70 e $76^{\circ} \mathrm{C}$ a $3.200 \mathrm{~Pa}$. O CAP+EVA+PPA apresenta, em comparação ao CAP+EVA, resultados mais elevados de $R_{J}$ para todas as temperaturas e níveis de tensão, o que indica uma maior sensibilidade deste ligante asfáltico ao envelhecimento a curto prazo.

Tabela 37 - Relações entre as compliâncias não-recuperáveis $\left(R_{J}\right)$ do CAP 50/70, do $\mathrm{CAP}+\mathrm{PPA}$, do CAP+EVA e do CAP+EVA+PPA nos tempos de 1 e $9 \mathrm{~s}$

\begin{tabular}{ccccccccccc}
\hline \multirow{2}{*}{$\begin{array}{c}\text { Ligante } \\
\text { asfáltico }\end{array}$} & \multicolumn{9}{c}{$100 \mathrm{~Pa}$} \\
\cline { 2 - 10 } & $52^{\circ} \mathrm{C}$ & $58^{\circ} \mathrm{C}$ & $64^{\circ} \mathrm{C}$ & $70^{\circ} \mathrm{C}$ & $76^{\circ} \mathrm{C}$ & $52^{\circ} \mathrm{C}$ & $58^{\circ} \mathrm{C}$ & $64^{\circ} \mathrm{C}$ & $70^{\circ} \mathrm{C}$ & $76^{\circ} \mathrm{C}$ \\
\hline $50 / 70$ & 3,2 & 3,0 & 2,8 & 2,6 & 2,5 & 3,3 & 3,1 & 2,8 & 2,6 & 2,4 \\
PPA & 6,0 & 6,3 & 5,9 & 5,7 & 5,2 & 6,7 & 6,8 & 6,2 & 5,3 & 4,5 \\
EVA & 3,4 & 3,4 & 2,6 & 2,6 & 2,2 & 3,6 & 4,0 & 3,1 & 2,1 & 1,9 \\
EVA+PPA & 4,9 & 5,1 & 5,4 & 5,6 & 5,1 & 6,3 & 7,2 & 6,2 & 4,0 & 3,1 \\
\hline
\end{tabular}

A Figura 53 ilustra os gráficos de $\mathrm{R}_{\mathrm{J}}$ com a temperatura para o CAP 50/70, o $\mathrm{CAP}+\mathrm{PPA}$, o $\mathrm{CAP}+\mathrm{EVA}$ e o $\mathrm{CAP}+\mathrm{EVA}+\mathrm{PPA}$. O CAP+PPA e o CAP+EVA+PPA apresentam 
valores de $R_{J}$ muito próximos entre si nas temperaturas de 70 e $76^{\circ} \mathrm{C}$ e a $100 \mathrm{~Pa}$, o mesmo sendo observado para o CAP 50/70 e o CAP+EVA nestas mesmas condições. No caso dos ligantes asfálticos modificados, o incremento do nível de tensão de 100 para $3.200 \mathrm{~Pa}$ acarreta um aumento do parâmetro $R_{\jmath}$ nas temperaturas de até $64^{\circ} \mathrm{C}$ e uma redução deste parâmetro nas temperaturas de 70 e $76^{\circ} \mathrm{C}$. No caso do ligante asfáltico puro, o incremento da tensão ocasiona alterações muito pequenas de $R_{J}$ para qualquer temperatura, embora o padrão de comportamento deste material (aumento de $R_{J}$ nas temperaturas mais baixas $e$ redução nas mais altas) tenha semelhanças com os comportamentos dos ligantes asfálticos modificados deste grupo.

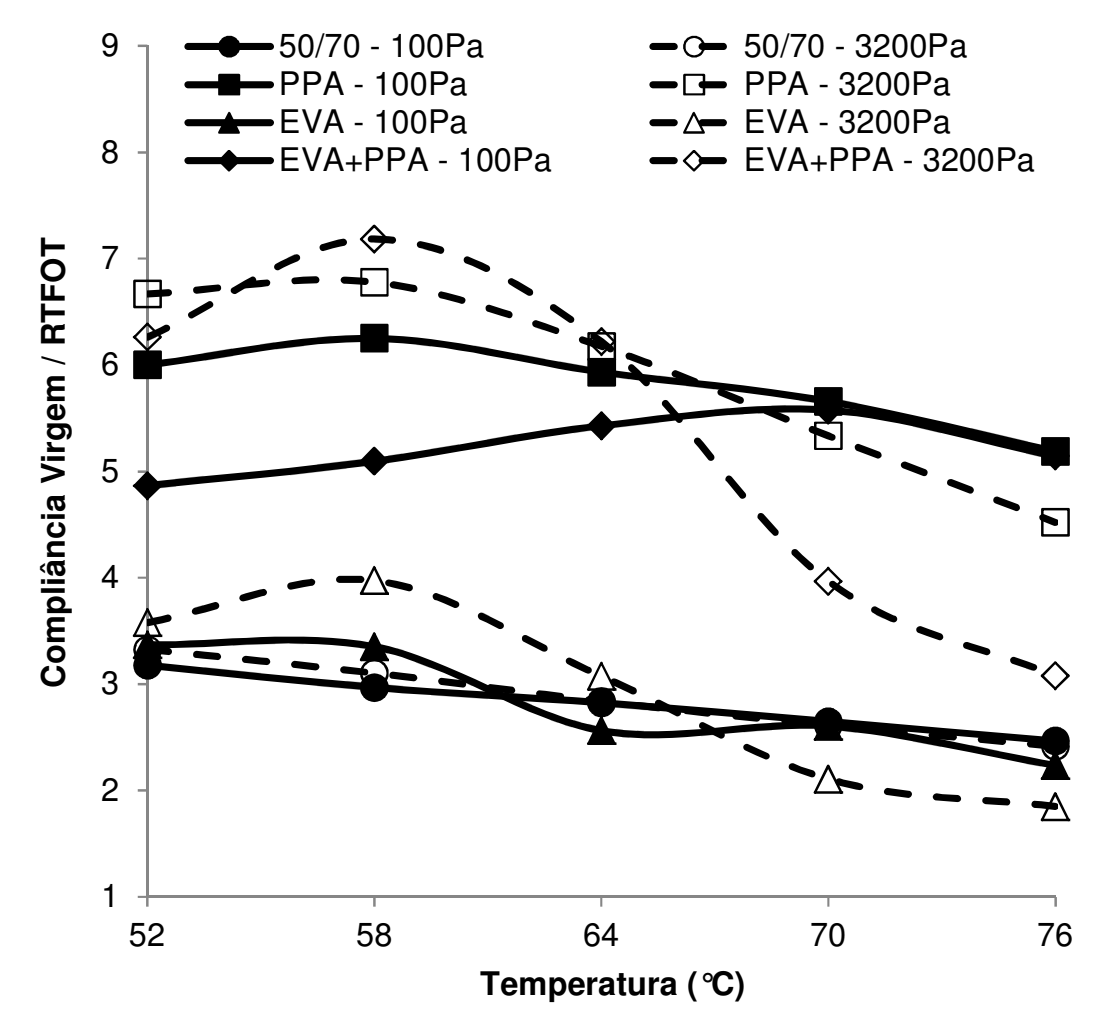

Figura 53 - Relações entre as compliâncias não-recuperáveis $\left(R_{J}\right)$ do CAP 50/70, do CAP+PPA, do CAP+EVA e do CAP+EVA+PPA nos tempos de 1 e $9 \mathrm{~s}$

A Tabela 38 apresenta as relações entre os percentuais de recuperação $\left(R_{R}\right)$ do CAP 50/70, do CAP+PPA, do CAP+EVA e do CAP+EVA+PPA, com a representação gráfica sendo mostrada na Figura 54. Alguns valores de $R_{R}$ não puderam ser calculados no nível de tensão de $3.200 \mathrm{~Pa}$ porque as recuperações dos ligantes asfálticos virgens são nulas nestas condições. Os incrementos do percentual de recuperação são muito próximos entre si para o $\mathrm{CAP}+\mathrm{EVA}$ e o CAP+EVA+PPA em todo o espectro de temperaturas a $100 \mathrm{~Pa}$, estando entre 1 e 3 vezes para ambos. Situação diferente ocorre com estes dois materiais no nível de tensão de 3.200 Pa, em que o parâmetro $R_{R}$ apresenta um crescimento maior para o CAP+EVA+PPA 
(resultados entre 1 e 7) em comparação ao CAP+EVA (resultados entre 1 e 5). O CAP+PPA possui os maiores valores de $R_{R}$ em todas as temperaturas a $100 \mathrm{~Pa}$, bem como nas temperaturas de até $64^{\circ} \mathrm{C}$ a 3.200 Pa. O CAP+EVA apresenta os menores valores de $R_{R}$ nas temperaturas de até $70^{\circ} \mathrm{C}$ a $100 \mathrm{~Pa}$ e nas temperaturas de até $64^{\circ} \mathrm{C}$ a $3.200 \mathrm{~Pa}$. O CAP+EVA+PPA apresenta incrementos do percentual de recuperação superiores aos do $\mathrm{CAP}+\mathrm{EVA}$ nas temperaturas de até $64^{\circ} \mathrm{C}$, tanto a 100 quanto a $3.200 \mathrm{~Pa}$.

Tabela 38 - Relações entre os percentuais de recuperação $\left(R_{R}\right)$ do CAP 50/70, do $\mathrm{CAP}+\mathrm{PPA}$, do CAP+EVA e do CAP+EVA+PPA nos tempos de 1 e $9 \mathrm{~s}$

\begin{tabular}{ccccccccccc}
\hline Ligante & \multicolumn{9}{c}{$100 \mathrm{~Pa}$} \\
\cline { 2 - 10 } asfáltico & $52^{\circ} \mathrm{C}$ & $58^{\circ} \mathrm{C}$ & $64^{\circ} \mathrm{C}$ & $70^{\circ} \mathrm{C}$ & $76{ }^{\circ} \mathrm{C}$ & $52^{\circ} \mathrm{C}$ & $58^{\circ} \mathrm{C}$ & $64^{\circ} \mathrm{C}$ & $70^{\circ} \mathrm{C}$ & $76{ }^{\circ} \mathrm{C}$ \\
\hline $50 / 70$ & 3,0 & 7,2 & - & - & - & - & - & - & - & - \\
PPA & 1,8 & 2,3 & 3,0 & 4,5 & 9,1 & 2,3 & 4,2 & 42,9 & - & - \\
EVA & 1,3 & 1,3 & 1,2 & 1,7 & 2,7 & 1,3 & 1,6 & 1,7 & 4,2 & - \\
EVA+PPA & 1,4 & 1,6 & 1,6 & 1,9 & 2,0 & 1,9 & 3,0 & 6,1 & - & - \\
\hline
\end{tabular}

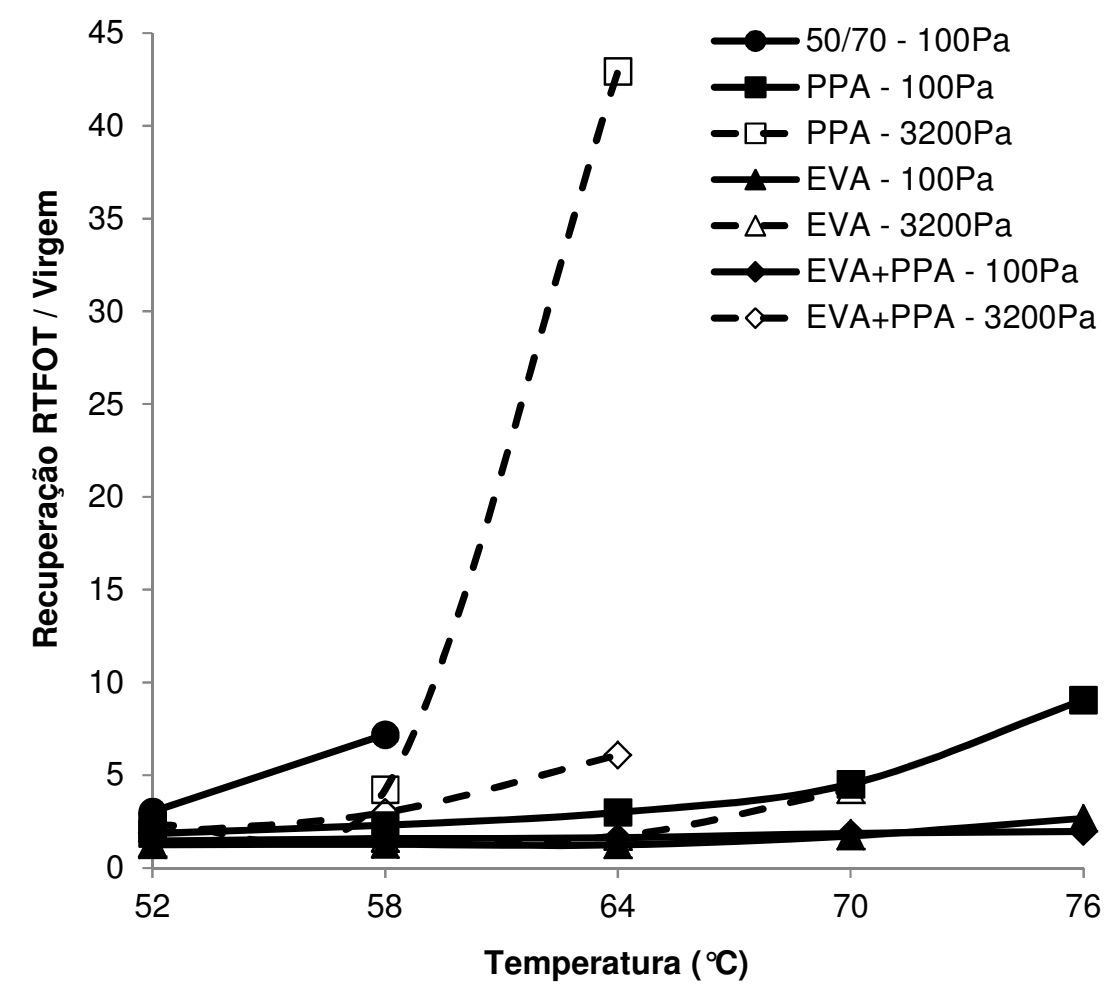

Figura 54 - Relações entre os percentuais de recuperação $\left(R_{R}\right)$ do CAP 50/70, do CAP+PPA, do CAP+EVA e do CAP+EVA+PPA nos tempos de 1 e $9 \mathrm{~s}$

Em uma avaliação dos resultados apresentados nas Tabelas 37 e 38 e nos gráficos das Figuras 53 e 54, observa-se que o CAP+PPA possui as maiores reduções de compliância 
162

não-recuperável (maiores valores de $R_{J}$ ) em todas as temperaturas a $100 \mathrm{~Pa}$ e nas temperaturas de 52,70 e $76{ }^{\circ} \mathrm{C}$ a $3.200 \mathrm{~Pa}$, bem como os maiores incrementos do percentual de recuperação (maiores valores de $R_{R}$ ) em todas as temperaturas a $100 \mathrm{~Pa}$ e nas temperaturas de até $64^{\circ} \mathrm{C}$ a $3.200 \mathrm{~Pa}$. O CAP+EVA apresenta as menores reduções de $J_{n r}$ (menor $R_{J}$ ) nas temperaturas de até $64^{\circ} \mathrm{C}$ a 100 e a $3.200 \mathrm{~Pa}$, bem como os menores aumentos de $\mathrm{R}$ (menor $\mathrm{R}_{\mathrm{R}}$ ) nas temperaturas de até $70^{\circ} \mathrm{C}$ a $100 \mathrm{~Pa}$ e de até $64^{\circ} \mathrm{C}$ a $3.200 \mathrm{~Pa}$. Estas análises permitem dizer que, de uma maneira geral, o CAP+PPA possui a maior sensibilidade ao envelhecimento a curto prazo e que o CAP+EVA possui a menor sensibilidade, à luz dos incrementos do percentual de recuperação e das reduções da compliância não-recuperável após o RTFOT. Por outro lado, resultados expressivos de $R_{J}$ e de $R_{R}$ indicam que o ligante asfáltico sofreu um acréscimo significativo de $R$ e uma redução acentuada de $J_{n r}$ após o envelhecimento a curto prazo, o que é bom para a resistência à deformação permanente. Deste ponto de vista, o $\mathrm{CAP}+\mathrm{PPA}$ apresenta melhores resultados do que o CAP+EVA por conta das maiores variações de $\mathrm{R}$ e de $\mathrm{J}_{\mathrm{nr}}$ após o envelhecimento a curto prazo.

A Tabela 39 mostra as diferenças percentuais entre as compliâncias $\left(\mathrm{J}_{\mathrm{nr}, \mathrm{diff}}\right)$ para 0 CAP 50/70, o CAP+PPA, o CAP+EVA e o CAP+EVA+PPA, tanto na condição virgem quanto na envelhecida a curto prazo. As duas formulações com EVA apresentam, na condição envelhecida a curto prazo e na temperatura do $P G$, resultados de $J_{n r \text {,diff }}$ superiores ao valor de 75\% estipulado pela AASHTO MP19, o que indica uma sensibilidade elevada destes materiais à tensão. O CAP+EVA+PPA apresenta as maiores diferenças percentuais em todo o espectro de temperaturas da condição virgem, o mesmo sendo observado nas temperaturas de 64, 70 e $76^{\circ} \mathrm{C}$ da condição envelhecida. O CAP+PPA apresenta, dentre os materiais modificados, as menores diferenças percentuais em todas as temperaturas e condições de envelhecimento. Os resultados do CAP 50/70 são inferiores aos do CAP+PPA em todas as temperaturas da condição virgem e nas temperaturas acima de $58^{\circ} \mathrm{C}$ da condição envelhecida. Em termos numéricos, os valores de $J_{\text {nr, diff }}$ estão entre 16 e 105\% para o CAP+EVA e entre 4 e 360\% para o $\mathrm{CAP}+\mathrm{EVA}+\mathrm{PPA}$, considerando as condições virgem e envelhecida de ambos os materiais. No caso do CAP 50/70, estes valores estão entre 11 e 16\% na condição virgem e entre 6 e $14 \%$ na envelhecida a curto prazo. No caso do CAP+PPA, os resultados não superam os $62 \%$ para ambas as condições.

A Figura 55 ilustra os gráficos de $J_{\text {nr,diff }}$ com a temperatura para o CAP 50/70, o $\mathrm{CAP}+\mathrm{PPA}$, o CAP+EVA e o CAP+EVA+PPA, considerando as condições virgem e envelhecida destes materiais. Os aumentos de $J_{\text {nr,diff }}$ seguem tendências aproximadamente lineares para o CAP+PPA em ambas as condições, o mesmo ocorrendo com o CAP+EVA+PPA na condição virgem. O CAP+EVA+PPA apresenta um crescimento expressivo de $J_{\text {nr,diff }}$ com a temperatura 
após o envelhecimento a curto prazo, ultrapassando os $200 \%$ na temperatura de $70^{\circ} \mathrm{C}$ e os $300 \%$ na temperatura de $76^{\circ} \mathrm{C}$. Embora em menor escala, este crescimento também é visualizado para o CAP+EVA+PPA na condição virgem, de modo que as diferenças percentuais deste material ultrapassam os $100 \%$ na temperatura de $64^{\circ} \mathrm{C}$ e os $150 \%$ nas temperaturas de 70 e $76^{\circ} \mathrm{C}$. Situação diferente ocorre com o CAP+EVA, para o qual os valores de $J_{\text {nr,diff }}$ sofrem aumentos até um valor máximo (105\% na condição virgem e $154 \%$ na envelhecida conforme Tabela 39) e, em seguida, diminuem de magnitude. As diferenças entre os valores de $J_{\text {nr,diff }}$ são pequenas para o CAP 50/70, de modo que o gráfico deste parâmetro não sofre grandes alterações após o envelhecimento a curto prazo.

Tabela 39 - Diferenças percentuais entre as compliâncias não-recuperáveis $\left(J_{\text {nr,diff }}\right)$ do $C A P$ 50/70, do CAP+PPA, do CAP+EVA e do CAP+EVA+PPA nos tempos de 1 e $9 \mathrm{~s}$

\begin{tabular}{ccccccccccc}
\hline \multirow{2}{*}{$\begin{array}{c}\text { Ligante } \\
\text { asfáltico }\end{array}$} & \multicolumn{4}{c}{ Materiais virgens } & \multicolumn{4}{c}{ Materiais envelhecidos (RTFOT) } \\
\cline { 2 - 11 } & $52^{\circ} \mathrm{C}$ & $58^{\circ} \mathrm{C}$ & $64^{\circ} \mathrm{C}$ & $70^{\circ} \mathrm{C}$ & $76^{\circ} \mathrm{C}$ & $52^{\circ} \mathrm{C}$ & $58^{\circ} \mathrm{C}$ & $64^{\circ} \mathrm{C}$ & $70^{\circ} \mathrm{C}$ & $76^{\circ} \mathrm{C}$ \\
\hline $50 / 70$ & 11,0 & 15,9 & 14,5 & 12,5 & 10,3 & 6,1 & 10,9 & 14,0 & 14,0 & 12,6 \\
PPA & 11,1 & 22,0 & 31,8 & 37,8 & 40,7 & 0,0 & 12,5 & 26,7 & 46,2 & 61,4 \\
EVA & 16,8 & 57,8 & 100,9 & 105,3 & 70,1 & 9,9 & 33,1 & 67,4 & 153,7 & 105,5 \\
EVA+PPA & 34,4 & 74,8 & 116,1 & 151,2 & 175,6 & 4,4 & 23,9 & 88,6 & 253,1 & 360,4 \\
\hline
\end{tabular}

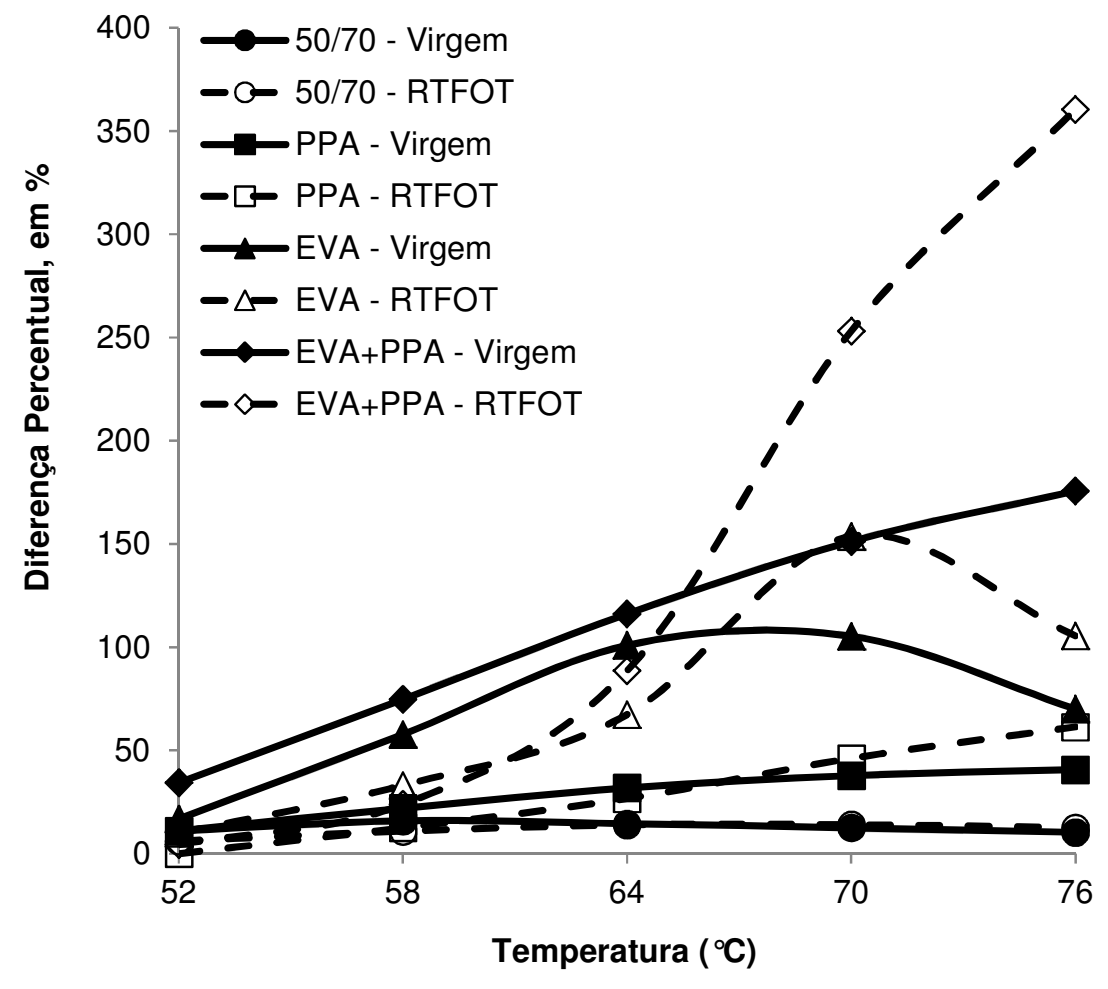

Figura 55 - Diferenças percentuais entre as compliâncias não-recuperáveis $\left(J_{n r, \text { diff }}\right)$ do CAP 50/70, do CAP+PPA, do CAP+EVA e do CAP+EVA+PPA nos tempos de 1 e $9 \mathrm{~s}$ 
Em uma avaliação geral das Tabelas 33 a 39 e das Figuras 49 a 55, é possível observar que o CAP+EVA possui os maiores percentuais de recuperação não-nulos e as menores compliâncias não-recuperáveis em todas as temperaturas a $3.200 \mathrm{~Pa}$ e nas temperaturas de até $64^{\circ} \mathrm{C}$ a $100 \mathrm{~Pa}$, ambos na condição virgem. Observa-se também que o CAP+PPA possui, nesta mesma condição, os menores percentuais de recuperação não-nulos e as maiores compliâncias não-recuperáveis em todas as temperaturas a 100 e a $3.200 \mathrm{~Pa}$. Após o envelhecimento a curto prazo, o CAP+EVA passa a apresentar os maiores valores de $\mathrm{R}$ nas temperaturas de até $64^{\circ} \mathrm{C}$ a 100 e a $3.200 \mathrm{~Pa}$, bem como o maior valor de $\mathrm{J}_{\mathrm{nr}}$ na temperatura de $76^{\circ} \mathrm{C}$ e para ambas as tensões. O CAP+PPA apresenta, na condição envelhecida a curto prazo, os menores valores de $\mathrm{R}$ e os maiores de $\mathrm{J}_{\mathrm{nr}}$ nas temperaturas de até $70^{\circ} \mathrm{C}$ a $100 \mathrm{~Pa}$ e de até $64^{\circ} \mathrm{C}$ a $3.200 \mathrm{~Pa}$. A análise da sensibilidade dos ligantes asfálticos modificados quanto ao envelhecimento (parâmetros $R_{J}$ e $R_{R}$ ) mostra que, em linhas gerais, o CAP+PPA possui a maior sensibilidade ao envelhecimento e que o CAP+EVA possui a menor sensibilidade, à luz das reduções de $J_{n r}$ e dos incrementos de $R$ após o RTFOT. O envelhecimento acarreta uma redução da sensibilidade dos ligantes asfálticos à tensão (redução de $\mathrm{J}_{\text {nr,diff) }}$ nas temperaturas de até $64^{\circ} \mathrm{C}$ e um aumento desta sensibilidade (aumento de $\left.J_{n r, d i f f}\right)$ nas temperaturas de 70 e $76^{\circ} \mathrm{C}$, de maneira mais intensa no caso do CAP+EVA+PPA e menos significativa no caso do CAP 50/70.

Uma comparação entre os resultados das formulações com EVA (Tabelas 33 a 39 e Figuras 49 a 55) permite observar que, na condição virgem, o CAP+EVA possui os maiores percentuais de recuperação e as menores compliâncias não-recuperáveis em todas as temperaturas a $3.200 \mathrm{~Pa}$, bem como nas temperaturas de até $64^{\circ} \mathrm{C}$ a $100 \mathrm{~Pa}$. Após o envelhecimento a curto prazo, o CAP+EVA+PPA apresenta valores maiores de $\mathrm{R}$ nas temperaturas de 70 e $76^{\circ} \mathrm{C}$ e menores de $\mathrm{J}_{\mathrm{nr}}$ nas temperaturas de 64,70 e $76^{\circ} \mathrm{C}$, tanto a 100 quanto a 3.200 Pa. As análises de sensibilidade ao envelhecimento $\left(R_{J}\right.$ e $\left.R_{R}\right)$ apontam que o CAP+EVA+PPA possui uma sensibilidade maior do que o CAP+EVA em quase todas as condições de temperatura e tensão, o que se traduz em uma maior redução de $J_{n r}$ e um maior incremento de $R$ para o CAP+EVA+PPA após o RTFOT. Além desta maior sensibilidade ao envelhecimento, os resultados do parâmetro $\mathrm{J}_{\text {nr,diff }}$ mostram que o $C A P+E V A+P P A$ também possui uma sensibilidade maior à tensão do que o CAP+EVA em todas as temperaturas da condição virgem, o mesmo sendo observado nas temperaturas de 64,70 e $76^{\circ} \mathrm{C}$ da condição envelhecida. As diferenças percentuais de ambos os ligantes asfálticos, entretanto, não atendem ao critério de sensibilidade da AASHTO MP19 $\left(\mathrm{J}_{\text {nr,diff }}<75 \%\right)$ na temperatura do PG a $3.200 \mathrm{~Pa}$ e na condição envelhecida a curto prazo, o que indica uma sensibilidade excessiva à tensão para as duas formulações com EVA. 


\subsubsection{CAP 50/70, $C A P+P P A, C A P+P E$ e $C A P+P E+P P A$}

A Tabela 40 apresenta os percentuais de recuperação do CAP 50/70, do $\mathrm{CAP}+\mathrm{PPA}$, do $\mathrm{CAP}+\mathrm{PE}$ e do $\mathrm{CAP}+\mathrm{PE}+\mathrm{PPA}$, considerando a condição virgem destes materiais. A incorporação dos modificadores acarreta, em linhas gerais, um aumento do percentual de recuperação dos ligantes asfálticos, especialmente no caso do PPA e do PE+PPA. O CAP+PPA possui os valores mais elevados de recuperação em todas as temperaturas a $100 \mathrm{~Pa}$, bem como nas temperaturas de até $64^{\circ} \mathrm{C}$ a $3.200 \mathrm{~Pa}$. O CAP+PE possui, dentre os ligantes asfálticos modificados, as menores recuperações em todas as temperaturas a $100 \mathrm{~Pa}$, o mesmo sendo observado nas temperaturas de até $64^{\circ} \mathrm{C}$ a $3.200 \mathrm{~Pa}$. A presença dos modificadores não é sentida nas temperaturas de 70 e $76^{\circ} \mathrm{C}$ a $3.200 \mathrm{~Pa}$, uma vez que os percentuais de recuperação dos ligantes asfálticos modificados e do CAP 50/70 são nulos nestas condições. No caso das duas formulações com PE, os percentuais de recuperação são de no máximo 16\% a 100 Pa e de no máximo $7 \%$ a 3.200 Pa para o CAP+PE, alcançando valores de até $29 \%$ a $100 \mathrm{~Pa}$ e de até $23 \%$ a 3.200 Pa para o CAP+PE+PPA. O CAP+PPA apresenta recuperações entre 2 e $35 \%$ a $100 \mathrm{~Pa}$, sendo de no máximo $28 \%$ a $3.200 \mathrm{~Pa}$. No caso do CAP 50/70, os percentuais de recuperação são nulos para a maioria das condições de temperatura e tensão, não o sendo apenas nas temperaturas de 52 e $58^{\circ} \mathrm{C}$ a $100 \mathrm{~Pa}$.

Tabela 40 - Percentuais de recuperação $(R)$ do CAP 50/70, do CAP+PPA, do CAP+PE e do $\mathrm{CAP}+\mathrm{PE}+\mathrm{PPA}$ nos tempos de 1 e $9 \mathrm{~s}$ e na condição virgem

\begin{tabular}{ccccccccccc}
\hline \multirow{2}{*}{$\begin{array}{c}\text { Ligante } \\
\text { asfáltico }\end{array}$} & \multicolumn{4}{c}{$100 \mathrm{~Pa}(\mathrm{R} 100), \mathrm{em} \%$} & \multicolumn{5}{c}{$3.200 \mathrm{~Pa}(\mathrm{R} 3200), \mathrm{em} \%$} \\
\cline { 2 - 10 } & $52^{\circ} \mathrm{C}$ & $58^{\circ} \mathrm{C}$ & $64^{\circ} \mathrm{C}$ & $70^{\circ} \mathrm{C}$ & $76^{\circ} \mathrm{C}$ & $52^{\circ} \mathrm{C}$ & $58^{\circ} \mathrm{C}$ & $64^{\circ} \mathrm{C}$ & $70^{\circ} \mathrm{C}$ & $76^{\circ} \mathrm{C}$ \\
\hline $50 / 70$ & 4,1 & 0,8 & 0,0 & 0,0 & 0,0 & 0,0 & 0,0 & 0,0 & 0,0 & 0,0 \\
PPA & 34,4 & 23,9 & 14,9 & 7,5 & 2,6 & 27,7 & 11,8 & 0,7 & 0,0 & 0,0 \\
PE & 15,5 & 10,4 & 6,8 & 4,1 & 0,7 & 6,9 & 0,0 & 0,0 & 0,0 & 0,0 \\
PE+PPA & 28,7 & 19,0 & 11,2 & 5,8 & 1,5 & 22,4 & 8,4 & 0,0 & 0,0 & 0,0 \\
\hline
\end{tabular}

A Figura 56 mostra os gráficos do percentual de recuperação para o CAP 50/70, o $\mathrm{CAP}+\mathrm{PPA}$, o $\mathrm{CAP}+\mathrm{PE}$ e o $\mathrm{CAP}+\mathrm{PE}+\mathrm{PPA}$, todos na condição virgem. A tendência linear de diminuição de $\mathrm{R}$ com a temperatura é fortemente visualizada para os ligantes asfálticos modificados e o nível de tensão de $100 \mathrm{~Pa}$, o mesmo não sendo observado para o CAP 50/70. $\mathrm{O} C A P+P E$ possui decréscimos menos significativos do percentual de recuperação a $100 \mathrm{~Pa}$ em comparação ao CAP+PE+PPA e ao CAP+PPA e, nas temperaturas de 70 e $76^{\circ} \mathrm{C}$,esta propriedade apresenta valores próximos entre si para os três materiais modificados. $O$ $\mathrm{CAP}+\mathrm{PE}+\mathrm{PPA}$ e o $\mathrm{CAP}+\mathrm{PPA}$ possuem reduções significativas do percentual de recuperação 
nas temperaturas de até $64^{\circ} \mathrm{C}$ a $3.200 \mathrm{~Pa}$, a partir da qual são observados valores nulos para os dois materiais. O CAP+PE possui recuperação não-nula apenas na temperatura mais baixa $\left(52^{\circ} \mathrm{C}\right)$ a $3.200 \mathrm{~Pa}$, não apresentando qualquer recuperação nas outras temperaturas deste mesmo nível de tensão.

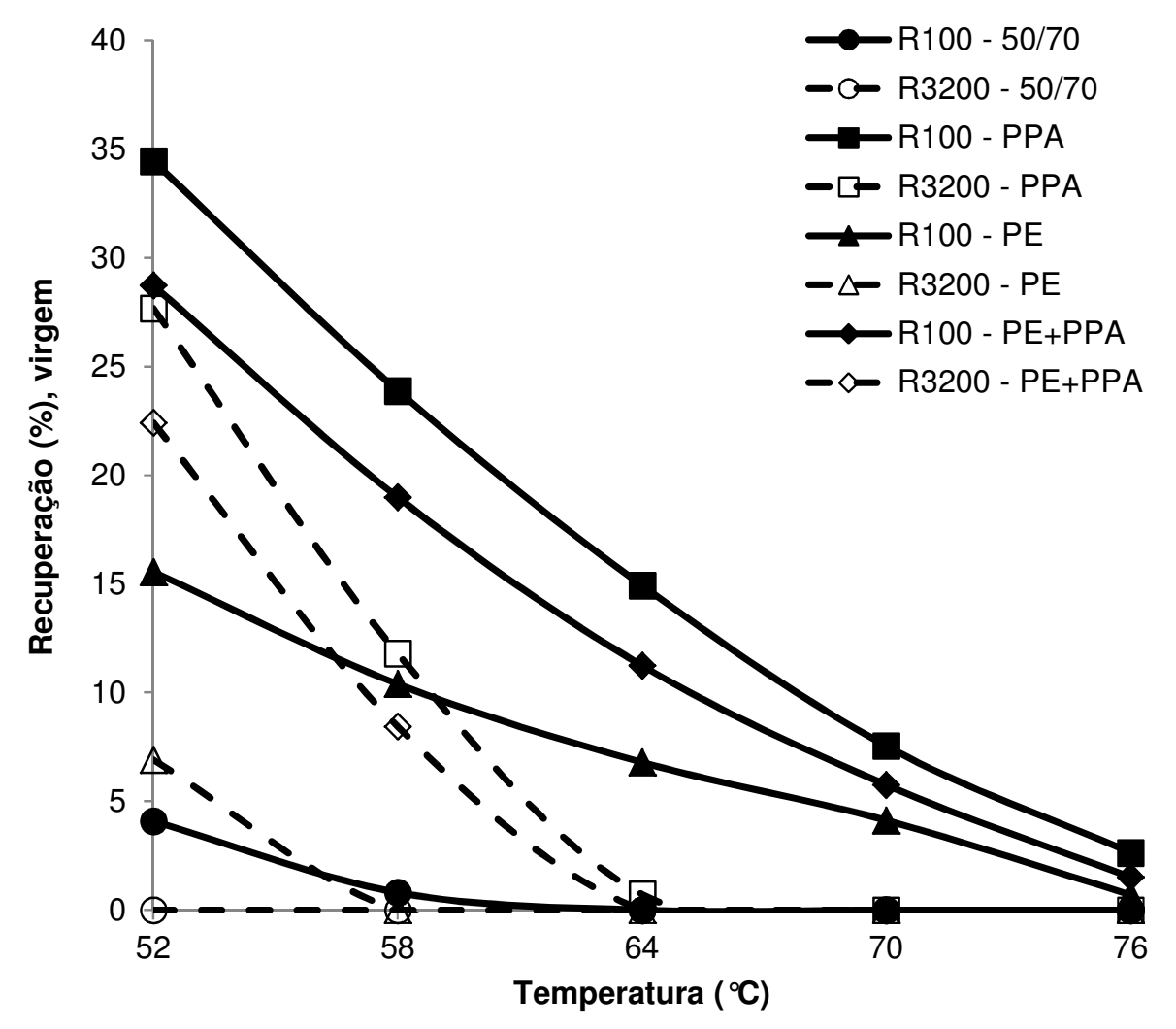

Figura 56 - Percentuais de recuperação (R) do CAP 50/70, do CAP+PPA, do CAP+PE e do $\mathrm{CAP}+\mathrm{PE}+\mathrm{PPA}$ na condição virgem e nos tempos de 1 e $9 \mathrm{~s}$

A Tabela 41 apresenta as compliâncias não-recuperáveis do CAP 50/70, do $\mathrm{CAP}+\mathrm{PPA}$, do $\mathrm{CAP}+\mathrm{PE}$ e do $\mathrm{CAP}+\mathrm{PE}+\mathrm{PPA}$, para materiais na condição virgem. $\mathrm{A}$ incorporação dos modificadores ao CAP 50/70 acarreta uma redução da compliância não-recuperável, especialmente no caso do $\mathrm{CAP}+\mathrm{PPA}$ e do $\mathrm{CAP}+\mathrm{PE}+\mathrm{PPA}$. O CAP+PE+PPA possui os valores mais baixos de $\mathrm{J}_{\mathrm{nr}}$ em todo o espectro de temperaturas, tanto a 100 quanto a $3.200 \mathrm{~Pa}$. O $\mathrm{CAP}+\mathrm{PE}$ apresenta, dentre os ligantes asfálticos modificados, os valores mais elevados de $\mathrm{J}_{\mathrm{nr}}$ em todas as temperaturas a 100 e a $3.200 \mathrm{~Pa}$. Em termos numéricos, as compliâncias do CAP+PE estão entre 0,2 e 10,0 kPa a $100 \mathrm{~Pa}$ e entre 0,3 e 13,1 $\mathrm{kPa}^{-1}$ a $3.200 \mathrm{~Pa}$. No caso do CAP+PE+PPA, estes valores estão entre 0,1 e 7,2 kPa ${ }^{-1}$ a $100 \mathrm{~Pa}$ e entre 0,1 e 9,4 $\mathrm{kPa}^{-1}$ a 3.200 Pa. No caso do CAP+PPA, as compliâncias não-recuperáveis estão entre 0,1 e 7,7 kPa-1 a $100 \mathrm{~Pa}$ e entre 0,2 e 10,8 $\mathrm{kPa}^{-1}$ a $3.200 \mathrm{~Pa}$. Já para o CAP 50/70, as compliâncias estão entre 1,0 e $33,4 \mathrm{kPa}^{-1}$ a $100 \mathrm{~Pa}$ e entre 1,0 e $36,8 \mathrm{kPa}^{-1}$ a $3.200 \mathrm{~Pa}$. 
Tabela 41 - Compliâncias não-recuperáveis $\left(J_{n r}\right)$ do CAP 50/70, do CAP+PPA, do CAP+PE e do $C A P+P E+P P A$ nos tempos de 1 e 9 s e na condição virgem

\begin{tabular}{ccccccccccc}
\hline \multirow{2}{*}{$\begin{array}{c}\text { Ligante } \\
\text { asfáltico }\end{array}$} & \multicolumn{4}{c}{$100 \mathrm{~Pa}\left(\mathrm{~J}_{\mathrm{nr}} 100\right), \mathrm{em} \mathrm{kPa}^{-1}$} & \multicolumn{4}{c}{$3.200 \mathrm{~Pa}\left(\mathrm{~J}_{\mathrm{nr}} 3200\right), \mathrm{em} \mathrm{kPa}^{-1}$} \\
\cline { 2 - 11 } & $52^{\circ} \mathrm{C}$ & $58^{\circ} \mathrm{C}$ & $64^{\circ} \mathrm{C}$ & $70^{\circ} \mathrm{C}$ & $76^{\circ} \mathrm{C}$ & $52^{\circ} \mathrm{C}$ & $58^{\circ} \mathrm{C}$ & $64^{\circ} \mathrm{C}$ & $70^{\circ} \mathrm{C}$ & $76{ }^{\circ} \mathrm{C}$ \\
\hline $50 / 70$ & 1,05 & 2,73 & 6,88 & 15,77 & 33,36 & 1,16 & 3,17 & 7,88 & 17,74 & 36,80 \\
PPA & 0,18 & 0,50 & 1,34 & 3,31 & 7,65 & 0,20 & 0,61 & 1,76 & 4,56 & 10,76 \\
PE & 0,29 & 0,79 & 1,96 & 4,49 & 9,84 & 0,34 & 0,96 & 2,48 & 5,91 & 13,02 \\
PE+PPA & 0,16 & 0,46 & 1,23 & 3,06 & 7,11 & 0,17 & 0,54 & 1,55 & 3,99 & 9,38 \\
\hline
\end{tabular}

A Figura 57 (página seguinte) ilustra os gráficos de $\mathrm{J}_{n r}$ com a temperatura para 0 $\mathrm{CAP}+\mathrm{PPA}$, o $\mathrm{CAP}+\mathrm{PE}$ e o $\mathrm{CAP}+\mathrm{PE}+\mathrm{PPA}$, todos na condição virgem. Os valores de $\mathrm{J}_{\mathrm{nr}}$ são pequenos (inferiores a $1,0 \mathrm{kPa}^{-1}$ conforme Tabela 41 ) para todos os ligantes asfálticos modificados nas temperaturas de até $58^{\circ} \mathrm{C}$ a 100 e a $3.200 \mathrm{~Pa}$, o que dificulta a distinção entre os modificadores. As compliâncias não-recuperáveis do CAP+PE+PPA e do CAP+PPA são próximas entre si ao longo de todo o espectro de temperaturas a $100 \mathrm{~Pa}$, de modo que as duas formulações podem ser consideradas equivalentes, à luz destes resultados. Situação parecida ocorre com o CAP+PE a 100 Pa e o CAP+PPA a 3.200 Pa, para os quais as diferenças entre as compliâncias não-recuperáveis são pequenas nas temperaturas de até $70^{\circ} \mathrm{C}$ e mais elevadas na temperatura de $76^{\circ} \mathrm{C}$. $\mathrm{O}$ incremento do nível de tensão de 100 para $3.200 \mathrm{~Pa}$ faz com que a distância entre as curvas do CAP+PE+PPA e do CAP+PPA seja maior ao longo de todo o espectro de temperaturas, com maior intensidade a 70 e a $76^{\circ} \mathrm{C}$.

Em uma avaliação dos resultados das Tabelas 40 e 41 e das Figuras 56 e 57 para os ligantes asfálticos modificados virgens, observa-se que o CAP+PE possui os menores percentuais de recuperação e as maiores compliâncias não-recuperáveis em todas as temperaturas a $100 \mathrm{~Pa}$, o mesmo sendo observado a 3.200 Pa. O CAP+PPA apresenta as maiores recuperações ao longo de todo o espectro de temperaturas a $100 \mathrm{~Pa}$ e nas temperaturas de até $64^{\circ} \mathrm{C}$ a $3.200 \mathrm{~Pa}$, sendo que as menores compliâncias não-recuperáveis são encontradas no CAP+PE+PPA tanto a 100 quanto a 3.200 Pa. Uma comparação entre os resultados das duas formulações com polietileno permite observar que o CAP+PE+PPA possui resultados melhores a 100 e a $3.200 \mathrm{~Pa}$, pois os percentuais de recuperação são maiores e as compliâncias não-recuperáveis são menores para este material em comparação ao CAP+PE.

A Tabela 42 mostra as os percentuais de recuperação do CAP 50/70 e dos ligantes asfálticos modificados com PPA, PE e PE+PPA, todos na condição envelhecida a curto prazo. De uma maneira geral, o envelhecimento proporciona um aumento nos percentuais de recuperação dos ligantes asfálticos, o que indica uma maior parcela elástica da 
deformação total sofrida pelos materiais. O CAP+PPA apresenta os valores mais elevados de $\mathrm{R}$ em todo o espectro de temperaturas a 100 e a $3.200 \mathrm{~Pa}$ e, à exceção do CAP 50/70, o $\mathrm{CAP}+\mathrm{PE}$ apresenta os valores mais baixos de $\mathrm{R}$ em praticamente todas as temperaturas a 100 e a $3.200 \mathrm{~Pa}$. O CAP+PE+PPA possui recuperações intermediárias em qualquer condição de temperatura e tensão, com valores entre 10 e 50\% a $100 \mathrm{~Pa}$ e de até $47 \%$ a $3.200 \mathrm{~Pa}$. No caso do CAP+PE, os percentuais de recuperação estão entre 4 e 31\% a $100 \mathrm{~Pa}$ e alcançam valores máximos de 23\% a 3.200 Pa. Estes percentuais estão entre 24 e 64\% a 100 Pa no caso do CAP+PPA, sendo de até 63\% a 3.200 Pa. O CAP 50/70 apresenta recuperações apenas nas temperaturas de até $64^{\circ} \mathrm{C}$ a 100 e de até $58^{\circ} \mathrm{C} 3.200 \mathrm{~Pa}$, com valores inferiores a $13 \%$ a $100 \mathrm{~Pa}$ e inferiores a $9 \%$ a $3.200 \mathrm{~Pa}$.

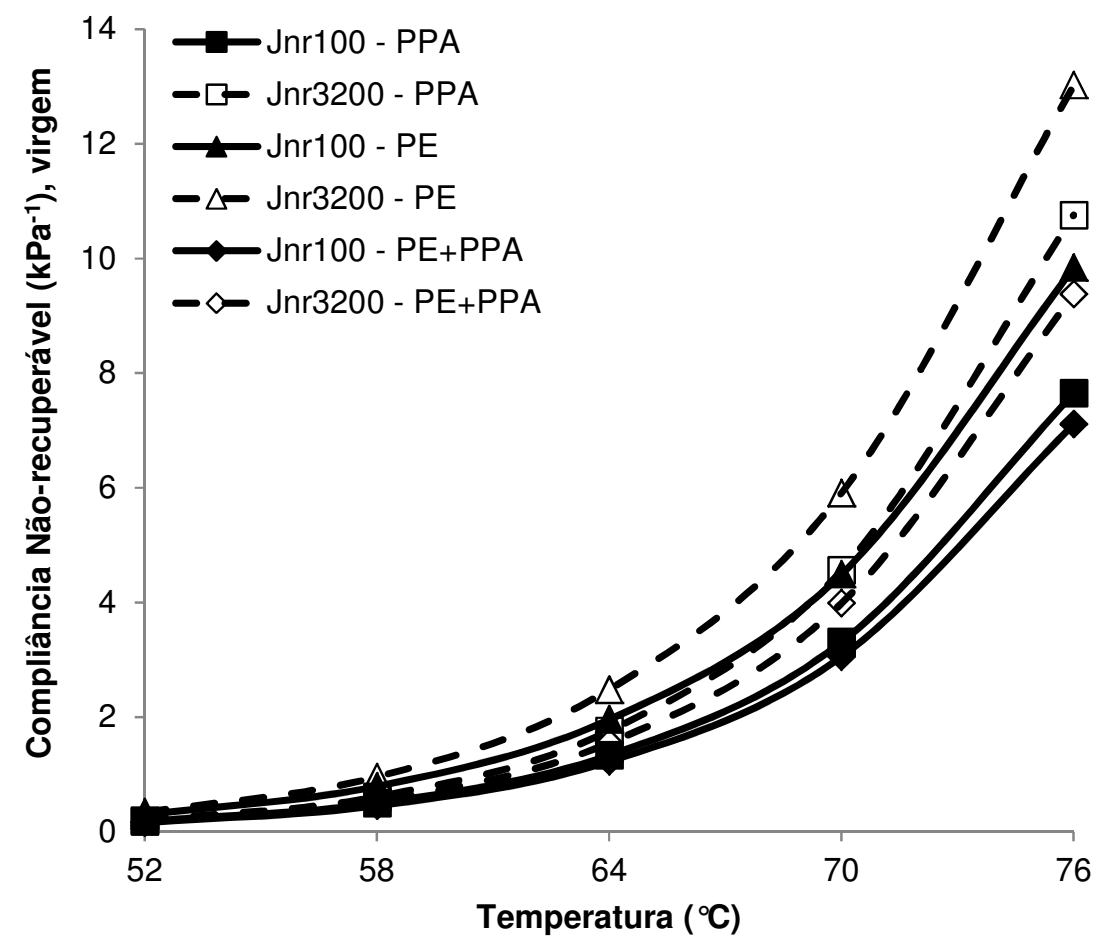

Figura 57- Compliâncias não-recuperáveis $\left(\mathrm{J}_{\mathrm{nr}}\right)$ do CAP+PPA, do CAP+PE e do $\mathrm{CAP}+\mathrm{PE}+\mathrm{PPA}$ na condição virgem e nos tempos de 1 e $9 \mathrm{~s}$

Tabela 42 - Percentuais de recuperação $(R)$ do CAP 50/70, do CAP+PPA, do CAP+PE e do $\mathrm{CAP}+\mathrm{PE}+\mathrm{PPA}$ nos tempos de 1 e 9 s e na condição envelhecida

\begin{tabular}{ccccccccccc}
\hline \multirow{2}{*}{$\begin{array}{c}\text { Ligante } \\
\text { asfáltico }\end{array}$} & \multicolumn{4}{c}{$100 \mathrm{~Pa}(\mathrm{R} 100), \mathrm{em} \%$} & \multicolumn{5}{c}{$3.200 \mathrm{~Pa}(\mathrm{R} 3200), \mathrm{em} \%$} \\
\cline { 2 - 11 } & $52^{\circ} \mathrm{C}$ & $58^{\circ} \mathrm{C}$ & $64^{\circ} \mathrm{C}$ & $70^{\circ} \mathrm{C}$ & $76^{\circ} \mathrm{C}$ & $52^{\circ} \mathrm{C}$ & $58^{\circ} \mathrm{C}$ & $64^{\circ} \mathrm{C}$ & $70^{\circ} \mathrm{C}$ & $76^{\circ} \mathrm{C}$ \\
\hline $50 / 70$ & 12,4 & 5,8 & 1,0 & 0,0 & 0,0 & 8,9 & 0,5 & 0,0 & 0,0 & 0,0 \\
PPA & 63,7 & 55,2 & 44,6 & 34,1 & 24,0 & 62,4 & 49,8 & 31,3 & 12,1 & 0,8 \\
PE & 30,3 & 21,7 & 14,8 & 9,1 & 4,8 & 22,6 & 10,5 & 1,5 & 0,0 & 0,0 \\
PE+PPA & 49,4 & 39,2 & 28,5 & 18,6 & 10,6 & 46,9 & 31,7 & 14,6 & 2,1 & 0,0 \\
\hline
\end{tabular}


A Figura 58 ilustra os gráficos de $\mathrm{R}$ com a temperatura para o CAP 50/70, o $\mathrm{CAP}+\mathrm{PPA}$, o CAP+PE e o CAP+PE+PPA, todos na condição envelhecida a curto prazo. Assim como na condição virgem, a tendência linear de redução do percentual de recuperação a $100 \mathrm{~Pa}$ é fortemente visualizada para todos os ligantes asfálticos modificados. Embora com menor destaque, esta tendência também é visualizada para os materiais modificados e as temperaturas de até $64^{\circ} \mathrm{C}$ a $3.200 \mathrm{~Pa}$, especialmente no caso do $\mathrm{CAP}+\mathrm{PE}$ e do CAP+PE+PPA. O incremento do nível de tensão acarreta reduções mais acentuadas do percentual de recuperação para os ligantes asfálticos, o que se reflete nas inclinações maiores dos gráficos. As recuperações dos ligantes asfálticos modificados são praticamente nulas nas condições mais críticas de ensaio (temperatura de $76^{\circ} \mathrm{C}$ e tensão de $3.200 \mathrm{~Pa}$ ), o mesmo sendo observado no CAP 50/70 para qualquer temperatura a 3.200 Pa.

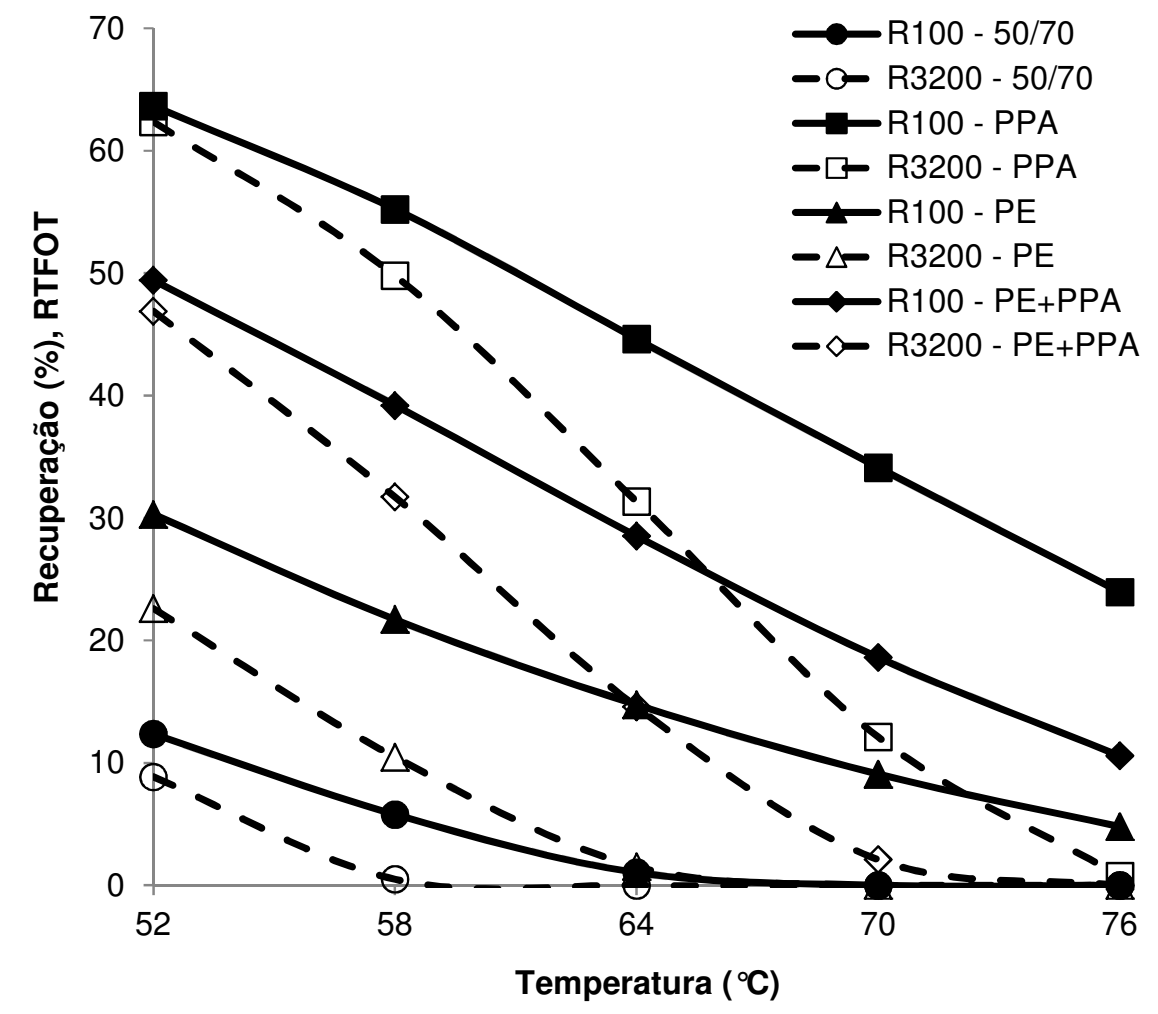

Figura 58 - Percentuais de recuperação $(R)$ do CAP 50/70, do CAP+PPA, do CAP+PE e do $\mathrm{CAP}+\mathrm{PE}+\mathrm{PPA}$ na condição envelhecida e nos tempos de 1 e $9 \mathrm{~s}$

A Tabela 43 apresenta as compliâncias não-recuperáveis do CAP 50/70, do $\mathrm{CAP}+\mathrm{PPA}$, do $\mathrm{CAP}+\mathrm{PE}$ e do $\mathrm{CAP}+\mathrm{PE}+\mathrm{PPA}$, para materiais na condição envelhecida a curto prazo. O envelhecimento proporciona uma redução nos valores de $\mathrm{J}_{\mathrm{nr}}$ dos ligantes asfálticos, o que indica uma menor suscetibilidade destes materiais à deformação permanente. $O$ CAP+PPA possui os valores mais baixos de compliância não-recuperável em todas as 
temperaturas a $100 \mathrm{~Pa}$, o mesmo ocorrendo a 3.200 Pa. Dentre os ligantes asfálticos modificados, o CAP+PE apresenta as maiores compliâncias não-recuperáveis em todo o espectro de temperaturas a 100 e a $3.200 \mathrm{~Pa}$, com valores inferiores a $4,0 \mathrm{kPa}^{-1}$ a $100 \mathrm{~Pa}$ e inferiores a 5,3 $\mathrm{kPa}^{-1}$ a $3.200 \mathrm{~Pa}$. Estes valores são de no máximo $2,5 \mathrm{kPa}^{-1}$ a $100 \mathrm{~Pa}$ e de no máximo $3,5 \mathrm{kPa}^{-1}$ a $3.200 \mathrm{~Pa}$ no caso do $\mathrm{CAP}+\mathrm{PE}+\mathrm{PPA}$, atingindo resultados de até $1,5 \mathrm{kPa}^{-1}$ a $100 \mathrm{~Pa}$ e de até 2,4 $\mathrm{kPa}^{-1}$ a 3.200 Pa para o CAP+PPA. As compliâncias não-recuperáveis do CAP 50/70 são significativamente maiores que as do CAP+PPA, do CAP+PE e do $\mathrm{CAP}+\mathrm{PE}+\mathrm{PPA}$, atingindo valores superiores a $13 \mathrm{kPa}^{-1}$ na temperatura de $76^{\circ} \mathrm{C}$ a $100 \mathrm{~Pa}$ e valores superiores a $15 \mathrm{kPa}^{-1}$ na temperatura de $76^{\circ} \mathrm{C}$ a $3.200 \mathrm{~Pa}$.

Tabela 43 - Compliâncias não-recuperáveis $\left(\mathrm{J}_{\text {nr }}\right)$ do CAP 50/70, do CAP+PPA, do CAP+PE e do $C A P+P E+P P A$ nos tempos de 1 e 9 s e na condição envelhecida

\begin{tabular}{ccccccccccc}
\hline \multirow{2}{*}{$\begin{array}{c}\text { Ligante } \\
\text { asfáltico }\end{array}$} & \multicolumn{4}{c}{$100 \mathrm{~Pa}\left(\mathrm{~J}_{\mathrm{nr}} 100\right), \mathrm{em} \mathrm{kPa}^{-1}$} & \multicolumn{5}{c}{$3.200 \mathrm{~Pa}\left(\mathrm{~J}_{\mathrm{nr}} 3200\right), \mathrm{em} \mathrm{kPa}^{-1}$} \\
\cline { 2 - 11 } & $52^{\circ} \mathrm{C}$ & $58^{\circ} \mathrm{C}$ & $64^{\circ} \mathrm{C}$ & $70^{\circ} \mathrm{C}$ & $76^{\circ} \mathrm{C}$ & $52^{\circ} \mathrm{C}$ & $58^{\circ} \mathrm{C}$ & $64^{\circ} \mathrm{C}$ & $70^{\circ} \mathrm{C}$ & $76^{\circ} \mathrm{C}$ \\
\hline $50 / 70$ & 0,33 & 0,92 & 2,44 & 5,96 & 13,53 & 0,35 & 1,02 & 2,78 & 6,79 & 15,23 \\
PPA & 0,03 & 0,08 & 0,23 & 0,59 & 1,48 & 0,03 & 0,09 & 0,29 & 0,86 & 2,38 \\
PE & 0,09 & 0,26 & 0,70 & 1,72 & 3,91 & 0,10 & 0,32 & 0,89 & 2,25 & 5,23 \\
PE+PPA & 0,04 & 0,13 & 0,37 & 1,00 & 2,52 & 0,05 & 0,15 & 0,46 & 1,34 & 3,50 \\
\hline
\end{tabular}

A Figura 59 (página seguinte) mostra os gráficos de $J_{\mathrm{nr}}$ com a temperatura para 0 $\mathrm{CAP}+\mathrm{PPA}$, o $\mathrm{CAP}+\mathrm{PE}$ e o $\mathrm{CAP}+\mathrm{PE}+\mathrm{PPA}$, todos na condição envelhecida a curto prazo. Não são observadas distinções significativas entre os modificadores nas temperaturas de 52 e $58^{\circ} \mathrm{C}$ a 100 e a $3.200 \mathrm{~Pa}$, uma vez que os valores de $\mathrm{J}_{\mathrm{nr}}$ são muito pequenos nestas condições. As compliâncias não-recuperáveis do CAP+PPA a 3.200 Pa e do CAP+PE+PPA a 100 Pa são próximas entre si em todo o espectro de temperaturas, de modo que, à luz destes resultados, as duas formulações podem ser consideradas equivalentes. O CAP+PE+PPA apresenta valores mais baixos de $\mathrm{J}_{\mathrm{nr}}$ do que o $\mathrm{CAP}+\mathrm{PE}$ em todo o espectro de temperaturas a $100 \mathrm{~Pa}$, o mesmo sendo observado a 3.200 Pa.

Em uma avaliação dos resultados apresentados nas Tabelas 42 e 43 e nos gráficos das Figuras 58 e 59, referentes aos ligantes asfálticos envelhecidos a curto prazo, observa-se que o CAP+PPA apresenta os maiores percentuais de recuperação e as menores compliâncias não-recuperáveis em todo o espectro de temperaturas a 100 e a 3.200 Pa. Dentre os materiais modificados deste grupo, o CAP+PE apresenta os menores percentuais de recuperação e as maiores compliâncias não-recuperáveis em qualquer condição de temperatura e tensão. Uma comparação entre os resultados do CAP+PE e do $\mathrm{CAP}+\mathrm{PE}+\mathrm{PPA}$ mostra que a formulação com PPA possui os melhores resultados tanto no 
percentual de recuperação quanto na compliância não-recuperável, pois os valores de $R$ são maiores e os valores de $J_{n r}$ são menores para este material em qualquer temperatura e nível de tensão.

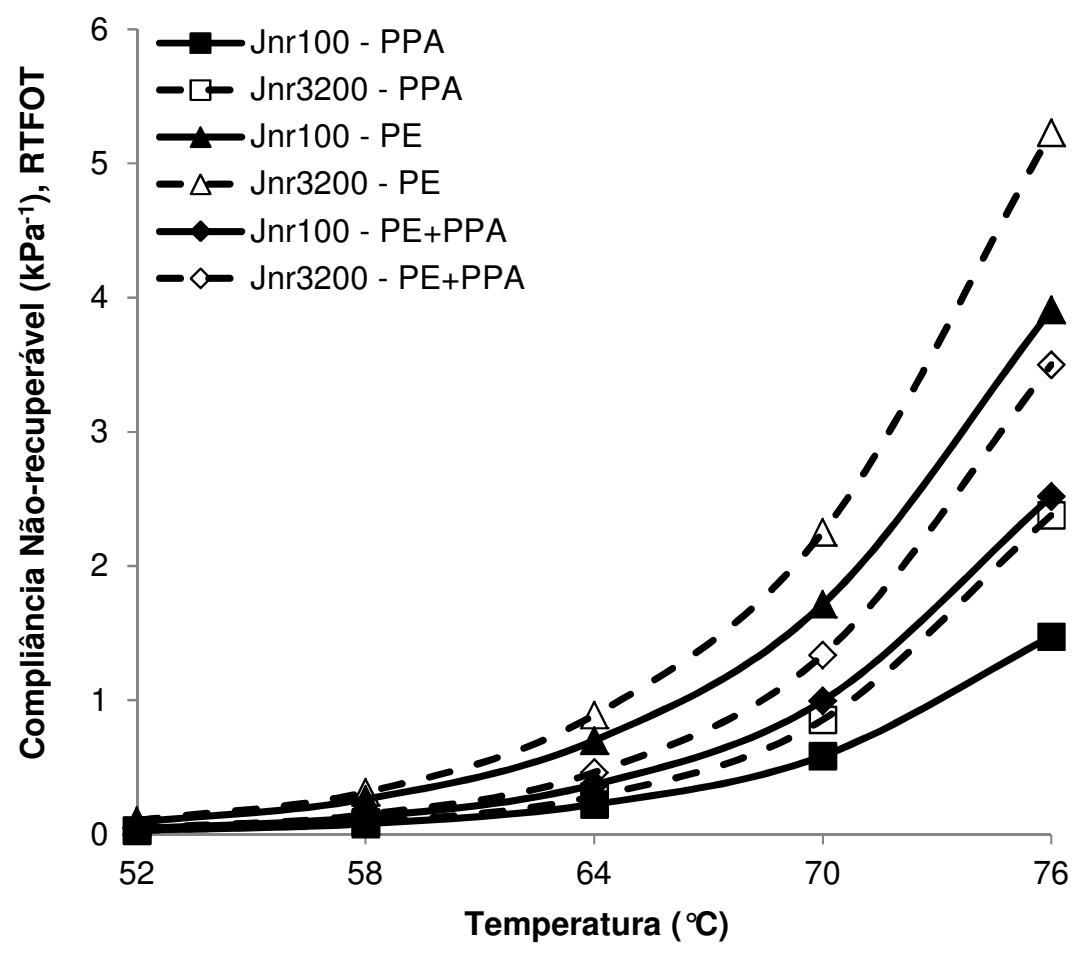

Figura 59 - Compliâncias não-recuperáveis $\left(\mathrm{J}_{\mathrm{nr}}\right)$ do CAP+PPA, do CAP+PE e do $\mathrm{CAP}+\mathrm{PE}+\mathrm{PPA}$ na condição envelhecida e nos tempos de 1 e $9 \mathrm{~s}$

A Tabela 44 apresenta as relações entre as compliâncias não-recuperáveis (parâmetro $\mathrm{R}_{\mathrm{J}}$ ) para o CAP 50/70, o CAP+PPA, o CAP+PE e o CAP+PE+PPA, com a representação gráfica sendo mostrada na Figura 60. O envelhecimento a curto prazo proporciona uma redução entre 2 e 7 vezes no valor da compliância não-recuperável dos ligantes asfálticos, sendo que a maioria dos resultados está situada entre 2 e 4 . O aumento do nível de tensão não acarreta alterações significativas nos valores de $R_{J}$ dos ligantes asfálticos, o que indica que o efeito do nível de tensão não é muito significativo na alteração da sensibilidade dos ligantes asfálticos ao envelhecimento a curto prazo. O CAP puro e o $\mathrm{CAP}+\mathrm{PE}$ possuem valores semelhantes de $\mathrm{R}_{\mathrm{J}}$ em todo o espectro de temperaturas a $100 \mathrm{~Pa}$ e, com o incremento da tensão para $3.200 \mathrm{~Pa}$, estes valores não apresentam diferenças significativas entre os materiais para uma mesma temperatura. O CAP+PPA possui os resultados mais elevados de $R_{J}$ (resultados entre 4 e 7) em todas as temperaturas a 100 e a 3.200 $\mathrm{Pa}$, de modo que este material pode ser considerado como o mais sensível ao envelhecimento a curto prazo, à luz das reduções de $J_{n r}$ após o RTFOT. O CAP+PE+PPA apresenta, em comparação ao CAP+PE, valores ligeiramente maiores de $R_{\jmath}$ em todo o 
espectro de temperaturas a 100 e a $3.200 \mathrm{~Pa}$, com resultados entre 2 e 4 para qualquer condição de temperatura e tensão.

Tabela 44 - Relações entre as compliâncias não-recuperáveis $\left(R_{J}\right)$ do CAP 50/70, do CAP+PPA, do CAP+PE e do CAP+PE+PPA nos tempos de 1 e $9 \mathrm{~s}$

\begin{tabular}{ccccccccccc}
\hline Ligante & \multicolumn{9}{c}{$100 \mathrm{~Pa}$} \\
\cline { 2 - 11 } asfáltico & $52^{\circ} \mathrm{C}$ & $58^{\circ} \mathrm{C}$ & $64^{\circ} \mathrm{C}$ & $70^{\circ} \mathrm{C}$ & $76^{\circ} \mathrm{C}$ & $52^{\circ} \mathrm{C}$ & $58^{\circ} \mathrm{C}$ & $64^{\circ} \mathrm{C}$ & $70^{\circ} \mathrm{C}$ & $76^{\circ} \mathrm{C}$ \\
\hline $50 / 70$ & 3,2 & 3,0 & 2,8 & 2,6 & 2,5 & 3,3 & 3,1 & 2,8 & 2,6 & 2,4 \\
PPA & 6,0 & 6,3 & 5,9 & 5,7 & 5,2 & 6,7 & 6,8 & 6,2 & 5,3 & 4,5 \\
PE & 3,2 & 3,0 & 2,8 & 2,6 & 2,5 & 3,2 & 3,0 & 2,8 & 2,6 & 2,5 \\
PE+PPA & 3,5 & 3,5 & 3,3 & 3,1 & 2,8 & 3,7 & 3,7 & 3,4 & 3,0 & 2,7 \\
\hline
\end{tabular}

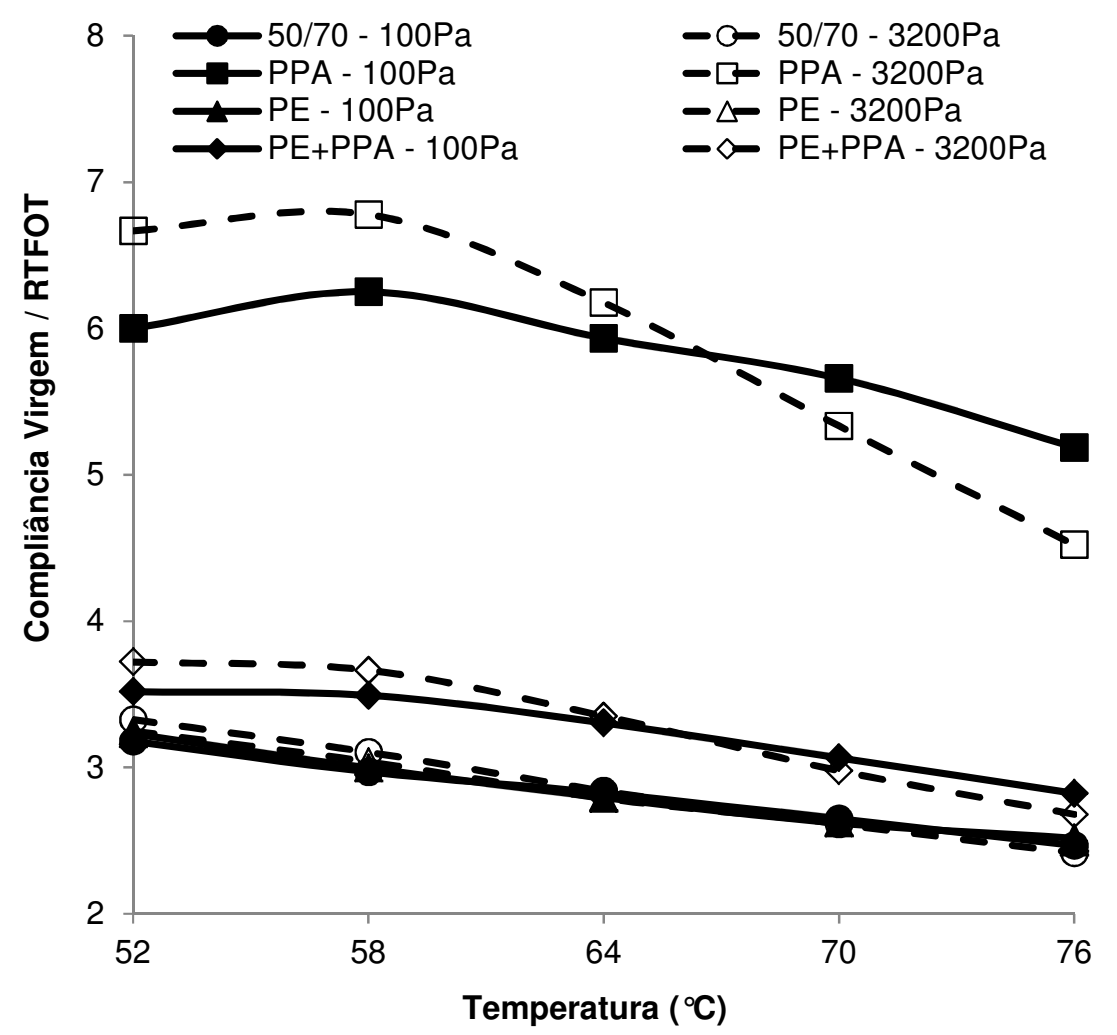

Figura 60 - Relações entre as compliâncias não-recuperáveis $\left(R_{J}\right)$ do CAP 50/70, do $\mathrm{CAP}+\mathrm{PPA}$, do CAP+PE e do CAP+PE+PPA nos tempos de 1 e $9 \mathrm{~s}$

A Tabela 45 apresenta as relações entre os percentuais de recuperação $\left(R_{R}\right)$ do CAP 50/70, do CAP+PPA, do CAP+PE e do CAP+PE+PPA, com a representação gráfica sendo mostrada na Figura 61. No caso dos materiais modificados, alguns valores de $R_{R}$ não puderam ser calculados no nível de tensão de 3.200 Pa porque os percentuais de recuperação virgens são nulos nestas condições. No caso do CAP 50/70, os valores puderam ser obtidos apenas nas temperaturas de 52 e $58^{\circ} \mathrm{C}$ a 100 Pa porque o material 
puro não apresenta recuperação nas outras temperaturas e níveis de tensão da condição virgem. O envelhecimento a curto prazo proporciona, na maioria das condições de temperatura e tensão, incrementos entre 1,5 e 7,5 vezes no valor do percentual de recuperação dos ligantes asfálticos. O CAP+PPA apresenta, dentre os ligantes asfálticos modificados, os valores mais elevados de $R_{R}$ nas temperaturas acima de $58^{\circ} \mathrm{C}$ a $100 \mathrm{~Pa} e$ na temperatura de $58^{\circ} \mathrm{C}$ a $3.200 \mathrm{~Pa}$, de modo que, em linhas gerais, este material pode ser classificado como o mais sensível ao envelhecimento a curto prazo. O CAP+PE possui os valores mais baixos de $R_{R}$ nas temperaturas de 64,70 e $76^{\circ} \mathrm{C}$ a $100 \mathrm{~Pa}$ (resultados entre 2 e 7) e o CAP+PE+PPA, os mais baixos nas temperaturas de 52 e $58^{\circ} \mathrm{C}$ a $3.200 \mathrm{~Pa}$ (resultados entre 2 e 4 ).

Tabela 45 - Relações entre os percentuais de recuperação $\left(R_{R}\right)$ do CAP 50/70, do $\mathrm{CAP}+\mathrm{PPA}$, do $\mathrm{CAP}+\mathrm{PE}$ e do $\mathrm{CAP}+\mathrm{PE}+\mathrm{PPA}$ nos tempos de 1 e $9 \mathrm{~s}$

\begin{tabular}{ccccccccccc}
\hline Ligante & \multicolumn{1}{c}{$100 \mathrm{~Pa}$} \\
\cline { 2 - 10 } asfáltico & $52^{\circ} \mathrm{C}$ & $58^{\circ} \mathrm{C}$ & $64^{\circ} \mathrm{C}$ & $70^{\circ} \mathrm{C}$ & $76^{\circ} \mathrm{C}$ & $52^{\circ} \mathrm{C}$ & $58^{\circ} \mathrm{C}$ & $64^{\circ} \mathrm{C}$ & $70^{\circ} \mathrm{C}$ & $76^{\circ} \mathrm{C}$ \\
\hline $50 / 70$ & 3,0 & 7,2 & - & - & - & - & - & - & - & - \\
PPA & 1,8 & 2,3 & 3,0 & 4,5 & 9,1 & 2,3 & 4,2 & 42,9 & - & - \\
PE & 1,9 & 2,1 & 2,2 & 2,2 & 6,8 & 3,3 & - & - & - & - \\
PE+PPA & 1,7 & 2,1 & 2,5 & 3,2 & 7,0 & 2,1 & 3,8 & - & - & - \\
\hline
\end{tabular}

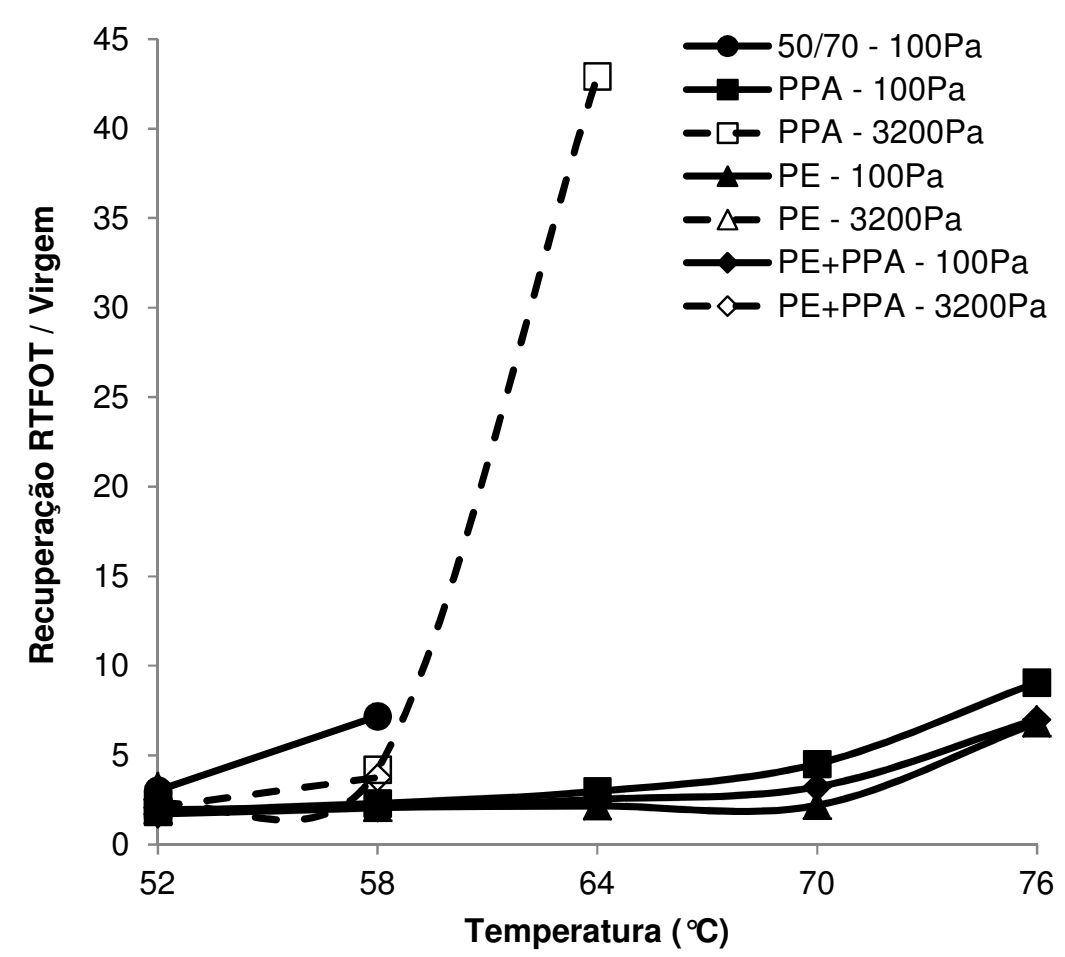

Figura 61 - Relações entre os percentuais de recuperação $\left(R_{R}\right)$ do CAP 50/70, do $\mathrm{CAP}+\mathrm{PPA}$, do $\mathrm{CAP}+\mathrm{PE}$ e do $\mathrm{CAP}+\mathrm{PE}+\mathrm{PPA}$ nos tempos de 1 e $9 \mathrm{~s}$ 
Em uma análise dos resultados das Tabelas 44 e 45 e das Figuras 60 e 61, visualiza-se que o CAP+PPA possui os valores mais elevados de $R_{J}$ em todo o espectro de temperaturas a 100 e a $3.200 \mathrm{~Pa}$, bem como os mais elevados de $R_{R}$ nas temperaturas acima de $58^{\circ} \mathrm{C}$ a $100 \mathrm{~Pa}$ e nas temperaturas de 58 e $64^{\circ} \mathrm{C}$ a $3.200 \mathrm{~Pa}$. O CAP+PE apresenta, em todas as temperaturas a 100 e a 3.200 Pa, valores de $R_{J}$ muito próximos aos do CAP 50/70, de modo que os dois materiais possuem sensibilidades parecidas quanto ao envelhecimento a curto prazo. Além dos resultados baixos para o parâmetro $R_{J}$, o CAP+PE possui também os valores mais baixos de $R_{R}$ nas temperaturas de 64,70 e $76^{\circ} \mathrm{C}$ a $100 \mathrm{~Pa}$, sendo que 0 $\mathrm{CAP}+\mathrm{PE}+\mathrm{PPA}$ possui estes valores mais baixos nas temperaturas de 52 e $58^{\circ} \mathrm{C}$ a $3.200 \mathrm{~Pa}$. De uma maneira geral, é possível dizer que o CAP+PPA possui a maior sensibilidade ao envelhecimento a curto prazo e que o CAP+PE possui a menor sensibilidade, levando-se em consideração os incrementos de $R$ e as reduções de $J_{n r}$ após o RTFOT. Por outro lado, valores elevados para os parâmetros $R_{J}$ e $R_{R}$ mostram que o percentual de recuperação aumentou significativamente e que a compliância não-recuperável reduziu de maneira acentuada com o envelhecimento, o que é favorável à resistência à deformação permanente. Deste ponto de vista, o CAP+PPA possui melhores resultados do que o CAP+PE por conta das maiores variações de suas propriedades após o envelhecimento a curto prazo.

A Tabela 46 mostra as diferenças percentuais entre as compliâncias $\left(J_{\text {nr,diff }}\right)$ para o CAP 50/70, o CAP+PPA, o CAP+PE e o CAP+PE+PPA, nas condições virgem e envelhecida a curto prazo. Os ligantes asfálticos deste grupo não apresentam, na condição envelhecida a curto prazo e na temperatura do $P G$, resultados de $J_{\text {nr,diff }}$ superiores ao valor de $75 \%$ estipulado pela norma AASHTO MP19, o que indica a baixa sensibilidade destes materiais à tensão. O CAP+PPA apresenta as diferenças percentuais mais elevadas nas temperaturas acima de $58^{\circ} \mathrm{C}$ da condição virgem, o mesmo ocorrendo nas temperaturas de 70 e $76^{\circ} \mathrm{C}$ da condição envelhecida. O CAP+PE+PPA possui, dentre os CAPs modificados, os menores valores de $J_{n r, d i f f}$ nas temperaturas acima de $58^{\circ} \mathrm{C}$ da condição virgem e na temperatura de $64^{\circ} \mathrm{C}$ da condição envelhecida. Em termos numéricos, as diferenças percentuais do $\mathrm{CAP}+\mathrm{PE}$ e do $C A P+P E+P P A$ estão entre 11 e $33 \%$ na condição virgem e entre 5 e $39 \%$ na envelhecida a curto prazo, sendo que os maiores valores são observados no CAP+PE em todas as temperaturas da condição virgem e nas temperaturas de até $64^{\circ} \mathrm{C}$ na condição envelhecida a curto prazo. O CAP 50/70 possui valores de $\mathrm{J}_{\text {nr,diff }}$ entre 6 e 15\% para ambas as condições e o CAP+PPA, valores de no máximo $62 \%$ nas duas condições.

A Figura 62 mostra os gráficos de $\mathrm{J}_{\mathrm{nr}, \text { diff }}$ com a temperatura para o CAP 50/70, o $\mathrm{CAP}+\mathrm{PPA}$, o $\mathrm{CAP}+\mathrm{PE}$ e o $\mathrm{CAP}+\mathrm{PE}+\mathrm{PPA}$. As diferenças percentuais do CAP+PE+PPA na condição virgem e do $C A P+P E$ nas condições virgem e envelhecida são próximas entre si em 
todo o espectro de temperaturas, especialmente a 64,70 e $76{ }^{\circ} \mathrm{C}$. O CAP+PPA apresenta um crescimento expressivo de $\mathrm{J}_{\text {nr,diff }}$ com a temperatura na condição envelhecida a curto prazo, sendo o único material a ultrapassar os $60 \%$ na temperatura de $76{ }^{\circ} \mathrm{C}$. O envelhecimento proporciona, em linhas gerais uma redução da sensibilidade à tensão nas temperaturas mais baixas e um aumento nas mais elevadas, especialmente no caso do CAP+PPA. As sensibilidades do CAP 50/70 e do CAP+PE ao nível de tensão foram pouco afetadas pelo envelhecimento, uma vez que não houve alterações significativas de $J_{n r \text {,diff }}$ para estes dois materiais após o RTFOT. Ou seja, o CAP+PPA apresentou as maiores reduções e aumentos da sensibilidade à tensão com o envelhecimento a curto prazo e os CAPs puro e modificado somente com PE, as menores reduções e aumentos desta sensibilidade.

Tabela 46 - Diferenças percentuais entre as compliâncias não-recuperáveis $\left(J_{\text {nr,diff }}\right)$ do CAP 50/70, do CAP+PPA, do CAP+PE e do CAP+PE+PPA nos tempos de 1 e $9 \mathrm{~s}$

\begin{tabular}{ccccccccccc}
\hline \multirow{2}{*}{$\begin{array}{c}\text { Ligante } \\
\text { asfáltico }\end{array}$} & \multicolumn{4}{c}{ Materiais virgens } & \multicolumn{4}{c}{ Materiais envelhecidos (RTFOT) } \\
\cline { 2 - 11 } & $52^{\circ} \mathrm{C}$ & $58^{\circ} \mathrm{C}$ & $64^{\circ} \mathrm{C}$ & $70^{\circ} \mathrm{C}$ & $76^{\circ} \mathrm{C}$ & $52^{\circ} \mathrm{C}$ & $58^{\circ} \mathrm{C}$ & $64^{\circ} \mathrm{C}$ & $70^{\circ} \mathrm{C}$ & $76^{\circ} \mathrm{C}$ \\
\hline $50 / 70$ & 11,0 & 15,9 & 14,5 & 12,5 & 10,3 & 6,1 & 10,9 & 14,0 & 14,0 & 12,6 \\
PPA & 11,1 & 22,0 & 31,8 & 37,8 & 40,7 & 0,0 & 12,5 & 26,7 & 46,2 & 61,4 \\
PE & 14,4 & 21,0 & 26,8 & 31,5 & 32,3 & 13,8 & 19,3 & 27,0 & 31,3 & 33,8 \\
PE+PPA & 11,1 & 18,9 & 26,3 & 30,4 & 31,8 & 5,1 & 13,3 & 24,5 & 34,3 & 38,9 \\
\hline
\end{tabular}

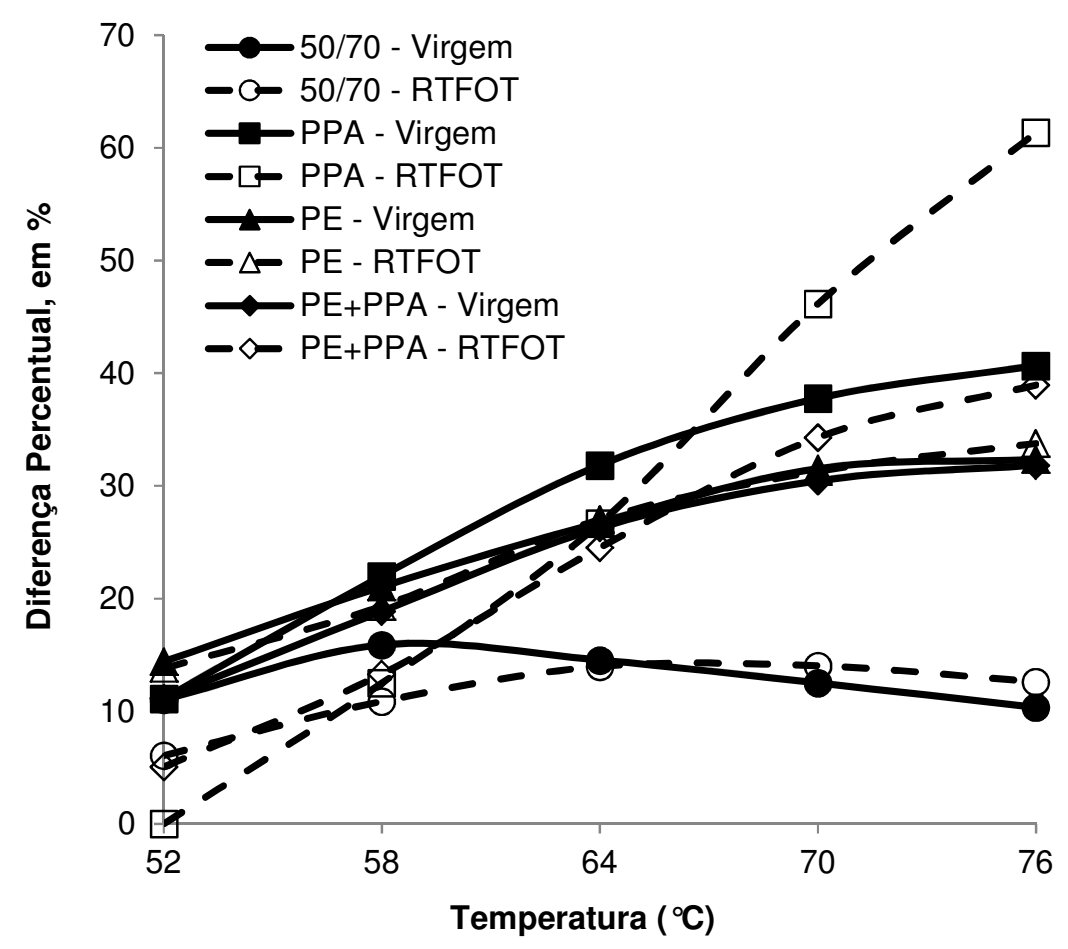

Figura 62 - Diferenças percentuais entre as compliâncias não-recuperáveis $\left(J_{\text {nr,diff }}\right)$ do CAP 50/70, do CAP+PPA, do CAP+PE e do CAP+PE+PPA nos tempos de 1 e $9 \mathrm{~s}$ 
Em uma avaliação geral dos resultados apresentados nas Tabelas 40 a 46 e nos gráficos das Figuras 56 a 62, observa-se que o CAP+PE possui os menores percentuais de recuperação e as maiores compliâncias não-recuperáveis nas temperaturas e níveis de tensão da condição virgem, sendo que o CAP+PPA possui os maiores percentuais de recuperação e o $\mathrm{CAP}+\mathrm{PE}+\mathrm{PPA}$ possui as menores compliâncias não-recuperáveis nas temperaturas e níveis de tensão desta mesma condição. Este quadro é alterado após o envelhecimento dos ligantes asfálticos na estufa de filme fino rotativo, de modo que o CAP+PPA apresenta os maiores valores de $\mathrm{R}$ e os menores de $\mathrm{J}_{\mathrm{nr}}$ em todo o espectro de temperaturas a 100 e a $3.200 \mathrm{~Pa}$ e o $\mathrm{CAP}+\mathrm{PE}$, os menores valores não-nulos de $\mathrm{R}$ e os maiores de $\mathrm{J}_{\mathrm{nr}}$ em qualquer temperatura e nível de tensão. A análise de sensibilidade dos ligantes asfálticos ao RTFOT (parâmetros $R_{J} e$ $R_{R}$ ) mostra que, em linhas gerais, o CAP+PPA possui a maior sensibilidade ao envelhecimento a curto prazo e que o CAP+PE possui a menor sensibilidade, à luz dos incrementos de $\mathrm{R}$ e das reduções de $J_{n r}$. As análises de sensibilidade à tensão (parâmetro $J_{n r, d i f f}$ ) apontam que, de uma maneira geral, o CAP+PPA possui a maior sensibilidade e que o $\mathrm{CAP}+\mathrm{PE}+\mathrm{PPA}$ possui a menor sensibilidade, tendo como base os incrementos de $\mathrm{J}_{\text {nr }}$ após o aumento do nível de tensão de 100 para $3.200 \mathrm{~Pa}$.

Em uma comparação dos resultados apresentados pelo CAP+PE e pelo $\mathrm{CAP}+\mathrm{PE}+\mathrm{PPA}$ em todas as propriedades e parâmetros, é possível observar que a formulação com PPA possui recuperações mais elevadas e compliâncias não-recuperáveis mais baixas em todas as temperaturas a 100 e a 3.200 Pa da condição virgem, o mesmo ocorrendo na condição envelhecida a curto prazo. Em termos da sensibilidade ao envelhecimento a curto prazo, o $\mathrm{CAP}+\mathrm{PE}$ apresenta valores mais baixos de $\mathrm{R}_{\mathrm{J}}$ em todo o espectro de temperaturas a 100 e a $3.200 \mathrm{~Pa}$, bem como valores mais baixos de $R_{R}$ nas temperaturas acima de $58^{\circ} \mathrm{C}$ e a $100 \mathrm{~Pa}$. No caso da sensibilidade à tensão, o $C A P+P E+P P A$ apresenta valores mais baixos para o parâmetro $J_{n r, d i f f}$ em todas as temperaturas da condição virgem e nas temperaturas acima de $58^{\circ} \mathrm{C}$ na condição envelhecida a curto prazo, embora ambos os materiais possuam diferenças percentuais inferiores a $40 \%$ em qualquer temperatura e condição. Com base nestes resultados, pode-se dizer que o CAP+PE possui uma menor sensibilidade ao envelhecimento a curto prazo e que o $\mathrm{CAP}+\mathrm{PE}+\mathrm{PPA}$ possui uma menor sensibilidade à tensão.

\subsection{6. $C A P$ 50/70, $C A P+P P A, C A P+S B R$ e $C A P+S B R+P P A$}

A Tabela 47 apresenta os percentuais de recuperação do CAP 50/70 e dos ligantes asfálticos modificados com PPA, SBR e SBR+PPA, todos na condição virgem. A 
incorporação dos modificadores ao material puro acarreta, de uma maneira geral, um aumento da recuperação dos ligantes asfálticos, o que indica uma maior parcela elástica da deformação total sofrida por estes materiais. Não são observadas distinções entre os modificadores nas temperaturas de 70 e $76^{\circ} \mathrm{C}$ a $3.200 \mathrm{~Pa}$, uma vez que os percentuais de recuperação dos ligantes asfálticos modificados são nulos nestas condições de temperatura e tensão. O CAP 50/70 apresenta recuperação não-nula apenas nas temperaturas de 52 e $58^{\circ} \mathrm{C}$ a $100 \mathrm{~Pa}$, não apresentando qualquer recuperação nas demais condições de temperatura e tensão. Um destaque especial pode ser dado ao CAP+SBR, o qual apresenta os maiores percentuais de recuperação nas temperaturas de 58 a $76{ }^{\circ} \mathrm{C}$ a $100 \mathrm{~Pa}$ e, ao mesmo tempo, os menores valores para esta propriedade nas temperaturas de 52 e $58^{\circ} \mathrm{C}$ a $3.200 \mathrm{~Pa}$ dentre os CAPs modificados. Outro destaque especial pode ser dado ao CAP+SBR+PPA, o qual possui os maiores percentuais de recuperação nas temperaturas de 58 e $64^{\circ} \mathrm{C}$ a $3.200 \mathrm{~Pa}$ e, ao mesmo tempo, os menores valores para esta propriedade nas temperaturas de $58,64,70$ e $76^{\circ} \mathrm{C} 100 \mathrm{~Pa}$ dentre os ligantes asfálticos modificados.

Tabela 47 - Percentuais de recuperação $(R)$ do CAP 50/70, do CAP+PPA, do CAP+SBR e do $\mathrm{CAP}+\mathrm{SBR}+\mathrm{PPA}$ nos tempos de 1 e $9 \mathrm{~s}$ e na condição virgem

\begin{tabular}{ccccccccccc}
\hline \multirow{2}{*}{$\begin{array}{c}\text { Ligante } \\
\text { asfáltico }\end{array}$} & \multicolumn{4}{c}{$100 \mathrm{~Pa}(\mathrm{R} 100), \mathrm{em} \%$} & \multicolumn{5}{c}{$3.200 \mathrm{~Pa}(\mathrm{R} 3200), \mathrm{em} \%$} \\
\cline { 2 - 11 } & $52^{\circ} \mathrm{C}$ & $58^{\circ} \mathrm{C}$ & $64^{\circ} \mathrm{C}$ & $70^{\circ} \mathrm{C}$ & $76^{\circ} \mathrm{C}$ & $52^{\circ} \mathrm{C}$ & $58^{\circ} \mathrm{C}$ & $64^{\circ} \mathrm{C}$ & $70^{\circ} \mathrm{C}$ & $76^{\circ} \mathrm{C}$ \\
\hline $50 / 70$ & 4,1 & 0,8 & 0,0 & 0,0 & 0,0 & 0,0 & 0,0 & 0,0 & 0,0 & 0,0 \\
PPA & 34,4 & 23,9 & 14,9 & 7,5 & 2,6 & 27,7 & 11,8 & 0,7 & 0,0 & 0,0 \\
SBR & 29,0 & 29,2 & 24,1 & 14,3 & 3,8 & 19,7 & 10,1 & 2,1 & 0,0 & 0,0 \\
SBR+PPA & 29,4 & 22,7 & 14,8 & 7,4 & 2,3 & 24,2 & 11,9 & 2,2 & 0,0 & 0,0 \\
\hline
\end{tabular}

A Figura 63 ilustra os gráficos de R com a temperatura para o CAP 50/70 e os ligantes asfálticos modificados com PPA, SBR e SBR+PPA, para materiais na condição virgem. O CAP+PPA e o CAP+SBR+PPA apresentam percentuais de recuperação praticamente semelhantes nas temperaturas acima de $58^{\circ} \mathrm{C}$ e a $100 \mathrm{~Pa}$, bem como na temperatura de $58^{\circ} \mathrm{C}$ a 3.200 Pa. Esta semelhança de valores também é encontrada para o CAP+SBR e o $\mathrm{CAP}+\mathrm{SBR}+\mathrm{PPA}$ na temperatura de $64^{\circ} \mathrm{C}$ e no nível de tensão de $3.200 \mathrm{~Pa}$, para os quais o percentual de recuperação é de aproximadamente $2 \%$ conforme Tabela 47. As reduções do percentual de recuperação seguem uma tendência aproximadamente linear para o CAP+PPA e o $\mathrm{CAP}+\mathrm{SBR}+\mathrm{PPA}$ em todo o espectro de temperaturas a $100 \mathrm{~Pa}$, sendo que esta tendência também pode ser observada para os três ligantes asfálticos modificados nas temperaturas de até $64^{\circ} \mathrm{C}$ a 3.200 Pa. As recuperações do CAP+SBR apresentam, no nível de tensão de $100 \mathrm{~Pa}$, reduções apenas nas temperaturas superiores a $58^{\circ} \mathrm{C}$, não sendo observada qualquer variação significativa desta propriedade com o aumento da temperatura de 52 para $58^{\circ} \mathrm{C}$. 


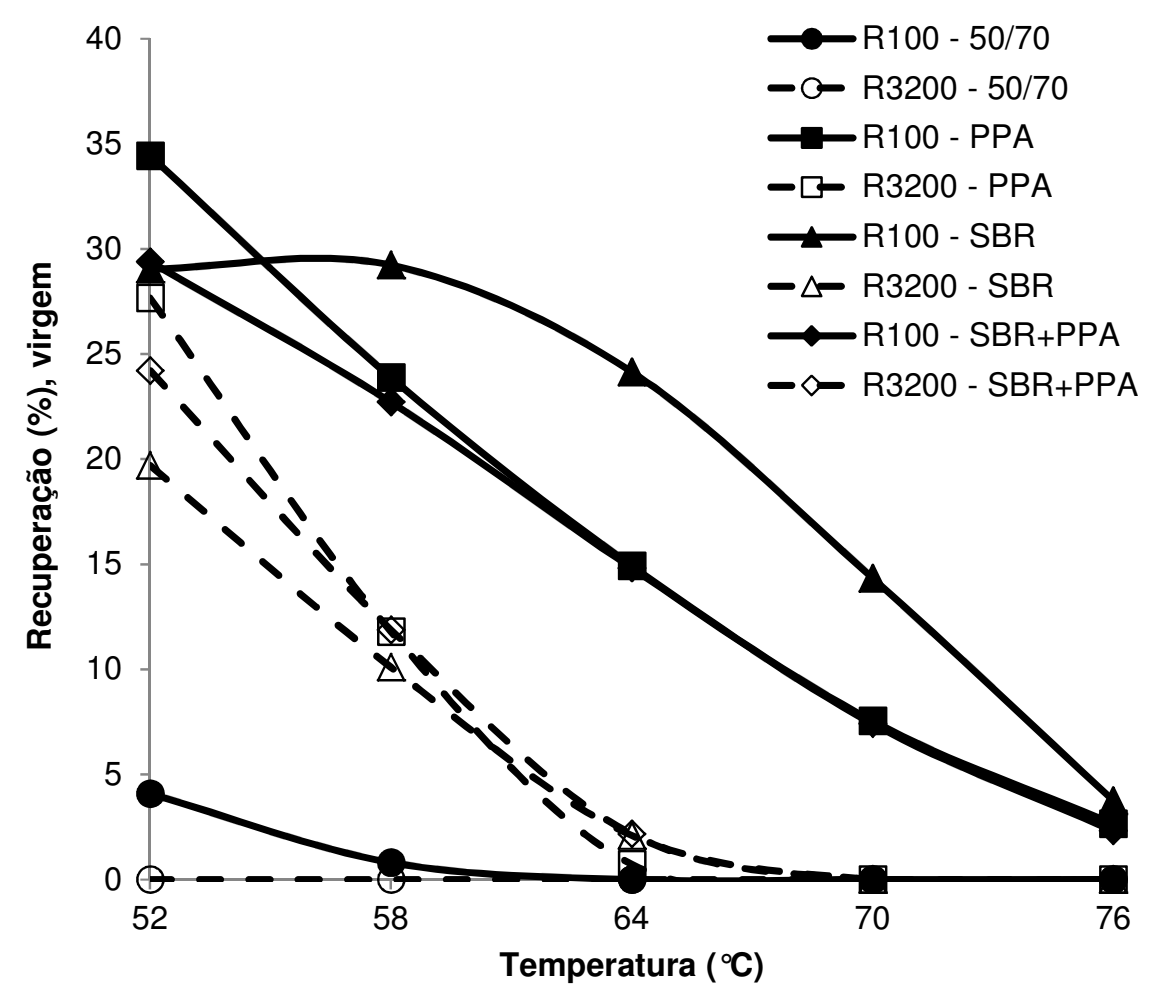

Figura 63 - Percentuais de recuperação (R) do CAP 50/70, do CAP+PPA, do CAP+SBR e do $C A P+S B R+P P A$ na condição virgem e nos tempos de 1 e $9 \mathrm{~s}$

A Tabela 48 mostra as compliâncias não-recuperáveis do CAP 50/70, do $\mathrm{CAP}+\mathrm{PPA}$, do CAP+SBR e do CAP+SBR+PPA, todos na condição virgem. A incorporação dos modificadores acarreta uma redução da compliância não-recuperável dos ligantes asfálticos, em proporções que variam de acordo com o tipo de modificador e com as condições de temperatura e tensão. O CAP+SBR+PPA possui os valores mais baixos de $J_{n r}$ nas temperaturas de 64, 70 e $76^{\circ} \mathrm{C}$, tanto a 100 quanto a $3.200 \mathrm{~Pa}$. À exceção do ligante asfáltico puro, cujas compliâncias não-recuperáveis superam os $15 \mathrm{kPa}^{-1}$ nas temperaturas acima de $64^{\circ} \mathrm{C}$ a $100 \mathrm{~Pa}$ e os $17 \mathrm{kPa}^{-1}$ nas temperaturas acima de $64^{\circ} \mathrm{C}$ a $3.200 \mathrm{~Pa}$, o CAP+SBR apresenta os maiores valores para esta propriedade em todo o espectro de temperaturas a 100 e a $3.200 \mathrm{~Pa}$. Em termos numéricos, as compliâncias do CAP+SBR estão entre 0,3 e 9,8 $\mathrm{kPa}^{-1}$ a $100 \mathrm{~Pa}$ e entre 0,4 e $13,5 \mathrm{kPa}^{-1}$ a 3.200 Pa. No caso do CAP+SBR+PPA, os valores de $J_{n r}$ estão entre 0,2 e 6,9 $\mathrm{kPa}^{-1}$ a $100 \mathrm{~Pa}$ e entre 0,2 e 9,1 $\mathrm{kPa}^{-1}$ a 3.200 Pa. Já para o CAP+PPA, estes valores não superam os $7,7 \mathrm{kPa}^{-1}$ a $100 \mathrm{~Pa}$ e não superam os $11,0 \mathrm{kPa}^{-1}$ a $3.200 \mathrm{~Pa}$.

A Figura 64 mostra os gráficos de $\mathrm{J}_{\mathrm{nr}}$ com a temperatura para o CAP+PPA, 0 $\mathrm{CAP}+\mathrm{SBR}$ e o $\mathrm{CAP}+\mathrm{SBR}+\mathrm{PPA}$, considerando a condição virgem destes materiais. A distinção entre os modificadores é difícil de ser realizada nas temperaturas de 52 e $58^{\circ} \mathrm{C}$ a 100 e a 3.200 Pa, uma vez que as diferenças entre as compliâncias não-recuperáveis do CAP+PPA, 
do $\mathrm{CAP}+\mathrm{SBR}$ e do $\mathrm{CAP}+\mathrm{SBR}+\mathrm{PPA}$ são pequenas nestas condições. Os valores de $\mathrm{J}_{\text {nr }}$ para o $\mathrm{CAP}+\mathrm{PPA}$ e o $\mathrm{CAP}+\mathrm{SBR}+\mathrm{PPA}$ são próximos entre si nas temperaturas de até $70^{\circ} \mathrm{C}$ a 100 e a 3.200 $\mathrm{Pa}$, de modo que, à luz destes resultados, as duas formulações podem ser consideradas equivalentes. O CAP+SBR possui, ao longo de todo o espectro de temperaturas a $100 \mathrm{~Pa}$, valores de $\mathrm{J}_{\mathrm{nr}}$ comparáveis aos do CAP+PPA e do CAP+SBR+PPA a 3.200 Pa, sendo que as diferenças mais significativas entre os resultados são observadas na temperatura de $76^{\circ} \mathrm{C}$. O CAP+SBR apresenta compliâncias não-recuperáveis maiores que o $\mathrm{CAP}+\mathrm{SBR}+\mathrm{PPA}$ e o $\mathrm{CAP}+\mathrm{PPA}$ em todo o espectro de temperaturas a 100 e a $3.200 \mathrm{~Pa}$, sendo que as diferenças entre os resultados são mais significativas nas temperaturas de 64, 70 e $76^{\circ} \mathrm{C}$ e no nível de tensão de $3.200 \mathrm{~Pa}$.

Tabela 48 - Compliâncias não-recuperáveis $\left(\mathrm{J}_{\mathrm{nr}}\right)$ do CAP 50/70, do CAP+PPA, do CAP+SBR e do $C A P+S B R+P P A$ nos tempos de 1 e 9 s e na condição virgem

\begin{tabular}{ccccccccccc}
\hline \multirow{2}{*}{$\begin{array}{c}\text { Ligante } \\
\text { asfáltico }\end{array}$} & \multicolumn{4}{c}{$100 \mathrm{~Pa}\left(\mathrm{~J}_{\mathrm{nr}} 100\right), \mathrm{em} \mathrm{kPa}^{-1}$} & \multicolumn{5}{c}{$3.200 \mathrm{~Pa}\left(\mathrm{~J}_{\mathrm{nr}} 3200\right), \mathrm{em} \mathrm{kPa}^{-1}$} \\
\cline { 2 - 11 } & $52^{\circ} \mathrm{C}$ & $58^{\circ} \mathrm{C}$ & $64^{\circ} \mathrm{C}$ & $70^{\circ} \mathrm{C}$ & $76^{\circ} \mathrm{C}$ & $52^{\circ} \mathrm{C}$ & $58^{\circ} \mathrm{C}$ & $64^{\circ} \mathrm{C}$ & $70^{\circ} \mathrm{C}$ & $76^{\circ} \mathrm{C}$ \\
\hline $50 / 70$ & 1,05 & 2,73 & 6,88 & 15,77 & 33,36 & 1,16 & 3,17 & 7,88 & 17,74 & 36,80 \\
PPA & 0,18 & 0,50 & 1,34 & 3,31 & 7,65 & 0,20 & 0,61 & 1,76 & 4,56 & 10,76 \\
SBR & 0,36 & 0,80 & 1,84 & 4,30 & 9,80 & 0,43 & 1,13 & 2,82 & 6,42 & 13,42 \\
SBR+PPA & 0,20 & 0,53 & 1,31 & 3,09 & 6,81 & 0,22 & 0,64 & 1,71 & 4,11 & 9,08 \\
\hline
\end{tabular}

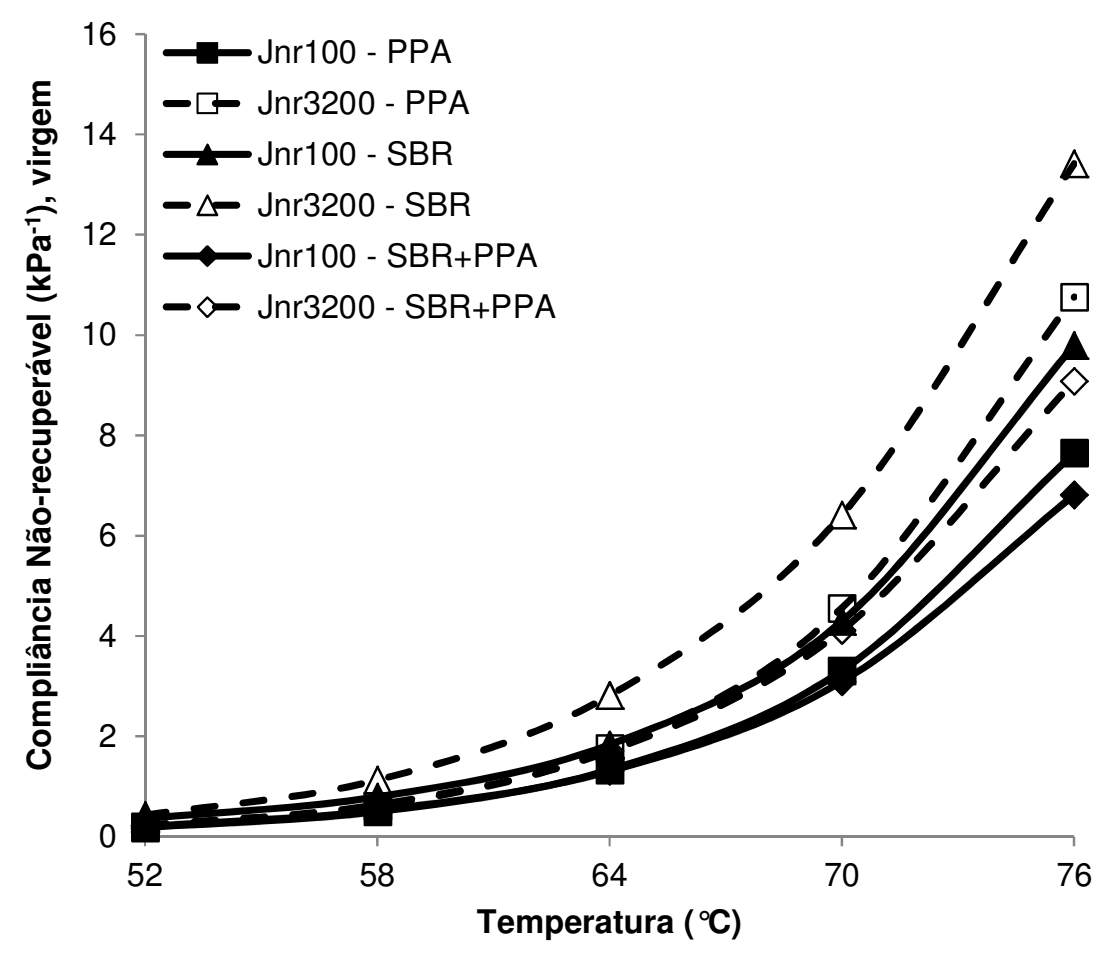

Figura 64 - Compliâncias não-recuperáveis $\left(\mathrm{J}_{\text {nr }}\right)$ do CAP+PPA, do CAP+SBR e do $\mathrm{CAP}+\mathrm{SBR}+\mathrm{PPA}$ na condição virgem e nos tempos de 1 e $9 \mathrm{~s}$ 
Em uma avaliação dos resultados das Tabelas 47 e 48 e das Figuras 63 e 64, referentes aos ligantes asfálticos virgens, observa-se que o CAP+SBR possui os maiores percentuais de recuperação nas temperaturas acima de $58^{\circ} \mathrm{C}$ a $100 \mathrm{~Pa}$, bem como as menores recuperações nas temperaturas de 52 e $58^{\circ} \mathrm{C}$ a $3.200 \mathrm{~Pa}$ dentre os materiais modificados. $\mathrm{O}$ $\mathrm{CAP}+\mathrm{SBR}+\mathrm{PPA}$ apresenta os maiores percentuais de recuperação nas temperaturas de $58 \mathrm{e}$ $64^{\circ} \mathrm{C}$ a $3.200 \mathrm{~Pa}$ e, à exceção do ligante asfáltico puro, apresenta também os menores percentuais nas temperaturas acima de $58^{\circ} \mathrm{C}$ a $100 \mathrm{~Pa}$. O CAP+SBR possui, dentre os ligantes asfálticos modificados, os maiores valores de compliância não-recuperável em todo o espectro de temperaturas a 100 e a $3.200 \mathrm{~Pa}$, sendo que os menores valores pertencem ao $\mathrm{CAP}+\mathrm{SBR}+\mathrm{PPA}$ nas temperaturas acima de $64^{\circ} \mathrm{C}$ a 100 e a $3.200 \mathrm{~Pa}$.

A Tabela 49 apresenta os percentuais de recuperação do CAP 50/70, do $\mathrm{CAP}+\mathrm{PPA}$, do $\mathrm{CAP}+\mathrm{SBR}$ e do $\mathrm{CAP}+\mathrm{SBR}+\mathrm{PPA}$, para materiais na condição envelhecida a curto prazo. De uma maneira geral, o envelhecimento proporciona um aumento nos percentuais de recuperação dos ligantes asfálticos, o que indica uma maior resposta elástica destes materiais ao carregamento aplicado. O CAP 50/70 possui recuperações não-nulas apenas nas temperaturas de 52 e $58^{\circ} \mathrm{C}$ a 100 e a $3.200 \mathrm{~Pa}$, não possuindo qualquer recuperação nas demais condições de temperatura e tensão. O CAP+SBR possui, dentre os ligantes asfálticos modificados, os menores valores de $\mathrm{R}$ em todo o espectro de temperaturas a 100 e a $3.200 \mathrm{~Pa}$, com valores entre 13 e $44 \%$ a $100 \mathrm{~Pa}$ e de no máximo $39 \%$ a $3.200 \mathrm{~Pa}$. O $\mathrm{CAP}+\mathrm{SBR}+\mathrm{PPA}$ apresenta os valores mais elevados de $\mathrm{R}$ nas temperaturas de 58 a $76^{\circ} \mathrm{C}$ a 100 e a $3.200 \mathrm{~Pa}$, com resultados entre 30 e $63 \%$ a $100 \mathrm{~Pa}$ e entre 5 e $62 \%$ a $3.200 \mathrm{~Pa}$. Estes percentuais não ultrapassam os $64 \%$ a $100 \mathrm{~Pa}$ e os $63 \%$ a $3.200 \mathrm{~Pa}$ no caso do CAP+PPA, sendo todos inferiores a $13 \%$ para o CAP 50/70.

Tabela 49 - Percentuais de recuperação (R) do CAP 50/70, do CAP+PPA, do CAP+SBR e do $\mathrm{CAP}+\mathrm{SBR}+\mathrm{PPA}$ nos tempos de 1 e 9 s e na condição envelhecida

\begin{tabular}{ccccccccccc}
\hline \multirow{2}{*}{$\begin{array}{c}\text { Ligante } \\
\text { asfáltico }\end{array}$} & \multicolumn{4}{c}{$100 \mathrm{~Pa}(\mathrm{R} 100), \mathrm{em} \%$} & \multicolumn{5}{c}{$3.200 \mathrm{~Pa}(\mathrm{R} 3200), \mathrm{em} \%$} \\
\cline { 2 - 11 } & $52^{\circ} \mathrm{C}$ & $58^{\circ} \mathrm{C}$ & $64^{\circ} \mathrm{C}$ & $70^{\circ} \mathrm{C}$ & $76^{\circ} \mathrm{C}$ & $52^{\circ} \mathrm{C}$ & $58^{\circ} \mathrm{C}$ & $64^{\circ} \mathrm{C}$ & $70^{\circ} \mathrm{C}$ & $76^{\circ} \mathrm{C}$ \\
\hline $50 / 70$ & 12,4 & 5,8 & 1,0 & 0,0 & 0,0 & 8,9 & 0,5 & 0,0 & 0,0 & 0,0 \\
PPA & 63,7 & 55,2 & 44,6 & 34,1 & 24,0 & 62,4 & 49,8 & 31,3 & 12,1 & 0,8 \\
SBR & 43,3 & 38,6 & 31,8 & 22,5 & 13,2 & 39,1 & 26,7 & 12,5 & 3,3 & 0,0 \\
SBR+PPA & 62,6 & 56,6 & 49,3 & 40,8 & 30,2 & 61,5 & 51,6 & 36,6 & 18,7 & 5,4 \\
\hline
\end{tabular}

A Figura 65 mostra os gráficos do percentual de recuperação com a temperatura para o CAP 50/70 e os materiais modificados com PPA, SBR e SBR+PPA, todos na condição envelhecida a curto prazo. A tendência linear de redução da recuperação com a temperatura 
pode ser nitidamente observada a $100 \mathrm{~Pa}$ para os ligantes asfálticos modificados, com menor intensidade a 3.200 Pa. Os percentuais de recuperação do CAP+PPA e do CAP+SBR+PPA são muito próximos entre si nas temperaturas de 52 e $58^{\circ} \mathrm{C}$ a 100 e a $3.200 \mathrm{~Pa}$, sendo que as diferenças entre os valores são maiores nas temperaturas acima de $64^{\circ} \mathrm{C}$. As recuperações do $C A P+S B R$ são menores que as do $C A P+S B R+P P A$ e do CAP+PPA em todo o espectro de temperaturas a 100 e a $3.200 \mathrm{~Pa}$, sendo que as diferenças entre os valores são mais significativas nas temperaturas de 52 e $58^{\circ} \mathrm{C}$ a $3.200 \mathrm{~Pa}$.

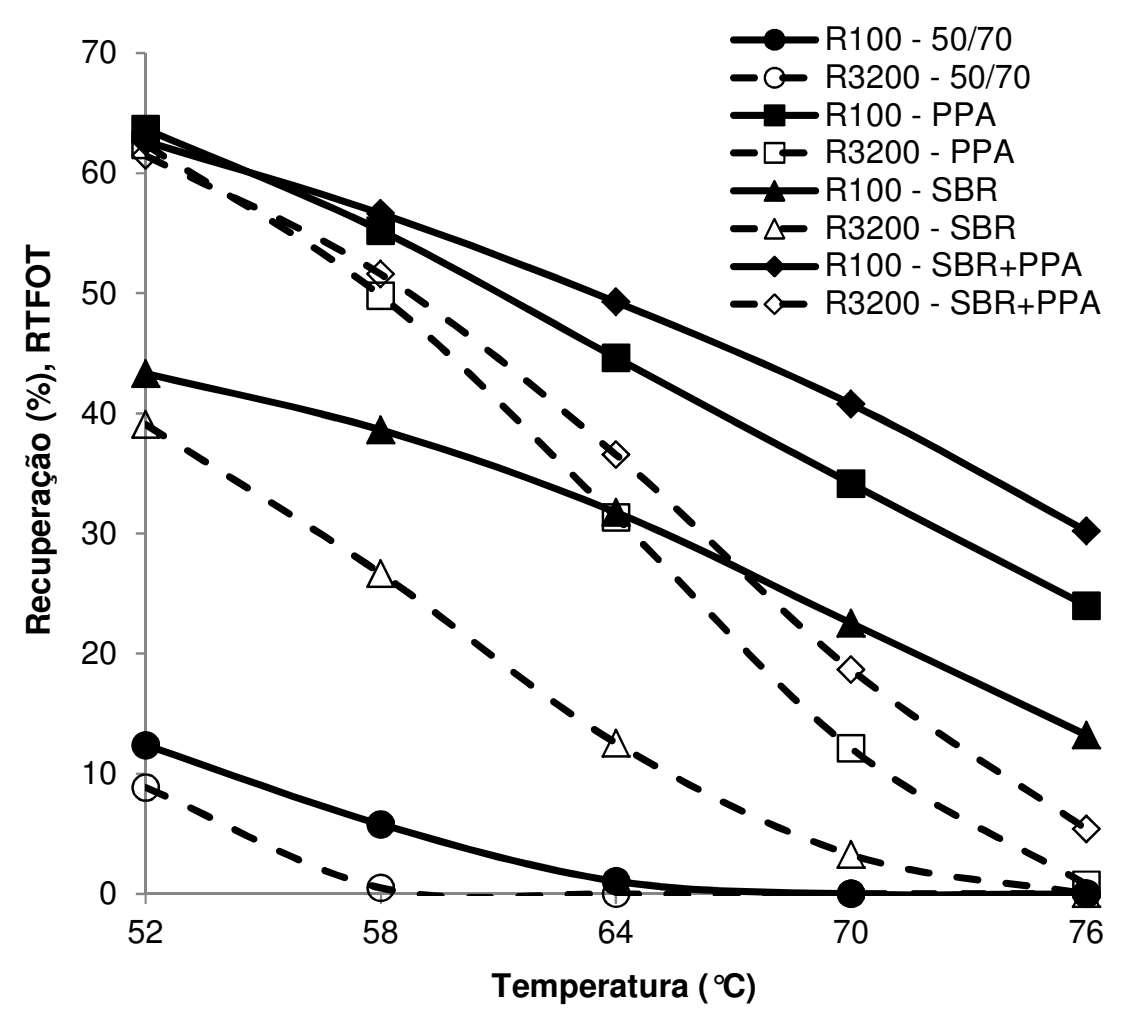

Figura 65 - Percentuais de recuperação $(R)$ do CAP 50/70, do CAP+PPA, do CAP+SBR e do $C A P+S B R+P P A$ na condição envelhecida e nos tempos de 1 e $9 \mathrm{~s}$

A Tabela 50 mostra as compliâncias não-recuperáveis do CAP 50/70, do $\mathrm{CAP}+\mathrm{PPA}$, do $\mathrm{CAP}+\mathrm{SBR}$ e do $\mathrm{CAP}+\mathrm{SBR}+\mathrm{PPA}$, todos na condição envelhecida a curto prazo. O envelhecimento proporciona uma redução da compliância não-recuperável dos ligantes asfálticos e, à exceção do CAP 50/70, os maiores valores são encontrados no CAP+SBR para todas as temperaturas a 100 e a 3.200 Pa. O CAP+SBR+PPA apresenta os menores valores de compliância não-recuperável nas temperaturas de 64,70 e $76^{\circ} \mathrm{C}$ a 100 e a $3.200 \mathrm{~Pa}$, com resultados de até $1,2 \mathrm{kPa}^{-1}$ a $100 \mathrm{~Pa}$ e de até $2,0 \mathrm{kPa}^{-1}$ a $3.200 \mathrm{~Pa}$. No caso do CAP+SBR, as compliâncias não-recuperáveis estão entre 0,1 e 3,8 $\mathrm{kPa}^{-1}$ a $100 \mathrm{~Pa}$ e entre 0,1 e 6,0 kPa-1 a 3.200 Pa. Já para o CAP+PPA, os valores são de no máximo $1,5 \mathrm{kPa}^{-1}$ a $100 \mathrm{~Pa}$ e de no máximo 2,4 $\mathrm{kPa}^{-1}$ a $3.200 \mathrm{~Pa}$. O CAP 50/70 apresenta compliâncias não-recuperáveis 
significativamente maiores que o $\mathrm{CAP}+\mathrm{PPA}$, o $\mathrm{CAP}+\mathrm{SBR}$ e o $\mathrm{CAP}+\mathrm{SBR}+\mathrm{PPA}$ para uma mesma temperatura, atingindo valores superiores a $5,0 \mathrm{kPa}^{-1}$ nas temperaturas de 70 e $76{ }^{\circ} \mathrm{C}$ a $100 \mathrm{~Pa}$ e superiores a $6,0 \mathrm{kPa}^{-1}$ nas temperaturas de 70 e $76^{\circ} \mathrm{C}$ a $3.200 \mathrm{~Pa}$.

Tabela 50 - Compliâncias não-recuperáveis $\left(\mathrm{J}_{\text {nr }}\right)$ do CAP 50/70, do CAP+PPA, do CAP+SBR e do CAP+SBR+PPA nos tempos de 1 e 9 s e na condição envelhecida

\begin{tabular}{ccccccccccc}
\hline \multirow{2}{*}{$\begin{array}{c}\text { Ligante } \\
\text { asfáltico }\end{array}$} & \multicolumn{4}{c}{$100 \mathrm{~Pa}\left(\mathrm{~J}_{\mathrm{nr}} 100\right), \mathrm{em} \mathrm{kPa}^{-1}$} & \multicolumn{4}{c}{$3.200 \mathrm{~Pa}\left(\mathrm{~J}_{\mathrm{nr}} 3200\right), \mathrm{em} \mathrm{kPa}^{-1}$} \\
\cline { 2 - 11 } & $52^{\circ} \mathrm{C}$ & $58^{\circ} \mathrm{C}$ & $64^{\circ} \mathrm{C}$ & $70^{\circ} \mathrm{C}$ & $76^{\circ} \mathrm{C}$ & $52^{\circ} \mathrm{C}$ & $58^{\circ} \mathrm{C}$ & $64^{\circ} \mathrm{C}$ & $70^{\circ} \mathrm{C}$ & $76{ }^{\circ} \mathrm{C}$ \\
\hline $50 / 70$ & 0,33 & 0,92 & 2,44 & 5,96 & 13,53 & 0,35 & 1,02 & 2,78 & 6,79 & 15,23 \\
PPA & 0,03 & 0,08 & 0,23 & 0,59 & 1,48 & 0,03 & 0,09 & 0,29 & 0,86 & 2,38 \\
SBR & 0,12 & 0,29 & 0,70 & 1,67 & 3,83 & 0,13 & 0,36 & 1,02 & 2,57 & 5,99 \\
SBR+PPA & 0,03 & 0,08 & 0,20 & 0,48 & 1,17 & 0,03 & 0,09 & 0,26 & 0,76 & 2,03 \\
\hline
\end{tabular}

A Figura 66 (página seguinte) ilustra os gráficos de $\mathrm{J}_{\mathrm{nr}}$ com a temperatura para 0 $\mathrm{CAP}+\mathrm{PPA}$, o $\mathrm{CAP}+\mathrm{SBR}$ e o $\mathrm{CAP}+\mathrm{SBR}+\mathrm{PPA}$, todos na condição envelhecida a curto prazo. Não são observadas distinções significativas entre os modificadores nas temperaturas de 52 e $58^{\circ} \mathrm{C}$ a 100 e a $3.200 \mathrm{~Pa}$, uma vez que as diferenças entre as compliâncias não-recuperáveis dos ligantes asfálticos são pequenas nestas condições. O CAP+PPA e o CAP+SBR+PPA apresentam compliâncias não-recuperáveis próximas entre si em todo o espectro de temperaturas a 100 e a $3.200 \mathrm{~Pa}$, de modo que, à luz destes resultados, as duas formulações podem ser consideradas equivalentes. O incremento do nível de tensão de 100 para 3.200 Pa não altera significativamente os valores de $J_{n r}$ para o CAP+PPA e o CAP+SBR+PPA nas temperaturas de 52,58 e $64^{\circ} \mathrm{C}$, o contrário sendo observado nas temperaturas superiores a $64^{\circ} \mathrm{C}$. Este incremento da tensão também altera o valor de $\mathrm{J}_{\mathrm{nr}}$ de maneira significativa para 0 $\mathrm{CAP}+\mathrm{SBR}$ e o CAP 50/70 nas temperaturas de 64,70 e $76^{\circ} \mathrm{C}$.

Em uma avaliação dos resultados das Tabelas 49 e 50 e das Figuras 65 e 66, referentes aos ligantes asfálticos envelhecidos a curto prazo, visualiza-se que o CAP+SBR possui os menores percentuais de recuperação e as maiores compliâncias não-recuperáveis a 100 e a 3.200 Pa dentre os materiais modificados, o que indica uma baixa componente elástica da deformação total sofrida por este material e uma maior suscetibilidade à deformação permanente. O CAP+SBR+PPA apresenta os maiores percentuais de recuperação nas temperaturas acima de $58^{\circ} \mathrm{C}$ a 100 e a $3.200 \mathrm{~Pa}$ e as menores compliâncias não-recuperáveis nas temperaturas acima de $64^{\circ} \mathrm{C}$ a 100 e a $3.200 \mathrm{~Pa}$, o que sinaliza uma maior resposta elástica e uma menor suscetibilidade deste ligante asfáltico à deformação permanente. O CAP+PPA apresenta percentuais de recuperação e compliâncias não-recuperáveis mais próximos aos do CAP+SBR+PPA tanto a 100 quanto a 3.200 Pa, especialmente no caso da compliância. 


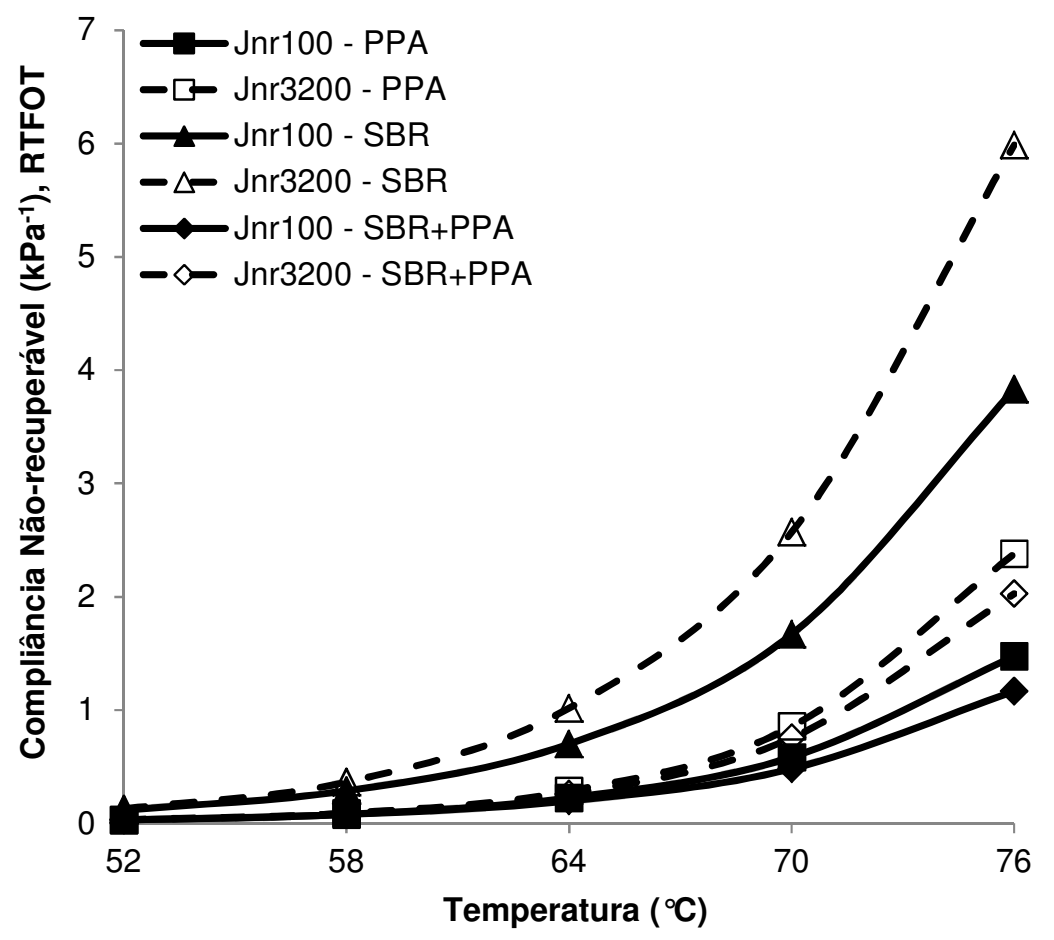

Figura 66 - Compliâncias não-recuperáveis $\left(\mathrm{J}_{n r}\right)$ do CAP+PPA, do CAP+SBR e do $\mathrm{CAP}+\mathrm{SBR}+\mathrm{PPA}$ na condição envelhecida e nos tempos de 1 e $9 \mathrm{~s}$

A Tabela 51 apresenta as relações entre as compliâncias não-recuperáveis $\left(R_{J}\right)$ do CAP 50/70, do CAP+PPA, do CAP+SBR e do CAP+SBR+PPA. O envelhecimento a curto prazo proporciona uma redução entre 2 e 8 vezes no valor da compliância não-recuperável dos ligantes asfálticos. De uma maneira geral, o incremento da tensão de 100 para 3.200 Pa não ocasiona alterações significativas de $R_{\jmath}$ para um mesmo tipo de material e uma mesma temperatura, o que indica que o efeito do nível de tensão não é muito significativo na alteração da sensibilidade dos ligantes asfálticos ao RTFOT, à luz das reduções de $J_{n r}$. $O$ CAP+SBR+PPA possui os valores mais elevados de $R_{J}$ em todo o espectro de temperaturas a $100 \mathrm{~Pa}$ e nas temperaturas de até $70^{\circ} \mathrm{C}$ a $3.200 \mathrm{~Pa}$. O CAP+SBR apresenta valores de $\mathrm{R}_{\mathrm{J}}$ iguais ou muito próximos aos do CAP 50/70 em qualquer condição de temperatura e tensão, com resultados entre 2 e 4 para ambos os materiais. No caso do CAP+PPA, os valores de $R_{J}$ estão entre 4 e 7 para todas as condições de temperatura e de tensão, sendo ligeiramente inferiores aos do CAP+SBR+PPA. Em linhas gerais, estes resultados permitem dizer que o CAP+SBR+PPA possui a maior sensibilidade ao envelhecimento a curto prazo e que o CAP+SBR possui sensibilidade baixa e comparável à do CAP 50/70.

A Figura 67 mostra os gráficos de $\mathrm{R}_{\mathrm{J}}$ com a temperatura para o CAP 50/70, o $\mathrm{CAP}+\mathrm{PPA}$, o $\mathrm{CAP}+\mathrm{SBR}$ e o $\mathrm{CAP}+\mathrm{SBR}+\mathrm{PPA}$. O incremento do nível de tensão de 100 para $3.200 \mathrm{~Pa}$ acarreta um aumento deste parâmetro nas temperaturas de até $64^{\circ} \mathrm{C}$ e uma redução 
nas temperaturas de 70 e $76^{\circ} \mathrm{C}$ no caso dos CAPs modificados, sendo que as maiores variações são observadas no CAP+PPA e no CAP+SBR+PPA. No caso do CAP 50/70 e do $\mathrm{CAP}+\mathrm{SBR}$, este incremento da tensão acarreta variações muito pequenas de $R_{\lrcorner}$para qualquer temperatura, especialmente no caso do material puro. O CAP+SBR apresenta variações levemente superiores de $R_{J}$ em comparação ao CAP 50/70, com intensidade maior nas temperaturas de 58 e $76^{\circ} \mathrm{C}$.

Tabela 51 - Relações entre as compliâncias não-recuperáveis $\left(R_{J}\right)$ do CAP 50/70, do $\mathrm{CAP}+\mathrm{PPA}$, do $\mathrm{CAP}+\mathrm{SBR}$ e do CAP+SBR+PPA nos tempos de 1 e $9 \mathrm{~s}$

\begin{tabular}{ccccccccccc}
\hline Ligante & \multicolumn{9}{c}{$100 \mathrm{~Pa}$} \\
\cline { 2 - 11 } asfáltico & $52^{\circ} \mathrm{C}$ & $58^{\circ} \mathrm{C}$ & $64^{\circ} \mathrm{C}$ & $70^{\circ} \mathrm{C}$ & $76^{\circ} \mathrm{C}$ & $52^{\circ} \mathrm{C}$ & $58^{\circ} \mathrm{C}$ & $64^{\circ} \mathrm{C}$ & $70^{\circ} \mathrm{C}$ & $76^{\circ} \mathrm{C}$ \\
\hline $50 / 70$ & 3,2 & 3,0 & 2,8 & 2,6 & 2,5 & 3,3 & 3,1 & 2,8 & 2,6 & 2,4 \\
PPA & 6,0 & 6,3 & 5,9 & 5,7 & 5,2 & 6,7 & 6,8 & 6,2 & 5,3 & 4,5 \\
SBR & 3,1 & 2,8 & 2,6 & 2,6 & 2,6 & 3,3 & 3,1 & 2,8 & 2,5 & 2,2 \\
SBR+PPA & 6,6 & 6,7 & 6,6 & 6,4 & 5,8 & 7,0 & 7,2 & 6,6 & 5,4 & 4,5 \\
\hline
\end{tabular}

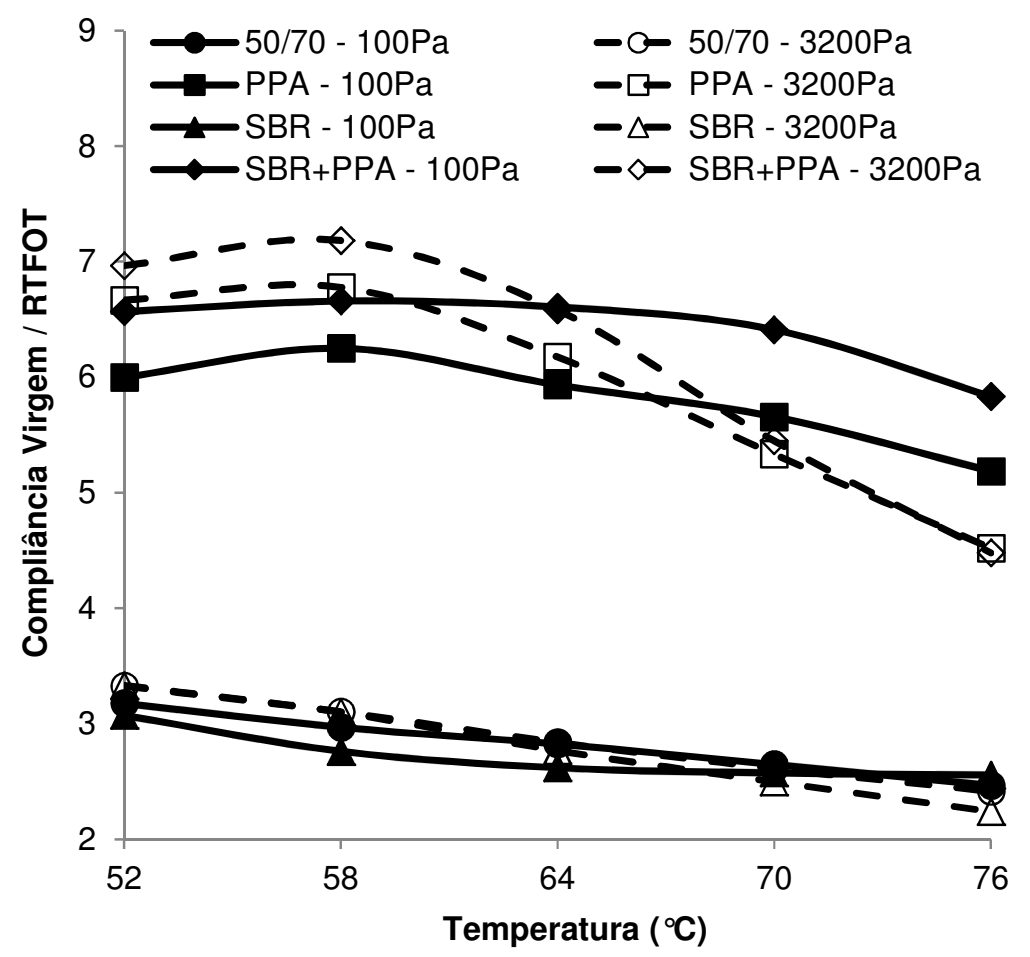

Figura 67 - Relações entre as compliâncias não-recuperáveis $\left(R_{J}\right)$ do CAP 50/70, do $\mathrm{CAP}+\mathrm{PPA}$, do CAP+SBR e do CAP+SBR+PPA nos tempos de 1 e $9 \mathrm{~s}$

A Tabela 52 mostra as relações entre os percentuais de recuperação $\left(R_{R}\right)$ do CAP puro, do $C A P+P P A$, do $C A P+S B R$ e do $C A P+S B R+P P A$, com a representação gráfica sendo mostrada na Figura 68. Alguns valores de $R_{R}$ não puderam ser calculados porque o percentual 
de recuperação do ligante asfáltico puro ou modificado é nulo nestas condições. Diferentemente do observado no parâmetro $R_{J}$, o incremento do nível de tensão de 100 para $3.200 \mathrm{~Pa}$ proporciona alterações maiores para o parâmetro $R_{R}$ em um mesmo tipo de material e uma mesma temperatura, o que indica que o efeito do nível de tensão é mais significativo na sensibilidade do percentual de recuperação do CAP ao envelhecimento do que na sensibilidade da compliância não-recuperável. O CAP+SBR possui os menores valores de $R_{R}$ em todas as temperaturas a $100 \mathrm{~Pa}$, bem como nas temperaturas de até $64^{\circ} \mathrm{C}$ a $3.200 \mathrm{~Pa}$. À exceção do CAP 50/70, o CAP+SBR+PPA apresenta os maiores valores de $R_{R}$ em todo o espectro de temperaturas a $100 \mathrm{~Pa}$ e nas temperaturas de até $64^{\circ} \mathrm{C}$ a $3.200 \mathrm{~Pa}$. À luz destes resultados, pode-se dizer que o CAP+SBR possui a menor sensibilidade ao RTFOT e que o CAP+SBR+PPA possui a maior sensibilidade dentre os materiais modificados.

Tabela 52 - Relações entre os percentuais de recuperação $\left(R_{R}\right)$ do CAP 50/70, do $\mathrm{CAP}+\mathrm{PPA}$, do $\mathrm{CAP}+\mathrm{SBR}$ e do $\mathrm{CAP}+\mathrm{SBR}+\mathrm{PPA}$ nos tempos de 1 e $9 \mathrm{~s}$

\begin{tabular}{ccccccccccc}
\hline Ligante & \multicolumn{9}{c}{$100 \mathrm{~Pa}$} \\
\cline { 2 - 11 } asfáltico & $52^{\circ} \mathrm{C}$ & $58^{\circ} \mathrm{C}$ & $64^{\circ} \mathrm{C}$ & $70^{\circ} \mathrm{C}$ & $76^{\circ} \mathrm{C}$ & $52^{\circ} \mathrm{C}$ & $58^{\circ} \mathrm{C}$ & $64^{\circ} \mathrm{C}$ & $70^{\circ} \mathrm{C}$ & $76^{\circ} \mathrm{C}$ \\
\hline $50 / 70$ & 3,0 & 7,2 & - & - & - & - & - & - & - & - \\
PPA & 1,8 & 2,3 & 3,0 & 4,5 & 9,1 & 2,3 & 4,2 & 42,9 & - & - \\
SBR & 1,5 & 1,3 & 1,3 & 1,6 & 3,5 & 2,0 & 2,6 & 6,0 & - & - \\
SBR+PPA & 2,1 & 2,5 & 3,3 & 5,5 & 13,1 & 2,5 & 4,3 & 16,9 & - & - \\
\hline
\end{tabular}

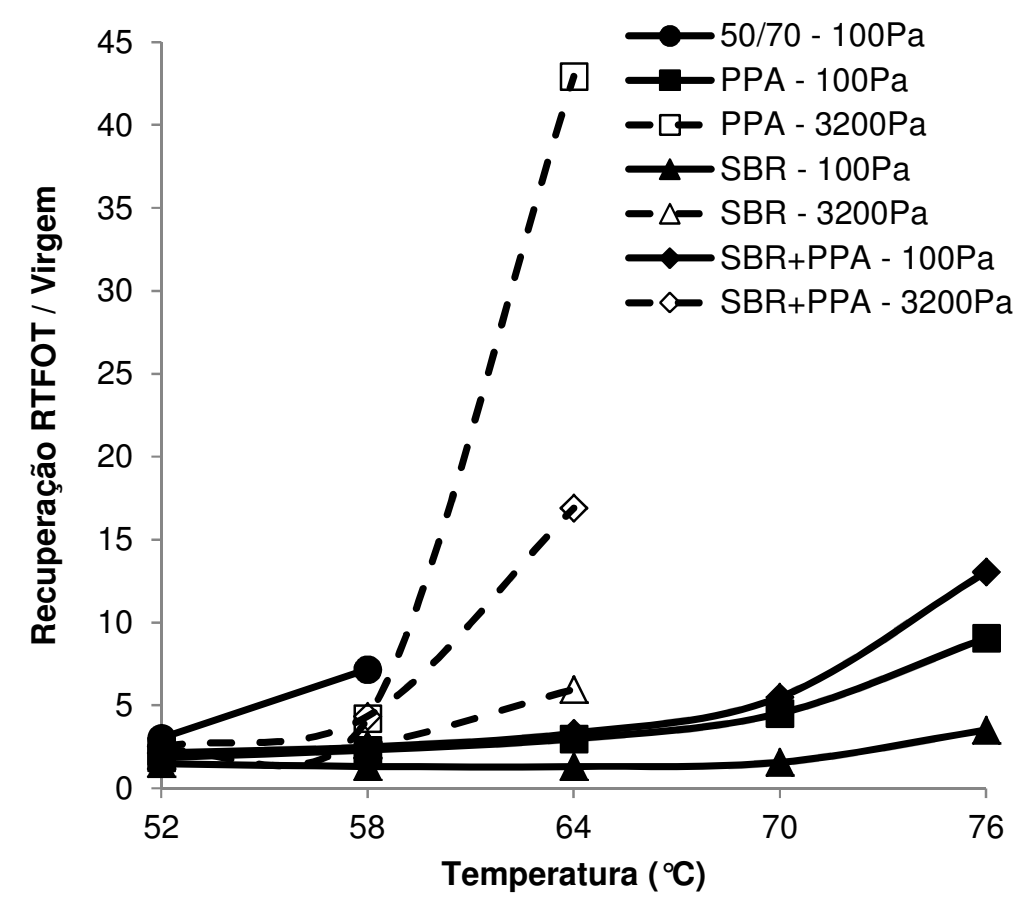

Figura 68 - Relações entre os percentuais de recuperação $\left(R_{R}\right)$ do CAP 50/70, do CAP+PPA, do CAP+SBR e do CAP+SBR+PPA nos tempos de 1 e $9 \mathrm{~s}$ 
Em uma análise dos resultados apresentados nas Tabelas 51 e 52 e nos gráficos das Figuras 67 e 68, é possível observar que o CAP+SBR+PPA possui os valores mais elevados de $R_{J}$ e de $R_{R}$ em praticamente todas as temperaturas a 100 e a $3.200 \mathrm{~Pa}$, sendo que o CAP+SBR possui os valores mais baixos de $R_{R}$ nestas mesmas temperaturas e tensões e valores baixos de $R_{J}$, comparáveis aos do CAP 50/70. Em linhas gerais, pode-se afirmar que o $C A P+S B R+P P A$ possui a maior sensibilidade ao envelhecimento a curto prazo e que o CAP+SBR possui a menor sensibilidade, à luz dos incrementos do percentual de recuperação e das reduções de compliância não-recuperável após o RTFOT. Por outro lado, valores elevados para os parâmetros $R_{J}$ e $R_{R}$ apontam que o envelhecimento reduziu a compliância não-recuperável e aumentou a recuperação de maneira acentuada, o que é favorável à resistência à deformação permanente. Deste ponto de vista, o CAP+SBR+PPA apresenta resultados melhores do que o CAP+SBR por conta das variações mais significativas de $R$ e de $J_{n r}$ após o envelhecimento a curto prazo.

A Tabela 53 apresenta as diferenças percentuais entre as compliâncias $\left(\mathrm{J}_{\mathrm{nr}, \mathrm{diff}}\right)$ do CAP 50/70, do CAP+PPA, do CAP+SBR e do CAP+SBR+PPA, nas condições virgem e envelhecida a curto prazo. Não são observados resultados de $J_{\text {nr,diff }}$ superiores ao valor de $75 \%$ estipulado pela AASHTO MP19 em qualquer temperatura e condição de envelhecimento, embora o CAP+SBR+PPA apresente um valor muito próximo a este limite $(73,6 \%)$ na condição envelhecida a curto prazo e na temperatura do PG. O CAP+SBR possui as diferenças percentuais mais elevadas nas temperaturas de até $70^{\circ} \mathrm{C}$ da condição virgem (valores entre 18 e $37 \%$ ) e de até $64^{\circ} \mathrm{C}$ na condição envelhecida a curto prazo (valores entre 9 e 56\%). À exceção do CAP 50/70, cujas diferenças percentuais estão entre 6 e 15\% para qualquer temperatura e condição de envelhecimento, o CAP+SBR+PPA possui os valores mais baixos de $J_{n r, d i f f}$ em todas as temperaturas da condição virgem e o CAP+PPA possui estes valores mais baixos nas temperaturas de até $70^{\circ} \mathrm{C}$ da condição envelhecida. Em termos numéricos, as diferenças percentuais do CAP+SBR+PPA estão entre 9 e 34\% na condição virgem e entre 3 e 74\% na envelhecida a curto prazo, sendo todas inferiores a $62 \%$ no caso do CAP+PPA.

Tabela 53 - Diferenças percentuais entre as compliâncias não-recuperáveis $\left(J_{\text {rr,diff }}\right)$ do CAP 50/70, do CAP+PPA, do CAP+SBR e do CAP+SBR+PPA nos tempos de 1 e $9 \mathrm{~s}$

\begin{tabular}{ccccccccccc}
\hline \multirow{2}{*}{$\begin{array}{c}\text { Ligante } \\
\text { asfáltico }\end{array}$} & \multicolumn{4}{c}{ Materiais virgens } & \multicolumn{5}{c}{ Materiais envelhecidos (RTFOT) } \\
\cline { 2 - 11 } & $52^{\circ} \mathrm{C}$ & $58^{\circ} \mathrm{C}$ & $64^{\circ} \mathrm{C}$ & $70^{\circ} \mathrm{C}$ & $76^{\circ} \mathrm{C}$ & $52^{\circ} \mathrm{C}$ & $58^{\circ} \mathrm{C}$ & $64^{\circ} \mathrm{C}$ & $70^{\circ} \mathrm{C}$ & $76^{\circ} \mathrm{C}$ \\
\hline $50 / 70$ & 11,0 & 15,9 & 14,5 & 12,5 & 10,3 & 6,1 & 10,9 & 14,0 & 14,0 & 12,6 \\
PPA & 11,1 & 22,0 & 31,8 & 37,8 & 40,7 & 0,0 & 12,5 & 26,7 & 46,2 & 61,4 \\
SBR & 18,7 & 42,0 & 53,3 & 49,4 & 37,0 & 9,5 & 26,5 & 45,1 & 53,9 & 56,2 \\
SBR+PPA & 9,7 & 21,7 & 30,4 & 33,1 & 33,3 & 3,4 & 12,8 & 30,9 & 56,6 & 73,6 \\
\hline
\end{tabular}


A Figura 69 ilustra os gráficos de $J_{\text {nr,diff }}$ com a temperatura para o CAP 50/70, o CAP+PPA, o $C A P+S B R$ e o $C A P+S B R+P P A$, nas condições virgem e envelhecida a curto prazo. As diferenças percentuais do $C A P+P P A$ e do $C A P+S B R+P P A$ são muito próximas entre si nas temperaturas de até $64^{\circ} \mathrm{C}$ da condição virgem, o mesmo sendo observado na temperatura de $58^{\circ} \mathrm{C}$ da condição envelhecida. $\mathrm{O}$ envelhecimento proporciona uma redução das diferenças percentuais dos ligantes asfálticos nas temperaturas de até $64^{\circ} \mathrm{C}$ e um aumento nas temperaturas de 70 e $76^{\circ} \mathrm{C}$, sendo que as variações menos significativas desta sensibilidade são observadas no CAP 50/70 e as mais significativas são observadas no CAP+PPA e no $\mathrm{CAP}+\mathrm{SBR}$. Diferentemente do CAP+SBR+PPA e do CAP+PPA na condição virgem, os quais apresentam um aumento contínuo de $\mathrm{J}_{\text {nr, diff }}$ com a temperatura, o CAP+SBR virgem possui um crescimento das diferenças percentuais nas temperaturas de até $64^{\circ} \mathrm{C}$ e uma redução destes valores nas temperaturas subsequentes. Este comportamento, entretanto, não é observado para qualquer material modificado e na condição envelhecida a curto prazo, em que as diferenças percentuais de todos eles aumentam com o incremento da temperatura.

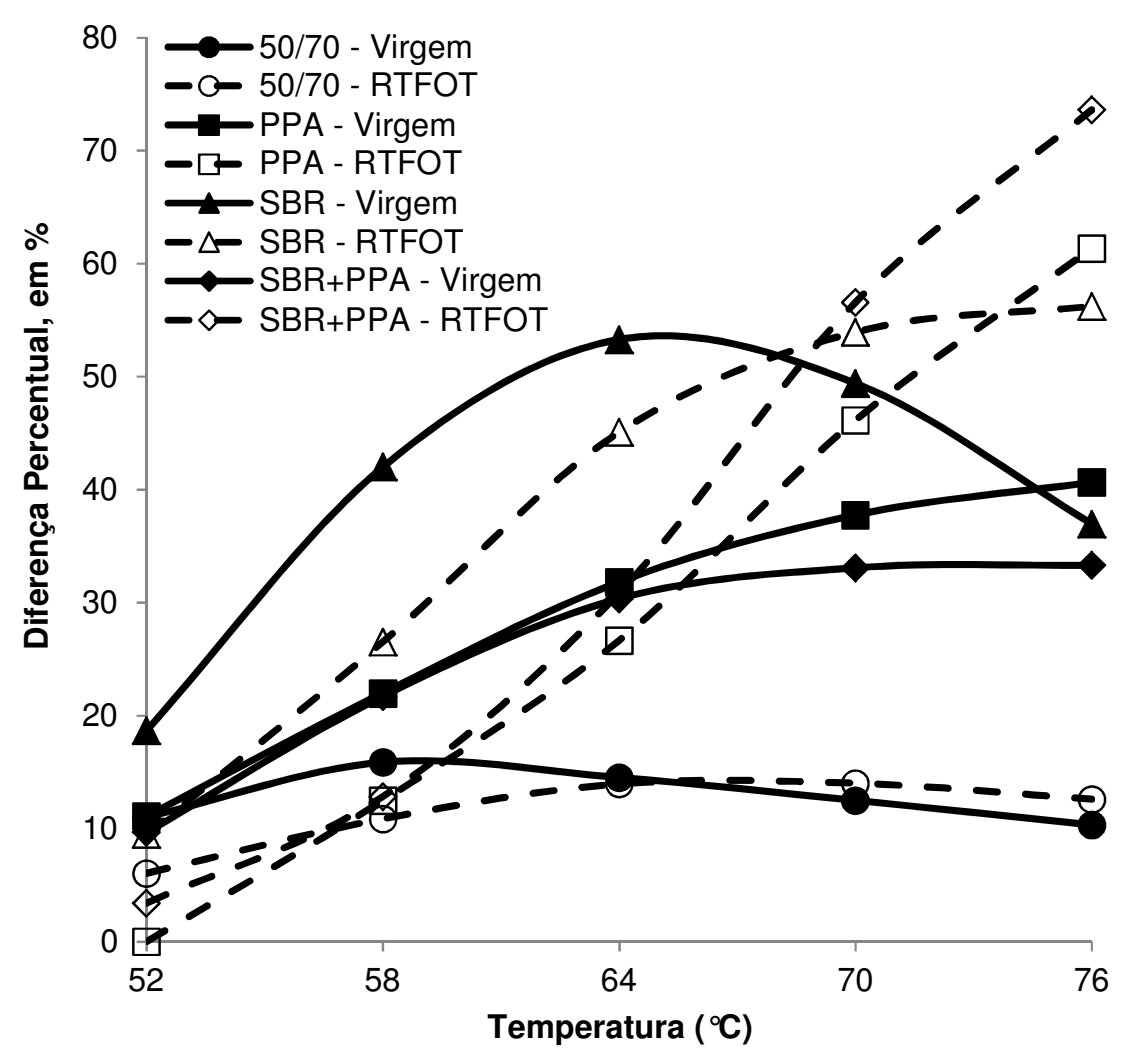

Figura 69 - Diferenças percentuais entre as compliâncias não-recuperáveis $\left(J_{n r, \text { diff }}\right)$ do CAP 50/70, do CAP+PPA, do CAP+SBR e do CAP+SBR+PPA nos tempos de 1 e $9 \mathrm{~s}$

Em uma análise sintetizada dos resultados das Tabelas 47 a 53 e dos gráficos das Figuras 63 a 69, observa-se que o $\mathrm{CAP}+\mathrm{SBR}+\mathrm{PPA}$ possui os maiores percentuais de 
recuperação nas temperaturas de 58 e $64^{\circ} \mathrm{C}$ a $3.200 \mathrm{~Pa}$ e as menores compliâncias nas temperaturas acima de $64^{\circ} \mathrm{C}$ a 100 e a $3.200 \mathrm{~Pa}$ da condição virgem, sendo que o CAP+SBR possui, à exceção do CAP 50/70, os menores percentuais de recuperação nas temperaturas de 52 e $58^{\circ} \mathrm{C}$ a $3.200 \mathrm{~Pa}$ e as maiores compliâncias não-recuperáveis em todas as temperaturas e tensões desta mesma condição. O CAP+SBR apresenta, dentre os materiais modificados, as menores recuperações e as maiores compliâncias não-recuperáveis em todas as temperaturas e níveis de tensão da condição envelhecida a curto prazo, com o CAP+SBR+PPA possuindo, nesta mesma condição, as maiores recuperações elásticas nas temperaturas acima de $52^{\circ} \mathrm{C}$ a 100 e a 3.200 Pa e as menores compliâncias não-recuperáveis nos dois níveis de tensão. A análise da sensibilidade dos ligantes asfálticos ao RTFOT $\left(R_{J}\right.$ e $\left.R_{R}\right)$ aponta que, de uma maneira geral, o CAP+SBR+PPA possui a maior sensibilidade ao envelhecimento a curto prazo e que o $C A P+S B R$ possui a menor sensibilidade, à luz dos incrementos de $R$ e das reduções de $J_{n r}$ após o RTFOT. Em termos da sensibilidade à tensão, o CAP+SBR possui os valores mais elevados de $J_{n r, d i f f}$ nas temperaturas de até $70^{\circ} \mathrm{C}$ da condição virgem e nas temperaturas de até $64^{\circ} \mathrm{C}$ da condição envelhecida a curto prazo, sendo que o CAP+SBR+PPA possui os valores mais baixos de $J_{\text {nr,diff }}$ em todas as temperaturas da condição virgem.

\subsection{Resultados do ensaio MSCR para os tempos de 2 e 18 s e discussão}

As análises dos resultados do ensaio MSCR nos tempos de 2 e $18 \mathrm{~s}$ foram realizadas de maneira parecida com as avaliações nos tempos de 1 e $9 \mathrm{~s}$, sendo que os grupos de ligantes asfálticos foram mantidos (Tabela 11, página 114). A estrutura de cada análise foi dividida nas seguintes etapas: (1) percentual de recuperação; (2) compliância não-recuperável; (3) sensibilidade dos ligantes asfálticos ao incremento do nível de tensão; e (4) resumo global. Nestes resumos globais, são destacados aspectos como os ligantes asfálticos com maiores e menores resultados em cada propriedade e parâmetro.

\subsubsection{CAP 50/70, CAP+PPA e CAP+Elvaloy+PPA}

A Tabela 54 apresenta os percentuais de recuperação do CAP 50/70 e dos materiais modificados com PPA e Elvaloy+PPA, todos na condição envelhecida a curto prazo. Em linhas gerais, a incorporação dos modificadores acarreta um aumento do percentual de recuperação dos ligantes asfálticos. O CAP 50/70 possui recuperações 
inferiores a $10 \%$ em qualquer situação, mesmo nas temperaturas e níveis de tensão mais baixos. O CAP+Elvaloy+PPA possui os valores mais elevados de $\mathrm{R}$ em todo o espectro de temperaturas a 100 e a $3.200 \mathrm{~Pa}$, com resultados superiores a $60 \%$ na tensão de $100 \mathrm{~Pa}$ e superiores a $50 \%$ na tensão de $3.200 \mathrm{~Pa}$. O CAP+PPA apresenta percentuais de recuperação entre 17 e 60\% a $100 \mathrm{~Pa}$ e, com o aumento para $3.200 \mathrm{~Pa}$, estes percentuais são todos inferiores a $57 \%$. Dentre os ligantes asfálticos analisados neste grupo, o CAP+Elvaloy+PPA é o único que apresenta recuperação não-nula nas condições mais críticas de ensaio: temperatura de $76^{\circ} \mathrm{C}$ e nível de tensão de $3.200 \mathrm{~Pa}$.

Tabela 54-Percentuais de recuperação (R) do CAP 50/70, do CAP+PPA e do CAP+Elvaloy+PPA nos tempos de 2 e 18 s e na condição envelhecida

\begin{tabular}{ccccccccccc}
\hline Ligante & \multicolumn{4}{c}{$100 \mathrm{~Pa}(\mathrm{R} 100), \mathrm{em} \%$} & \multicolumn{4}{c}{$3.200 \mathrm{~Pa}(\mathrm{R} 3200), \mathrm{em} \%$} \\
\cline { 2 - 11 } asfáltico & $52^{\circ} \mathrm{C}$ & $58^{\circ} \mathrm{C}$ & $64^{\circ} \mathrm{C}$ & $70^{\circ} \mathrm{C}$ & $76^{\circ} \mathrm{C}$ & $52^{\circ} \mathrm{C}$ & $58^{\circ} \mathrm{C}$ & $64^{\circ} \mathrm{C}$ & $70^{\circ} \mathrm{C}$ & $76^{\circ} \mathrm{C}$ \\
\hline $50 / 70$ & 7,9 & 2,9 & 0,0 & 0,0 & 0,0 & 3,4 & 0,0 & 0,0 & 0,0 & 0,0 \\
PPA & 59,4 & 50,2 & 38,8 & 27,1 & 17,7 & 56,4 & 40,0 & 19,0 & 3,3 & 0,0 \\
Elvaloy+PPA & 80,0 & 79,5 & 75,5 & 69,0 & 61,2 & 80,5 & 78,9 & 74,6 & 65,6 & 50,7 \\
\hline
\end{tabular}

A Figura 70 (página seguinte) mostra os gráficos do percentual de recuperação com a temperatura para o CAP 50/70, o CAP+PPA e o CAP+Elvaloy+PPA, considerando os tempos de 2 e $18 \mathrm{~s}$ e a condição envelhecida destes ligantes asfálticos. As diferenças entre os percentuais de recuperação a 100 e a $3.200 \mathrm{~Pa}$ se mostram relativamente pequenas para o CAP+Elvaloy+PPA em todo o espectro de temperaturas, sendo de no máximo 11\% (Tabela 54). Esta situação, entretanto, não ocorre com o CAP+PPA, para o qual as diferenças são significativas nas temperaturas acima de $64^{\circ} \mathrm{C}$. Em termos do percentual de recuperação, podese dizer que o efeito da tensão é mais significativo no CAP+PPA do que no CAP+Elvaloy+PPA, pois o aumento de 100 para 3.200 Pa no nível de tensão ocasiona uma redução maior no valor desta propriedade para o CAP+PPA do que para o CAP+Elvaloy+PPA.

A Tabela 55 mostra as compliâncias não-recuperáveis do CAP 50/70 e dos materiais modificados com PPA e Elvaloy+PPA, todos na condição envelhecida a curto prazo. A adição dos modificadores ocasiona uma redução no valor de $\mathrm{J}_{\mathrm{nr}}$ do ligante asfáltico, de modo que há uma diminuição da suscetibilidade do material à deformação permanente. O CAP 50/70 apresenta valores de $J_{n r}$ significativamente superiores aos dos materiais modificados em qualquer condição de temperatura e tensão, sendo, portanto, o ligante asfáltico com a maior suscetibilidade à deformação permanente. O CAP+Elvaloy+PPA apresenta os resultados mais baixos de $\mathrm{J}_{\mathrm{nr}}$ em praticamente todo o espectro de temperaturas, sendo, portanto, o ligante asfáltico com menor suscetibilidade à deformação permanente. O CAP+PPA possui 
compliâncias não-recuperáveis relativamente próximas às do CAP+Elvaloy+PPA, tanto a 100 quanto a $3.200 \mathrm{~Pa}$ e com maior proximidade nas temperaturas de até $58^{\circ} \mathrm{C}$. Em termos numéricos, as compliâncias não-recuperáveis do CAP+PPA variam entre 0,05 e 2,80 $\mathrm{kPa}^{-1} \mathrm{a}$ $100 \mathrm{~Pa}$ e entre 0,05 e 4,80 $\mathrm{kPa}^{-1}$ a $3.200 \mathrm{~Pa}$. No caso do CAP+Elvaloy+PPA, os valores de $\mathrm{J}_{\mathrm{nr}}$ estão entre 0,05 e 1,20 $\mathrm{kPa}^{-1}$ para todas as temperaturas a 100 e a $3.200 \mathrm{~Pa}$.

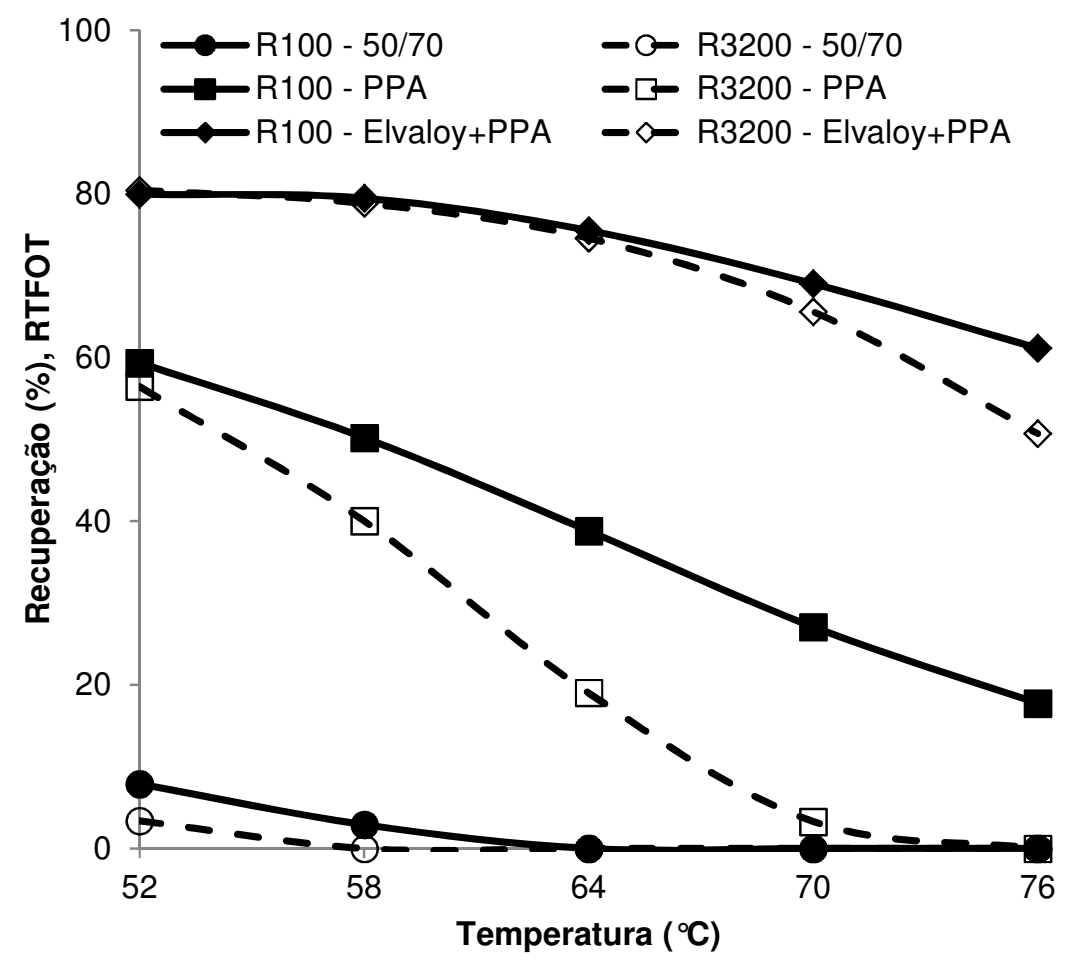

Figura 70 - Percentuais de recuperação (R) do CAP 50/70, do CAP+PPA e do $\mathrm{CAP}+$ Elvaloy+PPA na condição envelhecida e nos tempos de 2 e $18 \mathrm{~s}$

Tabela 55 - Compliâncias não-recuperáveis $\left(\mathrm{J}_{\text {nr }}\right)$ do CAP 50/70, do CAP+PPA e do $\mathrm{CAP}+$ Elvaloy+PPA nos tempos de 2 e $18 \mathrm{~s}$ e na condição envelhecida

\begin{tabular}{ccccccccccc}
\hline \multirow{2}{*}{$\begin{array}{c}\text { Ligante } \\
\text { asfáltico }\end{array}$} & \multicolumn{4}{c}{$100 \mathrm{~Pa}\left(\mathrm{~J}_{\mathrm{nr}} 100\right), \mathrm{em} \mathrm{kPa}^{-1}$} & \multicolumn{5}{c}{$3.200 \mathrm{~Pa}\left(\mathrm{~J}_{\mathrm{nr}} 3200\right), \mathrm{em} \mathrm{kPa}^{-1}$} \\
\cline { 2 - 11 } & $52^{\circ} \mathrm{C}$ & $58^{\circ} \mathrm{C}$ & $64^{\circ} \mathrm{C}$ & $70^{\circ} \mathrm{C}$ & $76{ }^{\circ} \mathrm{C}$ & $52^{\circ} \mathrm{C}$ & $58^{\circ} \mathrm{C}$ & $64^{\circ} \mathrm{C}$ & $70^{\circ} \mathrm{C}$ & $76{ }^{\circ} \mathrm{C}$ \\
\hline $50 / 70$ & 0,63 & 1,75 & 4,69 & 11,70 & 26,49 & 0,68 & 2,01 & 5,43 & 13,34 & 30,14 \\
PPA & 0,05 & 0,14 & 0,41 & 1,10 & 2,78 & 0,05 & 0,17 & 0,57 & 1,74 & 4,77 \\
Elvaloy+PPA & 0,05 & 0,10 & 0,23 & 0,53 & 1,19 & 0,05 & 0,10 & 0,21 & 0,49 & 1,20 \\
\hline
\end{tabular}

A Figura 71 ilustra os gráficos de $\mathrm{J}_{\mathrm{nr}}$ com a temperatura para os ligantes asfálticos modificados com PPA e Elvaloy+PPA, ambos na condição envelhecida a curto prazo. Não são observadas distinções significativas entre os valores de $J_{n r}$ a 100 e a $3.200 \mathrm{~Pa}$ para o $\mathrm{CAP}+$ Elvaloy+PPA, de modo que os gráficos de $\mathrm{J}_{\mathrm{nr}}$ são praticamente coincidentes para este material em todo o espectro de temperaturas. As compliâncias não-recuperáveis do 
$\mathrm{CAP}+\mathrm{PPA}$ e do CAP+Elvaloy+PPA são muito próximas entre si nas temperaturas de 52 e $58^{\circ} \mathrm{C}$ a 100 e a $3.200 \mathrm{~Pa}$, o que dificulta a distinção entre os modificadores. No caso do CAP+PPA, os gráficos de $\mathrm{J}_{\mathrm{nr}}$ a 100 e a $3.200 \mathrm{~Pa}$ apresentam distinções mais elevadas apenas nas temperaturas de 70 e $76^{\circ} \mathrm{C}$. Assim, o incremento do nível de tensão de 100 para $3.200 \mathrm{~Pa}$ afeta a compliância não-recuperável do CAP+PPA de maneira mais significativa do que o $\mathrm{CAP}+$ Elvaloy+PPA para as temperaturas acima de $64^{\circ} \mathrm{C}$.

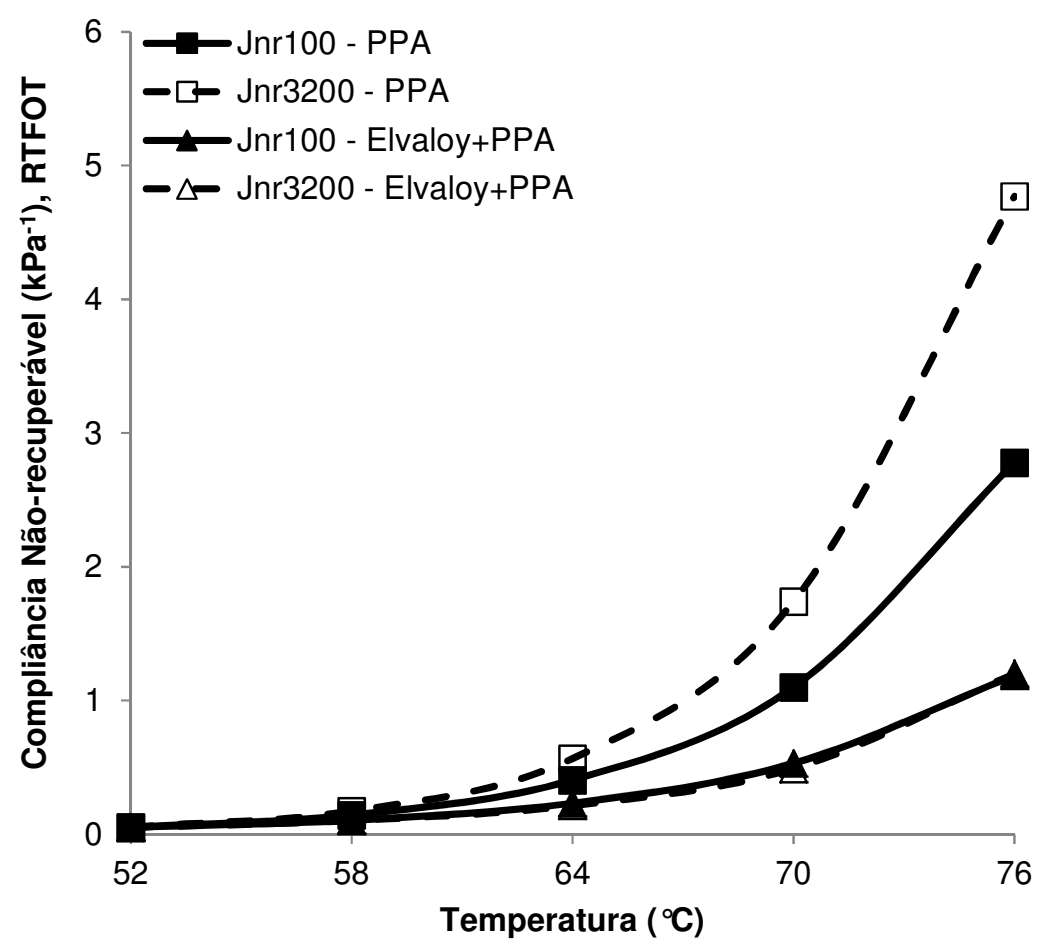

Figura 71 - Compliâncias não-recuperáveis $\left(J_{n r}\right)$ do CAP+PPA e do CAP+Elvaloy+PPA na condição envelhecida e nos tempos de 2 e $18 \mathrm{~s}$

A Tabela 56 mostra os valores de $\mathrm{J}_{\mathrm{nr}, \text { diff }}$ para o CAP 50/70, o CAP+PPA e o CAP+Elvaloy+PPA, considerando os tempos de 2 e $18 \mathrm{~s}$ para estes materiais e a condição envelhecida a curto prazo. Os resultados estão todos situados abaixo do valor de $75 \%$ na temperatura do PG e, na extensão em que é válida a aplicação do limite de $75 \%$ estipulado pela AASHTO MP19 a ligantes asfálticos envelhecidos a curto prazo e ensaiados nos tempos de fluência e recuperação de 2 e $18 \mathrm{~s}$, nenhum dos materiais deste grupo possui uma sensibilidade excessiva à tensão. O CAP+Elvaloy+PPA possui as diferenças percentuais mais baixas em todo o espectro de temperaturas, sendo, portanto, o material com a menor sensibilidade à tensão. $O$ $\mathrm{CAP}+\mathrm{PPA}$ apresenta os valores mais elevados de $\mathrm{J}_{\mathrm{nr} \text {, diff }}$ nas temperaturas acima de $58^{\circ} \mathrm{C}$, o que, em linhas gerais, Ihe confere a maior sensibilidade à tensão. O CAP 50/70 possui, em geral, diferenças percentuais entre os resultados do CAP+PPA e os do CAP+Elvaloy+PPA, com valores de $\mathrm{J}_{\text {nr,diff }}$ entre 7 e $16 \%$ nas temperaturas consideradas. 
192

Tabela 56 - Diferenças percentuais entre as compliâncias não-recuperáveis $\left(J_{\text {rr,diff }}\right)$ do CAP 50/70, do CAP+PPA e do CAP+Elvaloy+PPA nos tempos de 2 e $18 \mathrm{~s}$

\begin{tabular}{cccccc}
\hline \multirow{2}{*}{ Ligante asfáltico } & \multicolumn{5}{c}{ Materiais envelhecidos (RTFOT) } \\
\cline { 2 - 6 } & $52^{\circ} \mathrm{C}$ & $58^{\circ} \mathrm{C}$ & $64^{\circ} \mathrm{C}$ & $70^{\circ} \mathrm{C}$ & $76{ }^{\circ} \mathrm{C}$ \\
\hline $50 / 70$ & 7,5 & 14,5 & 15,7 & 13,9 & 13,8 \\
PPA & 5,6 & 20,0 & 39,5 & 58,2 & 71,6 \\
Elvaloy+PPA & $-4,0$ & $-2,2$ & $-7,6$ & $-7,4$ & 1,0 \\
\hline
\end{tabular}

A Figura 72 mostra as variações de $\mathrm{J}_{\mathrm{nr} \text {,diff }}$ com a temperatura para o CAP 50/70 e os ligantes asfálticos modificados com PPA e Elvaloy+PPA, todos na condição envelhecida a curto prazo e considerando os tempos de 2 e $18 \mathrm{~s}$. O aumento das diferenças percentuais do CAP+PPA com a temperatura segue uma tendência aproximadamente linear, com os valores passando de $5,6 \%$ a $52^{\circ} \mathrm{C}$ para $71,6 \%$ a $76{ }^{\circ} \mathrm{C}$ conforme Tabela 56. O CAP 50/70 e o CAP+Elvaloy+PPA apresentam variações menores de $J_{\text {nr,diff }}$ em todo o espectro de temperaturas, sendo de até $9 \%$ em módulo (de $7,5 \%$ para $15,7 \%$ no caso do CAP puro e de $-7,6 \%$ para $1,0 \%$ no caso do CAP+Elvaloy+PPA conforme Tabela 56 ) para ambos os materiais. Desta maneira, pode-se dizer que o aumento da temperatura afeta a sensibilidade do CAP+PPA à tensão em uma intensidade maior do que a verificada no CAP 50/70 e no CAP+Elvaloy+PPA.

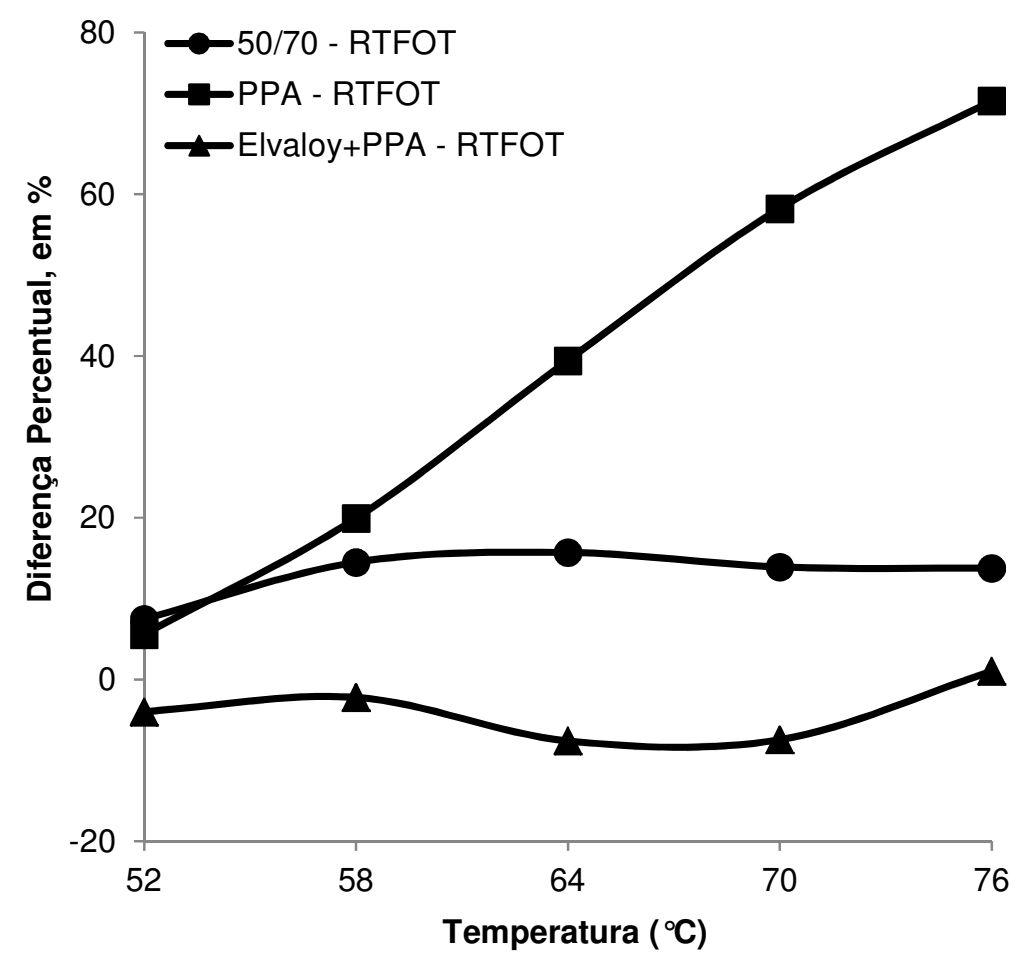

Figura 72 - Diferenças percentuais entre as compliâncias não-recuperáveis $\left(J_{\text {nr,diff }}\right)$ do CAP 50/70, do CAP+PPA e do CAP+Elvaloy+PPA nos tempos de 2 e $18 \mathrm{~s}$ 
Os resultados do CAP 50/70, do CAP+PPA e do CAP+Elvaloy+PPA para os tempos de 2 e 18 s (Tabelas 54 a 56 e Figuras 70 a 72) mostram que o CAP+Elvaloy+PPA apresenta os percentuais de recuperação mais elevados e, ao mesmo tempo, as compliâncias nãorecuperáveis mais baixas em todo o espectro de temperaturas a 100 e a 3.200 Pa. O CAP 50/70 possui os valores mais baixos de $R$ e os mais elevados de $J_{n r}$, mesmo nas temperaturas e níveis de tensão mais baixos. As análises de sensibilidade à tensão indicam que o CAP+Elvaloy+PPA possui a menor sensibilidade em qualquer temperatura, bem como a menor variação do parâmetro $J_{\text {nr,diff. }}$ Estas análises também indicam que a sensibilidade do CAP+PPA à tensão possui uma dependência maior da temperatura em comparação ao CAP 50/70 e ao $\mathrm{CAP}+$ Elvaloy+PPA, uma vez que o parâmetro $J_{\text {nr,diff }}$ varia com grande intensidade para 0 CAP+PPA e com pequena intensidade para o CAP 50/70 e o CAP+Elvaloy+PPA.

\subsubsection{CAP 50/70, $C A P+P P A, C A P+$ borracha e $C A P+$ borracha+PPA}

A Tabela 57 mostra os percentuais de recuperação do CAP 50/70 e dos ligantes asfálticos modificados com PPA, borracha e borracha+PPA, todos na condição envelhecida a curto prazo e nos tempos de 2 e $18 \mathrm{~s}$. De uma maneira geral, a incorporação dos modificadores acarreta um aumento do percentual de recuperação dos ligantes asfálticos, o que indica uma maior parcela elástica da deformação total sofrida por estes materiais. $O$ CAP+borracha+PPA possui os valores mais elevados de $\mathrm{R}$ em todo o espectro de temperaturas a 100 e a $3.200 \mathrm{~Pa}$, com resultados entre 32 e $68 \%$ a $100 \mathrm{~Pa}$ e entre 1 e $60 \%$ a $3.200 \mathrm{~Pa}$. À exceção do ligante asfáltico puro, o CAP+borracha apresenta as recuperações mais baixas nas temperaturas de 52 a $64^{\circ} \mathrm{C}$ a $3.200 \mathrm{~Pa}$ e o CAP+PPA, as recuperações mais baixas em todas as temperaturas a $100 \mathrm{~Pa}$. Em termos numéricos, as diferenças entre os percentuais de recuperação do CAP+borracha e do CAP+borracha+PPA são mais elevadas nas temperaturas de até $64^{\circ} \mathrm{C}$ a $3.200 \mathrm{~Pa}$. Como um exemplo, os percentuais do CAP+borracha e do CAP+borracha+PPA diferem entre si em mais de $10 \%$ na temperatura de $58^{\circ} \mathrm{C}$ a $3.200 \mathrm{~Pa}(32,8 \%$ para o $\mathrm{CAP}+$ borracha e $44,1 \%$ para 0 CAP+borracha+PPA) e menos de $4 \%$ para esta mesma temperatura a $100 \mathrm{~Pa}(58,8 \%$ para o CAP+borracha e 62,2\% para o CAP+borracha+PPA).

A Figura 73 ilustra os gráficos do percentual de recuperação para o CAP 50/70, o CAP+PPA, o CAP+borracha e o CAP+borracha+PPA, todos na condição envelhecida a curto prazo e considerando os tempos de 2 e 18 s. O CAP 50/70 apresenta recuperações não-nulas apenas nas temperaturas de 52 e $58^{\circ} \mathrm{C}$ a $100 \mathrm{~Pa}$ e na temperatura de $52^{\circ} \mathrm{C}$ a $3.200 \mathrm{~Pa}$. As 
reduções dos percentuais de recuperação seguem uma tendência aproximadamente linear para o CAP+PPA, o CAP+borracha e o CAP+borracha+PPA, tanto a $100 \mathrm{~Pa}$ quanto nas temperaturas de até $64^{\circ} \mathrm{C}$ a $3.200 \mathrm{~Pa}$. As recuperações são nulas ou muito pequenas para os ligantes asfálticos modificados deste grupo na temperatura de $76^{\circ} \mathrm{C}$ e no nível de tensão de 3.200 Pa. O CAP+PPA apresenta um decréscimo mais acentuado de recuperação do que o CAP+borracha na tensão de 3.200 Pa, o que ocasiona o cruzamento das curvas de ambos os materiais entre as temperaturas de 64 e $70^{\circ} \mathrm{C}$. Este fenômeno, entretanto, não é observado a $100 \mathrm{~Pa}$, em que as curvas do CAP+PPA e do CAP+borracha mantêm um certo grau de paralelismo nas temperaturas acima de $58^{\circ} \mathrm{C}$.

Tabela 57 - Percentuais de recuperação (R) do CAP 50/70, do CAP+PPA, do CAP+borracha e do CAP+borracha+PPA nos tempos de 2 e 18 s e na condição envelhecida

\begin{tabular}{ccccccccccc}
\hline \multirow{2}{*}{$\begin{array}{c}\text { Ligante } \\
\text { asfáltico }\end{array}$} & \multicolumn{4}{c}{$100 \mathrm{~Pa}(\mathrm{R} 100), \mathrm{em} \%$} & \multicolumn{4}{c}{$3.200 \mathrm{~Pa}(\mathrm{R} 3200), \mathrm{em} \%$} \\
\cline { 2 - 11 } & $52^{\circ} \mathrm{C}$ & $58^{\circ} \mathrm{C}$ & $64^{\circ} \mathrm{C}$ & $70^{\circ} \mathrm{C}$ & $76^{\circ} \mathrm{C}$ & $52^{\circ} \mathrm{C}$ & $58^{\circ} \mathrm{C}$ & $64^{\circ} \mathrm{C}$ & $70^{\circ} \mathrm{C}$ & $76^{\circ} \mathrm{C}$ \\
\hline $50 / 70$ & 7,9 & 2,9 & 0,0 & 0,0 & 0,0 & 3,4 & 0,0 & 0,0 & 0,0 & 0,0 \\
PPA & 59,4 & 50,2 & 38,8 & 27,1 & 17,7 & 56,4 & 40,0 & 19,0 & 3,3 & 0,0 \\
Borracha & 63,2 & 58,8 & 49,6 & 38,0 & 29,2 & 50,6 & 32,8 & 15,2 & 4,7 & 0,0 \\
Borracha+PPA & 67,5 & 62,2 & 53,6 & 42,7 & 32,1 & 59,8 & 44,1 & 24,7 & 9,5 & 1,8 \\
\hline
\end{tabular}

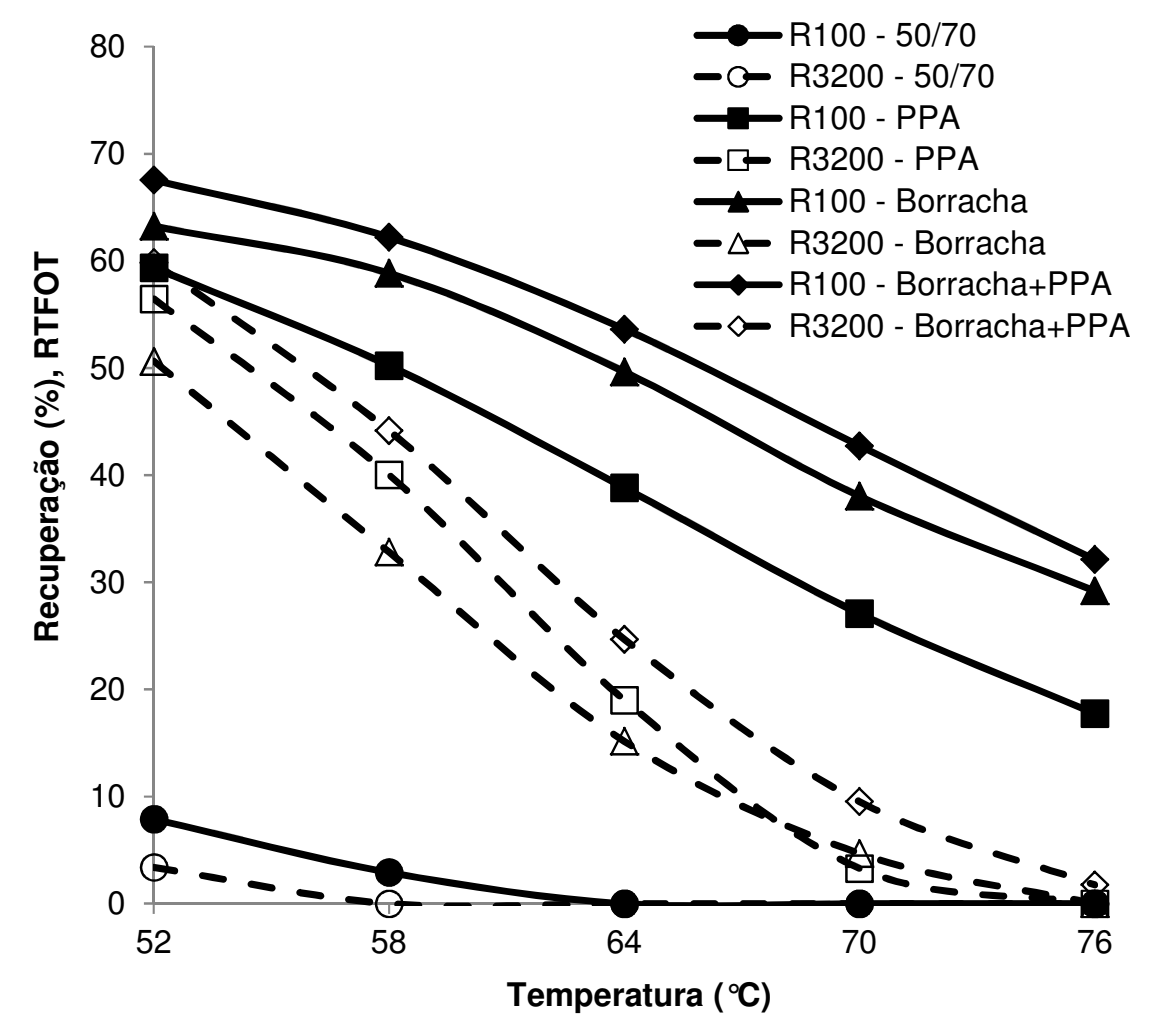

Figura 73 - Percentuais de recuperação (R) do CAP 50/70, do CAP+PPA, do CAP+borracha e do CAP+borracha+PPA na condição envelhecida e nos tempos de 2 e $18 \mathrm{~s}$ 
A Tabela 58 apresenta as compliâncias não-recuperáveis do CAP 50/70, do CAP+PPA, do CAP+borracha e do CAP+borracha+PPA, considerando os tempos de 2 e $18 \mathrm{~s}$ e a condição envelhecida destes materiais. A adição dos modificadores ocasiona uma redução na compliância não-recuperável do ligante asfáltico, o que indica uma menor suscetibilidade à deformação permanente. O CAP+borracha+PPA possui os valores mais baixos de $J_{n r}$ nas temperaturas acima de $58^{\circ} \mathrm{C}$ a $100 \mathrm{~Pa}$, bem como nas temperaturas de 70 e $76{ }^{\circ} \mathrm{C}$ a $3.200 \mathrm{~Pa}$. O CAP+borracha apresenta, à exceção do material puro, os valores mais elevados de compliância não-recuperável em todo o espectro de temperaturas a 100 e a $3.200 \mathrm{~Pa}$, com resultados entre 0,1 e $6,0 \mathrm{kPa}^{-1}$ a $3.200 \mathrm{~Pa}$ e de até $3,0 \mathrm{kPa}^{-1}$ a $100 \mathrm{~Pa}$. As compliâncias do CAP+borracha+PPA são de 0,03 a 2,15 $\mathrm{kPa}^{-1}$ inferiores às compliâncias do CAP+borracha para todo o espectro de temperaturas, sendo que as diferenças mais significativas são observadas nas temperaturas de 70 e $76^{\circ} \mathrm{C}$ a 100 e a 3.200 Pa.

Tabela 58-Compliâncias não-recuperáveis $\left(\mathrm{J}_{\mathrm{nr}}\right)$ do CAP 50/70, do CAP+PPA, do CAP+borracha e do CAP+borracha+PPA nos tempos de 2 e $18 \mathrm{~s}$ e na condição envelhecida

\begin{tabular}{ccccccccccc}
\hline \multirow{2}{*}{$\begin{array}{c}\text { Ligante } \\
\text { asfáltico }\end{array}$} & \multicolumn{4}{c}{$100 \mathrm{~Pa}\left(\mathrm{~J}_{\mathrm{nr}} 100\right), \mathrm{em} \mathrm{kPa}^{-1}$} & \multicolumn{5}{c}{$3.200 \mathrm{~Pa}\left(\mathrm{~J}_{\mathrm{nr}} 3200\right), \mathrm{em} \mathrm{kPa}^{-1}$} \\
\cline { 2 - 11 } & $52^{\circ} \mathrm{C}$ & $58^{\circ} \mathrm{C}$ & $64^{\circ} \mathrm{C}$ & $70^{\circ} \mathrm{C}$ & $76^{\circ} \mathrm{C}$ & $52^{\circ} \mathrm{C}$ & $58^{\circ} \mathrm{C}$ & $64^{\circ} \mathrm{C}$ & $70^{\circ} \mathrm{C}$ & $76^{\circ} \mathrm{C}$ \\
\hline $50 / 70$ & 0,63 & 1,75 & 4,69 & 11,70 & 26,49 & 0,68 & 2,01 & 5,43 & 13,34 & 30,14 \\
PPA & 0,05 & 0,14 & 0,41 & 1,10 & 2,78 & 0,05 & 0,17 & 0,57 & 1,74 & 4,77 \\
Borracha & 0,08 & 0,19 & 0,50 & 1,30 & 2,94 & 0,11 & 0,34 & 1,01 & 2,58 & 5,88 \\
Borracha+PPA & 0,05 & 0,12 & 0,31 & 0,78 & 1,84 & 0,06 & 0,19 & 0,57 & 1,55 & 3,74 \\
\hline
\end{tabular}

A Figura 74 mostra os gráficos de $\mathrm{J}_{\mathrm{nr}}$ com a temperatura para os materiais modificados com PPA, borracha e borracha+PPA, todos na condição envelhecida a curto prazo e considerando os tempos de 2 e $18 \mathrm{~s}$. Os valores de compliância não-recuperável para o CAP+PPA e o CAP+borracha apresentam diferenças pequenas em todo o espectro de temperaturas a $100 \mathrm{~Pa}$, o mesmo sendo observado para o CAP+PPA e o CAP+borracha+PPA nas temperaturas de até $70^{\circ} \mathrm{C}$ a $3.200 \mathrm{~Pa}$. O incremento de 100 para $3.200 \mathrm{~Pa}$ no nível de tensão aumenta a compliância não-recuperável do CAP+borracha em uma intensidade maior do que a verificada no CAP+PPA e no CAP+borracha+PPA e, em virtude deste aumento, 0 gráfico do CAP+borracha mantém um afastamento razoável dos gráficos do CAP+PPA e do $\mathrm{CAP}+$ borracha+PPA a $3.200 \mathrm{~Pa}$, especialmente nas temperaturas de 64 e $70^{\circ} \mathrm{C}$.

A Tabela 59 apresenta os valores de $\mathrm{J}_{\text {nr,diff }}$ para o CAP 50/70 e os ligantes asfálticos modificados com PPA, borracha e borracha+PPA, todos na condição envelhecida e considerando os tempos de 2 e 18 s. O CAP+borracha e o CAP+borracha+PPA possuem 
valores de $\mathrm{J}_{\text {nr,diff }}$ superiores a $75 \%$ na temperatura do $P G$ e, na extensão em que é válida a aplicação do limite de 75\% estipulado pela AASHTO MP19 a materiais envelhecidos a curto prazo e submetidos aos tempos de fluência e recuperação de 2 e $18 \mathrm{~s}$, ambos podem ser considerados como muito sensíveis à tensão. O CAP 50/70 apresenta diferenças percentuais inferiores a $16 \%$ e o CAP+PPA possui valores inferiores a $72 \%$, ambos para qualquer temperatura. O CAP+borracha possui os valores mais elevados de $J_{n r \text {,diff }}$ nas temperaturas de até $64^{\circ} \mathrm{C}$ e, nas temperaturas de 70 e $76{ }^{\circ} \mathrm{C}$, os resultados são parecidos para o $\mathrm{CAP}+$ borracha e o CAP+borracha+PPA. O CAP+PPA apresenta, dentre os materiais modificados, a menor sensibilidade à tensão em todo o espectro de temperaturas. Em comparação ao CAP+borracha, o CAP+borracha+PPA possui valores menores de $\mathrm{J}_{\mathrm{nr} \text {,diff }}$ nas temperaturas de até $64^{\circ} \mathrm{C}$.

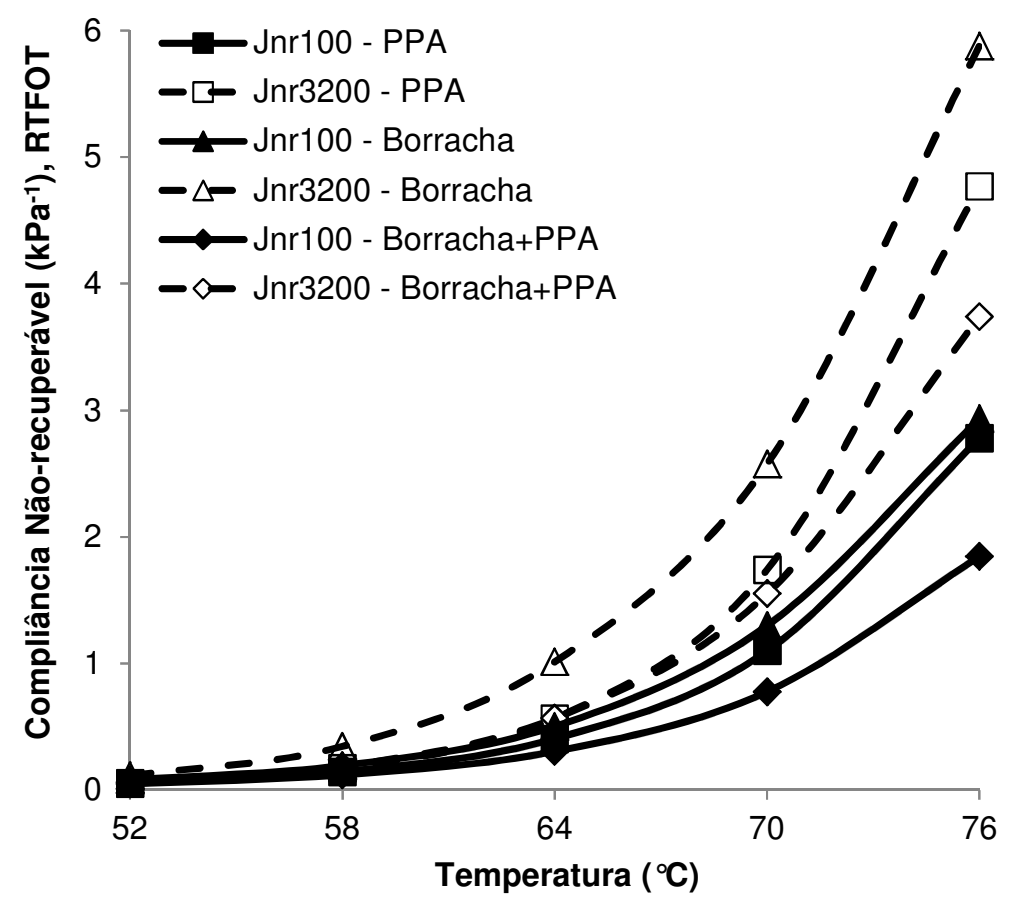

Figura 74 - Compliâncias não-recuperáveis $\left(\mathrm{J}_{n r}\right)$ do CAP+PPA, do CAP+borracha e do CAP+borracha+PPA na condição envelhecida e nos tempos de 2 e $18 \mathrm{~s}$

Tabela 59 - Diferenças percentuais entre as compliâncias não-recuperáveis $\left(\mathrm{J}_{\text {nr,diff }}\right)$ do CAP 50/70, do CAP+PPA, do CAP+borracha e do CAP+borracha+PPA nos tempos de 2 e $18 \mathrm{~s}$

\begin{tabular}{cccccc}
\hline \multirow{2}{*}{ Ligante asfáltico } & \multicolumn{5}{c}{ Materiais envelhecidos (RTFOT) } \\
\cline { 2 - 6 } & $52^{\circ} \mathrm{C}$ & $58^{\circ} \mathrm{C}$ & $64^{\circ} \mathrm{C}$ & $70^{\circ} \mathrm{C}$ & $76{ }^{\circ} \mathrm{C}$ \\
\hline $50 / 70$ & 7,5 & 14,5 & 15,7 & 13,9 & 13,8 \\
PPA & 5,6 & 20,0 & 39,5 & 58,2 & 71,6 \\
Borracha & 39,4 & 77,5 & 101,3 & 98,3 & 100,2 \\
Borracha+PPA & 26,7 & 55,4 & 85,7 & 99,8 & 102,7 \\
\hline
\end{tabular}


A Figura 75 ilustra os gráficos de $J_{\text {rr,diff }}$ com a temperatura para o CAP 50/70 e os ligantes asfálticos modificados com PPA, borracha e borracha+PPA, todos na condição envelhecida a curto prazo e nos tempos de 2 e $18 \mathrm{~s}$. As diferenças percentuais do $\mathrm{CAP}+$ borracha e do CAP+borracha+PPA sofrem incrementos significativos até a temperatura de $64{ }^{\circ} \mathrm{C}$, a partir da qual estes aumentos passam a ser menores (no caso do CAP+borracha+PPA) ou há uma relativa estabilização dos resultados (no caso do CAP+borracha). O CAP+borracha e o CAP+borracha+PPA possuem resultados superiores aos do CAP+PPA em qualquer temperatura, alcançando inclusive diferenças percentuais superiores a $75 \%$ nas temperaturas de 64,70 e $76{ }^{\circ} \mathrm{C}$. O CAP 50/70 apresenta variações relativamente pequenas de $\mathrm{J}_{\mathrm{nr} \text {,diff }}$ em todo o espectro de temperaturas, especialmente a 58 , 64,70 e $76^{\circ} \mathrm{C}$. As diferenças percentuais mostram uma tendência aproximadamente linear de crescimento com a temperatura no caso do CAP+PPA, atingindo valores superiores a $40 \%$ nas temperaturas de 70 e $76^{\circ} \mathrm{C}$.

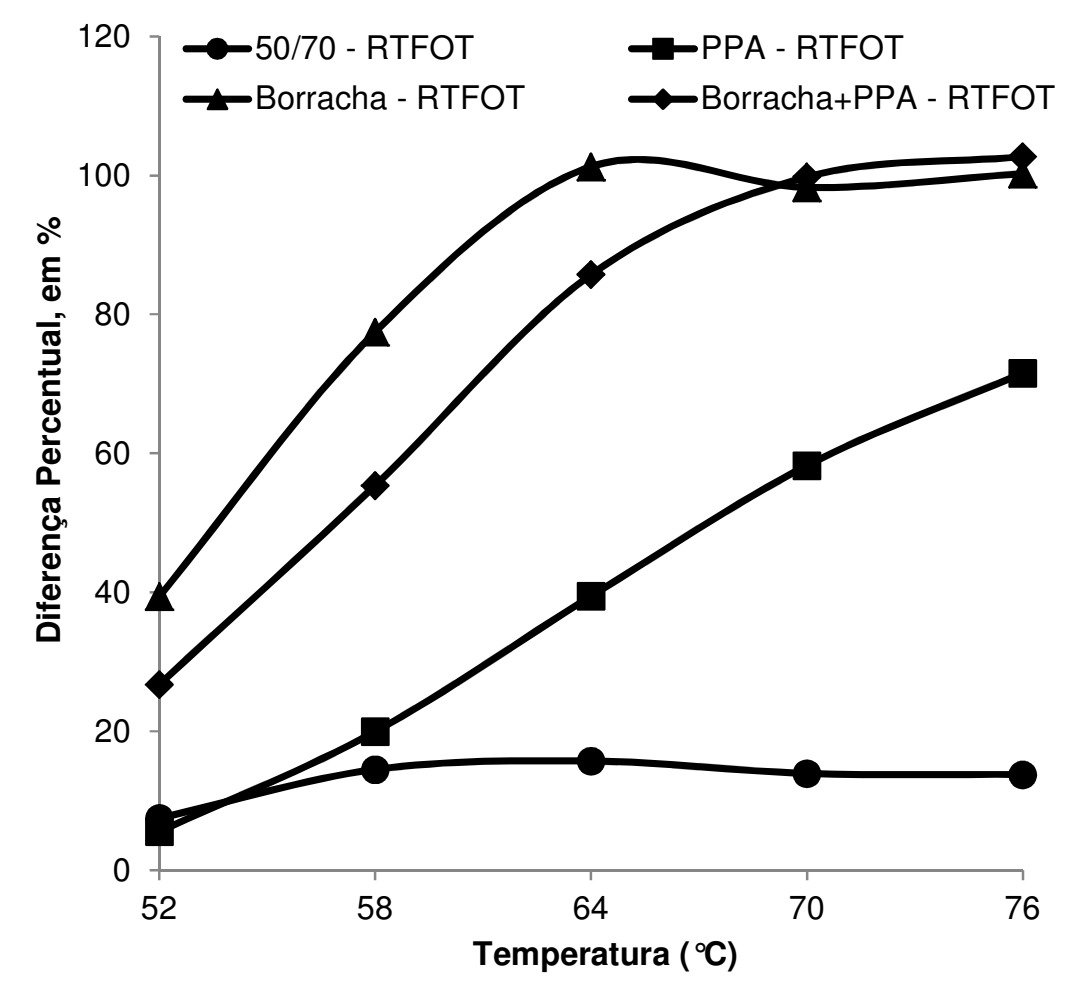

Figura 75 - Diferenças percentuais entre as compliâncias não-recuperáveis $\left(J_{n r, \text { diff }}\right)$ do CAP 50/70, do CAP+PPA, do CAP+borracha e do CAP+borracha+PPA nos tempos de 2 e $18 \mathrm{~s}$

Os resultados do CAP 50/70, do CAP+PPA, do CAP+borracha e do CAP+borracha+PPA para os tempos de 2 e 18 s (Tabelas 57 a 59 e Figuras 73 a 75) mostram que o CAP+borracha+PPA possui os maiores percentuais de recuperação em qualquer temperatura a 100 e a $3.200 \mathrm{~Pa}$, bem como as menores compliâncias não-recuperáveis nas 
temperaturas acima de $58^{\circ} \mathrm{C}$ a $100 \mathrm{~Pa}$ e nas temperaturas de 70 e $76^{\circ} \mathrm{C}$ a $3.200 \mathrm{~Pa}$. Em termos do percentual de recuperação e à exceção do material puro, o CAP+PPA apresenta os resultados mais baixos em todas as temperaturas a $100 \mathrm{~Pa}$ e o CAP+borracha, os valores mais baixos nas temperaturas de até $64^{\circ} \mathrm{C}$ a $3.200 \mathrm{~Pa}$. Em termos da compliância não-recuperável, os maiores resultados são encontrados no CAP+borracha em todas as temperaturas a 100 e a 3.200 Pa dentre os materiais modificados. As análises de sensibilidade à tensão apontam que os CAPs modificados com borracha e com borracha+PPA possuem uma sensibilidade excessiva (valor elevado de $J_{n r, d i f f}$ ) nas temperaturas de 64,70 e $76{ }^{\circ} \mathrm{C}$, com diferenças percentuais iguais ou superiores a $100 \%$ para ambos na temperatura de $76{ }^{\circ} \mathrm{C}$.

\subsection{3. $C A P 50 / 70, C A P+P P A, C A P+S B S$ e $C A P+S B S+P P A$}

A Tabela 60 apresenta os percentuais de recuperação do CAP 50/70 e dos ligantes asfálticos modificados com PPA, SBS e SBS+PPA, todos na condição envelhecida a curto prazo e nos tempos de 2 e $18 \mathrm{~s}$. A adição dos modificadores acarreta, em linhas gerais, um aumento dos percentuais de recuperação dos ligantes asfálticos, especialmente no caso do $\mathrm{CAP}+\mathrm{PPA}$ e do $\mathrm{CAP}+\mathrm{SBS}+\mathrm{PPA}$. O CAP+PPA possui as recuperações mais elevadas a 100 e a $3.200 \mathrm{~Pa}$, com resultados entre 17 e $60 \%$ a $100 \mathrm{~Pa}$ e de até $57 \%$ a $3.200 \mathrm{~Pa}$. O CAP+SBS apresenta, dentre os ligantes asfálticos modificados, os percentuais de recuperação mais baixos em todo o espectro de temperaturas a $100 \mathrm{~Pa}$ e nas temperaturas de até $70^{\circ} \mathrm{C}$ a $3.200 \mathrm{~Pa}$. As diferenças entre os percentuais de recuperação do CAP+SBS e do CAP+SBS+PPA são elevadas (superiores a $11 \%$ ) nas temperaturas de até $64^{\circ} \mathrm{C}$ a $100 \mathrm{~Pa}$ e de até $58^{\circ} \mathrm{C}$ a $3.200 \mathrm{~Pa}$. O CAP 50/70 apresenta recuperação não-nula apenas nas temperaturas de 52 e $58^{\circ} \mathrm{C}$ a $100 \mathrm{~Pa}$ e na temperatura de $52^{\circ} \mathrm{C}$ a $3.200 \mathrm{~Pa}$, não apresentando qualquer recuperação nas demais temperaturas. Não são observadas distinções significativas entre os modificadores nas temperaturas de 70 e $76{ }^{\circ} \mathrm{C}$ e no nível de tensão de $3.200 \mathrm{~Pa}$, em que os percentuais de recuperação dos ligantes asfálticos são nulos ou muito pequenos (inferiores a $4 \%$ ).

A Figura 76 ilustra as variações de R com a temperatura para o CAP 50/70 e os ligantes asfálticos modificados com PPA, SBS e SBS+PPA, considerando a condição envelhecida destes materiais e os tempos de 2 e 18 s. À tensão de $100 \mathrm{~Pa}$, observa-se que os decréscimos do percentual de recuperação com a temperatura seguem uma tendência aproximadamente linear para os três ligantes asfálticos modificados em todo o espectro de temperaturas. Esta tendência também é visualizada nas temperaturas de até $64^{\circ} \mathrm{C}$ a $3.200 \mathrm{~Pa}$, 
com a diferença de que as diminuições do percentual de recuperação são mais acentuadas (maior inclinação dos gráficos). Interessante observar que a ordenação dos ligantes asfálticos modificados segundo os valores decrescentes de recuperação - CAP+PPA, CAP+SBS+PPA e CAP+SBS, respectivamente - é a mesma em todo o espectro de temperaturas a $100 \mathrm{~Pa}$, bem como nas temperaturas de até $70^{\circ} \mathrm{C}$ a $3.200 \mathrm{~Pa}$. Em termos gráficos, esta constatação se reflete no não cruzamento das curvas dos ligantes asfálticos na faixa considerada de temperaturas, tanto a 100 quanto a 3.200 Pa.

Tabela 60 - Percentuais de recuperação (R) do CAP 50/70, do CAP+PPA, do CAP+SBS e do $C A P+S B S+P P A$ nos tempos de 2 e $18 \mathrm{~s}$ e na condição envelhecida

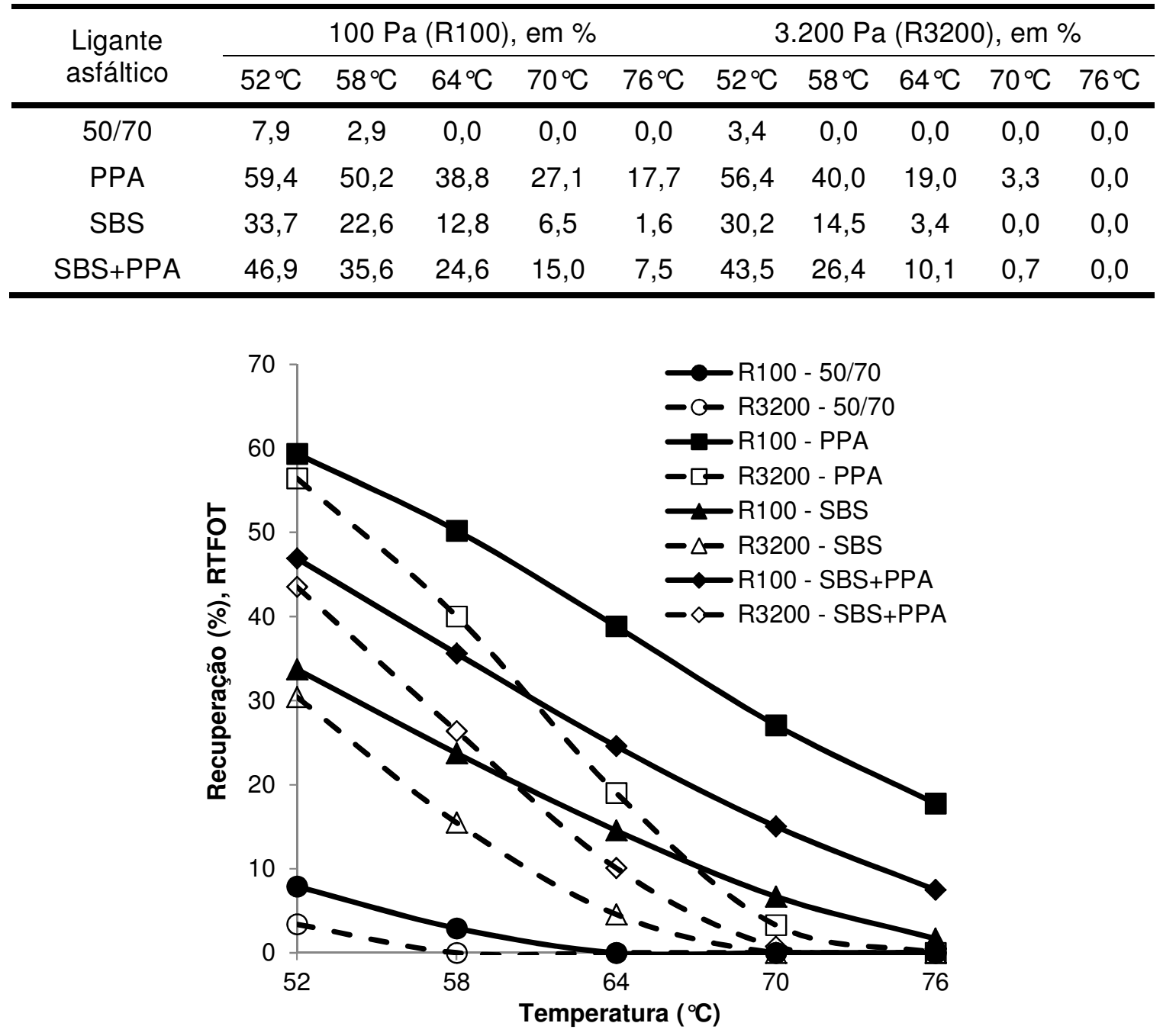

Figura 76 - Percentuais de recuperação (R) do CAP 50/70, do CAP+PPA, do CAP+SBS e do CAP+SBS+PPA na condição envelhecida e nos tempos de 2 e $18 \mathrm{~s}$

A Tabela 61 apresenta as compliâncias não-recuperáveis do CAP 50/70, do $\mathrm{CAP}+\mathrm{PPA}$, do $\mathrm{CAP}+\mathrm{SBS}$ e do $\mathrm{CAP}+\mathrm{SBS}+\mathrm{PPA}$, todos na condição envelhecida a curto prazo e nos tempos de 2 e 18 s. A adição dos modificadores ocasiona uma redução nas 
compliâncias não-recuperáveis do ligante asfáltico em todas as temperaturas e níveis de tensão. Dentre os materiais modificados, o CAP+SBS possui os valores mais elevados de $\mathrm{J}_{\mathrm{nr}}$ em todo o espectro de temperaturas a 100 e a $3.200 \mathrm{~Pa}$, com resultados entre 0,1 e $6,2 \mathrm{kPa}^{-1}$ a $100 \mathrm{~Pa}$ e entre 0,1 e $7,9 \mathrm{kPa}^{-1}$ a $3.200 \mathrm{~Pa}$. O CAP+PPA possui os valores mais baixos para esta propriedade em qualquer temperatura (resultados entre 0,05 e $4,77 \mathrm{kPa}^{-1}$ ), tanto a 100 quanto a 3.200 Pa. Interessante observar que a ordenação dos ligantes asfálticos segundo os valores decrescentes de compliância não-recuperável - CAP+SBS, CAP+SBS+PPA e $\mathrm{CAP}+\mathrm{PPA}$, respectivamente - é a mesma em todas as temperaturas a 100 e a 3.200 Pa. Em termos numéricos, as compliâncias não-recuperáveis do CAP+SBS+PPA estão entre 0,08 e $5,37 \mathrm{kPa}^{-1}$ e as do CAP 50/70 estão entre 0,63 e 30,14 $\mathrm{kPa}^{-1}$, ambas para qualquer temperatura e nível de tensão.

Tabela 61 - Compliâncias não-recuperáveis $\left(\mathrm{J}_{\text {nr }}\right)$ do CAP 50/70, do CAP+PPA, do CAP+SBS e do $C A P+S B S+P P A$ nos tempos de 2 e 18 s e na condição envelhecida

\begin{tabular}{ccccccccccc}
\hline \multirow{2}{*}{$\begin{array}{c}\text { Ligante } \\
\text { asfáltico }\end{array}$} & \multicolumn{4}{c}{$100 \mathrm{~Pa}\left(\mathrm{~J}_{\mathrm{nr}} 100\right), \mathrm{em} \mathrm{kPa}^{-1}$} & \multicolumn{5}{c}{$3.200 \mathrm{~Pa}\left(\mathrm{~J}_{\mathrm{nr}} 3200\right), \mathrm{em} \mathrm{kPa}^{-1}$} \\
\cline { 2 - 11 } & $52^{\circ} \mathrm{C}$ & $58^{\circ} \mathrm{C}$ & $64^{\circ} \mathrm{C}$ & $70^{\circ} \mathrm{C}$ & $76^{\circ} \mathrm{C}$ & $52^{\circ} \mathrm{C}$ & $58^{\circ} \mathrm{C}$ & $64^{\circ} \mathrm{C}$ & $70^{\circ} \mathrm{C}$ & $76^{\circ} \mathrm{C}$ \\
\hline $50 / 70$ & 0,63 & 1,75 & 4,69 & 11,70 & 26,49 & 0,68 & 2,01 & 5,43 & 13,34 & 30,14 \\
PPA & 0,05 & 0,14 & 0,41 & 1,10 & 2,78 & 0,05 & 0,17 & 0,57 & 1,74 & 4,77 \\
SBS & 0,13 & 0,37 & 1,02 & 2,58 & 6,19 & 0,14 & 0,43 & 1,26 & 3,29 & 7,86 \\
SBS+PPA & 0,08 & 0,22 & 0,60 & 1,56 & 3,83 & 0,08 & 0,25 & 0,77 & 2,14 & 5,37 \\
\hline
\end{tabular}

A Figura 77 ilustra os gráficos de $\mathrm{J}_{\mathrm{nr}}$ com a temperatura para o CAP+PPA, o $\mathrm{CAP}+\mathrm{SBS}$ e o $\mathrm{CAP}+\mathrm{SBS}+\mathrm{PPA}$, todos na condição envelhecida a curto prazo e nos tempos de 2 e $18 \mathrm{~s}$. A distinção entre os modificadores é difícil de ser realizada nas temperaturas de 52 e $58^{\circ} \mathrm{C}$ a 100 e a $3.200 \mathrm{~Pa}$, uma vez que as compliâncias não-recuperáveis dos ligantes asfálticos são próximas entre si. O incremento do nível de tensão de 100 para $3.200 \mathrm{~Pa}$ acarreta um deslocamento dos gráficos na direção vertical, não alterando, porém, a ordenação dos ligantes asfálticos segundo os valores decrescentes de $\mathrm{J}_{\mathrm{nr}}$. Esta constância na ordenação dos ligantes asfálticos permite que, para um mesmo nível de tensão, não haja qualquer cruzamento entre os gráficos dos materiais. As compliâncias não-recuperáveis do CAP+SBS+PPA a 100 Pa são parecidas com as do CAP+PPA a $3.200 \mathrm{~Pa}$ até a temperatura de $70^{\circ} \mathrm{C}$, a partir da qual a diferença entre os dois valores é maior: $4,77 \mathrm{kPa}^{-1}$ para o CAP+PPA e $3,83 \mathrm{kPa}^{-1}$ para 0 CAP+SBS+PPA a $76^{\circ} \mathrm{C}$, uma diferença de $0,94 \mathrm{kPa}^{-1}$ conforme Tabela 61.

A Tabela 62 mostra as diferenças percentuais entre as compliâncias $\left(J_{n r, d i f f}\right)$ do CAP puro, do $C A P+P P A$, do $C A P+S B S$ e do $C A P+S B S+P P A$, considerando a condição envelhecida destes materiais e os tempos de 2 e $18 \mathrm{~s}$. Em linhas gerais, o CAP+PPA possui a maior 
sensibilidade à tensão porque seus valores de $J_{\text {rr,diff }}$ são os mais elevados nas temperaturas acima de $52^{\circ} \mathrm{C}$. O CAP+SBS apresenta, dentre os materiais modificados, a menor sensibilidade à tensão (menor $\mathrm{J}_{n r, \text { diff }}$ ) nas temperaturas acima de $52^{\circ} \mathrm{C}$, sendo que o $\mathrm{CAP}+\mathrm{SBS}+\mathrm{PPA}$ possui resultados intermediários entre o $\mathrm{CAP}+\mathrm{SBS}$ e o $\mathrm{CAP}+\mathrm{PPA}$ nestas mesmas temperaturas. $\mathrm{O}$ CAP 50/70 possui diferenças percentuais mais próximas às do CAP+SBS, com valores entre 7 e 16\% para qualquer temperatura. Não são observadas distinções significativas entre as sensibilidades dos materiais nas temperaturas de 52 e $58^{\circ} \mathrm{C}$, nas quais as diferenças entre os valores de $\mathrm{J}_{\text {nr,diff }}$ são pequenas. Estas distinções, entretanto, passam a ser maiores com o aumento da temperatura, fazendo com que a diferença numérica entre o maior e o menor valor de $J_{\text {nr,diff }}$ passe de $1,9 \%(7,5-5,6 \%)$ a $52^{\circ} \mathrm{C}$ para $57,8 \%(71,6-13,8 \%)$ a $76{ }^{\circ} \mathrm{C}$.

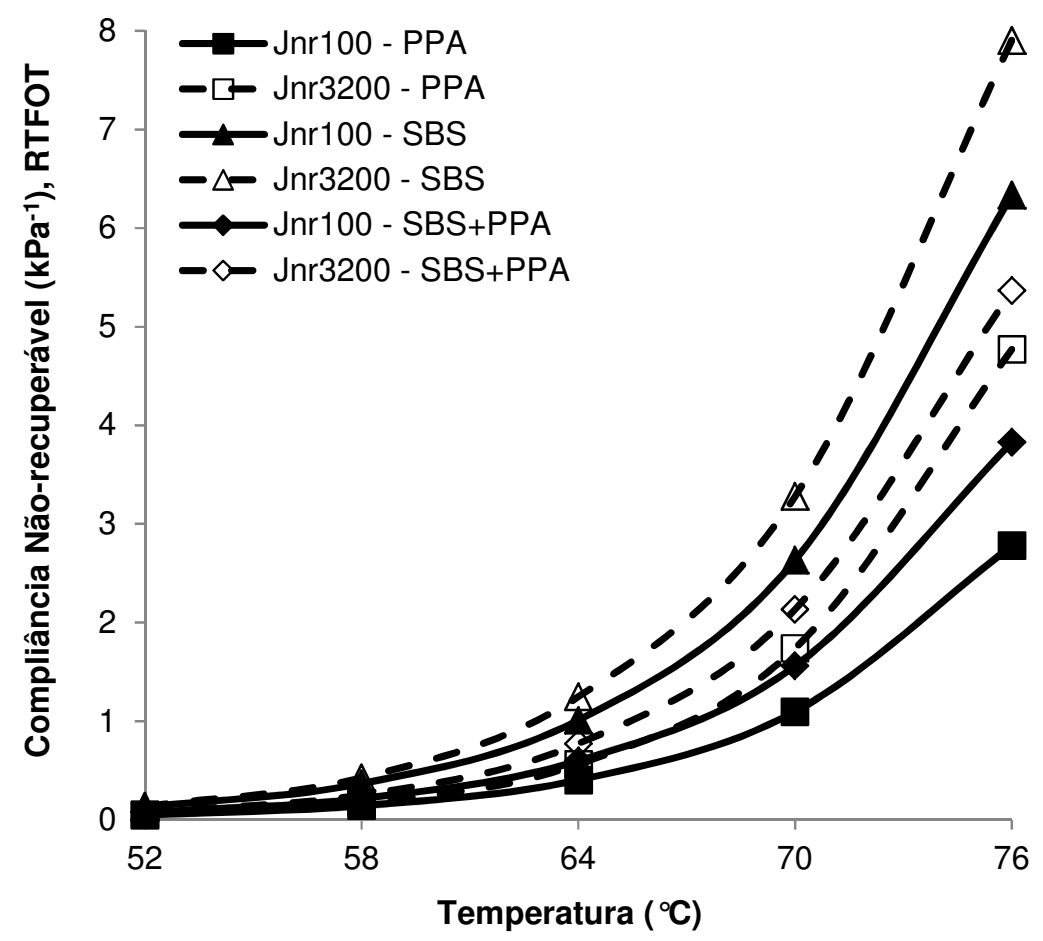

Figura 77 - Compliâncias não-recuperáveis $\left(\mathrm{J}_{\text {nr }}\right)$ do CAP+PPA, do CAP+SBS e do $\mathrm{CAP}+\mathrm{SBS}+\mathrm{PPA}$ na condição envelhecida e nos tempos de 2 e $18 \mathrm{~s}$

Tabela 62 - Diferenças percentuais entre as compliâncias não-recuperáveis $\left(J_{\text {nr,diff }}\right)$ do CAP 50/70, do CAP+PPA, do CAP+SBS e do CAP+SBS+PPA nos tempos de 2 e $18 \mathrm{~s}$

\begin{tabular}{cccccc}
\hline \multirow{2}{*}{ Ligante asfáltico } & \multicolumn{5}{c}{ Materiais envelhecidos (RTFOT) } \\
\cline { 2 - 6 } & $52^{\circ} \mathrm{C}$ & $58^{\circ} \mathrm{C}$ & $64^{\circ} \mathrm{C}$ & $70^{\circ} \mathrm{C}$ & $76^{\circ} \mathrm{C}$ \\
\hline $50 / 70$ & 7,5 & 14,5 & 15,7 & 13,9 & 13,8 \\
PPA & 5,6 & 20,0 & 39,5 & 58,2 & 71,6 \\
SBS & 6,9 & 15,6 & 22,8 & 27,2 & 27,0 \\
SBS+PPA & 6,5 & 16,5 & 29,2 & 36,8 & 40,2 \\
\hline
\end{tabular}


A Figura 78 apresenta os gráficos de $\mathrm{J}_{\mathrm{nr} \text {,diff }}$ com a temperatura para o CAP 50/70, o $\mathrm{CAP}+\mathrm{PPA}, \mathrm{O} \mathrm{CAP}+\mathrm{SBS}$ e o $\mathrm{CAP}+\mathrm{SBS}+\mathrm{PPA}$, considerando os tempos de 2 e $18 \mathrm{~s}$ e a condição envelhecida destes materiais. Na extensão em que é válida a aplicação do limite de $75 \%$ estipulado pela AASHTO MP19 a ligantes asfálticos envelhecidos a curto prazo e submetidos aos tempos de fluência e recuperação de 2 e $18 \mathrm{~s}$ na temperatura do $P G$, nenhum dos materiais deste grupo possui uma sensibilidade excessiva à tensão. O CAP 50/70 não apresenta variações significativas de $\mathrm{J}_{\mathrm{nr} \text {,diff }}$ nas temperaturas acima de $58^{\circ} \mathrm{C}$, para o qual as diferenças percentuais variam entre 13 e 16\% conforme Tabela 62 . Os incrementos de $J_{\text {nr,diff }}$ são maiores para o CAP+PPA em comparação ao CAP+SBS e ao CAP+SBS+PPA e, assim, pode-se dizer que a temperatura afeta a sensibilidade do CAP+PPA de uma maneira mais significativa do que nos outros dois ligantes asfálticos. No caso do CAP+SBS e do CAP+SBS+PPA, os valores de $J_{\text {nr,diff }}$ sofrem incrementos maiores para ambos até a temperatura de $64^{\circ} \mathrm{C}$, a partir da qual há uma tendência de estabilização dos valores (no caso do CAP+SBS) ou um crescimento menos significativo da sensibilidade à tensão (no caso do CAP+SBS+PPA).

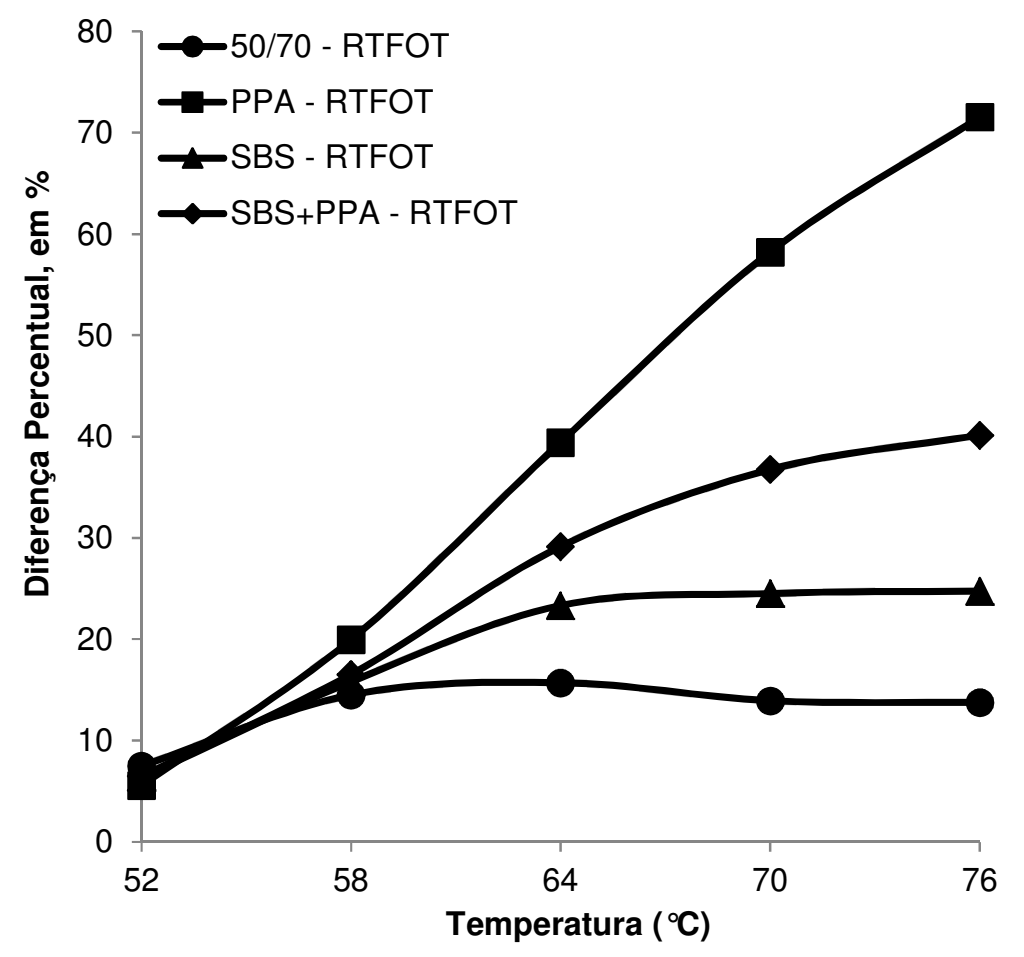

Figura 78 - Diferenças percentuais entre as compliâncias não-recuperáveis $\left(J_{\text {nr,diff }}\right)$ do CAP 50/70, do CAP+PPA, do CAP+SBS e do CAP+SBS+PPA nos tempos de 2 e $18 \mathrm{~s}$

As análises dos resultados do CAP 50/70, do CAP+PPA, do CAP+SBS e do CAP+SBS+PPA (Tabelas 60 a 62 e Figuras 76 a 78) mostram que o CAP+PPA possui os maiores percentuais de recuperação não-nulos e as menores compliâncias não-recuperáveis em todas as temperaturas, tanto a 100 quanto a 3.200 Pa. O CAP+SBS apresenta, dentre os 
ligantes asfálticos modificados, os menores percentuais de recuperação em todo o espectro de temperaturas a $100 \mathrm{~Pa}$ e nas temperaturas de até $70^{\circ} \mathrm{C}$ a $3.200 \mathrm{~Pa}$, apresentando também as maiores compliâncias não-recuperáveis. Um destaque especial pode ser dado às ordenações dos ligantes asfálticos segundo os valores decrescentes de $R$ ou de $J_{n r}$, as quais se mantêm constantes nas temperaturas do MSCR. As análises de sensibilidade dos ligantes asfálticos à tensão apontam que, em linhas gerais, o CAP+PPA possui a maior sensibilidade e o CAP+SBS possui a menor dentre os materiais modificados, sendo que as distinções entre as sensibilidades dos ligantes asfálticos são maiores nas temperaturas de 70 e $76{ }^{\circ} \mathrm{C}$.

\subsubsection{CAP 50/70, CAP+PPA, CAP+EVA e CAP+EVA+PPA}

A Tabela 63 apresenta os percentuais de recuperação do CAP 50/70 e dos ligantes asfálticos modificados com PPA, EVA e EVA+PPA, considerando a condição envelhecida destes materiais e os tempos de 2 e $18 \mathrm{~s}$. A adição dos modificadores ocasiona, de uma maneira geral, um aumento dos percentuais de recuperação do ligante asfáltico, especialmente no caso do CAP+EVA e do CAP+EVA+PPA. O CAP+EVA possui as recuperações mais elevadas nas temperaturas de até $64^{\circ} \mathrm{C}$ a 100 e a $3.200 \mathrm{~Pa}$, com resultados entre 17 e $91 \%$ a $100 \mathrm{~Pa}$ e de até $86 \%$ a $3.200 \mathrm{~Pa}$. O CAP+PPA possui, à exceção do material puro, os valores mais baixos de $R$ nas temperaturas de até $70^{\circ} \mathrm{C}$ a $100 \mathrm{~Pa}$ e de até $64^{\circ} \mathrm{C}$ a $3.200 \mathrm{~Pa}$. Os percentuais de recuperação do CAP+EVA+PPA variam em uma faixa menor de valores que a do CAP+EVA para um mesmo nível de tensão, indicando que a temperatura afeta a recuperação do CAP+EVA de uma maneira mais significativa do que no CAP+EVA+PPA. Como um exemplo, os percentuais de recuperação do CAP+EVA variam de 17 a $91 \%$ ao longo de todo o espectro de temperaturas a $100 \mathrm{~Pa}$, enquanto que, para este mesmo nível de tensão, os percentuais do $C A P+E V A+P P A$ variam de 41 a $66 \%$.

Tabela 63 - Percentuais de recuperação $(R)$ do CAP 50/70, do CAP+PPA, do CAP+EVA e do CAP+EVA+PPA nos tempos de 2 e $18 \mathrm{~s}$ e na condição envelhecida

\begin{tabular}{ccccccccccc}
\hline \multirow{2}{*}{$\begin{array}{c}\text { Ligante } \\
\text { asfáltico }\end{array}$} & \multicolumn{4}{c}{$100 \mathrm{~Pa}(\mathrm{R} 100), \mathrm{em} \%$} & \multicolumn{5}{c}{$3.200 \mathrm{~Pa}(\mathrm{R} 3200), \mathrm{em} \%$} \\
\cline { 2 - 11 } & $52^{\circ} \mathrm{C}$ & $58^{\circ} \mathrm{C}$ & $64^{\circ} \mathrm{C}$ & $70^{\circ} \mathrm{C}$ & $76^{\circ} \mathrm{C}$ & $52^{\circ} \mathrm{C}$ & $58^{\circ} \mathrm{C}$ & $64^{\circ} \mathrm{C}$ & $70^{\circ} \mathrm{C}$ & $76^{\circ} \mathrm{C}$ \\
\hline $50 / 70$ & 7,9 & 2,9 & 0,0 & 0,0 & 0,0 & 3,4 & 0,0 & 0,0 & 0,0 & 0,0 \\
PPA & 59,4 & 50,2 & 38,8 & 27,1 & 17,7 & 56,4 & 40,0 & 19,0 & 3,3 & 0,0 \\
EVA & 90,5 & 88,1 & 63,2 & 31,9 & 17,3 & 86,1 & 84,6 & 49,9 & 2,2 & 0,0 \\
EVA+PPA & 65,9 & 62,6 & 55,2 & 48,8 & 41,6 & 59,7 & 43,4 & 21,3 & 3,9 & 0,0 \\
\hline
\end{tabular}


A Figura 79 mostra os gráficos do percentual de recuperação para o CAP 50/70, o $\mathrm{CAP}+\mathrm{PPA}$, o CAP+EVA e do CAP+EVA+PPA, considerando os tempos de 2 e $18 \mathrm{~s}$ e a condição envelhecida destes materiais. O CAP 50/70 possui recuperação não-nula apenas nas temperaturas de 52 e $58^{\circ} \mathrm{C}$ a $100 \mathrm{~Pa}$ e na temperatura de $52^{\circ} \mathrm{C}$ a $3.200 \mathrm{~Pa}$, não possuindo qualquer recuperação nas demais condições de temperatura e tensão. Os decréscimos de recuperação com a temperatura se mostram mais acentuados para o CAP+EVA em comparação ao CAP+EVA+PPA e ao CAP+PPA, tanto a 100 quanto a $3.200 \mathrm{~Pa}$. O $\mathrm{CAP}+\mathrm{EVA}+\mathrm{PPA}$ e o CAP+PPA apresentam valores parecidos de $\mathrm{R}$ em todo o espectro de temperaturas a 3.200 $\mathrm{Pa}$ e, à luz destes resultados, pode-se dizer que as formulações dos dois ligantes asfálticos são equivalentes. Este fenômeno, entretanto, não é observado para o $\mathrm{CAP}+\mathrm{PPA}$ e o $\mathrm{CAP}+\mathrm{EVA}+\mathrm{PPA}$ a $100 \mathrm{~Pa}$, em que os percentuais de recuperação do CAP+EVA+PPA são maiores que os do CAP+PPA em todas as temperaturas. Interessante observar que os decréscimos do percentual de recuperação para o CAP+EVA+PPA e o CAP+PPA seguem tendências aproximadamente lineares em todo o espectro de temperaturas a $100 \mathrm{~Pa}$, bem como nas temperaturas de até $70^{\circ} \mathrm{C}$ a $3.200 \mathrm{~Pa}$.

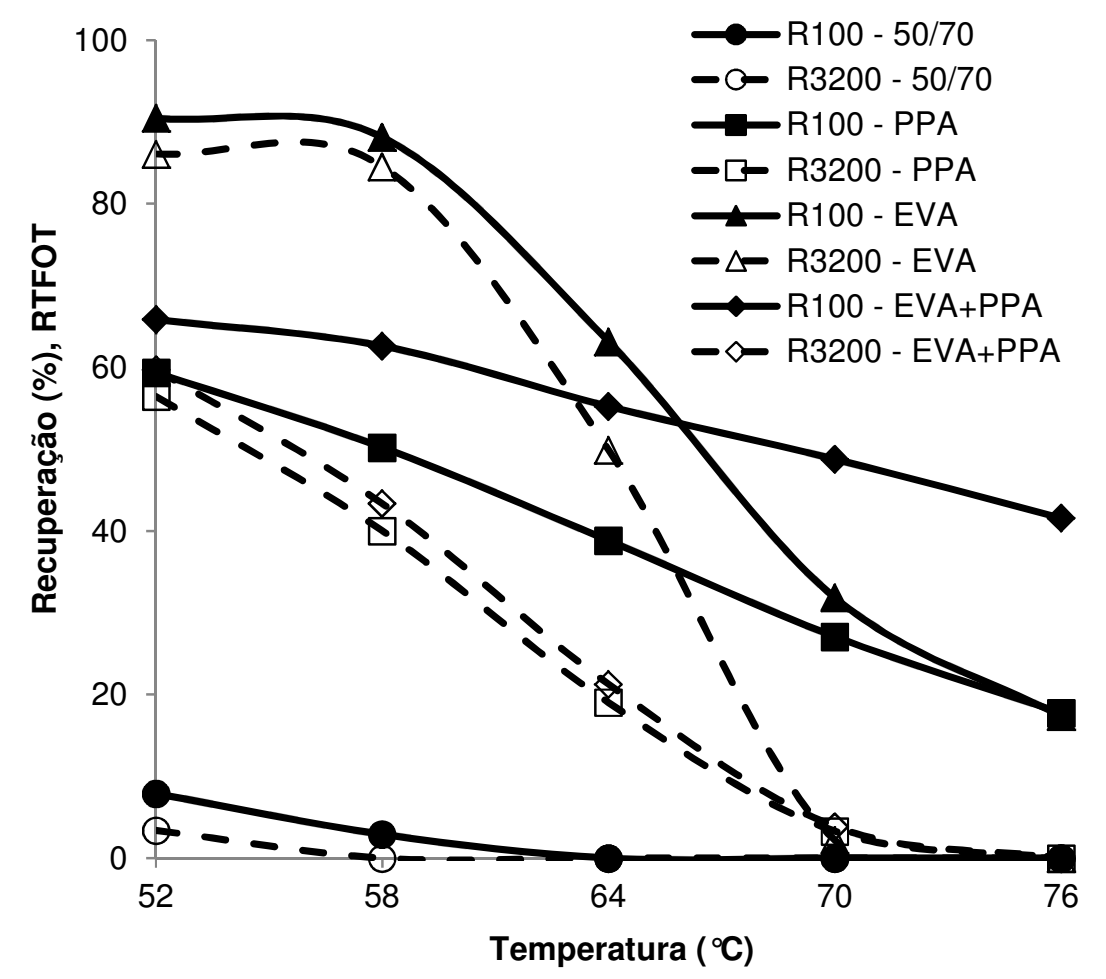

Figura 79 - Percentuais de recuperação $(R)$ do CAP 50/70, do CAP+PPA, do CAP+EVA e do $\mathrm{CAP}+\mathrm{EVA}+\mathrm{PPA}$ na condição envelhecida e nos tempos de 2 e $18 \mathrm{~s}$

A Tabela 64 apresenta as compliâncias não-recuperáveis do CAP 50/70 e dos ligantes asfálticos modificados com PPA, EVA e EVA+PPA, considerando a condição envelhecida destes materiais e os tempos de 2 e $18 \mathrm{~s}$. A incorporação dos modificadores 
ocasiona uma redução da compliância não-recuperável do ligante asfáltico, sendo que o $\mathrm{CAP}+\mathrm{EVA}$ possui os valores mais baixos para esta propriedade nas temperaturas de até $64^{\circ} \mathrm{C}$ a 100 e a 3.200 Pa. O CAP 50/70 possui compliâncias não-recuperáveis entre 0,6 e 26,50 kPa a $100 \mathrm{~Pa}$, atingindo valores superiores a $13,0 \mathrm{kPa}^{-1}$ nas temperaturas de 70 e $76{ }^{\circ} \mathrm{C}$ a $3.200 \mathrm{~Pa}$. O $\mathrm{CAP}+\mathrm{PPA}$ apresenta, dentre os ligantes asfálticos modificados deste grupo, os maiores valores de $\mathrm{J}_{\mathrm{nr}}$ nas temperaturas de $58,64,70$ e $76^{\circ} \mathrm{C}$ a $100 \mathrm{~Pa}$, sendo que o CAP+EVA+PPA apresenta os maiores resultados nas temperaturas de até $70^{\circ} \mathrm{C}$ a $3.200 \mathrm{~Pa}$. Em termos numéricos, as compliâncias não-recuperáveis dos três materiais modificados variam entre 0,01 e 2,78 $\mathrm{kPa}^{-1} \mathrm{a}$ $100 \mathrm{~Pa}$ e entre 0,02 e $6,36 \mathrm{kPa}^{-1}$ a $3.200 \mathrm{~Pa}$. Assim como observado no percentual de recuperação, os valores de $\mathrm{J}_{\mathrm{nr}}$ para o $\mathrm{CAP}+\mathrm{EVA}$ variam em uma faixa mais ampla de resultados do que no CAP+EVA+PPA para um mesmo nível de tensão, indicando a maior suscetibilidade desta propriedade ao aumento da temperatura no caso do CAP+EVA. Como um exemplo, os resultados de $J_{n r}$ para o CAP+EVA variam entre 0,01 a 2,69 $\mathrm{kPa}^{-1}$ a $100 \mathrm{~Pa}$ (uma diferença de 2,68 $\mathrm{kPa}^{-1}$ ), enquanto que, para o CAP+EVA+PPA e este mesmo nível de tensão, os resultados variam entre 0,05 a $1,19 \mathrm{kPa}^{-1}$ (uma diferença de $1,14 \mathrm{kPa}^{-1}$ ).

Tabela 64 - Compliâncias não-recuperáveis $\left(J_{\text {nr }}\right)$ do CAP 50/70, do CAP+PPA, do CAP+EVA e do CAP+EVA+PPA nos tempos de 2 e 18 s e na condição envelhecida

\begin{tabular}{ccccccccccc}
\hline \multirow{2}{*}{$\begin{array}{c}\text { Ligante } \\
\text { asfáltico }\end{array}$} & \multicolumn{4}{c}{$100 \mathrm{~Pa}\left(\mathrm{~J}_{\mathrm{nr}} 100\right), \mathrm{em} \mathrm{kPa}^{-1}$} & \multicolumn{3}{c}{$3.200 \mathrm{~Pa}\left(\mathrm{~J}_{\mathrm{nr}} 3200\right), \mathrm{em} \mathrm{kPa}^{-1}$} \\
\cline { 2 - 11 } & $52^{\circ} \mathrm{C}$ & $58^{\circ} \mathrm{C}$ & $64^{\circ} \mathrm{C}$ & $70^{\circ} \mathrm{C}$ & $76^{\circ} \mathrm{C}$ & $52^{\circ} \mathrm{C}$ & $58^{\circ} \mathrm{C}$ & $64^{\circ} \mathrm{C}$ & $70^{\circ} \mathrm{C}$ & $76^{\circ} \mathrm{C}$ \\
\hline $50 / 70$ & 0,63 & 1,75 & 4,69 & 11,70 & 26,49 & 0,68 & 2,01 & 5,43 & 13,34 & 30,14 \\
PPA & 0,05 & 0,14 & 0,41 & 1,10 & 2,78 & 0,05 & 0,17 & 0,57 & 1,74 & 4,77 \\
EVA & 0,01 & 0,02 & 0,18 & 0,97 & 2,69 & 0,02 & 0,03 & 0,38 & 2,93 & 6,36 \\
EVA+PPA & 0,05 & 0,10 & 0,23 & 0,51 & 1,19 & 0,06 & 0,19 & 0,68 & 2,24 & 6,12 \\
\hline
\end{tabular}

A Figura 80 ilustra os gráficos de $J_{n r}$ com a temperatura para os ligantes asfálticos modificados com PPA, EVA e EVA+PPA, todos na condição envelhecida a curto prazo e ensaiados nos tempos de fluência e recuperação de 2 e $18 \mathrm{~s}$. Os valores de $\mathrm{J}_{\mathrm{nr}}$ para o CAP+EVA e o CAP+EVA+PPA apresentam um crescimento maior com a temperatura na tensão de 3.200 $\mathrm{Pa}$ em comparação ao CAP+PPA, desde resultados inferiores a $0,1 \mathrm{kPa}^{-1}$ na temperatura de $52^{\circ} \mathrm{C}$ até resultados superiores a $6,0 \mathrm{kPa}^{-1}$ na temperatura de $76{ }^{\circ} \mathrm{C}$. Estes crescimentos, entretanto, não seguem um mesmo padrão para ambos os materiais, pois enquanto o CAP+EVA apresenta um crescimento aproximadamente linear de $J_{n r}$ nas temperaturas acima de $64^{\circ} \mathrm{C}$, o CAP+EVA+PPA apresenta uma tendência exponencial de crescimento desta propriedade em todo o espectro de temperaturas. Para o nível de tensão de $100 \mathrm{~Pa}$, observa-se que as compliâncias não-recuperáveis do CAP+EVA aumentam em uma taxa maior que a do CAP+EVA+PPA, sobretudo nas temperaturas de 64,70 e $76^{\circ} \mathrm{C}$. O 
$\mathrm{CAP}+\mathrm{EVA}$ e o CAP+PPA possuem valores parecidos de $\mathrm{J}_{\mathrm{nr}}$ nas temperaturas de 70 e $76^{\circ} \mathrm{C}$ a $100 \mathrm{~Pa}$, o mesmo não sendo observado paras estas temperaturas a $3.200 \mathrm{~Pa}$.

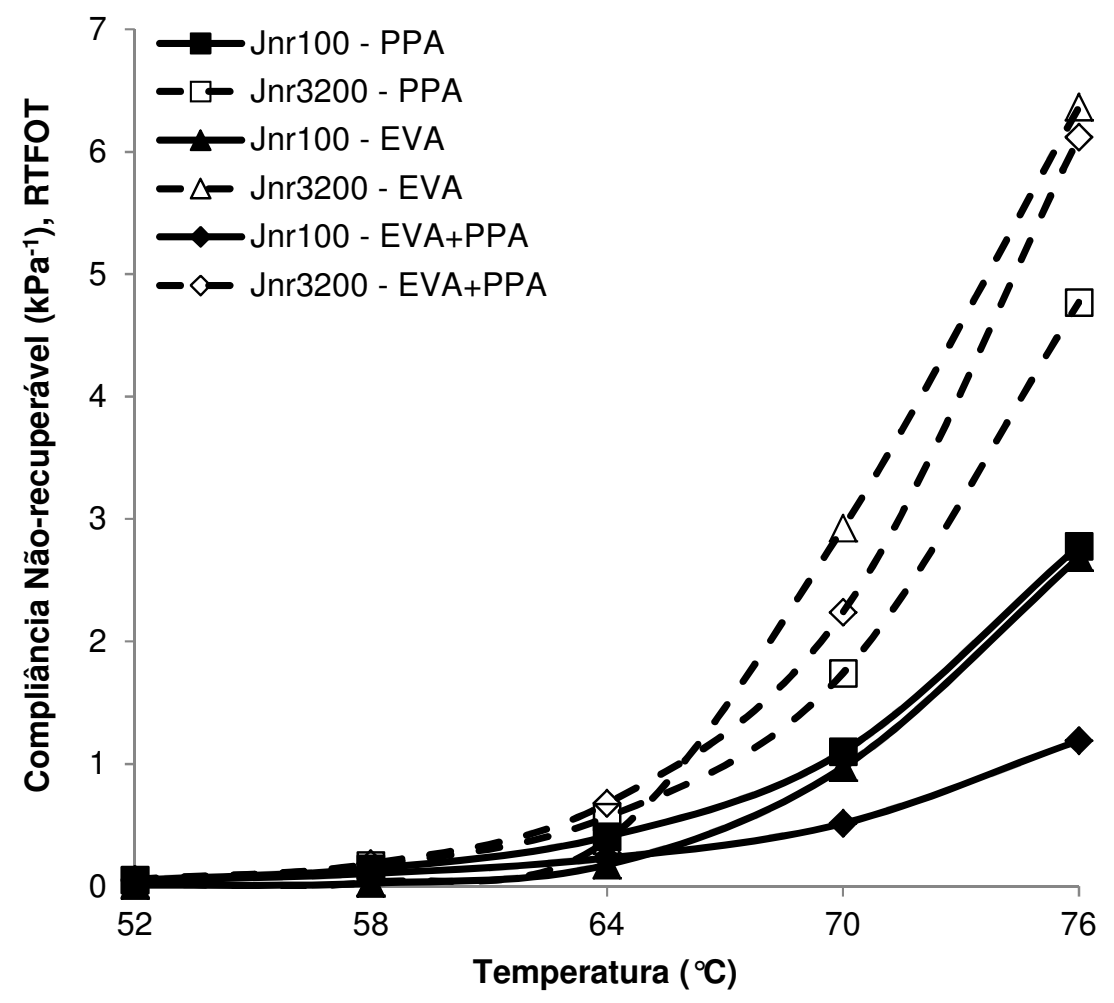

Figura 80 - Compliâncias não-recuperáveis $\left(\mathrm{J}_{n r}\right)$ do CAP+PPA, do CAP+EVA e do $\mathrm{CAP}+\mathrm{EVA}+\mathrm{PPA}$ na condição envelhecida e nos tempos de 2 e $18 \mathrm{~s}$

A Tabela 65 mostra as diferenças percentuais entre as compliâncias (parâmetro $J_{\text {nr,diff }}$ ) do CAP 50/70, do CAP+PPA, do CAP+EVA e do CAP+EVA+PPA, todos na condição envelhecida a curto prazo e considerando os tempos de 2 e $18 \mathrm{~s}$. Na extensão em que é válida a aplicação do limite de 75\% estipulado pela AASHTO MP19 a ligantes asfálticos envelhecidos a curto prazo e submetidos aos tempos de fluência e recuperação de 2 e $18 \mathrm{~s}$ na temperatura do $\mathrm{PG}$, o $\mathrm{CAP}+\mathrm{EVA}$ e o $\mathrm{CAP}+\mathrm{EVA}+\mathrm{PPA}$ podem ser considerados como muito sensíveis à tensão $\left(J_{n r, d i f f}>75 \%\right)$. O CAP+EVA+PPA apresenta os maiores valores de $J_{n r, d i f f}$ nas temperaturas de $58,64,70$ e $76^{\circ} \mathrm{C}$ e, em linhas gerais, pode-se dizer que este material possui a maior sensibilidade à tensão. O CAP+PPA apresenta, dentre os ligantes asfálticos modificados, as menores diferenças percentuais em todo o espectro de temperaturas, sendo, portanto, o material com a menor sensibilidade ao incremento do nível de tensão de 100 para 3.200 Pa. Em termos numéricos, o CAP+EVA possui diferenças percentuais entre 34 e $202 \%$ e o CAP+EVA+PPA, valores entre 24 e 415\%. No caso do CAP+PPA e do CAP 50/70, estes valores estão entre 5 e 72\% para qualquer temperatura, sendo que os maiores resultados pertencem ao CAP+PPA nas temperaturas de $58,64,70$ e $76^{\circ} \mathrm{C}$. 
Tabela 65 - Diferenças percentuais entre as compliâncias não-recuperáveis $\left(J_{\text {nr,diff }}\right)$ do CAP 50/70, do CAP+PPA, do CAP+EVA e do CAP+EVA+PPA nos tempos de 2 e $18 \mathrm{~s}$

\begin{tabular}{cccccc}
\hline \multirow{2}{*}{ Ligante asfáltico } & \multicolumn{5}{c}{ Materiais envelhecidos (RTFOT) } \\
\cline { 2 - 6 } & $52^{\circ} \mathrm{C}$ & $58^{\circ} \mathrm{C}$ & $64^{\circ} \mathrm{C}$ & $70^{\circ} \mathrm{C}$ & $76{ }^{\circ} \mathrm{C}$ \\
\hline $50 / 70$ & 7,5 & 14,5 & 15,7 & 13,9 & 13,8 \\
PPA & 5,6 & 20,0 & 39,5 & 58,2 & 71,6 \\
EVA & 69,6 & 34,9 & 114,5 & 201,6 & 136,9 \\
EVA+PPA & 24,3 & 78,1 & 194,4 & 336,1 & 414,3 \\
\hline
\end{tabular}

A Figura 81 (página seguinte) mostra os gráficos de $\mathrm{J}_{\mathrm{nr} \text {, diff }}$ com a temperatura para o CAP 50/70 e os ligantes asfálticos modificados com PPA, EVA e EVA+PPA, todos na condição envelhecida a curto prazo e nos tempos de 2 e $18 \mathrm{~s}$. As diferenças percentuais do $\mathrm{CAP}+\mathrm{PPA}$ e do CAP+EVA+PPA aumentam continuamente com o incremento da temperatura, alcançando, nas temperaturas de 70 e $76^{\circ} \mathrm{C}$, resultados superiores a $300 \%$ no caso do CAP+EVA+PPA e superiores a 50\% no caso do CAP+PPA. Para o CAP 50/70, estes percentuais variam em uma escala muito menor do que a observada nos ligantes asfálticos modificados, especialmente nas temperaturas acima de $64^{\circ} \mathrm{C}$. Não se pode estabelecer qualquer padrão de comportamento para as diferenças percentuais do CAP+EVA, uma vez que os valores de $J_{\text {nr,diff }}$ para este material ora aumentam ora diminuem com o incremento da temperatura. O CAP+EVA apresenta um valor máximo de $\mathrm{J}_{\mathrm{nr} \text {, diff }}$ superior a $200 \%$ a $70^{\circ} \mathrm{C}$ e um valor mínimo de $35 \%$ a $58^{\circ} \mathrm{C}$, conforme resultados da Tabela 65.

As análises realizadas no CAP 50/70 e nos ligantes asfálticos modificados com PPA, EVA e EVA+PPA (Tabelas 63 a 65 e Figuras 79 a 81) mostram que o CAP+EVA possui recuperações elevadas nas temperaturas de até $64^{\circ} \mathrm{C}$ a 100 e a $3.200 \mathrm{~Pa}$, porém os decréscimos desta propriedade com a temperatura são significativos em comparação ao $C A P+E V A+P P A$ e ao CAP+PPA. O CAP+PPA possui, à exceção do ligante asfáltico puro, os percentuais de recuperação mais baixos nas temperaturas de até $70^{\circ} \mathrm{C}$ a $100 \mathrm{~Pa}$ e de até $64^{\circ} \mathrm{C}$ a $3.200 \mathrm{~Pa}$. Em termos da compliância não-recuperável, o CAP+PPA apresenta os maiores resultados nas temperaturas acima de $58^{\circ} \mathrm{C}$ a $100 \mathrm{~Pa}$ no grupo dos ligantes asfálticos modificados e o $C A P+E V A+P P A$, os maiores resultados nas temperaturas de até $70^{\circ} \mathrm{C}$ a $3.200 \mathrm{~Pa}$. As diferenças percentuais do CAP+EVA e do CAP+EVA+PPA ultrapassam o valor de $75 \%$ em determinadas temperaturas, o que indica a elevada sensibilidade destes ligantes asfálticos à tensão. Em uma avaliação resumida e restrita aos ligantes asfálticos modificados, o CAP+EVA+PPA possui a maior sensibilidade à tensão e o CAP+PPA possui a menor sensibilidade, à luz dos incrementos de $J_{n r}$ após a elevação do nível de tensão de 100 para 3.200 Pa. 


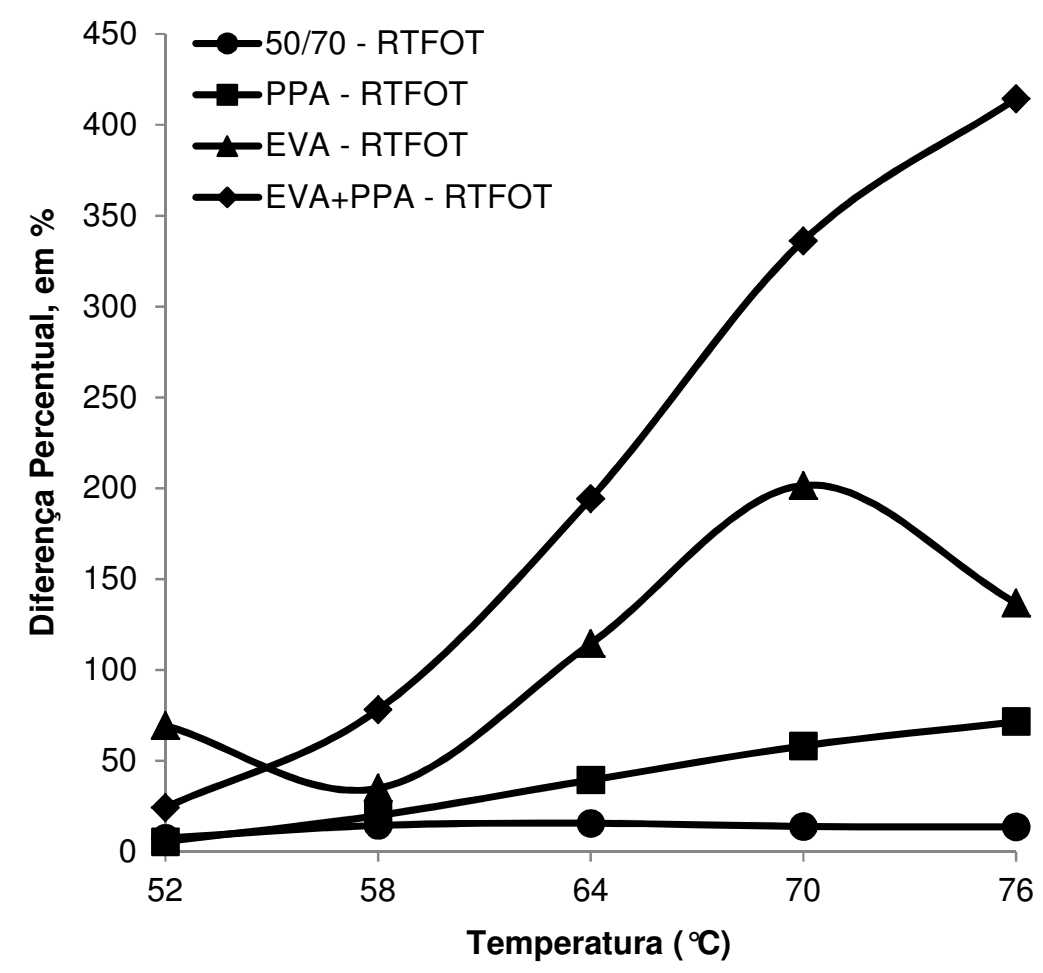

Figura 81 - Diferenças percentuais entre as compliâncias não-recuperáveis $\left(\mathrm{J}_{\text {nr,diff }}\right)$ do CAP 50/70, do CAP+PPA, do CAP+EVA e do CAP+EVA+PPA nos tempos de 2 e $18 \mathrm{~s}$

\subsubsection{CAP 50/70, CAP+PPA, CAP+PE e CAP+PE+PPA}

A Tabela 66 mostra os percentuais de recuperação do CAP 50/70 e dos ligantes asfálticos modificados com PPA, PE e PE+PPA, todos na condição envelhecida a curto prazo e considerando os tempos de 2 e 18 s. A adição dos modificadores ocasiona, em linhas gerais, um aumento dos percentuais de recuperação dos ligantes asfálticos. O CAP+PPA apresenta as recuperações mais elevadas em todo o espectro de temperaturas a $100 \mathrm{~Pa}$ e nas temperaturas de até $70^{\circ} \mathrm{C} 3.200 \mathrm{~Pa}$, sendo o material que recupera mais nestas condições. O CAP+PE apresenta os menores percentuais de recuperação dentre os ligantes asfálticos modificados, sendo o que recupera menos nestas condições. Em termos numéricos, o CAP+PE possui recuperações de até $24 \%$ a $100 \mathrm{~Pa}$ e de até $15 \%$ a $3.200 \mathrm{~Pa}$, com o CAP+PE+PPA possuindo valores entre 6 e 45\% a $100 \mathrm{~Pa}$ e de até $40 \%$ a $3.200 \mathrm{~Pa}$ para esta propriedade. As diferenças entre os percentuais do CAP+PE e do CAP+PE+PPA são elevadas em qualquer temperatura a $100 \mathrm{~Pa}$, bem como nas temperaturas de até $58^{\circ} \mathrm{C}$ a $3.200 \mathrm{~Pa}$. Como um exemplo, os percentuais de recuperação do CAP+PE e do $\mathrm{CAP}+\mathrm{PE}+\mathrm{PPA}$ são respectivamente iguais a 6,8 e $22,8 \%$ a $64^{\circ} \mathrm{C}$ e $100 \mathrm{~Pa}$, uma diferença de $16 \%$ entre os dois valores. 
Tabela 66 - Percentuais de recuperação $(\mathrm{R})$ do CAP 50/70, do CAP+PPA, do CAP+PE e do $\mathrm{CAP}+\mathrm{PE}+\mathrm{PPA}$ nos tempos de 2 e $18 \mathrm{~s}$ e na condição envelhecida

\begin{tabular}{ccccccccccc}
\hline \multirow{2}{*}{$\begin{array}{c}\text { Ligante } \\
\text { asfáltico }\end{array}$} & \multicolumn{4}{c}{$100 \mathrm{~Pa}(\mathrm{R} 100), \mathrm{em} \%$} & \multicolumn{5}{c}{$3.200 \mathrm{~Pa}(\mathrm{R} 3200), \mathrm{em} \%$} \\
\cline { 2 - 11 } & $52^{\circ} \mathrm{C}$ & $58^{\circ} \mathrm{C}$ & $64^{\circ} \mathrm{C}$ & $70^{\circ} \mathrm{C}$ & $76^{\circ} \mathrm{C}$ & $52^{\circ} \mathrm{C}$ & $58^{\circ} \mathrm{C}$ & $64^{\circ} \mathrm{C}$ & $70^{\circ} \mathrm{C}$ & $76^{\circ} \mathrm{C}$ \\
\hline $50 / 70$ & 7,9 & 2,9 & 0,0 & 0,0 & 0,0 & 3,4 & 0,0 & 0,0 & 0,0 & 0,0 \\
PPA & 59,4 & 50,2 & 38,8 & 27,1 & 17,7 & 56,4 & 40,0 & 19,0 & 3,3 & 0,0 \\
PE & 23,5 & 14,8 & 6,8 & 2,3 & 0,0 & 14,6 & 3,3 & 0,0 & 0,0 & 0,0 \\
PE+PPA & 44,5 & 33,6 & 22,8 & 13,4 & 6,3 & 39,3 & 21,6 & 5,7 & 0,0 & 0,0 \\
\hline
\end{tabular}

A Figura 82 ilustra os gráficos do percentual de recuperação com a temperatura para o CAP 50/70, o CAP+PPA, o CAP+PE e o CAP+PE+PPA, todos na condição envelhecida a curto prazo e nos tempos de 2 e 18 s. A tendência aproximadamente linear de redução desta propriedade com a temperatura é observada para os ligantes asfálticos modificados em todo o espectro de temperaturas a $100 \mathrm{~Pa}$, bem como nas temperaturas de até $64^{\circ} \mathrm{C}$ a $3.200 \mathrm{~Pa}$. As recuperações do CAP 50/70 são nulas nas temperaturas de 64,70 e $76{ }^{\circ} \mathrm{C}$ a $100 \mathrm{~Pa}$, bem como nas temperaturas de $58,64,70$ e $76^{\circ} \mathrm{C}$ a $3.200 \mathrm{~Pa}$. Interessante observar que a ordenação dos CAPs segundo os valores decrescentes de $R$ (CAP+PPA, CAP+PE+PPA e CAP+PE, respectivamente) não sofre alterações em qualquer temperatura a $100 \mathrm{~Pa}$, o mesmo ocorrendo nas temperaturas de até $64^{\circ} \mathrm{C}$ a $3.200 \mathrm{~Pa}$. Em termos gráficos, esta observação se reflete no não cruzamento das curvas dos materiais dentro de um mesmo nível de tensão.

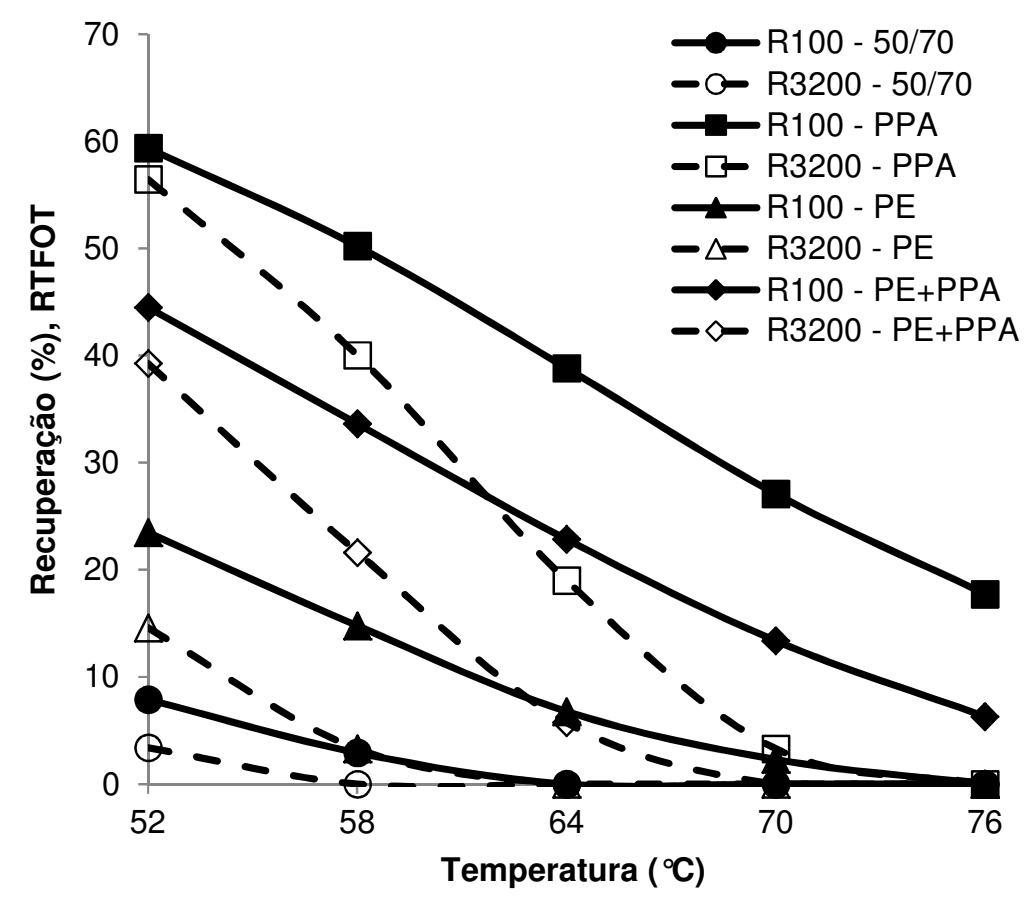

Figura 82 - Percentuais de recuperação $(R)$ do CAP 50/70, do CAP+PPA, do CAP+PE e do $\mathrm{CAP}+\mathrm{PE}+\mathrm{PPA}$ na condição envelhecida e nos tempos de 2 e $18 \mathrm{~s}$ 
A Tabela 67 apresenta os valores de $\mathrm{J}_{n r}$ do CAP 50/70, do CAP+PPA, do CAP+PE e do CAP+PE+PPA, considerando a condição envelhecida destes materiais e os tempos de 2 e 18 s. A adição dos modificadores ao CAP 50/70 ocasiona uma redução dos valores desta propriedade, o que indica uma menor suscetibilidade dos ligantes asfálticos modificados quanto à deformação permanente. O CAP+PE possui os valores mais elevados de $\mathrm{J}_{\mathrm{nr}}$ em todo o espectro de temperaturas a 100 e a $3.200 \mathrm{~Pa}$, com resultados entre 0,1 e $10,0 \mathrm{kPa}^{-1}$ a $100 \mathrm{~Pa}$ e entre 0,2 e 12,3 $\mathrm{kPa}^{-1}$ a $3.200 \mathrm{~Pa}$. As compliâncias não-recuperáveis do CAP+PE+PPA são menores que as do $\mathrm{CAP}+\mathrm{PE}$ em qualquer condição de temperatura e tensão, sendo que os valores estão entre 0,08 e 4,83 $\mathrm{kPa}^{-1}$ a $100 \mathrm{~Pa}$ e entre 0,09 e $6,90 \mathrm{kPa}^{-1}$ a $3.200 \mathrm{~Pa}$ para a formulação com PE+PPA. Os menores resultados de $J_{n r}$ são encontrados no CAP+PPA dentre os ligantes asfálticos modificados, com valores entre 0,05 e 2,78 $\mathrm{kPa}^{-1}$ a $100 \mathrm{~Pa}$ e entre $0,05 \mathrm{e}$ $4,77 \mathrm{kPa}^{-1}$ a $3.200 \mathrm{~Pa}$.

Tabela 67 - Compliâncias não-recuperáveis $\left(J_{\text {nr }}\right)$ do CAP 50/70, do CAP+PPA, do CAP+PE e do $C A P+P E+P P A$ nos tempos de 2 e $18 \mathrm{~s}$ e na condição envelhecida

\begin{tabular}{ccccccccccc}
\hline \multirow{2}{*}{$\begin{array}{c}\text { Ligante } \\
\text { asfáltico }\end{array}$} & \multicolumn{4}{c}{$100 \mathrm{~Pa}\left(\mathrm{~J}_{\mathrm{nr}} 100\right), \mathrm{em} \mathrm{kPa}^{-1}$} & \multicolumn{5}{c}{$3.200 \mathrm{~Pa}\left(\mathrm{~J}_{\mathrm{nr}} 3200\right), \mathrm{em} \mathrm{kPa}^{-1}$} \\
\cline { 2 - 11 } & $52^{\circ} \mathrm{C}$ & $58^{\circ} \mathrm{C}$ & $64^{\circ} \mathrm{C}$ & $70^{\circ} \mathrm{C}$ & $76^{\circ} \mathrm{C}$ & $52^{\circ} \mathrm{C}$ & $58^{\circ} \mathrm{C}$ & $64^{\circ} \mathrm{C}$ & $70^{\circ} \mathrm{C}$ & $76^{\circ} \mathrm{C}$ \\
\hline $50 / 70$ & 0,63 & 1,75 & 4,69 & 11,70 & 26,49 & 0,68 & 2,01 & 5,43 & 13,34 & 30,14 \\
PPA & 0,05 & 0,14 & 0,41 & 1,10 & 2,78 & 0,05 & 0,17 & 0,57 & 1,74 & 4,77 \\
PE & 0,17 & 0,54 & 1,55 & 4,06 & 9,80 & 0,20 & 0,65 & 1,92 & 5,07 & 12,27 \\
PE+PPA & 0,08 & 0,25 & 0,71 & 1,92 & 4,83 & 0,09 & 0,30 & 0,95 & 2,68 & 6,90 \\
\hline
\end{tabular}

A Figura 83 mostra os gráficos de $\mathrm{J}_{\mathrm{nr}}$ com a temperatura para o CAP+PPA, o $\mathrm{CAP}+\mathrm{PE}$ e o $\mathrm{CAP}+\mathrm{PE}+\mathrm{PPA}$, todos na condição envelhecida a curto prazo e nos tempos de 2 e 18 s. O incremento do nível de tensão de 100 para $3.200 \mathrm{~Pa}$ proporciona um deslocamento dos gráficos na direção vertical, não alterando, porém, a ordenação dos ligantes asfálticos segundo os valores decrescentes de $J_{n r}(C A P+P E, C A P+P E+P P A$ e CAP+PPA, respectivamente). As compliâncias não-recuperáveis do CAP+PE+PPA a $100 \mathrm{~Pa}$ e do CAP+PPA a 3.200 Pa são muito próximas entre si em todo o espectro de temperaturas e, à luz destes resultados, pode-se dizer que as formulações dos dois materiais são equivalentes. As diferenças entre os valores de $J_{n r}$ dos ligantes asfálticos a 100 e a 3.200 Pa são pequenas nas temperaturas de até $64^{\circ} \mathrm{C}$, sendo mais elevadas nas temperaturas superiores a $64^{\circ} \mathrm{C}$.

A Tabela 68 apresenta os valores de $J_{n r, d i f f}$ para o CAP 50/70 e os ligantes asfálticos modificados com PPA, PE e PE+PPA, considerando a condição envelhecida destes materiais e os tempos de 2 e 18 s. Não são observadas diferenças percentuais 
superiores ao valor de $75 \%$ e, na extensão em que é válida a aplicação do limite de $75 \%$ estipulado pela AASHTO MP19 a ligantes asfálticos envelhecidos a curto prazo e submetidos aos tempos de fluência e recuperação de 2 e $18 \mathrm{~s}$ na temperatura do $P G$, nenhum dos materiais deste grupo possui uma sensibilidade excessiva à tensão. $O$ CAP+PPA possui os maiores valores de $J_{\text {nr,diff }}$ nas temperaturas de 64,70 e $76{ }^{\circ} \mathrm{C}$ e o $\mathrm{CAP}+\mathrm{PE}$, os menores nestas mesmas temperaturas dentre os ligantes asfálticos modificados. Esta situação, entretanto, se inverte a $52^{\circ} \mathrm{C}$, na qual o CAP+PE apresenta a diferença percentual mais elevada (16,5\%) e o CAP+PPA apresenta a mais baixa $(5,6 \%)$. As diferenças percentuais do $\mathrm{CAP}+\mathrm{PE}+\mathrm{PPA}$ são superiores às do CAP+PE nas temperaturas de 64,70 e $76^{\circ} \mathrm{C}$, sendo iguais ou menores nas temperaturas de 52 e $58^{\circ} \mathrm{C}$.

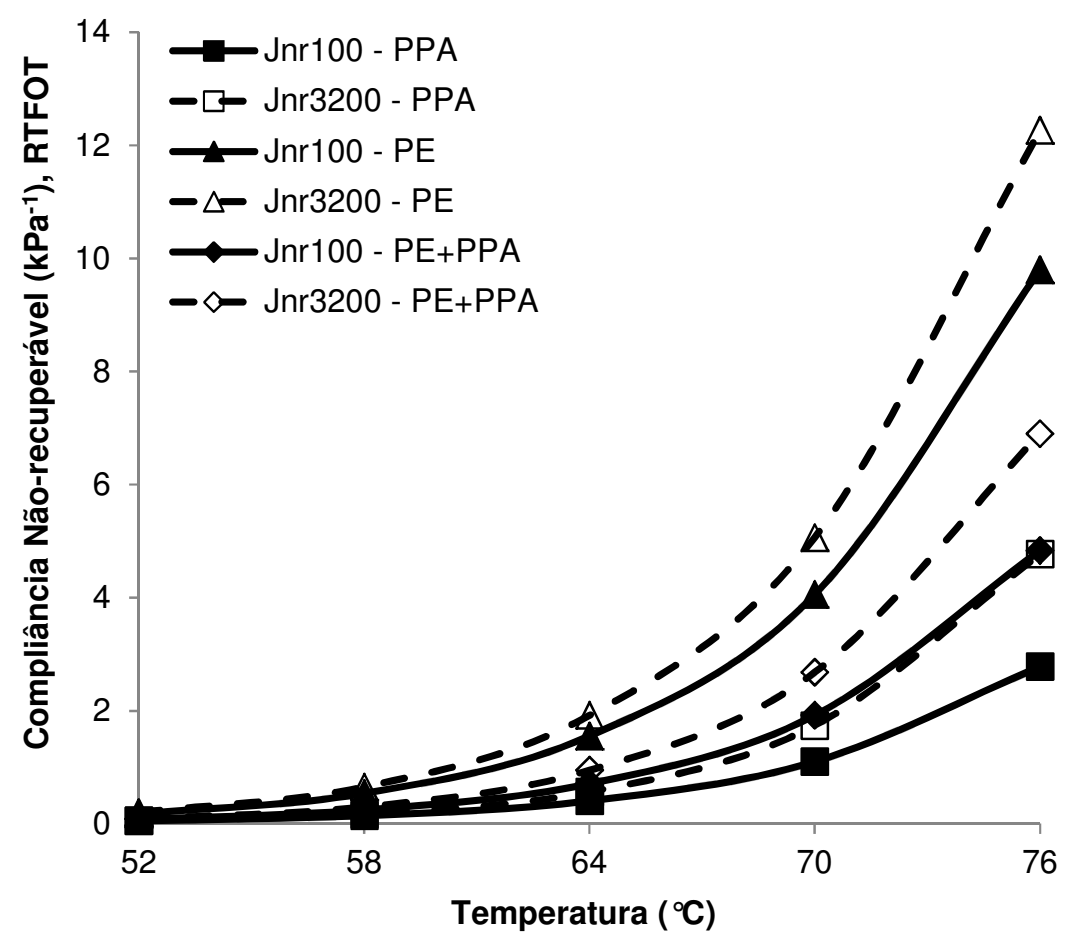

Figura 83 - Compliâncias não-recuperáveis $\left(\mathrm{J}_{\mathrm{nr}}\right)$ do CAP+PPA, do CAP+PE e do $\mathrm{CAP}+\mathrm{PE}+\mathrm{PPA}$ na condição envelhecida e nos tempos de 2 e $18 \mathrm{~s}$

Tabela 68 - Diferenças percentuais entre as compliâncias não-recuperáveis $\left(J_{\text {nr,diff }}\right)$ do CAP 50/70, do CAP+PPA, do CAP+PE e do CAP+PE+PPA nos tempos de 2 e $18 \mathrm{~s}$

\begin{tabular}{cccccc}
\hline \multirow{2}{*}{ Ligante asfáltico } & \multicolumn{5}{c}{ Materiais envelhecidos (RTFOT) } \\
\cline { 2 - 6 } & $52^{\circ} \mathrm{C}$ & $58^{\circ} \mathrm{C}$ & $64^{\circ} \mathrm{C}$ & $70^{\circ} \mathrm{C}$ & $76{ }^{\circ} \mathrm{C}$ \\
\hline $50 / 70$ & 7,5 & 14,5 & 15,7 & 13,9 & 13,8 \\
PPA & 5,6 & 20,0 & 39,5 & 58,2 & 71,6 \\
PE & 16,5 & 21,2 & 23,4 & 24,9 & 25,2 \\
PE+PPA & 9,9 & 21,2 & 33,3 & 39,5 & 42,7 \\
\hline
\end{tabular}


A Figura 84 ilustra os gráficos de $\mathrm{J}_{\text {nr,diff }}$ com a temperatura para o CAP 50/70 e os ligantes asfálticos modificados com PPA, PE e PE+PPA, todos na condição envelhecida a curto prazo e nos tempos de 2 e 18 s. O CAP 50/70 apresenta variações pequenas de $J_{\text {nr,diff }}$ em todo o espectro de temperaturas, especialmente a $58,64,70$ e $76{ }^{\circ} \mathrm{C}$. Os três materiais modificados possuem valores próximos de $J_{n r, d i f f}$ a $58^{\circ} \mathrm{C}$ (entre 20 e $22 \%$ conforme Tabela 68), indicando sensibilidades parecidas quanto ao incremento do nível de tensão. Embora os ligantes asfálticos modificados apresentem um aumento dos valores de $J_{\text {rr,diff }}$ com a temperatura, as inclinações dos gráficos não se mostram iguais para todos eles, sendo mais elevadas para o CAP+PPA, mais baixas para o CAP+PE e com valores intermediários para o $\mathrm{CAP}+\mathrm{PE}+\mathrm{PPA}$. Em linhas gerais, o $\mathrm{CAP}+\mathrm{PPA}$ possui a maior sensibilidade à tensão e 0 $\mathrm{CAP}+\mathrm{PE}$ possui a menor dentre os materiais modificados, com o CAP+PE+PPA apresentando uma sensibilidade intermediária.

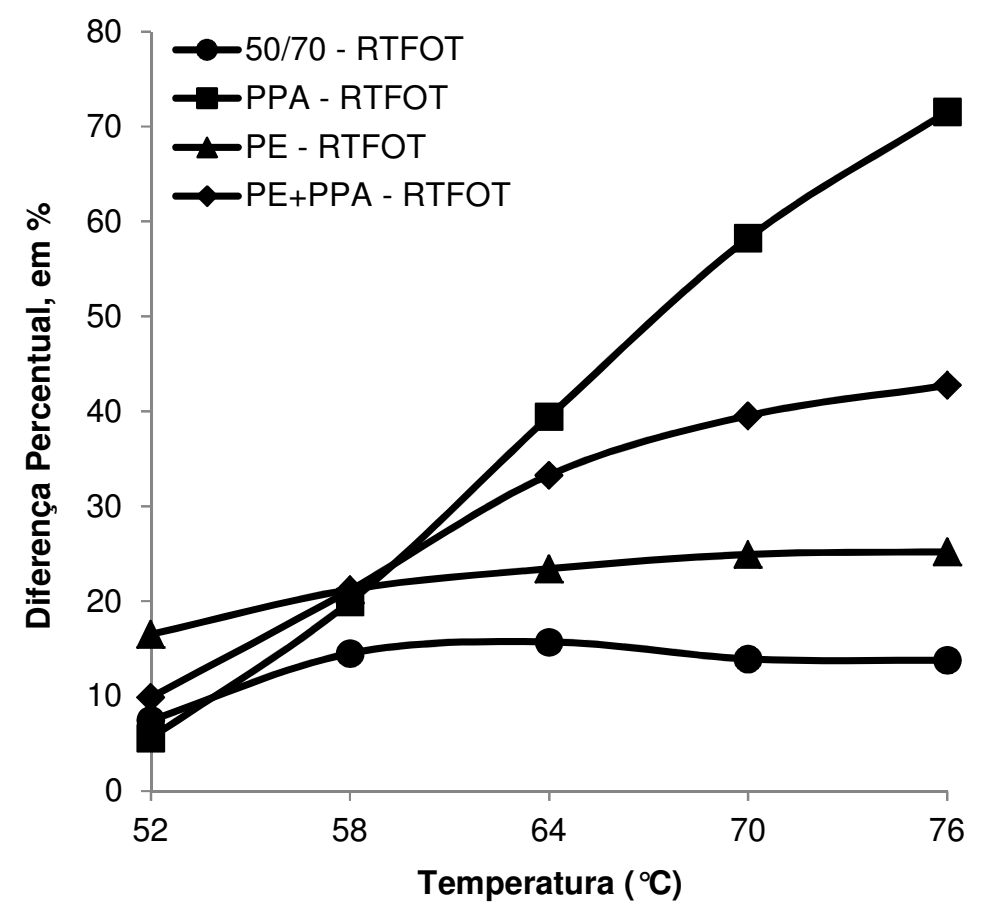

Figura 84 - Diferenças percentuais entre as compliâncias não-recuperáveis $\left(J_{\text {nr,diff }}\right)$ do CAP 50/70, do CAP+PPA, do CAP+PE e do CAP+PE+PPA nos tempos de 2 e $18 \mathrm{~s}$

As análises realizadas no CAP 50/70 e nos ligantes asfálticos modificados com PPA, PE e PE+PPA (Tabelas 66 a 68 e Figuras 82 a 84) mostram que o CAP+PPA possui os maiores percentuais de recuperação não-nulos e, ao mesmo tempo, as menores compliâncias não-recuperáveis em todo o espectro de temperaturas a 100 e a $3.200 \mathrm{~Pa}$. O CAP+PE apresenta, dentre todos os ligantes asfálticos modificados deste grupo, os menores percentuais de recuperação e as maiores compliâncias não-recuperáveis a 100 e a 3.200 Pa. $\mathrm{O} C A P+P E+P P A$ apresenta compliâncias não-recuperáveis menores que as encontradas no 
$\mathrm{CAP}+\mathrm{PE}$, bem como percentuais de recuperação mais elevados em todas as temperaturas a $100 \mathrm{~Pa}$ e nas temperaturas de até $64^{\circ} \mathrm{C}$ a $3.200 \mathrm{~Pa}$. Em uma avaliação global dos valores de $J_{n r, d i f f}$ para os ligantes asfálticos modificados, o CAP+PPA possui a maior sensibilidade ao incremento do nível de tensão e o CAP+PE possui a menor sensibilidade, sendo que o $\mathrm{CAP}+\mathrm{PE}+\mathrm{PPA}$ possui uma sensibilidade intermediária.

\subsection{6. $C A P$ 50/70, $C A P+P P A, C A P+S B R$ e $C A P+S B R+P P A$}

A Tabela 69 apresenta os percentuais de recuperação dos ligantes asfálticos modificados com PPA, SBR e SBR+PPA, todos na condição envelhecida a curto prazo e nos tempos de 2 e 18 s. A adição dos modificadores ao CAP 50/70 proporciona, em linhas gerais, um aumento dos percentuais de recuperação dos ligantes asfálticos, sendo que o CAP puro possui recuperações não-nulas apenas nas temperaturas de 52 e $58^{\circ} \mathrm{C}$ a $100 \mathrm{~Pa}$ e na temperatura de $52^{\circ} \mathrm{C}$ a $3.200 \mathrm{~Pa}$. O CAP+SBR+PPA possui as recuperações mais elevadas em todo o espectro de temperaturas a 3.200 Pa (valores de até $57 \%$ ) e nas temperaturas de 58,64 , 70 e $76^{\circ} \mathrm{C}$ a $100 \mathrm{~Pa}$ (valores entre 23 e 59\%). O CAP+SBR apresenta os valores mais baixos para esta propriedade dentre os ligantes asfálticos modificados, tanto a 100 (valores entre 7 e $39 \%$ ) quanto a $3.200 \mathrm{~Pa}$ (valores de no máximo 32\%). As diferenças entre os percentuais de recuperação do $\mathrm{CAP}+\mathrm{SBR}$ e do $\mathrm{CAP}+\mathrm{SBR}+\mathrm{PPA}$ são significativas em todas as temperaturas a $100 \mathrm{~Pa}$, bem como nas temperaturas de até $64^{\circ} \mathrm{C}$ a $3.200 \mathrm{~Pa}$. Os percentuais de recuperação do CAP+PPA são razoavelmente próximos aos do CAP+SBR+PPA, especialmente nas temperaturas de 52 e $58^{\circ} \mathrm{C}$ a 100 e a $3.200 \mathrm{~Pa}$.

Tabela 69 - Percentuais de recuperação (R) do CAP 50/70, do CAP+PPA, do CAP+SBR e do $\mathrm{CAP}+\mathrm{SBR}+\mathrm{PPA}$ nos tempos de 2 e $18 \mathrm{~s}$ e na condição envelhecida

\begin{tabular}{ccccccccccc}
\hline \multirow{2}{*}{$\begin{array}{c}\text { Ligante } \\
\text { asfáltico }\end{array}$} & \multicolumn{4}{c}{$100 \mathrm{~Pa}(\mathrm{R} 100), \mathrm{em} \%$} & \multicolumn{5}{c}{$3.200 \mathrm{~Pa}(\mathrm{R} 3200), \mathrm{em} \%$} \\
\cline { 2 - 11 } & $52^{\circ} \mathrm{C}$ & $58^{\circ} \mathrm{C}$ & $64^{\circ} \mathrm{C}$ & $70^{\circ} \mathrm{C}$ & $76^{\circ} \mathrm{C}$ & $52^{\circ} \mathrm{C}$ & $58^{\circ} \mathrm{C}$ & $64^{\circ} \mathrm{C}$ & $70^{\circ} \mathrm{C}$ & $76^{\circ} \mathrm{C}$ \\
\hline $50 / 70$ & 7,9 & 2,9 & 0,0 & 0,0 & 0,0 & 3,4 & 0,0 & 0,0 & 0,0 & 0,0 \\
PPA & 59,4 & 50,2 & 38,8 & 27,1 & 17,7 & 56,4 & 40,0 & 19,0 & 3,3 & 0,0 \\
SBR & 38,9 & 35,9 & 26,1 & 15,9 & 7,2 & 31,2 & 17,1 & 5,8 & 0,0 & 0,0 \\
SBR+PPA & 58,6 & 52,5 & 44,9 & 33,9 & 23,1 & 56,5 & 43,4 & 25,1 & 9,0 & 0,5 \\
\hline
\end{tabular}

A Figura 85 mostra os gráficos de R com a temperatura para o CAP 50/70 e os ligantes asfálticos modificados com PPA, SBR e SBR+PPA, todos na condição envelhecida a curto prazo e nos tempos de 2 e $18 \mathrm{~s}$. Os gráficos do percentual de recuperação mantêm um 
certo grau de paralelismo para os três ligantes asfálticos modificados nas temperaturas acima de $64^{\circ} \mathrm{C}$ a $100 \mathrm{~Pa}$, o mesmo não sendo observado a $3.200 \mathrm{~Pa}$. Os percentuais de recuperação são praticamente nulos para todos os ligantes asfálticos modificados na temperatura de $76^{\circ} \mathrm{C}$ e a $3.200 \mathrm{~Pa}$, sendo inferiores a $10 \%$ para o CAP+PPA e o $\mathrm{CAP}+\mathrm{SBR}+\mathrm{PPA}$ na temperatura de $70^{\circ} \mathrm{C}$ a $3.200 \mathrm{~Pa}$. Interessante observar que estes dois materiais possuem recuperações próximas entre si nas temperaturas de 52 e $58^{\circ} \mathrm{C}$, tanto a 100 quanto a $3.200 \mathrm{~Pa}$.

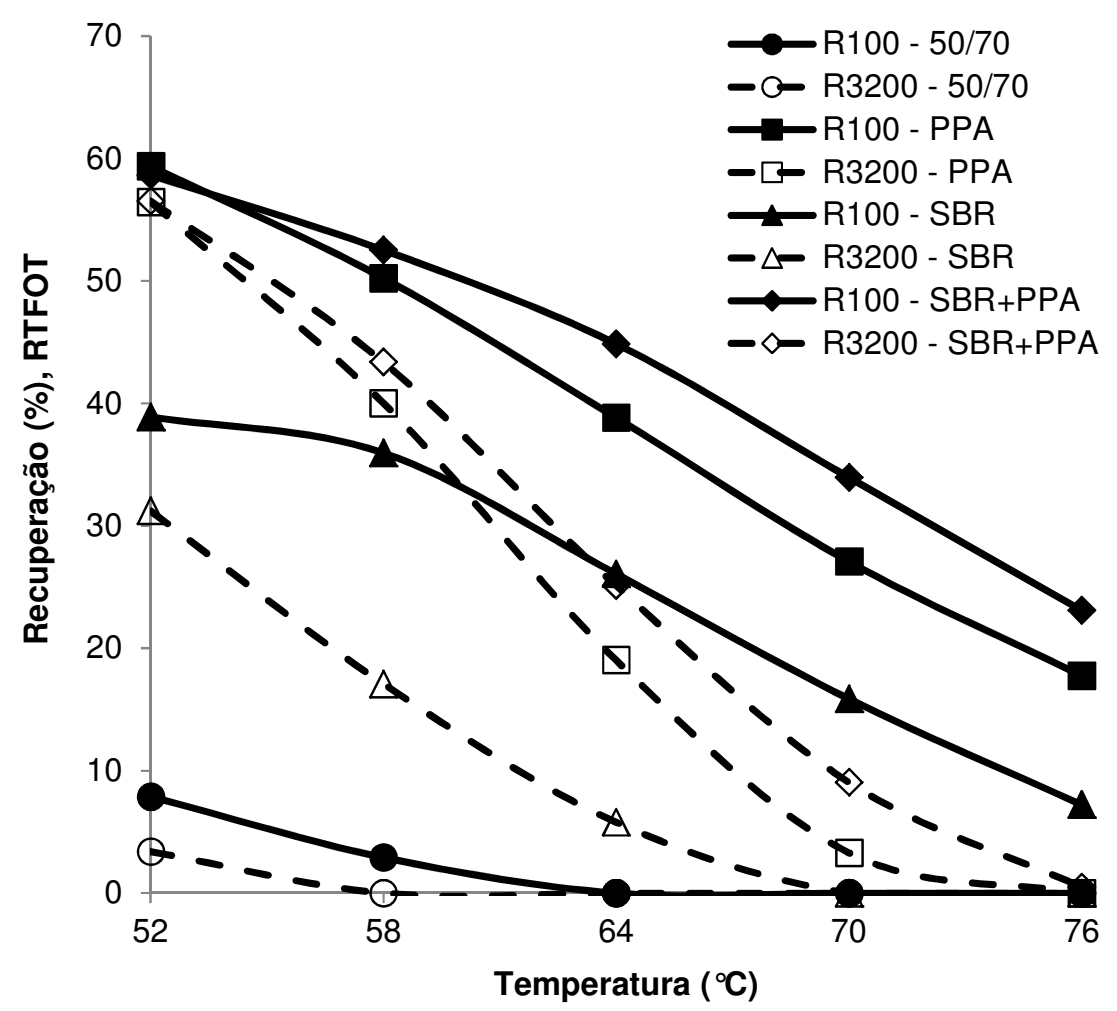

Figura 85 - Percentuais de recuperação $(R)$ do CAP 50/70, do CAP+PPA, do CAP+SBR e do CAP+SBR+PPA na condição envelhecida e nos tempos de 2 e $18 \mathrm{~s}$

A Tabela 70 apresenta as compliâncias não-recuperáveis do CAP 50/70 e dos ligantes asfálticos modificados com PPA, SBR e SBR+PPA, todos na condição envelhecida a curto prazo e nos tempos de fluência e recuperação de 2 e 18 s. O CAP 50/70 possui as compliâncias não-recuperáveis mais elevadas em qualquer temperatura a 100 e a $3.200 \mathrm{~Pa}$, atingindo valores superiores a $11 \mathrm{kPa}^{-1}$ nas temperaturas de 70 e $76{ }^{\circ} \mathrm{C}$ a $100 \mathrm{~Pa}$ e valores superiores a $13 \mathrm{kPa}^{-1}$ nestas mesmas temperaturas a $3.200 \mathrm{~Pa}$. O CAP+SBR+PPA possui os valores mais baixos de $\mathrm{J}_{\mathrm{nr}}$ nas temperaturas de 64,70 e $76{ }^{\circ} \mathrm{C}$, tanto a 100 quanto a $3.200 \mathrm{~Pa}$. $\mathrm{O} C A P+S B R$ apresenta, dentre os materiais modificados, os valores mais elevados de $\mathrm{J}_{\mathrm{nr}} \mathrm{em}$ todo o espectro de temperaturas a 100 e a $3.200 \mathrm{~Pa}$, com resultados entre 0,2 e $8,1 \mathrm{kPa}^{-1} \mathrm{a}$ $100 \mathrm{~Pa}$ e entre 0,2 e 13,0 $\mathrm{kPa}^{-1}$ a $3.200 \mathrm{~Pa}$. Em termos numéricos, as compliâncias não- 
recuperáveis do $\mathrm{CAP}+\mathrm{SBR}+\mathrm{PPA}$ são de 0,1 a $8,8 \mathrm{kPa}^{-1}$ menores que as encontradas no $\mathrm{CAP}+\mathrm{SBR}$, para qualquer condição de temperatura e tensão.

Tabela 70 - Compliâncias não-recuperáveis $\left(\mathrm{J}_{n r}\right)$ do CAP 50/70, do CAP+PPA, do CAP+SBR e do $C A P+S B R+P P A$ nos tempos de 2 e 18 s e na condição envelhecida

\begin{tabular}{ccccccccccc}
\hline \multirow{2}{*}{$\begin{array}{c}\text { Ligante } \\
\text { asfáltico }\end{array}$} & \multicolumn{4}{c}{$100 \mathrm{~Pa}\left(\mathrm{~J}_{\mathrm{nr}} 100\right), \mathrm{em} \mathrm{kPa}^{-1}$} & \multicolumn{4}{c}{$3.200 \mathrm{~Pa}\left(\mathrm{~J}_{\mathrm{nr}} 3200\right), \mathrm{em} \mathrm{kPa}^{-1}$} \\
\cline { 2 - 11 } & $52^{\circ} \mathrm{C}$ & $58^{\circ} \mathrm{C}$ & $64^{\circ} \mathrm{C}$ & $70^{\circ} \mathrm{C}$ & $76^{\circ} \mathrm{C}$ & $52^{\circ} \mathrm{C}$ & $58^{\circ} \mathrm{C}$ & $64^{\circ} \mathrm{C}$ & $70^{\circ} \mathrm{C}$ & $76^{\circ} \mathrm{C}$ \\
\hline $50 / 70$ & 0,63 & 1,75 & 4,69 & 11,70 & 26,49 & 0,68 & 2,01 & 5,43 & 13,34 & 30,14 \\
PPA & 0,05 & 0,14 & 0,41 & 1,10 & 2,78 & 0,05 & 0,17 & 0,57 & 1,74 & 4,77 \\
SBR & 0,23 & 0,56 & 1,44 & 3,53 & 8,08 & 0,27 & 0,81 & 2,25 & 5,66 & 12,90 \\
SBR+PPA & 0,06 & 0,14 & 0,36 & 0,92 & 2,26 & 0,06 & 0,17 & 0,54 & 1,57 & 4,17 \\
\hline
\end{tabular}

A Figura 86 (página seguinte) ilustra os gráficos de $J_{\mathrm{nr}}$ com a temperatura para os ligantes asfálticos modificados com PPA, SBR e SBR+PPA, todos na condição envelhecida a curto prazo e nos tempos de 2 e $18 \mathrm{~s}$. O CAP+PPA e o CAP+SBR+PPA apresentam valores próximos de $\mathrm{J}_{\mathrm{nr}}$ em todo o espectro de temperaturas a 100 e a $3.200 \mathrm{~Pa}$ e, à luz destes resultados, as formulações dos dois materiais podem ser consideradas equivalentes. Um destaque especial pode ser dado ao $C A P+S B R$, cujos resultados de $J_{n r}$ são significativamente maiores que os do $\mathrm{CAP}+\mathrm{SBR}+\mathrm{PPA}$ e do $\mathrm{CAP}+\mathrm{PPA}$ dentro de um mesmo nível de tensão e para todo o espectro de temperaturas consideradas.

A Tabela 71 mostra as diferenças percentuais entre as compliâncias (parâmetro

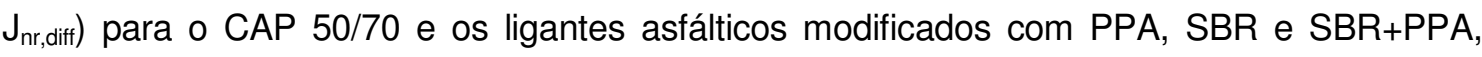
considerando a condição envelhecida destes materiais e os tempos de 2 e $18 \mathrm{~s}$. Na extensão em que é válida a aplicação do limite de 75\% estipulado pela AASHTO MP19 a ligantes asfálticos envelhecidos a curto prazo e submetidos aos tempos de fluência e recuperação de 2 e 18 s na temperatura do PG, o CAP+SBR+PPA é o único material deste grupo a possuir uma sensibilidade excessiva à tensão $\left(J_{\text {nr,diff }}>75 \%\right)$. O CAP+SBR apresenta as maiores diferenças percentuais nas temperaturas de até $64^{\circ} \mathrm{C}$ e $0 \mathrm{CAP}+\mathrm{SBR}+\mathrm{PPA}$, as maiores diferenças a 70 e a $76^{\circ} \mathrm{C}$. O CAP+PPA possui, dentre os ligantes asfálticos modificados, as diferenças percentuais mais baixas nas temperaturas de 58, 64 e $70^{\circ} \mathrm{C}$. O CAP 50/70 apresenta diferenças percentuais pequenas em todas as temperaturas, atingindo um valor máximo de $16 \%$ na temperatura de $64^{\circ} \mathrm{C}$. Em uma análise geral dos resultados dos materiais modificados, o CAP+SBR possui a maior sensibilidade à tensão por conta dos maiores valores de $J_{\text {rr,diff }}$ nas temperaturas de 52,58 e $64^{\circ} \mathrm{C}$. Da mesma maneira, o CAP+PPA possui a menor sensibilidade à tensão dentre os CAPs modificados por conta das menores diferenças percentuais nas temperaturas de 58,64 e $70^{\circ} \mathrm{C}$. 


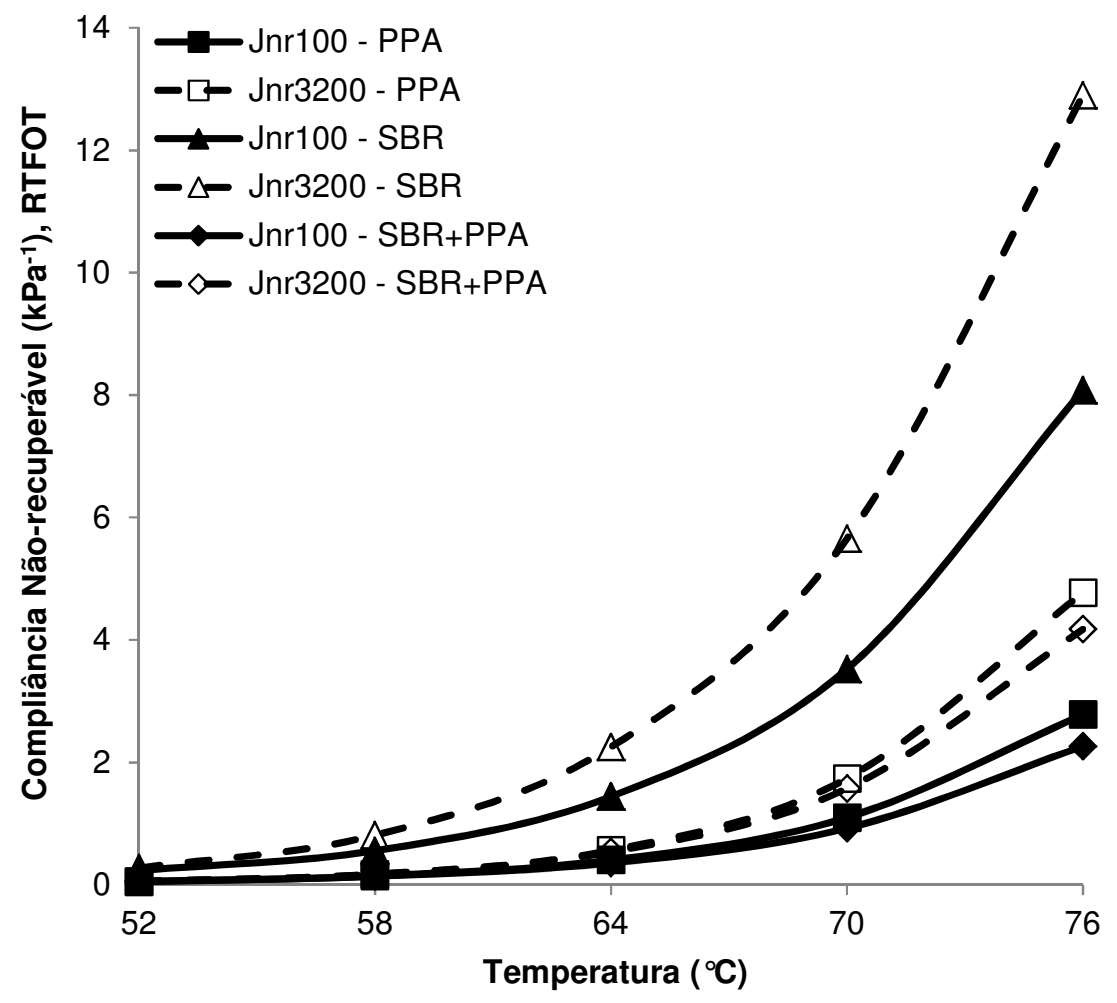

Figura 86 - Compliâncias não-recuperáveis $\left(\mathrm{J}_{\text {nr }}\right)$ do CAP 50/70, do CAP+PPA, do CAP+SBR e do $C A P+S B R+P P A$ na condição envelhecida e nos tempos de 2 e $18 \mathrm{~s}$

Tabela 71 - Diferenças percentuais entre as compliâncias não-recuperáveis $\left(\mathrm{J}_{\text {nr,diff }}\right)$ do $C A P$ 50/70, do CAP+PPA, do CAP+SBR e do CAP+SBR+PPA nos tempos de 2 e $18 \mathrm{~s}$

\begin{tabular}{cccccc}
\hline \multirow{2}{*}{ Ligante asfáltico } & \multicolumn{5}{c}{ Materiais envelhecidos (RTFOT) } \\
\cline { 2 - 6 } & $52^{\circ} \mathrm{C}$ & $58^{\circ} \mathrm{C}$ & $64^{\circ} \mathrm{C}$ & $70^{\circ} \mathrm{C}$ & $76{ }^{\circ} \mathrm{C}$ \\
\hline $50 / 70$ & 7,5 & 14,5 & 15,7 & 13,9 & 13,8 \\
PPA & 5,6 & 20,0 & 39,5 & 58,2 & 71,6 \\
SBR & 17,4 & 45,2 & 56,0 & 60,4 & 59,6 \\
SBR+PPA & 5,3 & 22,4 & 50,3 & 70,2 & 84,5 \\
\hline
\end{tabular}

A Figura 87 ilustra os gráficos de $J_{n r, \text { diff }}$ para o CAP 50/70 e os ligantes asfálticos modificados com PPA, SBR e SBR+PPA, todos na condição envelhecida a curto prazo e nos tempos de 2 e $18 \mathrm{~s}$. Dentre os materiais modificados, visualiza-se que as diferenças percentuais do $\mathrm{CAP}+\mathrm{SBR}+\mathrm{PPA}$ e do $\mathrm{CAP}+\mathrm{PPA}$ possuem valores próximos entre si nas temperaturas de 52 e $58^{\circ} \mathrm{C}$, o mesmo sendo observado para o CAP+PPA e o CAP+SBR na temperatura de $70^{\circ} \mathrm{C}$. $O$ aumento dos valores de $J_{\text {nr,diff }}$ é verificado em todo o espectro de temperaturas para o $\mathrm{CAP}+\mathrm{PPA}$ e o $\mathrm{CAP}+\mathrm{SBR}+\mathrm{PPA}$, sendo ligeiramente superior para 0 $\mathrm{CAP}+\mathrm{SBR}+\mathrm{PPA}$. Há um incremento deste parâmetro até a temperatura de $70^{\circ} \mathrm{C}$ no caso do $\mathrm{CAP}+\mathrm{SBR}$, a partir da qual se observa uma tendência de estabilização em valores próximos 
de $60 \%$. O CAP 50/70 possui diferenças percentuais entre 10 e $20 \%$ nas temperaturas de 58 , 64,70 e $76^{\circ} \mathrm{C}$, com variações pequenas entre os valores em comparação ao CAP+PPA, ao $\mathrm{CAP}+\mathrm{SBR}$ e ao $\mathrm{CAP}+\mathrm{SBR}+\mathrm{PPA}$.

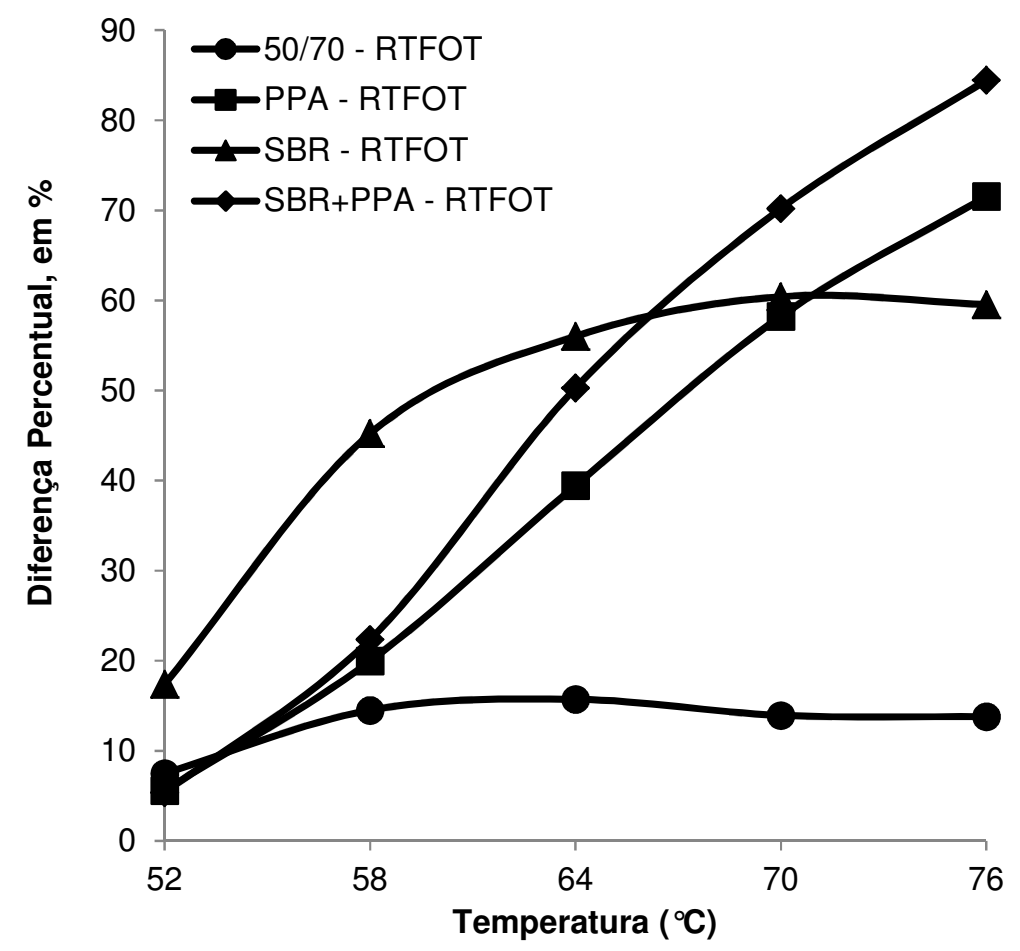

Figura 87 - Diferenças percentuais entre as compliâncias não-recuperáveis $\left(\mathrm{J}_{\text {nr,diff }}\right)$ do CAP 50/70, do CAP+PPA, do CAP+SBR e do CAP+SBR+PPA nos tempos de 2 e $18 \mathrm{~s}$

As análises realizadas no CAP 50/70, no CAP+PPA, no CAP+SBR e no CAP+SBR+PPA (Tabelas 69 a 71 e Figuras 85 a 87) mostram que o CAP+SBR+PPA possui os maiores percentuais de recuperação em todo o espectro de temperaturas a $3.200 \mathrm{~Pa}$, bem como nas temperaturas de 58, 64, 70 e $76^{\circ} \mathrm{C}$ a $100 \mathrm{~Pa}$. Este material também possui as menores compliâncias não-recuperáveis nas temperaturas acima de $64^{\circ} \mathrm{C}$ a 100 e a $3.200 \mathrm{~Pa}$, com valores de 0,1 a $8,8 \mathrm{kPa}^{-1}$ menores em relação às compliâncias do CAP+SBR. Dentre todos os CAPs modificados deste grupo, observa-se que os menores percentuais de recuperação e as maiores compliâncias não-recuperáveis são encontrados no $\mathrm{CAP}+\mathrm{SBR}$ para qualquer condição de temperatura e tensão, bem como as maiores diferenças percentuais nas temperaturas de até $64^{\circ} \mathrm{C}$. Em uma análise geral dos ligantes asfálticos modificados, o CAP+PPA apresenta a menor sensibilidade ao incremento do nível de tensão de 100 para 3.200 Pa porque este material possui os menores valores de $J_{n r, \text { diff }}$ nas temperaturas de 58,64 e $70^{\circ} \mathrm{C}$. Da mesma maneira, o CAP+SBR apresenta a maior sensibilidade à tensão por conta dos maiores valores de $\mathrm{J}_{\text {nr,diff }}$ nas temperaturas de até $64^{\circ} \mathrm{C}$. 


\subsection{Efeitos do aumento dos tempos de fluência e recuperação nas propriedades dos ligantes asfálticos envelhecidos a curto prazo}

Os efeitos do aumento dos tempos de fluência e recuperação de 1 e $9 \mathrm{~s}$ para 2 e $18 \mathrm{~s}$ nos comportamentos dos ligantes asfálticos foram analisados em termos das alterações no percentual de recuperação e na compliância não-recuperável (parâmetros $R_{P}$ e $R_{C}$, respectivamente). Estas análises foram divididas por nível de tensão (100 e 3.200 Pa) e por parâmetro $\left(R_{P}\right.$ e $R_{C}$ ) com o propósito de atingir os seguintes objetivos: (1) facilitar a visualização das diferenças entre os resultados de cada nível de tensão; e (2) permitir uma identificação mais fácil das diferenças entre as formulações CAP+modificador+PPA e das formulações correspondentes CAP+modificador.

A Tabela 72 (página seguinte) apresenta as relações entre os percentuais de recuperação $\left(R_{P}\right)$ para o CAP 50/70 e todos os ligantes asfálticos modificados, considerando a condição envelhecida destes materiais e os níveis de tensão de 100 e 3.200 Pa. Alguns valores não puderam ser calculados porque a recuperação do ligante asfáltico é nula nos tempos de $2 \mathrm{e}$ $18 \mathrm{~s}$, enquanto outros são iguais a zero porque o percentual de recuperação é nulo nos tempos de 1 e $9 \mathrm{~s}$ e não o é nos tempos de 2 e $18 \mathrm{~s}$ - caso do CAP+borracha+PPA na temperatura de $76{ }^{\circ} \mathrm{C}$ e na tensão de $3.200 \mathrm{~Pa}$. Valores superiores à unidade mostram que o percentual de recuperação do ligante asfáltico é maior nos tempos de 1 e $9 \mathrm{~s}$ do que nos tempos de 2 e $18 \mathrm{~s}$, ao passo que valores inferiores à unidade mostram que o material possui recuperação maior nos tempos de 2 e $18 \mathrm{~s}$ do que a 1 e $9 \mathrm{~s}$. Ou seja, os resultados de $R_{P}$ permitem avaliar os aumentos $\left(R_{P}<1\right)$ ou reduções $\left(R_{P}>1\right)$ no percentual de recuperação do ligante asfáltico após o aumento dos tempos de fluência e de recuperação de 1 e 9 s para 2 e $18 \mathrm{~s}$.

Tendo como base os resultados da Tabela 72, é possível observar que a maioria dos ligantes asfálticos apresenta reduções no percentual de recuperação após o aumento dos tempos de fluência e recuperação de 1 e $9 \mathrm{~s}$ para 2 e $18 \mathrm{~s}$. São exceções a esta observação os ligantes asfálticos modificados com borracha+PPA e EVA, para os quais os valores de $R_{P}$ são inferiores à unidade em todas as temperaturas a 100 e a $3.200 \mathrm{~Pa}$ (caso do CAP+borracha+PPA) ou na maioria delas (caso do CAP+EVA). No caso do CAP 50/70, os poucos valores calculados mostram que o percentual de recuperação nos tempos de 1 e $9 \mathrm{~s}$ é de 1,5 a 2,7 vezes o valor obtido nos tempos de 2 e $18 \mathrm{~s}$. Dentre os materiais modificados, visualiza-se que o $\mathrm{CAP}+\mathrm{SBS}$ e o $\mathrm{CAP}+\mathrm{PE}$ apresentam os maiores valores de $\mathrm{R}_{\mathrm{P}}$ em todas as temperaturas calculadas a $100 \mathrm{~Pa}$ e nas temperaturas de até $64^{\circ} \mathrm{C}$ a $3.200 \mathrm{~Pa}$, o que indica a elevada sensibilidade destes ligantes asfálticos ao aumento dos tempos de fluência e 
recuperação de 1 e $9 \mathrm{~s}$ para 2 e $18 \mathrm{~s}$. Os resultados de $R_{P}$ estão entre 1,2 e 4,0 para 0 $C A P+P E$ e entre 1,3 e 7,2 para o $C A P+S B S$, sendo que, à exceção do material puro, o $\mathrm{CAP}+\mathrm{SBS}$ possui os maiores resultados nas temperaturas de 52,58 e $76^{\circ} \mathrm{C}$ a $100 \mathrm{~Pa}$ e o $\mathrm{CAP}+\mathrm{PE}$ possui os maiores nas temperaturas de 52 e $58^{\circ} \mathrm{C}$ a $3.200 \mathrm{~Pa}$.

Tabela 72 - Relações entre os percentuais de recuperação $\left(R_{P}\right)$ nos tempos de 1 e $9 \mathrm{~s}$ e nos tempos de 2 e 18 s para os ligantes asfálticos na condição envelhecida

\begin{tabular}{cccccccccccc}
\hline \multirow{2}{*}{ Ligante asfáltico } & \multicolumn{9}{c}{$100 \mathrm{~Pa}$} & \multicolumn{7}{c}{$3.200 \mathrm{~Pa}$} \\
\cline { 2 - 11 } & $52^{\circ} \mathrm{C}$ & $58^{\circ} \mathrm{C}$ & $64^{\circ} \mathrm{C}$ & $70^{\circ} \mathrm{C}$ & $76^{\circ} \mathrm{C}$ & $52^{\circ} \mathrm{C}$ & $58^{\circ} \mathrm{C}$ & $64^{\circ} \mathrm{C}$ & $70^{\circ} \mathrm{C}$ & $76^{\circ} \mathrm{C}$ \\
\hline $50 / 70$ & 1,57 & 1,99 & - & - & - & 2,62 & - & - & - & - \\
PPA & 1,07 & 1,10 & 1,15 & 1,26 & 1,35 & 1,10 & 1,24 & 1,65 & 3,67 & - \\
Elvaloy+PPA & 1,00 & 1,00 & 1,02 & 1,05 & 1,08 & 1,00 & 1,01 & 1,04 & 1,09 & 1,19 \\
Borracha & 1,01 & 0,98 & 1,01 & 1,08 & 1,19 & 1,05 & 1,14 & 1,30 & 1,59 & - \\
Borracha+PPA & 0,90 & 0,85 & 0,83 & 0,80 & 0,79 & 0,90 & 0,86 & 0,81 & 0,69 & 0,00 \\
SBS & 1,35 & 1,52 & 1,97 & 2,73 & 7,16 & 1,42 & 1,88 & 3,47 & - & - \\
SBS+PPA & 1,05 & 1,05 & 1,09 & 1,12 & 1,19 & 1,08 & 1,19 & 1,50 & 4,43 & - \\
EVA & 0,88 & 0,89 & 0,94 & 1,09 & 1,05 & 0,91 & 0,86 & 0,97 & 3,86 & - \\
EVA+PPA & 1,05 & 1,07 & 1,02 & 1,08 & 1,09 & 1,14 & 1,39 & 1,86 & 4,22 & - \\
PE & 1,29 & 1,47 & 2,18 & 3,97 & - & 1,55 & 3,19 & - & - & - \\
PE+PPA & 1,11 & 1,17 & 1,25 & 1,39 & 1,68 & 1,19 & 1,47 & 2,54 & - & - \\
SBR & 1,11 & 1,07 & 1,22 & 1,42 & 1,83 & 1,25 & 1,56 & 2,17 & - & - \\
SBR+PPA & 1,07 & 1,08 & 1,10 & 1,20 & 1,31 & 1,09 & 1,19 & 1,46 & 2,06 & 11,00 \\
\hline
\end{tabular}

Ainda sobre os resultados da Tabela 72, observa-se que o CAP+Elvaloy+PPA possui valores de $R_{P}$ muito próximos à unidade (resultados entre 1,0 e 1,1) em todo o espectro de temperaturas a $100 \mathrm{~Pa}$ e nas temperaturas de até $70^{\circ} \mathrm{C}$ a $3.200 \mathrm{~Pa}$, o que indica a baixa sensibilidade deste material ao aumento nos tempos de fluência e recuperação de 1 e $9 \mathrm{~s}$ para 2 e 18 s. Situação parecida ocorre com o CAP+borracha, cujos valores de $R_{P}$ estão entre 1,0 e 1,1 nas temperaturas de até $70^{\circ} \mathrm{C}$ a $100 \mathrm{~Pa}$ e na temperatura de $52^{\circ} \mathrm{C}$ a $3.200 \mathrm{~Pa}$. Quando comparados aos demais ligantes asfálticos modificados, o CAP+Elvaloy+PPA e 0 CAP+borracha apresentam as menores variações do percentual de recuperação $\left(R_{P} \approx 1\right)$ nas temperaturas de 52 a $70^{\circ} \mathrm{C}$, tanto a 100 quanto a 3.200 Pa. Em termos numéricos, os valores de $R_{P}$ estão entre 1,0 e 1,2 para o CAP+Elvaloy+PPA e entre 1,0 e 1,6 para o CAP+borracha em todas as temperaturas calculadas a 100 e a $3.200 \mathrm{~Pa}$, sendo menores para o CAP+Elvaloy+PPA em praticamente todas as condições de temperatura e tensão. À exceção das formulações já mencionadas, as recuperações a 1 e $9 \mathrm{~s}$ são de até 3,7 vezes superiores às recuperações a 2 e $18 \mathrm{~s}$ para o $\mathrm{CAP}+\mathrm{PPA}$, de até 4,5 vezes para o $C A P+S B S+P P A$, de até 4,3 
vezes para o $C A P+E V A+P P A$, de até 2,6 vezes para o $C A P+P E+P P A$, de até 2,2 vezes para o $\mathrm{CAP}+\mathrm{SBR}$ e de até 11 vezes para o CAP+SBR+PPA.

Em uma comparação dos valores de $\mathrm{R}_{\mathrm{P}}$ para as formulações $\mathrm{CAP}+$ modificador $\mathrm{e}$ suas correspondentes CAP+modificador+PPA, é possível observar que as formulações com PPA possuem, na maioria dos casos, valores mais baixos de $R_{P}$ do que as correspondentes sem PPA. São enquadrados nesta situação os ligantes asfálticos modificados com borracha moída de pneus, SBS, PE e SBR, para os quais as diferenças entre os resultados numéricos de $R_{P}$ são maiores nas temperaturas acima de $64^{\circ} \mathrm{C}$ a 100 e a $3.200 \mathrm{~Pa}$ e menores nas demais temperaturas. No caso das duas formulações com EVA, observa-se que o CAP+EVA+PPA possui valores maiores de $R_{P}$ em relação ao $C A P+E V A$ em praticamente todas as condições de temperatura e tensão, porém com diferenças pequenas (inferiores a 1,0) entre os resultados dos dois materiais. De uma maneira geral, pode-se dizer que as formulações CAP+modificador+PPA possuem menor sensibilidade ao aumento dos tempos de fluência e recuperação de 1 e 9 s para 2 e $18 \mathrm{~s}$ do que as correspondentes CAP+modificador. Ou seja, a presença do PPA nas formulações ajuda na preservação do percentual de recuperação dos ligantes asfálticos em tempos de fluência e recuperação maiores.

Uma análise sintetizada dos resultados da Tabela 72 aponta que, à exceção de algumas formulações e temperaturas, o aumento dos tempos de fluência e recuperação de 1 e 9 s para 2 e $18 \mathrm{~s}$ acarreta reduções nos percentuais de recuperação dos ligantes asfálticos. Em linhas gerais, o CAP+SBS e o CAP+PE possuem as maiores sensibilidades a este aumento dos tempos de fluência e recuperação e o CAP+Elvaloy+PPA e o CAP+borracha apresentam pequenas alterações no percentual de recuperação $\left(R_{P} \approx 1\right)$. Os valores mais baixos de $R_{P}$ são encontrados no $C A P+$ borracha+PPA e no CAP+EVA, sendo que estes materiais apresentam ganhos de recuperação $\left(R_{P}<1\right)$ em todas as temperaturas a 100 e a $3.200 \mathrm{~Pa}$ (caso do CAP+borracha+PPA) ou na maioria delas (caso do CAP+EVA). As formulações $C A P+$ modificador+PPA possuem, à exceção do CAP+EVA e do $C A P+E V A+P P A$, sensibilidades menores ao aumento dos tempos de fluência e recuperação de 1 e 9 s para 2 e 18 s em comparação às suas correspondentes CAP+modificador, sendo que as diferenças mais significativas entre os valores de $R_{P}$ são encontradas nas temperaturas acima de $64^{\circ} \mathrm{C}$ para as formulações com borracha moída, SBS, PE e SBR.

A Tabela 73 apresenta as relações entre as compliâncias não-recuperáveis $\left(R_{C}\right)$ para o CAP 50/70 e todos os ligantes asfálticos modificados, considerando a condição envelhecida destes materiais e os níveis de tensão de 100 e 3.200 Pa. Resultados superiores à unidade mostram que a compliância não-recuperável do ligante asfáltico é maior nos tempos de 
2 e $18 \mathrm{~s}$ do que nos tempos de 1 e $9 \mathrm{~s}$, ao passo que resultados inferiores à unidade mostram o contrário: a compliância não-recuperável do material é maior nos tempos de 1 e $9 \mathrm{~s}$ do que nos tempos de 2 e $18 \mathrm{~s}$. Ou seja, os valores de $R_{C}$ permitem verificar os aumentos $\left(R_{C}>1\right)$ ou reduções $\left(R_{C}<1\right)$ na suscetibilidade do ligante asfáltico à deformação permanente após o aumento dos tempos de fluência e recuperação de 1 e $9 \mathrm{~s}$ para 2 e $18 \mathrm{~s}$.

Tabela 73 - Relações entre as compliâncias não-recuperáveis $\left(R_{C}\right)$ nos tempos de 2 e $18 \mathrm{~s}$ e nos tempos de 1 e $9 \mathrm{~s}$ para os ligantes asfálticos na condição envelhecida

\begin{tabular}{ccccccccccc}
\hline \multirow{2}{*}{ Ligante asfáltico } & \multicolumn{9}{c}{$100 \mathrm{~Pa}$} \\
\cline { 2 - 11 } & $52^{\circ} \mathrm{C}$ & $58^{\circ} \mathrm{C}$ & $64^{\circ} \mathrm{C}$ & $70^{\circ} \mathrm{C}$ & $76^{\circ} \mathrm{C}$ & $52^{\circ} \mathrm{C}$ & $58^{\circ} \mathrm{C}$ & $64^{\circ} \mathrm{C}$ & $70^{\circ} \mathrm{C}$ & $76{ }^{\circ} \mathrm{C}$ \\
\hline $50 / 70$ & 1,91 & 1,91 & 1,93 & 1,97 & 1,96 & 1,94 & 1,97 & 1,96 & 1,96 & 1,98 \\
PPA & 1,73 & 1,81 & 1,80 & 1,88 & 1,89 & 1,82 & 1,93 & 1,99 & 2,04 & 2,00 \\
Elvaloy+PPA & 1,76 & 1,50 & 1,60 & 1,71 & 1,76 & 1,69 & 1,58 & 1,59 & 1,72 & 1,83 \\
Borracha & 1,54 & 1,49 & 1,56 & 1,68 & 1,78 & 1,61 & 1,69 & 1,73 & 1,75 & 1,74 \\
Borracha+PPA & 0,99 & 0,93 & 0,94 & 0,97 & 1,01 & 1,04 & 1,04 & 1,08 & 1,12 & 1,14 \\
SBS & 2,11 & 2,18 & 2,32 & 2,34 & 2,39 & 2,14 & 2,22 & 2,27 & 2,25 & 2,21 \\
SBS+PPA & 1,52 & 1,47 & 1,48 & 1,50 & 1,54 & 1,44 & 1,53 & 1,58 & 1,59 & 1,61 \\
EVA & 0,52 & 0,66 & 1,23 & 1,79 & 1,66 & 0,80 & 0,67 & 1,57 & 2,13 & 1,91 \\
EVA+PPA & 1,86 & 1,90 & 1,91 & 2,07 & 2,13 & 2,22 & 2,73 & 2,98 & 2,56 & 2,38 \\
PE & 1,90 & 2,04 & 2,22 & 2,36 & 2,51 & 1,94 & 2,07 & 2,16 & 2,25 & 2,35 \\
PE+PPA & 1,85 & 1,89 & 1,91 & 1,93 & 1,92 & 1,93 & 2,02 & 2,05 & 2,00 & 1,97 \\
SBR & 1,99 & 1,94 & 2,06 & 2,11 & 2,11 & 2,14 & 2,23 & 2,21 & 2,20 & 2,15 \\
SBR+PPA & 1,79 & 1,80 & 1,81 & 1,92 & 1,94 & 1,82 & 1,95 & 2,08 & 2,08 & 2,06 \\
\hline
\end{tabular}

Com base nos resultados da Tabela 73, é possível observar que a maioria dos ligantes asfálticos apresenta aumento de $J_{n r}\left(R_{C}>1\right)$ após o aumento dos tempos de fluência e recuperação de 1 e 9 s para 2 e $18 \mathrm{~s}$. De uma maneira geral, as formulações com SBS, PE, SBR e EVA+PPA possuem os valores mais elevados para o parâmetro $R_{C}$ em todo o espectro de temperaturas a 100 e a $3.200 \mathrm{~Pa}$, o que indica crescimentos acentuados na suscetibilidade destes materiais à deformação permanente. O CAP+SBS apresenta os maiores valores de $\mathrm{R}_{\mathrm{C}}$ nas temperaturas de 52 a $64^{\circ} \mathrm{C}$ a $100 \mathrm{~Pa}$ e o CAP+PE, os maiores nas temperaturas de $70 \mathrm{e}$ $76^{\circ} \mathrm{C}$ a $100 \mathrm{~Pa}$. O CAP+EVA+PPA apresenta os maiores valores para o parâmetro $\mathrm{R}_{\mathrm{C}}$ em qualquer temperatura a $3.200 \mathrm{~Pa}$, tanto nas mais baixas quanto nas mais elevadas. Em termos numéricos, o aumento dos tempos de fluência e recuperação de 1 e $9 \mathrm{~s}$ para 2 e $18 \mathrm{~s}$ acarreta aumentos entre 2,1 e 2,4 vezes nas compliâncias não-recuperáveis do CAP+SBS, entre 1,9 e 2,3 vezes nas compliâncias do CAP+SBR, entre 1,8 e 3,0 vezes nas compliâncias do CAP+EVA+PPA e entre 1,9 e 2,6 vezes nas compliâncias do CAP+PE. 
Ainda sobre os resultados da Tabela 73, é possível observar que as formulações com borracha+PPA, EVA e SBS+PPA possuem, de uma maneira geral, os valores mais baixos de $R_{C}$ em todas as temperaturas a 100 e a $3.200 \mathrm{~Pa}$. No caso do CAP+EVA e do CAP+borracha+PPA, observa-se também que os resultados são inferiores à unidade em determinadas temperaturas e níveis de tensão, especialmente nas temperaturas de 52 e $58^{\circ} \mathrm{C}$ e na tensão de100 Pa. O CAP+borracha+PPA apresenta valores de $\mathrm{R}_{\mathrm{C}}$ próximos à unidade (entre 0,9 e 1,2) ao longo de todo o espectro de temperaturas a 100 e a $3.200 \mathrm{~Pa}$, o que indica a baixa sensibilidade deste ligante asfáltico ao aumento nos tempos de fluência e recuperação de 1 e $9 \mathrm{~s}$ para 2 e $18 \mathrm{~s}$. Em termos numéricos, os valores de $R_{C}$ estão entre 0,5 e 2,2 para o $\mathrm{CAP}+\mathrm{EVA}$ e entre 1,4 e 1,7 para o $\mathrm{CAP}+\mathrm{SBS}+\mathrm{PPA}$. No caso dos demais ligantes asfálticos, estes resultados estão entre 1,9 e 2,0 para o CAP 50/70, entre 1,7 e 2,1 para o CAP+PPA, entre 1,5 e 1,9 para o CAP+Elvaloy+PPA, entre 1,4 e 1,8 para o CAP+borracha e entre 1,8 e 2,1 para o $\mathrm{CAP}+\mathrm{PE}+\mathrm{PPA}$ e o $\mathrm{CAP}+\mathrm{SBR}+\mathrm{PPA}$.

Em uma comparação dos resultados de $R_{C}$ para as formulações CAP+modificador+PPA e suas correspondentes CAP+modificador, é possível visualizar que as formulações com PPA possuem, na maioria dos casos, valores mais baixos para este parâmetro em relação às formulações sem PPA. São enquadrados nesta situação os ligantes asfálticos modificados com borracha moída, SBS, PE e SBR, para os quais as diferenças entre os resultados numéricos de $\mathrm{R}_{\mathrm{C}}$ são, em geral, maiores nas temperaturas acima de $64^{\circ} \mathrm{C}$ a $100 \mathrm{~Pa}$ e nas temperaturas de até $64^{\circ} \mathrm{C}$ a $3.200 \mathrm{~Pa}$. No caso do CAP+EVA e do $\mathrm{CAP}+E V A+P P A$, visualiza-se que a formulação sem PPA apresenta os valores mais baixos de $R_{C}$ em todas as temperaturas a 100 e a $3.200 \mathrm{~Pa}$, com as diferenças mais significativas entre os dois valores sendo observadas nas temperaturas de 52 e $58^{\circ} \mathrm{C}$ a 100 e a $3.200 \mathrm{~Pa}$. Em linhas gerais, pode-se dizer que as formulações CAP+modificador+PPA possuem menor sensibilidade ao aumento nos tempos de fluência e recuperação de 1 e $9 \mathrm{~s}$ para 2 e $18 \mathrm{~s}$ do que as correspondentes CAP+modificador. Ou seja, a presença do PPA nas formulações ajuda a preservar os valores de compliância não-recuperável dos ligantes asfálticos para tempos de fluência e recuperação maiores, evitando, assim, um aumento significativo da suscetibilidade do material à deformação permanente.

Uma análise sintetizada dos resultados da Tabela 73 permite visualizar que, à exceção de algumas formulações e temperaturas, o aumento dos tempos de fluência e recuperação de 1 e 9 s para 2 e 18 s ocasiona aumentos nas compliâncias não-recuperáveis dos ligantes asfálticos, o que indica uma maior suscetibilidade destes materiais à deformação permanente. De uma maneira geral, as formulações com SBS, PE, SBR e EVA+PPA possuem os maiores aumentos de $J_{n r}$ após estas alterações (maiores valores de $R_{C}$ ) e as formulações 
com borracha+PPA, EVA e SBS+PPA possuem os menores aumentos (menores valores de $R_{C}$ ), sendo que o $C A P+$ borracha+PPA e o $C A P+E V A$ apresentam reduções da compliância não-recuperável $\left(R_{C}<1\right)$ em determinadas temperaturas e níveis de tensão. As formulações CAP+modificador+PPA possuem, à exceção do CAP+EVA e do CAP+EVA+PPA, menores sensibilidades ao aumento nos tempos de fluência e recuperação em comparação às formulações correspondentes CAP+modificador.

Os resultados das Tabelas 72 e 73 permitem observar que, na maioria dos casos, o aumento nos tempos de fluência e recuperação de 1 e $9 \mathrm{~s}$ para 2 e $18 \mathrm{~s}$ acarretam reduções nas recuperações $\left(R_{P}>1\right)$ e aumentos nas compliâncias não-recuperáveis $\left(R_{C}>1\right)$ dos ligantes asfálticos. $\mathrm{O} C A P+S B S$ e o $C A P+P E$ possuem as maiores reduções de $R$ e os maiores incrementos de $J_{n r}$ em quase todas as temperaturas a $100 \mathrm{~Pa}$, bem como alterações significativas em ambas as propriedades a 3.200 Pa. Em termos numéricos, os valores mais baixos de $R_{P}$ e $R_{C}$ são encontrados no CAP+EVA e no CAP+borracha+PPA para a maioria das temperaturas a 100 e a $3.200 \mathrm{~Pa}$, sendo que aumentos do percentual de recuperação $\left(R_{P}<1\right)$ e reduções da compliância não-recuperável $\left(R_{C}<1\right)$ podem ser observados nestes dois materiais em algumas temperaturas e níveis de tensão. O CAP+EVA+PPA possui incrementos elevados de $J_{n r}$ em todo o espectro de temperaturas a 100 e a $3.200 \mathrm{~Pa}$, embora as reduções de $\mathrm{R}$ não sejam tão significativas para este material em todas as temperaturas a $100 \mathrm{~Pa}$ e nas temperaturas de até $64^{\circ} \mathrm{C}$ a $3.200 \mathrm{~Pa}$. O CAP+Elvaloy+PPA e o CAP+borracha apresentam variações muito pequenas do percentual de recuperação $\left(R_{P} \approx 1\right)$ em todas (caso do $\mathrm{CAP}+$ Elvaloy+PPA) ou na maioria (caso do CAP+borracha) das condições de temperatura e de tensão, o mesmo não sendo observado na compliância não-recuperável para ambos os materiais. As formulações CAP+modificador+PPA possuem, à exceção do CAP+EVA e do $C A P+E V A+P P A$, sensibilidades menores ao aumento nos tempos de fluência e recuperação de 1 e $9 \mathrm{~s}$ para 2 e $18 \mathrm{~s}$ em comparação às suas correspondentes CAP+modificador, indicando que a presença do PPA nas formulações pode auxiliar na preservação das propriedades do ligante asfáltico para tempos de fluência e recuperação maiores.

\subsection{Tabelas normalizadas dos ligantes asfálticos e discussão}

A construção das tabelas normalizadas tem, como objetivo principal, a comparação entre os resultados de todos os ligantes asfálticos e os de um material de referência. Estas comparações permitem verificar os ligantes asfálticos com os resultados mais positivos e os mais negativos em ambas as propriedades ( $R$ e $J_{n r}$ ), sendo que os resultados mais positivos 
contemplam recuperações maiores e compliâncias não-recuperáveis menores e os mais negativos, recuperações menores e compliâncias não-recuperáveis maiores. Neste estudo, foram escolhidos o CAP 50/70 e o CAP+PPA como materiais de referência, seguindo a padronização das análises dos resultados do MSCR.

A normalização dos resultados de $R$ foi realizada por meio do parâmetro $N_{R}$, tendo como base as recuperações do CAP 50/70 e do CAP+PPA. Valores de $\mathrm{N}_{R}$ superiores à unidade mostram quantas vezes o percentual de recuperação do ligante asfáltico em questão é maior que a do ligante asfáltico de referência, ao passo que valores inferiores à unidade mostram que o percentual de recuperação do ligante asfáltico em questão é menor que a do material de referência. No caso do CAP 50/70, os resultados de $N_{R}$ também mostram quantas vezes o percentual de recuperação do material aumentou por conta das modificações. Já no caso do CAP+PPA, os resultados de $N_{R}$ permitem avaliar o desempenho das diversas formulações $\mathrm{CAP}+$ modificador e CAP+modificador+PPA (bem como o CAP+Elvaloy+PPA) de classificação PG 76-XX em relação ao desempenho de uma formulação modificada apenas com PPA (CAP+PPA) e de classificação PG 76-XX. Desta maneira, percentuais de recuperação maiores conduzem a valores maiores de $\mathrm{N}_{\mathrm{R}}$ e, por consequência, a resultados melhores.

A normalização dos resultados de $\mathrm{J}_{\mathrm{nr}}$ foi realizada por meio do parâmetro $\mathrm{N}_{C}$, tendo como base as compliâncias não-recuperáveis do CAP 50/70 e do CAP+PPA. Valores de $\mathrm{N}_{C}$ superiores à unidade mostram quantas vezes a compliância não-recuperável do ligante asfáltico em questão é menor que a do material de referência, ao passo que valores inferiores à unidade mostram que a compliância não-recuperável do ligante asfáltico em questão é maior que a do material de referência. No caso do CAP 50/70, os resultados de $\mathrm{N}_{\mathrm{C}}$ também mostram quantas vezes a compliância não-recuperável do ligante asfáltico diminuiu por conta das modificações. Já no caso do CAP+PPA, os resultados de $\mathrm{N}_{C}$ permitem avaliar o desempenho das diversas formulações CAP+modificador e CAP+modificador+PPA (bem como o CAP+Elvaloy+PPA) de classificação $P G$ 76-XX em relação ao desempenho de uma formulação modificada apenas com PPA (CAP+PPA) e de classificação PG 76-XX. Assim, compliâncias não-recuperáveis menores conduzem a valores maiores de $\mathrm{N}_{C}$ e, por consequência, a resultados melhores.

\subsubsection{Tempos de 1 e 9 s e condição virgem}

A Tabela 74 apresenta os valores normalizados do percentual de recuperação $\left(N_{R}\right)$ em todas as temperaturas a 100 e a 3.200 Pa da condição virgem nos tempos de 1 e 9 s, tendo 
como referência o CAP 50/70. A maioria dos valores não pôde ser calculada porque o percentual de recuperação do material puro é nulo nestas condições de temperatura e de tensão. O CAP+Elvaloy+PPA possui os incrementos mais elevados de $\mathrm{R}$ nas temperaturas de 52 e $58^{\circ} \mathrm{C}$ (entre 17 e 87 vezes), seguido pelo CAP+EVA (entre 15 e 78 vezes), depois pelo CAP+EVA+PPA (entre 11 e 53 vezes), em seguida pelo CAP+borracha+PPA (entre 10 e 45 vezes) e então pelo CAP+borracha (entre 9 e 41 vezes). O CAP+PE apresenta os incrementos mais baixos desta propriedade em ambas as temperaturas (entre 3 e 13 vezes), seguido pelo $\mathrm{CAP}+\mathrm{PE}+\mathrm{PPA}$ (entre 7 e 24 vezes). $\mathrm{O} \mathrm{CAP}+\mathrm{SBR}$ apresenta um incremento relativamente baixo do percentual de recuperação a $52^{\circ} \mathrm{C}\left(7,1\right.$ vezes) e mais significativo a $58^{\circ} \mathrm{C}$ (36,2 vezes). No caso dos demais ligantes asfálticos modificados, estes incrementos estão entre 8 e 30 vezes para o CAP+PPA, entre 8 e 32 vezes para o CAP+SBS, entre 7 e 25 vezes para 0 $\mathrm{CAP}+\mathrm{SBS}+\mathrm{PPA}$ e entre 7 e 29 vezes para o $\mathrm{CAP}+\mathrm{SBR}+\mathrm{PPA}$.

Tabela 74 - Percentuais de recuperação normalizados $\left(N_{R}\right)$ dos ligantes asfálticos virgens em relação ao CAP 50/70 e nos tempos de 1 e $9 \mathrm{~s}$

\begin{tabular}{ccccccccccc}
\hline Ligante & \multicolumn{9}{c}{$100 \mathrm{~Pa}$} \\
\cline { 2 - 9 } asfáltico & $52^{\circ} \mathrm{C}$ & $58^{\circ} \mathrm{C}$ & $64^{\circ} \mathrm{C}$ & $70^{\circ} \mathrm{C}$ & $76^{\circ} \mathrm{C}$ & $52^{\circ} \mathrm{C}$ & $58^{\circ} \mathrm{C}$ & $64^{\circ} \mathrm{C}$ & $70^{\circ} \mathrm{C}$ & $76^{\circ} \mathrm{C}$ \\
\hline $50 / 70$ & 1,0 & 1,0 & - & - & - & - & - & - & - & - \\
PPA & 8,4 & 29,6 & - & - & - & - & - & - & - & - \\
Elvaloy+PPA & 17,8 & 86,1 & - & - & - & - & - & - & - & - \\
Borracha & 9,5 & 40,4 & - & - & - & - & - & - & - & - \\
Borracha+PPA & 10,7 & 44,1 & - & - & - & - & - & - & - & - \\
SBS & 8,7 & 31,7 & - & - & - & - & - & - & - & - \\
SBS+PPA & 7,3 & 25,2 & - & - & - & - & - & - & - & - \\
EVA & 15,6 & 77,0 & - & - & - & - & - & - & - & - \\
EVA+PPA & 11,7 & 52,5 & - & - & - & - & - & - & - & - \\
PE & 3,8 & 12,9 & - & - & - & - & - & - & - & - \\
PE+PPA & 7,0 & 23,6 & - & - & - & - & - & - & - & - \\
SBR & 7,1 & 36,2 & - & - & - & - & - & - & - & - \\
SBR+PPA & 7,2 & 28,2 & - & - & - & - & - & - & - & - \\
\hline
\end{tabular}

A Tabela 75 apresenta os valores normalizados de compliância não-recuperável $\left(N_{C}\right)$ em todas as temperaturas e níveis de tensão da condição virgem nos tempos de 1 e $9 \mathrm{~s}$, tendo como referência o CAP puro. Para o nível de tensão de $100 \mathrm{~Pa}$, visualiza-se que as maiores reduções de $J_{n r}$ após as modificações são encontradas no CAP+Elvaloy+PPA (entre 7 e 11 vezes), no CAP+EVA+PPA (entre 8 e 12 vezes) e no CAP+EVA (entre 9 e 23 vezes) para toda a faixa de temperaturas. As menores reduções da compliância não-recuperável são 
encontradas no $\mathrm{CAP}+\mathrm{PE}$ (entre 3 e 4 vezes) e no $\mathrm{CAP}+\mathrm{SBR}$ (entre 2 e 4 vezes), ambos em todo o espectro de temperaturas. O CAP+PE+PPA e o CAP+PPA apresentam reduções elevadas de $\mathrm{J}_{n r}$ nas temperaturas de até $64^{\circ} \mathrm{C}$ e menores nas temperaturas de 70 e $76{ }^{\circ} \mathrm{C}$, sendo que a formulação com PE+PPA possui valores maiores de $N_{C}$ (entre 4 e 7 ) em comparação à formulação com PPA (entre 4 e 6). O CAP+SBS apresenta reduções elevadas de $J_{n r}$ em todo o espectro de temperaturas (entre 5 e 7 vezes), porém inferiores às obtidas para as formulações com Elvaloy+PPA, EVA+PPA e EVA. O CAP+borracha, o CAP+borracha+PPA, o $\mathrm{CAP}+\mathrm{SBS}+\mathrm{PPA}$ e o $\mathrm{CAP}+\mathrm{SBR}+\mathrm{PPA}$ apresentam, em todas as temperaturas, reduções de $4 \mathrm{a}$ 6 vezes na compliância não-recuperável após as modificações.

Tabela 75 - Compliâncias não-recuperáveis normalizadas $\left(\mathrm{N}_{\mathrm{C}}\right)$ dos ligantes asfálticos virgens em relação ao CAP 50/70 e nos tempos de 1 e $9 \mathrm{~s}$

\begin{tabular}{ccccccccccc}
\hline Ligante & \multicolumn{9}{c}{$100 \mathrm{~Pa}$} \\
\cline { 2 - 10 } asfáltico & $52^{\circ} \mathrm{C}$ & $58^{\circ} \mathrm{C}$ & $64^{\circ} \mathrm{C}$ & $70^{\circ} \mathrm{C}$ & $76^{\circ} \mathrm{C}$ & $52^{\circ} \mathrm{C}$ & $58^{\circ} \mathrm{C}$ & $64^{\circ} \mathrm{C}$ & $70^{\circ} \mathrm{C}$ & $76{ }^{\circ} \mathrm{C}$ \\
\hline $50 / 70$ & 1,0 & 1,0 & 1,0 & 1,0 & 1,0 & 1,0 & 1,0 & 1,0 & 1,0 & 1,0 \\
PPA & 5,8 & 5,5 & 5,1 & 4,8 & 4,4 & 5,8 & 5,2 & 4,5 & 3,9 & 3,4 \\
Elvaloy+PPA & 7,5 & 9,1 & 10,6 & 11,0 & 10,6 & 8,9 & 10,9 & 11,6 & 10,8 & 9,0 \\
Borracha & 4,2 & 4,3 & 4,5 & 4,7 & 4,9 & 3,3 & 3,2 & 3,2 & 3,2 & 3,2 \\
Borracha+PPA & 5,3 & 5,4 & 5,5 & 5,7 & 5,9 & 4,1 & 3,9 & 3,8 & 3,8 & 3,7 \\
SBS & 6,2 & 6,2 & 6,0 & 5,8 & 5,5 & 6,1 & 5,8 & 5,3 & 4,9 & 4,5 \\
SBS+PPA & 5,5 & 5,2 & 5,0 & 4,8 & 4,5 & 5,5 & 5,0 & 4,6 & 4,2 & 3,8 \\
EVA & 17,5 & 22,8 & 18,6 & 11,2 & 9,2 & 16,6 & 15,9 & 10,6 & 6,1 & 6,0 \\
EVA+PPA & 8,8 & 9,8 & 10,6 & 11,4 & 11,6 & 7,3 & 6,5 & 5,6 & 5,1 & 4,6 \\
PE & 3,6 & 3,5 & 3,5 & 3,5 & 3,4 & 3,4 & 3,3 & 3,2 & 3,0 & 2,8 \\
PE+PPA & 6,6 & 5,9 & 5,6 & 5,2 & 4,7 & 6,8 & 5,9 & 5,1 & 4,4 & 3,9 \\
SBR & 2,9 & 3,4 & 3,7 & 3,7 & 3,4 & 2,7 & 2,8 & 2,8 & 2,8 & 2,7 \\
SBR+PPA & 5,3 & 5,2 & 5,3 & 5,1 & 4,9 & 5,3 & 5,0 & 4,6 & 4,3 & 4,1 \\
\hline
\end{tabular}

Ainda sobre os resultados da Tabela 75, observa-se que as formulações com Elvaloy+PPA, EVA+PPA e EVA mantêm as maiores reduções de $\mathrm{J}_{\mathrm{nr}}$ no nível de tensão de $3.200 \mathrm{~Pa}$, com valores de $\mathrm{N}_{\mathrm{C}}$ entre 8 e 12, entre 4 e 8 e entre 6 e 17, respectivamente. $\mathrm{O}$ CAP+borracha, o CAP+SBR e o CAP+PE apresentam as menores reduções da compliância não-recuperável a $3.200 \mathrm{~Pa}$ após as modificações, com resultados de $\mathrm{N}_{\mathrm{C}}$ entre 3 e 4 para a formulação com borracha moída, entre 2 e 3 para a formulação com SBR e entre 2 e 4 para a formulação com PE. O CAP+PE+PPA e o CAP+PPA possuem, assim como a $100 \mathrm{~Pa}$, reduções maiores de $\mathrm{J}_{\mathrm{nr}}$ nas temperaturas de até $64^{\circ} \mathrm{C}$ e menores nas temperaturas de 70 e $76{ }^{\circ} \mathrm{C}$, sendo que os valores de $\mathrm{N}_{\mathrm{C}}$ estão entre 3 e 7 para ambos os materiais. Da mesma maneira, o 
$\mathrm{CAP}+\mathrm{SBS}$ possui reduções elevadas de $\mathrm{J}_{\mathrm{nr}}$ em todo o espectro de temperaturas a $3.200 \mathrm{~Pa}$, sendo que os valores estão entre 4 e 7 para este material e são inferiores aos obtidos para 0 $\mathrm{CAP}+$ Elvaloy+PPA, o CAP+EVA+PPA e o CAP+EVA. Os ligantes asfálticos modificados com borracha+PPA, SBS+PPA e SBR+PPA apresentam, após as modificações, reduções entre 3 e 6 vezes na compliância não-recuperável a 3.200 Pa.

Em uma avaliação sintetizada dos resultados das Tabelas 74 e 75, ambas referentes aos ligantes asfálticos virgens, é possível observar que as formulações com Elvaloy+PPA, EVA+PPA e EVA possuem os melhores resultados em todo o espectro de temperaturas a 100 e a $3.200 \mathrm{~Pa}$, uma vez que estes materiais apresentam os maiores incrementos de $\mathrm{R}$ e as maiores reduções de $J_{\mathrm{nr}}$ após as modificações. A formulação com $\mathrm{PE}$ possui os piores resultados em todas as temperaturas a 100 e a $3.200 \mathrm{~Pa}$, uma vez que este material apresenta os menores incrementos do percentual de recuperação e as menores reduções da compliância não-recuperável após a modificação. No caso do CAP+SBR, os incrementos de $R$ são mais baixos a $52^{\circ} \mathrm{C}$ e mais elevados a $58^{\circ} \mathrm{C}$, ao passo que as reduções de $J_{n r}$ são baixas em todo o espectro de temperaturas a 100 e a $3.200 \mathrm{~Pa}$. Os incrementos do percentual de recuperação são relativamente pequenos em todas as temperaturas no caso do CAP+PE+PPA e, no caso da compliância não-recuperável, as reduções são baixas para este material nas temperaturas de 70 e $76{ }^{\circ} \mathrm{C}$.

A Tabela 76 mostra os valores normalizados do percentual de recuperação em todas as temperaturas e níveis de tensão da condição virgem nos tempos de 1 e $9 \mathrm{~s}$, tendo como referência o CAP+PPA. Alguns valores não puderam ser calculados porque o percentual de recuperação do CAP+PPA é nulo nestas condições de temperatura e de tensão. À tensão de $100 \mathrm{~Pa}$, observa-se que os ligantes asfálticos modificados com Elvaloy+PPA, EVA, EVA+PPA, borracha+PPA e borracha possuem resultados superiores à unidade em todo o espectro de temperaturas, com valores de $N_{R}$ entre 1 e 18 para todos eles. Dentre os materiais modificados, as formulações com SBS+PPA, PE+PPA e PE possuem resultados inferiores à unidade em todas as temperaturas a $100 \mathrm{~Pa}$, com valores de $N_{R}$ entre 0,2 e 0,9 para todos eles. $O$ $\mathrm{CAP}+\mathrm{SBR}+\mathrm{PPA}$ e o $\mathrm{CAP}+\mathrm{SBS}$ apresentam recuperações elásticas próximas às do CAP+PPA em todo o espectro de temperaturas a $100 \mathrm{~Pa}$ (resultados entre 0,9 e 1,3 para ambos), especialmente no caso da formulação com SBR+PPA. O CAP+SBR apresenta recuperação menor que a do CAP+PPA na temperatura de $52^{\circ} \mathrm{C}\left(\mathrm{N}_{\mathrm{R}}=0,8\right)$ e maior nas demais temperaturas a $100 \mathrm{~Pa}\left(\mathrm{~N}_{\mathrm{R}}\right.$ entre 1,2 e 1,9$)$.

Com relação aos resultados da Tabela 76 para o nível de tensão de $3.200 \mathrm{~Pa}$, é possível observar que as formulações com Elvaloy+PPA, EVA+PPA e EVA apresentam 
recuperações maiores que as do CAP+PPA nas temperaturas de 52,58 e $64^{\circ} \mathrm{C}\left(\mathrm{N}_{\mathrm{R}}\right.$ entre 1 e 84), ao passo que as formulações com PE+PPA, borracha moída e PE apresentam recuperações menores que as do CAP+PPA nestas mesmas temperaturas (valores inferiores a 0,9). Os percentuais de recuperação do $C A P+S B R+P P A$, do $\mathrm{CAP}+$ borracha+PPA, do $\mathrm{CAP}+\mathrm{SBS}+\mathrm{PPA}$ e do CAP+SBR são aproximadamente iguais aos do CAP+PPA nas temperaturas de 52 e $58^{\circ} \mathrm{C}\left(\mathrm{N}_{\mathrm{R}} \approx 1\right)$ e maiores na temperatura de $64^{\circ} \mathrm{C}$ $\left(\mathrm{N}_{\mathrm{R}}\right.$ entre 1 e 4). O CAP+SBS possui recuperação aproximadamente igual à do CAP+PPA na temperatura de $52^{\circ} \mathrm{C}\left(\mathrm{N}_{\mathrm{R}} \approx 1\right)$ e valores maiores para esta propriedade nas temperaturas de 58 e $64^{\circ} \mathrm{C}\left(\mathrm{N}_{\mathrm{R}}\right.$ entre 1 e 4$)$.

Tabela 76 - Percentuais de recuperação normalizados $\left(N_{R}\right)$ dos ligantes asfálticos virgens em relação ao CAP+PPA e nos tempos de 1 e $9 \mathrm{~s}$

\begin{tabular}{cccccccccccc}
\hline Ligante & \multicolumn{9}{c}{$100 \mathrm{~Pa}$} \\
\cline { 2 - 10 } asfáltico & $52^{\circ} \mathrm{C}$ & $58^{\circ} \mathrm{C}$ & $64^{\circ} \mathrm{C}$ & $70^{\circ} \mathrm{C}$ & $76^{\circ} \mathrm{C}$ & $52^{\circ} \mathrm{C}$ & $58^{\circ} \mathrm{C}$ & $64^{\circ} \mathrm{C}$ & $70^{\circ} \mathrm{C}$ & $76^{\circ} \mathrm{C}$ \\
\hline $50 / 70$ & 0,1 & 0,0 & 0,0 & 0,0 & 0,0 & 0,0 & 0,0 & 0,0 & - & - \\
PPA & 1,0 & 1,0 & 1,0 & 1,0 & 1,0 & 1,0 & 1,0 & 1,0 & - & - \\
Elvaloy+PPA & 2,1 & 2,9 & 4,3 & 7,4 & 17,5 & 2,6 & 5,8 & 83,1 & - & - \\
Borracha & 1,1 & 1,4 & 1,7 & 2,6 & 5,2 & 0,7 & 0,6 & 0,0 & - & - \\
Borracha+PPA & 1,3 & 1,5 & 1,8 & 2,7 & 5,7 & 0,9 & 0,8 & 2,0 & - & - \\
SBS & 1,0 & 1,1 & 1,0 & 1,3 & 1,3 & 1,0 & 1,1 & 3,6 & - & - \\
SBS+PPA & 0,9 & 0,8 & 0,8 & 0,7 & 0,2 & 0,9 & 0,9 & 1,4 & - & - \\
EVA & 1,8 & 2,6 & 3,2 & 2,7 & 2,6 & 2,1 & 3,9 & 40,4 & - & - \\
EVA+PPA & 1,4 & 1,8 & 2,3 & 3,8 & 8,8 & 1,3 & 1,7 & 9,3 & - & - \\
PE & 0,5 & 0,4 & 0,5 & 0,5 & 0,3 & 0,2 & 0,0 & 0,0 & - & - \\
PE+PPA & 0,8 & 0,8 & 0,8 & 0,8 & 0,6 & 0,8 & 0,7 & 0,0 & - & - \\
SBR & 0,8 & 1,2 & 1,6 & 1,9 & 1,5 & 0,7 & 0,9 & 3,0 & - & - \\
SBR+PPA & 0,9 & 0,9 & 1,0 & 1,0 & 0,9 & 0,9 & 1,0 & 3,1 & - & - \\
\hline
\end{tabular}

A Tabela 77 mostra os valores normalizados de compliância não-recuperável em todas as temperaturas e níveis de tensão da condição virgem nos tempos de 1 e $9 \mathrm{~s}$, tendo como referência o CAP+PPA. Em uma análise dos resultados obtidos a $100 \mathrm{~Pa}$, visualiza-se que o $\mathrm{CAP}+$ Elvaloy+PPA, o CAP+EVA+PPA e o CAP+EVA apresentam os valores mais baixos de $J_{n r}$ (maiores valores de $N_{C}$ ) em todo o espectro de temperaturas, indicando a menor suscetibilidade destes materiais à deformação permanente. O CAP+SBR e o CAP+PE, possuem, dentre os materiais modificados, os valores mais elevados de $\mathrm{J}_{\mathrm{nr}}$ (menores valores de $\mathrm{N}_{\mathrm{C}}$ ) em todas as temperaturas, indicando a maior suscetibilidade destes materiais à deformação permanente. Como esperado, o CAP puro apresenta as maiores compliâncias não-recuperáveis 
em qualquer temperatura $\left(N_{C}\right.$ inferior a 0,5$)$, tanto a 100 quanto a $3.200 \mathrm{~Pa}$. O CAP+borracha+PPA e o CAP+SBS possuem, a 100 Pa, compliâncias não-recuperáveis aproximadamente iguais às do $\mathrm{CAP}+\mathrm{PPA}\left(\mathrm{N}_{\mathrm{C}} \approx 1\right)$ nas temperaturas de até $64^{\circ} \mathrm{C}$ e valores menores para esta propriedade $\left(N_{C}>1\right)$ nas temperaturas de 70 e $76^{\circ} \mathrm{C}$. No caso do $\mathrm{CAP}+$ borracha, este material possui compliâncias não-recuperáveis aproximadamente iguais às do $\mathrm{CAP}+\mathrm{PPA}\left(\mathrm{N}_{\mathrm{C}} \approx 1\right)$ em todas as temperaturas a $100 \mathrm{~Pa}$.

Tabela 77 - Compliâncias não-recuperáveis normalizadas $\left(\mathrm{N}_{\mathrm{C}}\right)$ dos ligantes asfálticos virgens em relação ao CAP+PPA e nos tempos de 1 e $9 \mathrm{~s}$

\begin{tabular}{ccccccccccc}
\hline Ligante & \multicolumn{9}{c}{$100 \mathrm{~Pa}$} \\
\cline { 2 - 10 } asfáltico & $52^{\circ} \mathrm{C}$ & $58^{\circ} \mathrm{C}$ & $64^{\circ} \mathrm{C}$ & $70^{\circ} \mathrm{C}$ & $76^{\circ} \mathrm{C}$ & $52^{\circ} \mathrm{C}$ & $58^{\circ} \mathrm{C}$ & $64^{\circ} \mathrm{C}$ & $70^{\circ} \mathrm{C}$ & $76^{\circ} \mathrm{C}$ \\
\hline $50 / 70$ & 0,2 & 0,2 & 0,2 & 0,2 & 0,2 & 0,2 & 0,2 & 0,2 & 0,3 & 0,3 \\
PPA & 1,0 & 1,0 & 1,0 & 1,0 & 1,0 & 1,0 & 1,0 & 1,0 & 1,0 & 1,0 \\
Elvaloy+PPA & 1,3 & 1,7 & 2,1 & 2,3 & 2,4 & 1,5 & 2,1 & 2,6 & 2,8 & 2,6 \\
Borracha & 0,7 & 0,8 & 0,9 & 1,0 & 1,1 & 0,6 & 0,6 & 0,7 & 0,8 & 0,9 \\
Borracha+PPA & 0,9 & 1,0 & 1,1 & 1,2 & 1,3 & 0,7 & 0,8 & 0,9 & 1,0 & 1,1 \\
SBS & 1,1 & 1,1 & 1,2 & 1,2 & 1,3 & 1,1 & 1,1 & 1,2 & 1,2 & 1,3 \\
SBS+PPA & 0,9 & 0,9 & 1,0 & 1,0 & 1,0 & 1,0 & 1,0 & 1,0 & 1,1 & 1,1 \\
EVA & 3,0 & 4,2 & 3,6 & 2,3 & 2,1 & 2,9 & 3,1 & 2,4 & 1,6 & 1,7 \\
EVA+PPA & 1,5 & 1,8 & 2,1 & 2,4 & 2,7 & 1,3 & 1,2 & 1,2 & 1,3 & 1,4 \\
PE & 0,6 & 0,6 & 0,7 & 0,7 & 0,8 & 0,6 & 0,6 & 0,7 & 0,8 & 0,8 \\
PE+PPA & 1,1 & 1,1 & 1,1 & 1,1 & 1,1 & 1,2 & 1,1 & 1,1 & 1,1 & 1,1 \\
SBR & 0,5 & 0,6 & 0,7 & 0,8 & 0,8 & 0,5 & 0,5 & 0,6 & 0,7 & 0,8 \\
SBR+PPA & 0,9 & 0,9 & 1,0 & 1,1 & 1,1 & 0,9 & 1,0 & 1,0 & 1,1 & 1,2 \\
\hline
\end{tabular}

Com relação aos resultados da Tabela 77 para o nível de tensão de $3.200 \mathrm{~Pa}$, é possível observar que as formulações com Elvaloy+PPA, EVA+PPA e EVA apresentam as menores compliâncias não-recuperáveis (maiores valores de $\mathrm{N}_{C}$ ) em todo o espectro de temperaturas, sendo que as maiores compliâncias não-recuperáveis (menores valores de $\mathrm{N}_{\mathrm{C}}$ ) são encontradas no CAP 50/70, no CAP+SBR e no CAP+PE para qualquer temperatura. O $\mathrm{CAP}+\mathrm{SBS}$ possui valores de $\mathrm{J}_{\mathrm{nr}}$ aproximadamente iguais aos do CAP+PPA $\left(\mathrm{N}_{\mathrm{C}} \approx 1\right)$ nas temperaturas de 52 e $58^{\circ} \mathrm{C}$ e valores menores $\left(N_{C}>1\right)$ nas temperaturas de 64,70 e $76{ }^{\circ} \mathrm{C}$. No caso das duas formulações com borracha moída, ambas apresentam valores maiores de compliância não-recuperável $\left(N_{C}<1\right)$ nas temperaturas de 52 a $64^{\circ} \mathrm{C}$ e resultados aproximadamente iguais aos do CAP+PPA nas demais temperaturas. Os materiais modificados com SBS+PPA, PE+PPA e SBR+PPA possuem compliâncias não-recuperáveis próximas às do $\mathrm{CAP}+\mathrm{PPA}\left(\mathrm{N}_{\mathrm{C}} \approx 1\right)$, tanto nas temperaturas mais elevadas quanto nas mais baixas. 
Em uma avaliação resumida dos valores apresentados nas Tabelas 76 e 77, referentes aos ligantes asfálticos virgens, observa-se que os materiais modificados com Elvaloy+PPA, EVA+PPA e EVA possuem os melhores resultados do percentual de recuperação (maiores valores de $N_{R}$ ) e de compliância não-recuperável (maiores valores de $N_{C}$ ) em todo o espectro de temperaturas, tanto a 100 quanto a 3.200 Pa. O ligante asfáltico modificado com PE apresenta, em comparação ao CAP+PPA, os piores resultados para ambas as propriedades, uma vez que os valores de $N_{R}$ e de $N_{C}$ para este material são inferiores à unidade em todas as temperaturas a 100 e a 3.200 Pa. O CAP+SBR apresenta compliâncias não-recuperáveis superiores às do CAP+PPA em todas as temperaturas e níveis de tensão, bem como percentuais de recuperação iguais ou mais elevados na maioria das condições de temperatura e tensão. O CAP+PE+PPA possui compliâncias não-recuperáveis próximas às do CAP+PPA em qualquer condição de temperatura e tensão, embora os percentuais de recuperação deste material sejam mais baixos tanto a 100 quanto a 3.200 Pa.

\subsubsection{Tempos de 1 e 9 s e condição envelhecida a curto prazo}

A Tabela 78 mostra os valores normalizados do percentual de recuperação $\left(N_{R}\right)$ em relação ao CAP 50/70, considerando a condição envelhecida dos ligantes asfálticos e os tempos de 1 e $9 \mathrm{~s}$. Assim como na condição virgem, alguns valores de $N_{R}$ não puderam ser calculados porque o percentual de recuperação do CAP 50/70 é nulo nestas condições de temperatura e tensão. Em uma avaliação dos resultados a $100 \mathrm{~Pa}$, visualiza-se que os maiores incrementos do percentual de recuperação (maiores valores de $N_{R}$ ) após as modificações são encontrados respectivamente no CAP+Elvaloy+PPA, no CAP+EVA, no $C A P+E V A+P P A$ e no $C A P+$ borracha, para os quais estes incrementos são de 5 a 78 vezes nas temperaturas de 52,58 e $64^{\circ} \mathrm{C}$. O CAP+PE apresenta os menores incrementos de $\mathrm{R}$ após a modificação, com valores de $N_{R}$ entre 2 e 15 nas temperaturas de 52,58 e $64^{\circ} \mathrm{C}$. As formulações com PPA, SBR+PPA e borracha+PPA possuem incrementos significativos do percentual de recuperação (entre 4 e 50 vezes) em qualquer temperatura, porém menores do que os encontrados no $C A P+E l v a l o y+P P A$, no $C A P+E V A$, no $C A P+E V A+P P A$ e no CAP+borracha. Os ligantes asfálticos modificados com PE+PPA, SBS+PPA, SBS e SBR apresentam incrementos baixos do percentual de recuperação nas temperaturas de até $64^{\circ} \mathrm{C}$ (entre 3 e 32 vezes), porém maiores do que os encontrados no CAP+PE.

Uma avaliação dos resultados da Tabela 78 para o nível de tensão de $3.200 \mathrm{~Pa}$

permite observar que o CAP+Elvaloy+PPA, o CAP+EVA e o CAP+EVA+PPA mantêm os 
maiores incrementos do percentual de recuperação a 52 e $58^{\circ} \mathrm{C}$ após as modificações, com valores de $\mathrm{N}_{\mathrm{R}}$ entre 7 e 160 para todos eles. Em outro extremo, o CAP+PE mantém os menores incrementos desta propriedade nas temperaturas de 52 e $58^{\circ} \mathrm{C}$, com resultados entre 2 e 21 para o parâmetro $N_{R}$. O CAP+SBR e o CAP+SBS também apresentam incrementos baixos para o percentual de recuperação após as modificações, sendo de 4 e 53 vezes para a formulação com SBR e de 5 e 58 vezes para a formulação com SBS. Os ligantes asfálticos modificados com PPA, SBR+PPA, borracha e borracha+PPA possuem incrementos significativos de $R$ (valores de $N_{R}$ entre 6 e 104), porém menores do que os observados no CAP+Elvaloy+PPA, no CAP+EVA e no CAP+EVA+PPA. Os aumentos do percentual de recuperação se mostram mais baixos para o $\mathrm{CAP}+\mathrm{PE}+\mathrm{PPA}$ e o $\mathrm{CAP}+\mathrm{SBS}+\mathrm{PPA}$ (entre 5 e 64 vezes) em comparação a muitos dos ligantes asfálticos modificados, embora sejam maiores do que os observados no CAP+PE, no $\mathrm{CAP}+\mathrm{SBR}$ e no $\mathrm{CAP}+\mathrm{SBS}$.

Tabela 78 - Percentuais de recuperação normalizados $\left(N_{R}\right)$ dos ligantes asfálticos envelhecidos em relação ao CAP 50/70 e nos tempos de 1 e $9 \mathrm{~s}$

\begin{tabular}{ccccccccccc}
\hline Ligante & \multicolumn{9}{c}{$100 \mathrm{~Pa}$} & \multicolumn{7}{c}{$3.200 \mathrm{~Pa}$} \\
\cline { 2 - 11 } asfáltico & $52^{\circ} \mathrm{C}$ & $58^{\circ} \mathrm{C}$ & $64^{\circ} \mathrm{C}$ & $70^{\circ} \mathrm{C}$ & $76^{\circ} \mathrm{C}$ & $52^{\circ} \mathrm{C}$ & $58^{\circ} \mathrm{C}$ & $64^{\circ} \mathrm{C}$ & $70^{\circ} \mathrm{C}$ & $76^{\circ} \mathrm{C}$ \\
\hline $50 / 70$ & 1,0 & 1,0 & 1,0 & - & & 1,0 & 1,0 & - & - & - \\
PPA & 5,1 & 9,5 & 44,6 & - & - & 7,0 & 99,6 & - & - & - \\
Elvaloy+PPA & 6,5 & 13,8 & 77,1 & - & - & 9,1 & 159,6 & - & - & - \\
Borracha & 5,2 & 10,0 & 50,1 & - & - & 6,0 & 74,8 & - & - & - \\
Borracha+PPA & 4,9 & 9,1 & 44,5 & - & - & 6,1 & 76,2 & - & - & - \\
SBS & 3,7 & 6,2 & 28,7 & - & - & 4,9 & 58,2 & - & - & - \\
SBS+PPA & 4,0 & 6,5 & 26,7 & - & - & 5,3 & 62,8 & - & - & - \\
EVA & 6,4 & 13,5 & 59,5 & - & - & 8,8 & 145,0 & - & - & - \\
EVA+PPA & 5,6 & 11,5 & 56,4 & - & - & 7,6 & 120,2 & - & - & - \\
PE & 2,4 & 3,7 & 14,8 & - & - & 2,5 & 21,0 & - & - & - \\
PE+PPA & 4,0 & 6,8 & 28,5 & - & - & 5,3 & 63,4 & - & - & - \\
SBR & 3,5 & 6,7 & 31,8 & - & - & 4,4 & 53,4 & - & - & - \\
SBR+PPA & 5,0 & 9,8 & 49,3 & - & - & 6,9 & 103,2 & - & - & - \\
\hline
\end{tabular}

A Tabela 79 apresenta os valores normalizados de compliância não-recuperável $\left(N_{C}\right)$ em relação ao CAP 50/70, levando em consideração a condição envelhecida dos ligantes asfálticos e os tempos de 1 e $9 \mathrm{~s}$. Em uma análise dos resultados a $100 \mathrm{~Pa}$, visualiza-se que os ligantes asfálticos modificados com Elvaloy+PPA, EVA, EVA+PPA, PPA e SBR+PPA possuem as maiores reduções de compliância não-recuperável (entre 8 e 25 vezes) em todo o espectro de temperaturas, sendo que os maiores resultados pertencem às duas formulações 
com EVA. Os ligantes asfálticos modificados com SBS, PE e SBR apresentam as menores reduções de $J_{n r}$ (entre 2 e 6 vezes) em qualquer temperatura após as modificações e, dentre estes materiais, os menores resultados pertencem ao CAP+SBR. No caso dos demais ligantes asfálticos modificados, as reduções da compliância não-recuperável estão entre 6 e 8 vezes para o CAP+borracha+PPA, entre 6 e 9 vezes para o CAP+borracha, entre 5 e 9 vezes para o $\mathrm{CAP}+\mathrm{PE}+\mathrm{PPA}$ e entre 5 e 7 vezes para o $\mathrm{CAP}+\mathrm{SBS}+\mathrm{PPA}$.

Tabela 79 - Compliâncias não-recuperáveis normalizadas $\left(N_{C}\right)$ dos ligantes asfálticos envelhecidos em relação ao CAP 50/70 e nos tempos de 1 e $9 \mathrm{~s}$

\begin{tabular}{ccccccccccc}
\hline Ligante & \multicolumn{9}{c}{$100 \mathrm{~Pa}$} \\
\cline { 2 - 10 } asfáltico & $52^{\circ} \mathrm{C}$ & $58^{\circ} \mathrm{C}$ & $64^{\circ} \mathrm{C}$ & $70^{\circ} \mathrm{C}$ & $76^{\circ} \mathrm{C}$ & $52^{\circ} \mathrm{C}$ & $58^{\circ} \mathrm{C}$ & $64^{\circ} \mathrm{C}$ & $70^{\circ} \mathrm{C}$ & $76^{\circ} \mathrm{C}$ \\
\hline $50 / 70$ & 1,0 & 1,0 & 1,0 & 1,0 & 1,0 & 1,0 & 1,0 & 1,0 & 1,0 & 1,0 \\
PPA & 11,0 & 11,5 & 10,6 & 10,1 & 9,1 & 11,7 & 11,3 & 9,6 & 7,9 & 6,4 \\
Elvaloy+PPA & 11,0 & 13,1 & 16,3 & 19,2 & 19,9 & 11,7 & 14,6 & 19,9 & 23,4 & 23,1 \\
Borracha & 6,6 & 7,1 & 7,6 & 7,6 & 8,2 & 5,0 & 5,1 & 4,7 & 4,6 & 4,5 \\
Borracha+PPA & 6,6 & 7,1 & 7,4 & 7,4 & 7,4 & 5,8 & 5,7 & 5,2 & 4,9 & 4,6 \\
SBS & 5,5 & 5,4 & 5,5 & 5,3 & 5,1 & 5,0 & 5,4 & 5,1 & 4,7 & 4,3 \\
SBS+PPA & 6,6 & 6,1 & 6,0 & 5,7 & 5,4 & 5,8 & 6,0 & 5,7 & 5,1 & 4,6 \\
EVA & 16,5 & 23,0 & 17,4 & 11,0 & 8,4 & 17,5 & 20,4 & 11,6 & 5,0 & 4,6 \\
EVA+PPA & 16,5 & 18,4 & 20,3 & 23,8 & 24,2 & 11,7 & 14,6 & 12,1 & 7,7 & 5,9 \\
PE & 3,7 & 3,5 & 3,5 & 3,5 & 3,5 & 3,5 & 3,2 & 3,1 & 3,0 & 2,9 \\
PE+PPA & 8,3 & 7,1 & 6,6 & 6,0 & 5,4 & 7,0 & 6,8 & 6,0 & 5,1 & 4,4 \\
SBR & 2,8 & 3,2 & 3,5 & 3,6 & 3,5 & 2,7 & 2,8 & 2,7 & 2,6 & 2,5 \\
SBR+PPA & 11,0 & 11,5 & 12,2 & 12,4 & 11,6 & 11,7 & 11,3 & 10,7 & 8,9 & 7,5 \\
\hline
\end{tabular}

Uma avaliação dos resultados da Tabela 79 para o nível de tensão de $3.200 \mathrm{~Pa}$ permite observar que, diferentemente do nível de tensão de $100 \mathrm{~Pa}$, a modificação do ligante asfáltico com EVA apresenta reduções elevadas da compliância não-recuperável (entre 11 e 21 vezes) apenas nas temperaturas de 52,58 e $64^{\circ} \mathrm{C}$, sendo menores (entre 4 e 5 vezes) nas temperaturas de 70 e $76^{\circ} \mathrm{C}$. Reduções elevadas para esta propriedade também são encontradas nas formulações com Elvaloy+PPA, EVA+PPA, PPA e SBR+PPA em todo o espectro de temperaturas a $3.200 \mathrm{~Pa}$, com valores de $\mathrm{N}_{\mathrm{C}}$ entre 5 e 24 para todos estes materiais. Os ligantes asfálticos modificados com PE e SBR apresentam reduções pequenas da compliância não-recuperável em todas as temperaturas a $3.200 \mathrm{~Pa}$, sendo de no mínimo 2 e no máximo 4 vezes para estas duas formulações. No caso do CAP+PE+PPA, do $C A P+S B S+P P A$ e do $C A P+$ borracha+PPA, os valores de $N_{C}$ estão entre 4 e 7 em todas as temperaturas a $3.200 \mathrm{~Pa}$. 
De maneira resumida, os resultados das Tabelas 78 e 79 mostram que as formulações com Elvaloy+PPA, EVA+PPA e EVA apresentam os incrementos mais elevados do percentual de recuperação em todas as temperaturas a 100 e a $3.200 \mathrm{~Pa}$, além de reduções elevadas da compliância não-recuperável em todo o espectro de temperaturas a $100 \mathrm{~Pa}$ e nas temperaturas de até $64^{\circ} \mathrm{C}$ a $3.200 \mathrm{~Pa}$. Em linhas gerais, as formulações com PE e com SBR apresentam incrementos pequenos no percentual de recuperação e reduções pequenas na compliância não-recuperável do ligante asfáltico após a modificação, tanto a 100 quanto a 3.200 Pa. As modificações do ligante asfáltico com PPA e com SBR+PPA acarretam reduções significativas na compliância não-recuperável do material em todo o espectro de temperaturas a 100 e a $3.200 \mathrm{~Pa}$, além de incrementos altos no percentual de recuperação para estas mesmas condições de temperatura e tensão. No caso da modificação com SBS, verifica-se que as reduções de compliância não-recuperável e os incrementos do percentual de recuperação são pequenos em comparação aos demais ligantes asfálticos modificados, tanto a 100 quanto a 3.200 Pa.

A Tabela 80 (página seguinte) mostra os valores normalizados do percentual de recuperação $\left(\mathrm{N}_{\mathrm{R}}\right)$ em relação ao CAP+PPA, considerando a condição envelhecida dos materiais e os tempos de 1 e 9 s. Em uma avaliação dos resultados obtidos a $100 \mathrm{~Pa}$, é possível observar que o CAP+Elvaloy+PPA apresenta os maiores percentuais de recuperação em todo o espectro de temperaturas $\left(N_{R}\right.$ entre 1 e 3 ) e, por sua vez, o CAP+PE apresenta os menores percentuais $\left(N_{R} \leq 0,5\right)$ nas mesmas condições de temperatura e tensão. As formulações com SBS, SBS+PPA, SBR e PE+PPA também possuem recuperações inferiores às do CAP+PPA em qualquer temperatura, porém maiores do que os resultados obtidos para o CAP+PE. $O$ CAP+borracha+PPA apresenta valores de $R$ próximos aos do CAP+PPA $\left(N_{R} \approx 1\right)$ em todo o espectro de temperaturas a 100 e a $3.200 \mathrm{~Pa}$, especialmente nas temperaturas de até $64^{\circ} \mathrm{C}$. Interessante observar que, dentre estes resultados a $100 \mathrm{~Pa}$, o CAP+EVA possui recuperações maiores que o CAP+PPA $\left(N_{R}>1\right)$ nas temperaturas de até $64^{\circ} \mathrm{C}$ e resultados iguais ou menores nas temperaturas de 70 e $76^{\circ} \mathrm{C}$. O CAP+borracha e o CAP+SBR+PPA possuem resultados próximos aos do CAP+PPA nas temperaturas de até $64^{\circ} \mathrm{C}$ e valores mais elevados nas temperaturas de 70 e $76^{\circ} \mathrm{C}$. Os percentuais de recuperação do CAP+EVA+PPA são maiores do que os observados no CAP+PPA em todo o espectro de temperaturas, sendo que as diferenças mais significativas estão nas temperaturas de 70 e $76{ }^{\circ} \mathrm{C}$.

Com relação aos resultados da Tabela 80 para o nível de tensão de $3.200 \mathrm{~Pa}$, visualiza-se que o CAP+Elvaloy+PPA mantém os resultados mais elevados de $\mathrm{R}$ em todo o espectro de temperaturas, com as diferenças mais significativas (resultados maiores de $N_{R}$ ) sendo observadas a 70 e $76^{\circ} \mathrm{C}$. Em outro extremo, as formulações com PE, SBR, PE+PPA e 
SBS+PPA apresentam percentuais de recuperação mais baixos do que o CAP+PPA em todas as temperaturas, especialmente no caso do CAP+PE e do CAP+SBR. O CAP+SBS apresenta recuperações menores do que o CAP+PPA nas temperaturas de até $70^{\circ} \mathrm{C}$ e valores mais elevados para esta propriedade na temperatura de $76^{\circ} \mathrm{C}$. Situação diferente ocorre com o CAP+EVA, o qual possui recuperações maiores do que o CAP+PPA nas temperaturas de 52, 58 e $64^{\circ} \mathrm{C}$ e resultados menores nas temperaturas de 70 e $76^{\circ} \mathrm{C}$. Os percentuais de recuperação do $C A P+E V A+P P A$ e do $C A P+S B R+P P A$ são iguais ou maiores do que os observados no CAP+PPA para todas as temperaturas, sendo que a maior diferença entre os resultados é encontrada na temperatura de $76^{\circ} \mathrm{C}$. No caso do CAP+borracha e do CAP+borracha+PPA, os percentuais de recuperação destes materiais são iguais ou mais baixos do que os encontrados no CAP+PPA para a maioria das temperaturas, especialmente nas temperaturas de até $64^{\circ} \mathrm{C}$.

Tabela 80 - Percentuais de recuperação normalizados $\left(N_{R}\right)$ dos ligantes asfálticos envelhecidos em relação ao CAP+PPA e nos tempos de 1 e $9 \mathrm{~s}$

\begin{tabular}{ccccccccccc}
\hline Ligante & \multicolumn{9}{c}{$100 \mathrm{~Pa}$} \\
\cline { 2 - 10 } asfáltico & $52^{\circ} \mathrm{C}$ & $58^{\circ} \mathrm{C}$ & $64^{\circ} \mathrm{C}$ & $70^{\circ} \mathrm{C}$ & $76^{\circ} \mathrm{C}$ & $52^{\circ} \mathrm{C}$ & $58^{\circ} \mathrm{C}$ & $64^{\circ} \mathrm{C}$ & $70^{\circ} \mathrm{C}$ & $76^{\circ} \mathrm{C}$ \\
\hline $50 / 70$ & 0,2 & 0,1 & 0,0 & 0,0 & 0,0 & 0,1 & 0,0 & 0,0 & 0,0 & 0,0 \\
PPA & 1,0 & 1,0 & 1,0 & 1,0 & 1,0 & 1,0 & 1,0 & 1,0 & 1,0 & 1,0 \\
Elvaloy+PPA & 1,3 & 1,4 & 1,7 & 2,1 & 2,8 & 1,3 & 1,6 & 2,5 & 5,9 & 75,6 \\
Borracha & 1,0 & 1,0 & 1,1 & 1,2 & 1,4 & 0,9 & 0,8 & 0,6 & 0,6 & 1,0 \\
Borracha+PPA & 1,0 & 1,0 & 1,0 & 1,0 & 1,1 & 0,9 & 0,8 & 0,6 & 0,5 & 0,0 \\
SBS & 0,7 & 0,7 & 0,6 & 0,5 & 0,5 & 0,7 & 0,6 & 0,5 & 0,6 & 1,3 \\
SBS+PPA & 0,8 & 0,7 & 0,6 & 0,5 & 0,4 & 0,8 & 0,6 & 0,5 & 0,3 & 0,0 \\
EVA & 1,3 & 1,4 & 1,3 & 1,0 & 0,8 & 1,3 & 1,5 & 1,6 & 0,7 & 0,0 \\
EVA+PPA & 1,1 & 1,2 & 1,3 & 1,5 & 1,9 & 1,1 & 1,2 & 1,3 & 1,3 & 3,3 \\
PE & 0,5 & 0,4 & 0,3 & 0,3 & 0,2 & 0,4 & 0,2 & 0,0 & 0,0 & 0,0 \\
PE+PPA & 0,8 & 0,7 & 0,6 & 0,5 & 0,4 & 0,8 & 0,6 & 0,5 & 0,2 & 0,0 \\
SBR & 0,7 & 0,7 & 0,7 & 0,7 & 0,6 & 0,6 & 0,5 & 0,4 & 0,3 & 0,0 \\
SBR+PPA & 1,0 & 1,0 & 1,1 & 1,2 & 1,3 & 1,0 & 1,0 & 1,2 & 1,5 & 6,8 \\
\hline
\end{tabular}

A Tabela 81 mostra os valores normalizados de compliância não-recuperável (parâmetro $\mathrm{N}_{\mathrm{C}}$ ) em relação ao CAP+PPA, considerando a condição envelhecida destes materiais e os tempos de 1 e $9 \mathrm{~s}$. Em termos dos resultados a $100 \mathrm{~Pa}$ para os ligantes asfálticos modificados, visualiza-se que o CAP+EVA+PPA apresenta valores mais baixos de compliância não-recuperável $\left(N_{C}>1\right)$ em todo o espectro de temperaturas e as formulações com SBS, PE e SBR, os valores mais elevados para esta propriedade $\left(\mathrm{N}_{\mathrm{C}}<1\right)$ em todas as 
temperaturas. Os ligantes asfálticos modificados com Elvaloy+PPA e SBR+PPA possuem compliâncias não-recuperáveis aproximadamente iguais às do CAP+PPA ( $\left.\mathrm{N}_{C} \approx 1\right)$ nas temperaturas de 52 e $58^{\circ} \mathrm{C}$, bem como valores mais baixos para esta propriedade nas temperaturas acima de $64^{\circ} \mathrm{C}$. No caso do CAP+EVA, observa-se que este material possui compliâncias não-recuperáveis menores do que o CAP+PPA $\left(\mathrm{N}_{C}>1\right)$ nas temperaturas de até $70^{\circ} \mathrm{C}$ e mais elevadas $\left(N_{C}=0,9\right)$ na temperatura de $76^{\circ} \mathrm{C}$. As formulações com borracha, borracha+PPA, SBS+PPA e PE+PPA apresentam compliâncias não-recuperáveis maiores do que o CAP+PPA em todo o espectro de temperaturas, porém menores do que as observadas no CAP+PE, no CAP+SBR, no CAP+SBS e no CAP 50/70.

Tabela 81 - Compliâncias não-recuperáveis normalizadas $\left(\mathrm{N}_{\mathrm{C}}\right)$ dos ligantes asfálticos envelhecidos em relação ao CAP+PPA e nos tempos de 1 e $9 \mathrm{~s}$

\begin{tabular}{ccccccccccc}
\hline Ligante & \multicolumn{9}{c}{$100 \mathrm{~Pa}$} \\
\cline { 2 - 10 } asfáltico & $52^{\circ} \mathrm{C}$ & $58^{\circ} \mathrm{C}$ & $64^{\circ} \mathrm{C}$ & $70^{\circ} \mathrm{C}$ & $76^{\circ} \mathrm{C}$ & $52^{\circ} \mathrm{C}$ & $58^{\circ} \mathrm{C}$ & $64^{\circ} \mathrm{C}$ & $70^{\circ} \mathrm{C}$ & $76^{\circ} \mathrm{C}$ \\
\hline $50 / 70$ & 0,1 & 0,1 & 0,1 & 0,1 & 0,1 & 0,1 & 0,1 & 0,1 & 0,1 & 0,2 \\
PPA & 1,0 & 1,0 & 1,0 & 1,0 & 1,0 & 1,0 & 1,0 & 1,0 & 1,0 & 1,0 \\
Elvaloy+PPA & 1,0 & 1,1 & 1,5 & 1,9 & 2,2 & 1,0 & 1,3 & 2,1 & 3,0 & 3,6 \\
Borracha & 0,6 & 0,6 & 0,7 & 0,8 & 0,9 & 0,4 & 0,5 & 0,5 & 0,6 & 0,7 \\
Borracha+PPA & 0,6 & 0,6 & 0,7 & 0,7 & 0,8 & 0,5 & 0,5 & 0,5 & 0,6 & 0,7 \\
SBS & 0,5 & 0,5 & 0,5 & 0,5 & 0,6 & 0,4 & 0,5 & 0,5 & 0,6 & 0,7 \\
SBS+PPA & 0,6 & 0,5 & 0,6 & 0,6 & 0,6 & 0,5 & 0,5 & 0,6 & 0,6 & 0,7 \\
EVA & 1,5 & 2,0 & 1,6 & 1,1 & 0,9 & 1,5 & 1,8 & 1,2 & 0,6 & 0,7 \\
EVA+PPA & 1,5 & 1,6 & 1,9 & 2,4 & 2,6 & 1,0 & 1,3 & 1,3 & 1,0 & 0,9 \\
PE & 0,3 & 0,3 & 0,3 & 0,3 & 0,4 & 0,3 & 0,3 & 0,3 & 0,4 & 0,5 \\
PE+PPA & 0,8 & 0,6 & 0,6 & 0,6 & 0,6 & 0,6 & 0,6 & 0,6 & 0,6 & 0,7 \\
SBR & 0,3 & 0,3 & 0,3 & 0,4 & 0,4 & 0,2 & 0,3 & 0,3 & 0,3 & 0,4 \\
SBR+PPA & 1,0 & 1,0 & 1,2 & 1,2 & 1,3 & 1,0 & 1,0 & 1,1 & 1,1 & 1,2 \\
\hline
\end{tabular}

Tomando como base os resultados da Tabela 81 para a tensão de $3.200 \mathrm{~Pa}$, é possível observar que os ligantes asfálticos modificados com Elvaloy+PPA e SBR+PPA apresentam valores de $J_{n r}$ iguais ou menores do que o CAP+PPA $\left(N_{C} \geq 1\right)$ em todo o espectro de temperaturas, o mesmo ocorrendo com o CAP+EVA+PPA nas temperaturas de até $70^{\circ} \mathrm{C}$. No caso do CAP+EVA, visualiza-se que as compliâncias não-recuperáveis deste material modificado são menores do que o CAP+PPA nas temperaturas de até $64^{\circ} \mathrm{C}$, sendo mais elevadas nas temperaturas de 70 e $76^{\circ} \mathrm{C}$. As formulações com PE e SBR apresentam, dentre os ligantes asfálticos modificados, as maiores compliâncias não-recuperáveis (menores valores de $\mathrm{N}_{\mathrm{C}}$ ) em todo o espectro de temperaturas, sendo que estas compliâncias são 
maiores para o $\mathrm{CAP}+\mathrm{SBR}$ e menores para o $\mathrm{CAP}+\mathrm{PE}$. As formulações com PE+PPA, SBS+PPA, borracha, borracha+PPA e SBS possuem valores mais elevados de $\mathrm{J}_{\mathrm{nr}}$ em todo o espectro de temperaturas em comparação ao CAP+PPA, com resultados de $\mathrm{N}_{\mathrm{C}}$ entre $0,4 \mathrm{e}$ 0,7 para todos eles. O CAP 50/70 apresenta compliâncias não-recuperáveis significativamente superiores às do CAP+PPA em qualquer temperatura e nível de tensão, o que se reflete nos valores muito baixos de $\mathrm{N}_{\mathrm{C}}$ para este material (máximo de 0,2 ).

Os resultados das Tabelas 80 e 81 mostram que as formulações com Elvaloy+PPA e EVA+PPA apresentam percentuais de recuperação mais elevados do que o CAP+PPA em todo o espectro de temperaturas a 100 e a $3.200 \mathrm{~Pa}$, além de compliâncias não-recuperáveis aproximadamente iguais ou menores em todas (CAP+Elvaloy+PPA) ou quase todas (CAP+EVA+PPA) as condições de temperatura e tensão. Os ligantes asfálticos modificados com PE e SBR apresentam percentuais de recuperação menores e compliâncias não-recuperáveis maiores do que o $C A P+P P A$ em qualquer condição de temperatura e tensão. As formulações com borracha e borracha+PPA apresentam recuperações aproximadamente iguais às do CAP+PPA nas temperaturas de até $70^{\circ} \mathrm{C}$ a $100 \mathrm{~Pa}$ e de até $58^{\circ} \mathrm{C}$ a $3.200 \mathrm{~Pa}$, ao mesmo tempo em que as compliâncias não-recuperáveis de ambos os ligantes asfálticos são maiores em todas as temperaturas a 100 e a $3.200 \mathrm{~Pa}$. O CAP+SBS apresenta recuperações menores do que o CAP+PPA em todas as temperaturas a $100 \mathrm{~Pa}$ e nas temperaturas de até $70^{\circ} \mathrm{C}$ a $3.200 \mathrm{~Pa}$, bem como compliâncias não-recuperáveis maiores em todas as temperaturas a 100 e a $3.200 \mathrm{~Pa}$.

\subsubsection{Tempos de 2 e 18 s e condição envelhecida a curto prazo}

A Tabela 82 apresenta os valores normalizados do percentual de recuperação (parâmetro $N_{R}$ ) em relação ao CAP 50/70, considerando a condição envelhecida dos ligantes asfálticos e os tempos de 2 e $18 \mathrm{~s}$. Similarmente ao observado em ocasiões anteriores, alguns valores de $N_{R}$ não puderam ser calculados porque a recuperação do CAP puro é nula nestas condições de temperatura e tensão. As formulações com EVA, Elvaloy+PPA, borracha+PPA e EVA+PPA apresentam os maiores valores de $N_{R}$ nas temperaturas e níveis de tensão considerados, o que se traduz em incrementos do percentual de recuperação entre 8 e 31 vezes para estes materiais após os processos de modificação. Em outro extremo, as formulações com PE, SBS, SBR, PE+PPA e SBS+PPA possuem os menores valores de $N_{R}$ nas temperaturas e níveis de tensão considerados, para as quais os aumentos do percentual de recuperação estão entre 3 e 13 vezes após as 
modificações. No caso do CAP+borracha, do CAP+PPA e do CAP+SBR+PPA, estes aumentos de $\mathrm{R}$ são de no mínimo 7 e no máximo 21 vezes nas temperaturas de 52 e $58^{\circ} \mathrm{C}$ a $100 \mathrm{~Pa}$ e na temperatura de $52^{\circ} \mathrm{C}$ a $3.200 \mathrm{~Pa}$.

Tabela 82 - Percentuais de recuperação normalizados $\left(N_{R}\right)$ dos ligantes asfálticos envelhecidos em relação ao CAP 50/70 e nos tempos de 2 e $18 \mathrm{~s}$

\begin{tabular}{ccccccccccc}
\hline Ligante & \multicolumn{9}{c}{$100 \mathrm{~Pa}$} & \multicolumn{7}{c}{$3.200 \mathrm{~Pa}$} \\
\cline { 2 - 11 } asfáltico & $52^{\circ} \mathrm{C}$ & $58{ }^{\circ} \mathrm{C}$ & $64^{\circ} \mathrm{C}$ & $70^{\circ} \mathrm{C}$ & $76^{\circ} \mathrm{C}$ & $52^{\circ} \mathrm{C}$ & $58^{\circ} \mathrm{C}$ & $64^{\circ} \mathrm{C}$ & $70^{\circ} \mathrm{C}$ & $76^{\circ} \mathrm{C}$ \\
\hline $50 / 70$ & 1,0 & 1,0 & - & - & - & 1,0 & - & - & - & - \\
PPA & 7,5 & 17,3 & - & - & - & 16,6 & - & - & - & - \\
Elvaloy+PPA & 10,1 & 27,4 & - & - & - & 23,7 & - & - & - & - \\
Borracha & 8,0 & 20,3 & - & - & - & 14,9 & - & - & - & - \\
Borracha+PPA & 8,5 & 21,4 & - & - & - & 17,6 & - & - & - & - \\
SBS & 4,3 & 7,8 & - & - & - & 8,9 & - & - & - & - \\
SBS+PPA & 5,9 & 12,3 & - & - & - & 12,8 & - & - & - & - \\
EVA & 11,5 & 30,4 & - & - & - & 25,3 & - & - & - & - \\
EVA+PPA & 8,3 & 21,6 & - & - & - & 17,6 & - & - & - & - \\
PE & 3,0 & 5,1 & - & - & - & 4,3 & - & - & - & - \\
PE+PPA & 5,6 & 11,6 & - & - & - & 11,6 & - & - & - & - \\
SBR & 4,9 & 12,4 & - & - & - & 9,2 & - & - & - & - \\
SBR+PPA & 7,4 & 18,1 & - & - & - & 16,6 & - & - & - & - \\
\hline
\end{tabular}

A Tabela 83 apresenta os valores normalizados (parâmetro $N_{C}$ ) de compliância não-recuperável em relação ao CAP 50/70, considerando a condição envelhecida dos ligantes asfálticos e os tempos de 2 e $18 \mathrm{~s}$. Em uma análise dos resultados a $100 \mathrm{~Pa}$, é possível observar que as formulações com EVA, PPA, Elvaloy+PPA, borracha+PPA, EVA+PPA e SBR+PPA possuem as maiores reduções de $J_{\mathrm{nr}}$ em todo o espectro de temperaturas após as modificações: entre 9 e 88 vezes para todos eles. Em outro extremo, as modificações do ligante asfáltico com SBS, PE e SBR acarretam as menores reduções de compliância não-recuperável nestas mesmas temperaturas: entre 2 e 5 vezes para todos os materiais. As reduções observadas nos ligantes asfálticos modificados com borracha, SBS+PPA e PE+PPA estão entre 5 e 10 vezes para qualquer temperatura, sendo maiores para o $\mathrm{CAP}+$ borracha e menores para - CAP+PE+PPA. Interessante observar que os valores de $\mathrm{N}_{\mathrm{C}}$ diminuem para 0 CAP+EVA com o aumento da temperatura no nível de tensão de $100 \mathrm{~Pa}$ (de 63 para $9,8)$, o contrário sendo observado para o CAP+EVA+PPA neste mesmo nível de tensão (de 12,6 para valores entre 22 e 23). 
Tabela 83 - Compliâncias não-recuperáveis normalizadas $\left(\mathrm{N}_{\mathrm{C}}\right)$ dos ligantes asfálticos envelhecidos em relação ao CAP 50/70 e nos tempos de 2 e $18 \mathrm{~s}$

\begin{tabular}{ccccccccccc}
\hline Ligante & \multicolumn{9}{c}{$100 \mathrm{~Pa}$} \\
\cline { 2 - 10 } asfáltico & $52^{\circ} \mathrm{C}$ & $58^{\circ} \mathrm{C}$ & $64^{\circ} \mathrm{C}$ & $70^{\circ} \mathrm{C}$ & $76^{\circ} \mathrm{C}$ & $52^{\circ} \mathrm{C}$ & $58^{\circ} \mathrm{C}$ & $64^{\circ} \mathrm{C}$ & $70^{\circ} \mathrm{C}$ & $76^{\circ} \mathrm{C}$ \\
\hline $50 / 70$ & 1,0 & 1,0 & 1,0 & 1,0 & 1,0 & 1,0 & 1,0 & 1,0 & 1,0 & 1,0 \\
PPA & 12,6 & 12,5 & 11,4 & 10,6 & 9,5 & 13,6 & 11,8 & 9,5 & 7,7 & 6,3 \\
Elvaloy+PPA & 12,6 & 17,5 & 20,4 & 22,1 & 22,3 & 13,6 & 20,1 & 25,9 & 27,2 & 25,1 \\
Borracha & 7,9 & 9,2 & 9,4 & 9,0 & 9,0 & 6,2 & 5,9 & 5,4 & 5,2 & 5,1 \\
Borracha+PPA & 12,6 & 14,6 & 15,1 & 15,0 & 14,4 & 11,3 & 10,6 & 9,5 & 8,6 & 8,1 \\
SBS & 4,8 & 4,7 & 4,6 & 4,5 & 4,3 & 4,9 & 4,7 & 4,3 & 4,1 & 3,8 \\
SBS+PPA & 7,9 & 8,0 & 7,8 & 7,5 & 6,9 & 8,5 & 8,0 & 7,1 & 6,2 & 5,6 \\
EVA & 63,0 & 87,5 & 26,1 & 12,1 & 9,8 & 34,0 & 67,0 & 14,3 & 4,6 & 4,7 \\
EVA+PPA & 12,6 & 17,5 & 20,4 & 22,9 & 22,3 & 11,3 & 10,6 & 8,0 & 6,0 & 4,9 \\
PE & 3,7 & 3,2 & 3,0 & 2,9 & 2,7 & 3,4 & 3,1 & 2,8 & 2,6 & 2,5 \\
PE+PPA & 7,9 & 7,0 & 6,6 & 6,1 & 5,5 & 7,6 & 6,7 & 5,7 & 5,0 & 4,4 \\
SBR & 2,7 & 3,1 & 3,3 & 3,3 & 3,3 & 2,5 & 2,5 & 2,4 & 2,4 & 2,3 \\
SBR+PPA & 10,5 & 12,5 & 13,0 & 12,7 & 11,7 & 11,3 & 11,8 & 10,1 & 8,5 & 7,2 \\
\hline
\end{tabular}

Com relação aos resultados da Tabela 83 para o nível de tensão de $3.200 \mathrm{~Pa}$, visualiza-se que as formulações com Elvaloy+PPA, PPA, borracha+PPA e SBR+PPA apresentam reduções elevadas de compliância não-recuperável (valores elevados de $N_{C}$ ) em todo o espectro de temperaturas, especialmente no caso do CAP+Elvaloy+PPA. As modificações do ligante asfáltico com EVA e EVA+PPA acarretam reduções elevadas da compliância não-recuperável nas temperaturas de até $64^{\circ} \mathrm{C}$ (entre 8 e 67 vezes), o mesmo não sendo observado nas temperaturas de 70 e $76^{\circ} \mathrm{C}$ (entre 4 e 6 vezes). As formulações com SBS, PE e SBR apresentam as menores reduções de $J_{n r}$ em todo o espectro de temperaturas: entre 2 e 5 vezes para todos os materiais. Os valores de $N_{C}$ estão entre 4 e 9 para qualquer temperatura no caso do CAP+borracha, do CAP+SBS+PPA e do CAP+PE+PPA, sendo mais elevados para a formulação com SBS+PPA.

Em uma avaliação dos valores de $N_{R}$ e $N_{C}$ apresentados nas Tabelas 82 e 83, referentes aos materiais envelhecidos a curto prazo e aos tempos de 2 e $18 \mathrm{~s}$, visualiza-se que as modificações com Elvaloy+PPA e borracha+PPA acarretam incrementos significativos no percentual de recuperação e reduções acentuadas na compliância nãorecuperável do ligante asfáltico, tanto a 100 quanto a $3.200 \mathrm{~Pa}$. Em contraste, as modificações com PE, SBS e SBR ocasionam as reduções menos significativas na compliância não-recuperável e os incrementos mais baixos do percentual de recuperação do 
ligante asfáltico, tanto a 100 e a $3.200 \mathrm{~Pa}$. As reduções de $\mathrm{J}_{\mathrm{nr}}$ também se mostram acentuadas para o CAP+PPA e o CAP+SBR+PPA em ambos os níveis de tensão, ao passo que os incrementos do percentual de recuperação são próximos aos obtidos para o CAP+borracha. No caso das modificações com PE+PPA e SBS+PPA, ambas acarretam incrementos baixos de $\mathrm{R}$ em todas as condições de temperatura e de tensão, bem como reduções intermediárias de $J_{n r}$ em comparação às demais formulações.

A Tabela 84 (página seguinte) mostra os valores normalizados do percentual de recuperação $\left(N_{R}\right)$ em relação ao $C A P+P P A$, levando em consideração a condição envelhecida dos ligantes asfálticos e os tempos de 2 e $18 \mathrm{~s}$. Os valores de $N_{R}$ não puderam ser calculados na temperatura de $76^{\circ} \mathrm{C}$ e a 3.200 Pa porque o percentual de recuperação do CAP+PPA é nulo nestas condições. Em uma avaliação dos resultados a $100 \mathrm{~Pa}$, é possível observar que o CAP+Elvaloy+PPA possui recuperações maiores do que o CAP+PPA em todo o espectro de temperaturas $\left(\mathrm{N}_{\mathrm{R}}>1\right)$, o mesmo ocorrendo com o CAP+EVA nas temperaturas de até $70^{\circ} \mathrm{C}$ e com o CAP+EVA+PPA nas temperaturas acima de $58^{\circ} \mathrm{C}$. As formulações com SBS+PPA, PE+PPA, SBR, SBS e PE apresentam percentuais de recuperação menores do que o CAP+PPA $\left(N_{R}<1\right)$ em qualquer temperatura, sendo que os valores mais baixos pertencem ao CAP+PE. Os materiais modificados com borracha+PPA, borracha e SBR+PPA apresentam recuperações aproximadamente iguais $\left(N_{R} \approx 1\right)$ ou maiores do que o CAP+PPA em todas as temperaturas, sendo que o CAP+borracha+PPA possui os resultados mais elevados e o CAP+SBR+PPA, os mais baixos. O CAP 50/70 apresenta recuperações nulas $\left(N_{R}=0\right)$ ou significativamente menores do que o CAP+PPA $\left(N_{R}=0,1\right)$ em qualquer temperatura.

Com relação aos resultados da Tabela 84 para o nível de tensão de $3.200 \mathrm{~Pa}$, visualiza-se que o CAP+Elvaloy+PPA apresenta valores de $R$ maiores do que o CAP+PPA $\left(N_{R}>1\right)$ em todo o espectro de temperaturas consideradas $\left(52,58,64\right.$ e $\left.70^{\circ} \mathrm{C}\right)$, o mesmo sendo observado para o CAP+EVA nas temperaturas de 52,58 e $64^{\circ} \mathrm{C}$. Em outro extremo, os ligantes asfálticos modificados com SBS+PPA, PE+PPA, SBS, SBR e PE apresentam recuperações menores do que o CAP+PPA $\left(N_{R}<1\right)$ em todas as temperaturas consideradas, sendo que o CAP+PE possui os resultados mais baixos e o CAP+SBS+PPA possui os mais elevados. As formulações com borracha+PPA e SBR+PPA possuem recuperações aproximadamente iguais às do CAP+PPA nas temperaturas de 52 e $58^{\circ} \mathrm{C}$ e valores mais elevados para esta propriedade $\left(N_{R}>1\right)$ nas temperaturas de 64 e $70^{\circ} \mathrm{C}$. No caso do $\mathrm{CAP}+\mathrm{EVA}+\mathrm{PPA}$, os percentuais de recuperação deste material são aproximadamente iguais ou levemente superiores aos do CAP+PPA em todas as temperaturas. Já para o CAP+borracha, os percentuais de recuperação são mais baixos $\left(N_{R}<1\right)$ nas temperaturas de até $64^{\circ} \mathrm{C}$ e mais elevados $\left(N_{R}>1\right)$ na temperatura de $70^{\circ} \mathrm{C}$. 
Tabela 84 - Percentuais de recuperação normalizados $\left(N_{R}\right)$ dos ligantes asfálticos envelhecidos em relação ao CAP+PPA e nos tempos de 2 e $18 \mathrm{~s}$

\begin{tabular}{cccccccccccc}
\hline Ligante & \multicolumn{9}{c}{$100 \mathrm{~Pa}$} \\
\cline { 2 - 10 } asfáltico & $52^{\circ} \mathrm{C}$ & $58^{\circ} \mathrm{C}$ & $64^{\circ} \mathrm{C}$ & $70^{\circ} \mathrm{C}$ & $76^{\circ} \mathrm{C}$ & $52^{\circ} \mathrm{C}$ & $58^{\circ} \mathrm{C}$ & $64^{\circ} \mathrm{C}$ & $70^{\circ} \mathrm{C}$ & $76^{\circ} \mathrm{C}$ \\
\hline $50 / 70$ & 0,1 & 0,1 & 0,0 & 0,0 & 0,0 & 0,1 & 0,0 & 0,0 & 0,0 & - \\
PPA & 1,0 & 1,0 & 1,0 & 1,0 & 1,0 & 1,0 & 1,0 & 1,0 & 1,0 & - \\
Elvaloy+PPA & 1,3 & 1,6 & 1,9 & 2,5 & 3,5 & 1,4 & 2,0 & 3,9 & 19,9 & - \\
Borracha & 1,1 & 1,2 & 1,3 & 1,4 & 1,6 & 0,9 & 0,8 & 0,8 & 1,4 & - \\
Borracha+PPA & 1,1 & 1,2 & 1,4 & 1,6 & 1,8 & 1,1 & 1,1 & 1,3 & 2,9 & - \\
SBS & 0,6 & 0,5 & 0,3 & 0,2 & 0,1 & 0,5 & 0,4 & 0,2 & 0,0 & - \\
SBS+PPA & 0,8 & 0,7 & 0,6 & 0,6 & 0,4 & 0,8 & 0,7 & 0,5 & 0,2 & - \\
EVA & 1,5 & 1,8 & 1,6 & 1,2 & 1,0 & 1,5 & 2,1 & 2,6 & 0,7 & - \\
EVA+PPA & 1,1 & 1,2 & 1,4 & 1,8 & 2,4 & 1,1 & 1,1 & 1,1 & 1,2 & - \\
PE & 0,4 & 0,3 & 0,2 & 0,1 & 0,0 & 0,3 & 0,1 & 0,0 & 0,0 & - \\
PE+PPA & 0,7 & 0,7 & 0,6 & 0,5 & 0,4 & 0,7 & 0,5 & 0,3 & 0,0 & - \\
SBR & 0,7 & 0,7 & 0,7 & 0,6 & 0,4 & 0,6 & 0,4 & 0,3 & 0,0 & - \\
SBR+PPA & 1,0 & 1,0 & 1,2 & 1,3 & 1,3 & 1,0 & 1,1 & 1,3 & 2,7 & - \\
\hline
\end{tabular}

A Tabela 85 (página seguinte) mostra as compliâncias não-recuperáveis normalizadas dos ligantes asfálticos (parâmetro $\mathrm{N}_{\mathrm{C}}$ ) em relação ao CAP+PPA, considerando a condição envelhecida destes materiais e os tempos de 2 e 18 s. Uma avaliação dos resultados a $100 \mathrm{~Pa}$ mostra que o CAP+EVA possui compliâncias não-recuperáveis menores do que o CAP+PPA $\left(\mathrm{N}_{\mathrm{C}}>1\right)$ nas temperaturas de 52,58 e $64^{\circ} \mathrm{C}$ e valores aproximadamente iguais nas temperaturas de 70 e $76^{\circ} \mathrm{C}$. Ainda com relação aos resultados a $100 \mathrm{~Pa}$, as formulações com Elvaloy+PPA, EVA+PPA e borracha+PPA apresentam compliâncias nãorecuperáveis aproximadamente iguais às do CAP+PPA $\left(N_{C} \approx 1\right)$ na temperatura de $52^{\circ} \mathrm{C} e$ valores mais baixos $\left(N_{C}>1\right)$ nas demais temperaturas. Os ligantes asfálticos modificados com SBS+PPA, PE+PPA, SBS, PE e SBR apresentam compliâncias não-recuperáveis maiores do que o CAP+PPA $\left(\mathrm{N}_{\mathrm{C}}<1\right)$ em todo o espectro de temperaturas, tanto no menor quanto no maior nível de tensão. O CAP+SBR+PPA apresenta, tanto a 100 quanto a $3.200 \mathrm{~Pa}$, valores de $J_{n r}$ maiores do que o CAP+PPA na temperatura de $52^{\circ} \mathrm{C}\left(N_{C}=0,8\right)$ e valores aproximadamente iguais ou menores $\left(N_{C} \geq 1\right)$ nas demais temperaturas.

Com relação aos demais resultados da Tabela 85 para a tensão de $3.200 \mathrm{~Pa}$, é possível observar que o CAP+EVA apresenta compliâncias não-recuperáveis menores do que o CAP+PPA nas temperaturas de 52,58 e $64^{\circ} \mathrm{C}$ e valores maiores nas temperaturas de 70 e $76^{\circ} \mathrm{C}$. No caso do CAP+Elvaloy+PPA, este material modificado apresenta valores 
aproximadamente iguais ou menores de $\mathrm{J}_{\mathrm{nr}}\left(\mathrm{N}_{\mathrm{C}} \geq 1\right)$ em comparação ao CAP+PPA, tanto nas temperaturas mais baixas quanto nas mais elevadas. No caso do CAP+EVA+PPA e do CAP+borracha, estes ligantes asfálticos apresentam compliâncias não-recuperáveis maiores $\left(N_{C} \leq 1\right)$ do que o CAP+PPA em todo o espectro de temperaturas, especialmente no caso do $\mathrm{CAP}+$ borracha. Já para o CAP+borracha+PPA, as compliâncias não-recuperáveis são maiores para este material modificado em comparação ao CAP+PPA na temperatura de $52^{\circ} \mathrm{C}\left(\mathrm{N}_{\mathrm{C}}=0,8\right)$, sendo aproximadamente iguais ou menores $\left(\mathrm{N}_{\mathrm{C}} \geq 1\right)$ nas demais temperaturas.

Tabela 85 - Compliâncias não-recuperáveis normalizadas $\left(\mathrm{N}_{\mathrm{C}}\right)$ dos ligantes asfálticos envelhecidos em relação ao CAP+PPA e nos tempos de 2 e $18 \mathrm{~s}$

\begin{tabular}{ccccccccccc}
\hline Ligante & \multicolumn{9}{c}{$100 \mathrm{~Pa}$} \\
\cline { 2 - 10 } asfálico & $52^{\circ} \mathrm{C}$ & $58^{\circ} \mathrm{C}$ & $64^{\circ} \mathrm{C}$ & $70^{\circ} \mathrm{C}$ & $76^{\circ} \mathrm{C}$ & $52^{\circ} \mathrm{C}$ & $58^{\circ} \mathrm{C}$ & $64^{\circ} \mathrm{C}$ & $70{ }^{\circ} \mathrm{C}$ & $76^{\circ} \mathrm{C}$ \\
\hline $50 / 70$ & 0,1 & 0,1 & 0,1 & 0,1 & 0,1 & 0,1 & 0,1 & 0,1 & 0,1 & 0,2 \\
PPA & 1,0 & 1,0 & 1,0 & 1,0 & 1,0 & 1,0 & 1,0 & 1,0 & 1,0 & 1,0 \\
Elvaloy+PPA & 1,0 & 1,4 & 1,8 & 2,1 & 2,3 & 1,0 & 1,7 & 2,7 & 3,6 & 4,0 \\
Borracha & 0,6 & 0,7 & 0,8 & 0,8 & 0,9 & 0,5 & 0,5 & 0,6 & 0,7 & 0,8 \\
Borracha+PPA & 1,0 & 1,2 & 1,3 & 1,4 & 1,5 & 0,8 & 0,9 & 1,0 & 1,1 & 1,3 \\
SBS & 0,4 & 0,4 & 0,4 & 0,4 & 0,4 & 0,4 & 0,4 & 0,5 & 0,5 & 0,6 \\
SBS+PPA & 0,6 & 0,6 & 0,7 & 0,7 & 0,7 & 0,6 & 0,7 & 0,7 & 0,8 & 0,9 \\
EVA & 5,0 & 7,0 & 2,3 & 1,1 & 1,0 & 2,5 & 5,7 & 1,5 & 0,6 & 0,8 \\
EVA+PPA & 1,0 & 1,4 & 1,8 & 2,2 & 2,3 & 0,8 & 0,9 & 0,8 & 0,8 & 0,8 \\
PE & 0,3 & 0,3 & 0,3 & 0,3 & 0,3 & 0,3 & 0,3 & 0,3 & 0,3 & 0,4 \\
PE+PPA & 0,6 & 0,6 & 0,6 & 0,6 & 0,6 & 0,6 & 0,6 & 0,6 & 0,6 & 0,7 \\
SBR & 0,2 & 0,3 & 0,3 & 0,3 & 0,3 & 0,2 & 0,2 & 0,3 & 0,3 & 0,4 \\
SBR+PPA & 0,8 & 1,0 & 1,1 & 1,2 & 1,2 & 0,8 & 1,0 & 1,1 & 1,1 & 1,1 \\
\hline
\end{tabular}

De maneira resumida, os resultados das Tabelas 84 e 85 apontam que o CAP+Elvaloy+PPA apresenta recuperações maiores do que o CAP+PPA em todo o espectro de temperaturas a 100 e a $3.200 \mathrm{~Pa}$, bem como compliâncias não-recuperáveis iguais ou menores em todas as condições de temperatura e tensão. As formulações com SBS+PPA, PE+PPA, SBS, PE e SBR possuem recuperações menores do que o CAP+PPA em todas as temperaturas a 100 e a $3.200 \mathrm{~Pa}$, além de compliâncias não-recuperáveis mais elevadas nestas mesmas condições. O CAP+EVA apresenta, em linhas gerais, percentuais de recuperação mais elevados e compliâncias não-recuperáveis mais baixas do que o CAP+PPA em ambos os níveis de tensão, especialmente a 100 Pa. O CAP+EVA+PPA apresenta recuperações aproximadamente iguais ou maiores do que o CAP+PPA em todo o espectro de temperaturas a 100 e a $3.200 \mathrm{~Pa}$, apresentando também compliâncias não-recuperáveis mais elevadas a $3.200 \mathrm{~Pa}$ e mais baixas nas temperaturas acima de $58^{\circ} \mathrm{C}$ a $100 \mathrm{~Pa}$. 


\subsection{Elasticidade dos ligantes asfálticos envelhecidos a curto prazo e na temperatura do PG}

A Tabela 86 apresenta as propriedades dos ligantes asfálticos na condição envelhecida a curto prazo, considerando a temperatura de $76^{\circ} \mathrm{C}$, o nível de tensão de $3.200 \mathrm{~Pa}$ e os tempos de fluência e recuperação respectivamente iguais a 1 e $9 \mathrm{~s}$. À exceção do $\mathrm{CAP}+$ Elvaloy+PPA e do $\mathrm{CAP}+\mathrm{SBR}+\mathrm{PPA}$, os quais apresentam compliâncias não-recuperáveis menores ou aproximadamente iguais a 2,0 $\mathrm{kPa}^{-1}$, todos os demais ligantes asfálticos apresentam valores de $\mathrm{J}_{\mathrm{nr}}$ superiores a $2,0 \mathrm{kPa}^{-1}$, o que dispensa a recomendação de um valor mínimo do percentual de recuperação para tais materiais. Desta maneira, o gráfico do nível de elasticidade foi construído apenas com os resultados do CAP+Elvaloy+PPA e do $\mathrm{CAP}+\mathrm{SBR}+\mathrm{PPA}$, para os quais são recomendados os percentuais de recuperação mínimos de 30 e $45 \%$ respectivamente conforme Tabela 2 (página 51).

Tabela 86 - Propriedades dos ligantes asfálticos envelhecidos a curto prazo na temperatura do PG, no nível de tensão de 3.200 Pa e nos tempos de 1 e $9 \mathrm{~s}$

\begin{tabular}{ccc}
\hline Ligante & \multicolumn{2}{c}{ Propriedades a $76^{\circ} \mathrm{C}$ e $3.200 \mathrm{~Pa}$} \\
\cline { 2 - 3 } asfáltico & Percentual de recuperação $(\%)$ & Compliância não-recuperável $\left(\mathrm{kPa}^{-1}\right)$ \\
\hline $50 / 70$ & 0,0 & 2,78 \\
PPA & 6,8 & 2,38 \\
Elvaloy+PPA & 0,8 & 0,66 \\
Borracha & 0,0 & 3,38 \\
Borracha+PPA & 1,0 & 3,30 \\
SBS & 0,0 & 3,58 \\
SBS+PPA & 0,0 & 3,33 \\
EVA & 2,6 & 3,33 \\
EVA+PPA & 0,0 & 2,58 \\
PE & 0,0 & 5,23 \\
PE+PPA & 0,0 & 3,50 \\
SBR & 5,4 & 5,99 \\
SBR+PPA & & 2,03 \\
\hline
\end{tabular}

A Figura 88 ilustra os resultados do $\mathrm{CAP}+$ Elvaloy+PPA e do $\mathrm{CAP}+\mathrm{SBR}+\mathrm{PPA}$ para verificação do nível de elasticidade. Os resultados mostram que o CAP+Elvaloy+PPA apresenta um percentual de recuperação maior do que o mínimo recomendado para o seu valor de $J_{n r}$, 0 que resultou na localização acima da curva de valores mínimos (zona de alta elasticidade). Por 
outro lado, o CAP+SBR+PPA apresenta um percentual de recuperação menor do que o mínimo recomendado para o seu valor de $J_{n r}$, resultando na localização abaixo da curva de valores mínimos (zona de baixa elasticidade). Desta maneira, pode-se dizer que o CAP+Elvaloy+PPA possui uma elasticidade alta e o $\mathrm{CAP}+\mathrm{SBR}+\mathrm{PPA}$, uma elasticidade baixa.

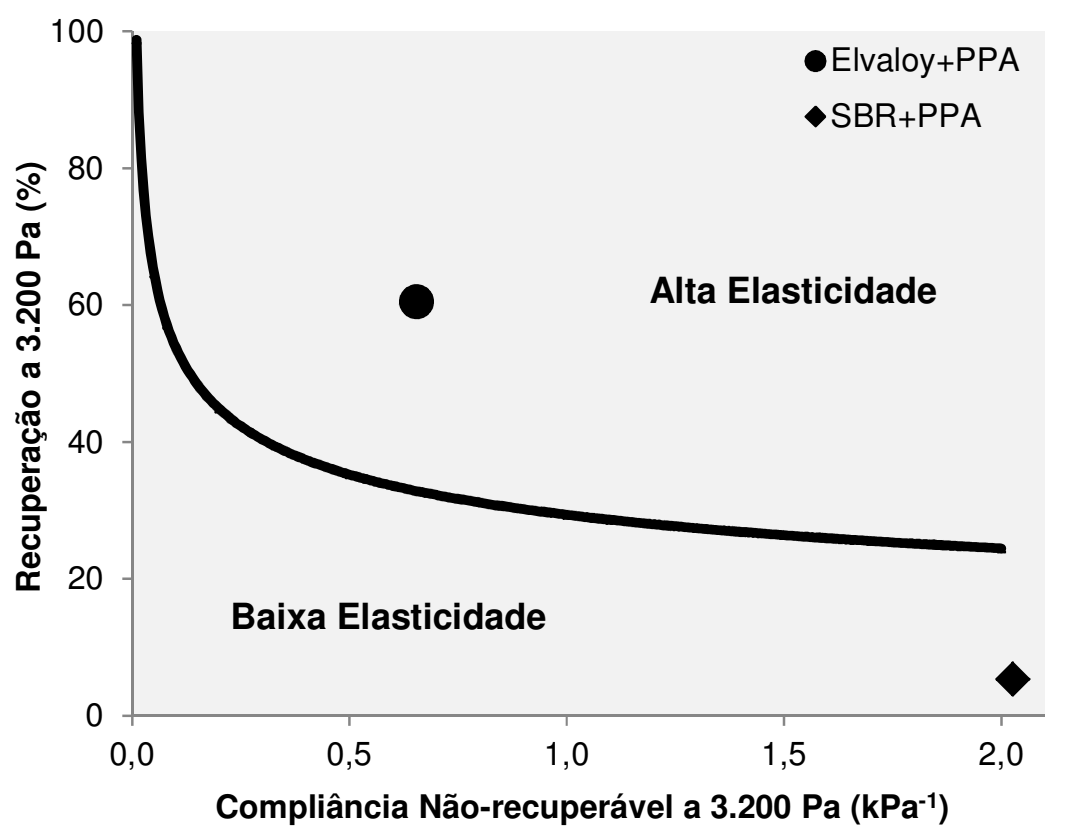

Figura 88 - Verificação do nível de elasticidade do CAP+Elvaloy+PPA e do CAP+SBR+PPA na temperatura de $76^{\circ} \mathrm{C}$ e nos tempos de 1 e $9 \mathrm{~s}$

A Tabela 87 mostra as propriedades dos ligantes asfálticos na condição envelhecida a curto prazo, considerando a temperatura de $76^{\circ} \mathrm{C}$, a tensão de $3.200 \mathrm{~Pa}$ e os tempos de fluência e recuperação respectivamente iguais a 2 e $18 \mathrm{~s}$. Valores de compliância não-recuperável superiores a $2,0 \mathrm{kPa}^{-1}$ são encontrados em quase todos os ligantes asfálticos, sendo que o CAP+Elvaloy+PPA é o único material a apresentar um valor inferior a $2,0 \mathrm{kPa}^{-1}$ para esta propriedade. Na extensão em que é válida a aplicação dos percentuais de recuperação mínimos a ligantes asfálticos analisados nos tempos de fluência e recuperação de 2 e 18 s, o valor mínimo sugerido para o CAP+Elvaloy+PPA é de 30\% (Tabela 2), não sendo sugerida qualquer recuperação mínima para os demais ligantes asfálticos.

Na extensão em que é válida a aplicação do gráfico de nível de elasticidade a ligantes asfálticos envelhecidos a curto prazo e submetidos aos tempos de fluência e recuperação iguais a 2 e $18 \mathrm{~s}$, a Figura 89 mostra os resultados do CAP+Elvaloy+PPA para verificação do nível de elasticidade deste material. Assim como observado nos tempos de 1 e $9 \mathrm{~s}$, os resultados mostram que o CAP+Elvaloy+PPA apresenta um percentual de recuperação maior do que a mínima recomendada para o seu valor de $\mathrm{J}_{\mathrm{nr}}$, o que resultou na 
localização acima da curva de valores mínimos (zona de alta elasticidade). Em conjunto com o gráfico da Figura 88, pode-se dizer que o CAP+Elvaloy+PPA possui uma alta elasticidade tanto nos tempos de 1 e $9 \mathrm{~s}$ quanto nos tempos de 2 e $18 \mathrm{~s}$.

Tabela 87 - Propriedades dos ligantes asfálticos envelhecidos a curto prazo na temperatura do PG, no nível de tensão de 3.200 Pa e nos tempos de 2 e $18 \mathrm{~s}$

\begin{tabular}{ccc}
\hline \multirow{2}{*}{$\begin{array}{c}\text { Ligante } \\
\text { asfáltico }\end{array}$} & \multicolumn{2}{c}{ Propriedades a $76^{\circ} \mathrm{C}$ e 3.200 Pa } \\
\cline { 2 - 3 } Percentual de recuperação (\%) & Compliância não-recuperável $\left(\mathrm{kPa}^{-1}\right)$ \\
\hline PPA & 0,0 & 5,43 \\
Elvaloy+PPA & 0,0 & 4,77 \\
Borracha & 50,7 & 1,20 \\
Borracha+PPA & 0,0 & 5,88 \\
SBS & 1,8 & 3,74 \\
SBS+PPA & 0,0 & 7,90 \\
EVA & 0,0 & 5,37 \\
EVA+PPA & 0,0 & 6,36 \\
PE & 0,0 & 6,12 \\
PE+PPA & 0,0 & 12,27 \\
SBR & 0,0 & 6,90 \\
SBR+PPA & 0,0 & 12,90 \\
\hline
\end{tabular}

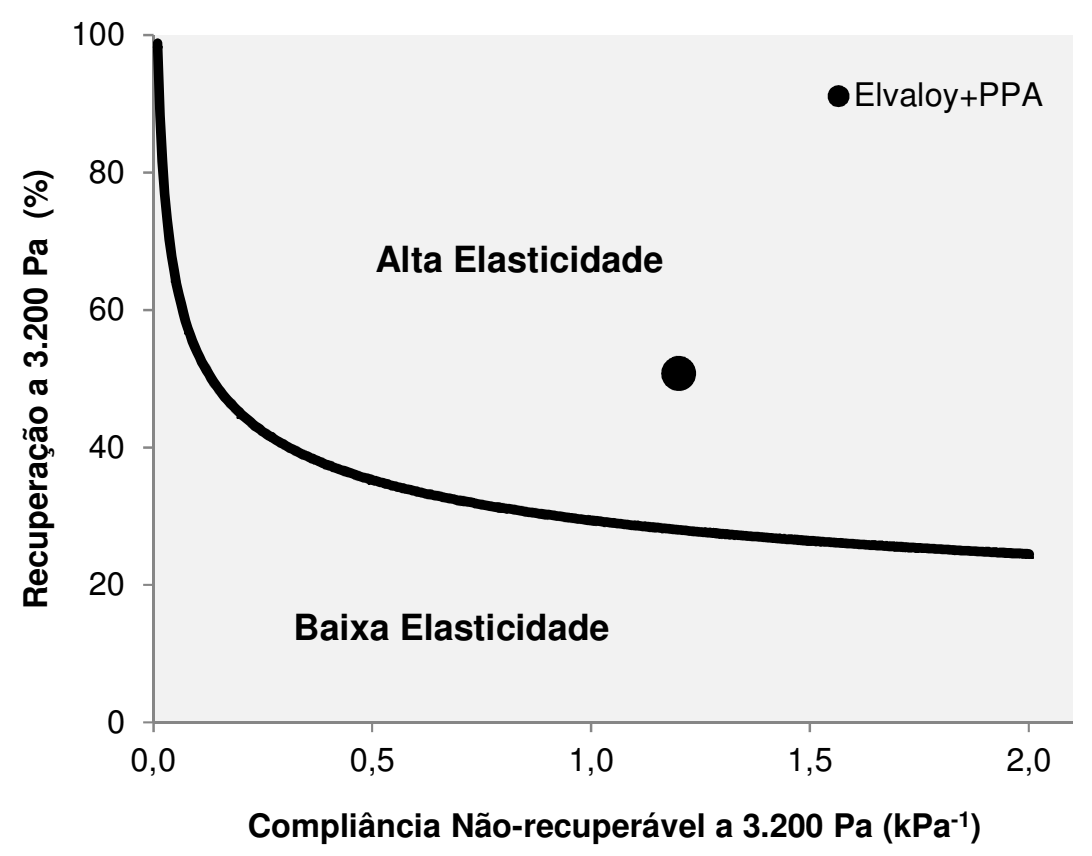

Figura 89 - Verificação do nível de elasticidade do CAP+Elvaloy+PPA na temperatura de $76{ }^{\circ} \mathrm{C}$ e nos tempos de 2 e $18 \mathrm{~s}$ 
As análises dos resultados apresentados nas Tabelas 86 e 87 e nas Figuras 88 e 89 mostram que, à exceção do CAP+Elvaloy+PPA em ambos os tempos de fluência e recuperação ( 1 e 9 s e 2 e $18 \mathrm{~s}$ ) e do CAP+SBR+PPA nos tempos de 1 e $9 \mathrm{~s}$, todos os demais ligantes asfálticos possuem valores elevados de $J_{n r}$ na temperatura do $P G$ e na tensão de $3.200 \mathrm{~Pa}$, de modo que não são recomendados percentuais de recuperação mínimos para tais materiais. $\mathrm{Na}$ extensão em que é válida a aplicação do critério do nível de elasticidade a ligantes asfálticos ensaiados nos tempos de fluência e recuperação de 2 e 18 s, o CAP+Elvaloy+PPA é classificado como um material de elasticidade elevada (acima do valor mínimo) tanto nos tempos de 1 e 9 s quanto nos tempos de 2 e $18 \mathrm{~s}$, e o CAP+SBR+PPA é classificado como um material de elasticidade baixa (abaixo do valor mínimo) nos tempos de 1 e $9 \mathrm{~s}$.

\subsection{Classificação dos ligantes asfálticos no critério de tráfego do FHWA}

O critério de tráfego do FHWA leva em consideração o valor de $J_{\mathrm{nr}}$ a $3.200 \mathrm{~Pa}$ e na temperatura máxima do PG do CAP envelhecido a curto prazo, considerando o novo critério da especificação Superpave para determinação do PG. Na extensão em que é válida a aplicação deste critério de tráfego a ligantes asfálticos classificados segundo o critério original da especificação Superpave, a Tabela 88 apresenta os resultados para os CAPs envelhecidos a curto prazo e ensaiados na temperatura do PG a 3.200 Pa. O CAP+PE e o CAP+SBR apresentam compliâncias não-recuperáveis maiores do que o valor máximo estipulado pela classificação $\left(4,0 \mathrm{kPa}^{-1}\right)$ e, em virtude desta suscetibilidade elevada à deformação permanente, ambos os materiais não podem ser aplicados em pavimentos. À exceção do CAP+Elvaloy+PPA, do CAP+PE e do CAP+SBR, O CAP 50/70 e os demais ligantes asfálticos modificados apresentam uma classificação de tráfego do tipo padrão (S), para o qual é especificado um número equivalente de passadas de um eixo padrão simples (ESAL) inferior a 10 milhões (Tabela 1, página 51). No caso do CAP+Elvaloy+PPA, o tipo de tráfego adequado a este material é o do tipo muito pesado $(\mathrm{V})$, para o qual o número equivalente de passadas de um eixo padrão simples é superior a 30 milhões (Tabela 1). Estas análises permitem dizer que o CAP+Elvaloy+PPA é capaz de suportar um tráfego mais pesado do que os demais ligantes asfálticos, o que é decorrente do seu valor mais baixo de $\mathrm{J}_{\mathrm{nr}} \mathrm{e}$, por consequência, da sua menor suscetibilidade à deformação permanente.

Uma avaliação dos resultados apresentados nos itens 4.7 e 4.8 permite observar que o CAP+Elvaloy+PPA possui os melhores resultados, tanto no nível de elasticidade (alto) quanto no tipo de tráfego (muito pesado). O CAP+SBR+PPA apresenta uma compliância 
não-recuperável $\left(2,03 \mathrm{kPa}^{-1}\right)$ muito próxima ao valor mínimo estipulado na faixa de valores do tráfego padrão $\left(2,0 \mathrm{kPa}^{-1}\right)$, embora o nível de elasticidade deste material esteja abaixo do mínimo recomendado (baixo). Os valores elevados de $J_{n r}$ não permitem uma verificação do nível de elasticidade dos demais ligantes asfálticos e, no caso do CAP+PE e do CAP+SBR, os resultados de $\mathrm{J}_{\mathrm{nr}}$ ultrapassam o valor máximo estipulado no critério do FHWA.

Tabela 88 - Classificação dos ligantes asfálticos segundo o critério de tráfego do FHWA nos tempos de 1 e $9 \mathrm{~s}$

\begin{tabular}{|c|c|c|c|c|}
\hline $\begin{array}{l}\text { Ligante } \\
\text { asfáltico } \\
\end{array}$ & $\begin{array}{c}\text { Temperatura } \\
\left({ }^{\circ} \mathrm{C}\right) \\
\end{array}$ & $\begin{array}{c}J_{n r} \text { a } 3.200 \mathrm{~Pa} \\
\left(\mathrm{kPa}^{-1}\right)\end{array}$ & $\begin{array}{c}\text { Faixa de } \mathrm{J}_{\mathrm{nr}} \mathrm{na} \\
\text { classificação }\left(\mathrm{kPa}^{-1}\right) \\
\end{array}$ & Tipo de tráfego \\
\hline $50 / 70$ & 64 & 2,78 & $2,0 \leq J_{\mathrm{nr}} \leq 4,0$ & Padrão (S) \\
\hline PPA & 76 & 2,38 & $2,0 \leq \mathrm{J}_{\mathrm{nr}} \leq 4,0$ & Padrão (S) \\
\hline Elvaloy+PPA & 76 & 0,66 & $0,5 \leq \mathrm{J}_{\mathrm{nr}} \leq 1,0$ & Muito Pesado (V) \\
\hline Borracha & 76 & 3,38 & $2,0 \leq J_{\mathrm{nr}} \leq 4,0$ & Padrão (S) \\
\hline Borracha+PPA & 76 & 3,30 & $2,0 \leq \mathrm{J}_{\mathrm{nr}} \leq 4,0$ & Padrão (S) \\
\hline SBS & 76 & 3,58 & $2,0 \leq \mathrm{J}_{\mathrm{nr}} \leq 4,0$ & Padrão (S) \\
\hline SBS+PPA & 76 & 3,33 & $2,0 \leq J_{\mathrm{nr}} \leq 4,0$ & Padrão (S) \\
\hline EVA & 76 & 3,33 & $2,0 \leq \mathrm{J}_{\mathrm{nr}} \leq 4,0$ & Padrão (S) \\
\hline $\mathrm{EVA}+\mathrm{PPA}$ & 76 & 2,58 & $2,0 \leq \mathrm{J}_{\mathrm{nr}} \leq 4,0$ & Padrão (S) \\
\hline $\mathrm{PE}$ & 76 & 5,23 & - & - \\
\hline $\mathrm{PE}+\mathrm{PPA}$ & 76 & 3,50 & $2,0 \leq \mathrm{J}_{\mathrm{nr}} \leq 4,0$ & Padrão (S) \\
\hline SBR & 76 & 5,99 & - & - \\
\hline SBR+PPA & 76 & 2,03 & $2,0 \leq J_{\mathrm{nr}} \leq 4,0$ & Padrão (S) \\
\hline
\end{tabular}

\subsection{Análises simultâneas dos resultados dos ligantes asfálticos}

A análise simultânea dos resultados dos ligantes asfálticos foi realizada em termos da ordenação destes materiais para cada propriedade e parâmetro. Esta ordenação consiste na atribuição de um valor numérico entre 1 e 13, referente à classificação do ligante asfáltico em um "ranking" dos resultados de todos os materiais. A numeração foi efetuada dos resultados melhores para os piores, de modo que os resultados melhores receberam valores mais baixos e os resultados piores, valores mais elevados. É importante observar que a classificação dos resultados dos ligantes asfálticos como "melhores" e "piores" foi feita com base em determinadas características e que, caso outros pontos de vista (e, por consequência, outras características) sejam adotados na classificação, as ordenações serão consequentemente diferentes. Os resultados melhores correspondem às seguintes características: 
a) Menor perda de massa;

b) Maior penetração retida;

c) Menores temperaturas de usinagem e de compactação;

d) Menor incremento do ponto de amolecimento;

e) Menores viscosidades rotacionais virgens e envelhecidas a curto prazo;

f) Menor incremento de viscosidade rotacional;

g) Maiores percentuais de recuperação virgens e envelhecidos a curto prazo;

h) Menores compliâncias não-recuperáveis virgens e envelhecidas a curto prazo;

i) Menores incrementos do percentual de recuperação após o RTFOT;

j) Menores reduções de compliância não-recuperável após o RTFOT;

k) Menor sensibilidade à tensão.

A Tabela 89 apresenta as ordenações dos ligantes asfálticos para cada propriedade e parâmetro. Os resultados nulos ou inexistentes estão indicados com um traço horizontal (-), não sendo considerados nas ordenações dos ligantes asfálticos e nos cálculos das médias parciais e finais. É importante observar que, neste trabalho, as propriedades e parâmetros não apresentam pesos iguais para todos eles, sendo uma função da quantidade de leituras efetuadas em cada caso. Neste aspecto, itens como "penetração retida", "temperatura de usinagem" e "incremento do ponto de amolecimento" possuem peso 1 no cálculo da média final (um valor numérico para cada item), ao passo que outros como "viscosidade virgem", "compliância não-recuperável" e "percentual de recuperação" possuem peso 5 no cálculo da média final (cinco valores numéricos para cada item).

Além das limitações relacionadas aos pesos diferentes das propriedades e parâmetros em questão, outra limitação das ordenações médias dos ligantes asfálticos está nos pesos semelhantes adotados em grupos específicos de itens, não permitindo a distinção entre as importâncias reais de cada um deles de acordo com o critério em avaliação. Desta maneira, propriedades como "viscosidade virgem" possuem pesos semelhantes ao de outras como "compliância não-recuperável" e "percentual de recuperação" (peso 5 para todas elas), o mesmo sendo observado em itens como "penetração retida", "incremento do ponto de amolecimento" e "temperatura de usinagem" (peso 1 para todos eles). Ou seja, foi adotada a suposição de que os itens contidos em um mesmo grupo possuem importâncias (e pesos) semelhantes nas avaliações dos resultados dos ligantes asfálticos, embora se saiba que esta afirmação nem sempre é verdadeira para todos os casos e situações possíveis de utilização dos CAPs. Como um exemplo, o item "compliância não-recuperável" possui um peso muito maior na avaliação da suscetibilidade do ligante asfáltico à deformação permanente do que o item "viscosidade virgem" e, neste estudo, ambos possuem pesos iguais (peso 5) nos cálculos das ordenações médias. 
Tabela 89 - Ordenações dos ligantes asfálticos em todas as propriedades e parâmetros (continua)

\begin{tabular}{|c|c|c|c|c|c|c|c|c|c|c|c|c|c|c|}
\hline \multirow[b]{2}{*}{$\begin{array}{l}\text { Propriedade ou } \\
\text { parâmetro }\end{array}$} & \multirow[b]{2}{*}{$\begin{array}{c}\text { Temperatura } \\
\left({ }^{\circ} \mathrm{C}\right)\end{array}$} & \multicolumn{13}{|c|}{ Ligantes asfálticos } \\
\hline & & $50 / 70$ & PPA & $\begin{array}{c}\text { Elvaloy } \\
\text { PPA }\end{array}$ & Borracha & $\begin{array}{c}\text { Borracha } \\
\text { PPA }\end{array}$ & SBS & $\begin{array}{l}\text { SBS } \\
\text { PPA }\end{array}$ & EVA & $\begin{array}{l}\text { EVA } \\
\text { PPA }\end{array}$ & PE & $\begin{array}{l}\text { PE } \\
\text { PPA }\end{array}$ & SBR & $\begin{array}{l}\text { SBR } \\
\text { PPA }\end{array}$ \\
\hline Penetração retida & - & 13 & 7 & 9 & 10 & 8 & 11 & 4 & 12 & 5 & 2 & 3 & 1 & 6 \\
\hline $\begin{array}{l}\text { Incremento do ponto } \\
\text { de amolecimento }\end{array}$ & - & 6 & 13 & 8 & 9 & 11 & 3 & 7 & 4 & 12 & 1 & 5 & 2 & 10 \\
\hline Perda de massa & - & 5 & 10 & 1 & 11 & 13 & 6 & 8 & 9 & 2 & 4 & 7 & 3 & 12 \\
\hline \multirow{5}{*}{$\begin{array}{c}\text { Viscosidade } \\
\text { rotacional virgem }\end{array}$} & 135 & 1 & 2 & 10 & 12 & 11 & 8 & 5 & 13 & 9 & 7 & 6 & 4 & 3 \\
\hline & 143 & 1 & 2 & 10 & 12 & 11 & 5 & 6 & 13 & 9 & 8 & 7 & 4 & 3 \\
\hline & 150 & 1 & 2 & 8 & 12 & 11 & 6 & 7 & 13 & 9 & 10 & 5 & 4 & 3 \\
\hline & 163 & 1 & 2 & 5 & 12 & 11 & 9 & 7 & 13 & 8 & 10 & 4 & 6 & 3 \\
\hline & 177 & 1 & 2 & 3 & 12 & 11 & 8 & 7 & 13 & 6 & 10 & 5 & 9 & 4 \\
\hline \multirow{5}{*}{$\begin{array}{c}\text { Viscosidade } \\
\text { rotacional RTFOT }\end{array}$} & 135 & 1 & 4 & 10 & 12 & 13 & 3 & 6 & 11 & 8 & 5 & 7 & 2 & 9 \\
\hline & 143 & 1 & 2 & 10 & 12 & 13 & 4 & 7 & 11 & 9 & 5 & 8 & 3 & 6 \\
\hline & 150 & 1 & 2 & 10 & 12 & 13 & 4 & 8 & 11 & 9 & 6 & 7 & 3 & 5 \\
\hline & 163 & 1 & 2 & 10 & 12 & 13 & 6 & 9 & 11 & 8 & 7 & 5 & 3 & 4 \\
\hline & 177 & 1 & 2 & 6 & 12 & 13 & 8 & 10 & 11 & 7 & 9 & 5 & 3 & 4 \\
\hline \multirow{5}{*}{$\begin{array}{l}\text { Incremento de } \\
\text { viscosidade } \\
\text { rotacional após o } \\
\text { RTFOT }\end{array}$} & 135 & 5 & 11 & 10 & 9 & 12 & 1 & 7 & 2 & 6 & 3 & 8 & 4 & 13 \\
\hline & 143 & 4 & 12 & 11 & 10 & 13 & 3 & 8 & 6 & 5 & 2 & 7 & 1 & 9 \\
\hline & 150 & 4 & 12 & 11 & 10 & 13 & 3 & 7 & 6 & 5 & 2 & 8 & 1 & 9 \\
\hline & 163 & 4 & 12 & 10 & 11 & 13 & 3 & 7 & 5 & 6 & 2 & 8 & 1 & 9 \\
\hline & 177 & 6 & 12 & 10 & 11 & 13 & 3 & 8 & 5 & 4 & 2 & 7 & 1 & 9 \\
\hline
\end{tabular}


Tabela 89 - Ordenações dos ligantes asfálticos em todas as propriedades e parâmetros (continuação)

\begin{tabular}{|c|c|c|c|c|c|c|c|c|c|c|c|c|c|c|}
\hline \multirow[b]{2}{*}{$\begin{array}{l}\text { Propriedade ou } \\
\text { parâmetro }\end{array}$} & \multirow[b]{2}{*}{$\begin{array}{c}\text { Temperatura } \\
\left({ }^{\circ} \mathrm{C}\right)\end{array}$} & \multicolumn{13}{|c|}{ Ligantes asfálticos } \\
\hline & & $50 / 70$ & PPA & $\begin{array}{c}\text { Elvaloy } \\
\text { PPA }\end{array}$ & Borracha & $\begin{array}{c}\text { Borracha } \\
\text { PPA }\end{array}$ & SBS & $\begin{array}{l}\text { SBS } \\
\text { PPA }\end{array}$ & EVA & $\begin{array}{l}\text { EVA } \\
\text { PPA }\end{array}$ & PE & $\begin{array}{c}\text { PE } \\
\text { PPA }\end{array}$ & SBR & $\begin{array}{l}\text { SBR } \\
\text { PPA }\end{array}$ \\
\hline $\begin{array}{c}\text { Temperatura de } \\
\text { usinagem }\end{array}$ & - & 1 & 2 & 3 & 12 & 13 & 7 & 5 & 11 & 6 & 9 & 10 & 8 & 4 \\
\hline $\begin{array}{l}\text { Temperatura de } \\
\text { compactação }\end{array}$ & - & 1 & 2 & 4 & 13 & 11 & 9 & 7 & 12 & 8 & 10 & 5 & 6 & 3 \\
\hline \multirow{5}{*}{$\begin{array}{l}\text { Percentual de } \\
\text { recuperação virgem e } \\
\text { tempos de } 1 \text { e } 9 \mathrm{~s}- \\
100 \mathrm{~Pa}\end{array}$} & 52 & 13 & 7 & 1 & 5 & 4 & 6 & 8 & 2 & 3 & 12 & 11 & 10 & 9 \\
\hline & 58 & 13 & 8 & 1 & 5 & 4 & 7 & 10 & 2 & 3 & 12 & 11 & 6 & 9 \\
\hline & 64 & - & 8 & 1 & 5 & 4 & 7 & 10 & 2 & 3 & 12 & 11 & 6 & 9 \\
\hline & 70 & - & 8 & 1 & 5 & 3 & 7 & 11 & 4 & 2 & 12 & 10 & 6 & 9 \\
\hline & 76 & - & 8 & 1 & 4 & 3 & 7 & 12 & 5 & 2 & 11 & 10 & 6 & 9 \\
\hline \multirow{5}{*}{$\begin{array}{l}\text { Percentual de } \\
\text { recuperação virgem e } \\
\text { tempos de } 1 \text { e } 9 \mathrm{~s}- \\
3.200 \mathrm{~Pa}\end{array}$} & 52 & - & 5 & 1 & 10 & 6 & 4 & 7 & 2 & 3 & 12 & 9 & 11 & 8 \\
\hline & 58 & - & 6 & 1 & 11 & 9 & 4 & 7 & 2 & 3 & - & 10 & 8 & 5 \\
\hline & 64 & - & 9 & 1 & - & 7 & 4 & 8 & 2 & 3 & - & - & 6 & 5 \\
\hline & 70 & - & - & 1 & - & - & - & - & 2 & - & - & - & - & - \\
\hline & 76 & - & - & 1 & - & - & - & - & - & - & - & - & - & - \\
\hline \multirow{5}{*}{$\begin{array}{c}\text { Percentual de } \\
\text { recuperação RTFOT } \\
\text { e tempos de } 1 \text { e } 9 \mathrm{~s}- \\
100 \mathrm{~Pa}\end{array}$} & 52 & 13 & 5 & 1 & 4 & 7 & 10 & 9 & 2 & 3 & 12 & 8 & 11 & 6 \\
\hline & 58 & 13 & 6 & 1 & 4 & 7 & 11 & 10 & 2 & 3 & 12 & 8 & 9 & 5 \\
\hline & 64 & 13 & 6 & 1 & 4 & 7 & 9 & 11 & 2 & 3 & 12 & 10 & 8 & 5 \\
\hline & 70 & - & 6 & 1 & 3 & 7 & 10 & 11 & 5 & 2 & 12 & 9 & 8 & 4 \\
\hline & 76 & - & 6 & 1 & 3 & 5 & 9 & 11 & 7 & 2 & 12 & 10 & 8 & 4 \\
\hline
\end{tabular}


Tabela 89 - Ordenações dos ligantes asfálticos em todas as propriedades e parâmetros (continuação)

\begin{tabular}{|c|c|c|c|c|c|c|c|c|c|c|c|c|c|c|}
\hline \multirow[b]{2}{*}{$\begin{array}{l}\text { Propriedade ou } \\
\text { parâmetro }\end{array}$} & \multirow[b]{2}{*}{$\begin{array}{c}\text { Temperatura } \\
\left({ }^{\circ} \mathrm{C}\right)\end{array}$} & \multicolumn{13}{|c|}{ Ligantes asfálticos } \\
\hline & & $50 / 70$ & PPA & $\begin{array}{c}\text { Elvaloy } \\
\text { PPA }\end{array}$ & Borracha & $\begin{array}{c}\text { Borracha } \\
\text { PPA }\end{array}$ & SBS & $\begin{array}{l}\text { SBS } \\
\text { PPA }\end{array}$ & EVA & $\begin{array}{l}\text { EVA } \\
\text { PPA }\end{array}$ & PE & $\begin{array}{c}\text { PE } \\
\text { PPA }\end{array}$ & SBR & $\begin{array}{l}\text { SBR } \\
\text { PPA }\end{array}$ \\
\hline \multirow{5}{*}{$\begin{array}{c}\text { Percentual de } \\
\text { recuperação RTFOT } \\
\text { e tempos de } 1 \text { e } 9 \mathrm{~s} \\
-3.200 \mathrm{~Pa}\end{array}$} & 52 & 13 & 4 & 1 & 7 & 6 & 10 & 8 & 2 & 3 & 12 & 9 & 11 & 5 \\
\hline & 58 & 13 & 5 & 1 & 7 & 6 & 10 & 9 & 2 & 3 & 12 & 8 & 11 & 4 \\
\hline & 64 & - & 5 & 1 & 7 & 6 & 8 & 9 & 2 & 3 & 12 & 10 & 11 & 4 \\
\hline & 70 & - & 4 & 1 & 6 & 8 & 7 & 9 & 5 & 3 & - & 11 & 10 & 2 \\
\hline & 76 & - & 5 & 1 & 6 & - & 4 & - & - & 3 & - & - & - & 2 \\
\hline \multirow{5}{*}{$\begin{array}{l}\text { Compliância não- } \\
\text { recuperável virgem e } \\
\text { tempos de } 1 \text { e } 9 \mathrm{~s}- \\
100 \mathrm{~Pa}\end{array}$} & 52 & 13 & 6 & 3 & 10 & 8 & 5 & 7 & 1 & 2 & 11 & 4 & 12 & 9 \\
\hline & 58 & 13 & 6 & 3 & 10 & 7 & 4 & 8 & 1 & 2 & 11 & 5 & 12 & 9 \\
\hline & 64 & 13 & 8 & 2 & 10 & 6 & 4 & 9 & 1 & 3 & 12 & 5 & 11 & 7 \\
\hline & 70 & 13 & 9 & 3 & 10 & 5 & 4 & 8 & 2 & 1 & 12 & 6 & 11 & 7 \\
\hline & 76 & 13 & 10 & 2 & 6 & 4 & 5 & 9 & 3 & 1 & 12 & 8 & 11 & 7 \\
\hline \multirow{5}{*}{$\begin{array}{l}\text { Compliância não- } \\
\text { recuperável virgem e } \\
\text { tempos de } 1 \text { e } 9 \mathrm{~s}- \\
3.200 \mathrm{~Pa}\end{array}$} & 52 & 13 & 6 & 2 & 11 & 9 & 5 & 7 & 1 & 3 & 10 & 4 & 12 & 8 \\
\hline & 58 & 13 & 6 & 2 & 11 & 9 & 5 & 7 & 1 & 3 & 10 & 4 & 12 & 8 \\
\hline & 64 & 13 & 8 & 1 & 10 & 9 & 4 & 7 & 2 & 3 & 11 & 5 & 12 & 6 \\
\hline & 70 & 13 & 8 & 1 & 10 & 9 & 4 & 7 & 2 & 3 & 11 & 5 & 12 & 6 \\
\hline & 76 & 13 & 9 & 1 & 10 & 8 & 4 & 7 & 2 & 3 & 11 & 6 & 12 & 5 \\
\hline \multirow{5}{*}{$\begin{array}{l}\text { Compliância não- } \\
\text { recuperável RTFOT } \\
\text { e tempos de } 1 \text { e } 9 \mathrm{~s} \\
-100 \mathrm{~Pa}\end{array}$} & 52 & 13 & 3 & 4 & 7 & 8 & 10 & 9 & 1 & 2 & 11 & 6 & 12 & 5 \\
\hline & 58 & 13 & 4 & 3 & 6 & 7 & 10 & 9 & 1 & 2 & 11 & 8 & 12 & 5 \\
\hline & 64 & 13 & 5 & 3 & 6 & 7 & 10 & 9 & 2 & 1 & 11 & 8 & 12 & 4 \\
\hline & 70 & 13 & 5 & 2 & 6 & 7 & 10 & 9 & 4 & 1 & 12 & 8 & 11 & 3 \\
\hline & 76 & 13 & 4 & 2 & 6 & 7 & 10 & 8 & 5 & 1 & 12 & 9 & 11 & 3 \\
\hline
\end{tabular}


Tabela 89 - Ordenações dos ligantes asfálticos em todas as propriedades e parâmetros (continuação)

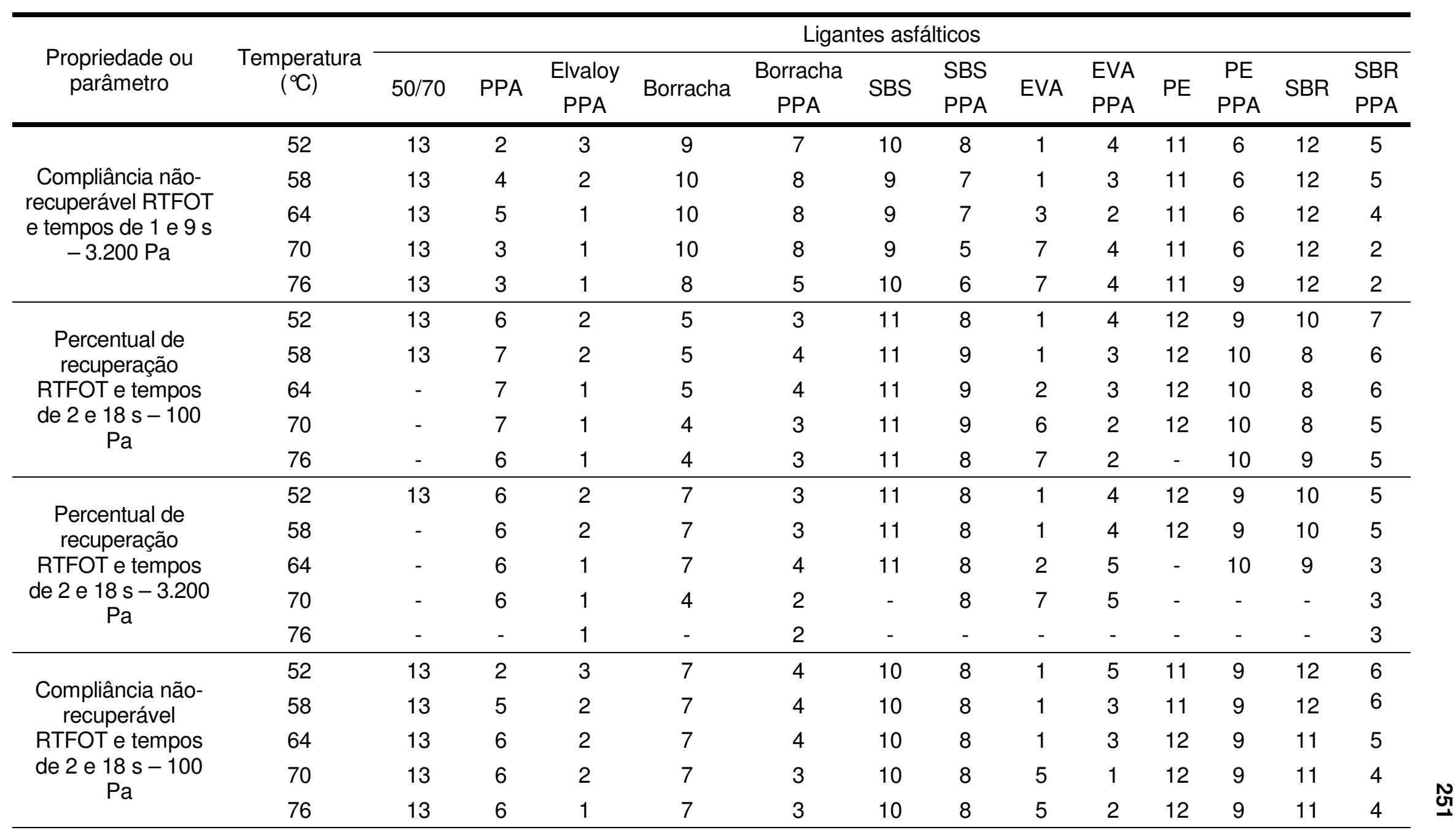


Tabela 89 - Ordenações dos ligantes asfálticos em todas as propriedades e parâmetros (continuação)

\begin{tabular}{|c|c|c|c|c|c|c|c|c|c|c|c|c|c|c|}
\hline \multirow[b]{2}{*}{$\begin{array}{l}\text { Propriedade ou } \\
\text { parâmetro }\end{array}$} & \multirow[b]{2}{*}{$\begin{array}{c}\text { Temperatura } \\
\left({ }^{\circ} \mathrm{C}\right)\end{array}$} & \multicolumn{13}{|c|}{ Ligantes asfálticos } \\
\hline & & $50 / 70$ & PPA & $\begin{array}{c}\text { Elvaloy } \\
\text { PPA }\end{array}$ & Borracha & $\begin{array}{c}\text { Borracha } \\
\text { PPA }\end{array}$ & SBS & $\begin{array}{l}\text { SBS } \\
\text { PPA }\end{array}$ & EVA & $\begin{array}{l}\text { EVA } \\
\text { PPA }\end{array}$ & PE & $\begin{array}{c}\text { PE } \\
\text { PPA }\end{array}$ & SBR & $\begin{array}{l}\text { SBR } \\
\text { PPA }\end{array}$ \\
\hline \multirow{5}{*}{$\begin{array}{l}\text { Compliância não- } \\
\text { recuperável RTFOT e } \\
\text { tempos de } 2 \text { e } 18 \mathrm{~s}- \\
3.200 \mathrm{~Pa}\end{array}$} & 52 & 13 & 2 & 3 & 9 & 4 & 10 & 7 & 1 & 5 & 11 & 8 & 12 & 6 \\
\hline & 58 & 13 & 3 & 2 & 9 & 5 & 10 & 7 & 1 & 6 & 11 & 8 & 12 & 4 \\
\hline & 64 & 13 & 4 & 1 & 9 & 5 & 10 & 7 & 2 & 6 & 11 & 8 & 12 & 3 \\
\hline & 70 & 13 & 4 & 1 & 7 & 2 & 10 & 5 & 9 & 6 & 11 & 8 & 12 & 3 \\
\hline & 76 & 13 & 4 & 1 & 6 & 2 & 10 & 5 & 8 & 7 & 11 & 9 & 12 & 3 \\
\hline \multirow{5}{*}{$\begin{array}{l}\text { Incremento do } \\
\text { percentual de } \\
\text { recuperação após o } \\
\text { RTFOT na tensão de } \\
100 \mathrm{~Pa}\end{array}$} & 52 & 13 & 10 & 1 & 8 & 4 & 3 & 7 & 2 & 5 & 11 & 9 & 6 & 12 \\
\hline & 58 & 13 & 11 & 1 & 7 & 5 & 4 & 8 & 2 & 6 & 10 & 9 & 3 & 12 \\
\hline & 64 & - & 11 & 1 & 7 & 5 & 6 & 9 & 2 & 4 & 8 & 10 & 3 & 12 \\
\hline & 70 & - & 11 & 1 & 7 & 3 & 6 & 9 & 4 & 5 & 8 & 10 & 2 & 12 \\
\hline & 76 & - & 10 & 1 & 4 & 2 & 6 & 12 & 5 & 3 & 8 & 9 & 7 & 11 \\
\hline \multirow{5}{*}{$\begin{array}{l}\text { Incremento do } \\
\text { percentual de } \\
\text { recuperação após o } \\
\text { RTFOT na tensão de } \\
\text { 3.200 Pa }\end{array}$} & 52 & - & 9 & 1 & 11 & 8 & 3 & 5 & 2 & 4 & 12 & 7 & 6 & 10 \\
\hline & 58 & - & 9 & 1 & 11 & 8 & 3 & 6 & 2 & 5 & - & 7 & 4 & 10 \\
\hline & 64 & - & 9 & 1 & - & 6 & 5 & 7 & 2 & 4 & - & - & 3 & 8 \\
\hline & 70 & - & - & 1 & - & - & - & - & 2 & - & - & - & - & - \\
\hline & 76 & - & - & 1 & - & - & - & - & - & - & - & - & - & - \\
\hline \multirow{5}{*}{$\begin{array}{c}\text { Redução de } \\
\text { compliância não- } \\
\text { recuperável após o } \\
\text { RTFOT na tensão de } \\
100 \mathrm{~Pa}\end{array}$} & 52 & 3 & 12 & 9 & 10 & 8 & 1 & 7 & 5 & 11 & 4 & 6 & 2 & 13 \\
\hline & 58 & 3 & 12 & 9 & 10 & 8 & 1 & 7 & 5 & 11 & 4 & 6 & 2 & 13 \\
\hline & 64 & 5 & 12 & 9 & 10 & 8 & 3 & 7 & 1 & 11 & 4 & 6 & 2 & 13 \\
\hline & 70 & 5 & 12 & 10 & 9 & 8 & 1 & 7 & 3 & 11 & 4 & 6 & 2 & 13 \\
\hline & 76 & 3 & 12 & 10 & 9 & 8 & 2 & 7 & 1 & 11 & 4 & 6 & 5 & 13 \\
\hline
\end{tabular}


Tabela 89 - Ordenações dos ligantes asfálticos em todas as propriedades e parâmetros (continuação)

\begin{tabular}{|c|c|c|c|c|c|c|c|c|c|c|c|c|c|c|}
\hline \multirow[b]{2}{*}{$\begin{array}{l}\text { Propriedade ou } \\
\text { parâmetro }\end{array}$} & \multirow[b]{2}{*}{$\begin{array}{c}\text { Temperatura } \\
\left({ }^{\circ} \mathrm{C}\right)\end{array}$} & \multicolumn{13}{|c|}{ Ligantes asfálticos } \\
\hline & & $50 / 70$ & PPA & $\begin{array}{c}\text { Elvaloy } \\
\text { PPA }\end{array}$ & Borracha & $\begin{array}{c}\text { Borracha } \\
\text { PPA }\end{array}$ & SBS & $\begin{array}{l}\text { SBS } \\
\text { PPA }\end{array}$ & EVA & $\begin{array}{l}\text { EVA } \\
\text { PPA } \\
\end{array}$ & PE & $\begin{array}{c}\text { PE } \\
\text { PPA } \\
\end{array}$ & SBR & $\begin{array}{l}\text { SBR } \\
\text { PPA } \\
\end{array}$ \\
\hline \multirow{3}{*}{$\begin{array}{c}\text { Redução de } \\
\text { compliância não- } \\
\text { recuperável após o } \\
\text { RTFOT na tensão de } \\
\text { 3.200 Pa }\end{array}$} & 58 & 4 & 11 & 8 & 10 & 9 & 1 & 6 & 7 & 13 & 2 & 5 & 3 & 12 \\
\hline & 64 & 4 & 11 & 10 & 9 & 8 & 1 & 7 & 5 & 12 & 3 & 6 & 2 & 13 \\
\hline & 70 & 4 & 11 & 13 & 9 & 8 & 3 & 7 & 1 & 10 & 5 & 6 & 2 & 12 \\
\hline \multirow{5}{*}{$\begin{array}{c}\text { Redução do } \\
\text { percentual de } \\
\text { recuperação após o } \\
\text { aumento nos tempos } \\
\text { de fluência e } \\
\text { recuperação a } 100 \mathrm{~Pa}\end{array}$} & 52 & 13 & 8 & 3 & 4 & 2 & 12 & 5 & 1 & 6 & 11 & 9 & 10 & 7 \\
\hline & 58 & 13 & 9 & 4 & 3 & 1 & 12 & 5 & 2 & 6 & 11 & 10 & 7 & 8 \\
\hline & 64 & - & 8 & 4 & 3 & 1 & 11 & 6 & 2 & 5 & 12 & 10 & 9 & 7 \\
\hline & 70 & - & 8 & 2 & 3 & 1 & 11 & 6 & 5 & 4 & 12 & 9 & 10 & 7 \\
\hline & 76 & - & 8 & 3 & 5 & 1 & 11 & 6 & 2 & 4 & - & 9 & 10 & 7 \\
\hline \multirow{2}{*}{$\begin{array}{c}\text { Redução do } \\
\text { percentual de } \\
\text { recuperação após o } \\
\text { aumento nos } \\
\text { tempos de fluência } \\
\text { e recuperação a } \\
3.200 \mathrm{~Pa} \\
\end{array}$} & 70 & - & 5 & 2 & 3 & 1 & - & 8 & 6 & 7 & - & - & - & 4 \\
\hline & 76 & - & - & 2 & - & 1 & - & - & - & - & - & - & - & 3 \\
\hline \multirow{5}{*}{$\begin{array}{c}\text { Aumento de } \\
\text { compliância não- } \\
\text { recuperável após o } \\
\text { aumento nos tempos } \\
\text { de fluência e } \\
\text { recuperação a } 100 \mathrm{~Pa}\end{array}$} & 52 & 11 & 5 & 6 & 4 & 2 & 13 & 3 & 1 & 9 & 10 & 8 & 12 & 7 \\
\hline & 58 & 10 & 7 & 5 & 4 & 2 & 13 & 3 & 1 & 9 & 12 & 8 & 11 & 6 \\
\hline & 64 & 10 & 6 & 5 & 4 & 1 & 13 & 3 & 2 & 8 & 12 & 9 & 11 & 7 \\
\hline & 70 & 9 & 6 & 4 & 3 & 1 & 12 & 2 & 5 & 10 & 13 & 8 & 11 & 7 \\
\hline & 76 & 9 & 6 & 4 & 5 & 1 & 12 & 2 & 3 & 11 & 13 & 7 & 10 & 8 \\
\hline
\end{tabular}


Tabela 89 - Ordenações dos ligantes asfálticos em todas as propriedades e parâmetros (conclusão)

\begin{tabular}{|c|c|c|c|c|c|c|c|c|c|c|c|c|c|c|}
\hline \multirow[b]{2}{*}{$\begin{array}{l}\text { Propriedade ou } \\
\text { parâmetro }\end{array}$} & \multirow[b]{2}{*}{$\begin{array}{c}\text { Temperatura } \\
\left({ }^{\circ} \mathrm{C}\right)\end{array}$} & \multicolumn{13}{|c|}{ Ligantes asfálticos } \\
\hline & & $50 / 70$ & PPA & $\begin{array}{c}\text { Elvaloy } \\
\text { PPA }\end{array}$ & Borracha & $\begin{array}{c}\text { Borracha } \\
\text { PPA }\end{array}$ & SBS & $\begin{array}{l}\text { SBS } \\
\text { PPA }\end{array}$ & EVA & $\begin{array}{l}\text { EVA } \\
\text { PPA }\end{array}$ & $\mathrm{PE}$ & $\begin{array}{c}\text { PE } \\
\text { PPA }\end{array}$ & SBR & $\begin{array}{l}\text { SBR } \\
\text { PPA }\end{array}$ \\
\hline \multirow{5}{*}{$\begin{array}{c}\text { Aumento de } \\
\text { compliância não- } \\
\text { recuperável após o } \\
\text { aumento nos tempos } \\
\text { de fluência e } \\
\text { recuperação a } 3.200 \\
\mathrm{~Pa} \\
\end{array}$} & 52 & 9 & 6 & 5 & 4 & 2 & 12 & 3 & 1 & 13 & 10 & 8 & 11 & 7 \\
\hline & 58 & 8 & 6 & 4 & 5 & 2 & 11 & 3 & 1 & 13 & 10 & 9 & 12 & 7 \\
\hline & 64 & 6 & 7 & 4 & 5 & 1 & 12 & 3 & 2 & 13 & 10 & 8 & 11 & 9 \\
\hline & 70 & 5 & 7 & 3 & 4 & 1 & 11 & 2 & 9 & 13 & 12 & 6 & 10 & 8 \\
\hline & 76 & 7 & 8 & 4 & 3 & 1 & 11 & 2 & 5 & 13 & 12 & 6 & 10 & 9 \\
\hline \multirow{5}{*}{$\begin{array}{l}\text { Sensibilidade ao nível } \\
\text { de tensão na } \\
\text { condição virgem e } \\
\text { nos tempos de } 1 \text { e } 9 \mathrm{~s}\end{array}$} & 52 & 4 & 5 & 1 & 12 & 13 & 7 & 3 & 9 & 11 & 8 & 6 & 10 & 2 \\
\hline & 58 & 2 & 7 & 1 & 10 & 12 & 8 & 4 & 11 & 13 & 5 & 3 & 9 & 6 \\
\hline & 64 & 2 & 8 & 1 & 10 & 11 & 6 & 3 & 12 & 13 & 5 & 4 & 9 & 7 \\
\hline & 70 & 1 & 8 & 2 & 10 & 11 & 7 & 3 & 12 & 13 & 5 & 4 & 9 & 6 \\
\hline & 76 & 1 & 9 & 3 & 10 & 12 & 7 & 2 & 11 & 13 & 5 & 4 & 8 & 6 \\
\hline \multirow{5}{*}{$\begin{array}{c}\text { Sensibilidade ao } \\
\text { nível de tensão na } \\
\text { condição } \\
\text { envelhecida e nos } \\
\text { tempos de } 1 \text { e } 9 \mathrm{~s}\end{array}$} & 52 & 7 & 1 & 2 & 13 & 12 & 5 & 10 & 9 & 4 & 11 & 6 & 8 & 3 \\
\hline & 58 & 2 & 4 & 1 & 13 & 12 & 7 & 3 & 11 & 9 & 8 & 6 & 10 & 5 \\
\hline & 64 & 2 & 6 & 1 & 12 & 10 & 5 & 3 & 11 & 13 & 7 & 4 & 9 & 8 \\
\hline & 70 & 2 & 7 & 1 & 11 & 10 & 4 & 3 & 12 & 13 & 5 & 6 & 8 & 9 \\
\hline & 76 & 2 & 8 & 1 & 11 & 10 & 5 & 3 & 12 & 13 & 4 & 6 & 7 & 9 \\
\hline \multirow{5}{*}{$\begin{array}{l}\text { Sensibilidade ao } \\
\text { nível de tensão na } \\
\text { condição } \\
\text { envelhecida e nos } \\
\text { tempos de } 2 \text { e } 18 \mathrm{~s}\end{array}$} & 52 & 6 & 3 & 1 & 12 & 11 & 4 & 5 & 13 & 10 & 8 & 7 & 9 & 2 \\
\hline & 58 & 2 & 5 & 1 & 12 & 11 & 3 & 4 & 9 & 13 & 7 & 6 & 10 & 8 \\
\hline & 64 & 2 & 7 & 1 & 11 & 10 & 3 & 5 & 12 & 13 & 4 & 6 & 9 & 8 \\
\hline & 70 & 2 & 7 & 1 & 10 & 11 & 3 & 5 & 12 & 13 & 4 & 6 & 8 & 9 \\
\hline & 76 & 2 & 8 & 1 & 10 & 11 & 3 & 5 & 12 & 13 & 4 & 6 & 7 & 9 \\
\hline
\end{tabular}


As médias finais foram calculadas pela média aritmética simples de todas as ordenações recebidas pelos ligantes asfálticos, estando reproduzidas na Figura 90. O $\mathrm{CAP}+$ Elvaloy+PPA $(3,4)$ e o CAP+EVA $(4,9)$ possuem as menores médias finais e, portanto, os melhores resultados em um contexto geral. O CAP+PE $(9,0)$ e o CAP 50/70 $(8,1)$ possuem as maiores médias finais e, portanto, os piores resultados em um contexto geral. Chama a atenção a diferença significativa entre o resultado do CAP+Elvaloy+PPA e os resultados dos demais ligantes asfálticos, o que indica que a formulação com Elvaloy+PPA possui desempenho muito bom em diversas propriedades e parâmetros analisados neste estudo. O CAP+EVA+PPA, o CAP+PPA, o CAP+borracha+PPA, o CAP+SBS+PPA e o CAP+SBR+PPA possuem resultados muito próximos entre si (entre 6,2 e 6,9), o que indica desempenhos parecidos para estes materiais segundo as propriedades e parâmetros avaliados.

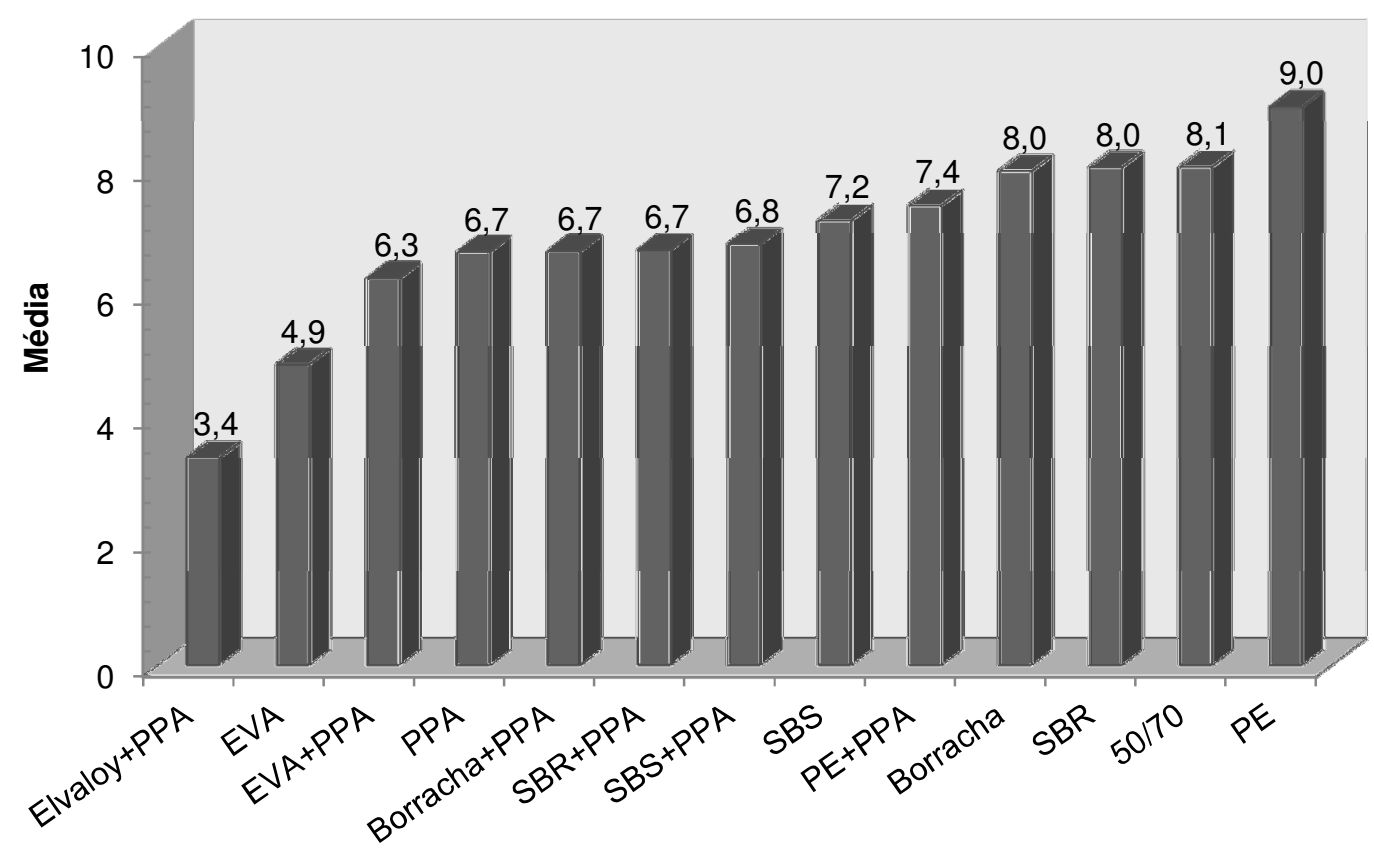

Figura 90 - Posição dos ligantes asfálticos segundo os critérios contemplados neste estudo

Além das avaliações das médias finais dos ligantes asfálticos em todas as propriedades e parâmetros considerados, foram analisadas também as alterações das ordenações médias dos materiais em cada propriedade do MSCR (percentual de recuperação e compliância não-recuperável) e na diferença percentual $J_{\text {rr,diff }}$ após o envelhecimento a curto prazo. Estas análises permitem observar quais CAPs apresentam, em termos classificatórios, maiores ganhos (redução da ordenação média) e perdas (aumento da ordenação média) em cada propriedade e parâmetro ou, em outras palavras, quais CAPs sofrem as maiores e menores alterações relativas de $R, J_{n r}$ e $J_{n r \text {, diff }}$ após o envelhecimento na estufa de filme fino rotativo. 
A Figura 91 mostra as ordenações médias dos ligantes asfálticos nas cinco temperaturas de realização do $\operatorname{MSCR}\left(52,58,64,70\right.$ e $\left.76^{\circ} \mathrm{C}\right)$ e nos dois níveis de tensão, considerando o percentual de recuperação nos tempos de 1 e $9 \mathrm{~s}$ e as condições virgem e envelhecida a curto prazo. O CAP 50/70, o CAP+Elvaloy+PPA, o CAP+EVA+PPA e o CAP+PE praticamente não sofrem variações significativas de suas ordenações médias após o RTFOT, de modo que as alterações no percentual de recuperação não são suficientemente elevadas para mudar a classificação destes materiais. O CAP+PE+PPA, o CAP+PPA, o CAP+borracha e o $C A P+S B R+P P A$ sofrem reduções de suas ordenações médias, especialmente no caso do $\mathrm{CAP}+\mathrm{SBR}+\mathrm{PPA}$ e do CAP+PPA, o que indica que o envelhecimento a curto prazo proporciona alterações suficientemente elevadas de $\mathrm{R}$ para permitir uma melhor classificação destes materiais na condição envelhecida. O CAP+SBS+PPA, o CAP+SBR, o CAP+SBS, o CAP+borracha+PPA e o CAP+EVA sofrem aumentos de suas ordenações médias, especialmente no caso do $C A P+S B R$ e do CAP+SBS, o que indica que o RTFOT não proporciona alterações suficientemente elevadas de $\mathrm{R}$ para permitir a manutenção da classificação destes materiais após o envelhecimento. Dentre todos os ligantes asfálticos analisados, pode-se dizer que o CAP+SBR+PPA apresenta os maiores benefícios com o envelhecimento a curto prazo por conta da maior redução da ordenação média deste material. Em outro extremo, o CAP+SBS apresenta os maiores prejuízos com o envelhecimento por conta do maior incremento da ordenação média deste ligante asfáltico.

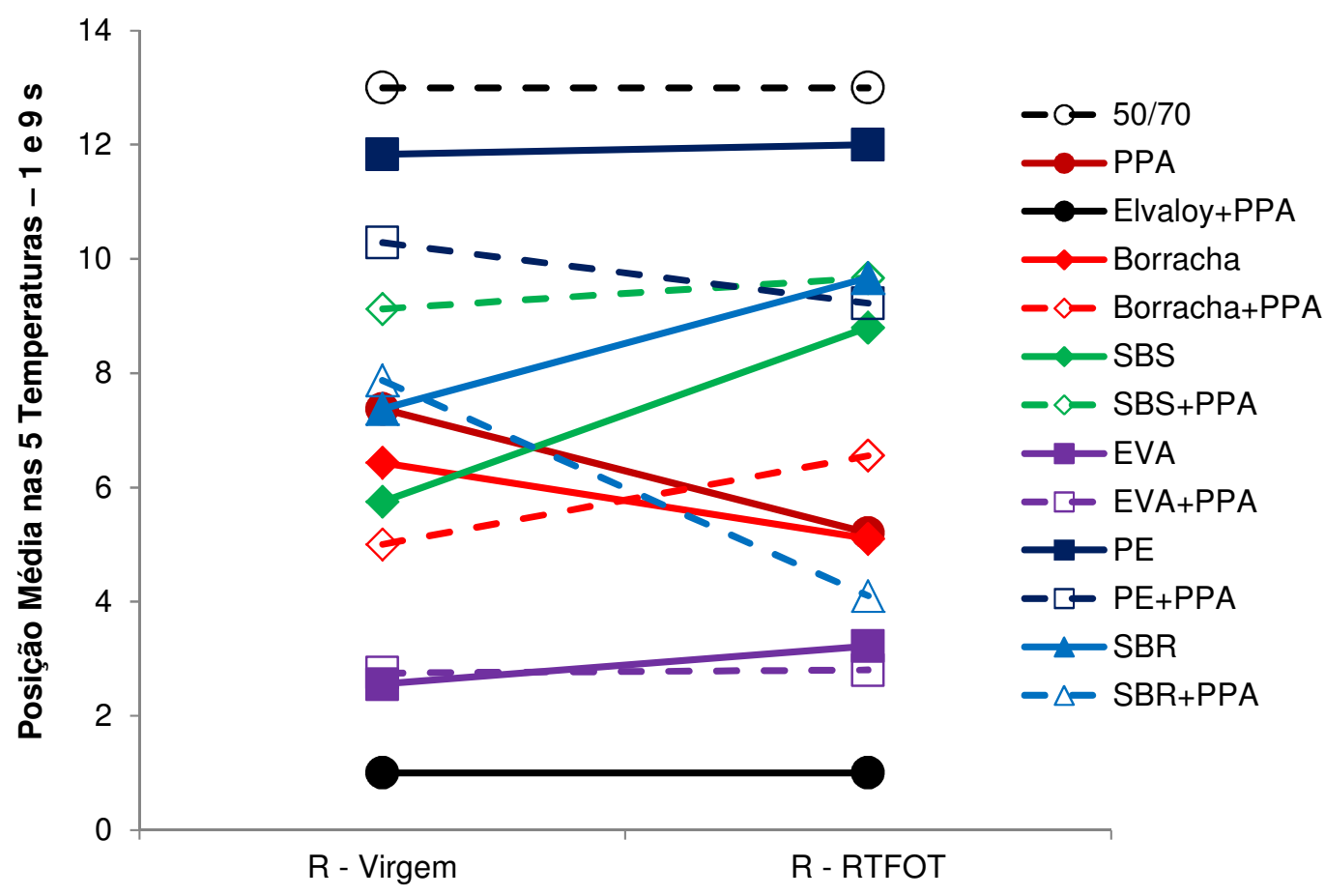

Figura 91 - Posições médias dos ligantes asfálticos virgens e envelhecidos a curto prazo com base nos resultados do percentual de recuperação $(R)$ a 100 e a $3.200 \mathrm{~Pa}$ 
A Figura 92 mostra as ordenações médias dos ligantes asfálticos nas cinco temperaturas do MSCR a 100 e a $3.200 \mathrm{~Pa}$, considerando a compliância não-recuperável nos tempos de 1 e $9 \mathrm{~s}$ e as condições virgem e envelhecida a curto prazo. O CAP 50/70 e as formulações com SBR, PE, SBS+PPA, borracha+PPA, EVA+PPA e Elvaloy+PPA praticamente não sofrem variações significativas de suas ordenações médias após o RTFOT, de modo que as alterações na compliância não-recuperável não são suficientemente elevadas para mudar a classificação destes materiais. O CAP+borracha, o CAP+PPA e o CAP+SBR+PPA sofreram reduções substanciais de suas ordenações médias, especialmente no caso das formulações com PPA e com SBR+PPA, o que indica que o envelhecimento a curto prazo proporciona alterações elevadas o suficiente na compliância não-recuperável dos ligantes asfálticos para permitir uma classificação melhor destes materiais na condição envelhecida. O CAP+SBS, o $\mathrm{CAP}+\mathrm{PE}+\mathrm{PPA}$ e o $\mathrm{CAP}+\mathrm{EVA}$ sofrem aumentos de suas ordenações médias, especialmente no caso da formulação com SBS, o que indica que o envelhecimento não acarreta alterações significativas da compliância não-recuperável a ponto de permitir a manutenção da ordenação destes ligantes asfálticos após o RTFOT. Dentre todos os ligantes asfálticos analisados, podese dizer que o CAP+SBR+PPA e o CAP+PPA apresentam os maiores benefícios com o envelhecimento a curto prazo por conta das maiores reduções das ordenações médias destes materiais. Por outro lado, o CAP+SBS apresenta os maiores prejuízos com o envelhecimento devido ao maior incremento da ordenação média deste ligante asfáltico.

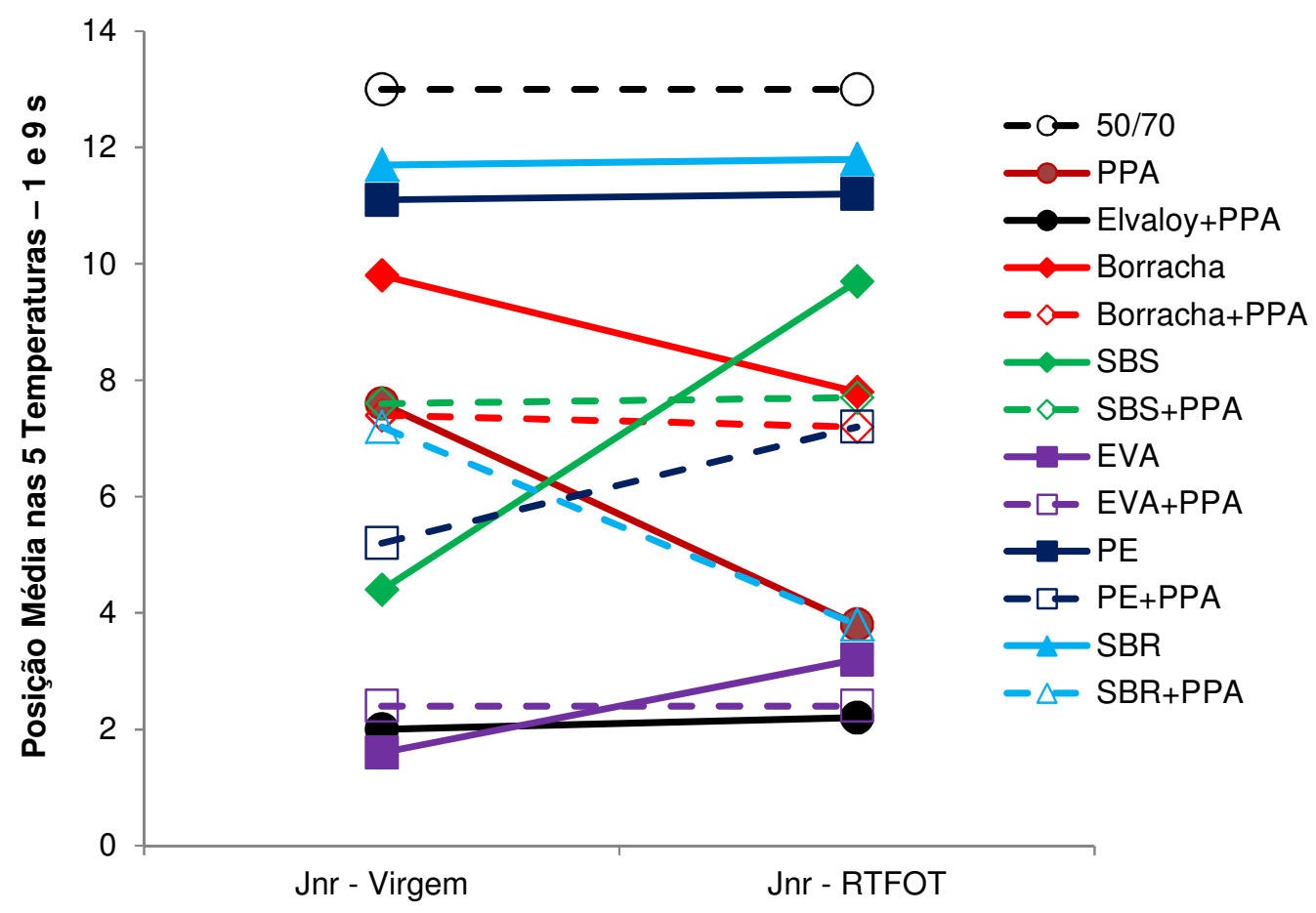

Figura 92 - Posições médias dos ligantes asfálticos virgens e envelhecidos a curto prazo com base nos resultados da compliância não-recuperável $\left(J_{n r}\right)$ a 100 e a $3.200 \mathrm{~Pa}$ 
A Figura 93 apresenta as ordenações médias dos ligantes asfálticos em todas as temperaturas do ensaio MSCR a 100 e a $3.200 \mathrm{~Pa}$, considerando as diferenças percentuais

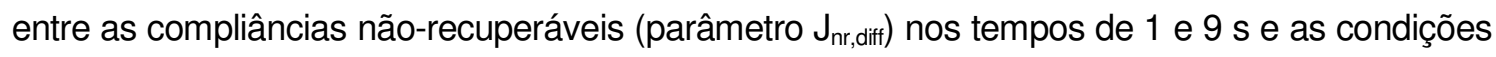
virgem e envelhecida a curto prazo. O CAP+borracha+PPA, o CAP+EVA, o CAP+SBR e o $\mathrm{CAP}+$ Elvaloy+PPA praticamente não sofrem variações significativas de suas ordenações médias após o RTFOT, o que indica que as alterações no parâmetro $J_{\text {nr,diff }}$ não são suficientemente elevadas para mudar a classificação destes materiais. O CAP+EVA+PPA, o $\mathrm{CAP}+\mathrm{PPA}$ e o $\mathrm{CAP}+\mathrm{SBS}$ sofrem reduções de suas ordenações médias, especialmente no caso do CAP+PPA, o que indica que o envelhecimento a curto prazo proporciona alterações elevadas o suficiente no parâmetro $J_{n r, d i f f}$ para permitir uma classificação melhor destes materiais na condição envelhecida. O CAP+borracha, o CAP+PE, o CAP+SBR+PPA, o CAP+PE+PPA, o $\mathrm{CAP}+\mathrm{SBS}+\mathrm{PPA}$ e o CAP puro sofrem aumentos de suas ordenações médias, o que indica que o envelhecimento a curto prazo não proporciona alterações significativas de $J_{n r, d i f f}$ a ponto de permitir a manutenção da ordenação destes materiais após o envelhecimento a curto prazo. Dentre todos os ligantes asfálticos analisados, pode-se dizer que o CAP+PPA e o CAP+EVA+PPA apresentam os maiores benefícios com o envelhecimento a curto prazo por conta das maiores reduções de suas ordenações médias. Por outro lado, o CAP+borracha apresenta os maiores prejuízos com o envelhecimento devido ao maior incremento da ordenação média deste ligante asfáltico.

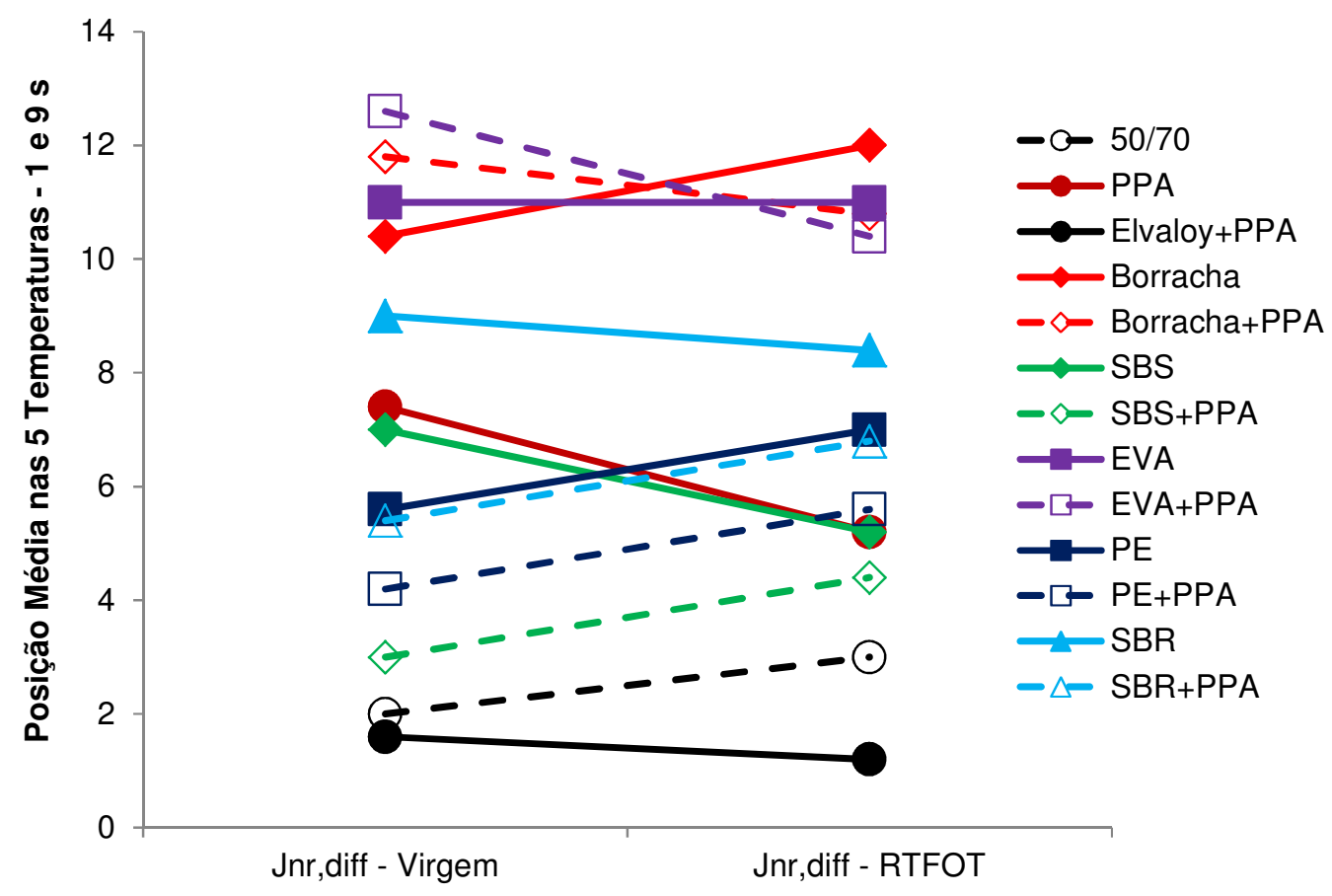

Figura 93 - Posições médias dos ligantes asfálticos virgens e envelhecidos a curto prazo com base nos resultados da diferença percentual entre compliâncias $\left(J_{n r, \text { diff }}\right)$ a 100 e a $3.200 \mathrm{~Pa}$ 
Em uma avaliação sintetizada dos resultados apresentados nas Figuras 91 a 93, referentes às variações das ordenações médias dos ligantes asfálticos em cada propriedade e parâmetro antes e após o RTFOT, é possível observar que o CAP+PPA sofre reduções nas ordenações médias de todas as propriedades e parâmetros considerados, sendo o ligante asfáltico mais beneficiado por conta do envelhecimento na estufa de filme fino rotativo. $O$ CAP+Elvaloy+PPA praticamente não sofre alterações significativas de suas ordenações médias em todas as propriedades e parâmetros considerados, o que indica que o envelhecimento não proporciona alterações suficientemente elevadas de $R, J_{n r}$ e $J_{n r \text {,diff }}$ para mudar a classificação deste material em relação aos demais. O CAP+SBS e o CAP+EVA sofrem aumentos das suas ordenações médias de $\mathrm{R}$ e $\mathrm{J}_{\mathrm{nr}}$ após o envelhecimento a curto prazo e, especialmente no caso do $C A P+S B S$, de modo que este material pode ser considerado como o mais prejudicado por conta do envelhecimento. No caso do CAP 50/70, do CAP+EVA+PPA e do CAP+PE, as ordenações de $\mathrm{R}$ e $\mathrm{J}_{\mathrm{nr}}$ destes materiais praticamente não sofrem alterações significativas com o RTFOT, o contrário sendo observado nas ordenações de $\mathrm{J}_{\text {nr,diff. }}$ As formulações com borracha+PPA e SBR possuem suas ordenações médias de $J_{n r}$ e $J_{n r, \text { dift }}$ praticamente inalteradas com o envelhecimento a curto prazo, sendo que as formulações com borracha, SBS+PPA, PE+PPA e SBR+PPA sofrem aumentos de suas ordenações médias de $J_{n r, \text { diff }}$.

A Figura 94 apresenta os percentuais de recuperação de todos os ligantes asfálticos, considerando o nível de tensão de $100 \mathrm{~Pa}$, os tempos de fluência e recuperação de 1 e $9 \mathrm{~s}$ e a condição virgem destes materiais. As formulações com EVA+PPA, borracha+PPA, borracha, SBS, PPA, SBR+PPA, SBS+PPA, PE+PPA, e PE possuem decréscimos aproximadamente lineares de $R$ com o aumento da temperatura, de modo que as sensibilidades destes ligantes asfálticos à temperatura podem ser consideradas parecidas. O CAP+Elvaloy+PPA possui recuperações superiores às dos demais ligantes asfálticos em qualquer temperatura, especialmente a 70 e a $76^{\circ} \mathrm{C}$. Os resultados do $\mathrm{CAP}+\mathrm{SBS}+\mathrm{PPA}$ e do $\mathrm{CAP}+\mathrm{PE}+\mathrm{PPA}$ são próximos entre si ao longo de todo o espectro de temperaturas e, da mesma maneira, o CAP+SBS e o CAP+PPA apresentam recuperações parecidas em todas as temperaturas. São observados percentuais de recuperação praticamente iguais nos seguintes conjuntos de ligantes asfálticos: (1) o conjunto formado pelo $\mathrm{CAP}+\mathrm{SBS}$, pelo $\mathrm{CAP}+\mathrm{PPA}$ e pelo $\mathrm{CAP}+\mathrm{SBR}+\mathrm{PPA}$ na temperatura de $64^{\circ} \mathrm{C}$; (2) o conjunto formado pelo $\mathrm{CAP}+\mathrm{SBS}+\mathrm{PPA}$ e pelo $\mathrm{CAP}+\mathrm{PE}+\mathrm{PPA}$ nas temperaturas de $64 \mathrm{e}$ $70^{\circ} \mathrm{C}$; (3) o conjunto formado pelo $\mathrm{CAP}+$ borracha, pelo $\mathrm{CAP}+$ borracha+PPA e pelo $\mathrm{CAP}+\mathrm{EVA}$ na temperatura de $70^{\circ} \mathrm{C}$; (4) o conjunto formado pelo $\mathrm{CAP}+$ borracha e pelo $\mathrm{CAP}+$ borracha+PPA na temperatura de $76^{\circ} \mathrm{C}$; e (5) o conjunto formado pelo CAP+SBR, pelo $\mathrm{CAP}+\mathrm{PE}+\mathrm{PPA}$, pelo $\mathrm{CAP}+\mathrm{SBR}+\mathrm{PPA}$ e pelo $\mathrm{CAP}+\mathrm{SBS}+\mathrm{PPA}$ na temperatura de $52^{\circ} \mathrm{C}$. A maioria dos ligantes asfálticos apresenta recuperações pequenas na temperatura de $76^{\circ} \mathrm{C}$, 


\section{0}

sendo eles o CAP 50/70, O CAP+PPA, O CAP+SBS, o CAP+SBS+PPA, O CAP+EVA, o $\mathrm{CAP}+\mathrm{PE}$, o $\mathrm{CAP}+\mathrm{PE}+\mathrm{PPA}$, o $\mathrm{CAP}+\mathrm{SBR}$ e o $\mathrm{CAP}+\mathrm{SBR}+\mathrm{PPA}$.

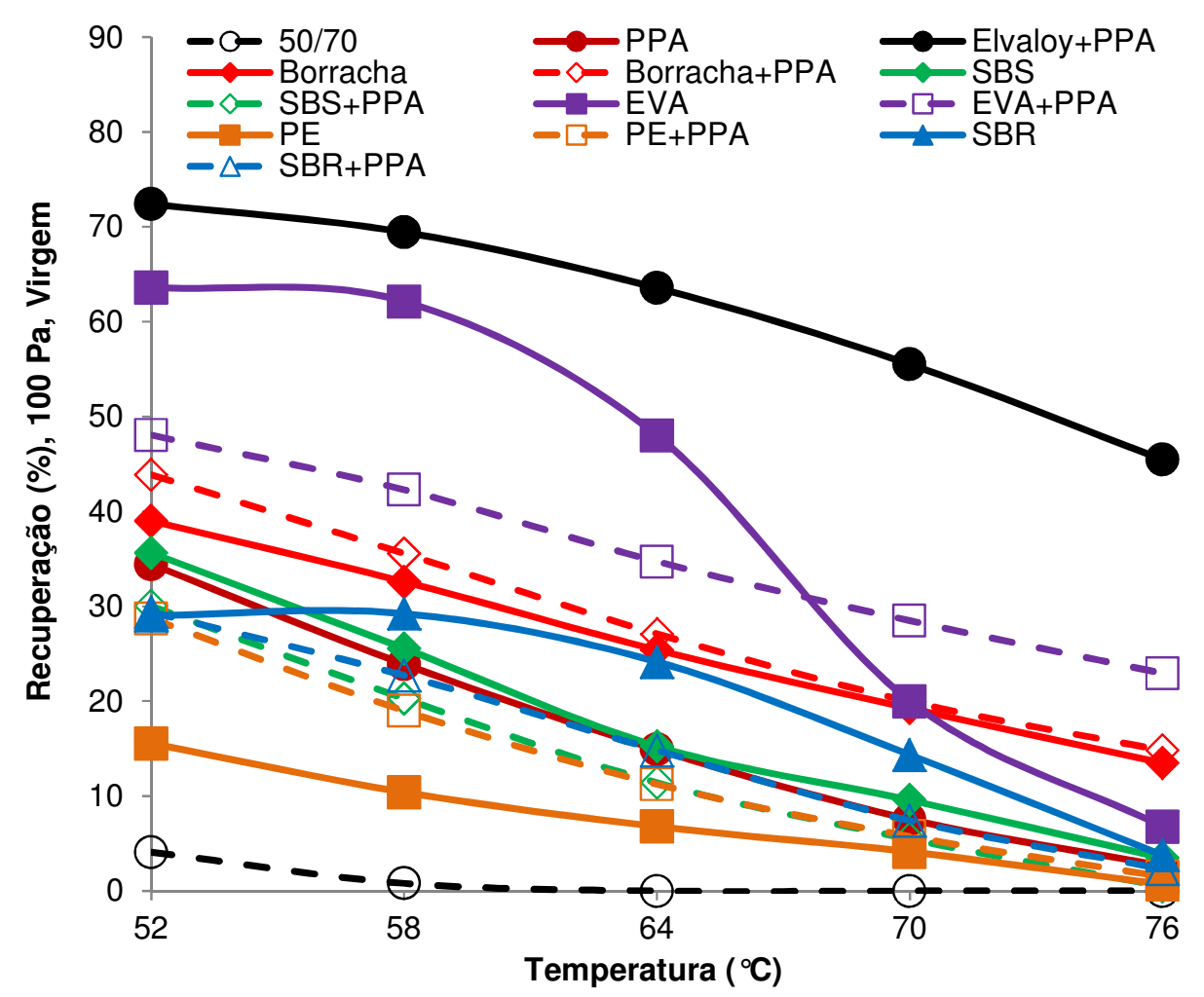

Figura 94 - Percentuais de recuperação $(R)$ dos ligantes asfálticos a 100 Pa na condição virgem e nos tempos de 1 e $9 \mathrm{~s}$

Ainda sobre os gráficos da Figura 94, é possível observar que os decréscimos do percentual de recuperação são significativos para o CAP+EVA nas temperaturas de 58, 64 e $70^{\circ} \mathrm{C}$, de modo que este material pode ser considerado como o mais sensível à temperatura. As variações do percentual de recuperação são pequenas nas temperaturas de 52,58 e $64^{\circ} \mathrm{C}$ para o $\mathrm{CAP}+\mathrm{SBR}$, de modo que este ligante asfáltico pode ser considerado como o menos sensível à temperatura nas condições citadas. O CAP 50/70 apresenta valores nulos para o percentual de recuperação nas temperaturas de 64,70 e $76^{\circ} \mathrm{C}$, sendo muito pequenos nas demais temperaturas. As recuperações do CAP+Elvaloy+PPA diminuem em uma taxa maior à medida que a temperatura aumenta, o que, em termos gráficos, se reflete no aumento gradativo da inclinação do gráfico deste material.

A Figura 95 apresenta os gráficos do percentual de recuperação para todos os ligantes asfálticos, considerando o nível de tensão de $3.200 \mathrm{~Pa}$, os tempos de fluência e recuperação de 1 e 9 s e a condição virgem destes materiais. À exceção do CAP+Elvaloy+PPA, todos os demais ligantes asfálticos (incluindo o CAP 50/70) possuem 
recuperações nulas ou muito pequenas nas temperaturas de 70 e $76{ }^{\circ} \mathrm{C}$. A maioria dos ligantes asfálticos apresenta percentuais de recuperação iguais ou inferiores a $30 \%$ nas temperaturas de 52, 58 e $64^{\circ} \mathrm{C}$, sendo eles o CAP 50/70, o CAP+PPA, o CAP+borracha, o $\mathrm{CAP}+$ borracha+PPA, O CAP+SBS, O CAP+SBS+PPA, O CAP+PE, O CAP+PE+PPA, 0 $\mathrm{CAP}+\mathrm{SBR}$ e o $\mathrm{CAP}+\mathrm{SBR}+\mathrm{PPA}$. Os percentuais de recuperação do CAP+EVA apresentam decréscimos acentuados nas temperaturas de até $70^{\circ} \mathrm{C}$, desde valores entre 40 e $60 \%$ nas temperaturas de 52 e $58^{\circ} \mathrm{C}$ até valores próximos de zero na temperatura de $70^{\circ} \mathrm{C}$. Situação diferente ocorre com o CAP+EVA+PPA, para 0 qual as recuperações diminuem gradativamente nas temperaturas de até $70^{\circ} \mathrm{C}$. No caso do CAP+Elvaloy+PPA, as recuperações deste material diminuem em uma taxa maior à medida que a temperatura aumenta, o que, em termos gráficos, se reflete no aumento gradativo da inclinação do gráfico.

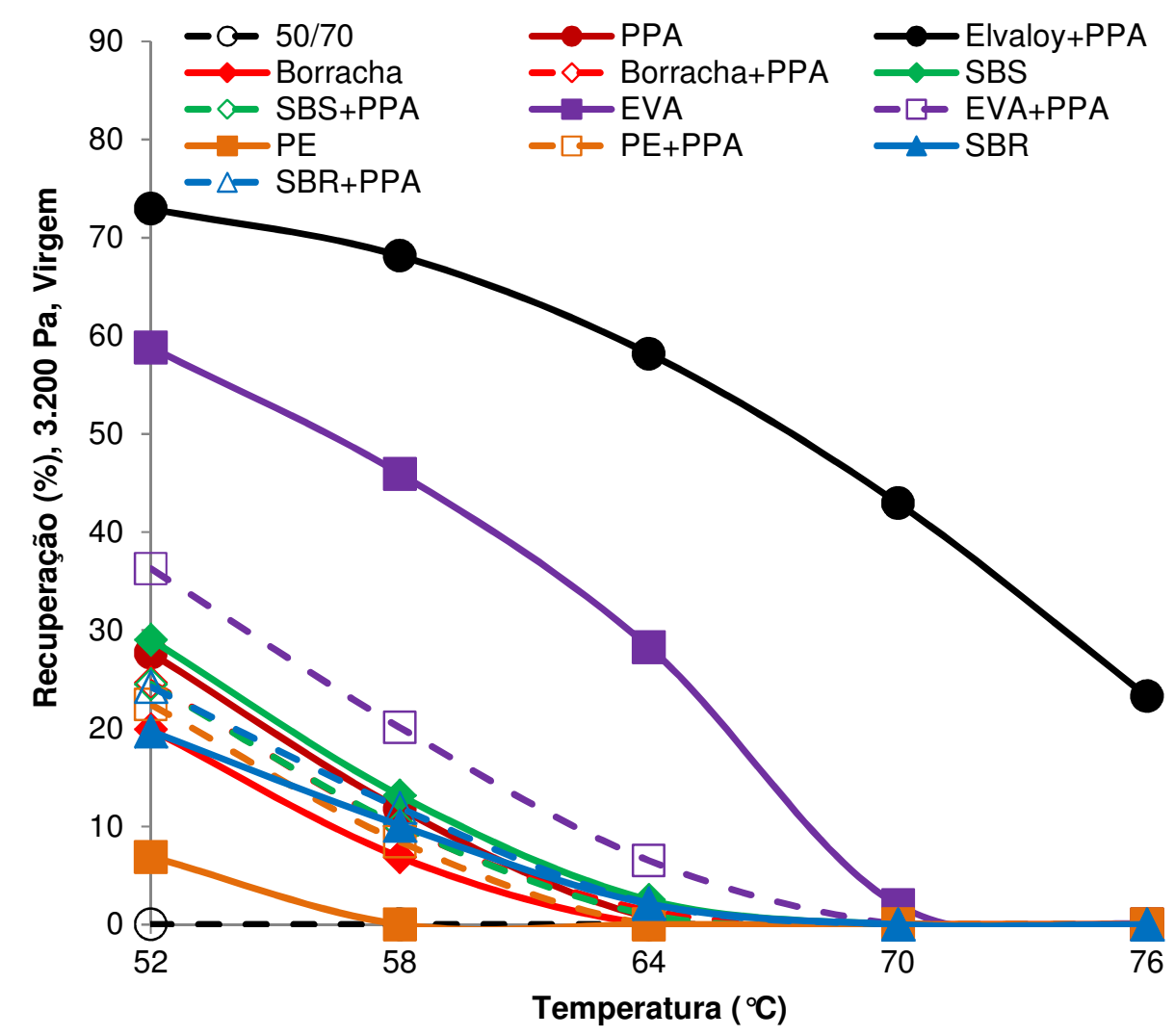

Figura 95 - Percentuais de recuperação $(R)$ dos ligantes asfálticos a 3.200 Pa na condição virgem e nos tempos de 1 e $9 \mathrm{~s}$

A Figura 96 apresenta os gráficos de compliância não-recuperável para todos os ligantes asfálticos modificados, considerando o nível de tensão de $100 \mathrm{~Pa}$, os tempos de fluência e recuperação de 1 e $9 \mathrm{~s}$ e a condição virgem destes materiais. A distinção entre os modificadores é relativamente difícil de ser realizada nas temperaturas de 52 e $58^{\circ} \mathrm{C}$, uma vez que os valores de $J_{n r}$ são parecidos para todos os materiais. O CAP+PE e o CAP+SBR 


\section{2}

possuem compliâncias não-recuperáveis muito próximas entre si ao longo de todo o espectro de temperaturas, de modo que, à luz destes resultados, as duas formulações podem ser consideradas equivalentes. Valores próximos de $J_{\mathrm{nr}}$ em todas as temperaturas também são encontrados nos seguintes grupos de ligantes asfálticos: (1) o grupo formado pelo $\mathrm{CAP}+\mathrm{PPA}$ e pelo $\mathrm{CAP}+\mathrm{SBS}+\mathrm{PPA}$; (2) o grupo formado pelo CAP+Elvaloy+PPA e pelo CAP+EVA+PPA; (3) o grupo formado pelo CAP+SBR+PPA e pelo CAP+borracha; e (4) o grupo formado pelo $\mathrm{CAP}+\mathrm{SBS}$ e pelo $\mathrm{CAP}+$ borracha+PPA. As formulações com Elvaloy+PPA, EVA e EVA+PPA possuem compliâncias não-recuperáveis menores do que os demais ligantes asfálticos modificados, especialmente nas temperaturas de 64,70 e $76{ }^{\circ} \mathrm{C}$, o que indica a menor suscetibilidade destes materiais à deformação permanente. $\mathrm{O}$ crescimento de $J_{n r}$ é maior para o CAP+EVA do que para o CAP+Elvaloy+PPA e o $\mathrm{CAP}+\mathrm{EVA}+\mathrm{PPA}$ nas temperaturas de 64,70 e $76^{\circ} \mathrm{C}$, o que se reflete no cruzamento dos gráficos destes materiais na temperatura de $70^{\circ} \mathrm{C}$.

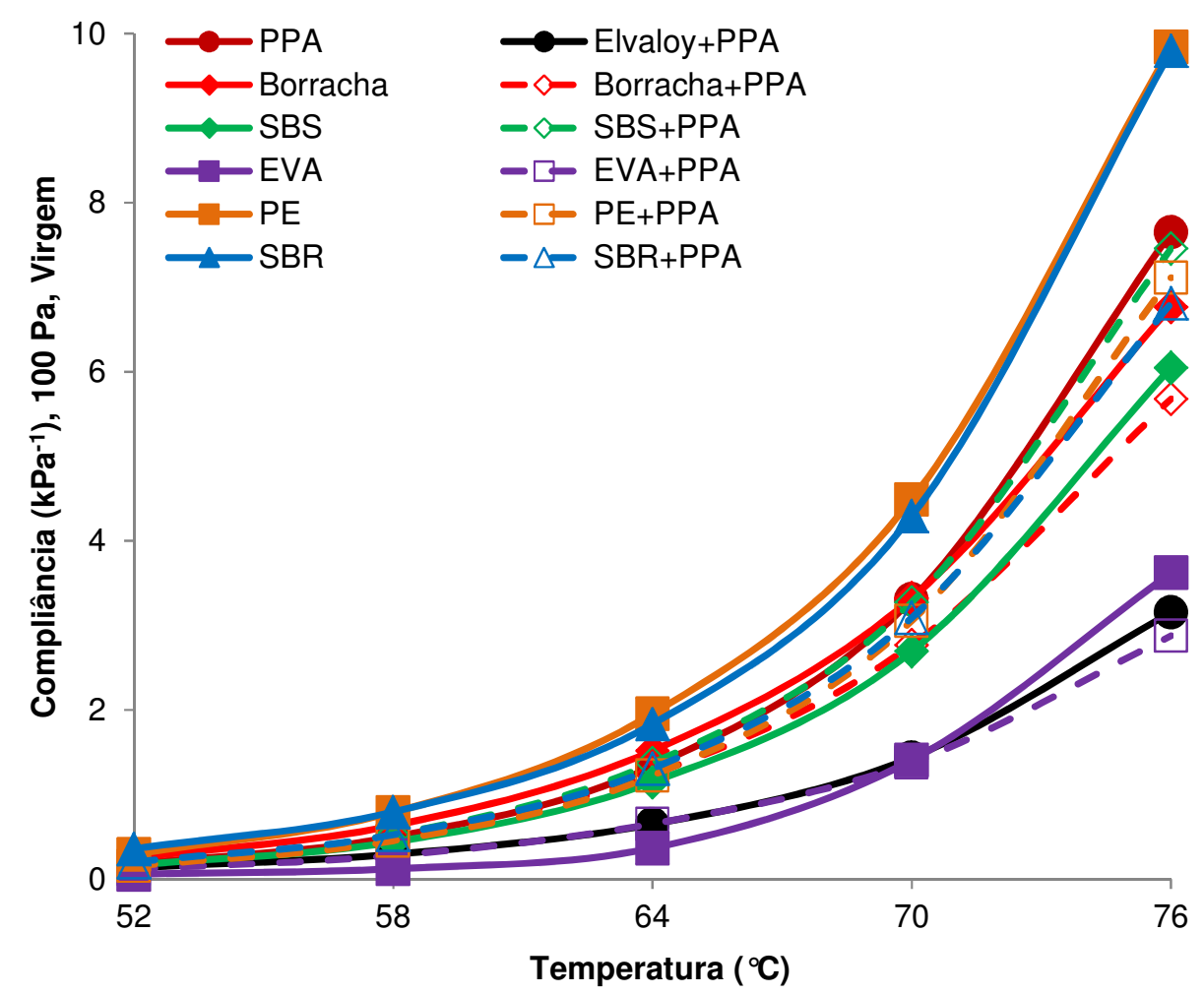

Figura 96 - Compliâncias não-recuperáveis $\left(\mathrm{J}_{\mathrm{nr}}\right)$ dos ligantes asfálticos modificados na condição virgem, na tensão de $100 \mathrm{~Pa}$ e nos tempos de 1 e $9 \mathrm{~s}$

A Figura 97 mostra os gráficos de $\mathrm{J}_{\mathrm{nr}}$ para todos os ligantes asfálticos modificados, considerando o nível de tensão de 3.200 Pa, os tempos de fluência e recuperação de 1 e 9 s e a condição virgem destes materiais. Assim como na tensão de $100 \mathrm{~Pa}$, o CAP+PE e o CAP+SBR apresentam compliâncias não-recuperáveis próximas entre si ao longo de todo o espectro de 
temperaturas, especialmente nas temperaturas de 52,58 e $76^{\circ} \mathrm{C}$. A distinção entre os modificadores é relativamente difícil de ser realizada nas temperaturas de 52 e $58^{\circ} \mathrm{C}$, uma vez que os valores de $J_{n r}$ dos materiais são próximos entre si. Valores parecidos de $J_{n r}$ também são encontrados nos seguintes grupos de ligantes asfálticos: (1) o grupo formado pelo CAP+PE e pelo CAP+borracha nas temperaturas de até $70^{\circ} \mathrm{C}$; (2) o grupo formado pelo CAP+SBS+PPA, pelo $\mathrm{CAP}+\mathrm{PE}+\mathrm{PPA}$, pelo $\mathrm{CAP}+$ borracha+PPA e pelo $\mathrm{CAP}+\mathrm{SBR}+\mathrm{PPA}$ ao longo de todo o espectro de temperaturas; (3) o grupo formado pelo $C A P+S B S$ e pelo $C A P+E V A+P P A$ em todas as temperaturas; e (4) o grupo formado pelo CAP+Elvaloy+PPA e pelo CAP+EVA nas temperaturas de até $64^{\circ} \mathrm{C}$. As formulações com Elvaloy+PPA e EVA apresentam valores mais baixos de $\mathrm{J}_{\mathrm{nr}}$ em comparação aos demais ligantes asfálticos, o que indica a menor suscetibilidade destes materiais à deformação permanente. O CAP+EVA possui um crescimento maior de $\mathrm{J}_{\mathrm{nr}}$ do que o CAP+Elvaloy+PPA nas temperaturas de 64,70 e $76^{\circ} \mathrm{C}$, o que se reflete em um distanciamento dos gráficos de ambos os materiais.

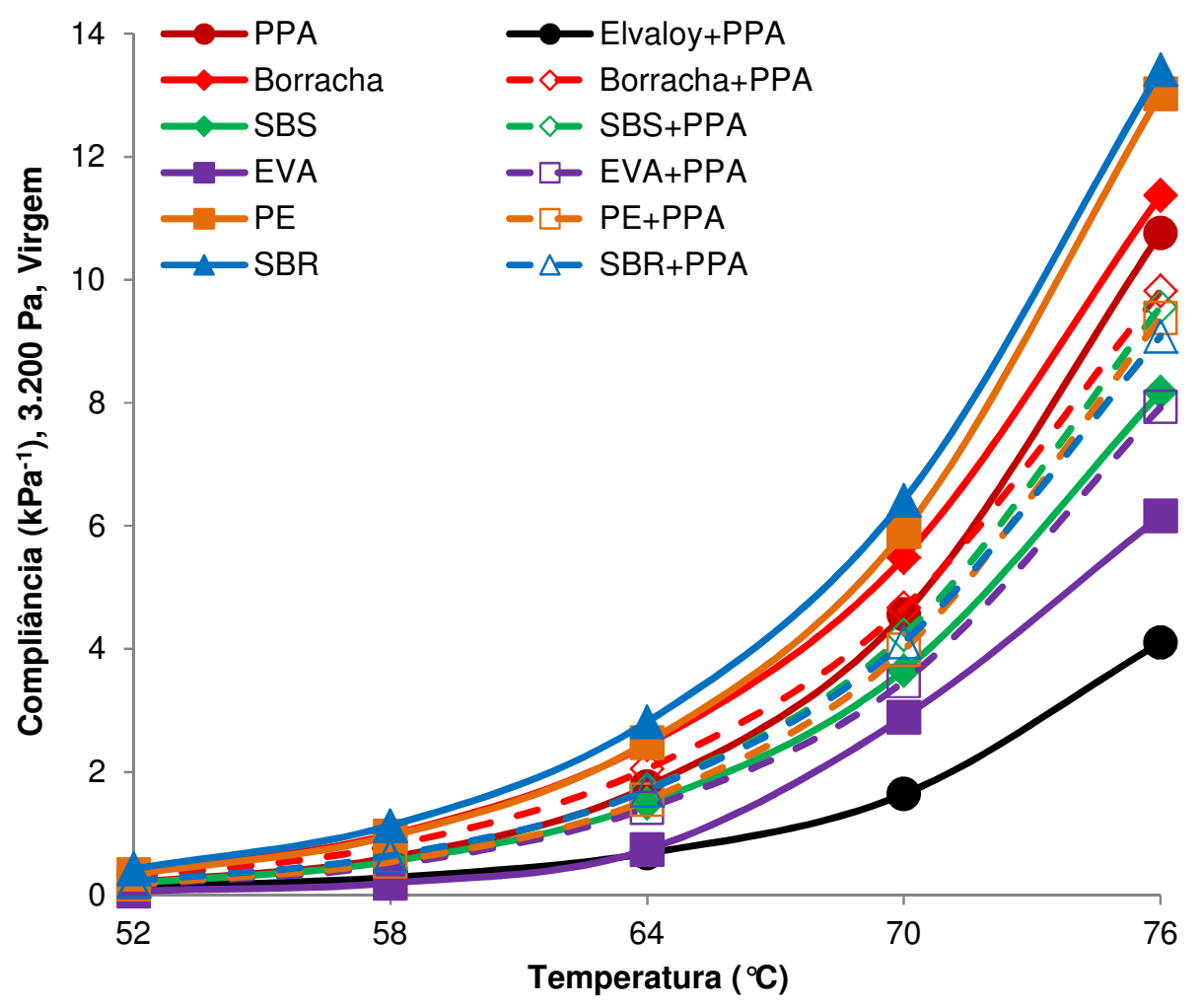

Figura 97 - Compliâncias não-recuperáveis $\left(\mathrm{J}_{\mathrm{nr}}\right)$ dos ligantes asfálticos modificados na condição virgem, na tensão de $3.200 \mathrm{~Pa}$ e nos tempos de 1 e $9 \mathrm{~s}$

A Figura 98 mostra os gráficos do percentual de recuperação para todos os ligantes asfálticos, considerando o nível de tensão de $100 \mathrm{~Pa}$, os tempos de fluência e recuperação de 1 e 9 s e a condição envelhecida destes materiais. À exceção do CAP+EVA e do CAP 50/70, todos os demais ligantes asfálticos apresentam decréscimos aproximadamente lineares de $R$ 


\section{4}

com a temperatura, de modo que as sensibilidades destes materiais à temperatura podem ser consideradas parecidas. Os percentuais de recuperação do CAP+EVA diminuem acentuadamente com a temperatura, de modo que este material pode ser considerado como o mais sensível à temperatura. O CAP+PPA e o CAP+borracha+PPA apresentam recuperações muito próximas entre si ao longo de todo o espectro de temperaturas, o mesmo sendo observado para o $\mathrm{CAP}+\mathrm{SBS}$, O $\mathrm{CAP}+\mathrm{SBS}+\mathrm{PPA}$ e o $\mathrm{CAP}+\mathrm{PE}+\mathrm{PPA}$. Os percentuais de recuperação da formulação com SBR são relativamente próximos aos das formulações com SBS, SBS+PPA e PE+PPA, especialmente nas temperaturas de 58 e $76{ }^{\circ} \mathrm{C}$. As recuperações do $C A P+E V A$ e do $C A P+E l v a l o y+P P A$ são praticamente iguais nas temperaturas de 52 e $58^{\circ} \mathrm{C}$ e, da mesma maneira, as recuperações do CAP+EVA, do CAP+PPA e do CAP+borracha+PPA podem ser consideradas iguais na temperatura de $70^{\circ} \mathrm{C}$. $\mathrm{O} C A P+$ borracha possui recuperações muito próximas às do $\mathrm{CAP}+\mathrm{SBR}+\mathrm{PPA}$ nas temperaturas de até $70^{\circ} \mathrm{C}$, sendo que as distinções entre os valores são maiores na temperatura de $76^{\circ} \mathrm{C}$. O CAP+EVA apresenta decréscimos acentuados do percentual de recuperação nas temperaturas acima de $58^{\circ} \mathrm{C}$ e, no caso do $\mathrm{CAP}+$ Elvaloy+PPA, estes decréscimos são relativamente pequenos ao longo de todo o espectro de temperaturas. O CAP 50/70 não apresenta qualquer recuperação nas temperaturas de 70 e $76{ }^{\circ} \mathrm{C}$, possuindo valores pequenos (inferiores a $20 \%$ ) nas demais temperaturas.

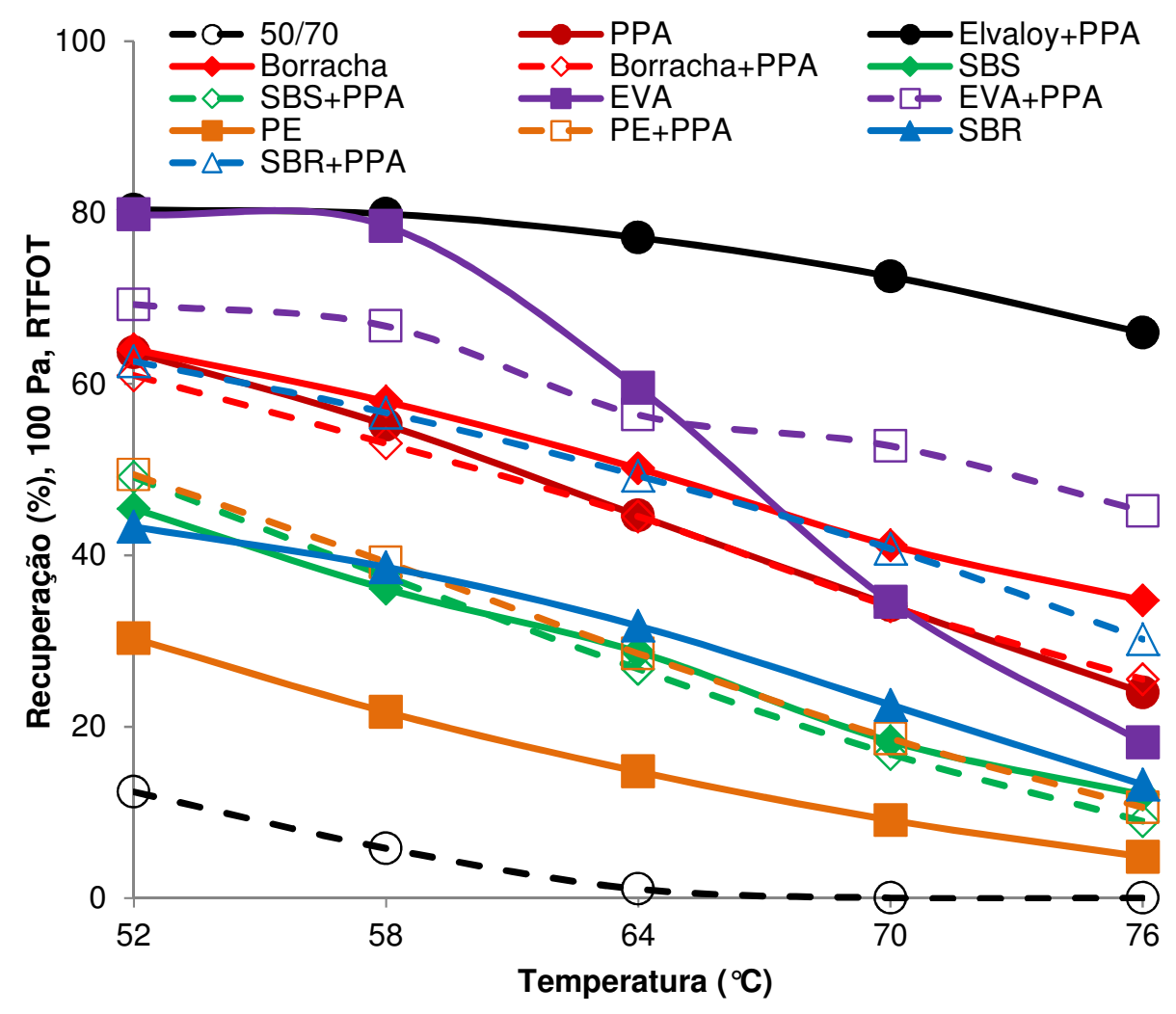

Figura 98 - Percentuais de recuperação $(R)$ dos ligantes asfálticos na condição envelhecida, na tensão de $100 \mathrm{~Pa}$ e nos tempos de 1 e $9 \mathrm{~s}$ 
A Figura 99 mostra os gráficos do percentual de recuperação para todos os ligantes asfálticos, considerando o nível de tensão de $3.200 \mathrm{~Pa}$, os tempos de 1 e $9 \mathrm{~s}$ e a condição envelhecida a curto prazo. O CAP+Elvaloy+PPA apresenta as maiores recuperações ao longo de todo o espectro de temperaturas, especialmente a 70 e a $76{ }^{\circ} \mathrm{C}$. $\mathrm{A}$ maioria dos ligantes asfálticos (incluindo o CAP 50/70) possui recuperações inferiores a 60\% em toda a faixa de temperaturas consideradas, sendo eles o CAP+borracha, o $\mathrm{CAP}+$ borracha+PPA, o $\mathrm{CAP}+\mathrm{PE}+\mathrm{PPA}$, o $\mathrm{CAP}+\mathrm{SBS}+\mathrm{PPA}$, o $\mathrm{CAP}+\mathrm{SBS}$, o $\mathrm{CAP}+\mathrm{SBR}$ e 0 $\mathrm{CAP}+\mathrm{PE}$. As reduções do percentual de recuperação são muito elevadas para o CAP+EVA, de um modo especial nas temperaturas de 58,64 e $70^{\circ} \mathrm{C}$, em que os valores desta propriedade reduzem de aproximadamente $70 \%$ a $58^{\circ} \mathrm{C}$ para $10 \%$ a $70^{\circ} \mathrm{C}$. O CAP+EVA+PPA também apresenta uma redução acentuada de $\mathrm{R}$ ao longo de todo o espectro de temperaturas, embora com menor intensidade do que a verificada no CAP+EVA. O CAP+Elvaloy+PPA não sofre reduções significativas do percentual de recuperação nas temperaturas de até $64^{\circ} \mathrm{C}$, sendo que os decréscimos desta propriedade passam a ser maiores nas temperaturas subsequentes. O CAP+SBR+PPA possui recuperações próximas às do $\mathrm{CAP}+\mathrm{PPA}$ nas temperaturas de 52 e $58^{\circ} \mathrm{C}$, sendo mais próximas às do $\mathrm{CAP}+\mathrm{EVA}+\mathrm{PPA}$ nas temperaturas de 64,70 e $76^{\circ} \mathrm{C}$.

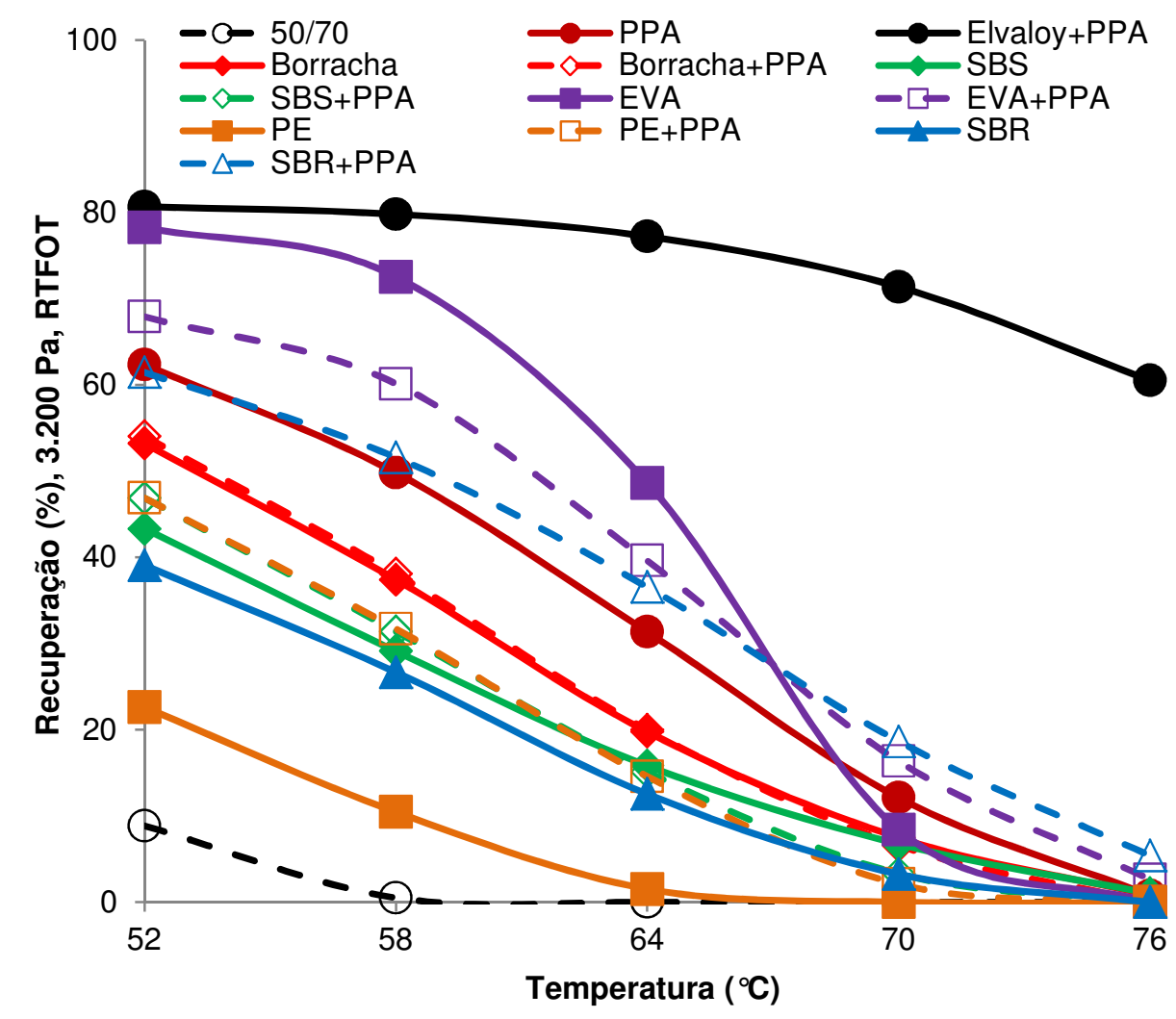

Figura 99 - Percentuais de recuperação $(R)$ dos ligantes asfálticos na condição envelhecida, na tensão de $3.200 \mathrm{~Pa}$ e nos tempos de 1 e $9 \mathrm{~s}$ 
A Figura 100 apresenta os gráficos de $J_{n r}$ para todos os ligantes asfálticos modificados, considerando o nível de tensão de $100 \mathrm{~Pa}$, os tempos de fluência e recuperação de 1 e $9 \mathrm{~s}$ e a condição envelhecida a curto prazo. A distinção entre os modificadores é relativamente difícil de ser realizada nas temperaturas de 52 e $58^{\circ} \mathrm{C}$, nas quais as compliâncias não-recuperáveis são próximas entre si para todos os ligantes asfálticos. Os valores de $\mathrm{J}_{\mathrm{nr}}$ para o $C A P+P E$ e o $C A P+S B R$ são praticamente iguais ao longo de todo o espectro de temperaturas, de modo que, à luz destes resultados, as duas formulações podem ser consideradas equivalentes. Situações parecidas são encontradas em outros três grupos de ligantes asfálticos: (1) o grupo formado pelo $\mathrm{CAP}+\mathrm{PE}+\mathrm{PPA}$ e pelo $\mathrm{CAP}+\mathrm{SBS}+\mathrm{PPA}$ em todo o espectro de temperaturas; e (2) o grupo formado pelo CAP+borracha e pelo CAP+borracha+PPA nas temperaturas de até $70^{\circ} \mathrm{C}$; e (3) o grupo formado pelo CAP+Elvaloy+PPA e pelo CAP+EVA+PPA em todas as temperaturas. O CAP+SBS possui compliâncias não-recuperáveis relativamente próximas às do $C A P+S B S+P P A$ e do $C A P+P E+P P A$, especialmente nas temperaturas de até $64^{\circ} \mathrm{C}$. A formulação com EVA apresenta, em comparação às formulações com Elvaloy+PPA, EVA+PPA, SBR+PPA e PPA, crescimentos mais acentuados de $J_{n r}$ nas temperaturas superiores a $64^{\circ} \mathrm{C}$, o que se reflete no valor mais elevado desta propriedade para a formulação com EVA na temperatura de $76^{\circ} \mathrm{C}$. As formulações com Elvaloy+PPA e EVA+PPA possuem os valores mais baixos de $\mathrm{J}_{\mathrm{nr}}$ nas temperaturas de 70 e $76{ }^{\circ} \mathrm{C}$, sendo menores para o $\mathrm{CAP}+\mathrm{EVA}+\mathrm{PPA}$ e maiores para o CAP+Elvaloy+PPA em ambas as temperaturas.

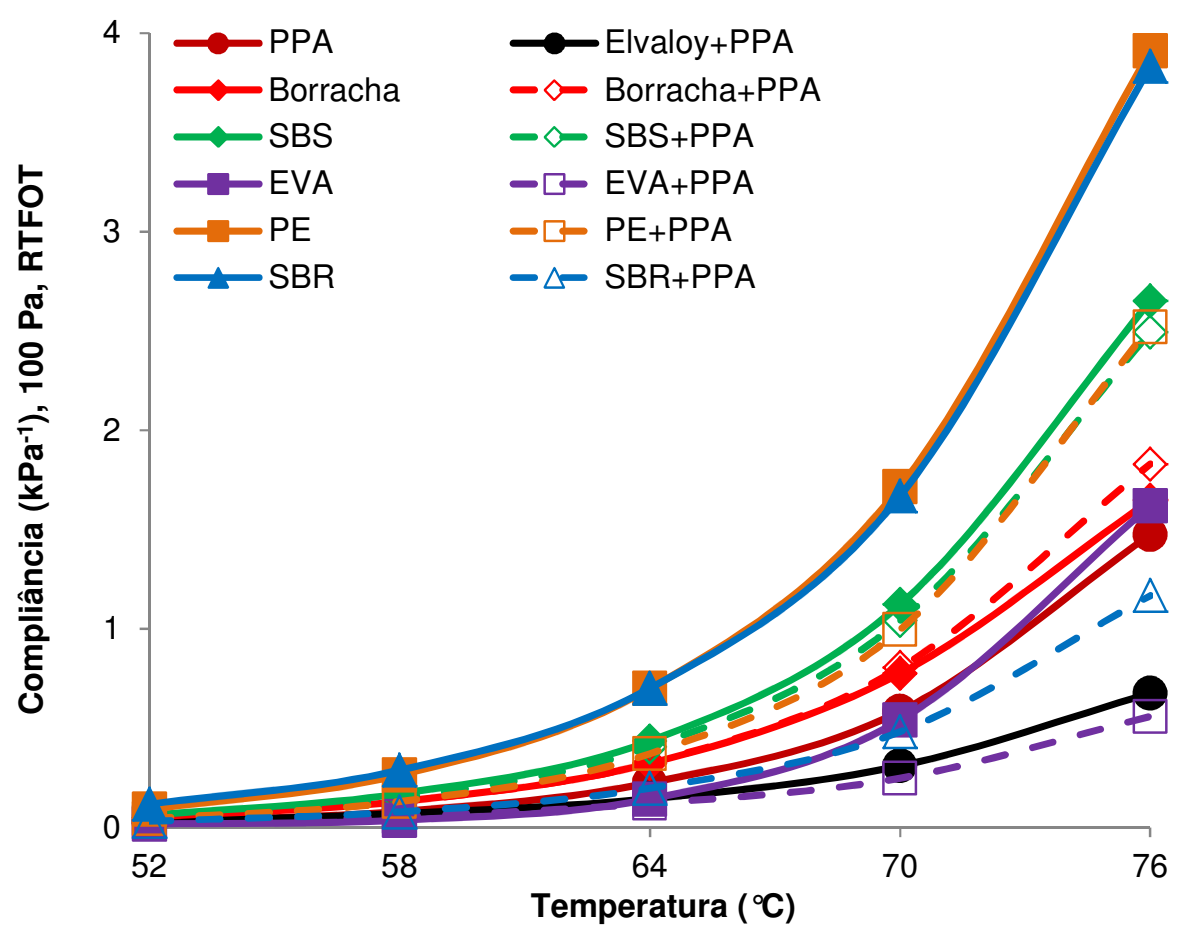

Figura 100 - Compliâncias não-recuperáveis $\left(\mathrm{J}_{\mathrm{nr}}\right)$ dos ligantes asfálticos modificados na condição envelhecida, na tensão de $100 \mathrm{~Pa}$ e nos tempos de 1 e $9 \mathrm{~s}$ 
A Figura 101 ilustra os gráficos de $J_{n r}$ para todos os ligantes asfálticos modificados, considerando o nível de tensão de $3.200 \mathrm{~Pa}$, os tempos de 1 e $9 \mathrm{~s}$ e a condição envelhecida destes materiais. A distinção entre os modificadores é relativamente difícil de ser realizada nas temperaturas de 52 e $58^{\circ} \mathrm{C}$, em que os valores de $\mathrm{J}_{\mathrm{nr}}$ são próximos entre si para todos os ligantes asfálticos. As compliâncias não-recuperáveis do $C A P+P E$ e do $C A P+S B R$ são relativamente próximas entre si ao longo de todo o espectro de temperaturas, sendo menores para o $\mathrm{CAP}+\mathrm{PE}$ e maiores para o $\mathrm{CAP}+\mathrm{SBR}$. As formulações com borracha, borracha+PPA, SBS, SBS+PPA e PE+PPA apresentam compliâncias não-recuperáveis praticamente iguais em todas as temperaturas e, à luz destes resultados, os materiais podem ser considerados equivalentes em termos de formulação. Situação parecida ocorre com os ligantes asfálticos modificados com PPA, EVA+PPA e SBR+PPA, para os quais os valores de $J_{\mathrm{nr}}$ são muito parecidos nas temperaturas de até $70^{\circ} \mathrm{C}$. A formulação com Elvaloy+PPA apresenta crescimentos pequenos de $\mathrm{J}_{\mathrm{nr}}$ com a temperatura, resultando em valores muito pequenos para esta propriedade nas temperaturas de 70 e $76{ }^{\circ} \mathrm{C}$.

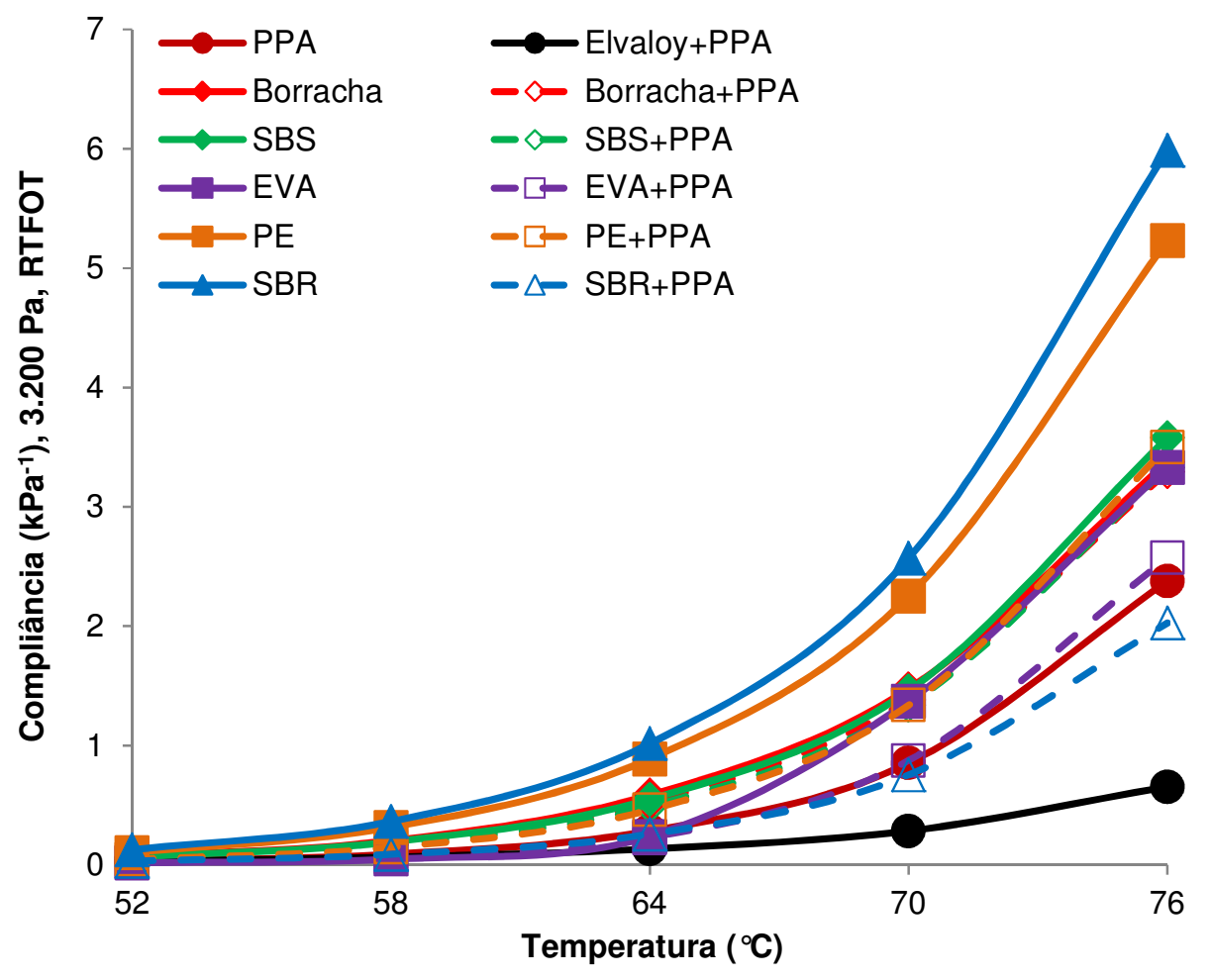

Figura 101 - Compliâncias não-recuperáveis $\left(\mathrm{J}_{\mathrm{nr}}\right)$ dos ligantes asfálticos modificados na condição envelhecida, na tensão de 3.200 Pa e nos tempos de 1 e $9 \mathrm{~s}$

A Figura 102 apresenta os gráficos do percentual de recuperação para todos os ligantes asfálticos, considerando o nível de tensão de $100 \mathrm{~Pa}$, os tempos de fluência e recuperação de 2 e $18 \mathrm{~s}$ e a condição envelhecida destes materiais. As formulações com 


\section{8}

SBR, SBS+PPA, PE+PPA, SBS e PE, bem como o CAP 50/70, possuem recuperações inferiores a $60 \%$ em qualquer temperatura, com valores baixos para esta propriedade (inferiores a 20\%) na temperatura de $76^{\circ} \mathrm{C}$. A maioria dos ligantes asfálticos apresenta decréscimos aproximadamente lineares do percentual de recuperação com a temperatura, exceções feitas ao material puro e às formulações com EVA e SBR. As recuperações do $\mathrm{CAP}+\mathrm{EVA}$ decrescem acentuadamente com a temperatura, especialmente a 58,64 e $70^{\circ} \mathrm{C}$, em que os valores desta propriedade diminuem de aproximadamente $90 \%$ a $58^{\circ} \mathrm{C}$ para valores inferiores a $40 \%$ nas temperaturas de 70 e $76^{\circ} \mathrm{C}$. O CAP+EVA apresenta os maiores percentuais de recuperação nas temperaturas de 52 e $58^{\circ} \mathrm{C}$ e o CAP+Elvaloy+PPA, os maiores nas temperaturas de 64,70 e $76{ }^{\circ} \mathrm{C}$. Os percentuais de recuperação do CAP+SBR sofrem variações muito pequenas com o aumento da temperatura de 52 para $58^{\circ} \mathrm{C}$, passando a sofrer reduções mais acentuadas nas temperaturas subsequentes. O CAP+PE+PPA, 0 $\mathrm{CAP}+\mathrm{SBS}+\mathrm{PPA}$ e o $\mathrm{CAP}+\mathrm{SBR}$ possuem valores de $\mathrm{R}$ muito próximos entre si nas temperaturas de $58,64,70$ e $76^{\circ} \mathrm{C}$, o mesmo sendo observado para o CAP+EVA e o CAP+PPA na temperatura de $76^{\circ} \mathrm{C}$. Situação parecida ocorre com outros dois pares de ligantes asfálticos nas temperaturas de 52 e $58^{\circ} \mathrm{C}$ : um par formado pelo CAP+borracha+PPA e pelo CAP+EVA+PPA e o outro formado pelo CAP+PPA e pelo CAP+SBR+PPA.

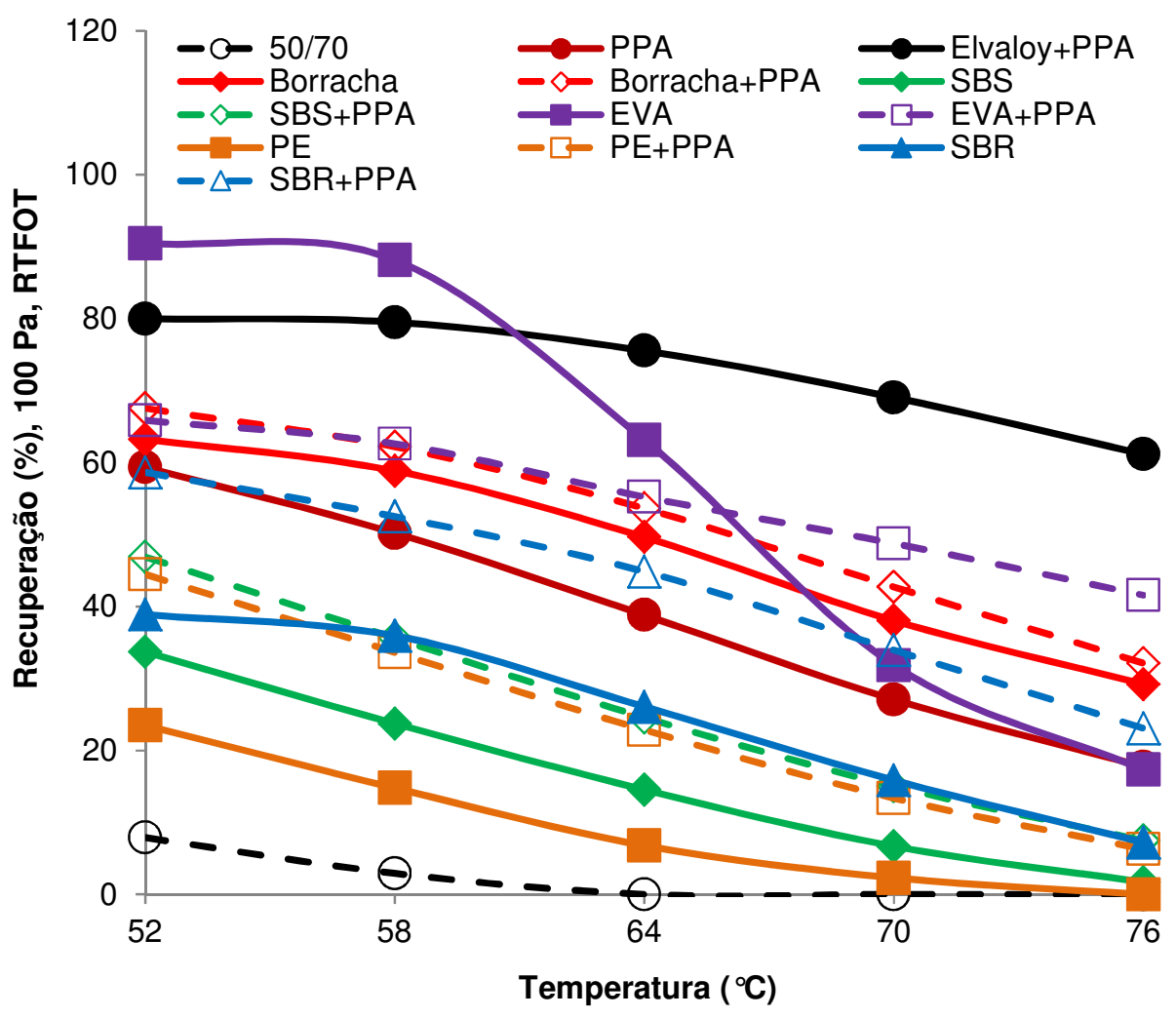

Figura 102 - Percentuais de recuperação $(R)$ dos ligantes asfálticos na condição envelhecida, na tensão de $100 \mathrm{~Pa}$ e nos tempos de 2 e $18 \mathrm{~s}$ 
A Figura 103 ilustra os gráficos do percentual de recuperação para todos os ligantes asfálticos, considerando o nível de tensão de $3.200 \mathrm{~Pa}$, os tempos de fluência e recuperação de 2 e 18 s e a condição envelhecida destes materiais. À exceção das formulações com Elvaloy+PPA e com EVA, todos os demais ligantes asfálticos modificados possuem recuperações inferiores a $80 \%$ ao longo de todo o espectro de temperaturas e reduções aproximadamente lineares desta propriedade nas temperaturas de até $70^{\circ} \mathrm{C}$. $\mathrm{O}$ $\mathrm{CAP}+$ Elvaloy+PPA apresenta variações pequenas de $\mathrm{R}$ nas temperaturas de até $64^{\circ} \mathrm{C}$, sendo que estas variações são maiores nas temperaturas subsequentes. As recuperações do $\mathrm{CAP}+\mathrm{EVA}$ decrescem acentuadamente nas temperaturas de 58,64 e $70^{\circ} \mathrm{C}$, desde valores superiores a $80 \%$ nas temperaturas de 52 e $58^{\circ} \mathrm{C}$ até valores inferiores a $20 \%$ nas temperaturas de 70 e $76{ }^{\circ} \mathrm{C}$, o que indica a sensibilidade elevada deste ligante asfáltico à temperatura. $\mathrm{O}$ CAP+EVA apresenta os maiores valores de $R$ nas temperaturas de 52 e $58^{\circ} \mathrm{C}$ e o $\mathrm{CAP}+$ Elvaloy+PPA, os maiores nas temperaturas de 64,70 e $76^{\circ} \mathrm{C}$. O CAP+SBS e o CAP+SBR possuem valores de $R$ praticamente iguais nas temperaturas de até $70^{\circ} \mathrm{C}$, o mesmo sendo observado no $\mathrm{CAP}+$ borracha+PPA e no $\mathrm{CAP}+\mathrm{SBR}+\mathrm{PPA}$ ao longo de todo o espectro de temperaturas e nas formulações com EVA+PPA e com PPA para as temperaturas de até $70^{\circ} \mathrm{C}$. O CAP 50/70 e o CAP+PE possuem recuperações pequenas ao longo de todo o espectro de temperaturas, sendo maiores para o CAP+PE nas temperaturas de 52 e $58^{\circ} \mathrm{C}$.

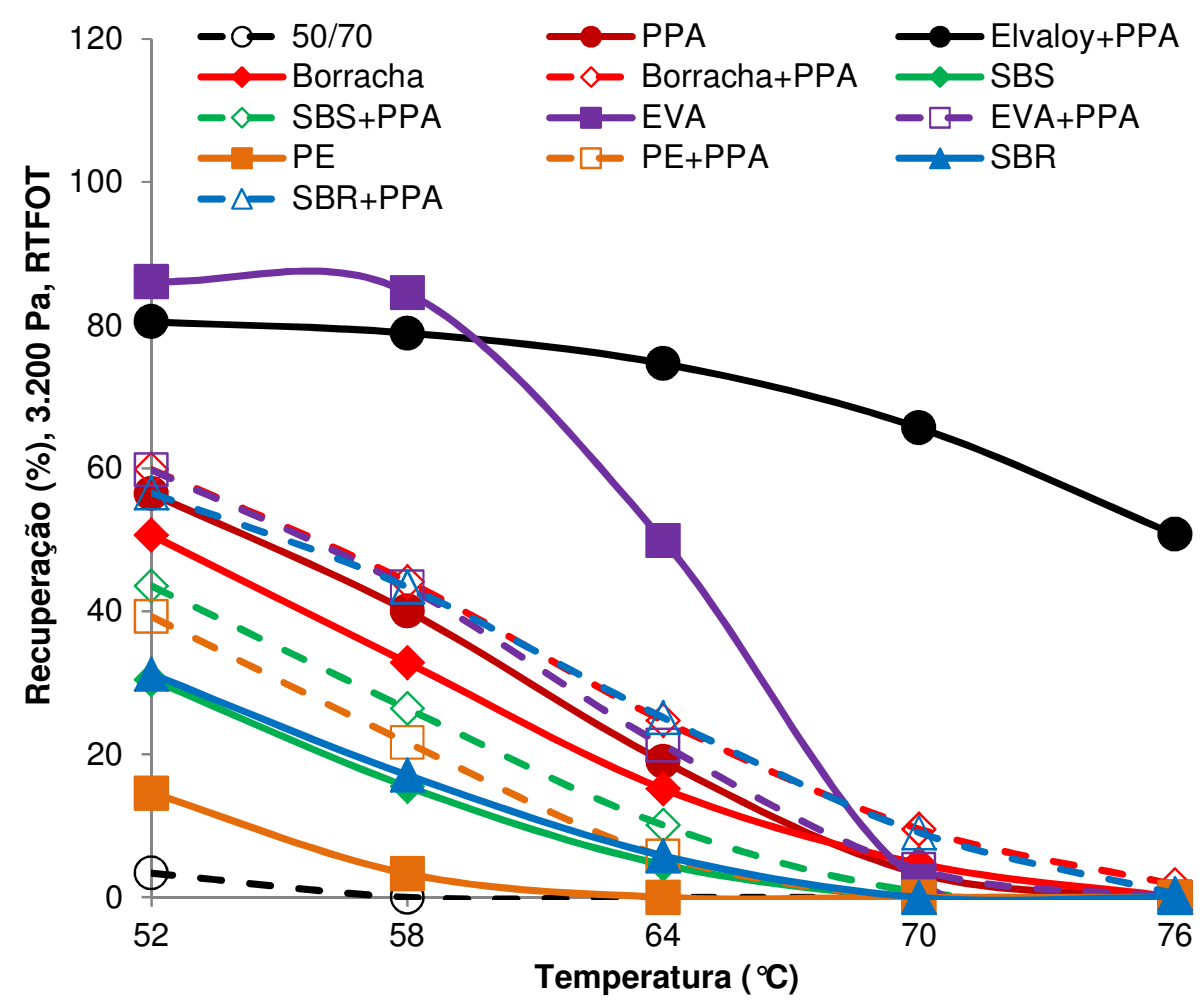

Figura 103 - Percentuais de recuperação $(R)$ dos ligantes asfálticos na condição envelhecida, na tensão de $3.200 \mathrm{~Pa}$ e nos tempos de 2 e $18 \mathrm{~s}$ 
A Figura 104 apresenta os gráficos de $\mathrm{J}_{\mathrm{nr}}$ com a temperatura para todos os ligantes asfálticos, considerando o nível de tensão de $100 \mathrm{~Pa}$, os tempos de fluência e recuperação de 2 e $18 \mathrm{~s}$ e a condição envelhecida destes materiais. A distinção entre os modificadores é relativamente difícil de ser realizada nas temperaturas de 52 e $58^{\circ} \mathrm{C}$, uma vez que as compliâncias não-recuperáveis dos ligantes asfálticos são próximas entre si. O CAP+EVA apresenta um crescimento relativamente expressivo de $J_{n r}$ com a temperatura, especialmente nas temperaturas acima de $64^{\circ} \mathrm{C}$. As compliâncias não-recuperáveis do $\mathrm{CAP}+\mathrm{PE}$ e do $\mathrm{CAP}+\mathrm{SBR}$ são parecidas nas temperaturas de até $70^{\circ} \mathrm{C}$, o mesmo sendo observado para o CAP+PE+PPA e o CAP+SBS+PPA. Valores parecidos de $J_{n r}$ também são encontrados nos seguintes grupos de ligantes asfálticos, considerando todo o espectro de temperaturas: (1) o grupo formado pelo CAP+Elvaloy+PPA e o CAP+EVA+PPA; (2) o grupo

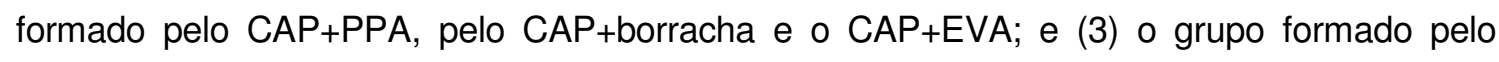
$\mathrm{CAP}+\mathrm{SBR}+\mathrm{PPA}$ e pelo $\mathrm{CAP}+$ borracha+PPA. No caso do $\mathrm{CAP}+\mathrm{SBS}$, os valores de $\mathrm{J}_{\text {nr }}$ para este material estão situados entre os do CAP+SBR e do CAP+PE+PPA, tanto nas temperaturas mais baixas quanto nas mais elevadas.

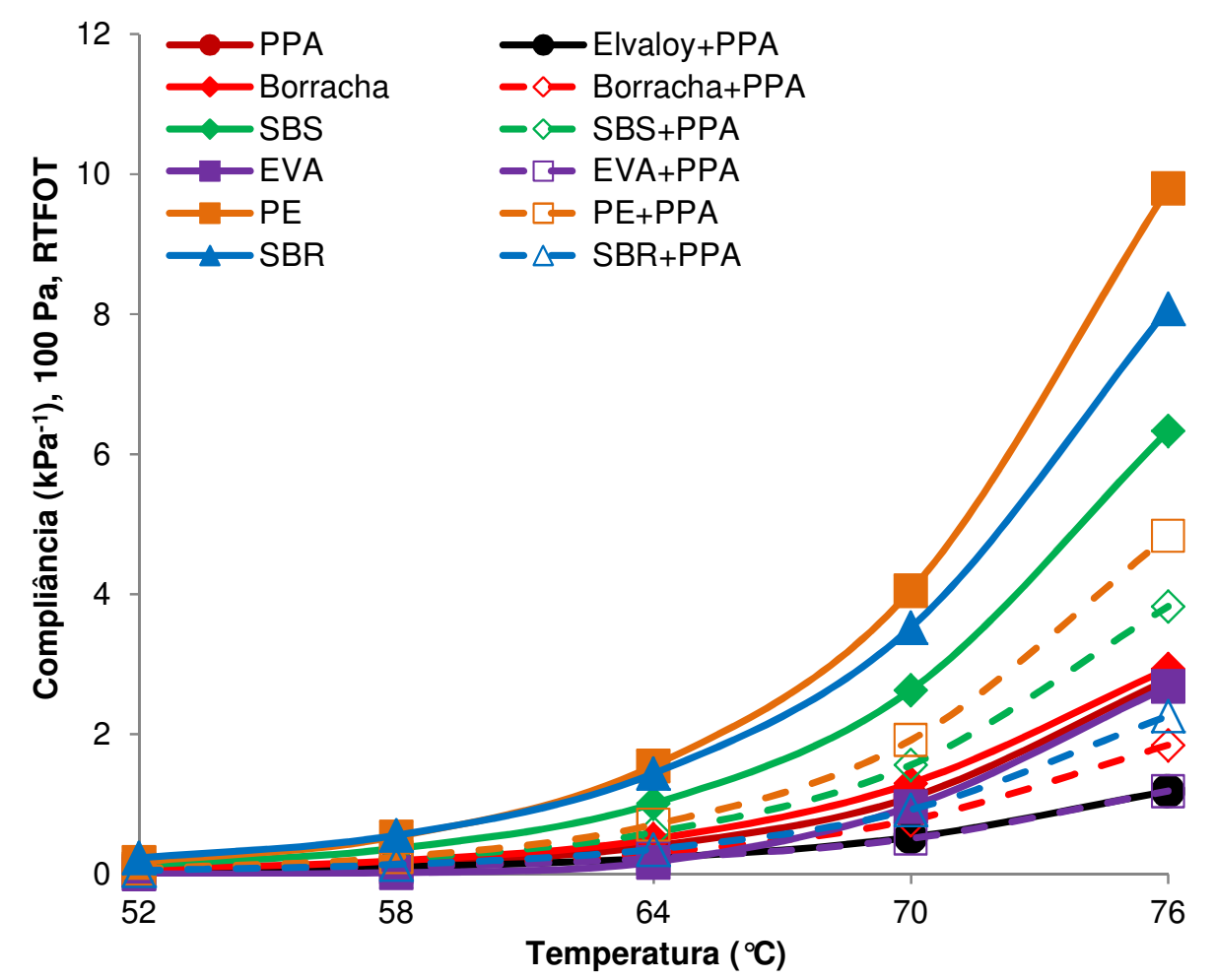

Figura 104 - Compliâncias não-recuperáveis $\left(\mathrm{J}_{\mathrm{nr}}\right)$ dos ligantes asfálticos na condição envelhecida, na tensão de $100 \mathrm{~Pa}$ e nos tempos de 2 e $18 \mathrm{~s}$

A Figura 105 ilustra os gráficos de compliância não-recuperável para todos os ligantes asfálticos modificados, considerando o nível de tensão de $3.200 \mathrm{~Pa}$, os tempos de 
fluência e recuperação de 2 e 18 s e a condição envelhecida destes materiais. A distinção entre os modificadores é relativamente difícil de ser realizada nas temperaturas mais baixas $\left(52\right.$ e $\left.58^{\circ} \mathrm{C}\right)$, uma vez que as compliâncias não-recuperáveis dos ligantes asfálticos são muito próximas entre si nestas condições. O CAP+PE e o CAP+SBR possuem valores parecidos de $\mathrm{J}_{\mathrm{nr}}$ ao longo de todo o espectro de temperaturas, de modo que, à luz destes resultados, ambas as formulações podem ser consideradas equivalentes. Esta proximidade de resultados também pode ser observada nos seguintes grupos de ligantes asfálticos: (1) o grupo formado pelo CAP+borracha e pelo CAP+PE+PPA nas temperaturas de até $70^{\circ} \mathrm{C}$; (2) o grupo formado pelo CAP+borracha+PPA e pelo $\mathrm{CAP}+\mathrm{SBR}+\mathrm{PPA}$ nas temperaturas de até $70^{\circ} \mathrm{C}$; (3) o grupo formado pelo CAP+EVA e pelo $\mathrm{CAP}+$ Elvaloy+PPA nas temperaturas de até $64^{\circ} \mathrm{C}$; (4) o grupo formado pelo $\mathrm{CAP}+\mathrm{SBS}+\mathrm{PPA}$ e pelo CAP+EVA+PPA em todas as temperaturas. O CAP+EVA apresenta um crescimento significativo da compliância não-recuperável nas temperaturas de 64,70 e $76^{\circ} \mathrm{C}$, o que se reflete nos cruzamentos dos gráficos de $\mathrm{J}_{\mathrm{nr}}$ referentes a este material e a outros ligantes asfálticos modificados tais como o CAP+borracha+PPA, o $\mathrm{CAP}+\mathrm{SBR}+\mathrm{PPA}$, O CAP+PPA, o CAP+SBS+PPA, o CAP+borracha e o CAP+EVA+PPA. Este crescimento é pequeno para o $C A P+E l v a l o y+P P A$ ao longo de todo o espectro de temperaturas, de modo que os valores de $\mathrm{J}_{\mathrm{nr}}$ não ultrapassam os $2,0 \mathrm{kPa}^{-1}$.

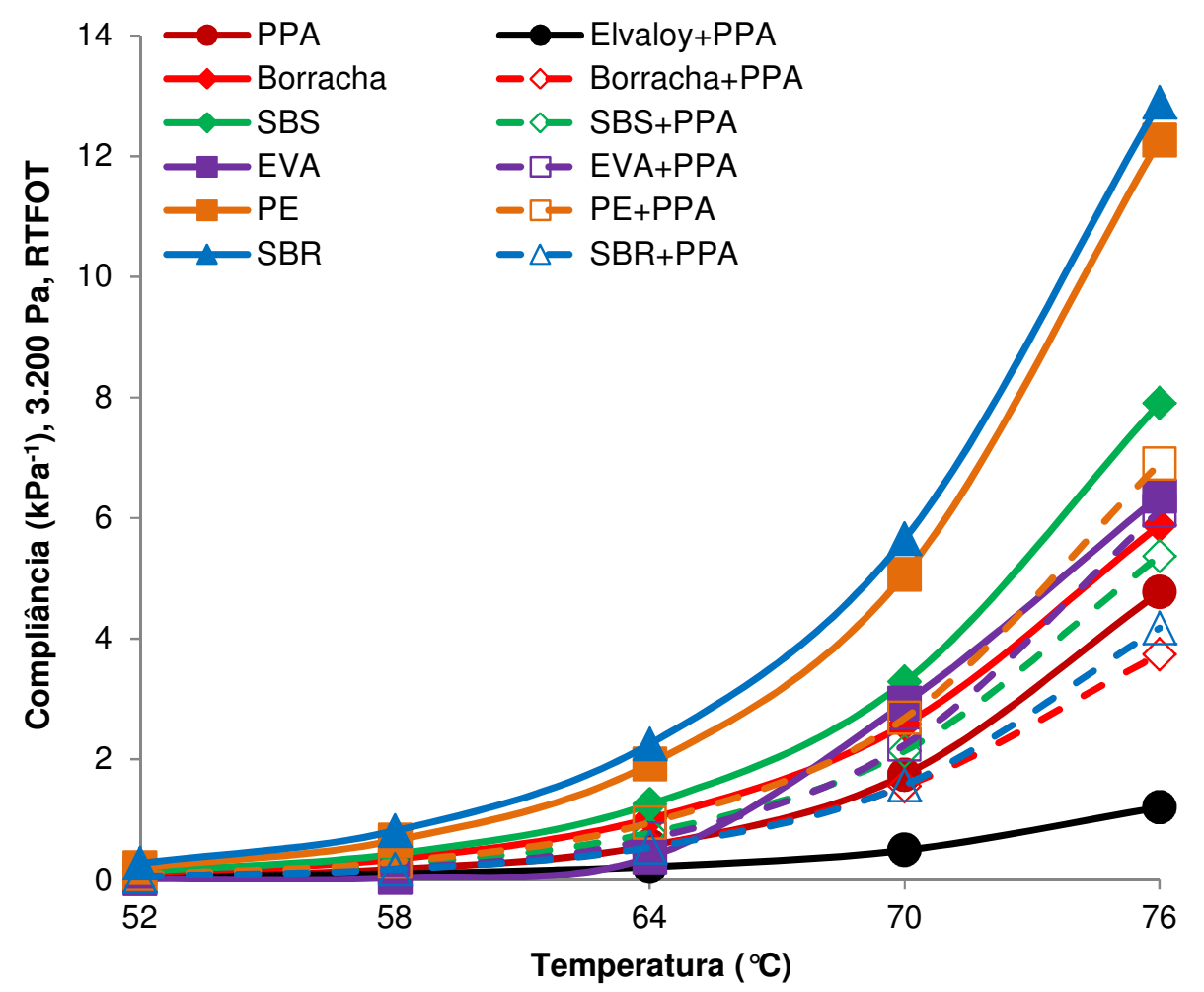

Figura 105 - Compliâncias não-recuperáveis $\left(\mathrm{J}_{\mathrm{nr}}\right)$ dos ligantes asfálticos na condição envelhecida, na tensão de $3.200 \mathrm{~Pa}$ e nos tempos de 2 e $18 \mathrm{~s}$ 
A Figura 106 apresenta os gráficos de $J_{\text {nr,diff }}$ na condição virgem e nos tempos de fluência e recuperação de 1 e $9 \mathrm{~s}$. As formulações com PPA, SBS, SBS+PPA, PE, PE+PPA e SBR+PPA possuem diferenças percentuais muito próximas entre si ao longo de todo o espectro de temperaturas, de modo que as sensibilidades destes materiais à tensão podem ser consideradas semelhantes. Os menores valores de $J_{n r, \text { diff }}$ são encontradas no CAP+Elvaloy+PPA (temperaturas de até $64^{\circ} \mathrm{C}$ ) e no CAP 50/70 (temperaturas de 70 e $76{ }^{\circ} \mathrm{C}$ ), de modo que, em linhas gerais, ambos os ligantes asfálticos podem ser considerados como os menos sensíveis à tensão. As sensibilidades do CAP+borracha e do CAP+borracha+PPA à tensão são muito parecidas ao longo de todo o espectro de temperaturas, especialmente a $52 \mathrm{e}$ a $58^{\circ} \mathrm{C}$, o que se reflete nos valores praticamente iguais de $J_{n r, d i f f}$ para ambos os materiais. $O$ $\mathrm{CAP}+\mathrm{EVA}+\mathrm{PPA}$ apresenta as maiores diferenças percentuais nas temperaturas de 58, 64, $70 \mathrm{e}$ $76{ }^{\circ} \mathrm{C}$, de modo que, em linhas gerais, este material pode ser considerado como o mais sensível ao incremento do nível de tensão de 100 para 3.200 Pa. Interessante observar que os gráficos do $\mathrm{CAP}+\mathrm{EVA}$ e do $\mathrm{CAP}+\mathrm{SBR}$ possuem comportamentos distintos da maioria dos ligantes asfálticos, uma vez que, pare estes materiais, as diferenças percentuais aumentam até uma determinada temperatura $\left(70^{\circ} \mathrm{C}\right.$ para o $\mathrm{CAP}+\mathrm{EVA}$ e $64^{\circ} \mathrm{C}$ para o $\left.\mathrm{CAP}+\mathrm{SBR}\right)$ e diminuem nas temperaturas subsequentes. Este comportamento também pode ser observado no CAP 50/70, embora com menor intensidade do que o verificado no CAP+EVA e no CAP+SBR.

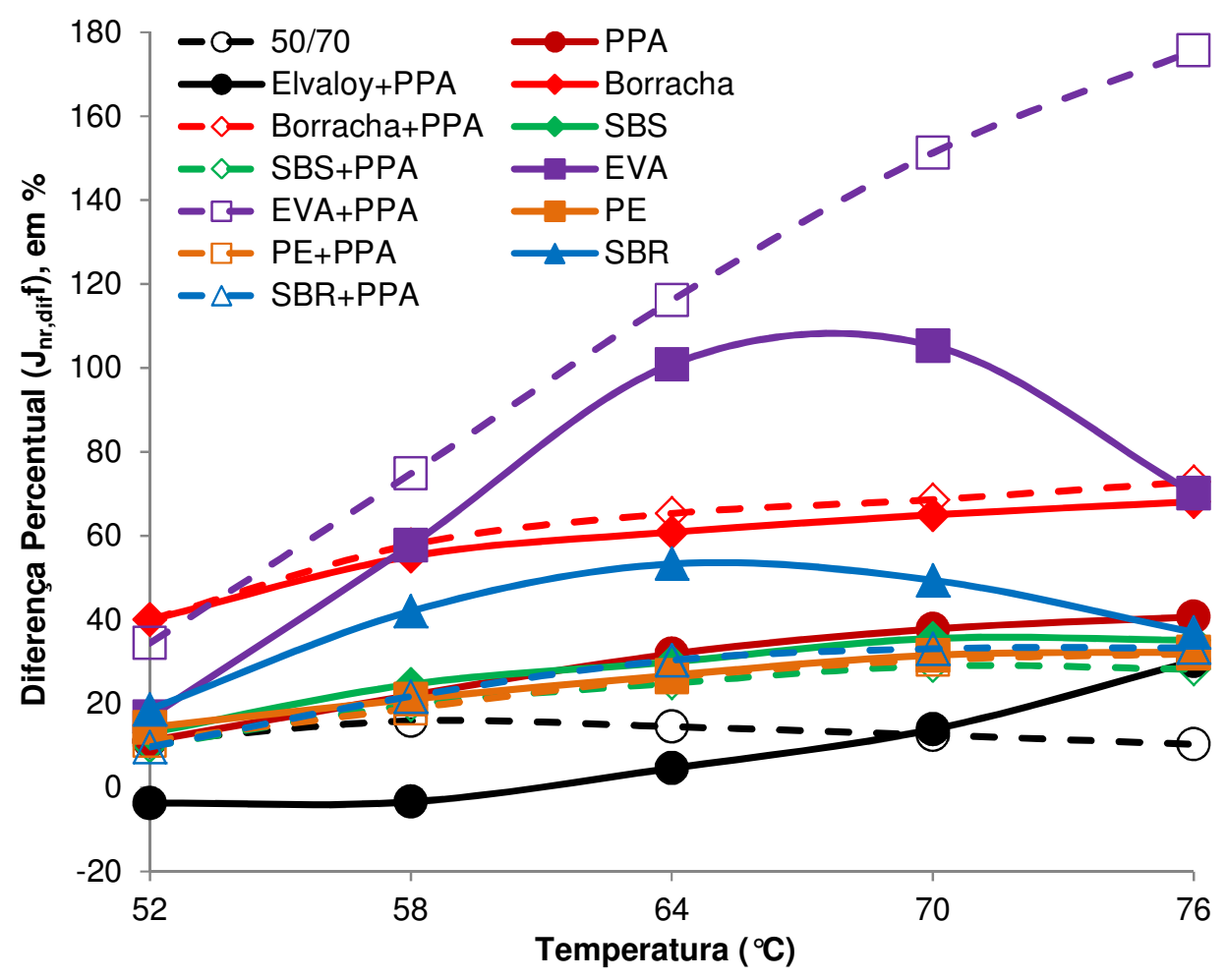

Figura 106 - Diferenças percentuais entre as compliâncias não-recuperáveis ( $\left.J_{\text {nr,diff }}\right)$ dos ligantes asfálticos na condição virgem e nos tempos de 1 e $9 \mathrm{~s}$ 
A Figura 107 mostra os gráficos de $J_{\text {nr,diff }}$ na condição envelhecida a curto prazo e nos tempos de fluência e recuperação de 1 e $9 \mathrm{~s}$. A distinção entre os valores de $J_{\text {nr,diff }}$ da maioria dos ligantes asfálticos é relativamente difícil de ser realizada nas temperaturas de 52 e $58^{\circ} \mathrm{C}$, o que pode ser atribuído aos resultados parecidos deste parâmetro em ambas as temperaturas. O CAP+Elvaloy+PPA apresenta as menores diferenças percentuais nas temperaturas de $58,64,70$ e $76^{\circ} \mathrm{C}$, de modo que, em linhas gerais, este ligante asfáltico pode ser considerado como o menos sensível à tensão. O CAP+EVA+PPA possui valores muito elevados de $J_{n r, d i f f}$ nas temperaturas de 70 e $76^{\circ} \mathrm{C}$, o que lhe confere a maior sensibilidade à tensão nestas condições. À exceção do CAP+EVA, do CAP+EVA+PPA, do CAP+Elvaloy+PPA e do CAP 50/70, todos os demais ligantes asfálticos possuem diferenças percentuais entre 0 e $110 \%$ e apresentam crescimentos contínuos desta propriedade ao longo de todo o espectro de temperaturas, sendo que os maiores valores são encontrados no CAP+borracha para todo o espectro de temperaturas. O CAP 50/70 apresenta valores baixos de $J_{n r, d i f f}$ em todas as temperaturas, sendo visivelmente superiores apenas aos do $\mathrm{CAP}+$ Elvaloy+PPA nas mais elevadas $\left(64,70\right.$ e $\left.76^{\circ} \mathrm{C}\right)$. Interessante observar que o gráfico do CAP+EVA apresenta um comportamento distinto dos demais ligantes asfálticos modificados, uma vez que as diferenças percentuais deste material aumentam até a temperatura de $70^{\circ} \mathrm{C}$ e em seguida diminuem de magnitude. Este comportamento também pode ser encontrado no CAP 50/70, embora com intensidade muito menor do que a observada no CAP+EVA.

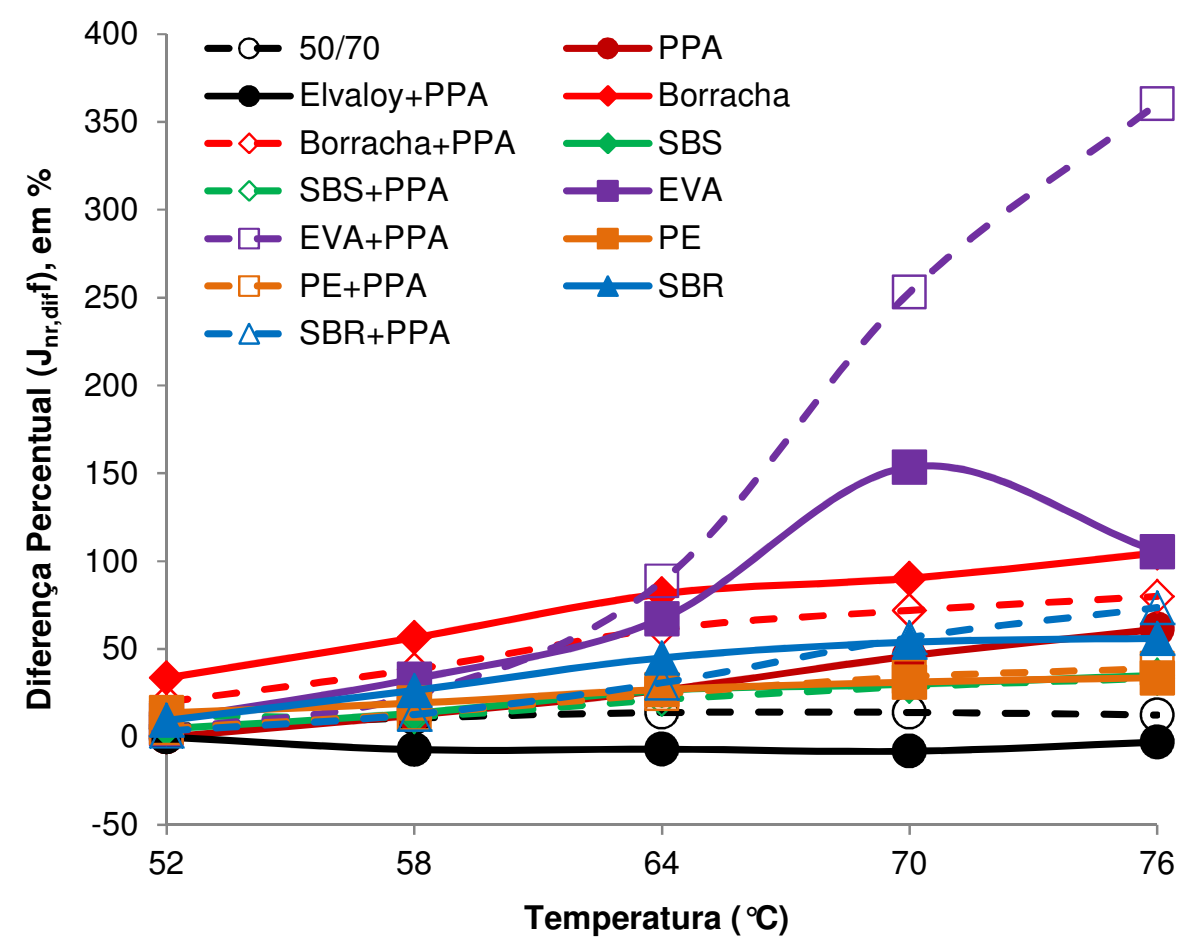

Figura 107 - Diferenças percentuais entre as compliâncias não-recuperáveis $\left(J_{n r, d i f f}\right)$ dos ligantes asfálticos na condição envelhecida e nos tempos de 1 e $9 \mathrm{~s}$ 
A Figura 108 mostra os gráficos de $J_{n r, d i f f}$ para todos os ligantes asfálticos, considerando a condição envelhecida destes materiais e os tempos de fluência e recuperação de 2 e $18 \mathrm{~s}$. O CAP+EVA+PPA possui as maiores diferenças percentuais nas temperaturas de 64,70 e $76^{\circ} \mathrm{C}$ e, por consequência, a maior sensibilidade à tensão nestas condições. $\mathrm{O}$ $\mathrm{CAP}+$ Elvaloy+PPA possui as menores diferenças percentuais ao longo de todo o espectro de temperaturas, de modo que este material pode ser considerado como o menos sensível à tensão. As duas formulações com borracha moída possuem valores praticamente semelhantes de $\mathrm{J}_{\text {nr,dift }}$ nas temperaturas de 70 e $76^{\circ} \mathrm{C}$, o que indica sensibilidades iguais para ambos os ligantes asfálticos ao incremento do nível de tensão de 100 para 3.200 Pa. Valores muito próximos de $J_{n r, d i f f}$ também podem ser encontrados nos seguintes grupos de ligantes asfálticos, dentre outros: (1) o grupo formado pelo $C A P+S B S+P P A$ e pelo $C A P+P E+P P A$ nas temperaturas de 70 e $76^{\circ} \mathrm{C}$; (2) o grupo formado pelo CAP+SBS e pelo CAP+PE nas temperaturas de 64,70 e $76{ }^{\circ} \mathrm{C}$; (3) o grupo formado pelo CAP 50/70, pelo CAP+PPA, pelo $\mathrm{CAP}+\mathrm{SBS}$, pelo $\mathrm{CAP}+\mathrm{SBS}+\mathrm{PPA}$, pelo $\mathrm{CAP}+\mathrm{PE}+\mathrm{PPA}$ e pelo $\mathrm{CAP}+\mathrm{SBR}+\mathrm{PPA}$ na temperatura de $52^{\circ} \mathrm{C}$; e (4) o grupo formado pelo $C A P+$ borracha e pelo $C A P+E V A+P P A$ na temperatura de $58^{\circ} \mathrm{C}$. Interessante observar que o gráfico do CAP+EVA possui um comportamento muito distinto dos demais ligantes asfálticos (incluindo o CAP 50/70), com um valor mínimo de $\mathrm{J}_{\text {nr,diff }}$ a $58^{\circ} \mathrm{C}$ e um valor máximo desta propriedade a $70^{\circ} \mathrm{C}$.

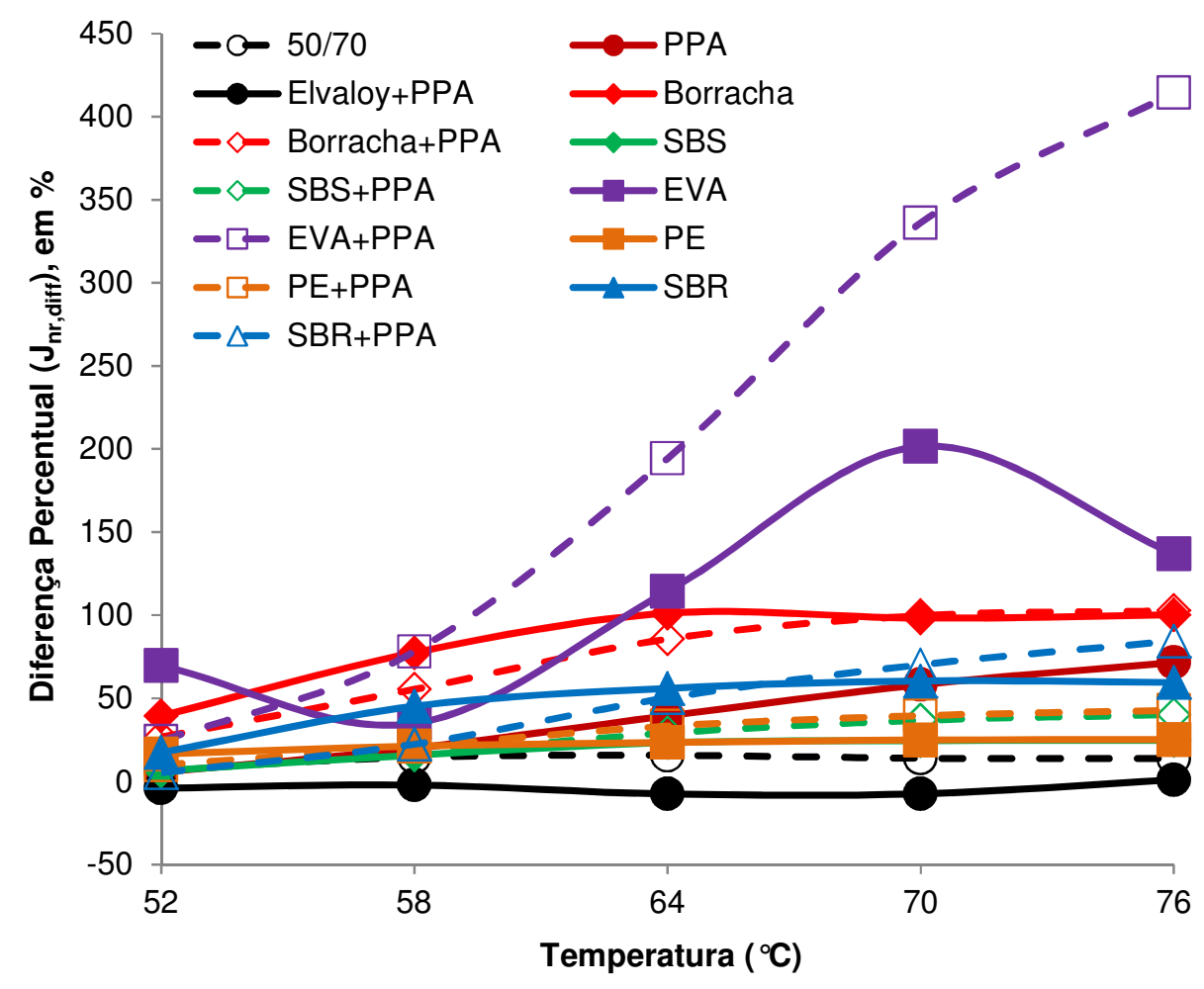

Figura 108 - Diferenças percentuais entre as compliâncias não-recuperáveis ( $\left.J_{n r, d i f f}\right)$ dos ligantes asfálticos na condição envelhecida e nos tempos de 2 e $18 \mathrm{~s}$ 
A Figura 109 mostra as relações entre os percentuais de recuperação dos ligantes asfálticos (parâmetro $\mathrm{R}_{\mathrm{R}}$ ) no nível de tensão de $100 \mathrm{~Pa}$. Os incrementos do percentual de recuperação são próximos entre si a 52 e a $58^{\circ} \mathrm{C}$ para todos os ligantes asfálticos modificados, o que, até certo ponto, dificulta a distinção entre os modificadores. $A$ formulação com SBR+PPA apresenta os valores mais elevados de $R_{R}$ nas temperaturas de até $70^{\circ} \mathrm{C}$ dentre os ligantes asfálticos modificados, de modo que, em linhas gerais, esta formulação pode ser considerada como a mais sensível ao envelhecimento a curto prazo. A formulação com SBS+PPA possui o maior valor de $R_{R}$ na temperatura de $76^{\circ} \mathrm{C}$, de modo que este ligante asfáltico pode ser considerado como o mais sensível ao envelhecimento a curto prazo nas condições citadas. Os incrementos do percentual de recuperação são elevados para o CAP 50/70 nas temperaturas de 52 e $58^{\circ} \mathrm{C}$, sendo maiores do que todos os ligantes asfálticos modificados nestas condições. Diversas formulações apresentam incrementos entre 1 e 4 vezes no percentual de recuperação a $100 \mathrm{~Pa}$ após o envelhecimento a curto prazo, sendo eles o CAP+Elvaloy+PPA, o CAP+borracha, 0 CAP+borracha+PPA, O CAP+SBS, O CAP+EVA, O CAP+EVA+PPA e o CAP+SBR. O $\mathrm{CAP}+\mathrm{PE}$ e o $\mathrm{CAP}+\mathrm{PE}+\mathrm{PPA}$ possuem valores praticamente iguais de $\mathrm{R}_{\mathrm{R}}$ na temperatura de $76^{\circ} \mathrm{C}$, o que indica sensibilidades similares para ambos os ligantes asfálticos ao envelhecimento a curto prazo nesta temperatura.

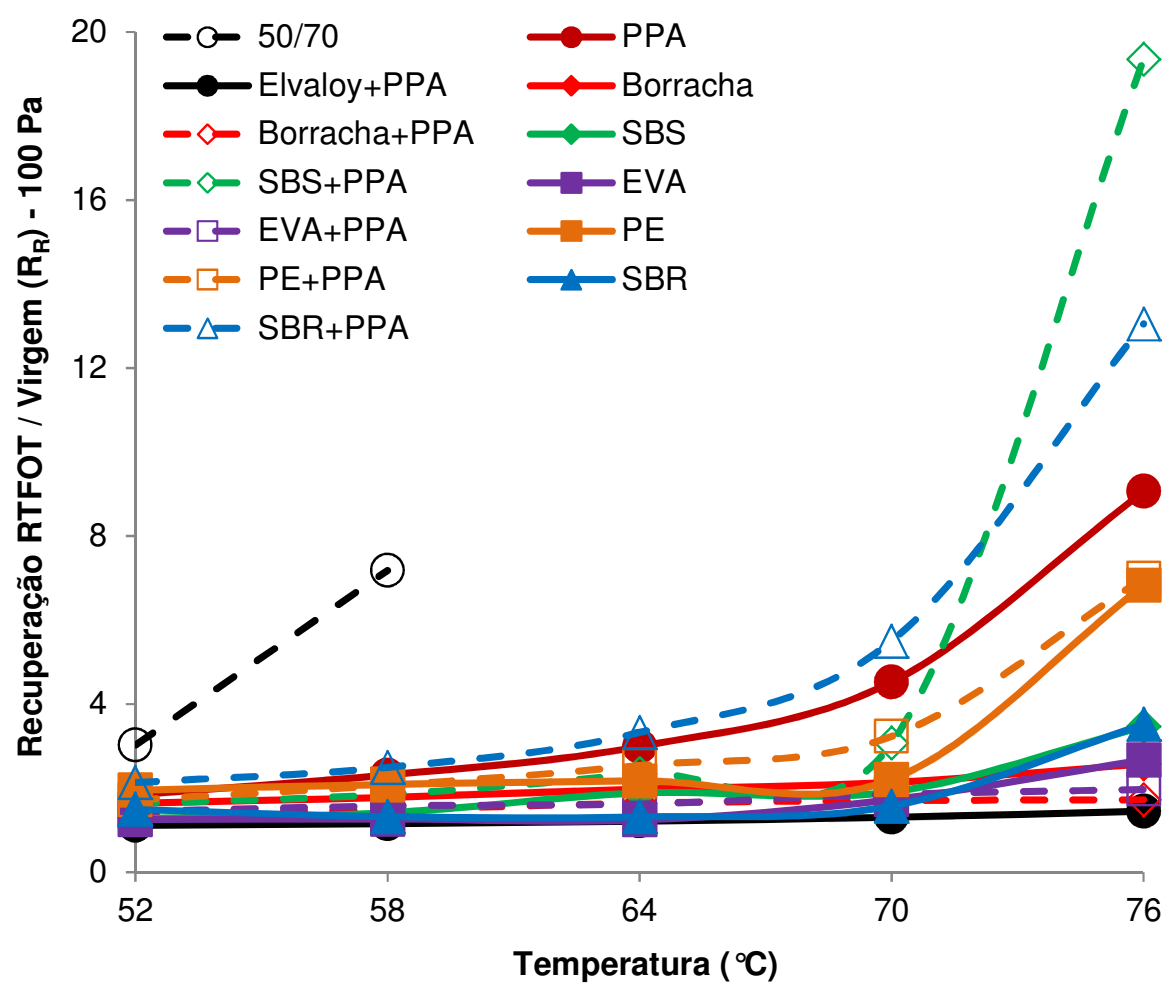

Figura 109 - Relações entre os percentuais de recuperação $\left(R_{R}\right)$ dos ligantes asfálticos na tensão de $100 \mathrm{~Pa}$ e nos tempos de 1 e $9 \mathrm{~s}$ 
A Figura 110 apresenta as relações entre os percentuais de recuperação dos ligantes asfálticos no nível de tensão de 3.200 Pa. Poucas relações puderam ser calculadas para a maioria dos ligantes asfálticos modificados, muitas delas apenas nas temperaturas de até $64^{\circ} \mathrm{C}$. O CAP+Elvaloy+PPA possui valores muito baixos de $R_{R}$ ao longo de todo o espectro de temperaturas, de modo que, em linhas gerais, este ligante asfáltico pode ser considerado como o menos sensível ao envelhecimento a curto prazo. Valores praticamente semelhantes de $R_{R}$ podem ser encontrados nos seguintes grupos de ligantes asfálticos: (1) o grupo formado pelo $\mathrm{CAP}+\mathrm{SBS}$, pelo $\mathrm{CAP}+\mathrm{SBR}$ e pelo $\mathrm{CAP}+\mathrm{EVA}+\mathrm{PPA}$ nas temperaturas de 52, 58 e $64^{\circ} \mathrm{C}$; (2) o grupo formado pelo $C A P+S B R+P P A$, pelo $C A P+$ borracha+PPA e pelo $\mathrm{CAP}+\mathrm{SBS}+\mathrm{PPA}$ nas temperaturas de até $64^{\circ} \mathrm{C}$; e (3) o grupo formado pelo $\mathrm{CAP}+$ Elvaloy+PPA e pelo $\mathrm{CAP}+\mathrm{EVA}$ nas temperaturas de até $64^{\circ} \mathrm{C}$. A formulação com PPA possui um valor significativamente alto de $R_{R}$ (superior a 40) na temperatura de $64^{\circ} \mathrm{C}$ e, da mesma maneira, as formulações com SBR+PPA, borracha+PPA e SBS+PPA possuem valores elevados de $R_{R}$ (superiores a 10) nesta mesma temperatura.

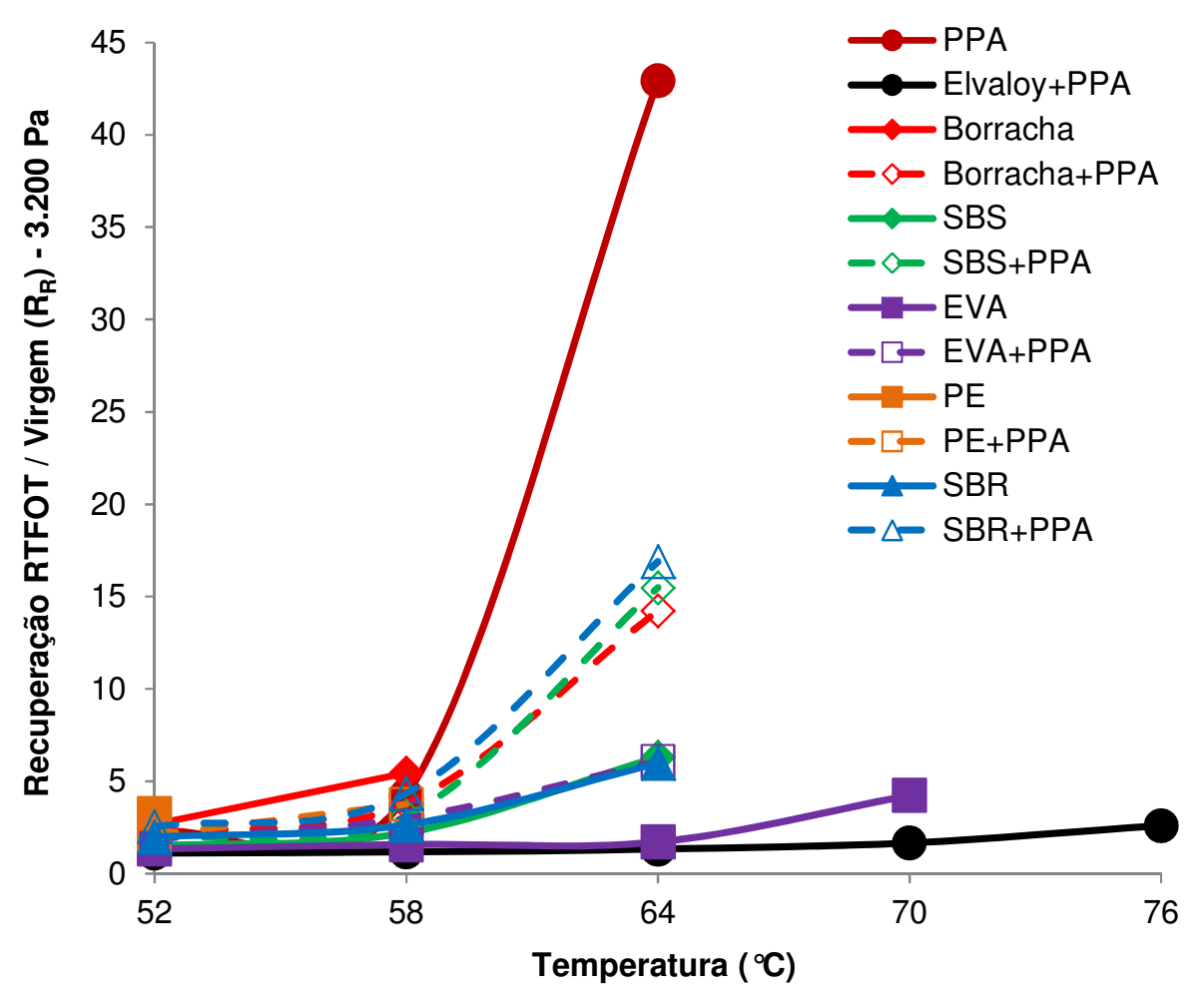

Figura 110 - Relações entre os percentuais de recuperação $\left(R_{R}\right)$ dos ligantes asfálticos na tensão de $3.200 \mathrm{~Pa}$ e nos tempos de 1 e $9 \mathrm{~s}$

A Figura 111 apresenta as relações entre as compliâncias não-recuperáveis dos ligantes asfálticos (parâmetro $R_{J}$ ) no nível de tensão de $100 \mathrm{~Pa}$. O CAP+SBR+PPA possui os valores mais elevados de $R_{J}$ ao longo de todo o espectro de temperaturas, de modo que esta 
formulação pode ser considerada como a mais sensível ao envelhecimento a curto prazo. $O$ CAP+SBS possui os valores mais baixos de $R_{\mathrm{J}}$ nas temperaturas de 52,58 e $70^{\circ} \mathrm{C}$, de modo que, em linhas gerais, este material pode ser considerado como o menos sensível ao envelhecimento a curto prazo. O CAP+PPA e o CAP+EVA+PPA apresentam valores praticamente similares de $R_{J}$ nas temperaturas de 70 e $76^{\circ} \mathrm{C}$, o que indica sensibilidades parecidas de ambos os materiais ao RTFOT. Valores similares para este parâmetro também são encontrados em outros grupos de ligantes asfálticos, tais como: (1) o grupo formado pelo $\mathrm{CAP}+\mathrm{SBS}+\mathrm{PPA}$ e pelo $\mathrm{CAP}+\mathrm{PE}+\mathrm{PPA}$ nas temperaturas de $58,64,70$ e $76^{\circ} \mathrm{C}$; (2) o grupo formado pelo CAP 50/70 e pelo CAP+PE ao longo de todo o espectro de temperaturas; e (3) o grupo formado pelo $\mathrm{CAP}+\mathrm{SBS}$, pelo $\mathrm{CAP}+\mathrm{EVA}$ e pelo $\mathrm{CAP}+\mathrm{SBR}$ nas temperaturas de $64 \mathrm{e}$ $70^{\circ} \mathrm{C}$. Em linhas gerais, as relações entre as compliâncias não-recuperáveis virgens e envelhecidas dos ligantes asfálticos a $100 \mathrm{~Pa}$ diminuem com o incremento da temperatura, o que indica uma redução da sensibilidade destes materiais ao envelhecimento a curto prazo. São exceções o $\mathrm{CAP}+\mathrm{EVA}+\mathrm{PPA}$, o $\mathrm{CAP}+\mathrm{Elvaloy+PPA}$, cujos gráficos registram aumentos do parâmetro $R_{J}$ (aumento da sensibilidade ao RTFOT) na maioria das temperaturas.

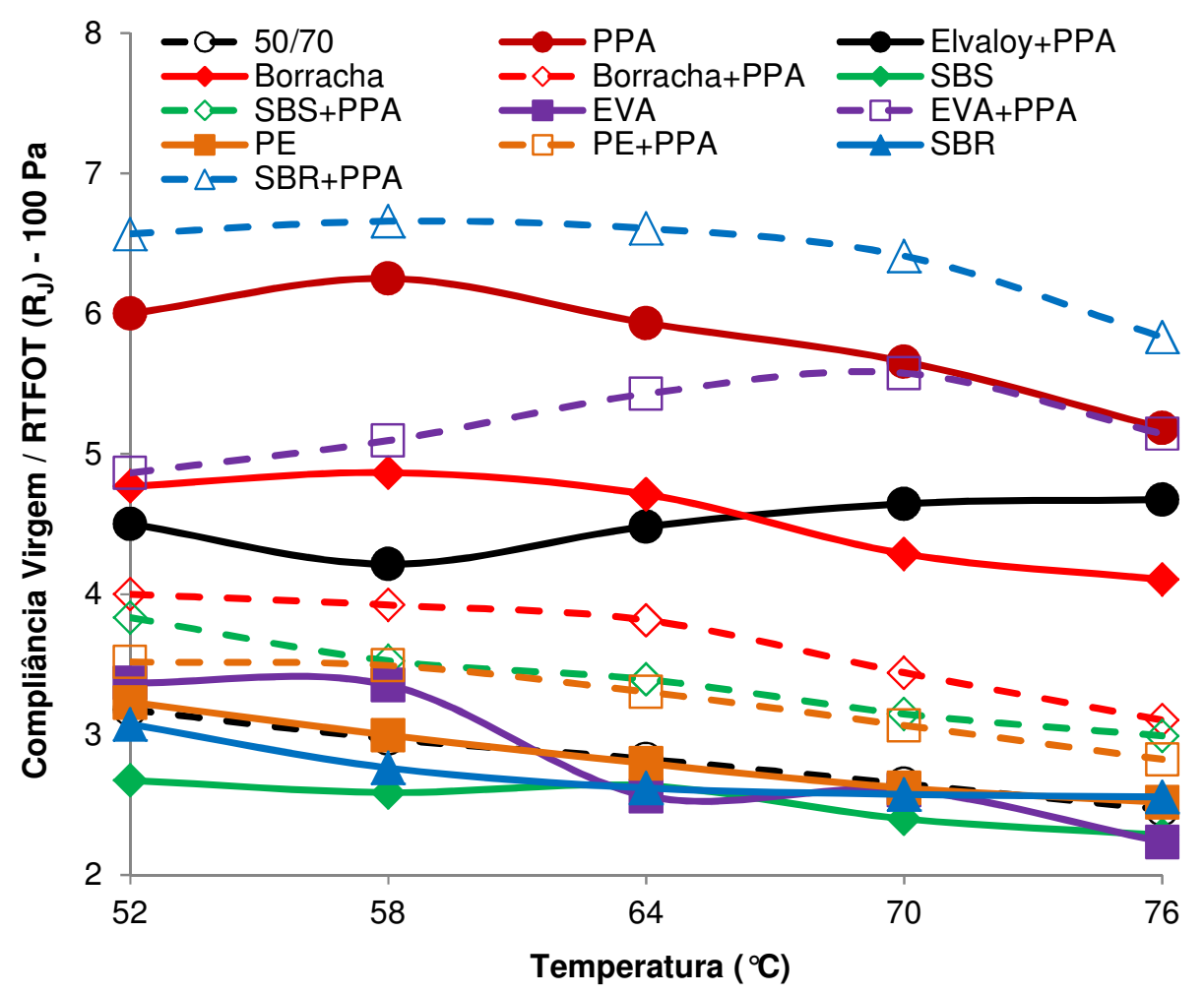

Figura 111 - Relações entre as compliâncias não-recuperáveis $\left(R_{J}\right)$ dos ligantes asfálticos na tensão de $100 \mathrm{~Pa}$ e nos tempos de 1 e $9 \mathrm{~s}$

A Figura 112 apresenta os valores do parâmetro $R_{J}$ para todos os ligantes asfálticos no nível de tensão de 3.200 Pa. De uma maneira geral, é possível observar que os valores de 


\section{8}

$\mathrm{R}_{\mathrm{J}}$ diminuem com o incremento da temperatura, o que indica uma diminuição da sensibilidade dos ligantes asfálticos ao envelhecimento a curto prazo. A exceção a este padrão de comportamento é o ligante asfáltico modificado com Elvaloy+PPA, para o qual o incremento da temperatura acarreta um aumento de $R_{J}$, especialmente nas temperaturas acima de $58^{\circ} \mathrm{C}$. $\mathrm{O}$ CAP+Elvaloy+PPA apresenta os maiores valores de $R_{J}$ (maior sensibilidade ao RTFOT) nas temperaturas de 70 e $76^{\circ} \mathrm{C}$ e o CAP+EVA possui os menores (menor sensibilidade ao RTFOT) nestas mesmas temperaturas. As formulações com PPA, EVA, EVA+PPA e SBR apresentam comportamentos distintos da maioria dos ligantes asfálticos, sendo que os valores de $R_{J}$ aumentam até a temperatura de $58^{\circ} \mathrm{C}$ e diminuem nas temperaturas subsequentes para estes três materiais. Não são observadas diferenças significativas entre os resultados do $\mathrm{CAP}+\mathrm{EVA}+\mathrm{PPA}$ e do $\mathrm{CAP}+\mathrm{SBR}+\mathrm{PPA}$ nas temperaturas de 58 e $64^{\circ} \mathrm{C}$, o mesmo ocorrendo com os seguintes grupos de ligantes asfálticos, dentre outros: (1) o grupo formado pelo $\mathrm{CAP}+\mathrm{SBS}+\mathrm{PPA}$ e pelo $\mathrm{CAP}+\mathrm{PE}+\mathrm{PPA}$ ao longo de todo o espectro de temperaturas; (2) o grupo formado pelo $\mathrm{CAP}+\mathrm{PE}$, pelo $\mathrm{CAP}$ 50/70 e pelo $\mathrm{CAP}+\mathrm{SBR}$ ao longo de todo o espectro de temperaturas; e (3) o grupo formado pelo $C A P+P P A$ e pelo $C A P+S B R+P P A$ nas temperaturas de 70 e $76^{\circ} \mathrm{C}$. O CAP+SBS apresenta resultados muito próximos aos do CAP 50/70, do $\mathrm{CAP}+\mathrm{PE}$ e do $\mathrm{CAP}+\mathrm{SBR}$, especialmente nas temperaturas de 64,70 e $76^{\circ} \mathrm{C}$.

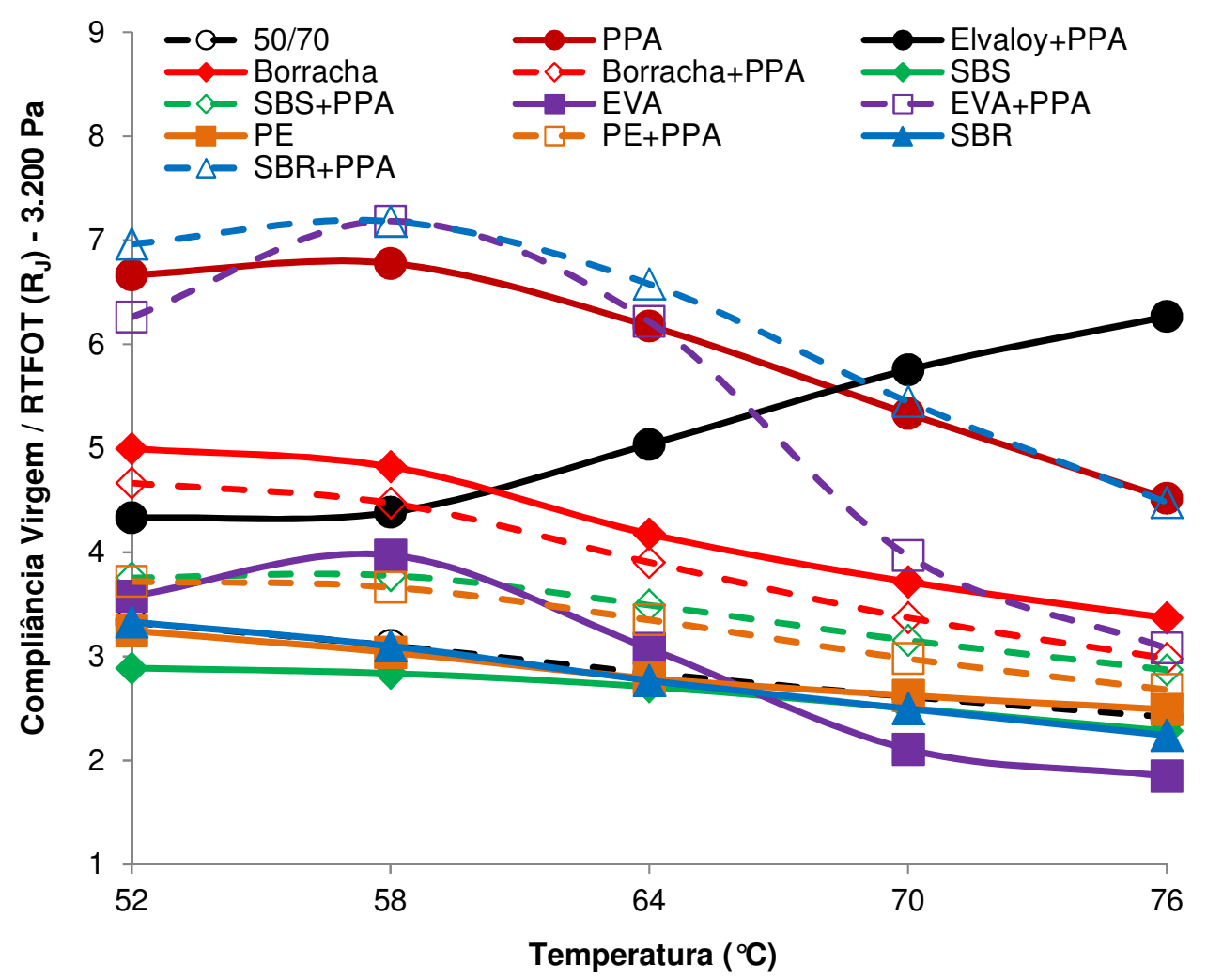

Figura 112 - Relações entre as compliâncias não-recuperáveis $\left(R_{J}\right)$ dos ligantes asfálticos na tensão de 3.200 Pa e nos tempos de 1 e $9 \mathrm{~s}$ 
A Figura 113 mostra os gráficos das relações entre os percentuais de recuperação dos ligantes asfálticos nos dois tempos de fluência e recuperação (parâmetro $R_{P}$ ), considerando o nível de tensão de $100 \mathrm{~Pa}$. À exceção do ligante asfáltico puro, o CAP+PE e o CAP+SBS apresentam os valores mais elevados de $R_{P}$ ao longo de todo o espectro de temperaturas, o que indica a elevada sensibilidade destes ligantes asfálticos ao aumento dos tempos de fluência e recuperação de 1 e $9 \mathrm{~s}$ para 2 e $18 \mathrm{~s}$. Os resultados do CAP+PE e do CAP+SBS são muito próximos entre si nas temperaturas de 52,58 e $64^{\circ} \mathrm{C}$, sendo maior para o CAP+PE na temperatura de $70^{\circ} \mathrm{C}$ e maior para o $\mathrm{CAP}+\mathrm{SBS}$ na temperatura de $76^{\circ} \mathrm{C}$. A maioria dos ligantes asfálticos (incluindo o CAP 50/70) apresenta valores de $R_{P}$ menores ou iguais a 2,0 ao longo de todo o espectro de temperaturas, sendo eles, o CAP 50/70, o CAP+PPA, o CAP+Elvaloy+PPA, o CAP+borracha, o CAP+borracha+PPA, o CAP+SBS+PPA, o CAP+EVA, o CAP+EVA+PPA, o $\mathrm{CAP}+\mathrm{PE}+\mathrm{PPA}$, O CAP+SBR e o $\mathrm{CAP}+\mathrm{SBR}+\mathrm{PPA}$. Os resultados de $\mathrm{R}_{\mathrm{P}}$ são visivelmente menores para o CAP+borracha+PPA nas temperaturas de 64,70 e $76{ }^{\circ} \mathrm{C}$ em comparação aos demais ligantes asfálticos, o que indica a baixa sensibilidade deste material ao aumento dos tempos de fluência e recuperação de 1 e $9 \mathrm{~s}$ para 2 e $18 \mathrm{~s}$.

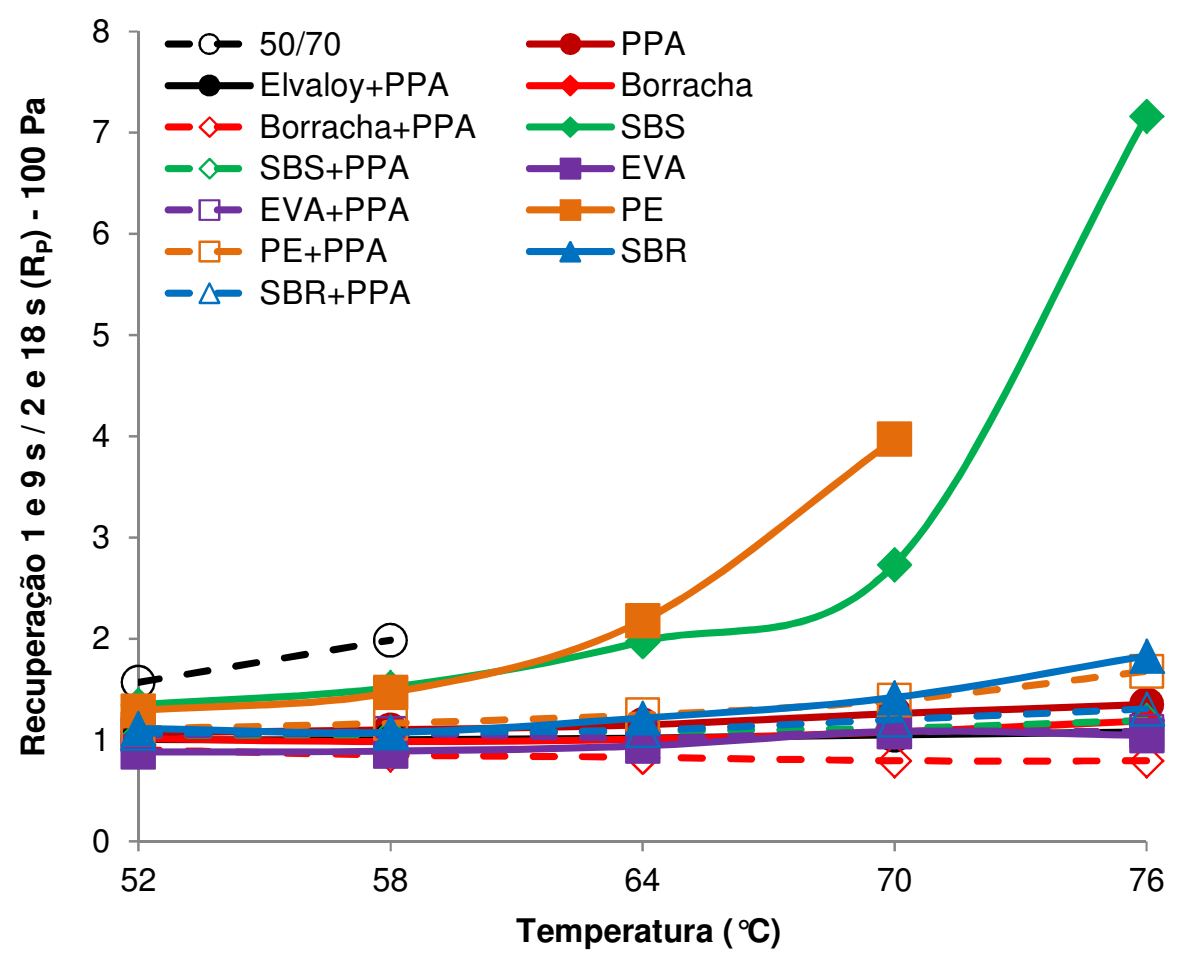

Figura 113 - Relações entre os percentuais de recuperação a 1 e 9 s e 2 e 18 s $\left(R_{P}\right)$ no nível de tensão de $100 \mathrm{~Pa}$

A Figura 114 apresenta os gráficos de $R_{P}$ para todos os ligantes asfálticos modificados e o CAP 50/70, considerando o nível de tensão de 3.200 Pa. Muitos valores de $R_{P}$ não puderam ser calculados para a maioria dos ligantes asfálticos, especialmente nas 


\section{0}

temperaturas mais elevadas, nas quais os percentuais de recuperação são nulos nos tempos de 2 e 18 s. As relações entre os percentuais de recuperação a $3.200 \mathrm{~Pa}$ são parecidas para a maioria dos ligantes asfálticos nas temperaturas de 52 e $58^{\circ} \mathrm{C}$, o mesmo ocorrendo com o $\mathrm{CAP}+\mathrm{EVA}$, o $\mathrm{CAP}+\mathrm{EVA}+\mathrm{PPA}$, o $\mathrm{CAP}+\mathrm{PPA}$ e o $\mathrm{CAP}+\mathrm{SBS}+\mathrm{PPA}$ na temperatura de $70^{\circ} \mathrm{C}$. $\mathrm{A}$ exceção do CAP 50/70, é possível observar que o CAP+PE possui os maiores valores de $R_{P}$ (maior sensibilidade ao aumento dos tempos de fluência e recuperação) nas temperaturas de 52 e $58^{\circ} \mathrm{C}$, sendo que estes maiores valores são encontrados no CAP+SBS, no CAP+SBS+PPA e no $\mathrm{CAP}+\mathrm{SBR}+\mathrm{PPA}$ nas temperaturas de 64,70 e $76{ }^{\circ} \mathrm{C}$, respectivamente. As formulações com Elvaloy+PPA e borracha+PPA possuem os menores valores de $R_{P}$ nas temperaturas de 70 e $76{ }^{\circ} \mathrm{C}$, o que indica as menores sensibilidades destes materiais ao aumento dos tempos de fluência e recuperação de 1 e $9 \mathrm{~s}$ para 2 e $18 \mathrm{~s}$. As variações de $\mathrm{R}_{\mathrm{P}}$ são muito pequenas para o $\mathrm{CAP}+$ Elvaloy+PPA ao longo de todo o espectro de temperaturas e, diferentemente do observado na maioria dos ligantes asfálticos, os valores de $R_{P}$ diminuem com o incremento da temperatura no caso do CAP+borracha+PPA, o que indica uma redução da sensibilidade deste material ao aumento dos tempos de fluência e recuperação de 1 e $9 \mathrm{~s}$ para 2 e $18 \mathrm{~s}$.

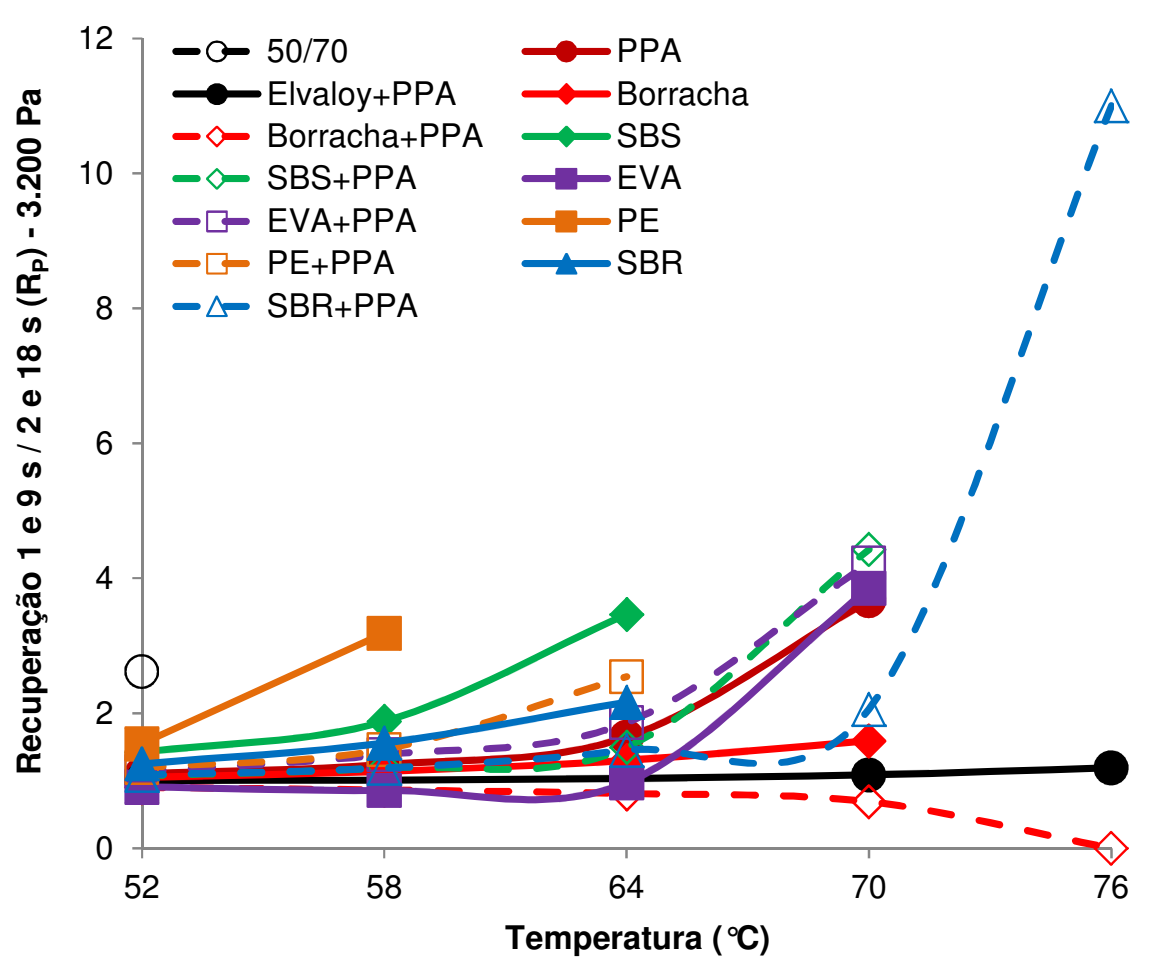

Figura 114 - Relações entre os percentuais de recuperação a 1 e 9 s e 2 e 18 s $\left(R_{P}\right)$ no nível de tensão de $3.200 \mathrm{~Pa}$

A Figura 115 (página 282) apresenta as relações entre as os valores de $J_{n r}$ dos ligantes asfálticos nos tempos de 2 e $18 \mathrm{~s}$ e nos tempos de 1 e $9 \mathrm{~s}$ (parâmetro $\mathrm{R}_{\mathrm{C}}$ ), considerando o nível de tensão de $100 \mathrm{~Pa}$. Os resultados dos ligantes asfálticos estão todos 
situados entre 0,5 e 2,5, sendo maiores para o CAP+SBS nas temperaturas de até $64^{\circ} \mathrm{C}$ e menores para o CAP+borracha+PPA nas temperaturas de 64,70 e $76{ }^{\circ} \mathrm{C}$. $\mathrm{O}$ incremento da temperatura acarreta, em linhas gerais, um aumento dos valores de $R_{C}$, o que indica uma maior sensibilidade dos materiais ao aumento dos tempos de fluência e recuperação de 1 e $9 \mathrm{~s}$ para 2 e $18 \mathrm{~s}$. O CAP+EVA apresenta um incremento significativo de $R_{C}$ em comparação aos demais ligantes asfálticos, especialmente nas temperaturas entre 58 e $70^{\circ} \mathrm{C}$, de modo que a sensibilidade deste ligante asfáltico à temperatura pode ser considerada elevada. Situação diferente ocorre com o CAP+borracha+PPA, o CAP+SBS+PPA, o CAP+PE+PPA e o CAP puro, para os quais o incremento da temperatura de 52 para $76^{\circ} \mathrm{C}$ praticamente não acarreta alterações nos valores de $R_{C}$. O CAP+Elvaloy+PPA e o $C A P+S B R$ apresentam valores mínimos de $R_{C}$ na temperatura de $58^{\circ} \mathrm{C}$, sendo mais visível para a formulação com Elvaloy+PPA e menos visível para a formulação com SBR. O CAP+borracha possui resultados muito próximos aos do CAP+Elvaloy+PPA nas temperaturas acima de $58^{\circ} \mathrm{C}$, o que indica que as sensibilidades destes ligantes asfálticos ao aumento dos tempos de fluência e recuperação de 1 e 9 s para 2 e $18 \mathrm{~s}$ podem ser consideradas similares nestas condições. Valores parecidos de $R_{C}$ também são encontrados nos seguintes grupos de ligantes asfálticos, dentre outros: (1) CAP+SBR+PPA e CAP+PPA ao longo de todo o espectro de temperaturas; (2) CAP 50/70 e CAP+PE+PPA ao longo de todo o espectro de temperaturas; e (3) CAP+PE+PPA, CAP 50/70 e CAP+EVA+PPA nas temperaturas de até $64^{\circ} \mathrm{C}$.

A Figura 116 ilustra os gráficos de $R_{C}$ para todos os ligantes asfálticos, considerando o nível de tensão de 3.200 Pa. Os resultados estão entre 0,5 e 3,0 para o CAP puro e os ligantes asfálticos modificados, sendo maiores para o CAP+EVA+PPA ao longo de todo o espectro de temperaturas e menores para o CAP+borracha+PPA nas temperaturas de 64,70 e $76^{\circ} \mathrm{C}$. Em linhas gerais, o incremento da temperatura acarreta um aumento dos valores de $R_{C}$, o que indica uma maior sensibilidade dos ligantes asfálticos ao aumento dos tempos de fluência e recuperação de 1 e $9 \mathrm{~s}$ para 2 e $18 \mathrm{~s}$. As duas formulações com EVA apresentam incrementos significativos de $R_{C}$ em comparação aos demais ligantes asfálticos, de modo que as sensibilidades de ambos os materiais à temperatura podem ser consideradas elevadas. Situação diferente ocorre com os demais ligantes asfálticos (incluindo o CAP 50/70), para os quais o incremento da temperatura de 52 para $76{ }^{\circ} \mathrm{C}$ praticamente não acarreta alterações significativas de $R_{C}$. O CAP+Elvaloy+PPA possui um valor mínimo de $R_{C}$ na temperatura de $58^{\circ} \mathrm{C}$ e o CAP+EVA+PPA, um valor máximo na temperatura de $64^{\circ} \mathrm{C}$. Resultados parecidos de $\mathrm{R}_{\mathrm{C}}-\mathrm{e}$, por consequência, sensibilidades parecidas ao aumento dos tempos de fluência e recuperação - são encontrados nos seguintes grupos de ligantes asfálticos, dentre outros: (1) $\mathrm{CAP}+\mathrm{SBS}$ e CAP+SBR em todas as temperaturas; (2) CAP 50/70 e CAP+PE+PPA em todas as temperaturas; e (3) CAP+PPA e CAP+SBR+PPA em todas as temperaturas. 


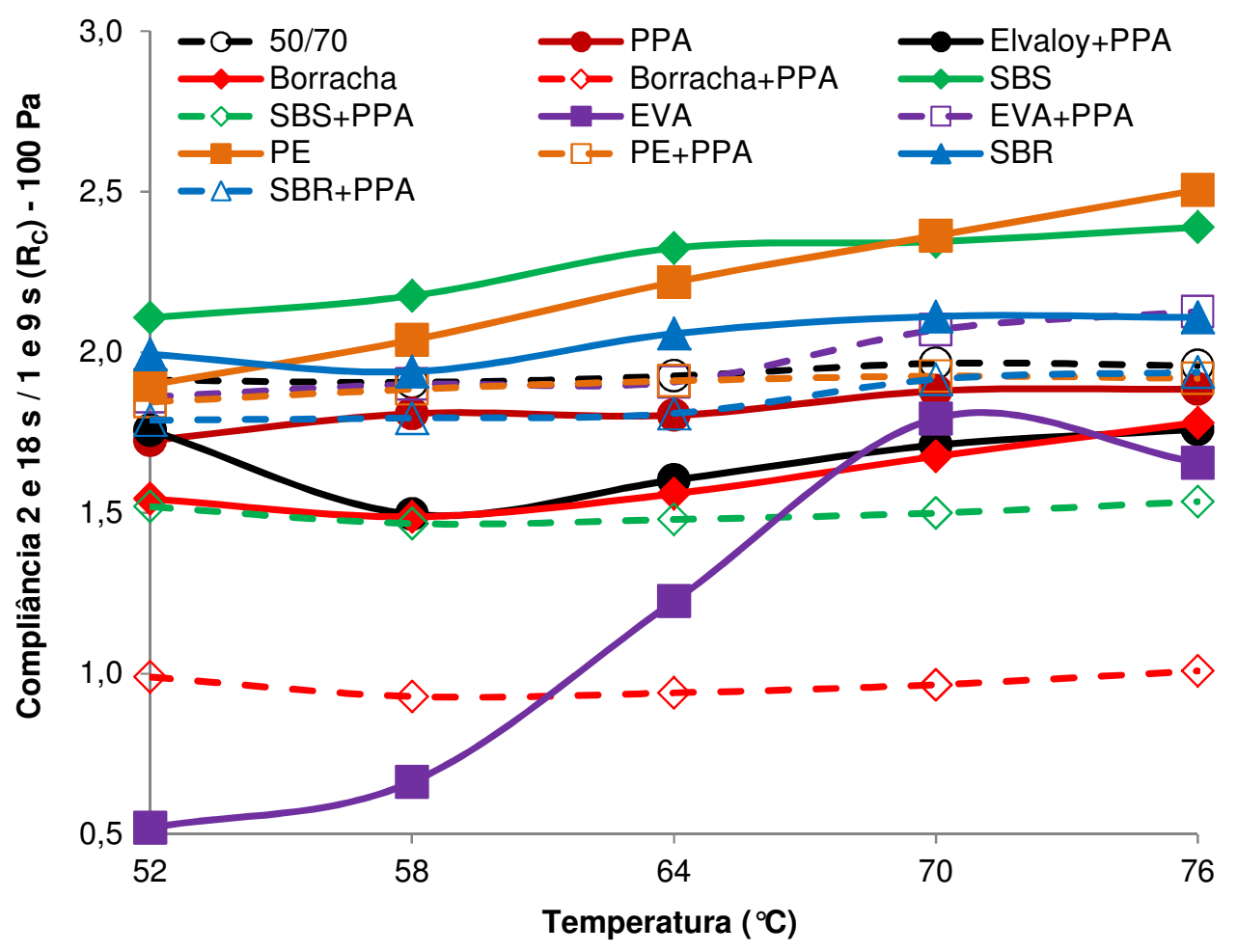

Figura 115 - Relações entre as compliâncias não-recuperáveis a 2 e 18 s e 1 e 9 s $\left(R_{C}\right)$ no nível de tensão de $100 \mathrm{~Pa}$

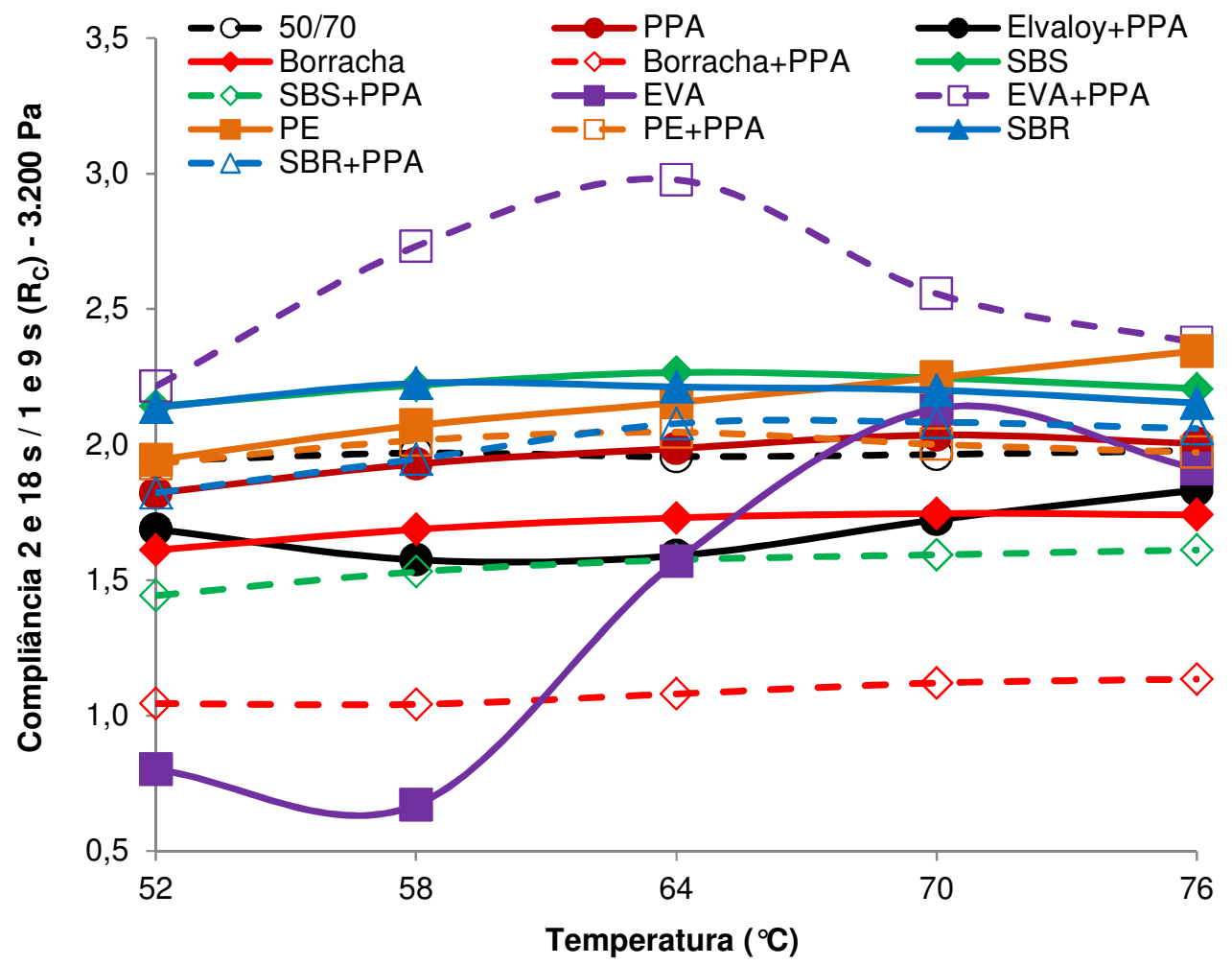

Figura 116 - Relações entre as compliâncias não-recuperáveis a 2 e 18 s e 1 e 9 s $\left(R_{C}\right)$ no nível de tensão de $3.200 \mathrm{~Pa}$ 


\section{CONCLUSÕES E SUGESTÕES DE PESQUISAS}

Este estudo teve, como objetivo principal, avaliar o efeito do tipo de modificador no comportamento fluência-recuperação de ligantes asfálticos modificados em temperaturas altas, considerando os procedimentos de ensaio prescritos na ASTM D7405 e utilizando materiais em suas condições virgem e envelhecida a curto prazo. Com o intuito de verificar os efeitos do aumento dos tempos de fluência e recuperação no percentual de recuperação e na compliância não-recuperável, foram realizados também ensaios nos tempos de 2 e $18 \mathrm{~s}$, considerando apenas os ligantes asfálticos envelhecidos a curto prazo. O programa experimental contemplou um total de 12 ligantes asfálticos modificados e de classificação PG 76-XX: CAP+PPA, $\mathrm{CAP}+$ Elvaloy+PPA, CAP+borracha, CAP+borracha+PPA, CAP+SBS, CAP+SBS+PPA, $\mathrm{CAP}+\mathrm{EVA}, \mathrm{CAP}+\mathrm{EVA}+\mathrm{PPA}, \mathrm{CAP}+\mathrm{PE}, \mathrm{CAP}+\mathrm{PE}+\mathrm{PPA}, \mathrm{CAP}+\mathrm{SBR}$ e CAP+SBR+PPA . Estes ligantes asfálticos modificados foram preparados com base em um CAP 50/70 de classificação PG 64-XX, fornecido pela REPLAN-Petrobras.

\subsection{Conclusões principais}

As propriedades e parâmetros de interesse foram organizados na forma de requisitos, conforme indicado na Tabela 90, aos quais foram associadas médias dos parâmetros e propriedades constantes de cada requisito. As perguntas a serem respondidas são:

a) Quais são os CAPs que apresentam maior ganho de $\mathrm{R}$ em relação ao CAP 50/70?

b) Quais são os CAPs que apresentam maior redução de $\mathrm{J}_{\mathrm{nr}}$ em relação ao ligante asfáltico puro?

c) Do ponto de vista de sensibilidade ao envelhecimento, quais são os ligantes asfálticos mais sensíveis ao envelhecimento a curto prazo?

d) Quais são os ligantes asfálticos mais sensíveis ao incremento do nível de tensão?

e) Quais são os ligantes asfálticos menos sensíveis ao aumento dos tempos de fluência e recuperação?

f) Quais são os ligantes asfálticos com resultados melhores do que o CAP+PPA em termos do percentual de recuperação e da compliância não-recuperável?

g) Dentre as formulações CAP+modificador e CAP+modificador+PPA, quais apresentam melhores e piores resultados?

h) Dentre as formulações de mesmo grau de desempenho, quais se destacam positiva e negativamente em relação ao CAP+PPA? 
Tabela 90 - Posições médias dos ligantes asfálticos por requisitos de interesse

\begin{tabular}{|c|c|c|c|c|c|c|c|c|c|c|c|c|c|}
\hline \multirow[b]{2}{*}{ Requisitos de interesse } & \multirow[b]{2}{*}{$50 / 70$} & \multirow[b]{2}{*}{ PPA } & \multicolumn{9}{|c|}{ Ligantes asfálticos } & \multirow[b]{2}{*}{ SBR } & \multirow[b]{2}{*}{$\begin{array}{l}\text { SBR } \\
\text { PPA }\end{array}$} \\
\hline & & & $\begin{array}{l}\text { Elvaloy } \\
\text { PPA }\end{array}$ & Borracha & $\begin{array}{l}\text { Borracha } \\
\text { PPA }\end{array}$ & SBS & $\begin{array}{l}\text { SBS } \\
\text { PPA }\end{array}$ & EVA & $\begin{array}{l}\text { EVA } \\
\text { PPA }\end{array}$ & PE & $\begin{array}{c}\text { PE } \\
\text { PPA }\end{array}$ & & \\
\hline $\begin{array}{l}\text { Penetração retida, incremento } \\
\text { do ponto de amolecimento e } \\
\text { perda de massa }\end{array}$ & 8,00 & 10,00 & 6,00 & 10,00 & 10,67 & 6,67 & 6,33 & 8,33 & 6,33 & 2,33 & 5,00 & 2,00 & 9,33 \\
\hline $\begin{array}{l}\text { Viscosidade rotacional na } \\
\text { condição virgem }\end{array}$ & 1,00 & 2,00 & 7,20 & 12,00 & 11,00 & 7,20 & 6,40 & 13,00 & 8,20 & 9,00 & 5,40 & 5,40 & 3,20 \\
\hline $\begin{array}{l}\text { Incremento de viscosidade } \\
\text { rotacional após o RTFOT }\end{array}$ & 4,60 & 11,80 & 10,40 & 10,20 & 12,80 & 2,60 & 7,40 & 4,80 & 5,20 & 2,20 & 7,60 & 1,60 & 9,80 \\
\hline $\begin{array}{c}\text { Percentual de recuperação após } \\
\text { o RTFOT }-1 \text { e } 9 \mathrm{~s}\end{array}$ & 13,00 & 5,20 & 1,00 & 5,10 & 6,56 & 8,80 & 9,67 & 3,22 & 2,80 & 12,00 & 9,22 & 9,67 & 4,10 \\
\hline $\begin{array}{c}\text { Percentual de recuperação após } \\
\text { o RTFOT - } 2 \text { e } 18 \mathrm{~s}\end{array}$ & 13,00 & 6,33 & 1,40 & 5,33 & 3,10 & 11,00 & 8,33 & 3,11 & 3,56 & 12,00 & 9,63 & 9,00 & 4,80 \\
\hline $\begin{array}{l}\text { Compliância não-recuperável } \\
\text { após o RTFOT - } 1 \text { e } 9 \mathrm{~s}\end{array}$ & 13,00 & 3,80 & 2,20 & 7,80 & 7,20 & 9,70 & 7,70 & 3,20 & 2,40 & 11,20 & 7,20 & 11,80 & 3,80 \\
\hline $\begin{array}{l}\text { Compliância não-recuperável } \\
\text { após o RTFOT - } 2 \text { e } 18 \mathrm{~s}\end{array}$ & 13,00 & 4,20 & 1,80 & 7,50 & 3,60 & 10,00 & 7,10 & 3,40 & 4,40 & 11,30 & 8,60 & 11,70 & 4,40 \\
\hline $\begin{array}{l}\text { Sensibilidade ao envelhecimento } \\
\text { (recuperação e compliância) }\end{array}$ & 5,33 & 10,94 & 5,45 & 8,88 & 6,83 & 2,94 & 7,33 & 3,00 & 8,11 & 5,88 & 7,06 & 3,33 & 11,83 \\
\hline $\begin{array}{c}\text { Sensibilidade à tensão virgem e } \\
\text { RTFOT a } 1 \text { e } 9 \mathrm{~s}\end{array}$ & 2,50 & 6,30 & 1,40 & 11,20 & 11,30 & 6,10 & 3,70 & 11,00 & 11,50 & 6,30 & 4,90 & 8,70 & 6,10 \\
\hline $\begin{array}{c}\text { Sensibilidade à tensão RTFOT } \\
\text { a } 2 \text { e } 18 \mathrm{~s}\end{array}$ & 2,80 & 6,00 & 1,00 & 11,00 & 10,80 & 3,20 & 4,80 & 11,60 & 12,40 & 5,40 & 6,20 & 8,60 & 7,20 \\
\hline $\begin{array}{l}\text { Sensibilidade ao aumento dos } \\
\text { tempos de fluência e } \\
\text { recuperação }(R)\end{array}$ & 13,00 & 7,44 & 2,90 & 3,67 & 1,20 & 11,25 & 5,89 & 2,56 & 6,22 & 11,67 & 9,38 & 9,38 & 5,90 \\
\hline $\begin{array}{l}\text { Sensibilidade ao aumento dos } \\
\text { tempos de fluência e } \\
\text { recuperação }\left(J_{n r}\right)\end{array}$ & 8,40 & 6,40 & 4,40 & 4,10 & 1,40 & 12,00 & 2,60 & 3,00 & 11,20 & 11,40 & 7,70 & 10,90 & 7,50 \\
\hline
\end{tabular}


Ensaios tradicionais e perda de massa. Os resultados destes ensaios foram avaliados em termos da média aritmética das ordenações dos ligantes asfálticos segundo os valores decrescentes de penetração retida, os valores crescentes do incremento do ponto de amolecimento e os valores crescentes de perda de massa. Neste aspecto, os melhores resultados (menores ordenações médias) foram obtidos para o $C A P+S B R(2,00)$, o $C A P+P E$ $(2,33)$ e o $C A P+P E+P P A(5,00)$, o que significa que estes ligantes asfálticos possuem as maiores penetrações retidas, os menores incrementos do ponto de amolecimento e as menores perdas de massa em um contexto geral. Os piores resultados (maiores ordenações médias) foram obtidos para o CAP+PPA $(10,00)$, o CAP+borracha $(10,00)$ e 0 CAP+borracha+PPA $(10,67)$, o que significa que estes ligantes asfálticos possuem as menores penetrações retidas, os maiores incrementos do ponto de amolecimento e as maiores perdas de massa em um contexto geral.

Percentual de recuperação após RTFOT. Os resultados do percentual de recuperação foram avaliados em termos das médias aritméticas dos valores individuais desta propriedade, considerando os tempos de 1 e $9 \mathrm{~s}$ e de 2 e $18 \mathrm{~s}$ de maneira separada. As médias nos tempos de 1 e $9 \mathrm{~s}$ foram calculadas pela média aritmética dos valores em todas as temperaturas a 100 e a 3.200 Pa na condição envelhecida a curto prazo e, da mesma maneira, as médias nos tempos de 2 e $18 \mathrm{~s}$ foram calculadas pela média aritmética dos valores em todo o espectro de temperaturas a 100 e a $3.200 \mathrm{~Pa}$ (apenas RTFOT). Os melhores resultados nos tempos de 1 e $9 \mathrm{~s}$ foram obtidos para o CAP+Elvaloy+PPA $(1,00)$, o CAP+EVA+PPA $(2,80)$ e o CAP+EVA $(3,22)$, o que significa que estas formulações acarretam os aumentos mais significativos no percentual de recuperação do CAP 50/70 nos tempos de 1 e $9 \mathrm{~s}$.

Com o aumento dos tempos de fluência e recuperação de 1 e $9 \mathrm{~s}$ para 2 e $18 \mathrm{~s}$, os melhores resultados foram obtidos para o CAP+Elvaloy+PPA $(1,40)$, o CAP+borracha+PPA $(3,10)$ e o CAP+EVA $(3,11)$, o que significa que estas formulações acarretam os aumentos mais significativos no percentual de recuperação do CAP 50/70 nos tempos de 2 e $18 \mathrm{~s}$. Um destaque especial pode ser dado à ausência do CAP+borracha+PPA no grupo dos melhores resultados a 1 e $9 \mathrm{~s}$ e à presença deste material no grupo dos melhores resultados a 2 e $18 \mathrm{~s}$, indicando que, em comparação aos demais ligantes asfálticos, o aumento dos tempos de fluência e recuperação de 1 e $9 \mathrm{~s}$ para 2 e $18 \mathrm{~s}$ permitiu ao CAP+borracha+PPA respostas elásticas melhores ao carregamento aplicado.

Compliância não-recuperável após RTFOT. Assim como no percentual de recuperação, os resultados de compliância não-recuperável foram avaliados em termos das médias aritméticas dos valores individuais desta propriedade, considerando os tempos de 1 e $9 \mathrm{~s}$ e 


\section{6}

de 2 e $18 \mathrm{~s}$ de maneira separada. As médias nos tempos de 1 e $9 \mathrm{~s}$ foram calculadas pela média aritmética dos valores em todas as temperaturas a 100 e a $3.200 \mathrm{~Pa}$ na condição envelhecida a curto prazo e, da mesma maneira, as médias nos tempos de 2 e $18 \mathrm{~s}$ foram calculadas pela média aritmética dos valores em todo o espectro de temperaturas a 100 e a 3.200 Pa (apenas RTFOT). Os melhores resultados nos tempos de 1 e $9 \mathrm{~s}$ foram obtidos para o CAP+Elvaloy+PPA $(2,20)$, o CAP+EVA+PPA $(2,40)$ e o CAP+EVA $(3,20)$, o que significa que estas formulações acarretam as maiores reduções na compliância nãorecuperável do CAP puro nos tempos de 1 e $9 \mathrm{~s}$.

Com o aumento nos tempos de fluência e recuperação de 1 e $9 \mathrm{~s}$ para 2 e $18 \mathrm{~s}$, os melhores resultados foram obtidos para o CAP+Elvaloy+PPA $(1,80)$, o CAP+EVA $(3,40)$ e o CAP+borracha+PPA $(3,60)$, o que significa que estas formulações acarretam as maiores reduções na compliância não-recuperável do CAP 50/70 nos tempos de 2 e 18 s. Similarmente ao observado no percentual de recuperação, um destaque especial pode ser dado à ausência do CAP+borracha+PPA no grupo dos melhores resultados a 1 e $9 \mathrm{~s}$ e à presença deste material no grupo dos melhores resultados a 2 e $18 \mathrm{~s}$, indicando que, em comparação aos demais ligantes asfálticos, o aumento dos tempos de fluência e recuperação permitiu ao CAP+borracha+PPA maiores reduções da compliância não-recuperável.

Sensibilidade ao envelhecimento a curto prazo. As médias foram calculadas pela média aritmética dos valores referentes aos incrementos de recuperação elástica e às reduções de compliância não-recuperável a 100 e a 3.200 Pa. As menores médias - e, por consequência, as menores sensibilidades ao envelhecimento - são encontradas no CAP+SBS $(2,94)$, no CAP+EVA $(3,00)$ e no CAP+SBR $(4,20)$, ao passo que as maiores médias - maiores sensibilidades ao envelhecimento - são encontradas no CAP+borracha $(8,88)$, no CAP+PPA $(10,94)$ e no CAP+SBR+PPA $(11,83)$.

Embora médias elevadas para este critério sejam negativas do ponto de vista de uma maior sensibilidade ao envelhecimento, elas também indicam aumentos significativos do percentual de recuperação e reduções acentuadas da compliância não-recuperável, o que é favorável à resistência à deformação permanente. Sob esta ótica, as formulações com borracha, PPA e SBR+PPA apresentam melhores resultados do que as formulações com EVA, SBS e SBR por conta dos maiores incrementos do percentual de recuperação e das maiores reduções da compliância não-recuperável após o RTFOT.

Sensibilidade ao incremento do nível de tensão. As médias foram calculadas pela média aritmética dos valores em todas as temperaturas das condições virgem e envelhecida a curto 
prazo nos tempos de 1 e $9 \mathrm{~s}$, bem como pela média aritmética dos valores em todas as temperaturas da condição envelhecida nos tempos de 2 e $18 \mathrm{~s}$. Os melhores resultados menores sensibilidades à tensão - nos tempos de 1 e $9 \mathrm{~s}$ foram obtidos para 0 CAP+Elvaloy+PPA $(1,40)$, o CAP puro $(2,50)$ e o CAP+SBS+PPA $(3,70)$, enquanto que os piores resultados - maiores sensibilidades à tensão - para estes mesmos tempos foram obtidos para o CAP+borracha $(11,20)$, o CAP+borracha+PPA $(11,30)$ e o CAP+EVA+PPA $(11,50)$.

Com o aumento nos tempos de fluência e recuperação de 1 e $9 \mathrm{~s}$ para 2 e $18 \mathrm{~s}$, os melhores resultados foram obtidos para o CAP+Elvaloy+PPA $(1,00)$, o CAP 50/70 $(2,80)$ e o $C A P+S B S(3,20)$ e os piores resultados foram obtidos para o CAP+borracha $(11,00)$, o CAP+EVA $(11,60)$ e o CAP+EVA+PPA $(12,40)$. Em linhas gerais, pode-se dizer que as formulações com Elvaloy+PPA e SBS apresentam sensibilidades baixas ao incremento do nível de tensão de 100 para 3.200 Pa e as formulações com borracha moída e EVA, sensibilidades elevadas.

Sensibilidade ao aumento dos tempos de fluência e recuperação. Este requisito foi avaliado em termos das variações da compliância não-recuperável e do percentual de recuperação após o aumento dos tempos de fluência e recuperação de 1 e $9 \mathrm{~s}$ para 2 e $18 \mathrm{~s}$. No caso do percentual de recuperação, as médias dos ligantes asfálticos foram calculadas por meio da média aritmética dos valores referentes às alterações desta propriedade a 100 e a 3.200 Pa e, no caso da compliância não-recuperável, as médias dos ligantes asfálticos foram calculadas por meio da média aritmética dos valores referentes às alterações desta propriedade a 100 e a $3.200 \mathrm{~Pa}$.

Os melhores resultados do percentual de recuperação - menores sensibilidades à luz dos valores de $R$ - são encontrados no $\operatorname{CAP}+$ borracha+PPA $(1,20)$, no CAP+EVA $(2,56)$ e no CAP+Elvaloy+PPA $(2,90)$, enquanto que os piores resultados - maiores sensibilidades à luz dos valores de $R$ - são encontrados no CAP+SBS $(11,25)$, no CAP+PE $(11,67)$ e no CAP puro $(13,00)$. Os melhores resultados de compliância não-recuperável menores sensibilidades à luz dos valores de $J_{n r}$ - são encontrados no CAP+borracha+PPA $(1,40)$, no $C A P+S B S+P P A(2,60)$ e no $C A P+E V A(3,00)$, enquanto que os piores resultados - maiores sensibilidades à luz dos valores de $\mathrm{J}_{n r}$ - são encontrados no CAP+EVA+PPA $(11,20)$, no CAP+PE $(11,40)$ e no CAP+SBS $(12,00)$.

Viscosidade rotacional virgem e incremento da viscosidade após RTFOT. As médias das viscosidades rotacionais foram calculadas pela média aritmética das ordenações referentes à viscosidade na condição virgem, enquanto que as médias dos incrementos de viscosidade 


\section{8}

foram calculadas pela média aritmética das ordenações referentes aos valores individuais destes incrementos. O CAP 50/70 (média 1,00) e as formulações com PPA (média 2,00) e SBR+PPA (média 3,20) apresentam os melhores resultados de viscosidade rotacional (viscosidades mais baixas) na condição virgem, ao passo que as formulações com borracha+PPA (média 11,00), borracha (média 12,00) e EVA (média 13,00) apresentam os piores resultados de viscosidade rotacional nesta mesma condição. No caso dos incrementos de viscosidade rotacional após o RTFOT, os resultados melhores (médias mais baixas) são encontrados no $\mathrm{CAP}+\mathrm{SBR}(1,60)$, no $\mathrm{CAP}+\mathrm{PE}(2,20)$ e no CAP+SBS $(2,60)$ e os resultados piores (médias mais elevadas) são encontrados no CAP+Elvaloy+PPA $(10,40)$, no CAP+PPA $(11,80)$ e no CAP+borracha+PPA $(12,80)$.

CAP+PPA e CAP+Elvaloy+PPA. Em uma comparação dos resultados das formulações com PPA e Elvaloy+PPA, é possível observar que o CAP+PPA possui resultados melhores (médias mais baixas) apenas na viscosidade rotacional virgem, sendo que 0 CAP+Elvaloy+PPA possui estes resultados melhores em todas as demais propriedades e parâmetros de interesse. Estes resultados indicam que o ligante asfáltico modificado com Elvaloy+PPA possui um melhor desempenho geral nas propriedades e parâmetros de interesse do que o modificado somente com PPA, sendo, portanto, mais adequado para utilização em pavimentação. As maiores diferenças entre os resultados dos dois materiais podem ser encontradas nos percentuais de recuperação e nas sensibilidades ao aumento do nível de tensão de 100 para 3.200 Pa (parâmetro $J_{\text {nr,diff }}$ ), em que as médias obtidas para o CAP+PPA são de 4 a 6 vezes superiores às médias obtidas para o CAP+Elvaloy+PPA. À exceção das propriedades e parâmetros já mencionados, as médias do CAP+PPA são de 1 a 3 vezes superiores às médias do CAP+Elvaloy+PPA.

CAP+borracha e CAP+borracha+PPA. No caso das duas formulações com borracha moída de pneus, ambos os materiais possuem resultados ruins quanto aos valores conjuntos de penetração retida, incremento do ponto de amolecimento e perda de massa, quanto à viscosidade rotacional virgem e quanto ao incremento de viscosidade, o que se reflete nas médias elevadas (iguais ou superiores a 10) para todas estas propriedades e parâmetros de interesse. Os resultados da compliância não-recuperável e do percentual de recuperação são considerados razoáveis (médias entre 3 e 9) para os dois materiais, sendo melhores para a formulação com borracha+PPA na compliância não-recuperável e no percentual de recuperação a 1 e $9 \mathrm{~s}$. As sensibilidades do CAP+borracha e do CAP+borracha+PPA à tensão e ao envelhecimento a curto prazo são ruins em um contexto geral (médias superiores a 6), o mesmo não sendo observado nas sensibilidades ao aumento dos tempos de fluência e recuperação (médias inferiores a 5). O CAP+borracha+PPA possui os melhores resultados 
para esta última sensibilidade dentre todos os ligantes asfálticos, tanto no percentual de recuperação (média 1,20) quanto na compliância não-recuperável (média 1,40).

CAP+SBS e CAP+SBS+PPA. Em termos do CAP+SBS e do CAP+SBS+PPA, as médias da Tabela 90 apontam que os dois ligantes asfálticos possuem classificações razoáveis quanto aos resultados conjuntos de penetração retida, incremento do ponto de amolecimento e perda de massa, quanto à viscosidade rotacional virgem e quanto ao incremento de viscosidade após o RTFOT. Situação parecida pode ser observada nas médias do percentual de recuperação e da compliância não-recuperável, em que as duas formulações com SBS apresentam classificação de razoável para ruim nos tempos de 1 e $9 \mathrm{~s}$ e nos tempos de 2 e $18 \mathrm{~s}$. O CAP+SBS possui uma sensibilidade baixa quanto ao envelhecimento a curto prazo $(2,94)$ e o CAP+SBS+PPA, uma sensibilidade mais elevada $(7,33)$. O CAP+SBS+PPA possui uma menor sensibilidade à tensão do que o CAP+SBS nos tempos de fluência e recuperação de 1 e $9 \mathrm{~s}$, o contrário sendo observado nos tempos de 2 e $18 \mathrm{~s}$. A formulação com SBS+PPA possui uma baixa sensibilidade ao aumento nos tempos de fluência e recuperação, tanto no percentual de recuperação (média 5,89) quanto na compliância não-recuperável (média 2,60). Esta sensibilidade é significativamente maior para o $\mathrm{CAP}+\mathrm{SBS}$, de modo que as médias obtidas para este material são superiores a 11 nas duas propriedades: 11,25 no caso do percentual de recuperação e 12,00 no caso da compliância não-recuperável.

CAP+EVA e CAP+EVA+PPA. No caso do CAP+EVA e do CAP+EVA+PPA, as médias da Tabela 90 apontam que ambos os materiais possuem classificações de razoáveis para ruins quanto aos resultados conjuntos de penetração retida, de incremento do ponto de amolecimento e de perda de massa, quanto à viscosidade rotacional virgem e quanto ao incremento de viscosidade, sendo que o CAP+EVA possui a pior classificação em termos da viscosidade rotacional virgem (média 13,00). Os resultados do percentual de recuperação e da compliância não-recuperável conferem ao CAP+EVA e ao CAP+EVA+PPA médias mais baixas, sendo que a formulação com EVA possui resultados melhores nos tempos de 2 e 18 $\mathrm{s}$ e a formulação com EVA+PPA possui resultados melhores nos tempos de 1 e $9 \mathrm{~s}$. A sensibilidade do CAP+EVA ao envelhecimento a curto prazo é baixa (média 3,00), o mesmo não sendo observado para o CAP+EVA+PPA (média 8,11). As sensibilidades à tensão são muito elevadas tanto para o $C A P+E V A$ quanto para o $C A P+E V A+P P A$, sendo ligeiramente menores para o CAP+EVA nos dois tempos de fluência e recuperação ( 1 e 9 s e 2 e $18 \mathrm{~s}$ ). As sensibilidades ao aumento dos tempos de fluência e recuperação são pequenas para o CAP+EVA (médias de 2,56 e 3,00) e maiores para o CAP+EVA+PPA (médias de 6,22 e $11,20)$, sobretudo no caso da compliância não-recuperável. 
CAP+PE e CAP+PE+PPA. Em termos do CAP+PE e do CAP+PE+PPA, ambos os materiais possuem classificações de razoáveis para boas (médias entre 2 e 9) quanto aos resultados conjuntos de penetração retida, incremento do ponto de amolecimento e perda de massa, à viscosidade rotacional na condição virgem e ao incremento de viscosidade após o RTFOT, especialmente no caso do CAP+PE. Os percentuais de recuperação e as compliâncias não-recuperáveis, entretanto, são relativamente ruins (médias elevadas) para o $\mathrm{CAP}+\mathrm{PE}$ e o $\mathrm{CAP}+\mathrm{PE}+\mathrm{PPA}$, tanto nos tempos de 1 e $9 \mathrm{~s}$ quanto nos tempos de $2 \mathrm{e}$ $18 \mathrm{~s}$. As sensibilidades ao envelhecimento a curto prazo e ao incremento do nível de tensão de 100 para 3.200 Pa são razoáveis para os dois materiais, sendo que o CAP+PE possui sensibilidades menores (médias mais baixas) do que o CAP+PE+PPA quanto ao envelhecimento e à tensão nos tempos de 2 e $18 \mathrm{~s}$. No caso da sensibilidade ao aumento dos tempos de fluência e recuperação de 1 e $9 \mathrm{~s}$ para 2 e $18 \mathrm{~s}$, é possível observar que os resultados do CAP+PE são ruins (médias de 11,67 e 11,40) e os do CAP+PE+PPA são ligeiramente melhores (médias de 7,70 e 9,38), o que indica que estas formulações são sensíveis a tempos maiores de fluência e recuperação.

CAP+SBR e CAP+SBR+PPA. Com relação aos resultados do CAP+SBR e do CAP+SBR+PPA, as médias da Tabela 90 apontam que o CAP+SBR possui classificação melhor (médias mais baixas) do que o CAP+SBR+PPA nos resultados conjuntos de penetração retida, incremento do ponto de amolecimento e perda de massa, bem como nos incrementos de viscosidade após o envelhecimento a curto prazo. Por outro lado, o $\mathrm{CAP}+\mathrm{SBR}+\mathrm{PPA}$ possui classificações significativamente melhores do que o CAP+SBR quanto ao percentual de recuperação e à compliância não-recuperável, tanto nos tempos de 1 e $9 \mathrm{~s}$ quanto nos tempos de 2 e $18 \mathrm{~s}$. As sensibilidades de ambos os materiais quanto ao envelhecimento e à tensão podem, em um contexto geral, ser consideradas como razoáveis, embora o CAP+SBR possua a maior sensibilidade ao envelhecimento a curto prazo (média 11,83) e o $C A P+S B R$ possua uma sensibilidade muito menor (média 3,33). No caso das sensibilidades ao aumento dos tempos de fluência e recuperação de 1 e $9 \mathrm{~s}$ para 2 e $18 \mathrm{~s}$, o $\mathrm{CAP}+\mathrm{SBR}+\mathrm{PPA}$ apresenta resultados melhores do que o $\mathrm{CAP}+\mathrm{SBR}$ para ambas as propriedades, sobretudo no caso do percentual de recuperação.

Comparação entre formulações de mesmo grau de desempenho. Uma comparação entre as médias do CAP+PPA e as médias dos demais ligantes asfálticos modificados permite observar que, em um contexto geral, as formulações com Elvaloy+PPA, SBS+PPA, EVA e EVA+PPA possuem resultados iguais ou melhores do que o CAP+PPA nas propriedades e parâmetros de interesse. Esta conclusão pode, em parte, ser explicada pelos bons resultados das formulações quanto aos ensaios tradicionais e de perda de massa, aos incrementos de 
viscosidade rotacional após o RTFOT, à sensibilidade ao envelhecimento a curto prazo e à sensibilidade do percentual de recuperação ao aumento dos tempos de fluência e recuperação. No caso do CAP+Elvaloy+PPA e das duas formulações com EVA, estes resultados são complementados pelas menores compliâncias não-recuperáveis e pelos maiores percentuais de recuperação em ambos os tempos de fluência e recuperação e na condição envelhecida a curto prazo, dentre outros fatores. No caso do CAP+SBS+PPA, estes resultados são complementados pelas menores sensibilidades ao incremento do nível de tensão de 100 para 3.200 Pa e pela menor sensibilidade da compliância não-recuperável ao aumento dos tempos de fluência e recuperação, dentre outros fatores.

Ainda sobre os resultados do CAP+PPA e os resultados de todos os ligantes asfálticos modificados nas propriedades e parâmetros de interesse, é possível observar que as formulações com SBS, PE, PE+PPA e SBR possuem resultados piores (médias mais elevadas) do que a formulação com PPA em um contexto geral. Esta conclusão pode ser, em parte, explicada pelos resultados ruins das formulações quanto à viscosidade rotacional na condição virgem, às sensibilidades de $\mathrm{R}$ e de $\mathrm{J}_{\mathrm{nr}}$ ao aumento dos tempos de fluência e recuperação e aos resultados de ambas as propriedades na condição envelhecida a curto prazo e nos dois tempos de fluência e recuperação. No caso do CAP+SBR estes resultados são complementados pelo desempenho ruim do material quanto à sensibilidade ao incremento do nível de tensão de 100 para 3.200 Pa, tanto nos tempos de 1 e $9 \mathrm{~s}$ quanto nos tempos de 2 e $18 \mathrm{~s}$.

Em termos das demais formulações de classificação $P G 76-X X$, os resultados obtidos para o $\mathrm{CAP}+\mathrm{SBR}+\mathrm{PPA}$ apontam que este material possui resultados melhores do que o CAP+PPA nas seguintes propriedades e parâmetros de interesse, dentre outros: (1) penetração retida, incremento do ponto de amolecimento e perda de massa; (2) incremento de viscosidade rotacional após o RTFOT; e (3) percentual de recuperação na condição envelhecida a curto prazo e nos dois tempos de fluência e recuperação. No caso das duas formulações com borracha moída de pneus, uma análise comparativa mostra que o CAP+borracha e o CAP+borracha+PPA possuem resultados piores do que o CAP+PPA na viscosidade rotacional virgem, na compliância não-recuperável a 1 e 9 s após o envelhecimento a curto prazo e nas sensibilidades à tensão. Estes dois materiais, entretanto, apresentam resultados melhores do que o CAP+PPA em aspectos como a sensibilidade ao aumento dos tempos de fluência e recuperação e a sensibilidade ao envelhecimento a curto prazo, dentre outros.

Efeito do PPA nos resultados dos requisitos de interesse. Os efeitos da presença do PPA nas formulações CAP+modificador foram avaliados em termos dos benefícios (redução 


\section{2}

da ordenação média) e prejuízos (aumento da ordenação média) nas propriedades e parâmetros de interesse. Neste aspecto, é possível observar que a presença do PPA acarreta benefícios aos ligantes asfálticos modificados com borracha moída de pneus, SBS, PE e SBR em um contexto geral, o que pode ser explicado pela menor ordenação média das formulações CAP+modificador+PPA em comparação às suas correspondentes CAP+modificador na maioria das propriedades e parâmetros de interesse. Estas propriedades incluem as seguintes: (1) a compliância não-recuperável na condição envelhecida a curto prazo e nos dois tempos de fluência e recuperação; (2) as sensibilidades de $R$ e $J_{n r}$ ao aumento dos tempos de fluência e recuperação de 1 e $9 \mathrm{~s}$ para 2 e 18 s; e (3) a viscosidade rotacional na condição virgem.

Diferentemente do observado na maioria das formulações CAP+modificador, os resultados da Tabela 90 mostram que a adição do PPA acarreta muitos prejuízos ao ligante asfáltico modificado com EVA na medida em que as sensibilidades ao envelhecimento a curto prazo ( $R$ e $J_{n r}$ ), ao incremento do nível de tensão ( 1 e $9 \mathrm{~s}$ e 2 e $18 \mathrm{~s}$ ) e ao aumento dos tempos de fluência e recuperação ( $R$ e $J_{n r}$ ) passam a ser maiores com a adição deste ácido. Em termos do percentual de recuperação e da compliância não-recuperável após o envelhecimento a curto prazo, observa-se que as ordenações médias do CAP+EVA+PPA não diferem significativamente das ordenações médias do CAP+EVA para ambos os tempos de fluência e recuperação, especialmente no caso do percentual de recuperação. Os benefícios mais significativos decorrentes da adição do PPA ao CAP+EVA podem ser observados nas propriedades tradicionais (incluindo a perda de massa) e na viscosidade rotacional virgem, em que as ordenações médias do CAP+EVA+PPA são menores que as encontradas no CAP+EVA.

\subsection{Considerações finais}

O CAP+Elvaloy+PPA apresenta o melhor desempenho nas propriedades e parâmetros analisados e o CAP+PE apresenta o pior desempenho, como visualizado na Figura 90 (página 255). O melhor desempenho do CAP+Elvaloy+PPA é explicado pelos resultados melhores (médias mais baixas) da compliância não-recuperável e do percentual de recuperação e pelas menores sensibilidades à tensão nas condições virgem e envelhecida a curto prazo, embora este material não apresente desempenho tão bom quanto ao incremento de viscosidade rotacional após o RTFOT e quanto à viscosidade rotacional na condição virgem. 
O pior desempenho do $\mathrm{CAP}+\mathrm{PE}$ é explicado pelas médias muito elevadas (resultados ruins) no percentual de recuperação e na compliância não-recuperável, pelo desempenho apenas razoável nas sensibilidades ao envelhecimento e ao nível de tensão e pelas sensibilidades muito elevadas ao aumento nos tempos de fluência e recuperação. Embora o CAP 50/70 também apresente um desempenho ruim quanto ao percentual de recuperação e à compliância não-recuperável, o desempenho do material puro é muito bom quanto à sensibilidade à tensão e à viscosidade rotacional (médias muito baixas), o que auxilia na obtenção de uma classificação melhor.

Dentre os demais, destaca-se o CAP+EVA por apresentar bons resultados (baixos valores numéricos) quanto ao percentual de recuperação, à compliância não-recuperável, à sensibilidade ao envelhecimento a curto prazo e ao aumento nos tempos de fluência e recuperação, o que indica um bom desempenho deste material em termos de resposta elástica, de suscetibilidade à deformação permanente e de sensibilidade a mudanças no regime de carregamento e de repouso. Por outro lado, o CAP+EVA apresenta um desempenho ruim quanto aos resultados conjuntos de penetração retida, incremento do ponto de amolecimento e perda de massa e quanto à viscosidade rotacional virgem, o que acarreta temperaturas de usinagem e de compactação elevadas. O incremento de viscosidade rotacional não é tão elevado para este ligante asfáltico (média 4,80), sendo próximo ao de outros materiais como o CAP 50/70 $(4,60)$ e o CAP+EVA+PPA $(5,20)$.

\subsection{Sugestões para pesquisas futuras}

Como fruto do desenvolvimento deste estudo, algumas sugestões de pesquisas futuras foram listadas para que se possa aumentar o conhecimento científico sobre o comportamento fluência-recuperação de ligantes asfálticos modificados. Estas sugestões de pesquisas incluem as seguintes:

a) Realizar ensaios de fluência e recuperação sob tensão múltipla (ou ensaios MSCR) em ligantes asfálticos modificados com base em outros tipos de CAP, com o intuito de visualizar o efeito do tipo de ligante-base nas propriedades de recuperação elástica e de compliância não-recuperável;

b) Realizar ensaios MSCR em ligantes asfálticos modificados com teores diferentes de modificadores, com o intuito de visualizar o efeito destes teores nas propriedades dos ligantes asfálticos ou, como uma possibilidade, a existência de um teor ótimo 
de modificador em que o ligante asfáltico apresenta os melhores resultados de recuperação elástica e de compliância não-recuperável;

c) Correlacionar os resultados do MSCR com valores de flow-number de misturas asfálticas e com ensaios de medida da profundidade de trilhas de roda, de maneira semelhante à realizada em estudos como o de Martins et al. (2011);

d) Adicionar um ou mais níveis de tensão às etapas do ensaio MSCR, de modo que a dependência dos ligantes asfálticos ao nível de tensão possa ser visualizada em gráficos como os publicados nos estudos de D’Angelo et al. (2007), D’Angelo (2008, 2010b) e Dreessen et al. (2009);

e) Utilizar outros tempos de fluência e recuperação além dos empregados neste estudo, de modo a se obter uma verificação mais detalhada do efeito de tempos diferentes nas propriedades de recuperação elástica e de compliância não-recuperável dos ligantes asfálticos modificados.

f) Estudar estes mesmos ligantes asfálticos quanto ao comportamento à fadiga por meio do ensaio de varredura com amplitude linear (LAS - linear amplitude sweep), o qual foi utilizado em estudos como o de Johnson (2010). 


\section{REFERÊNCIAS BIBLIOGRÁFICAS}

AIREY, G. D. (2002). Rheological evaluation of ethylene vinyl acetate polymer modified bitumens. Construction and Building Materials. Elsevier, v. 16, issue 8, p. 473-487.

(2003). Rheological properties of styrene butadiene styrene polymer modified

bitumens. Fuel. Elsevier, v. 82, issue 14, p. 1709-1719.

ANDERSON, M. (2010). Understanding and Implementing the Multiple Stress Creep Recovery (MSCR) Test and Specification. In: ASSOCIATION OF MODIFIED ASPHALT PRODUCERS - ANNUAL MEETING. Savannah, GA.

ANDERSON, M. et al. (2010). MSCR: a better tool for characterizing high-temperature performance properties. Asphalt - The magazine of the Asphalt Institute. Lexington, KY, v. 25 , p. 15-16.18.21-23. ISSN 0004-4594.

ASPHALT INSTITUTE. (2010a). Implementation of the multiple stress creep recovery test and specification. Asphalt Institute Technical Advisory Committee, Federal Highway Administration.

(2010b). Guidance on the use of the MSCR test with the AASHTO M320 specification. Asphalt Institute Technical Advisory Committee, Executive Offices and Research Center. Lexington, KY.

ASPHALT INSTITUTE ONLINE. (2003). Laboratory mixing and compaction temperatures. Asphalt Institute Technical Bulletin, Execute Offices and Research Center. Lexington, KY. Disponível em: <http://www.asphaltinstitute.org/public/engineering/PDFs/Su perpave/Lab_Mixing_Compaction_Temps.pdf>. Acesso em: 03 jul. 2011.

AWWAD, M. T.; SHBEEB, L. (2007). The use of polyethylene in hot asphalt mixtures. American Journal of Applied Sciences. Science Publications, v. 4, n. 6, p. 390-396.

BAHIA, H. U.; ANDERSON, D.A. (1995). Strategic highway research program binder rheological parameters: background and comparison with conventional properties. Transportation Research Record. Washington, n. 1488, p. 32-39.

BAHIA, H. U. et al. (2001). NCHRP Report 459: Characterization of modified asphalt binders in Superpave mix design. National Cooperative Highway Research Program, Washington.

BATES, R.; WORCH, R. J. (1987). Engineering brief $\mathbf{n}^{\circ}$ 39: styrene butadiene rubber (SBR) latex modified asphalt. Federal Aviation Administration, Washington. Disponível em: <http://www.faa.gov/airports/engineering/engineering_briefs/media/EB_39.pdf>. Acesso em: 14 fev. 2011. 
(1990). Engineering brief $\mathbf{n}^{\circ} \mathbf{4 5}$ : polyethylene modified asphalt cement. Federal Aviation Administration, Washington. Disponível em: <http://www.faa.gov/airports/enginee ring/engineering_briefs/media/EB_45.pdf>. Acesso em: 24 fev. 2011.

BAUMGARDNER, G. L. et al. (2005). Polyphosphoric acid modified asphalt: proposed mechanisms. Journal of the Association of Asphalt Paving Technologists. Long Beach, v. 74, p. $283-305$.

BECKER, Y. et al. (2001). Polymer modified asphalt. Vision Tecnologica. v. 9, n. 1, p. 39-50.

BERNUCCI, L. B. et al. (2006). Pavimentação asfáltica: formação básica para engenheiros. Rio de Janeiro, Petrobras e ABEDA. $504 \mathrm{f}$.

BILLITER, T. C. et al. (1996). Investigation of the curing variables of asphalt-rubber binder. In: AMERICAN CHEMICAL SOCIETY - DIVISION OF FUEL CHEMISTRY. Symposium on Modified Asphalts. 41, Orlando, FL. Anais... Orlando, v. 4, p. 1221-1226.

BOULDIN, M. G. et al. (2001). Proposed refinement of Superpave high-temperature specification parameter for performance-graded binders. Transportation Research Record. Washington, n. 1766, p. 40-47.

BUNCHER, M. (2005). Polyphosphoric acid modification of asphalt. Asphalt Magazine. Fall, p. 38-40. Disponível em: <http://www.asphaltmagazine.com/archives/2005/Fall/Fall_05_Pol yphosphoric_Modification_Of_Asphalt_511737418_105200611123.pdf>. Acesso em: 15 mar. 2011.

BRINGEL, R. M. et al. (2005). Propriedades químicas e reológicas de asfalto modificado por copolímero EVA. In: CONGRESSO BRASILEIRO DE P \& D EM PETRÓLEO E GÁS. 3, 2005, Salvador. Anais..., Salvador.

CAO, W-D. et al. (2011). Experimental study on polyphosphoric acid (PPA) modified asphalt binders. Advanced Materials Research. Trans Tech Publications, v. 152-153, p. 288-294.

COUTINHO, F. M. B. et al. (2003). Polietileno: principais tipos, propriedades e aplicações. Polímeros: Ciência e Tecnologia. Scientific Electronic Library Online, v. 13, n. 1, p. 1-13.

D'ANGELO, J. (2008). Multi-stress creep and recovery test method new specification. In: ASSOCIATION OF MODIFIED ASPHALT PRODUCERS. Austin, Texas. Disponível em: $<$ http://amap.ctcandassociates.com/wp/wp-content/uploads/dangelo-MSCR-2-08E.pdf>. Acesso em: 10 out. 2011.

. (2010a). The multiple stress creep recovery (MSCR) procedure. Technical Brief. Office of Pavement Technology. Federal Highway Administration, United States Department of Transportation. FHWA-HIF-10-XXX. 
(2010b). New high-temperature binder specification using multistress creep and recovery. Transportation Research Circular Number E-C147: Development in Asphalt Binder Specifications. Washington, D.C., p. 1-13.

D'ANGELO, J.; DONGRÉ, R. (2009). Practical Use of Multiple Stress Creep and Recovery Test: Characterization of Styrene-Butadiene-Styrene Dispersion and Other Additives in Polymer-Modified Asphalt Binders. Transportation Research Record. Washington, n. 2126, p. 73-82.

D'ANGELO, J. et al. (2007). Revision of the Superpave high-temperature binder specification: the multiple stress creep recovery test. Journal of the Association of Asphalt Paving Technologists. White Bear Lake, v. 76, p. 123-162.

DELGADILLO, R. et al. (2006). Nonlinearity of repeated creep and recovery binder test and relationship with mixture permanent deformation. Transportation Research Record. Washington, n. 1962, p. 3-11.

DONGRÉ, R. et al. (2004). New criterion for Superpave high-temperature binder specification. Transportation Research Record. Washington, n. 1875, p. 22-32.

DREESSEN, S. et al. (2009). A new performance related test method for rutting prediction: MSCRT. Advanced Testing and Characterization of Bituminous Materials. London, p. 971-980, ISBN 978-0-415-55854-9.

DUPONT WEBSITE. (2008a). How Elvaloy ${ }^{\circledR}$ reacts with asphalt. DuPont ${ }^{\mathrm{TM}}$ Elvaloy ${ }^{\circledR}$ RET: Reactive Elastomeric Terpolymers. Disponível em: <http://asphalt.dupont.com/link2.html>. Acesso em: 23 mar. 2011.

(2008b). Mechanism for reaction of RET with asphaltene molecule. DuPont ${ }^{\mathrm{TM}}$ Elvaloy $^{\circledR}$ RET: Reactive Elastomeric Terpolymers. Disponível em: <http://asphalt.dupont.com /react.html>. Acesso em: 23 mar. 2011.

. (2008c). Elvaloy ${ }^{\circledR}$ RET asphalt modifier product information. DuPont ${ }^{\mathrm{TM}}$ Elvaloy ${ }^{\circledR}$ RET: Reactive Elastomeric Terpolymers. Disponível em: <http://asphalt.dupont.com/link1. html>. Acesso em: 23 mar. 2011.

FAXINA, A. L. (2006). Estudo da viabilidade técnica do uso de resíduo de óleo de xisto como óleo extensor em ligantes asfalto-borracha. Tese (Doutorado) - Escola de Engenharia de São Carlos, Universidade de São Paulo, São Carlos.

FEE, D. et al. (2010). Polyphosphoric acid modification of asphalt. Transportation Research Record. Washington, n. 2179, p. 49-57.

GARCÍA-MORALES, M. et al. (2004). Linear viscoelasticity of recycled EVA-modified bitumens. Energy \& Fuels. ACS Publications, v. 18, n. 2, p. 357-364. 
GOODRICH, J. E. (1982). Asphalt composition for air-blowing. United States Patent Number 4338137. Disponível em: < http://www.patents.com/us-4338137.html>. Acesso em: 27 out. 2011.

GOODRICH, J. L. (1990). Asphaltic binder rheology, asphalt concrete rheology and asphalt concrete mix properties. Journal of the Association of Asphalt Paving Technologists. White Bear Lake, v. 60, p. 80-120.

ICL PERFORMANCE PRODUCTS LP. (2008). Best practices for PPA modification of asphalt. Final 053108.

IUPAC. (2006). Functional group. IUPAC Compendium of Chemical Terminology, $2^{\text {nd }}$ edition. The "Gold Book". Disponível em: <http://goldbook.iupac.org/F02555.html>. Acesso em: 27 out. 2011.

JOHNSON, C. M. (2010). Estimating asphalt binder fatigue resistance using an accelerated test method. Dissertation (Doctor of Philosophy) - Civil \& Environmental Engineering. University of Wisconsin-Madison.

KALANTAR, Z. N. et al. (2010). Properties of bituminous binder modified with waste polyethylene terephthalate. Proceeding of Malaysian Universities Transportation Research Forum and Conferences. Universiti Tenaga Nasional, Putrajaya. ISBN 978967-5770-08-1.

KHATRI, A. et al. (2001). Mixing and compaction temperatures for modified binders using the Superpave gyratory compactor. Journal of the Association of Asphalt Paving Technologists. White Bear Lake, v. 70, p. 368-402.

KHEDAYWI, T. S. et al. (1993). Laboratory investigation of properties of asphalt-rubber concrete mixtures. Transportation Research Record. Washington, n. 1417, p. 93-98.

KIM, H-S. et al. (2010). Rheology investigation of crumb rubber modified asphalt binders. KSCE Journal of Civil Engineering. Springer, v. 14, n. 6, p. 839-843.

KING, G. et al. (1999). Additives in asphalt. Journal of the Association of Asphalt Paving Technologists. White Bear Lake, v. 68, p. 32-69.

KODRAT, I. et al. (2007). Comparison of polyphosphoric acid-modified asphalt binders with straight and polymer-modified materials. Transportation Research Record. Washington, n. 1988 , p. 47-55.

LEITE, L. F. M. (1999). Estudos de preparo e caracterização de asfaltos modificados por polímero. Tese (Doutorado) - Instituto de Macromoléculas Professora Eloisa B. Mano, Universidade Federal do Rio de Janeiro, Rio de Janeiro. 
MARTINS, A. T. et al. (2011). Fluência e relaxação sob múltiplas tensões (MSCR): avaliação do desempenho de ligantes asfálticos. In: CILA - CONGRESSO IBERO-LATINOAMERICANO DO ASFALTO, 16, Rio de Janeiro. Anais... Rio de Janeiro: Clube de Ideias, v. 1, p. 711-721.

MASSON, J-F. (2008). Brief review of the chemistry of polyphosphoric acid (PPA) and bitumen. Energy \& Fuels. ACS Publications, v. 22, n. 4, p. 2637-2640.

MOHAMED, A. A. et al. (2008). Rheological properties of crumb-rubber modified bitumen containing antioxidant. The Arabian Journal for Science and Engineering. Dhahran, v. 34 , n. $1 B$, p. 3-12.

NAVARRO, F. J. et al. (2002). Rheological characteristics of ground tire rubber-modified bitumens. Chemical Engineering Journal. Elsevier, v. 89, issues 1-3, p. 53-61.

ODA, S. (2000). Análise da viabilidade técnica da utilização do ligante asfaltoborracha em obras de pavimentação. Tese (Doutorado) - Escola de Engenharia de São Carlos, Universidade de São Paulo, São Carlos.

PÉREZ-LEPE, A. et al. (2006). Destabilization mechanism of polyethylene-modified bitumen. Journal of Applied Polymer Science. v. 100, issue 1, p. 260-267.

POLACCO, G. et al. (2004). Rheology of asphalts modified with glycidylmethacrylate functionalized polymers. Journal of Colloid and Interface Science. Elsevier, v. 280, issue 2, p. 366-373.

(2005). Asphalt modification with different polyethylene-based polymers. European Polymer Journal. Elsevier, v. 41, issue 12, p. 2831-2844.

(2006). Relation between polymer architecture and nonlinear viscoelastic behavior of modified asphalts. Current Opinion in Colloid \& Interface Science. Elsevier, v. 11, issue 4 , p. 230-245.

PLASTICS FEDERATION OF SOUTH AFRICA. (2011). Properties of polyethylene terephthalate. The Plastics Federation of South Africa. Disponível em: <http://www.plasticsinfo.co.za/downloads/PET\%20info.pdf>. Acesso em: 08 nov. 2011.

RAJPAL, S. (2005). Rutting potential of polymer modified hot mix asphalt concrete mixes. University of Texas at EI Paso. EI Paso, TX.

SHENOY, A. (2001). Refinement of the Superpave specification parameter for performance grading of asphalt. Journal of Transportation Engineering. New York, v. 127, n. 5, p. 357-362.

(2004). High temperature performance grading of asphalts through a specification that could capture field performance. Journal of Transportation Engineering. New York, v. 130 , n. 1, p. 132-137. 
SILVA, L. S. et al. (2004). Study of rheological properties of pure and polymer-modified Brazilian asphalt binders. Journal of Materials Science. Springerlink, v. 39, n. 2, p. 539-546.

STUART, K. D.; MOGAWER, W. S. (1997). Validation of asphalt binder and mixture tests that could predict rutting susceptibility using FHWA accelerated loading facility. Journal of the Association of Asphalt Paving Technologists. White Bear Lake, v. 66, p. 109-152.

TOMÉ, L. G. A. et al. (2005). Estudo do cimento asfáltico de petróleo modificado pelo terpolímero de etileno-butilacrilato-glicidilmetacrilato. In: CONGRESSO BRASILEIRO DE P \& D EM PETRÓLEO E GÁS. 3, Salvador. Anais..., Salvador.

VAN DER WERFF, J. C.; NGUYEN, S. M. (1996). Process for the preparation of a phosphoric-acid-containing asphalt/polymer mixture and resulting asphalt composition thereof. United States Patent 5,519,073.

VLACHOVICOVA, Z. et al. (2005). Shear deformation and material properties of polymermodified asphalt. Petroleum \& Coal. Slovnaft VÚRUP, v. 47, issue 3, p. 38-48.

WEST, R. C. et al. (2010). NCHRP Report 648: Mixing and compaction temperatures of asphalt binders in hot-mix asphalt. National Cooperative Highway Research Program. Washington, D.C.

YEH, P-H. et al. (2010). Modifying asphalt with varying levels of polyethylene additives. Society of Plastic Engineers - Plastics Research Online. Disponível em: <http://www.4spepro. org/pdf/002911/002911.pdf>. Acesso em: 28 fev. 2011.

YILDIRIM, Y. (2007). Polymer modified asphalt binders. Construction and Building Materials. Elsevier, v. 21, issue 1, p. 66-72.

YILDIRIM, Y. et al. (2000). Research report number 1250-5: Mixing and compaction temperatures for hot mix asphalt concrete. The University of Texas, Austin, TX.

(2006). Evaluation of viscosity values for mixing and compaction temperatures. Journal of Materials in Civil Engineering. New York, v. 18, n. 4, p. 545-553.

YOUSEFI, A. A. et al. (2000). Effect of used-tire-derived pyrolytic oil residue on the properties of polymer-modified asphalts. Fuel. Elsevier, v. 79, issue 8, p. 975-986.

ZHANG, J. et al. (2009). Thermal behaviour and improved properties of SBR and SBR/natural bitumen modified bitumens. Iranian Polymer Journal. Iran Polymer and Petrochemical Institute, v. 18, n. 6, p. 465-478. 